UNIVERSIDADE DE BRASÍLIA - UnB

INSTITUTO DE GEOCIÊNCIAS - IGD

PROGRAMA DE PÓS-GRADUAÇÃO EM GEOLOGIA

\title{
O DEPÓSITO SULFETADO Ni-Cu-(PGE) DE \\ LIMOEIRO: METALOGÊNESE, MAGMATISMO \\ MÁFICO E METAMORFISMO NO LESTE DA \\ PROVÍNCIA BORBOREMA
}

Jonas Mota e Silva

TESE DE DOUTORADO № 118

Orientador: Prof. Dr. Cesar F. Ferreira Filho

Brasília-DF, 27 de Novembro de 2014 
Para Julia e Tito 
Injusto seria se eu não mencionasse em primeiro lugar o orientador deste trabalho: Cesar F Ferreira Filho. Obviamente foi ele o responsável pela maioria de meu conhecimento acumulado na área da petrologia ígnea de rochas máficas e ultramáficas e de seus depósitos associados. O que não é óbvio, mas igualmente valioso, foi o conhecimento que ele me passou sobre vida acadêmica, profissional e vida pela vida. Sabias são suas palavras: "A vida não é uma corrida de cem metros, mas uma maratona". Ou outra: "Silicatos são como flamenguistas, são abundantes, mas não necessariamente melhores ou mais bonitos".

Agradeço em segundo lugar à base (termo cunhado pelo Shimbão)! Obrigado pai e mãe pelo crescimento proporcionado numa esfera onde sempre permeou amor e interesse pelo conhecimento. Obrigado a Lia por ser irmã parceira. Obrigado vó Alice e vô João (in memoriam) pelo estilo cartesiano e pragmático de enxergar a vida (uma dose disso é bom, senão necessário). Obrigado Shimbo e Maria, sogro e sogra que mais parecem pais adotivos. Muito grato aos meus belíssimos sobrinhos Léo e Iara pela alegria e arte que tornam a vida mais leve. Obrigado aos cunhados (as) Lucia, Thiago e Gabriel: pessoas inteligentes e inspiradoras.

Não se pode ignorar o papel da empresa pela qual trabalho diretamente desde março de 2005. A Votorantim Metais e seu grupo de Exploração Mineral basicamente criado e idealizado por Jones Belther e aperfeiçoado com a chegada de Lucio Molinari foi peça fundamental para que chegasse a essa defesa de tese. A empresa tem uma organização moderna, pautada em meritocracia, e valorização do conhecimento e inovação. Tem excelente interface com academia e representa hoje o que existe de mais interessante em termos de pesquisa mineral de metais base neste país. 
Obrigado à todos envolvidos no Projeto Limoeiro pelo suporte: Monge, Manoel Felipe, Allan, Rafael, João Boniatti, Saulo, Cotoco, Rodrigo Pinho, Fuleragem, Gleydson, Célio, Deywid, Mariano, Roberto, Fabio, Oia, Marreco, Manelzinho, Jaqueline, Inácio, Machadão, Fú, Lucena, Thiago Medeiros, Fábio Sacerdote, Raffael 2F e Pirro. Aos prestadores de serviço e amigos Nenray, Manequim e Dinho. Aos cães do projeto: Pirrotita (in memoriam), Belinha (in memoriam) e Níquel. Aos amáveis habitantes de Limoeiro e região: Duba, Manuel do Bofe, Sr. Olegário, Usina Laranjeiras, Isaltino e ao pessoal do Maria Bonita (in memoriam).

Obrigado à paciência e esforço da turma do laboratório de geocronologia do IG/UnB que me ajudou a enxergar algum resultado nos terríveis zircões metamorfisados de Limoeiro: Érico, Bárbara, Lú, Gilbésio, Dudú e Mancini (pena que o enxofre não saiu a tempo). Obrigado ao Ricardo e Frederico pelo formidável apoio nas análises em microssonda.

Obrigado aos amigos de Brasília pela companhia na mesa do bar: Biel, Pedrão, Fabião, Leandra, Ivan e Tharsila. Valeu queridos vizinhos e amigos que sabem ajudar na hora certa: Dona Isa, Sr. Zé Jorge, Sandra, Peterson, Monica, Elisa, Sonia, Dona Betinha, Dona Maria e Sr. Zé.

Thanks to the Cardiff University dear new friends: Peter Fisher, Hazel Prichard, Saioa Suárez, Wolfgang Maier and Iain McDonald. Additionally, thanks to Kara and Juan (both wonderful neighbors), Daniel and Mike (great friends from the Tuesday's basketball). Thanks to CAPES for the sandwich doctorate fellowship (process BEX 3603/13-0) of $£ 1300 /$ month plus flight to UK and a few extras (not bad).

Thanks to Richard Hornsey, great person and geologist. He provided a carefully and top quality review of this volume weeks before the thesis defense. This guy is one of the most proficient professional in mafic-ultramafic rocks petrology and petrography, and in Ni-Cu-PGE ore deposits that I have ever met. 
Obrigado à banca de defesa desta tese. Excelentes contribuições de todos: Elton Dantas (UnB), Massimo Matteini (UnB), Haroldo Sá (UFBA) e Elson Oliveira (UNICAMP).

E é claro, obrigado àqueles dois para quem este trabalho é inteiramente dedicado; a base das bases: Julia e Tito. Nada mais nada menos que parceiros de vida... Enfrentaram comigo o desconforto de uma mudança atropelada para a porção mais chuvosa da terra da rainha. Viveram por entre ratos e mofos e foram de bicicleta na chuva para creche inúmeras vezes. O que falar deles? Amo vocês! 
"The noble science of Geology loses glory from the extreme imperfection of the record. The crust of the earth with its embedded remains must not be looked at as a well-filled museum, but as a poor collection made at hazard and at rare intervals." 
Mota-e-Silva, Jonas. O Depósito Sulfetado Ni-Cu-(PGE) de Limoeiro: Metalogênese, Magmatismo Máfico e Metamorfismo no Leste da Província Borborema. Tese (Doutorado em Geologia) - Instituto de Geociências, Universidade de Brasília, Brasília, 2014.

Complexos máficos, máfico-ultramáficos e ultramáficos são os típicos hospedeiros de mineralizações magmáticas sulfetadas de níquel, cobre e elementos do grupo da platina (PGE). Em 2009 a Votorantim Metais descobriu o depósito Ni-Cu(PGE) sulfetado de Limoeiro no leste do estado do Pernambuco. Motivado pela descoberta, esta tese objetivou entender a gênese e evolução geológica do Complexo Limoeiro e sua mineralização de Ni-Cu-(PGE) nas escalas local e regional. Para isso foram realizados trabalhos de campo, mapeamento geológico, descrição de testemunhos de sondagem, interpretação de seção de sondagem, amostragem seletiva de rochas frescas e de mineralizações, petrografia óptica, química de rocha total, química de minério, química mineral, imageamento em microscópio eletrônico de varredura (MEV), análises químicas pontuais por espectrômetro de massa acoplado a feixe laser (LA-ICP-MS), imagamento de zircões por cátodo luminescência (CL) e datação U-Pb.

A mineralização do depósito Limoeiro é essencialmente disseminada [pirrotita $(\sim 70 \%)$, calcopirita $(\sim 15 \%)$ e pentlandita $(\sim 15 \%)$ ] e hospeda-se no topo de uma intrusão tubular (Sequencia Superior), sub-horizontal, concentricamente zonada (harzburgito no centro e ortopiroxenito na borda) com centenas de metros na transversal e alguns quilômetros na longitudinal. Esta intrusão faz parte de um sistema de condutos que ocupa uma área de $70 \times 15 \mathrm{~km}$, orientado na direção ENE-WSW, totalizando cerca de $150 \mathrm{~km}$ lineares de rochas intrusivas. A estratigrafia da intrusão é 
formada por pelo menos quatro pulsos magmáticos principais (Baixo Cr, Superior, Zona de Transição e Inferior), sendo cada um deles distintos em termos de fracionamento e mineralização na região do depósito. Apesar disso, o magma parental formador de cada pulso magmático é similar entre eles. Trata-se de um magma toleítico picrítico de alto $\mathrm{MgO}$ com forte assinatura de contaminação crustal. O progressivo aumento da razão Cu/Pd (de 5200 para 5800) das rochas da Sequencia Superior em harmonia com a diminuição do tenor evidencia fluxo horizontal do magma para leste.

Todo o complexo foi metamorfisado na fácies granulito baixo $\left(750-800^{\circ} \mathrm{C} \mathrm{em}\right.$ 634 $\pm 6 \mathrm{Ma}$ ) o que promoveu a recristalização dos zircões, dos sulfetos de metal base e provavelmente a fusão dos bismutoteluretos portadores de PGE.

O tipo de intrusão conolítica como de Limoeiro é típico de intrusões relativamente rasas em ambientes compressivos. Não foi alcançada uma idade precisa para cristalização da intrusão que hospeda o depósito Limoeiro, mas correlação entre razões $\mathrm{Th} / \mathrm{U}$ e idades $\mathrm{U} / \mathrm{Pb}$ em zircões metamorfisados sugerem uma idade de ca. 800 Ma. Nesta idade é possível que o sul da Província Borborema e sua continuidade na Africa experimentaram de modo concomitante extensão com abertura de assoalho oceânico e colisão continental. Ao mesmo tempo em que se desenvolvia crosta oceânica na parte oeste (Riacho do Pontal), na parte leste dominava ambiente colisional compressivo (Limoeiro). Em uma escala global a intrusão de Limoeiro é contemporânea à quebra do supercontinente de Rodínia e a existência de uma superpluma que tornou o manto extraordinariamente quente.

Palavras chave: Intrusão ultramáfica; Depósito magmático sulfetado; Níquel, cobre e elementos do grupo da platina. 
Mota-e-Silva, Jonas. The Limoeiro Ni-Cu-(PGE) Sulfide Deposit: Metallogenesis, Mafic Magmatism and Metamorphism in Eastern Borborema Province. Thesis (PhD in Geology) - Geosciences Institute, University of Brasilia, Brasilia, 2014.

Magmatic sulfide nickel, copper and platinum-group elements (PGE) are typically hosted by mafic, mafic-ultramafic and ultramafic complexes. The Limoeiro NiCu-(PGE) sulfide deposit was discovered in 2009 by Votorantim Metais in the eastern part of Pernambuco state, northeastern Brazil. Driven by this discovery, this thesis was undertaken to understand the geological evolution of the Limoeiro Complex and the genesis of its Ni-Cu-(PGE) deposit in local and regional scales. The methods involved field work, geological mapping, drill core descriptions, drilling section interpretation, fresh rock and ore sampling, optical petrography, whole rock and ore chemistry, mineral chemistry, electronic petrography using $\mathrm{MEV}$, trace element mineral chemistry using LA-ICP-MS, zircon petrography using CL and U-Pb dating.

The mineralization is essentially disseminated sulfide [pyrrhotite $(\sim 70 \%)$, chalcopyrite $(\sim 15 \%)$ and pentlandite $(\sim 15 \%)]$ and is hosted in the upper part (Upper Sequence) of a tubular, sub-horizontal, concentrically zoned (harzburgite core surrounded by orthopyroxenite shell) intrusion, of scale of hundreds meters in crosssection by a few kilometers long. This intrusion is part of a conduit system (150 linear $\mathrm{km}$ of intrusive rocks), which occurs in an area of $70 \times 15 \mathrm{~km}$ elongated in the ENEWSW direction. The intrusion stratigraphy can be divided into at least four main magmatic pulses (Low-Cr, Upper, Transition Zone and Lower), which differ in terms of fractionation and mineralization-content. However, their parental magmas are similar, and can be classified as a high- $\mathrm{MgO}$ tholeiitic picrite with intense crustal 
contamination. The progressive increase of Upper Sequence $\mathrm{Cu} / \mathrm{Pd}$ ratio (5200 to 5800) together with metal tenor decrease suggests horizontal magma flux to the east.

The whole complex was metamorphosed in lower granulite facies $\left(750-800^{\circ} \mathrm{C}\right.$ at $634 \pm 6 \mathrm{Ma}$ ), which resulted in the zircons and base metal sulfides recrystallization and probably in the melt of the PGE-bearing bismuthotelurides.

Compressive geological settings are commonly associated with chonolithic intrusions, such as the Limoeiro Complex. The metamorphic zircons within the complex show a positive correlation between $\mathrm{U} / \mathrm{Pb}$ age and $\mathrm{Th} / \mathrm{U}$ ratio, which alow infer crystallization age of ca. $800 \mathrm{Ma}$ for Limoeiro. During that time the Southern part of Borborema Province and its African continuity have experienced contrasting tectonic settings. The Western side was rifting and forming oceanic crust (Riacho do Pontal), whereas in the Eastern counterpart collisional and compressive settings (Limoeiro) prevail. In a global scale, the Limoeiro intrusion emplacement was coeval to the Rodinia supercontinent break-up and to a superplume activity, which overheated the mantle at ca. $800 \mathrm{Ma}$.

Keywords: Ultramafic intrusion; Sulfide magmatic deposit; Nickel, copper and platinumgroup elements. 


\section{Lista de Figuras}

Figura 1.1: (A) Pre-rift reconstruction of western Gondwana showing the main cratons and Brasiliano/PanAfrican provinces (modified from Neves and Alcantara, 2010). Abbreviations: A, Amazonia; BP, CP, NP: Borborema, Nigeria and Cameroon provinces; K, Kalahari; RP, Rio de La Plata; SA, Sahara Metacraton; SCC, São Francisco/Congo; WA, West Africa. (B) Sketch showing the main shear zones that limits the domain subdivision of the Borborema Province. Abbreviations: PaSZ, Patos Shear Zone; PeSZ, Pernambuco Shear Zone.. 13

Figura 1.2: Geological map of the Limoeiro intrusion. The inset on the upper-left corner is the Reduced to Pole ground magnetic grid. The coordinates are in SAD-69 geographic projection. 19

Figura 1.3: Schematic 3D model of the chonolithic conduit of the ultramafic intrusion. 20

Figura 1.4: (A) Panoramic view of the ultramafic rocks and gossan outcrop area (4 $\mathrm{m}$ wide dirt roads are the scale). (B) An outcrop of harzburgite with preserved magmatic subhorizontal layering, consisting of olivine- and orthopyroxene-dominant layers (30 cm long hammer is the scale). (C) Sample of $\mathrm{Ni}-\mathrm{Cu}-\mathrm{PGE}-$ rich gossan (2 $\mathrm{cm}$ wide hammer neck is the scale). (D) Typical coarse-grained harzburgite. (E) Disseminated ore consisting of harzburgite with 5 vol\% sulfides. (F) Massive sulfide layer consisting mainly of pyrrhotite and pentlandite in the top and a chalcopyriteenriched less massive lower zone. (G) Garnet-sillimanite-biotite paragneiss of the Vertentes complex with small pegmatite batches interpreted as in-situ melting products. For scale purpose the diamond drill core presented in D, E, F and G has $4.7 \mathrm{~cm}$ diameter. Mineral symbols in accordance with Kretz (1983).

Figura 1.5: Longitudinal schematic section of the ultramafic intrusion. 22

Figura 1.6: Geological cross-sections of (A) Parnazo, (B) Retiro, (C) Piçarra and (D) Bofe targets. 24

Figura 1.7: SLM0053 (Parnazo) and SLM0002 (Retiro) drill holes strip log and its MgO, Cr, Al2O3 and S assay results. The thin dashed lines indicate stratigraphic correlations between drill holes, and the coarser gray dashed line shows the Upper and Lower Sequence limit. 26

Figura 1.8: (A) Typical texture of coarse-grained harzburgite with metamorphic amphiboles between large crystals of orthopyroxene and olivine. (B) Metamorphic amphiboles replacing large crystals of orthopyroxene and olivine. (C) Anhedral olivine crystal with corroded rounded margins enclosed in large orthopyroxene crystal. (D) Large orthopyroxene grain with optically continuous olivine grain inclusions, suggesting a reaction of destruction of olivine and crystallization of orthopyroxene. (E) Euhedral chromite crystals included in large orthopyroxene grain. (F) Sulfide blebs with MSS composition included in orthopyroxene. Mineral symbols in accordance with classification of Kretz (1983).

29

Figura 1.9: (A) A quartz- Kfeldspar-biotite schist showing a granolepidoblastic texture. (B) Same as " $A$ " but with crossed polarizers. (C) A quartz-biotite-sillimanite schist showing the almond-shape of the quartz grain. (D) The same quartz-biotite-sillimanite schist showing the opaque pyrite grains, a common constituent of this rock. Mineral symbols in accordance with classification of Kretz (1983). 31

Figura 1.10: (A) The peak metamorphic paragenesis with sub-grains of orthopyroxene in equilibrium with amphibole, chlorite and spinel. (B) Distinguishable amphiboles recognized here as a pale green hornblende and a colorless anthophyllite in equilibrium with a phlogopite crystal. (C) MSS sulfides with its external boundaries controlled by the metamorphic minerals fabric. (D) Same as "C" but in reflected light. (E) Low-temperature alteration paragenesis represented by $2^{\text {nd }}$ generation chlorite, calcite, talc, magnetite and antigorite. (F) Clear temporal relationship showing the high-grade metamorphic parageneses cross-cut by the low-temperature assemblage. Mineral symbols in accordance with classification of Kretz (1983). 
Figura 1.11: (A) Sulfide blebs from the disseminated ore included in a large olivine grain. (B) Sulfide blebs and intercumulus sulfide from the disseminated ore partly remobilized into the cleavage of the bent orthopyroxene crystal. (C) Intercumulus sulfide from the disseminated ore with individual rounded pentlandite grains and tiny exsolution flames. (D) The ribbon-texture network showing sub-solidus exsolution of chalcopyrite and pentlandite from pyrrhotite. Mineral symbols in accordance with classification of Kretz (1983).

Figura 1.12: Schematic geological sections showing the intrusive model for the ultramafic conduit that hosts the Limoeiro deposit.

Figura 2.1: (A) Prerift reconstruction of western Gondwana showing the main cratons in dark grey, the Andean in light grey and the Brasiliano/Pan-African provinces are marked with dashes (modified from Neves and Alcantara, 2010). Abbreviations for cratons: A, Amazonia; K, Kalahari; RP, Rio de La Plata; AS, Sahara Metacraton; SCC, São Francisco/Congo; WA, West Africa. Abbreviations for provinces: BP, Borborema; CP, Cameroon; NP, Nigeria. (B) Simplified geological map showing the main geotectonic units, the major shear zones and the location of the Limoeiro Ni-Cu-(PGE) deposit (modified from Medeiros, 2004). 57

Figura 2.2: Schematic three-dimensional model of the chonolithic conduit of the ultramafic intrusion (taken from Mota-e-Silva et al., 2013).

Figura 2.3: Longitudinal schematic section of the ultramafic intrusion, highlighting the major magmatic sequences and the disseminated and massive ore locations.

60

Figura 2.4: Geologic cross sections of the (A) Parnazo, (B) Retiro, (C) West Piçarra and (D) East Piçarra targets. 61

Figura 2.5: Box-and-Whisker plots of $\mathrm{MgO}, \mathrm{Cr}, \mathrm{S}$ and $\mathrm{Cu} / \mathrm{Pd}$ of four different magmatic sequences: Low $\mathrm{Cr}$, Upper, Transition Zone and Lower sequences. The center line is the median and the box is limited by upper and lower quartile. The dashed line comprises all data except the outliers that are shown in open circles. The letters exhibit the significant different groups of data according to Tukey's HSD test for $\mathrm{p}<0.01$.

Figura 2.6: Box-and-Whisker plots of $\mathrm{S}, \mathrm{Cu} / \mathrm{Pd}$ and $\mathrm{Pt} / \mathrm{Pd}$ for the Upper sequence in three different targets from the west to the east: Parnazo, Retiro and Piçarra. The center line is the median and the box is limited by upper and lower quartile. The dashed line comprises all data except the outliers that are shown in open circles.

Figura 2.7: Biplots of the metals $\mathrm{Ni}, \mathrm{Cu}, \mathrm{Pd}$ and Pt versus $\mathrm{S}$. The text indicates the orebody name, the line equation, the correlation coefficient (R2) and the calculated tenor for $35 \mathrm{wt} \% \mathrm{~S}$.

Figura 2.8: Biplots of the PGE Os, Ir and Rh versus S. The text indicates the line equation and the correlation coefficient $\left(R^{2}\right)$.

Figura 2.9: Spidergram of the 6 PGE plus $\mathrm{Ni}, \mathrm{Co}$ and $\mathrm{Cu}$. The values are normalized to the Primitive Mantle (Sun and McDonough, 1995) and by the Limoeiro deposit Ni grade, in order to highlight the curve slope for direct comparison with the degree of fractionation of the Noril'sk and Kambalda deposits.

68

Figura 2.10: Biplot of $\mathrm{Pd} / \mathrm{Ir}$ versus $\mathrm{Ni} / \mathrm{Cu}$ aiming to show the intensity of the Limoeiro deposit fractionation. For comparison the Noril'sk and Kambalda deposits are also plotted. The field contours and the graphic concept were taken from Barnes and Lightfoot (2005).

Figura 2.11: Biplots of $\mathrm{Ni}$ versus $\mathrm{Cu}(\mathrm{A}$ and $\mathrm{B})$ and $\mathrm{Pt}$ versus $\mathrm{Pd}(\mathrm{C}$ and $\mathrm{D})$. The figures $\mathrm{A}$ and $\mathrm{C}$ include all samples, but figures $B$ and $D$ are more representative of the disseminated sulfide ore. 70

Figura 2.12: Drillhole SLM0201 log and its $\mathrm{Ni}, \mathrm{Cu}$ and $\mathrm{S}$ concentrations. The topmost and the basal most samples are country rocks. The lithology codes are the same as those used in Fig. 2.4....... 71

Figura 2.13: A detail of the base of the Upper sequence in drillhole SLM0201 shown in Fig. 2.12. The charts display the concentrations of $\mathrm{Ni}$ and $\mathrm{Cu}(\mathrm{A})$, the Pt and $\mathrm{Pd}(\mathrm{B})$ and $\mathrm{S}(\mathrm{C})$. The numbers labeled in the spikes represent metal ratios. The lithology codes are the same as those used in Fig. 2.4. 
Figura 2.14: The forsterite and $\mathrm{Ni}$ content in olivines, the enstatite and $\mathrm{Ni}$ contents in orthopyroxenes, the whole rock $\mathrm{MgO}, \mathrm{S}, \mathrm{Al}_{2} \mathrm{O}_{3}$ and $\mathrm{K}_{2} \mathrm{O}$ concentrations for the drillholes SLM0251, 53, 2,21 and 4. The plotted mineral analyses are averages and error bars were calculated as plus and minus one standard deviation. The lithology codes are the same as those used in Fig. 2.4. 85

Figura 2.15: Forsterite versus Ni content averages of olivines in drillholes SLM0053, 70, 2, 21, 251 and 4. From the top left to the bottom right the charts are respectively moving from the west to the east portion of the intrusion.

Figura 2.16: Biplots of the major oxides $\mathrm{SiO}_{2}, \mathrm{FeO}, \mathrm{Al}_{2} \mathrm{O}_{3}, \mathrm{CaO}, \mathrm{Na}_{2} \mathrm{O}, \mathrm{K} 2 \mathrm{O}, \mathrm{TiO}_{2}, \mathrm{Cr}_{2} \mathrm{O}_{3}$ versus $\mathrm{MgO}$ for 78 whole rock samples of ultramafic rocks of the Limoeiro intrusion. The dashed line includes the samples potentially representative of the intrusion parental magma (liquid) and the black arrow points towards the samples with the dominance of cumulus minerals (more cumulus minerals and less liquid or intercumulus minerals). The red arrow points towards higher levels of localized country rock contamination.

88

Figura 2.17: Primitive mantle-normalized REE patterns for the calculated Limoeiro parental magma and for the Limoeiro intrusion ultramafic rocks. For comparison are shown N-MORB, E-MORB and OIB typical REE values (Sun and McDonough, 1989). The normalization values are from Sun and McDonough (1989). 105

Figura 2.18: Diagram showing variations in the primitive mantle-normalized $\mathrm{Eu} / \mathrm{Yb}$ and $\mathrm{La} / \mathrm{Yb}$ ratios for the the calculated Limoeiro parental magma and for the Limoeiro intrusion ultramafic rocks. For comparison are shown N-MORB, E-MORB and OIB typical values (Sun and McDonough, 1989). The normalization values are from Sun and McDonough (1989). 106

Figura 2.19: Primitive mantle-normalized lithophile element patterns for the calculated Limoeiro parental magma and for the Limoeiro intrusion ultramafic rocks. For comparison are shown N-MORB, E-MORB and OIB typical REE values (Sun and McDonough, 1989). The normalization values are from Sun and McDonough (1989). 107

Figura 2.20: Diagram showing variations in the $\mathrm{Th} / \mathrm{Yb}$ and $\mathrm{Nb} / \mathrm{Yb}$ ratios for the calculated Limoeiro parental magma and for the Limoeiro intrusion ultramafic rocks. The diagram was originally designed to discriminate basalts (Pearce, 2008) with the MORB-OIB array shaded while volcanic arc basalts or crustally-contaminated basalts and alkalic basalts containing a large recycled crustal component plot above the array. The curved AFC arrow indicates magma formed in an enriched mantle source that has passed through assimilation and fractional crystallization processes (DePaolo, 1981). The $\mathrm{F}$ number indicates different levels of fractionation (for a review see Pearce, 2008 and DePaolo, 1981)...... 108

Figura 2.21: Diagram showing variations in the primitive mantle-normalized $\mathrm{Nb} / \mathrm{Th}$ and $\mathrm{Th} / \mathrm{Yb}$ ratios for the the calculated Limoeiro parental magma and for the Limoeiro intrusion ultramafic rocks. For comparison are shown N-MORB, E-MORB, OIB (Sun and McDonough, 1989) and Upper Crust (Rudnick and Gao, 2004) typical values. The dashed lines related to two different magmatic complexes documented by Zhou et al. (2008) in the Emeishan large igneous province, China. The normalization values are from Sun and McDonough (1989).

Figura 2.22: Diagram showing variations in the $\mathrm{TiO}_{2} / \mathrm{Yb}$ and $\mathrm{Nb} / \mathrm{Yb}$ ratios for the calculated Limoeiro parental magma and for the Limoeiro intrusion ultramafic rocks. For comparison are shown N-MORB, E-MORB and OIB typical values (Sun and McDonough, 1989). The diagram was originally designed by Pearce (2008) to discriminate geotectonic setting where the oceanic islands basalts plot predictably in the OIB field (the alkalic lavas have the highest $\mathrm{Ti} / \mathrm{Yb}$ and $\mathrm{Nb} / \mathrm{Yb}$ ratios, whereas the tholeiitic basalts have the lowest) and the plume-distal ridges plot in the MORB field (shaded).

109

Figura 2.23: Biplots of $\mathrm{Ti}, \mathrm{Ce}$, Th and $\mathrm{K}$ versus $\mathrm{Zr}$ and $\mathrm{Ti} / \mathrm{Zr}$ and $\mathrm{K}$ versus loss on ignition for 78 whole rock samples of ultramafic rocks of the Limoeiro intrusion. 111

Figura 2.24: Drill core pictures showing critical aspects of the Limoeiro ore. (A) Disseminated sulfide ore with sulfides dominantly associated with orthopyroxenes. Drill hole SLM0201 at the depth of $\sim 144 \mathrm{~m}$. (B) Disseminated sulfide ore with sulfides dominantly associated with olivines. Drill hole SLM0004 at the depth of $\sim 70 \mathrm{~m}$. (C) Sharp contact between massive sulfide layer and host 
rock. Note ultramafic autoliths within the massive ore and the segregation of chalcopyrite from the other BMS to the most external part of the massive ore. Drill hole SLM0201 at the depth of $140.35 \mathrm{~m}$. (D) Garnet and biotite (xenolith remnants) patches within a massive sulfide ore. Drill hole SLM0002 at the depth of $199.60 \mathrm{~m}$. (E) Massive sulfide layer with pentlandite segregated to the most external parts, pyrrhotite in the core and chalcopyrite displaced to the ultramafics in the footwall. Drill hole SLM0201 at the depth of 146.85m. (F) Discordant, vertical and winding sulfide vein with alteration halo in the orthopyroxenite. Drill core SLM0108 at the depth of 50.50m. (G) Massive sulfide and stringer ore with a tectonic fabric parallel to metamorphic amphiboles. Drill hole SLM0004 at the depth of $115.85 \mathrm{~m}$. 121

Figura 2.25: Schematic model containing the most relevant discussions and conclusions made in this study. (A) A regional view showing partial melting in the shallow parts of an enriched mantle source and migration of the magma to the upper crust. (B) A longitudinal conduit view in the final stage of the inflation phase. (C) A longitudinal conduit view after crystallization. 126

Figura 3.1: (A) Pre-rift reconstruction of western Gondwana showing the main cratons and Brasiliano/PanAfrican provinces (modified from Neves and Alcantara, 2010). Abbreviations: A, Amazonia; BP, Borborema; CP, Cameroon; NP, Nigeria; K, Kalahari; RP, Rio de La Plata; SA, Sahara Metacraton; SCC, São Francisco/Congo; WA, West Africa. (B) Map showing the position of the Limoeiro Ni$\mathrm{Cu}(-\mathrm{PGE})$ sulfide deposit in the Borborema province (modified from Mota-e-Silva et al., 2013).

139

Figura 3.2: Representative longitudinal section along the chonolith. Note that the Upper sequence is the only sulfide-bearing unit in the Parnazo and Retiro targets. However this feature is not clear in the very tectonically-disrupted Piçarra target to the east. The density of red circles is proportional to sulfide abundance 139

Figura 3.3: Representative cross-sections of the two main drilling targets in the Limoeiro Ni-Cu(-PGE) sulfide deposit. 140

Figura 3.4: Examples of ore types from the Limoeiro $\mathrm{Ni}-\mathrm{Cu}(-\mathrm{PGE})$ deposit. (A) Drill core of a typical disseminated sulfide ore [pyrrhotite $(\mathrm{Po})$, pentlandite $(\mathrm{Pn})$ and chalcopyrite $(\mathrm{Ccp})$ ] hosted in orthopyroxenite. (B) Drill core of massive sulfide. (C) The honey-comb-like-texture showing chalcopyrite and pentlandite ribbons surrounding polygonal pyrrhotite grains in $120^{\circ}$ triple junctions. (D) Drill core of sample 004-115.80, an example of tectonically mobilized and sheared massive sulfide. In this case the massive sulfide has numerous ellipsoidal elongated silicate inclusions forming a typical "Durchbewegung" texture (term coined by Vokes, 1969) suggesting mechanical deformation involving milling of country rock inclusions.....

141

Figura 3.5: Representative bore hole strip log of the Retiro target. The massive sulfide horizons sampled are marked with a red star and labeled with the sample name. The lithology colors are the same as those used in Fig. 3.3. 143

Figura 3.6: Representative bore hole strip log of the east part of Piçarra target. The massive sulfide horizons sampled are marked with a red star and labeled with the sample name. The lithology colors are the same as those used in Fig. 3.3.

Figura 3.7: Pie charts showing the PGM frequency and area abundances in the disseminated ore from the Limoeiro $\mathrm{Ni}-\mathrm{Cu}(-\mathrm{PGE})$ sulfide deposit.

Figura 3.8: Back scattered electron images of: (A) Subhedral merenskyite grain with discrete cleavage, enclosed by pyrrhotite (Po), and attached to a rounded silicate in massive sulfide ore, sample 213-173.95, grain \# 3. (B) Euhedral merenskyite grain enclosed by pyrrhotite and pentlandite $(\mathrm{Pn})$, and attached to a rounded silicate in massive sulfide ore, sample 213-183.25, grain \# 6 . (C) Subhedral merenskyite grain with clear cleavage parallel to the longer crystal axis, enclosed by pyrrhotite, surrounded by open fractures in massive sulfide ore, sample 213-183.25, grain \# 12. (D) Subhedral merenskyite grain with discrete cleavage parallel to the longer crystal axis, enclosed by pyrrhotite, and affected by a fracture through the massive sulfide ore, sample 213173.95, grain \# 10. Mineral symbols based on Whitney and Evans (2010) listing

Figura 3.9: Back scattered electron images of: (A) Subhedral sperrylite (Spy) in contact with and partially surrounded by chalcopyrite (Ccp), both enclosed by silicate forming an orthopyroxenite 
containing disseminated sulfides, sample 213-185.00, grain \# 35. (B) Euhedral sperrylite with a typical diamond shape, forming a composite grain with cooperite (Cpr), both enclosed by magnetite (Mag) in an orthopyroxenite containing disseminated sulfides, sample 213-185.00, grain \# 3. (C) Subhedral sperrylite at the contact between BMS and a silicate in an orthopyroxenite containing disseminated sulfides, sample 002-125, grain \# 1. (D) Anhedral to subhedral sperrylite in contact with a silicate, both enclosed by chalcopyrite in an orthopyroxenite containing disseminated sulfides, sample 213-185.00, grain \# 29. (E) Euhedral sperrylite forming a composite grain with melonite (Mlt), both included in a spinel (Spl) grain (probably derived during metamorphism of chromite) in an orthopyroxenite containing disseminated sulfides, sample 213-185.00, grain \# 21. (F) Euhedral sperrylite in contact with chalcopyrite, both enclosed by magnetite in an orthopyroxenite, sample 213-185.00, grain \# 11. Mineral symbols mostly from Whitney and Evans (2010) and alternatively based on Kretz (1983) and Spear (1993) when not found in the first listing. 153

Figura 3.10: Bar charts showing the frequency of each mineral phase in contact with the PGM from the Limoeiro $\mathrm{Ni}$-Cu(-PGE) sulfide deposit......

Figura 3.11: Bar chart showing the frequency of PGM in different textural sites in the Limoeiro Ni-Cu-(PGE) deposit. The numbers on the bars refer to the proportions (in \%) of massive and disseminated sulfide ore for each texture.

Figura 3.12: Bar chart showing merenskyite and sperrylite abundances for each texture in the Limoeiro Ni$\mathrm{Cu}$-(PGE) deposit. These minerals are the two most abundant PGM phases in the Limoeiro deposit.

156

Figura 3.13: Back scattered electron images of: (A) An euhedral merenskyite enclosed by a BMS bleb included in an orthopyroxene (Opx), itself partly altered to talc (Tlc), in sample 018-155, grain \# 9. (B) An elongate merenskyite enclosed by a partly remobilized intercumulus BMS surrounded by orthopyroxene grains in sample 004-087, grain \# 14. (C) A subhedral merenskyite located between a BMS bleb surrounded by olivine that is partly serpentinized in sample 018-155, grain \# 17. (D) A subhedral elongate sperrylite (Spy) crystallized on the edge of a pyrrhotite (Po) and in contact with metamorphic hornblende ( $\mathrm{Hbl}$ ) in sample 002-125, grain \# 25. (E) A composite grain (merenskyite + hessite) at the edge of a pyrrhotite showing an irregular corroded contact with antigorite (Atg) in sample 021-137, grain \# 6. (F) A composite grain (merenskyite + hessite) at the edge of a chalcopyrite (Ccp) bleb showing an irregular corroded contact with the host orthopyroxenite that is itself crosscut by several veinlets containing remobilized sulfide in sample 213-185.00, grain \# 30. Mineral symbols mostly from Whitney and Evans (2010) and alternatively based on Kretz (1983) and Spear (1993) when not found in the first listing 157

Figura 3.13 cont.: (G) A merenskyite grain within a pentlandite-filled veinlet in sample 021-137, grain \# 1. (H) A merenskyite grain within a pentlandite-filled veinlet that occupies a fracture crosscutting a magnetite grain in sample 213-185, grain \# 66. (I) An elongate merenskyite grain within pyrrhotite situated in orthopyroxene cleavage in sample 004087, grain \# 12. (J) An elongate merenskyite grain with chalcopyrite located in a metamorphic hornblende cleavage in sample 004-067, grain \# 1. (K) An euhedral composite grain (sperrylite + melonite) enclosed by orthopyroxene in sample 213-185, grain \# 33. (L) An elongate merenskyite grain enclosed by antigorite in sample 055-228, grain \# 10. 158

Figura 3.14: Compositional variation of PGM belonging to the solid solution series of melonite, merenskyite and moncheite in the Limoeiro $\mathrm{Ni}-\mathrm{Cu}(\mathrm{PGE})$ sulfide deposit. Results of 60 analyses are projected onto the Ni-Pd-Pt ternary diagram (atomic proportions). The dashed line indicates the average $\mathrm{Pt} / \mathrm{Pd}$ atomic ratio for the two main Limoeiro deposit targets. "MS" = massive sulfide 159

Figura 3.15: Compositional Te and $\mathrm{Bi}$ variation of 60 merenskyite grains in the Limoeiro Ni-Cu(PGE) sulfide deposit. "MS" = massive sulfide. 160

Figura 3.16: Whole rock Pt and Pd contents of 2006 samples from the two main targets in the mineralized Upper sequence of the Limoeiro $\mathrm{Ni}-\mathrm{Cu}-(\mathrm{PGE})$ deposit. The linear trend (red dashed line) indicates the average $\mathrm{Pt} / \mathrm{Pd}$ ratio. Data from the VM drilling assay database. 164 
Figura 3.17: Whole rock $\mathrm{MgO}$ content versus $\mathrm{Pt} / \mathrm{Pd}$ weight ratio biplot of 2006 samples from different lithologies from the mineralized Upper sequence of the Retiro and Piçarra targets in the Limoeiro Ni-Cu-(PGE) deposit. The central red dashed line represents the bulk deposit average $\mathrm{Pt} / \mathrm{Pd}$ weight ratio. The top and bottom red dashed lines are respectively 5 times and a fifth of the average $\mathrm{Pt} / \mathrm{Pd}$ weight ratio and are plotted as a reference for the identification of the samples with relatively high and low Pt/Pd weight ratios. The text in black refers to the four samples (two at the top and two at the bottom) that are outside the red dashed lines. The $\mathrm{Pt} / \mathrm{Pd}$ weight ratio values are plotted on a base 10 logarithmic scale. Data from the VM drilling assay database......

Figura 3.18: Schematic model representing the Limoeiro chonolith showing an intrusion scale cross section and small scale chart of magmatic sulfide blebs showing the main geological phases that occurred during the formation of the primary, high grade metamorphic and lower temperature alteration secondary sulfide and PGM assemblages at the Limoeiro $\mathrm{Ni}-\mathrm{Cu}(-\mathrm{PGE})$ sulfide deposit. 171

Figura 4.1: (A) Pre-rift reconstruction of western Gondwana showing the main cratons and Brasiliano/PanAfrican provinces (modified from Neves and Alcantara, 2010). Craton abbreviations: A, Amazonia; SCC, São Francisco/Congo; WA, West Africa; RP, Rio de La Plata; SA, Sahara; and K, Kalahari. Provinces of the Brasiliano/Pan-African orogeny abbreviations: BP, Borborema; NP, Nigeria; and CP, Cameroon. (B) Sketch showing the position of the Limoeiro Ni-Cu-(PGE) sulfide deposit in the Borborema province (modified from Mota-e-Silva et al., 2013). 191

Figura 4.2: Simplified geological map of the Limoeiro intrusion showing the locations of the gossan occurrences and bore hole SLM0008. A simplified cross section is presented in the upper-left corner. The coordinates are from the SAD-69 geographic projection 192

Figura 4.3: (A) Panoramic view looking north towards the ultramafic rocks and the Bofe gossan. (B) Detail of the main in-situ Bofe gossan outcrop looking towards the south. Note that vegetation shows retarded growth where the gossan outcrops. (C) Sample of PGE-Cu-Ni-rich Bofe gossan (2 cm wide hammer handle shows the scale). Mineral symbols: Gt, goethite; Lim, limonite.

Figura 4.4: The SLM0008 log containing depth marks, lithology, and assay results for $\mathrm{Pt}, \mathrm{Pd}, \mathrm{Ni}, \mathrm{Cu}, \mathrm{Al}_{2} \mathrm{O}_{3}$, $\mathrm{MgO}$ and $\mathrm{Fe}$ represented as bar plots. The bar colors vary according to concentrations to distinguish between similar values and the interpretation of trends. Lithological abbreviations: SO, soil with a few gossan clasts; GS, gossan; HZ, harzburgite; PX, orthopyroxenite; GN, paragneiss.

Figura 4.5: Back scattered electron images of: (A) Sulfide bleb hosted by amphibole (Amp) and orthopyroxene (Opx) grains showing the distinct oxidation state of the base metal sulfides (BMS). Violarite (Vio) is the most oxidized BMS, whereas pyrite is slightly oxidized and chalcopyrite $(C p)$ is still fresh. This is a mineralized orthopyroxenite sample from a depth of $28.20 \mathrm{~m}$. (B) Partly oxidized pyrite with goethite crystallized in circular concentric fractures. Violarite is completely oxidized, whereas merenskyite (Mrk; detail in the bottom right inset) is still preserved but exhibits a diffuse outline hosted in a mineralized orthopyroxenite from a depth of $28.20 \mathrm{~m}$. (C) Partly oxidized pyrite, with fresh chalcopyrite and merenskyite, the latter showing a diffuse outline and oxidized fractures (detail in the bottom left inset). This is a mineralized orthopyroxenite sampled at a depth of $26.40 \mathrm{~m}$. (D) Oxidized sulfide (mostly replaced by goethite) included in partly altered orthopyroxene. Sperrylite (Spy) is still preserved whereas merenskyite (detail of these two PGM in the bottom right inset) is altered to a Pd-Te-Bi PGM that shows an irregular outline, in a mineralized harzburgite at a depth of $18.65 \mathrm{~m}$. (E) Oxidized sulfide included in a fresh amphibole and partly altered orthopyroxene. The oxidation of these mineral phases occurs by gradual replacement of them by veinlets of goethite (Gt). This sample is a mineralized ultramafic-derived saprolite in the transition zone to gossan at a depth of $6.50 \mathrm{~m}$. (F) A partly altered ultramafic rock; altered olivine, antigorite (Atg), phlogopite ( $\mathrm{Phl}$ ) and $\mathrm{Cr}$-spinel (Spl) occur in the lower part of the image, whereas a typical gossan mineralogy and texture (goethite, fine grained quartz and voids) dominate in the upper portion of the image. The sample consists of a mineralized ultramafic-derived saprolite in the transition zone to gossan at the depth of $6.50 \mathrm{~m}$. Mineral symbols are used in accordance with Kretz (1983). 
Figura 4.6: Schematic chart showing (solid black lines) the range of occurrence of each specific mineral phase along the weathering profile in the Limoeiro $\mathrm{Ni}-\mathrm{Cu}(-\mathrm{PGE})$ sulfide deposit . The dashed line indicates the zone where the mineral is altered. The question marks note uncertainties on the depth of alteration of pentlandite and pyrrhotite to violarite and pyrite. Mineral symbols are used in accordance with Kretz (1983) when available: olivine (OI), orthpyroxene (Opx), amphibole (Amp), chromite (Chr), pentlandite (Pn), pyrrhotite (Po), chalcopyrite (Cp), merenskyite (Mrk), sperrylite (Spy), hollingworthite (HIw), irarsite (Irs), violarite (Vio), pyrite (Py), goethite (Gt), silica (Sil), Pd-Te (Pd-Te \pm Bi PGM), Pd-Cu (Pd-Cu alloy) and $\mathrm{Pdl}_{2}$ (Pd iodide)...199

Figura 4.7: Pie charts showing the PGM frequency and area abundances in the Bofe and Paquivira gossans in the Limoeiro $\mathrm{Ni}-\mathrm{Cu}(-\mathrm{PGE})$ sulfide deposit. 200

Figura 4.8: Back scattered electron images of arsenide and sulfarsenide PGM in the gossan: (A) A sperrylite (Spy) with an oxidized rim preserving the original grain boundary. The sperrylite is hosted by goethite (Gt) which contains Pt-rich goethite patches adjacent to the sperrylite. Sample GS-BF2, grain 3. (B) A fresh irarsite (Irs) associated with a brighter (more dense) phase possibly sperrylite. This mineral is hosted by goethite. Sample GS-PQ-1, grain 9. (C) A partly altered and corroded irarsite and hollingworthite (Hlw) composite crystal hosted by goethite. A faceted dark line surrounding the PGM probably represents the original grain boundary of the irarsite and hollingworthite composite grain. Sample GS-PQ-1, grain 6. (D) A broken and partly corroded hollingworthite grain hosted by goethite. The cavity around the PGM is suggestive of the original hollingworthite grain boundary. Sample GS-PQ-2, grain 5. (E) A preserved cubic irarsite crystal and a broken and partly corroded hollingworthite forming a composite grain within goethite. A cavity around the PGM is suggestive of the original composite grain boundary. Sample GS-PQ-2, grain 3. (F) A broken and partly corroded hollingworthite grain hosted by goethite. A cavity around the PGM is suggestive of the original grain boundary. Sample GS-PQ2, grain 2. Mineral symbols are used in accordance with Kretz (1983).

201

Figura 4.9: Back scattered electron images of partly oxidized Pd-Te \pm Bi PGM: (A) Palladium-Te-Bi PGM (brightest) with oxidized parts (less bright) hosted by $\mathrm{Cu}$-bearing goethite (Gt). Sample 8-18.65 (mineralized weathered harzburgite), grain 1. (B) A pseudomorph of merenskyite filled with PdTe-Bi PGM (detail in Fig. 4.9C) and Cu-bearing goethite. A small electrum grain occurs on the boundary of the pseudomorph with the host goethite. Sample GS-PQ-1 (Paquivira gossan), grain 10. (C) Detail of the Pd-Te-Bi PGM exhibited in Fig. 4.9B. The oxidation of the Pd-Te-Bi PGM forms rounded alteration fronts crossing from the external limits of the grain towards the inner parts. Sample GS-PQ-1, grain 10. (D) Oxidized Fe-Pd-Cu-Pt phase hosted by Cu-bearing goethite. The difference in the grain brightness reflects compositional variation (Pd-rich in the top and Fe-rich in the bottom). Sample GS-BF-2, grain 1. (E) Preserved core of oxidized Fe-Pd$\mathrm{Pt}-\mathrm{Cu}-\mathrm{Ni}$ phase partly replaced by $\mathrm{Ni}-\mathrm{Cu}$ bearing goethite. Sample GS-BF-2, grain 4. Mineral symbols are used in accordance with Kretz (1983)...... 206

Figura 4.10: Back scattered electron images of the $\mathrm{Pd}-\mathrm{Cu}$ rich phases in the gossan: (A) Strongly dissolved and leached merenskyite enclosed in Te-bearing goethite. Relict PGM appears partially replaced by goethite and $\mathrm{Pd}-\mathrm{Cu}$-alloy masses (brightest in figure). Sample GS-PQ-2, grain 10. (B) Merenskyite pseudomorph composed of goethite and patches of $\mathrm{Pd}-\mathrm{Cu}$ alloy. Sample GS$\mathrm{PQ}-2$, grain 21.(C) Merenskyite pseudomorph composed of goethite including micrometric patches of $\mathrm{Pd}-\mathrm{Cu}-\mathrm{Bi}$ alloys and sparse $\mathrm{Pd}-\mathrm{Cu}$-rosettes on the surface. Sample $\mathrm{CS}-\mathrm{PQ}-2$, grain 11. (D) Merenskyite pseudomorph composed of goethite and very fine grains of $\mathrm{Pd}-\mathrm{Cu}$ alloy locally crystalized outside the pseudomorph outline. Sample GS-PQ-2, grain 13. (E) Merenskyite pseudomorph with extensive development of $\mathrm{Pd}-\mathrm{Cu}$ rosettes on the surface hosted by goethite and hematite (Hem) and close to $\mathrm{Cr}$-spinel ( $\mathrm{Cr}-\mathrm{Spl}$ ) crystals. Sample CSPQ-1, grain 11. (F) Detail of the Pd-Cu-Bi grain exhibited in Fig. 4.10E. The brightest grains are tiny rosette-like crystals of $\mathrm{Pd}-\mathrm{Cu}-\mathrm{Bi}$ alloy coating goethite. (G) Goethite partly coated by tiny rosette-like Pd-Cu crystals. Sample GS-PQ-2, grain 7. (H) Detail of the Pd-Cu grain exhibited in Fig. 4.10G. The rosette-like crystals form an orthogonal-disc-like framework. Mineral symbols are used in accordance with Kretz (1983). 208

Figura 4.11: Back scattered electron images of Pd iodide in the gossan: (A) Euhedral crystal of Pd iodide (PdI) hosted by goethite (Gt). Small veinlets of less bright material, probably represent oxidized 
areas, that crosscut parts of the Pd iodide. Sample GS-BF-1, grain 12. (B) Euhedral crystal of $\mathrm{Pd}$ iodide hosted by goethite. Less bright patches, concentrated in the outer parts of the grain, probably represent oxidized areas. Sample GS-BF-1, grain 3. (C) Partially corroded euhedral crystal of Pd iodide hosted by goethite. Less bright patches within the grain, concentrated in the outer parts, probably represent oxidized areas. Sample GS-BF-1, grain 6. (D) Partly corroded and rounded crystal of Pd iodide hosted by goethite. Less bright patches within the grain probably represent oxidized areas. Sample GS-BF-1, grain 13. (E) Pseudomorph of merenskyite containing voids (dark areas), goethite, Pd-Te-Bi PGM and Pd iodide (detail in Fig. 4.11F). The pseudomorph is hosted by goethite and has spatial proximity to $\mathrm{Cr}$-spinel $(\mathrm{Cr}-$ Spl). Sample GS-PQ-1, grain 1. (F) Detail of the Pd iodide exhibited in Fig. 4.11E, with less bright areas probably representing oxidized portions of the mineral. Sample GS-PQ-1, grain 1. Mineral symbols are used in accordance with Kretz (1983).

Figura 4.12: Back scattered electron images of common accessory minerals found in the weathered portions of the Limoeiro $\mathrm{Ni}-\mathrm{Cu}(-\mathrm{PGE})$ sulfide deposit: (A) Tiny electrum grain with a diffuse outline and irregular surface hosted by goethite (Gt). Sample GS-BF-1 (Bofe gossan), grain 8. (B) A subhedral bismoclite grain hosted in goethite. Sample 8-26.40 (weathered mineralized orthopyroxenite), grain 15. (C) Zn alloy (detail on Fig. 4.12D) in a crack which crosscuts a partly oxidized amphibole (Amp) grain and oxidized sulfide. The crack also contains broken pieces of amphibole and tiny mineral fragment aggregates. Sample 8-18.65 (weathered mineralized harzburgite), grain Zn10. (D) Detail of the $\mathrm{Zn}$ alloy showing an irregular diffuse outline in some parts of the grain, and growth lines in the internal structure. Sample 8-18.65, grain $\mathrm{Zn} 10$.

Figura 4.13: Schematic diagram illustrating how the weathering process transformed the original merenskyite in the Limoeiro $\mathrm{Ni}-\mathrm{Cu}(-\mathrm{PGE})$ sulfide deposit in stages from a depth of $30 \mathrm{~m}$ to the surface. The original merenskyite composition at the depth of $30 \mathrm{~m}$ deep is representative of the mineralogy of an example taken from Mota-e-Silva et al. (in review). The mineralogy and compositions at a depth of $20 \mathrm{~m}$ are from examples taken from Table 4.2 (this study)......218

Figura 5.1: (A) Prerift reconstruction of western Gondwana showing the main cratons in dark grey, the Andean in light grey and the Brasiliano/Pan-African provinces are marked by dashes (modified from Neves and Alcantara, 2010). Abbreviations for cratons: A, Amazonia; K, Kalahari; RP, Rio de La Plata; AS, Sahara Metacraton; SCC, São Francisco/Congo; WA, West Africa. Abbreviations for provinces: BP, Borborema; CP, Cameroon; NP, Nigeria. (B) Simplified geological map showing the main geotectonic units, the major shear zones and the location of the Limoeiro Ni-Cu-(PGE) deposit (modified from Medeiros, 2004). The Zona Transversal Domain is delimited by the Patos Lineament (PaL) to the north and Pernambuco Lineament (PeL) to the south. Internally this domain is subdivided into the terranes: "Faixa Piancó-Alto Brígida" (FPB), "Terreno Alto Pajeú" (TAP), "Terreno Alto Moxotó" (TAM) and Rio Capibaribe Terrane (RCT). 233

Figura 5.2: Schematic three-dimensional model of the main chonolith conduit in the Limoeiro region. Labels in red are the drill target names.

Figura 5.3: Geological map of the Limoeiro intrusion region. The rectangle with dashed outline refers to the detailed view of the central lozenge in Fig. 5.4

Figura 5.4: Detail of the central structural lozenge, highlighting the structural features associated with the ultramafic intrusions. Stereographic nets (equal area diagrams, lower hemisphere) show main foliation plane measurements for low-strain zones (top-left) and high-strain zones (bottomright), as well as stretching lineation (central-right)

Figura 5.5: PCA diagram containing all drill core analyses results of the most discriminatory elements $\left(\mathrm{Al}_{2} \mathrm{O}_{3}\right.$, $\mathrm{BaO}, \mathrm{CaO}, \mathrm{Co}, \mathrm{Cr}, \mathrm{Cu}, \mathrm{Fe}, \mathrm{K}_{2} \mathrm{O}, \mathrm{MgO}, \mathrm{MnO}, \mathrm{Na}_{2} \mathrm{O}, \mathrm{Ni}, \mathrm{P}_{2} \mathrm{O}_{5}, \mathrm{~Pb}, \mathrm{TiO}_{2}, \mathrm{~V}, \mathrm{Zn}$ and $\mathrm{Zr}$ ) for all amphibole-rich rocks from VM database. Clustering of samples are related to different "amphibolite" protoliths: (i) mafic volcanics to the top; (ii) calc-silicate to the bottom; (iii) tholeiitic precursor sill of the Limoeiro magmatism to the right. The PCl has a standard variation of 2.24 and a proportion of variance of 0.28 , whereas the PC2 has standard variation of 2.06 and a proportion of variance of 0.24 . 
Figura 5.6: Macro- and microscopic examples of the country rocks of the Limoeiro intrusions. (A) Fine grained banded paragneiss with successive clastic sequences (turbidite?) of pelitic- and psammitic-rich metamorphosed sediments affected by a recumbent asymmetrical fold. Rock exposed in a quarry close to the city of Toritama. (B) K-feldspar-sillimanite-biotiteplagioclase-quartz schist with retrograde muscovite (sample 100-097). In this sample the high-grade parageneses is relatively preserved. (C) Garnet-plagioclase-quartz schist with apatite, zircon and rutile (sample 1002-219). The retrometamorphism assemblage is absent in this case. (D) Detail of a mesoperthite (high-grade parageneses) transformed to microcline (retrograde) in sillimanite-K-feldspar-quartz schist (sample 118-158). (E) Extensive retrograde crystallization of chlorite at the expense of biotite in paragneiss containing quartz + biotite + hornblende + plagioclase + garnet \pm apatite \pm sulfides \pm magnetite \pm ilmenite as the high grade assemblage (sample 118-152). (F) Detail of a titanite (high-grade parageneses) partly transformed to rutile and ilmenite (retrograde) in the same sample as Fig. 5.6D. (G) Chlorite grain with rutile needles as result of retrometamorphism of biotite (same sample as Fig. 5.6D,F). (H) Clinopyroxene, hornblende, biotite and quartz representing the high-grade metamorphic assemblage of an amphibolite layer in the paragneiss (sample 100-186)......245

Figura 5.7: Metamorphic reactions and mineral stability fields in a temperature versus pressure diagram. The continuous lines are appropriate for metapelitic rocks that originally contained Chl-Ms-Qtz (model system KFMASH) and the dashed lines refer to mineral stability fields in ultramafic rocks. The chlorite stability field for metapelites (1) represents the growth of chlorite at the expense of garnet and biotite (Bucher and Grapes, 2011). The reaction (2) denotes the metamorphic formation of Kfeldspar and sillimanite at the expenses of the destruction of the quartz-muscovite pair (taken from the bathozones concept definition by Carmichael, 1978). This reaction releases water and can lead the system to the formation of melt. The curve (3) was taken from the low-pressure and high-temperature FASH system assemblage diagram (Bucher and Grapes, 2011). Commonly the first occurrence of Opx+Qtz is considered the beginning of the granulite facies in the FASH system. The curves (4) and (5) refer to typical isograds defined for Al-bearing Iherzolite under low pressure metamorphism (Bucher and Grapes, 2011)....247

Figura 5.8: Epoxy zircon mounts prepared from ultramafic rock samples of the Limoeiro deposit. Note the grain sizes and dominance of ovoid- and rounded-shape grains. The label beside each grain represents the zircon number exhibited in Table 5.1. 251

Figura 5.9: $C L$ images of metamorphic zircons. Note the soccer ball habit ( $A, B$ and $C)$, diffuse zoning nucleus ( $B$ and $C$ ), convoluted primary zoning in the outer rim (D), transgressive recrystallization (D) and sector zoning (A, B and C).

252

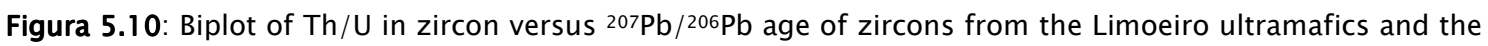
later granitic dyke. The positive correlation of these variables indicates different levels of zircon recrystallization. The completely recrystallized grains plot in the lower-left most clusters.

Figura 5.11: U-Pb concordia diagrams for zircons from samples of the Limoeiro ultramafics..... 253

Figura 5.12: (A) Drill core showing thickness and intrusive relationships between the granitic dyke and the ultramafics. (B) Detail of the contact between granitic dyke and ultramafics. (C) Epoxy zircon mounts prepared from granitic dyke intrusive in the Limoeiro ultramafics. (D) and (E) refer to $\mathrm{CL}$ images of analysed zircons from the granitic dyke. 255

Figura 5.13: U-Pb concordia diagrams for zircons from the sample of the granitic dyke. 256

Figura 5.14: Schematic cartoon illustrating a precursor sill fed by its feeder dyke or plug. The decrease in confining pressure as the magma propagates vertically through the feeder zone (dyke or plug) results in change of flow direction to horizontal (sill). The zone where the least compressive stress $\left(\sigma_{3}\right)$ changes from horizontal to vertical results in such reorientation. Illustration adapted from Hornsey (1999). 257

Figura 5.15: Occurrences of ca. $800 \mathrm{Ma}$ rocks in the central part of Western Gondwana. (A) Map of the restored geometry of the western Gondwana cratonic blocks and intervening PanAfrican/Brasiliano mobile belts (modified after Tohver et al., 2006). In red and labeled in blue 
are the ca. $800 \mathrm{Ma}$ rocks in central part of western Gondwana: (1) 750-700 Ma calc-alkaline plutonic rocks and ca $870 \mathrm{Ma}$ orogenic magmatism (Caby, 1998). (B) Detail of Borborema Province showing in the pale background the same geology presented in Fig. 5.1. In red and labeled in blue are the ca. 800 Ma rocks in Borborema Province: (2) 819 120 Ma metabasalts of Monte Orebe complex (Caxito et al., 2014); (3) ca. 800 Ma Limoeiro mafic magma conduit swarm (this study); Abbreviations for cratons: A, Amazonia; K, Kalahari; RP, Rio de La Plata; SA, Sahara Metacraton; SF, São Francisco and C, Congo; WA, West Africa; SL, São Luis; P, Paraná; LA; Luiz Alves; RA, Rio Apa.

Figura 5.16: Schematic geotectonic evolution of the Borborema Province during the Neoproterozoic. Special emphasis is given to the Limoeiro chonolith emplacement. Abbreviations for blocks: $\mathrm{N}-\mathrm{B}$, Northern Borborema; S-B, Southern Borborema; SF, São Francisco craton; C Congo craton; ZT; Zona Transversal domain; DS, Southern domain. 


\section{Lista de Tabelas}

Tabela 1.1: Mineralogy and petrographic summary of the units within the Limoeiro intrusion. Mineral symbols in accordance with classification of Kretz (1983).

Tabela 2.1: Calculated Ni, Cu, Pd and Pt tenors for Retiro and Piçarra targets. Metal tenor ratios and relative proportions between the three BMS phases: pyrrhotite, chalcopyrite and pentlandite for each target are also illustrated.

Tabela 2.2: Metal concentrations of 17 selected samples for the determination of the all 6 PGE grades for different types of ore.

Tabela 2.3: Representative microprobe analysis of olivine and orthopyroxene grains of the Limoeiro intrusion.

Tabela 2.4: Lithochemistry of 78 selected samples from the Limoeiro intrusion.

Tabela 3.1: Summary of trace element concentrations (in ppm) in LA-ICP-MS analyses of the Po724 standard. The $\left(^{*}\right)$ indicates the isotopes that were corrected for interferences. Certified values and 1 sigma uncertainties are shown.

Tabela 3.2: Platinum-group mineral frequency in the Limoeiro $\mathrm{Ni}-\mathrm{Cu}(-\mathrm{PGE})$ deposit...... 150

Tabela 3.3: Selective representative quantitative analyses of the PGM found in the Limoeiro deposit. 151

Tabela 3.4: Summary of average and 1 standard deviation of PGE and other metal and semimetal concentrations (in ppm) in the BMS.

Tabela 3.5: Calculated Ni, Cu, Pd and Pt tenors (from Mota-e-Silva and Ferreira Filho, unpublished), estimation of BMS proportions in the sulfide fraction, concentration of Pd for each BMS in a 100 vol\% sulfide rock and the partitioning of Pd between BMS and PGM....... 163

Tabela 3.6: Compilation of several mineralized intrusions listing characteristics with potential to influence PGM size and Pd distribution between BMS and PGM

Tabela 4.1: Platinum-group mineral abundances. The sample names have Bofe (BF) and Paquivira (PQ) gossans as abbreviations. Gossans were sampled on surface and the other samples from drill hole 8 at the depth mentioned on the number after the dash.

Tabela 4.2: Selective representative quantitative analyses [in wt\% and atomic proportion (norm. to 100\%)] of the PGM and associated minerals found in the gossans of the Limoeiro deposit. The sample names have Bofe (BF) and Paquivira (PQ) gossans as abbreviations

Tabela 4.3: Common accessory mineral abundances. The lithological codes are: GS, gossan; SAP, saprolite; oxHZ, oxidized harzburgite; oxPX, oxidized orthopyroxenite. The sample names have Bofe (BF) and Paquivira (PQ) gossans as abbreviations......

Tabela 5.1: U-Pb LA-ICPMS data. 
INTRODUÇÃO

OBJETIVO, PERGUNTAS E HIPÓTESES 2

ESTRUTURA DA TESE 3

Capítulo 1

Capítulo 2

Capítulo 3

Capítulo 4

Capítulo 5

REFERENNCIAS

The Limoeiro Deposit: Ni-Cu-PGE sulfide

CAPÍTULO 1 mineralization hosted within an ultramafic tubular magma conduit in the Borborema Province,

Northeastern Brazil

$\begin{array}{ll}\text { ABSTRACT } & 11 \\ \text { INTRODUCTION } & 12 \\ \text { DISCOVERY HISTORY } & 14 \\ \text { GEOLOGICAL SETTING } & 15 \\ \quad \text { Borborema Province } & 15 \\ \quad \text { Zona Transversal Domain } & 15 \\ \quad \text { Rio Capibaribe Terrane } & 16 \\ \text { Vertentes Complex } & 17 \\ \text { MATERIALS AND METHODS } & 17 \\ \text { GEOLOGY OF THE LIMOEIRO DEPOSIT } & 18 \\ \quad \text { Structure and stratigraphy of the ultramafic intrusion } & 18 \\ \text { Petrography of the ultramafic rocks } & 27 \\ \text { Structure and petrography of country rocks hosting the } & 30 \\ \text { ultramafic intrusions } & 31 \\ \text { METAMORPHIC TRANSFORMATION } & 34 \\ \text { MINERALIZATION } & 34 \\ \text { Ore bodies and ore types } & 35 \\ \text { Ore petrography } & 36 \\ \text { DISCUSSION } & 36 \\ \text { The primary magmatic structure } & 42 \\ \text { The ultramafic composition of the conduit } & 43\end{array}$


Implications for Exploration $\quad 45$

CONCLUSIONS 46

ACKNOWLEDGEMENTS 47

REFERENCES 48

CAPÍTULO $2 \mid \begin{aligned} & \text { Mineral and whole rock chemistry of the chonolith } \\ & \text { that hosts the Limoeiro Ni-Cu-(PGE) deposit: } \\ & \text { evidence of magma flow direction, siderophile element } \\ & \text { depletion and sulfide fractionation }\end{aligned}$

ABSTRACT 54

INTRODUCTION

GEOLOGICAL SETTING 56

SAMPLING AND ANALYTICAL PROCEDURES 58

RESULTS 59

Geology $\quad 59$

Minning database geochemistry $\quad 62$

Magmatic sequences $\quad 62$

Tenor calculation $\quad 64$

Platinum-group elements $\quad 66$

Base and noble metal distribution $\quad 69$

Mineral chemistry $\quad 72$

$\begin{array}{lr}\text { Whole rock geochemistry } & 87\end{array}$

$\begin{array}{ll}\text { Major elements } & 87\end{array}$

Trace elements (including the REE) 105

DISCUSSION 110

Metamorphism and elements mobility $\quad 110$

$\begin{array}{ll}\text { Primary assemblage } & 112\end{array}$

Magmatic sequences and magma flow direction $\quad 114$

Parental magma 116

Emplacement and source of the parental magma $\quad 118$

$\begin{array}{ll}\text { Ore genesis } & 120\end{array}$

CONCLUSION 126 
$\begin{array}{ll}\text { ACKNOWLEDGMENT } & 128\end{array}$

REFERENCES 128

Platinum-group minerals in the Limoeiro Ni-Cu-

(PGE) sulfide deposit, Brazil: the effect of magmatic and upper amphibolite to granulite metamorphic processes on PGM formation

$\begin{array}{ll}\text { ABSTRACT } & 135\end{array}$

KEYWORDS 136

INTRODUCTION 136

GEOLOGICAL SETTING 138

The Limoeiro Ni-Cu-(PGE) sulfide deposit 138

Drilling targets and recently recognized magmatic 142 sequences

SAMPLING AND ANALYTICAL METHODS 143

$\begin{array}{ll}\text { RESULTS } & 147\end{array}$

$\begin{array}{ll}\text { Platinum-group mineralogy } & 147\end{array}$

Merenskyite, $(\mathrm{Pd}, \mathrm{Pt}, \mathrm{Ni})(\mathrm{Te}, \mathrm{Bi})_{2}$

Sperrylite, $\mathrm{PtAs}_{2}$

Platinum-group mineral associations and textures $\quad 152$

Merenskyite cryptic variation $\quad 159$

PGE in the base metal sulfide $\quad 160$

Mass balance calculation $\quad 162$

Whole rock chemistry 163

$\begin{array}{ll}\text { DISCUSSION } & 165\end{array}$

The role of the primary magma in formation of the 165

PGM

$\begin{array}{ll}\text { High grade metamorphism } & 172\end{array}$

Low grade metamorphism, hydrothermalism and 175

$\begin{array}{ll}\text { CONCLUSIONS } & 177\end{array}$

$\begin{array}{ll}\text { ACKNOWLEDGMENTS } & 179\end{array}$

REFERENCES 179 
CAPÍTULO $4 \begin{aligned} & \text { Platinum-group minerals formed during weathering of } \\ & \text { the Limoeiro Ni-Cu(-PGE) deposit, northeastern } \\ & \text { Brazil: supergene dispersion of PGE and formation of } \\ & \text { Pd-Cu alloy and Pd iodide }\end{aligned}$

ABSTRACT

INTRODUCTION

The PGE and PGM in the Limoeiro sulfide deposit SAMPLING AND ANALYTICAL METHODS

RESULTS

The gossans

The weathering profile and its mineralogical changes

Platinum-group minerals

Arsenide and sulfarsenide

Partly oxidized Pd-Te \pm Bi PGM

Pd-Cu alloy

Pd iodide

Accessory minerals
187

188

189

190

191

193

193

195

199

200

205

207

210

212

213

213

215

220

221

223

224

225

REFERENCES

\begin{tabular}{l|l} 
CAPÍTULO 5 & $\begin{array}{l}\text { The ultramafic conduits system of the Limoeiro Ni- } \\
\text { Cu-(PGE) deposit: implications for the magmatic and } \\
\text { tectonic evolution of the eastern part of Borborema } \\
\text { Province, northeastern Brazil }\end{array}$
\end{tabular}

ABSTRACT

230

xxiv 
INTRODUCTION 231

GEOLOGICAL FRAMEWORK 232

Borborema Province $\quad 232$

Zona Transversal Domain 234

Rio Capibaribe Terrane (RCT) 235

The paragneisses in RCT 236

The Limoeiro Ni-Cu-(PGE) deposit and its host 237 intrusion

ANALYTICAL METHODS 238

RESULTS 239

Limoeiro conduit swarm and its country rocks 239

Paragneiss/schist petrography 243

Zircon LA-ICPMS U-Pb data 248

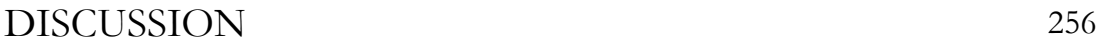

Structural controls on the emplacement of Limoeiro 256 chonoliths

$\begin{array}{ll}\mathrm{U}-\mathrm{Pb} \text { ages } & 258\end{array}$

The Limoeiro complex and geotectonics 260

The Limoeiro complex and other mafic-ultramafic 263 intrusions

$\begin{array}{ll}\text { CONCLUSIONS } & 264\end{array}$

ACKNOWLEDGMENTS 266

REFERENCES 266

CONCLUSÃO DA TESE 275 


\section{Introdução}

Os depósitos magmáticos sulfetados de $\mathrm{Ni}-\mathrm{Cu}$ e depósitos de PGE ocorrem dominantemente em intrusões acamadadas ou derrames de magma de composição máfica a ultramáfica. As intrusões férteis podem ter magmas parentais de diversas composições, originados em diferentes cenários tectônicos e em qualquer idade da era geológica (Naldrett, 2004). Apesar das amplas possibilidades de situações geológicas onde se formam as intrusões férteis, os grandes depósitos $\mathrm{Ni}$-Cu sulfetado do mundo relacionam-se com algumas situações peculiares: (i) sill formado por magmatismo dinâmico de Noril'sk na Rússia (Naldrett, 1992; Naldrett \& Lightfoot, 1999); (ii) base de grande intrusão máfica-ultrmáfica acamadada em Duluth nos EUA (Ripley, 1990); (iii) conduto magmático em forma de dique entre duas câmaras magmáticas em Voisey's Bay no Canadá (Naldrett et al., 1996; Lightfoot, 1997; Li \& Naldrett, 1999); (iv) diques alimentadores de grande sistema vulcânico máfico em Jinchuan na China (Naldrett, 1998); (v) magma máfico produzido a partir de fusão em impacto de meteorito em Sudbury no Canadá (Lightfoot et al., 2001); (vi) derrames e sills komatíticos em Kambalda na Austrália (Lesher \& Keays, 2002).

Em 2009 foi descoberto pela Exploração Mineral da Votorantim Metais um complexo ultramáfico mineralizado, doravante chamado de Complexo Ultramáfico Limoeiro. Ele é constituído de alguns corpos ultramáficos intrusivos zonados concentricamente com harzburgito no centro e ortopiroxenito nas bordas mais externas, com geometria de tubo de seção variável (conolito - ver origem, definição e usos do termo em Daly, 1914; Bates e Jackson, 1987; Goodgame et al., 2010), mas geralmente tem forma amendoada (ou "saucershaped" em inglês), subhorizontal, interpretados neste trabalho como antigos condutos de passagem magma máfico. Estes corpos estão principalmente alinhados na direção NEE-SWW e seccionados por sistemas de falhas rúptil-dúcteis N-S e NW-SE. Os corpos estão, em sua grande parte, encobertos por paragnaisses e xistos com foliação de baixo ângulo e desta forma, em grande parte, só podem ser acessados por sondagem.

Do ponto de vista regional o Complexo Ultramáfico Limoeiro insere-se na Zona Transversal da Província Borborema (Brito Neves \& Cordani, 1991; Santos \& Medeiros, 1999). 
Esta última é tradicionalmente classificada como um braço do Orógeno Brasiliano/Pan-africano do Neoproterozóico, que circundam as principais zonas cratônicas da América do Sul e África. No entanto, trabalhos mais recentes (e.g., Sá et al., 2002; Santos et al., 2010) vêm mostrando que a Província Borborema é formada por blocos crustais de diversas idades e gêneses seccionadas entre si e justapostas por intenso sistema de zonas de cisalhamento transcorrentes predominantemente E-W. Tal tectônica e metamorfismo relacionados ao Orógeno Brasiliano/Pan-africano afetam o Complexo Ultramáfico Limoeiro. As rochas do complexo contêm significantes quantidades de minerais metamórficos hidratados, sendo na borda da intrusão a mais forte obliteração metamórfica e deformacional, onde se encontram anfibolititos eventualmente foliados.

Deste modo a abordagem do tema não se limitou a escala local, mas também se estudou o contexto regional, o que culminou em novas interpretações e histórias geológicas na escala mais ampla. Assim, este trabalho além de contribuir para o entendimento geral de sistemas de condutos magmáticos conolíticos e suas mineralizações associadas, tem potencial para promover o melhor entendimento da evolução da Zona Transversal na Província Borborema.

\section{Objetivo, perguntas e hipóteses}

Este trabalho tem por objetivo principal entender a gênese e evolução geológica do Complexo Limoeiro e sua mineralização Ni-Cu(-EGP) nas escalas local e regional.

Este objetivo visa responder as seguintes perguntas que foram elaboradas quatro anos atrás:

(i) Como se caracteriza o sistema magmático de Limoeiro?

(ii) Como se deu a formação do depósito sulfetado $\mathrm{Ni}$-Cu(-EGP)? 
(iii) Qual a idade do Complexo Ultramáfico Limoeiro e de suas rochas encaixantes?

(iv) Em qual contexto tectônico essas rochas se formaram?

Para estas perguntas tínhamos as seguintes hipóteses no início da pesquisa:

(i) A intrusão trata-se de um conduto em forma de conolito onde predominou um sistema magmático de multi-pulsos de um mesmo magma parental primitivo, onde houve estágios iniciais dinâmicos e estágios mais tardios estáticos que permitiram a atuação da cristalização fracionada.

(ii) O magma parental contaminou-se com material das rochas encaixantes, o que introduziu elementos incompatíveis e S no sistema, e assim, diminuído a solubilidade e promovendo a supersaturação em $S$ e conseqüente segregação de gotículas de líquido sulfetado imiscível. Parte dessas gotículas (i.e. mais densas que o magma silicático) acumulouse no fundo do conduto magmático em armadilhas de embainhamento do embasamento formando o minério maciço e outra parte ficou suspensa no líquido devido ao fluxo turbulento, gerando grandes massas de minério disseminado.

(iii) O Complexo Ultramáfico Limoeiro pode relacionar-se à orogênese Cariris Velhos (0,95 a 1,0 Ga - Santos et al. 2010) ou ao grande evento extensional de 1,1 Ga identificado por Van Schmus et al. (1995) na parte central da Província Borborema. Já suas encaixantes devem ser de idade Meso- ou Paleoproterozóica, possivelmente próximas as idades de 1,97 Ga reportadas por Sá et al., 2002 a respeito de rochas do embasamento do Terreno Rio Capibaribe.

(iv) O Complexo Ultramáfico Limoeiro deve ter se formado em um contexto de regimes divergentes, seja na posição de retroarco da orogênse Cariris Velhos $(0,95$ a 1,0 Ga) ou no evento extensional de $1,1 \mathrm{Ga}$ já citados acima. Contextos de abertura na crosta poderiam proporcionar ascensão do magma máfico. 


\section{Estrutura da Tese}

Este doutorado está estruturado em cincos capítulos na forma de artigos que já foram ou ainda serão submetidos para publicação em periódicos científicos internacionais especializados sobre os temas abordados.

Os artigos contemplam as perguntas que este doutorado se propõe a responder e eles foram programados para serem submetidos ao longo da evolução deste trabalho. Os detalhamentos de cada tema com resultados e metodologias aplicadas estão especificados em cada um dos capítulos abaixo.

\section{Capítulo 1}

Este capítulo apresenta o artigo intitulado de "The Limoeiro Deposit: Ni-Cu-PGE sulfide mineralization hosted within an ultramafic tubular magma conduit in the Borborema Province, Northeastern Brazil" foi publicado no periódico "Economic Geology" em 2013 [Mota-eSilva, J., Ferreira Filho, C. F., \& Della Giustina, M. E. S. (2013). The Limoeiro Deposit: Ni-CuPGE Sulfide Mineralization Hosted Within an Ultramafic Tubular Magma Conduit in the Borborema Province, Northeastern Brazil. Economic Geology, 108(7), 1753-1771]. O artigo foi reformatado em um capítulo para atender aos padrões de diagramação de tese da UnB.

Este artigo fez a primeira descrição do depósito Ni-Cu(-PGE) de Limoeiro em termos de caracterização do sistema magmático, geologia, petrografia e transformações tectonometamórficas provocadas pela orogênese Brasiliana e suas implicações para exploração mineral. 


\section{Capítulo 2}

Este capítulo é intitulado "Mineral and whole rock chemistry of the chonolith that hosts the Limoeiro Ni-Cu-(PGE) deposit: evidence of magma flow direction, siderophile element depletion and sulfide fractionation". Possivelmente o artigo será submetido ao periódico "Economic Geology" até o fim de 2014.

Neste capítulo os diferentes pulsos magmáticos que formaram as intrusivas de Limoeiro, são discriminados quimicamente. Além disso, a variação química ao longo da estrutura de conduto (longitudinalmente) produziu interpretação de direção de fluxo magmático e vetores indicando a direção de outros possíveis depósitos minerais contidos na intrusão. Esta parte da tese sugere composição do magma parental de Limoeiro, propõe uma composição mineralógica primária para a intrusão (pré-metamorfismo), indica processo de segregação do líquido sulfetado residual em relação ao sulfeto sólido ("monosulfide solid solution" - MSS) e por fim debate sobre o tipo de fonte mantélica de onde foi formado o magma parental de Limoeiro.

\section{Capítulo 3}

Este artigo tem o título de "Platinum-group minerals in the Limoeiro Ni-Cu-(PGE) sulfide deposit, Brazil: the effect of magmatic and upper amphibolite to granulite metamorphic processes on PGM formation" e foi submetido à Mineralium Deposita em 19 de fevereiro de 2014. O manuscrito foi recentemente aceito pelo editor da revista e agora se encontra em revisão. Este trabalho foi um dos produtos gerados pelo doutorado sanduíche realizado entre julho e dezembro de 2013 na Cardiff University em País de Gales.

Neste trabalho é caracterizada a assembleia de minerais do grupo da platina (PGM) nas mineralizações disseminada e maciça. É mostrado que a variação composicional na solução sólida merenskyita-moncheita-melonita $\left[(\mathrm{Pd}, \mathrm{Pt}, \mathrm{Ni})(\mathrm{Te}, \mathrm{Bi})_{2}\right]$ têm relação com 
fracionamento magmático. Além disso, discute-se que metamorfismo de alto grau e posteriormente o hidrotermalismo produzem texturas, mineralogias e composições minerais próprias nos PGM. Este trabalho tem caráter inovador ao caracterizar o efeito do metamorfismo fácies granulito baixo nos PGM pela primeira vez.

\section{Capítulo 4}

Este trabalho tem o título de "Platinum-group minerals formed during weathering of the Limoeiro Ni-Cu(-PGE) deposit, northeastern Brazil: supergene dispersion of PGE and formation of Pd-Cu alloy and Pd iodide" e será submetido ao periódico Canadian Mineralogist, faltando apenas a última revisão de um dos co-autores. Do mesmo modo que no Capítulo 3 este trabalho é produto do doutorado sanduíche realizado entre julho e dezembro de 2013 na Cardiff University em País de Gales.

O estudo mostra a evolução das alterações intempéricas sobre os sulfetos de maetais base e PGM. Dentre outras coisas apresenta a forte mobilidade do Te que, sob influência do intemperismo, é lixiviado dos MGP e ficando parcialmente aprisionado em goetitas. Este trabalho também demonstra a destruição das merenskitas em detrimento da formação de ligas Pd-Cu e de iodeto de paládio. Este último é um mineral não registrado na International Mineralogical Association (IMA) e com muito pouca citação na literatura. Deste modo configura uma oportunidade de futuro aprofundamento dos estudos para caracterização mineralógica adequada que permita o registro desta nova espécie mineral na IMA.

\section{Capítulo 5}

O 5o artigo deverá ser nomeado de "The ultramafic conduit system of the Limoeiro NiCu-(PGE) deposit: implications for the magmatic and tectonic evolution of the eastern part of 
Borborema Province, northeastern Brazil" e deverá ser submetido à Precambrian Research ou Journal of South American Earth Sciences até o fim de 2014.

O estudo mostra que as intrusões de Limoeiro formaram-se em um evento de "enxame de condutos magmáticos" que devem relacionar-se com evento extensional compatível com escala de ruptura continental. É exibido um novo mapa regional onde se contabilizam cerca de $150 \mathrm{~km}$ lineares de condutos mapeados por afloramento, sondagem e geofísica. Os zircões analisados por U-Pb mostram-se severamente afetados por metamorfismo de alto grau datado em $634 \pm 6$ Ma. Todavia tendências da discórdia, análises Th/U e núcleos herdados de zircão sugerem uma idade de cristalização por volta 1 Ga para o Complexo Limoeiro. Esta informação pode posicionar Limoeiro com uma história geotectônica de abertura de um rifte continental no bloco cratônico Borborema-Trans-Sahara em época concomitante à formação do Supercontinente Rodínia.

Antes da submissão do artigo serão incorporados novos dados de datação U-Pb em zircões dos paragnaisses e possivelmente dados de isótopos de enxofre das mineralizações e das encaixantes. Essas análises estão em andamento no Laboratório de Geocronologia do IG/UnB. 


\section{Referências}

Bates, R.L.; and Jackson, J.A.J. (Eds.), 1987, Glossary of Geology: 3rd. Edition, American Geological Institute, Alexandria, USA.

Bender, K.M., Buhn, B.M., Mota-e-Silva, J., Chaves, J.G.S. (2008). 32S/34S Isotope analyses by laser ablation MC-ICPMS: Method and application. Anais do VI South American Symposium on Isotope Geology, San Carlos de Bariloche, Argentina.

Brito Neves, B.B., Cordani, U. (1991). Tectonic evolution of South America during the Late Proterozoic. Precambrian Research, v. 53, p. 23-40.

Daly, R. A., 1914, Igneous rocks and their origin: New York, McGraw-Hill Book Co., Inc., 563 p.

Goodgame, V. R., Johnson, J. R., MacTavish, A. D., Stone, W. E., Watkins, K. P., \& Wilson, G. C. (2010). The Thunder Bay North deposit: Chonolith-hosted Pt-Pd-Cu-Ni mineralization related to the Midcontinent Rift [abs.]. In International Platinum Symposium (Vol. 11).

Lesher, C.M., Keays, R.R. (2002). Komatiite-associated Ni-Cu-(PGE) deposits: mineralogy, geochemistry, and genesis. In: Cabri L.J. (ed) The geology, geochemistry, mineralogy, and mineral beneficiation of the platinum-group elements. Canadian Institute of Mining, Metallurgy and Petroleum, Special Volume, v. 54, p. 579-617.

Li, C., Naldrett, A.J. (1999). Geology and petrology of the Voisey's Bay intrusion: reaction of olivine with sulfide and silicate liquids. Lithos, v. 47, p. 1-31.

Lightfoot, P.C. (1997). Geological and geochemical relatioships in the Reid Brook intrusive complex, Labrador: implication for the origin of the Voisey's Bay $\mathrm{Ni-Cu}-\mathrm{Co}$ ores. Abstracts EOS Transations, v. 78, p. 810.

Lightfoot, P.C., Keays, R.R., Doherty, W. (2001). Chemical evolution and origin of nickel sulfide mineralization in the Sudbury Igneous Complex, Ontario, Canada. Economic Geology, v. 96, p. $1855-1875$.

Mota-e-Silva, J. (2009) O Complexo Máfico-ultramáfico Acamadado de Americano do Brasil e sua mineralização de Ni-Cu-Co. Dissertação de Mestrado, UnB 112p

Naldrett, A.J. (1992). A model for the Ni-Cu-PGE ores of the Noril'sk region and Its application to other areas of flood basalts. Economic Geology, v. 87, p. 1945-1962.

Naldrett, A.J. (1998). World-class Ni-Cu-PGE deposits: key factors in their genesis. Mineralium Deposita, v. 34, p. 227-240. 
Naldrett, A.J. (2004). Magmatic Sulfide Deposits - Geology, Geochemistry and Exploration. Germany, Springer Berlin, 724 p.

Naldrett, A.J., Keats, H., Sparkes, K., Moore, R. (1996). Geology of the Voisey's Bay Ni-Cu-Co deposit, Labrador, Canada. Exploration and Mining Geology, v. 5, p. 169-179.

Naldrett, A.J., Lightfoot P.C. (1999). Ni-Cu-PGE deposits of the Noril_sk region, Siberia: their formation in conduits for flood basalt volcanism. In: Keays R.R., Lesher C.M., Lightfoot P.C., Farrow C.F.G. (eds) Dynamic processes in magmatic ore deposits and their application to mineral exploration. Geological Association of Canada, Short Course Notes XIII, p. 195-250.

Ripley, E.M. (1990). Platinum-group element geochemistry of Cu-Ni mineralization in the basal zone of the Babbitt deposit, Duluth Complex, Minnesota. Economic Geology, v. 85, p. 830-841.

Sá, J.M., Bertrand, J.M., Leterrier, J., Macedo, M.H.F. (2002). Geochemistry and geochronology of pre-Brasiliano rocks from the Transversal Zone, Borborema Province, Northeast Brazil. Journal of South American Earth Sciences, v. 14, p. 851-866.

Santos, E.J., Medeiros, V.C. (1999). Constraints from granitic plutonism on Proterozoic crustal growth of the Transverse Zone, Borborema Province, Northeast Brazil. Revista Brasileira de Geociências, v. 29, p. 73-84.

Santos, E.J., Van Schmus, W.R., Kozuch, M., Brito Neves, B.B. (2010). The Cariris Velhos tectonic event in Northeast Brazil. Journal of South American Earth Sciences, v. 29, p. $61-76$.

Van Schmus, W.R., Brito Neves, B.B., Hackspacher, P.C., Babinski, M. (1995). U-Pb and SmNd geochronological studies of the Eastern Borborema Province, Northeast Brazil: initial conclusions. Journal of South American Earth Sciences, v. 8, p. 267-288. 


\section{CAPÍTULO 1}

The Limoeiro Deposit: Ni-Cu-PGE Sulfide Mineralization Hosted within an Ultramafic Tubular Magma Conduit in the Borborema Province, Northeastern Brazil 


\title{
The Limoeiro Deposit: Ni-Cu-PGE Sulfide Mineralization Hosted within an Ultramafic Tubular Magma Conduit in the Borborema Province, Northeastern Brazil
}

\author{
Jonas Mota-e-Silva ${ }^{1,2}$, Cesar Fonseca Ferreira Filho ${ }^{2}$, Maria Emilia Schutesky \\ DellaGiustina $^{2}$
}

\author{
${ }^{1}$ Votorantim Metais Ltda, Praça Ramos de Azevedo, 254, São Paulo, SP. 01037-912. Brazil \\ ${ }^{2}$ Instituto de Geociências, Universidade de Brasília, Brasília, DF. 70910-900. Brazil
}

\begin{abstract}
The Limoeiro deposit, located in a high-grade mobile belt of the Brasiliano Orogenic Cycle $(650-500 \mathrm{Ma})$, represents one of the few magmatic Ni-Cu(-PGE) sulfide discoveries in recent years. The deposit is hosted by an ultramafic chonolith consisting of a partly deformed and metamorphosed tube-like intrusion affected by brittle faults within high-grade gneiss and schist. The absolute age of the ultramafic intrusion that host the Limoeiro deposit is not yet known, but regional geological constraints suggest that both intrusion and hosts rocks belong to a terrain older than the orogenic cycle. Peak metamorphic parageneses of the ultramafic intrusion and country rocks indicates granulite facies metamorphism, interpreted to result from the Neoproterozoic Brasiliano Orogenic Cycle. The Limoeiro deposit is the first significant discovery of $\mathrm{Ni}-\mathrm{Cu}$ sulfide in the Borborema Province, opening a new window for exploration in this large orogenic belt.
\end{abstract}

Despite the high-grade metamorphism and the tectonic deformation, the primary magmatic structure of the intrusion hosting the Limoeiro deposit is remarkably well preserved. This intrusion forms a tube-like conduit (chonolith) with cross sections a few hundreds of meters in diameter and with a considerable length of more than $4 \mathrm{~km}$. The conduit consists of two distinct sequences of ultramafic rocks, denominated Upper and Lower sequences, each one consisting of a core of harzburgite enveloped by orthopyroxenite, with an irregular and 
discontinuous outer shell of amphibolite. These ultramafic sequences, characterized by similar composition and structure, have distinctively different $S$ contents resulting from the presence of disseminated Ni-Cu sulfide mineralization only in the Upper Sequence. The magmatic system of the Limoeiro deposit is interpreted to result from the input of two major pulses of magma with similar composition, but sulfide saturation and segregation is restricted to the second magma pulse (Upper Sequence). Nickel-Cu(-PGE) sulfide mineralization is broadly concordant with the Upper Sequence and different ore bodies resulted from subsequent tectonic slicing of the originally continuous tube-like structure. The bulk of the mineralization in all ore bodies consists of thick (up to 150 meters) and elongated (up to $1 \mathrm{~km}$ ) masses of rock containing disseminated sulfides broadly concordant with the chonolithic structure. Thin layers of massive ore occur in the lower portions of some of the ore bodies, and represent about 3 vol\% of the Limoeiro deposit. The intrusion hosting the Limoeiro deposit is probably the best-preserved chonolith that has been overprinted by granulite facies metamorphism within an orogenic terrain. This study indicates that reconstruction of small magma conduits, an important tool for exploration for $\mathrm{Ni}$ Cu sulfide deposits, may be successfully achieved within high-grade orogenic terrains.

\section{Introduction}

The Limoeiro Ni-Cu(-PGE) sulfide deposit was discovered in northeastern Brazil by Votorantim Metais Ltda (VM) in 2009 (Votorantim Metais Ltda, 2012). The deposit represents a recent nickel sulfide discovery, probably resulting from additional investments in exploration by the mining industry following the increase of base and precious metals prices in 2004. After the discovery in 2009, VM started an advanced project in the area to evaluate the deposit, including $27,500 \mathrm{~m}$ of diamond drilling completed in September 2012. Unfortunately Ni-Cu(-PGE) resources are not available for publication at this moment.

The deposit is hosted within a complex, concentrically zoned, tube-like (chonolithic) subhorizontal orthopyroxenite-harzburgite intrusion in the Borborema Province, northeastern 
Brazil (Fig. 1.1). The chonolithic architecture of the ultramafic intrusion has similarities with other mafic-ultramafic intrusions that host $\mathrm{Ni}-\mathrm{Cu}$ magmatic sulfide deposits, such as Nebo-Babel in Australia (Seat et al., 2007; Seat et al., 2011), the Kabanga North in Tanzania (Evans et al., 2000; Maier et al., 2010), Uitkomst in South Africa (Gauert et al., 1995; De Waal and Maier, 2001; Li et al., 2002), Eagle in USA (Ripley and Li, 2011) and Thunder Bay North in Canada (Goodgame et al., 2010). Although chonolithic structures have discrete geochemical and geophysical fingerprints, especially when deformed and metamorphosed in mobile belts, they are critical features for $\mathrm{Ni}$-Cu sulfide exploration.
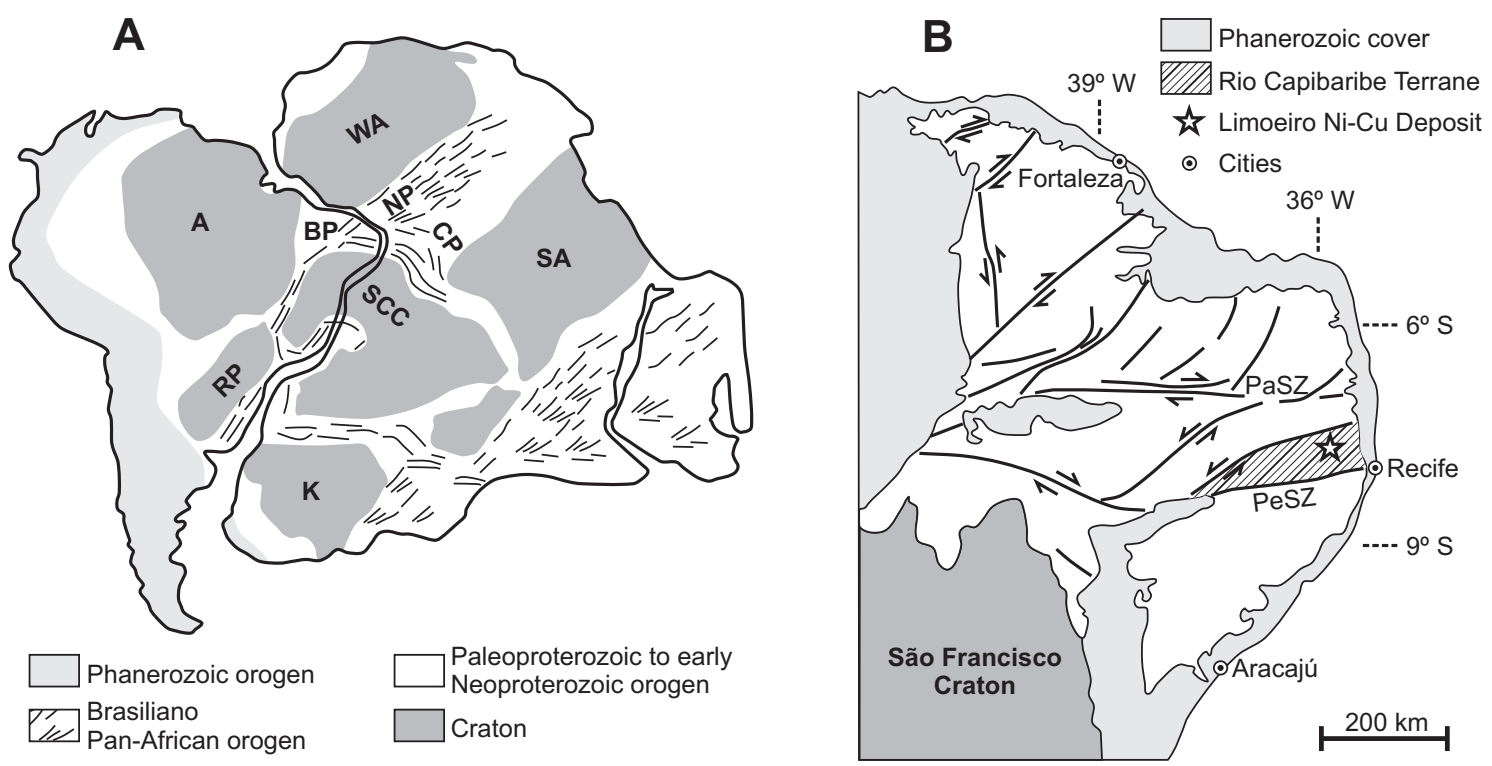

Fig. 1.1 (A) Pre-rift reconstruction of western Gondwana showing the main cratons and Brasiliano/Pan-African provinces (modified from Neves and Alcantara, 2010). Abbreviations: A, Amazonia; BP, CP, NP: Borborema, Nigeria and Cameroon provinces; K, Kalahari; RP, Rio de La Plata; SA, Sahara Metacraton; SCC, São Francisco/Congo; WA, West Africa. (B) Sketch showing the main shear zones that limit the domain subdivision of the Borborema Province. Abbreviations: PaSZ, Patos Shear Zone; PeSZ, Pernambuco Shear Zone.

The Limoeiro deposit is the first discovery of a nickel sulfide deposit in the Borborema Province (Almeida et al., 1981), a high-grade mobile belt formed during the Neoproterozoic Brasiliano/Pan-African orogenic cycle. This geological setting was usually considered barren regarding $\mathrm{Ni}-\mathrm{Cu}(-\mathrm{PGE})$ deposits, probably due to the dominance of gneiss, mylonite and migmatite rocks in a intensely deformed and faulted terrain. 
This study is part of an assessment of the Limoeiro deposit supported by VM (Mota-eSilva, in prep.). In this first paper, we present the results of a field and petrographic study of the Limoeiro deposit, host intrusion and country rocks. We discuss the intrusive architecture and localization of nickel sulfides, focusing on sections of the chonolith, which are best preserved from later metamorphism and deformation. Our findings provide new insights for the identification of $\mathrm{Ni}-\mathrm{Cu}$ sulfide deposits in high-grade mobile-belt terrains worldwide.

\section{Discovery History}

In 2008, the Brazilian Geological Survey (CPRM) flew regional magnetometry and gamma spectometry (500 m line spacing) over areas of the Borborema Province, as part of a national program to promote mineral exploration in the country. Based on this new regional geophysical survey, VM claimed for several mineral properties in the Borborema Province. One of the claimed properties includes a $1 \mathrm{~km}$ wide circular gamma spectrometry anomaly partly coincident with a 4 kilometer long discrete magnetic anomaly. During the first surface exploration campaign, VM geologists identified a dozen meters wide Ni-Cu-PGE-rich gossan within a domain of ultramafic rocks. The company carried out additional exploration, including an airborne electromagnetic survey (VTEM), leading to the discovery drill hole (SLM0004) in late 2009. This hole intercected $160 \mathrm{~m}$ of $\mathrm{Ni}-\mathrm{Cu}(-\mathrm{PGE})$ disseminated sulfide including four thin layers (metric to sub-metric) of massive sulfide. Following these results, a major exploration and resource definition drilling program started. 


\section{Geological Setting}

\section{Borborema Province}

The Borborema Province (Almeida et al., 1981) in northeastern South America is a typical branch of Neoproterozoic Brasiliano orogenic system. In pre-Gondwana-rift reconstructions the province shows its continuity in central-west Africa through the Pan-African belts of Nigeria and Cameroon (Fig. 1.1A). The province is positioned between the AmazonWest Africa craton to the north and the São Francisco- Congo craton to the south. In the Borborema Province there is a remarkable abundance of important shear zones that juxtaposed different Achaean, Paleo- and Mesoproterozoic terrains during the amalgamation of the Gondwana Supercontinent in late Neoproterozoic times (650-500 Ma). The Borborema Province lithosphere is strongly affected by the deformational, metamorphic, and magmatic episodes of the Brasiliano Orogenic Cycle (Santos et al., 2010).

The mosaic-like structural scheme and geochronological data have led many authors (e.g. Van Schmus et al., 1995; Brito Neves et al., 2000) to divide the Borborema Province into three main subprovinces (or domains). The Limoeiro deposit is located in the Central subprovince, also known as Zona Transversal Domain (Brito Neves et al., 2000), that is limited by the Patos and Pernambuco shear zones (Fig. 1.1B).

\section{Zona Transversal Domain}

The Zona Transversal Domain is bounded by the major E-W trending Patos and Pernambuco shear zones (Fig. 1.1B). These 2 shear zones represent an important dextral shear couple $150 \mathrm{~km}$ wide and $800 \mathrm{~km}$ long (not including the African continuation), that internally consists of a network of many sinistral NE-SW transcurrent shear zones that juxtapose 4 different subparallel terrains (Santos and Medeiros, 1999; Brito Neves et al., 2000). 
These shear zones rework an older, regionally developed, flat-lying foliation in orthogneiss and supracrustal rocks, which formed under amphibolite facies conditions of metamorphism (Neves et al., 2006). Despite the scarcity of geochronological data, U-Pb and Sm-Nd data suggest ages between 2.0 and 2.2 Ga for the orthogneiss and supracrustal rocks (Neves et al., 2006; Van Schmus et al., 2011). In the western part of the Zona Transversal domain, recent studies have revealed the presence of reworked remnants of early Tonian (1000-920 Ma) orthogneiss, metavolcanic rocks, and metasedimentary rocks imbricated with the basement (Santos et al., 2010). These rocks are considered to have formed during the Cariris Velhos orogenic event (Santos et al., 2010). The Limoeiro deposit, located within the Zona Transversal Domain, is hosted by rocks of the Rio Capibaribe Terrane (Fig. 1.1B; Santos and Medeiros, 1999; Brito Neves et al., 2000).

\section{Rio Capibaribe Terrane}

The Rio Capibaribe Terrane (Santos and Medeiros, 1999; Brito Neves et al., 2000) is essentially formed by a basement of orthogneisses of the Salgadinho complex, and paragneisses with amphibolites (metavolcanics) of the Vertentes complex. The latter partly underlies an allochthonous thrust-klippe composed of metapelite and meta-calcareous rocks of the Surubim Complex. These metasedimentary rocks have detrital zircons as young as $640-620$ Ma (Neves et al., 2009), thus indicating a younger Neoproterozoic age for the Surubim Complex. The best age constraint for the Rio Capibaribe Terrane is an U-Pb age of $1.97 \mathrm{Ga}$ obtained in prismatic zircons of the Salgadinho complex (Sá et al., 2002). Neves et al. (2006) summarizes the Rio Capibaribe Terrane geologic evolution to have been formed by the following events: (i) $2.15-2.10 \mathrm{Ga}$ juvenile magmatism; (ii) $2.05-2.03 \mathrm{Ga}$ for the peak of Transamazonian metamorphism; (iii) $1.99-1.97$ Ga late orogenic magmatism; (iv) deposition of supracrustal sequences; and $630-610 \mathrm{Ma}$ Brasiliano high-grade metamorphism. Although not mentioned in Neves et al. (2006), the significant amount of Brasiliano-Pan-African cycle (650- 
$500 \mathrm{Ma}$ ) syntectonic granite intrusions is an additional remarkable feature of this terrain (Santos and Medeiros, 1999).

\section{Vertentes complex}

The country rocks of the Limoeiro deposit belong to the Vertentes complex (Santos and Medeiros, 1999; Brito Neves et al., 2000), a metavolcano-sedimentary sequence metamorphosed under granulite facies condition. The depositional age of this complex is unknown, but field-based studies show that the Vertentes complex was intruded by the Passira Anorthositic Complex intrusion. The latter yields a U-Pb zircon age of $1,718 \pm 20 \mathrm{Ma}$ (Accioly et al., 2003), thus providing a minimum age for the metavolcano-sedimentary sequence. The ultramafic rocks that host the Limoeiro deposit intruded rocks of the Vertentes complex, and ongoing geochronological studies will provide absolute age constraints for the ultramafic magmatism and host rocks (Mota-e-Silva, in prep.).

\section{Materials and Methods}

Geological maps and sections of the Limoeiro deposit presented in this study were based upon extensive exploration data (e.g. maps, soil geochemistry, geophysical surveys) developed by VM. Nine drill holes have been described in detail and 78 thin sections were produced for petrographic studies.

We used 331 half-drill core whole rock assay results of $\mathrm{MgO}, \mathrm{Cr}, \mathrm{Al}_{2} \mathrm{O}_{3}$ and $\mathrm{S}$ from two bore holes from the VM database. They were sampled continuously at approximately $1 \mathrm{~m}$ intervals, respecting geological contacts. Each sample weighed about 2-kg and analyses were carried out at ALS Chemex, Toronto, Canada, using an inductively coupled plasma atomic emission spectrometer (ICP-AES) after fine crushing $(70 \mathrm{wt} \%<2 \mathrm{~mm})$, pulverizing (85 wt $\%<$ 
$75 \mu \mathrm{m})$ and four acid digestion. Some samples were also assayed using the LECO induction furnace-titration method for $S$ concentration determinations aiming to validate the ICP-AES analyses for this element.

\section{Geology of the Limoeiro deposit}

\section{Structure and stratigraphy of the ultramafic intrusion}

The Limoeiro deposit is associated with irregular bodies of ultramafic rocks, consisting mainly of orthopyroxenite and harzburgite (Fig. 1.2, 1.3, 1.4 and 1.5). Ultramafic rocks outcrop mainly in the eastern portion of the WSW-ENE elongated intrusion, which extends for at least 4 $\mathrm{km}$ as defined by drilling (Fig. 1.2 and 1.3). The intrusion is largely concordant with host paragneiss, although some segments locally cut up through the country rock's strata. Along the strike, the thickness and extent of the ultramafic bodies varies, often abruptly, from a cylindrical to an elliptic cylindrical geometry. The intrusion thickness is less than $250 \mathrm{~m}$, with width variable from 150 to $800 \mathrm{~m}$, and the length more than $4 \mathrm{~km}$. Several N-S and NW-SE ductile-brittle faults crosscut the intrusion, demarcating drilling targets along strike that are named from the shallower eastern part of the intrusion to the deeper western part as: Bofe, Piçarra, Retiro and Parnazo targets, respectively (Fig. 1.5). The term "target", used during the exploration campaign by VM geologists to indicate different sections of ultramafic rocks selected for drilling, was maintained in this study for consistency with reports and maps of the company.

Ultramafic rocks consist mainly of olivine and orthopyroxene cumulates (Fig. 1.4B, D and E) with minor chromite and sulfides. These rocks have been partly altered to a range of metamorphic assemblages that include a high degree paragenesis (i) formed by recrystallized orthopyroxene and olivine in equilibrium with an association of two amphiboles, chlorite and phlogopite, and a low degree one (ii) composed of antigorite, talc, chlorite, calcite and magnetite. The outer part of the ultramafic intrusion forms a 2-10 meter-wide rim in which the 
high grade metamorphic assemblage prevails. Because the original igneous texture is largely preserved in the ultramafic rocks, such that original cumulate minerals can be identified, rocks are described using igneous terminology. Therefore, harzburgite and orthopyroxenite terms are used in this paper for variably transformed rocks that were originally olivine dominant cumulates or orthopyroxene dominant cumulates, respectively. Highly transformed rocks with metamorphic texture and assemblage, consisting mainly of amphibole, are called amphibolite.

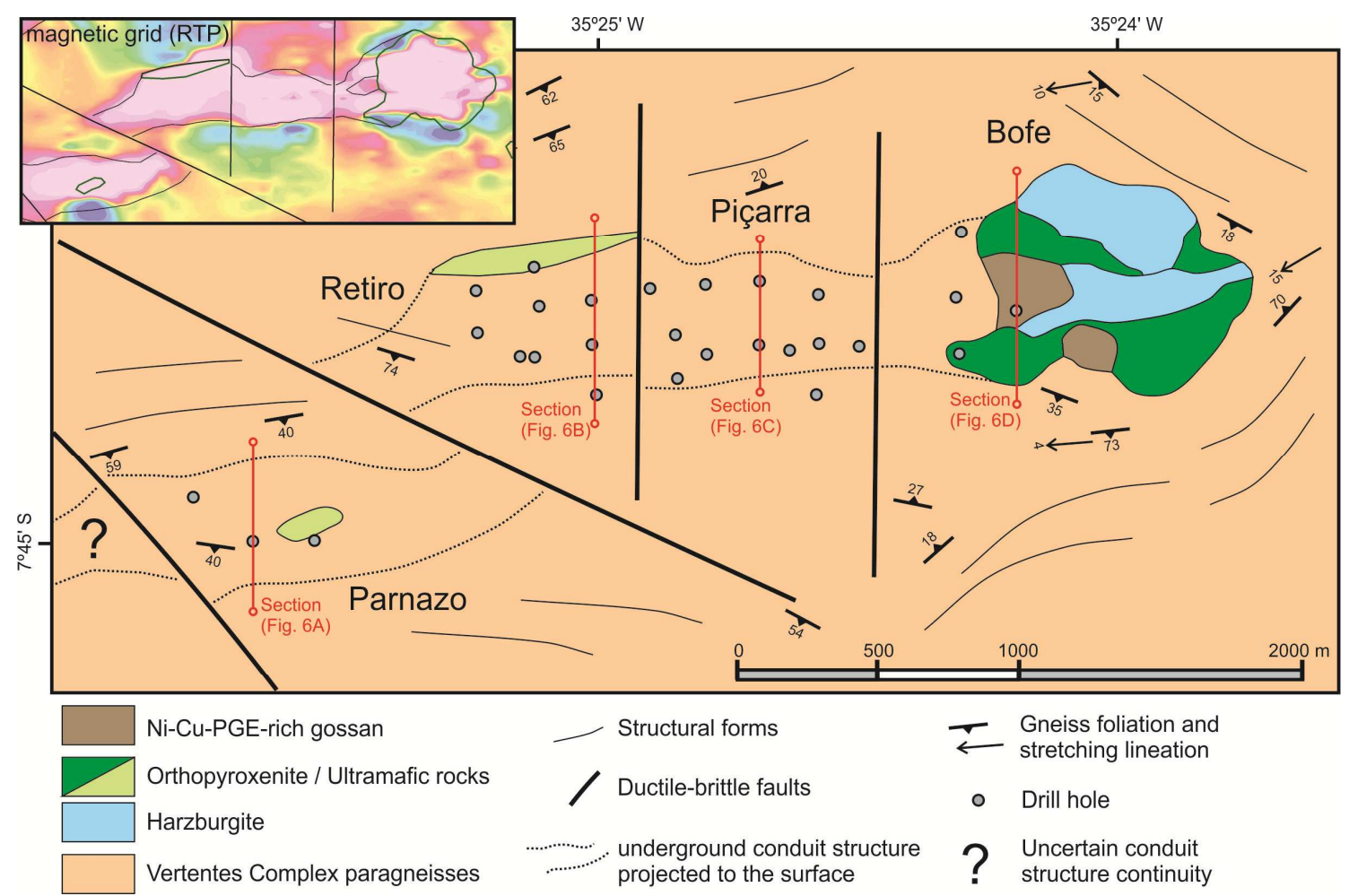

Fig. 1.2 Geological map of the Limoeiro intrusion. The inset on the upper-left corner is the Reduced to Pole ground magnetic grid. The coordinates are in SAD-69 geographic projection. 


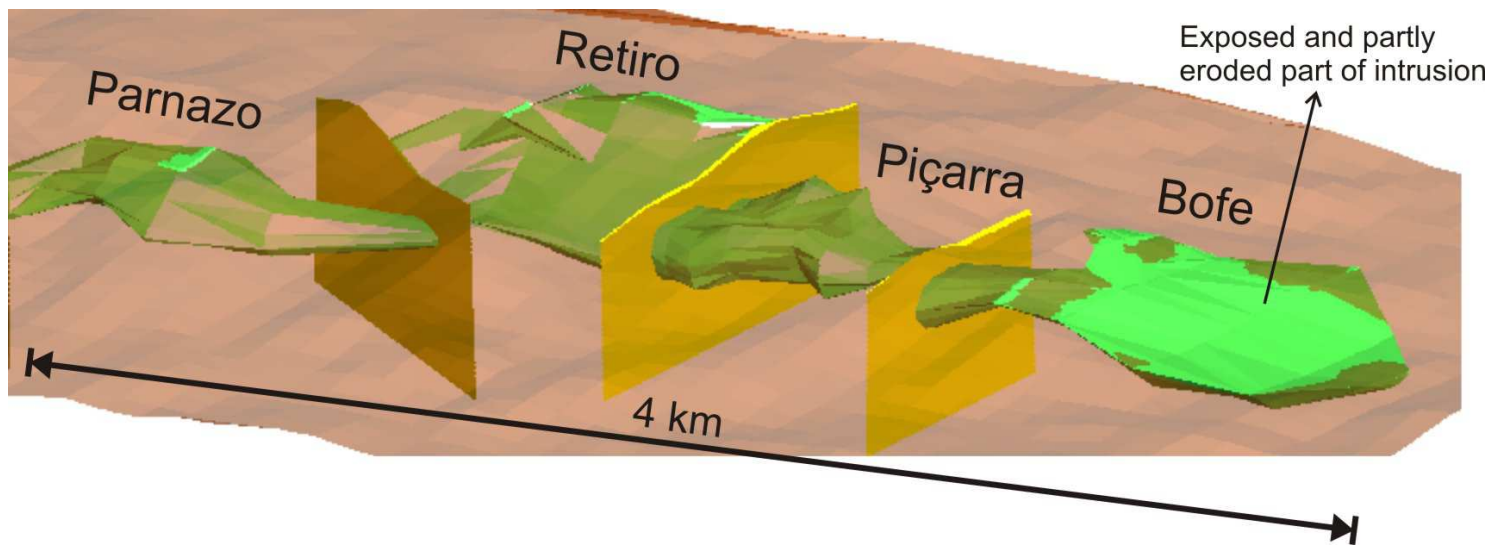

Fig. 1.3 Schematic 3D model of the chonolitic conduit of the ultramafic intrusion. 

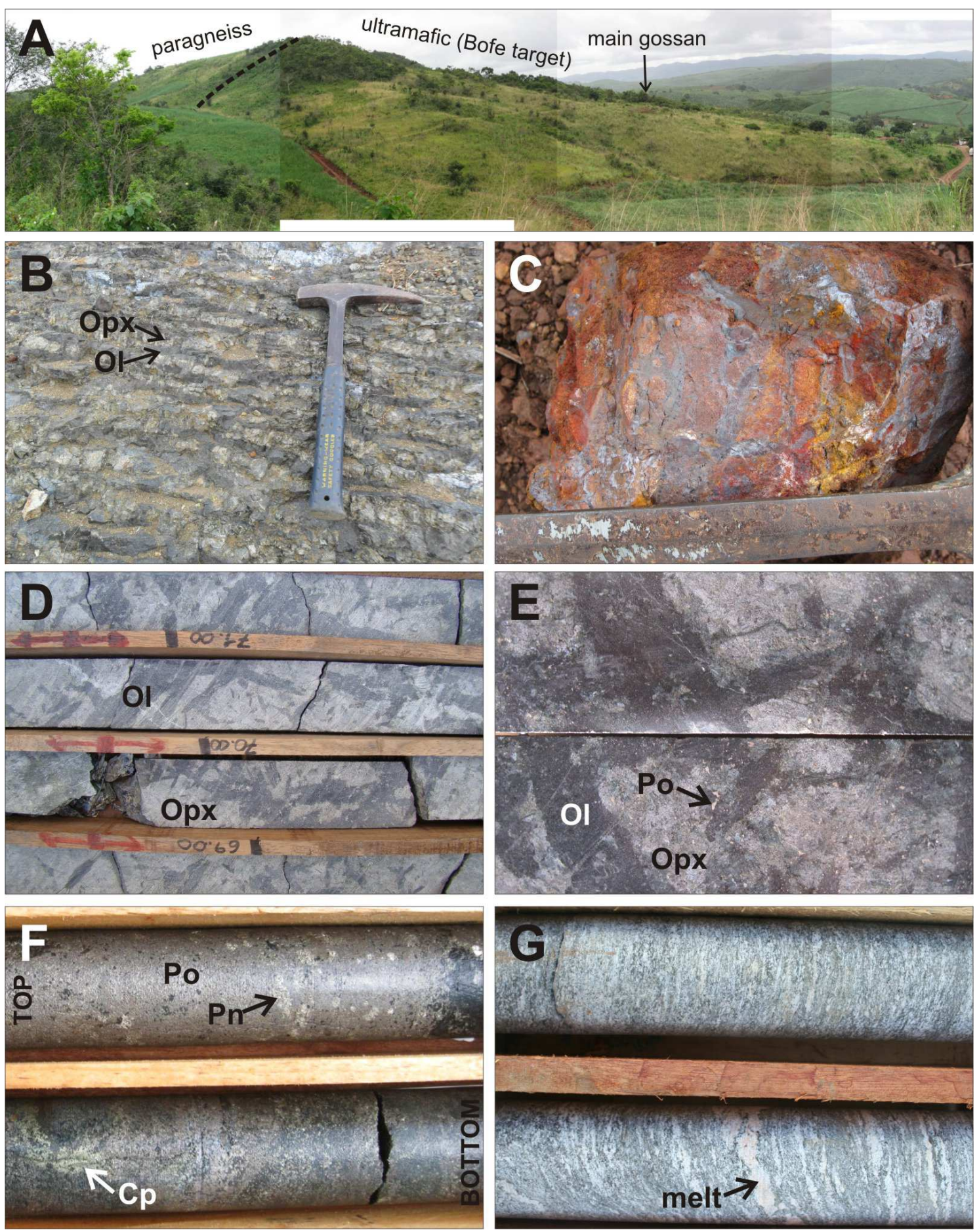

Fig. 1.4 (A) Panoramic view of the ultramafic rocks and gossan outcrop area (4 $\mathrm{m}$ wide dirt roads are the scale). (B) An outcrop of harzburgite with preserved magmatic subhorizontal layering, consisting of olivine- and orthopyroxenedominant layers (30 cm long hammer is the scale). (C) Sample of Ni-Cu-PGE-rich gossan $(2 \mathrm{~cm}$ wide hammer neck is the scale). (D) Typical coarse-grained harzburgite. (E) Disseminated ore consisting of harzburgite with 5 vol\% sulfides. (F) Massive sulfide layer consisting mainly of pyrrhotite and pentlandite in the top and a chalcopyrite-enriched less massive lower zone. (G) Garnet-sillimanite-biotite paragneiss of the Vertentes complex with small pegmatite batches interpreted as in-situ melting products. For scale purpose the diamond drill core presented in D, E, F and G has $4.7 \mathrm{~cm}$ diameter. Mineral symbols in accordance with Kretz (1983). 


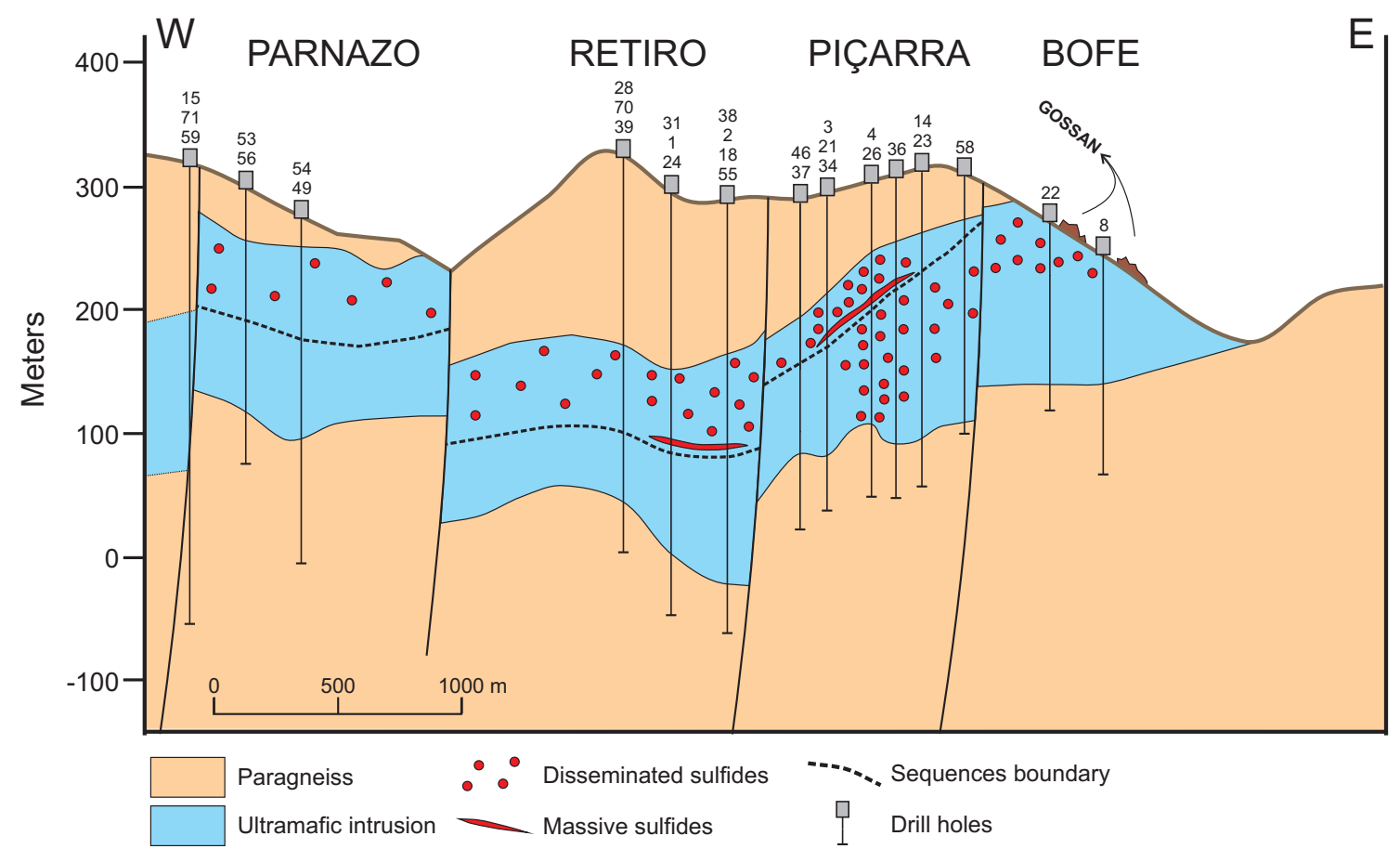

Fig. 1.5 Longitudinal schematic section of the ultramafic intrusion.

In the Parnazo target the fault-limited tube-like ultramafic body, with a $350 \mathrm{~m}$ width by $150 \mathrm{~m}$ height cross section, extends along strike for about $1 \mathrm{~km}$ (Fig. 1.6A). A rim of amphibolite, 5 to 1 meters wide, comprises the outermost part of the intrusion (Fig. 1.6A). Inside this rim, the Parnazo target consists of a barren Lower Sequence and a mineralized Upper Sequence, separated by an irregular but generally thin $(<5$ meter-thick) zone of amphibolite. The Lower sequence consists mainly of harzburgite and a rim of orthopyroxenite. The Upper Sequence consists of harzburgite at the base, followed by orthopyroxenite at the top. Both harzburgite and orthopyroxenite of the Upper Sequence have 2-5 vol\% of sulfide blebs.

The geological sequence for the Retiro target (Fig. 1.6B) is similar to the one described for the Parnazo target. It consists also of a barren Lower Sequence and a mineralized Upper Sequence, but it lacks the amphibolite zone that separates the two sequences in the Parnazo target. In the Retiro target the fault-limited tube-like ultramafic body is larger, with a $550 \mathrm{~m}$ width by $250 \mathrm{~m}$ height cross section that extends for about $1 \mathrm{~km}$. Unlike the Parnazo target, the Retiro target has a continuous submetric layer of massive sulfide located in the lower portion of the mineralized harzburgite. This target is also characterized by a greater amount of sulfide blebs (up to 10 vol\%) throughout the mineralized Upper Sequence. Rarely, the massive 
sulfide layer contains country rock fragments consisting of up to $2 \mathrm{~cm}$ xenoliths of paragneiss or garnet, plagioclase and biotite xenocrysts.

The structure of the ultramafic body in the Piçarra target is variable, and geological correlations between different geological cross-sections of the target are difficult to define. The Piçarra target consists of discrete ultramafic bodies that contain greater amphibolite rim zones, with preserved but locally non-complete stratigraphy interrupted by fault zones, suggesting that the original magmatic structure is partially disrupted (Fig. 1.6C). Unlike the Parnazo and Retiro targets, the foliation of paragneiss country rocks is variably folded with an E-W vertical ductilebrittle shear zone (Fig. 1.6C). This shear zone limits the main southern ultramafic body from smaller deformed parts of the intrusion to the north. In this larger ultramafic body, within variable-sized cross sections (averaging 200 by 200 meters) that extend for about $1 \mathrm{~km}$, Lower and Upper sequences similar to those described in the Parnazo and Retiro targets are recognized. However, different to those targets, sulfide mineralization is not restricted to the Upper Sequence in the Piçarra target, occurring throughout the entire sequence (e.g. Lower and Upper sequences). Several metric to submetric massive sulfide layers occur in both sequences of the Piçarra target. Some of them show pristine magmatic textures preserved, characterized by sharp contacts with host rocks at the bottom and a gradational net-textured contact at the top. Tectonized massive sulfide layers show tectonic structures, and sharp contacts with foliated amphibolites. Disseminated sulfide blebs are more abundant in the Piçarra target (up to 20 vol\%) than in the other targets.

The ultramafic intrusion and $\mathrm{Ni}-\mathrm{Cu}$ sulfide mineralization crop out at the Bofe target at the eastern portion of the tube-like structure (Fig. 1.2, 3 and 6D). In this target the upper portion of the ultramafic structure has been eroded away and gossans occur where the sulfide mineralization outcrops. The intrusion is up to $800 \mathrm{~m}$ wide and $100 \mathrm{~m}$ height in the Bofe target (Fig. 1.6D), and disseminated sulfides are restricted to the upper parts, possibly correlated to the Upper Sequence described in other targets. 

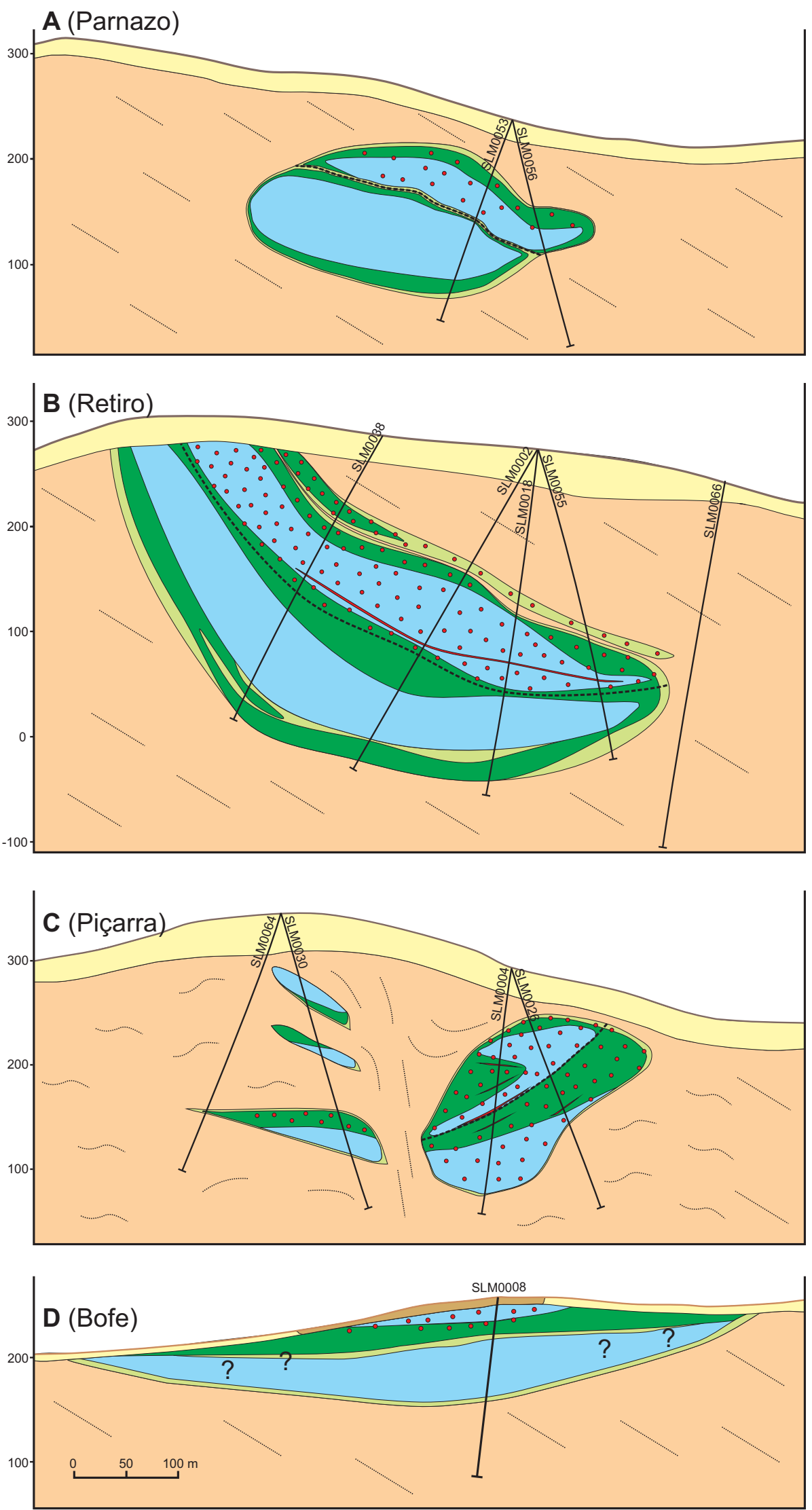

Soil / Gossan cap @ Disseminated sulfides

Paragneiss

Fig. 1.6 Geological cross-sections of (A) Parnazo, (B) Retiro, (C) Piçarra and (D) Bofe targets. 
The stratigraphy of the Parnazo and Retiro targets, where the tube-like structure was drilled within a less tectonized and disrupted domain, is represented in Figure 1.7. Assay results from the $\mathrm{VM}$ exploration database for $\mathrm{MgO}, \mathrm{Cr}, \mathrm{Al}_{2} \mathrm{O}_{3}$ and $\mathrm{S}$ throughout two representative drill cores (SLM0053 and SLM0002) are indicated to point out critical features of the stratigraphy.

In the drill hole SLM0053, representative of the Parnazo target, the $\mathrm{MgO}$ and $\mathrm{Cr}$ contents show a flat pattern of higher values in the central portions of the Upper ( 28 wt\% for $\mathrm{MgO}$ and $\sim 2000 \mathrm{ppm}$ for $\mathrm{Cr}$ ) and Lower sequences ( 31 wt\% for $\mathrm{MgO}$ and $\sim 1600 \mathrm{ppm}$ for $\mathrm{Cr}$ ), whereas contents are highly variable and progressively lower toward the amphibolite in the top and bottom of each sequence. The $\mathrm{Al}_{2} \mathrm{O}_{3}$ contents have a negative correlation with $\mathrm{MgO}$ and $\mathrm{Cr}$ contents, showing higher values in the top and bottom of each sequence, reaching values of up to $14-16$ wt\% in amphibolites (Fig. 1.7). In the drill hole SLM0002, representative of the Retiro target, the central portions of the Upper and Lower sequences are also characterized by homogeneous and higher contents of $\mathrm{MgO}$ and $\mathrm{Cr}$. However, in contrast with the Parnazo target, progressively lower and highly variable $\mathrm{MgO}$ and $\mathrm{Cr}$ contents, with negative correlation with $\mathrm{Al}_{2} \mathrm{O}_{3}$ contents, are restricted to the top of the Upper Sequence and bottom of the Lower Sequence. The higher $\mathrm{Al}_{2} \mathrm{O}_{3}$ contents associated with lower $\mathrm{MgO}$ and $\mathrm{Cr}$ contents, that characterize the contact zone between the Upper and Lower sequences in the Parnazo target, are not observed in the Retiro target (Fig. 1.7). This feature results from the fact that amphibolites are not present at the contact zone between the two sequences in the Retiro target, a feature already described in previous sections. 


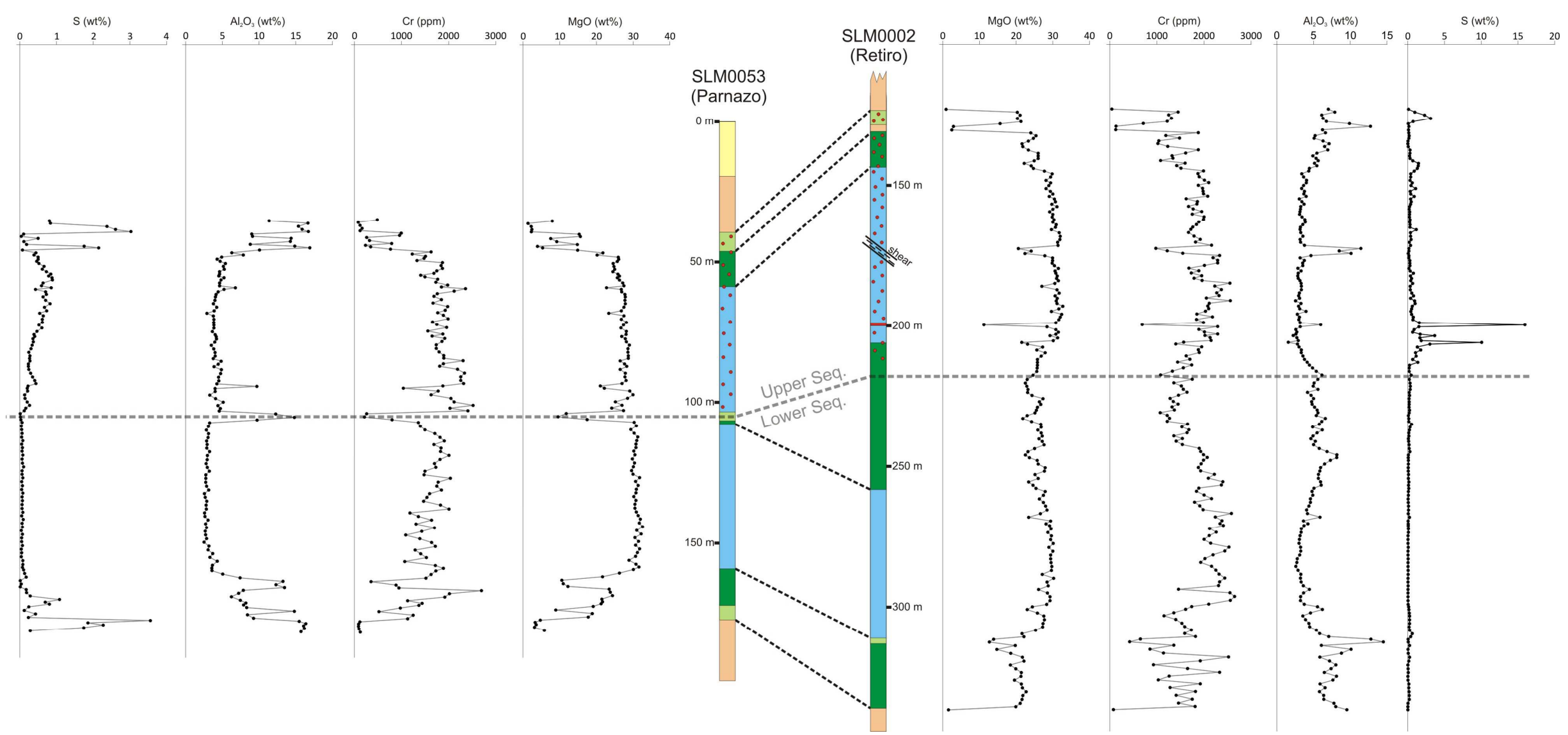

Fig. 1.7 SLM0053 (Parnazo) and SLM0002 (Retiro) drill holes strip log and its $\mathrm{MgO}, \mathrm{Cr}, \mathrm{Al}_{2} \mathrm{O}_{3}$ and $\mathrm{S}$ assay results. The thin dashed lines indicate stratigraphic correlations between drill holes, and the coarser gray dashed line shows the Upper and Lower Sequence limit. 
The $\mathrm{S}$ contents in Fig.7 reflect the presence of disseminated sulfides, providing a sharp geochemical contrast between the Ni-Cu sulfide-mineralized Upper Sequence and the barren Lower Sequence. In the selected drill holes the S contents are variable but consistently higher in the Upper Sequence, from 0.12 to $0.87 \mathrm{wt} \%$ (an average of $0.46 \mathrm{wt} \%$ ) and from 0.10 to $15.95 \mathrm{wt} \%$ (an average of $0.78 \mathrm{wt} \%$ ) in the drill cores representative of the Parnazo and Retiro targets respectively. On the other hand, S contents for the Lower Sequence of both drill holes are usually below $0.1 \mathrm{wt} . \%$. Samples with high $\mathrm{S}$ contents characterize the top and bottom contacts of the ultramafic intrusive body and host paragneiss (Fig. 1.7). These $S$ contents represent remobilized barren (i.e. very low $\mathrm{Ni}$ and $\mathrm{Cu}$ contents) sulfides within amphibolite or host gneiss in the contact zone, as well as disseminated sulfides in the country rocks. Because analytical data are restricted to the immediate contact of the ultramafic rocks, exploration assays are usually not available for the latter. In the drill hole SLM0053 in the Parnazo target, assays of sulfide-bearing samples of amphibolite and host gneiss are available for the top and bottom of the ultramafic intrusive body. Results are similar for both the upper contact of the Ni-Cu mineralized Upper Sequence and the lower contact of the barren Lower Sequence, indicating that they consist mainly of remobilized barren (i.e. very low $\mathrm{Ni}$ and $\mathrm{Cu}$ contents) sulfides within amphibolite or host gneiss in the contact zone. These results provide additional evidence that the ultramafic body is intrusive into sulfide-bearing country rocks.

\section{Petrography of the ultramafic rocks}

The most significant mineralogical and textural characteristics of the intrusive rock types are summarized in Table 1.1 and are briefly described below.

Ultramafic rocks of the tube-like ultramafic intrusion consist mainly of variably transformed harzburgite and orthopyroxenite. These rocks are coarse-grained (up to $4 \mathrm{~cm}$ orthopyroxene and $2 \mathrm{~cm}$ olivine crystals) olivine and orthopyroxene cumulates, commonly showing dark-colored aggregates of olivine crystals and irregular whitish patches of 
orthopyroxene and amphibole (Fig. 1.4D and E). Coarse-grained olivine and orthopyroxene crystals are usually partially replaced by medium- to fine-grained aggregates of metamorphic minerals (Fig. 1.8A and 8B). Olivine occurs commonly as anhedral crystals with corroded borders included in larger orthopyroxene crystals, suggesting that orthopyroxene grew through olivine reaction with the magma (Fig. $1.8 \mathrm{C}$ and $\mathrm{D}$ ). Chromite is a cumulus accessory mineral, usually ranging from $1-4$ vol\% but up to 6 vol\%, in orthopyroxenite and harzburgite of both Lower and Upper Sequences. Chromite occurs mainly as fine-grained (5-200 $\mu \mathrm{m})$ euhedral crystals included in orthopyroxene or olivine (Fig. 1.8E and 8F).

Table 1.1 Mineralogy and petrographic summary of the units within the Limoeiro intrusion. The mineral symbols are in accordance with classification of Kretz (1983).

\begin{tabular}{|c|c|c|c|c|c|}
\hline Sequence & $\begin{array}{c}\text { Lithostratigr } \\
\text { aphic unit }\end{array}$ & $\begin{array}{c}\text { Primary Minerals } \\
(\mathrm{vol} \%)\end{array}$ & Metamorphic Minerals (vol\%) & Textures and Fabrics & $\begin{array}{r}\text { Disseminated } \\
\text { Sulfide (vol\%) }\end{array}$ \\
\hline \multirow{3}{*}{ Upper } & AT & Opx 0-20 & $\begin{array}{c}\text { Mg-Hbl 40-60; Ath 0-30; Tlc 0- } \\
\text { 20; Atg 0-15; Mag 0-5; Chl 0- } \\
\text { 10; Phl 0-4; Cal 0-1 }\end{array}$ & $\begin{array}{l}\text { domain of diablastic texture with locally nematoblastic to } \\
\text { lepidoblastic texture given by orientation of amphiboles and micas; } \\
\text { minerals have polygonal contacts (triple junctions); }\end{array}$ & \multirow{3}{*}{$\begin{array}{l}\text { Parnazo 2-5; } \\
\text { Retiro 3-10; } \\
\text { Piçarra 5-20 }\end{array}$} \\
\hline & $\mathrm{PX}$ & $\begin{array}{c}\text { Opx } 30-60 ; \text { Ol 10- } \\
35 \text {; Chr 2-4 }\end{array}$ & $\begin{array}{c}\text { Mg-Hbl 10-50; Phl 0-20; Atg } 1 \text {. } \\
\text { 7; Mag 2-5; Chl 0-5; Tlc 0-3; } \\
\text { Cal 0-2 }\end{array}$ & \multirow{2}{*}{$\begin{array}{l}\text { pegmatitic coarse cumulatic texture with large crystals partially } \\
\text { altered (amphibole) and recrystallized (sub-grains with polygonal } \\
\text { contacts); sulfide blebs and chromite included in Opx and Ol; Ol } \\
\text { inclusions in Opx (reaction texture); }\end{array}$} & \\
\hline & $\mathrm{HZ}$ & $\begin{array}{l}\text { Ol } 25-65 ; \text { Opx } 5- \\
50 ; \text { Chr } 1-6\end{array}$ & $\begin{array}{l}\text { Mg-Hbl 5-40; Tlc 0-30; Atg 2- } \\
\text { 10; Mag 4-6; Phl 0-15; Chl 0- } \\
\text { 10; Cal 0-3 }\end{array}$ & & \\
\hline \multirow{3}{*}{ Lower } & AT & Opx 0-35 & $\begin{array}{l}\text { Mg-Hbl 45-60; Ath 0-40; Plag } \\
\text { 0-35; Chl 0-20; Atg 0-5; Mag 0- } \\
\text { 5; Tlc 0-5; Phl 0-4 }\end{array}$ & $\begin{array}{l}\text { domain of diablastic texture with locally nematoblastic to } \\
\text { lepidoblastic texture given by orientation of amphiboles and micas; } \\
\text { minerals have polygonal contacts (triple junctions); }\end{array}$ & \multirow{3}{*}{$\begin{array}{c}\text { Parnazo 0-2; } \\
\text { Retiro 0-2; } \\
\text { Piçarra 0-15 }\end{array}$} \\
\hline & PX & $\begin{array}{l}\text { Opx 40-70; Ol 0- } \\
\text { 30; Chr 1-6 }\end{array}$ & $\begin{array}{c}\text { Mg-Hbl 5-40; Chl 0-25; Ath 0- } \\
\text { 20; Atg 0-20; Mag 2-5; Phl 0- } \\
\text { 10; Cal 0-4; Tlc 0-3 } \\
\end{array}$ & \multirow{2}{*}{$\begin{array}{c}\text { pegmatitic coarse cumulatic texture with large crystals partially } \\
\text { altered (amphibole) and recrystallized (sub-grains with polygonal } \\
\text { contacts); sulfide blebs and chromite included in Opx and Ol; Ol } \\
\text { inclusions in Opx (reaction texture); }\end{array}$} & \\
\hline & $\mathrm{HZ}$ & $\begin{array}{l}\text { Ol 25-65; Opx 0- } \\
50 ; \text { Chr } 1-5\end{array}$ & $\begin{array}{c}\text { Mg-Hbl 5-35; Chl 0-15; Atg 2- } \\
\text { 10; Mag 4-6; Tlc 0-7; Phl 0-5; } \\
\text { Cal 0-2 }\end{array}$ & & \\
\hline
\end{tabular}

Deformation textures such as undulatory extinction, bent crystals, and recrystallization of coarse-grained crystals to fine-grained granoblastic aggregates with polygonal contacts are commonly observed in orthopyroxenite and harzburgite. These features, as well as the petrography of the amphibolites, will be described when the metamorphic processes are considered. 

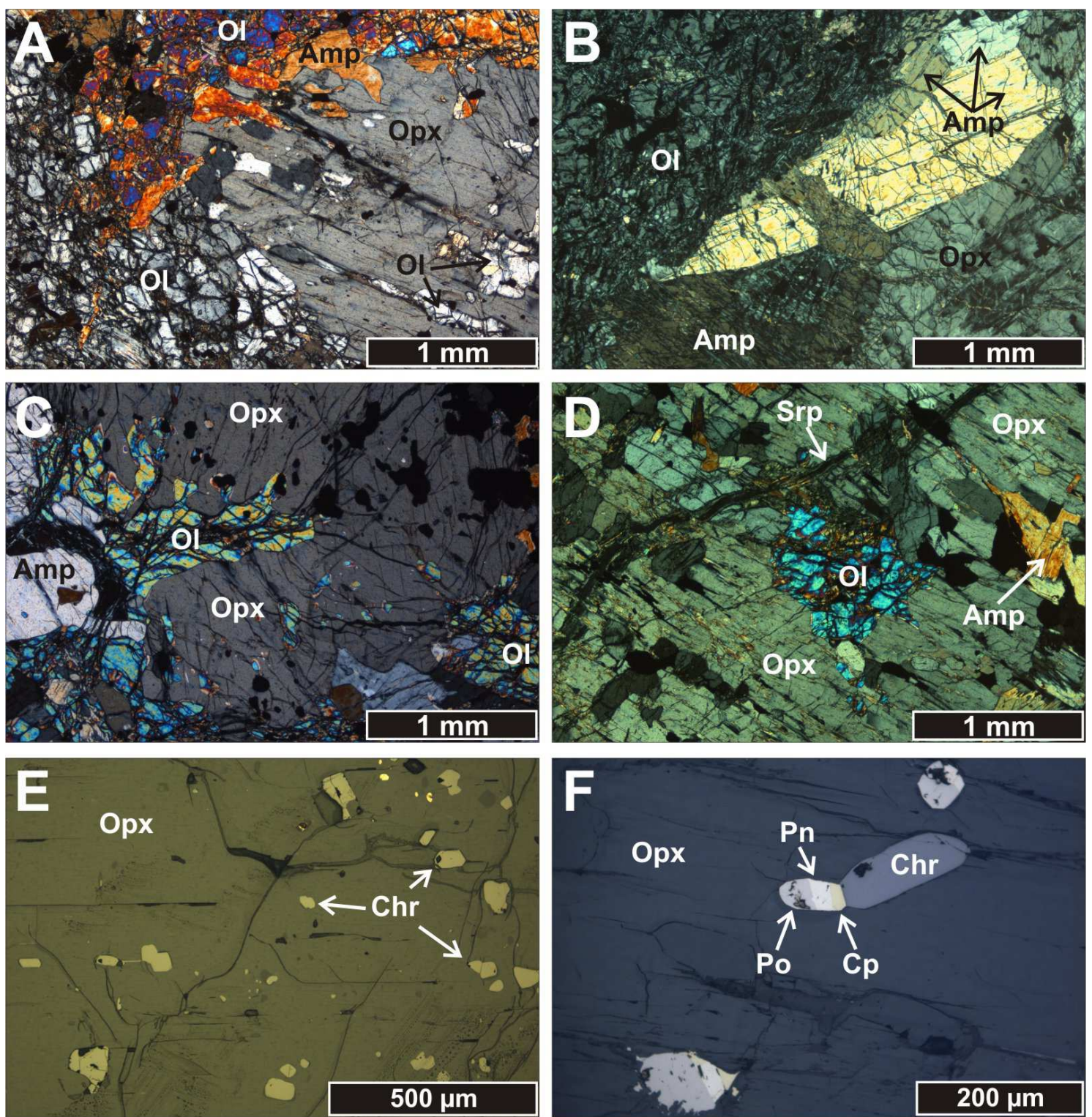

Fig. 1.8 (A) Typical texture of coarse-grained harzburgite with metamorphic amphiboles between large crystals of orthopyroxene and olivine. (B) Metamorphic amphiboles replacing large crystals of orthopyroxene and olivine. (C) Anhedral olivine crystal with corroded rounded margins enclosed in large orthopyroxene crystal. (D) Large orthopyroxene grain with optically continuous olivine grain inclusions, suggesting a reaction of destruction of olivine and crystallization of orthopyroxene. (E) Euhedral chromite crystals included in large orthopyroxene grain. (F) Sulfide blebs with MSS composition included in orthopyroxene. Mineral symbols in accordance with classification of Kretz (1983). 


\section{Structure and petrography of country rocks hosting the ultramafic intrusions}

The ultramafic rocks that host the Limoeiro deposit intruded a sequence of sulfidebearing paragneiss of the Vertentes complex (e.g. Santos et al., 2010). Close to the Limoeiro deposit, where the country rocks were investigated by VM during exploration mapping and drilling, the Vertentes complex consists mainly of quartz-feldspathic schist and gneiss (Fig. $1.4 \mathrm{G}$ ), with minor amphibolite (composed of plagioclase and hornblende, which differs from monomineralic amphibolite from the metamorphic rim of the ultramafic intrusion) and sulfidebearing calcsilicate rocks. The foliation in the country rocks has a gentle to moderate south to southwest $10-40^{\circ}$ dip. This foliation is frequently disturbed, possibly due to drag folds related to ductile-brittle sub-vertical N-S and NW-SE shear zones. In these disturbed zones, country rocks have a strong strike-slip stretching lineation, forming L-tectonites.

Banded rocks consisting of interlayered Kfeldspar-sillimanite-quartz-bearing bitotite schist (Fig. 1.9) and biotite-garnet-quartz-Kfeldspar-bearing gneiss containing from $<1$ to 2 vol\% of sulfides (pyrite and pyrrhotite) are the most common country rocks. These rocks are mediumgrained with textures varying progressively from lepidoblastic in biotite schist to granoblastic in garnet gneiss. Melting pods, consisting of irregular coarse-grained granite bands, are frequent within gneissic rocks (Fig. 1.4G). Accessory minerals in both biotite schist and gneiss consist of zircon, apatite, ilmenite and rutile. Retrometamorphic reactions are common in both gneiss and biotite schist, as indicated by the partial replacement of biotite by chlorite and of sillimanite by muscovite.

Amphibolite (the one associated with the country rocks) occurs in meter-scale (up to dozen meters) bands with sharp contacts with the host gneiss and biotite schist. Amphibolite bands consist of medium-grained magnetic rocks with nematoblastic texture, comprising mainly hornblende and plagioclase, with associated garnet in some bands. Calcsilicate rocks also contain from $<1$ to 2 vol\% of sulfides (pyrite and pyrrhotite) and occur in meter-scale layers with gradational contacts with the host gneiss and biotite schist. Calcsilicate layers consist of 
medium-grained rocks with nematoblastic texture consisting mainly of amphibole with minor calcite, dolomite, epidote and quartz.
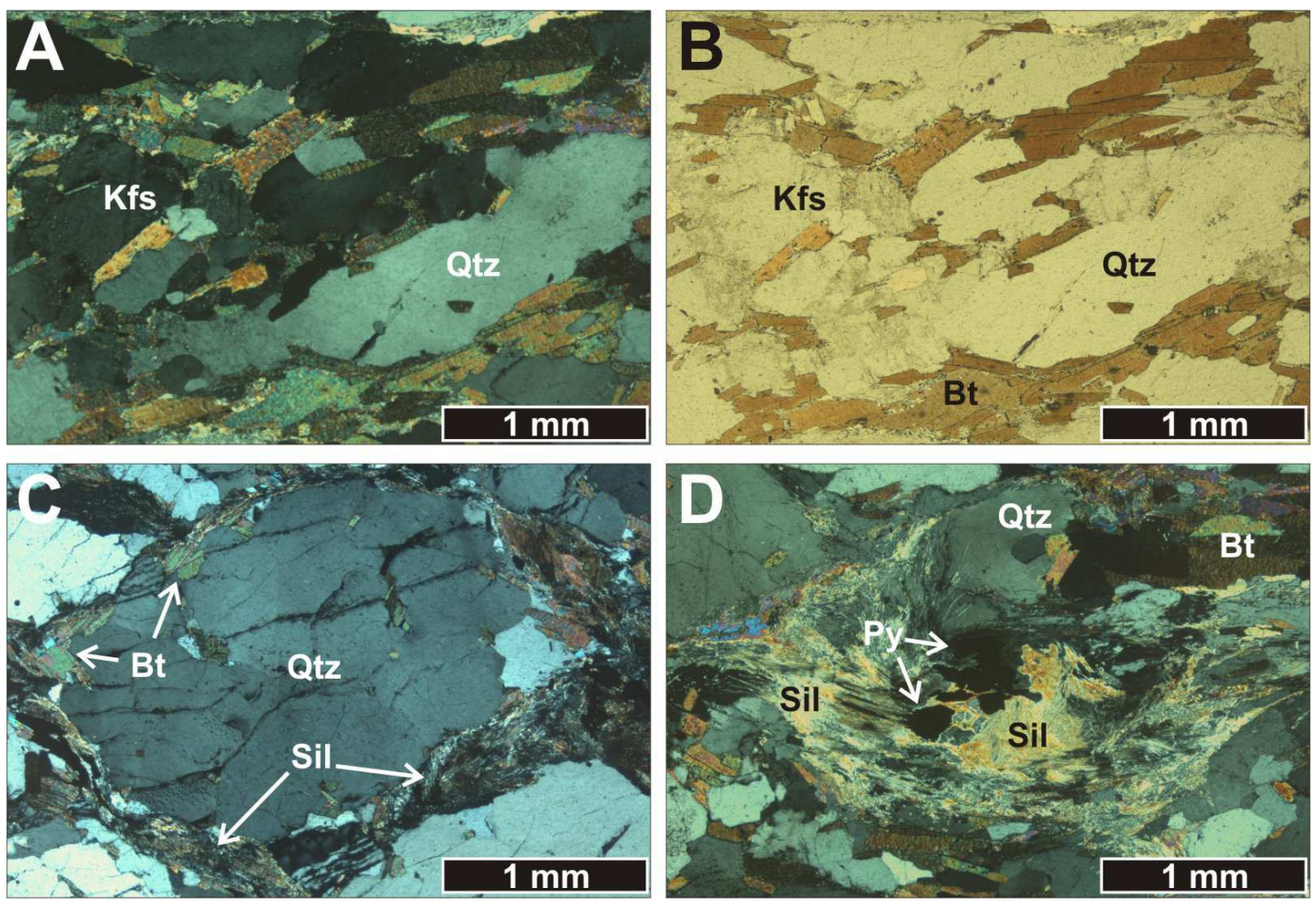

Fig. 1.9 (A) A quartz- Kfeldspar-biotite schist showing a granolepidoblastic texture. (B) Same as "A" but with crossed polarizers. (C) A quartz-biotite-sillimanite schist showing the almond-shape of the quartz grain. (D) The same quartzbiotite-sillimanite schist showing the opaque pyrite grains, a common constituent of this rock. Mineral symbols in accordance with classification of Kretz (1983).

\section{Metamorphic transformation}

Metamorphic recrystallization of the ultramafic rocks associated with the Limoeiro deposit is heterogeneous and mainly concentrated along the borders of the intrusion or along discrete shear zones. The conduit structure consists of a thin amphibolite rim, within which metamorphic minerals prevail, followed abruptly by domains with predominantly primary igneous minerals and textures. The amphibolite commonly has granoblastic texture consisting of equigranular medium-grained amphibole crystals with polygonal contacts. Nematoblastic textures, characterized by oriented amphiboles and different phyllosilicates, are restricted to shear zones. Metamorphosed ultramafic rocks are characterized by deformed and partially 
recrystallized relicts of larger orthopyroxene and olivine crystals. Igneous relicts of orthopyroxene and olivine are frequently deformed, consisting of bent (locally kinked) crystals with undulatory extinction. These relicts are usually surrounded by fine-grained polygonal aggregates.

The peak metamorphic paragenesis was defined for the amphibolite and for the recrystallized domains of harzburgite. In the first case, the peak metamorphic parageneses consists of hornblende, anthophyllite and phlogopite, whereas in the harzburgite it consists of orthopyroxene, olivine, hornblende, anthophyllite, chlorite $\left(\mathrm{Chl}_{1}-\right.$ i.e. chlorite belonging to the high grade metamorphism), phlogopite and spinel (Fig. 1.10A).

Amphiboles in peak metamorphic parageneses are represented by i) a colorless to pale green hornblende with distinct pleochroism, and ii) a colorless anthophyllite. Both amphiboles are closely associated, forming granoblastic textured aggregates (Fig. 1.10B and 10C). Chlorite $\left(\mathrm{Chl}_{1}\right)$ occurs mostly as euhedral to subhedral, colorless crystals with distinct polysynthetic twinning, whereas phlogopite is characterized by medium to coarse-sized, highly pleochroic light brown to reddish lamellae (Fig. 1.10B). Fine-grained green to brownish spinel crystals, that occur associated with peak metamorphic silicates in metamorphosed harzburgite, are interpreted to be recrystallized chromite. These spinel crystals also occur in irregular rims surrounding euhedral chromite crystals.

The ultramafic rocks are also affected by later low-temperature alteration. This later alteration, which transforms both igneous and peak metamorphic minerals, consists of veinlets and pervasive alteration to antigorite, talc, chlorite $\left(\mathrm{Chl}_{2}\right)$, calcite and magnetite (Fig. 1.10E). This alteration is commonly less dominant than the high grade event, composing on average 5 vol\% of the minerals in the whole rock of the Limoeiro intrusion. However locally (preferentially close to shear zones) it can reach up to 50 vol\% of the modal composition. 

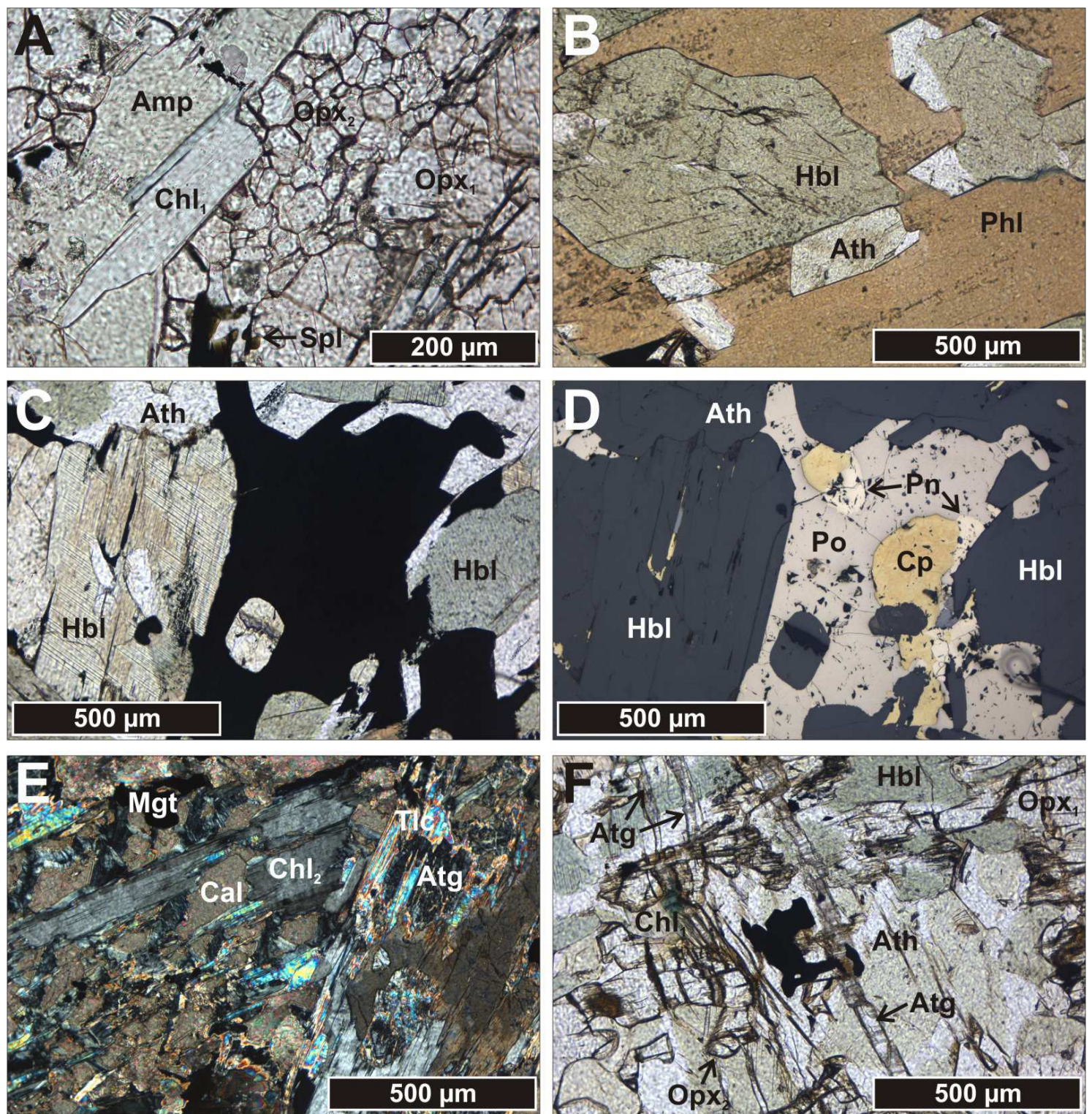

Fig. 1.10 (A) The peak metamorphic paragenesis with sub-grains of orthopyroxene in equilibrium with amphibole, chlorite and spinel. (B) Distinguishable amphiboles recognized here as a pale green hornblende and a colorless anthophyllite in equilibrium with a phlogopite crystal. (C) MSS sulfides with its external boundaries controlled by the metamorphic minerals fabric. (D) Same as "C" but in reflected light. (E) Low-temperature alteration paragenesis represented by $2^{\text {nd }}$ generation chlorite, calcite, talc, magnetite and antigorite. (F) Clear temporal relationship showing the high-grade metamorphic parageneses cross-cuted by the low-temperature assemblage. Mineral symbols in accordance with classification of Kretz (1983). 


\section{Mineralization}

\section{Ore bodies and ore types}

Nickel-Cu(-PGE) sulfide mineralization in the Limoeiro deposit is mainly associated with the Upper Sequence of ultramafic rocks. The different ore bodies resulted from tectonic slicing of the originally continuous tube-like structure. Where the complete magmatic structure is preserved, such as the Parnazo and Retiro targets (Figs. 6A and 6B), ore bodies closely resemble the form of the upper part of the tube-like (chonolith) structure. For the tectonically disturbed Piçarra target (Fig. 1.6C) and the partially eroded Bofe target (Fig. 1.6D), ore bodies have more complex geometries, which are nevertheless broadly characterized by elongated tube-like forms. The bulk of the mineralization in all ore bodies consists of thick (up to 150 meters) and elongated (up to $1 \mathrm{~km}$ ) masses of disseminated sulfides broadly concordant with the chonolithic structure. Three different types of ore occur in the Limoeiro deposit: disseminated, massive and tectonically remobilized stringers and massive sulfide bodies. Disseminated ore predominates in all ore bodies and represents about 97 vol\% of the Limoeiro deposit. Disseminated ore consists of interstitial sulfides and/or sulfide blebs, between 2-20 vol\%, hosted in orthopyroxenite and harzburgite. Massive ore occurs just in the Retiro and Piçarra targets and represents about 3 vol\% of the Limoeiro deposit. Massive ore contains more than 60 vol\% sulfide in one thin (usually less than 1 meter-thick) but continuous layer located in the basal zone of the ore body in the Retiro, and scattered, multiple and less continuous layers in the Picarra ore body. Tectonically remobilized stringers and massive ore occur in tectonically disturbed portions of the deposit, especially in the Piçarra target. Remobilized ore is characterized by cross-cutting sharp contacts with host harzburgite or orthopyroxenite, or by pervasive tectonic foliation concordant with highly transformed foliated ultramafic rocks.

The amount of disseminated sulfides in the Upper Sequence of the chonolith, e.g. the average vol\% sulfide in distinct ore bodies, increases eastward, being progressively enriched from Parnazo, to Retiro and Piçarra targets (Fig. 1.5; note that Bofe target is not considered in this assessment due to the eroded characteristic of the target). The eastward increase in 
disseminated sulfides is matched with consistent layers of massive sulfides starting at the eastern part of the Retiro target that become more abundant in the Picarra target (Fig. 1.5). The latter has a distinct distribution of disseminated sulfides, which are located throughout the tubelike structure (Fig. 1.5 and 6C), and not restricted just to the Upper Sequence as observed in all other targets. Because the Picarra target is tectonically disturbed, the implications of this distinct distribution of sulfides should be considered with discretion, a subject to be addressed during the discussion.

\section{Ore petrography}

The modal composition of sulfides in the Limoeiro deposit is homogeneous with no significant differences for distinct ore bodies or throughout the stratigraphy of each ore body. The sulfides consist of pyrrhotite ( 70 vol\%), chalcopyrite ( 15 vol\%) and pentlandite ( 15 vol\%). Dominantly, the sulfides are disseminated, forming interstitial aggregates $0.5 \mathrm{~mm}$ to 3 $\mathrm{mm}$ in size, and blebs $50 \mu \mathrm{m}$ up to $400 \mu \mathrm{m}$ in diameter. Sulfide blebs are usually included in coarse-grained orthopyroxene or olivine crystals (Fig. 1.11A and 11B). Larger blebs consist of aggregates of pyrrhotite, chalcopyrite and pentlandite and may be partially remobilized along cleavage or fractures in host silicates (Fig. 1.11B).

In the massive ore, pyrrhotite forms individual crystals (from 200 to $800 \mu \mathrm{m}$ ), containing tiny flames of pentlandite (from $5 \mu \mathrm{m}$ to $15 \mu \mathrm{m}$ ) and pentlandite and chalcopyrite ribbons ( $75 \mu \mathrm{m}$ wide; Fig. 1.11C and 11D).

The remobilized ore is also pyrrhotite-rich ( 70 vol\%) and preserves most of the primary textures described above. The modal composition is however generally different, characterized by more abundant pentlandite ( 25 vol\%) than chalcopyrite ( 5 vol\%). Different from the primary ore, in this type of mineralization the pyrrhotite is usually non-magnetic, which suggests the dominance of the troilite end-member. The external boundaries of the sulfides are reshaped, forming interstitial aggregates in a nematoblastic amphibole fabric. 

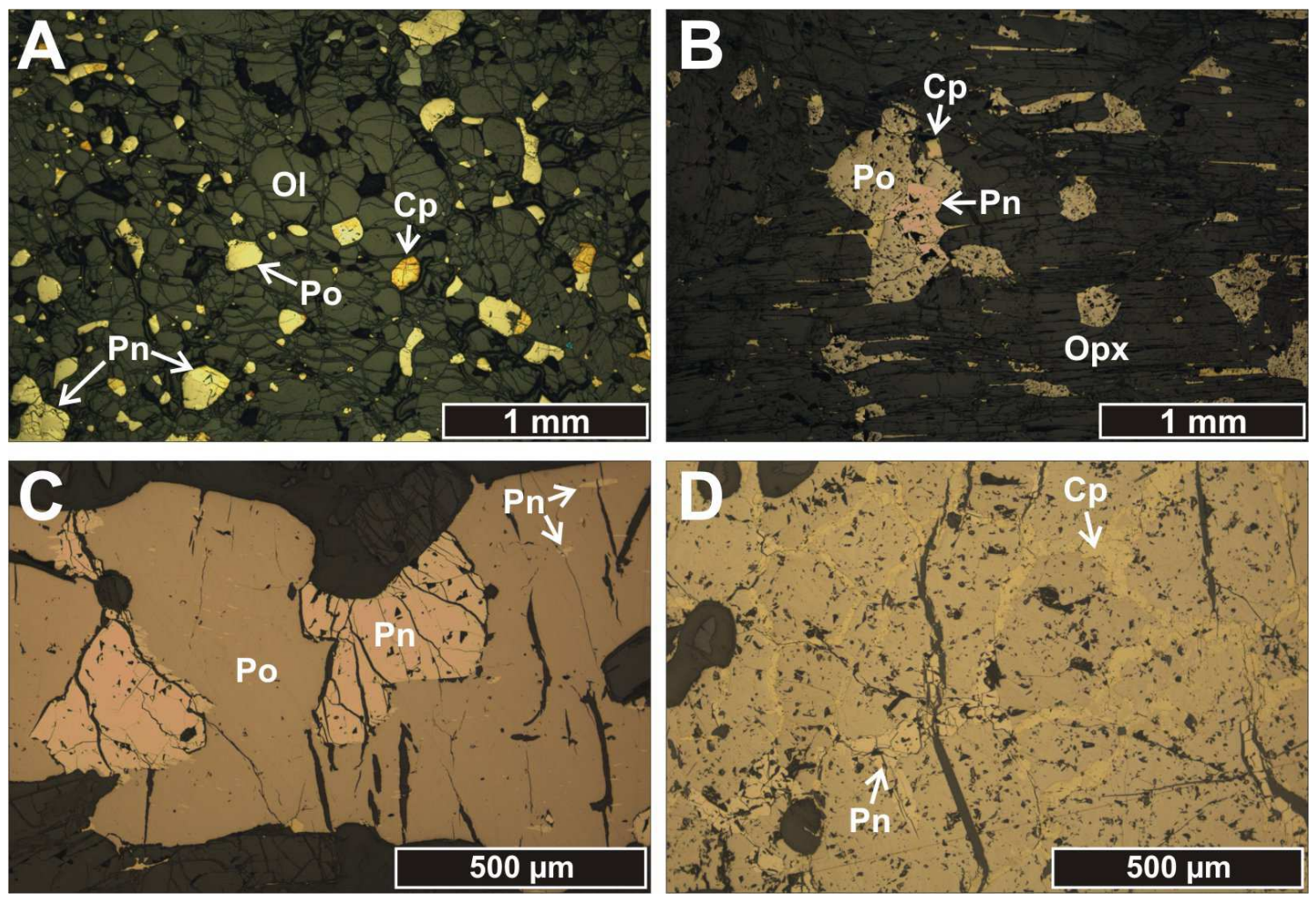

Fig. 1.11 (A) Sulfide blebs from the disseminated ore included in a large olivine grain. (B) Sulfide blebs and intercumulus sulfide from the disseminated ore partly remobilized into the cleavage of the bent orthopyroxene crystal. (C) Intercumulus sulfide from the disseminated ore with individual rounded pentlandite grains and tiny exsolution flames.

(D) The ribbon-texture network showing sub-solidus exsolution of chalcopyrite and pentlandite from pyrrhotite. Mineral symbols in accordance with classification of Kretz (1983).

Barren sulfides are commonly remobilized in the contact of the ultramafic intrusion with the paragneiss and also within the paragneiss. They are dominantly composed of pyrrhotite with minor amounts of pyrite and rare chalcopyrite. These sulfides are formed by fine-grained ( $200 \mu \mathrm{m})$ crystals elongated parallel to the regional foliation or to discrete shear zones.

\section{Discussion}

\section{The primary magmatic structure}

Despite the high-grade metamorphism and tectonics, the primary magmatic structure of the Limoeiro deposit is remarkably well preserved. The intrusive structure of Limoeiro forms a tube-like conduit with cross sections a few hundreds of meters in diameter for a considerable 
length of more than $4 \mathrm{~km}$. This sort of irregular intrusive geometry that cannot be classified as a laccolith, dyke, sill or other recognized body is called chonolith as defined by Bates and Jackson (1987). The chonolithic geometry is also used to describe other mafic-ultramafic intrusions that host Ni-Cu magmatic sulfide deposits, such as Nebo-Babel, in Australia (Seat et al., 2007; Seat et al., 2011), Kabanga North, in Tanzania (Evans et al., 2000; Maier et al., 2010), Uitkomst in South Africa (Gauert et al., 1995; De Waal and Maier, 2001; Li et al., 2002), Eagle in USA (Ripley and Li, 2011) and Thunder Bay North in Canada (Goodgame et al., 2010), and thus represent a very significant phase of the mafic-ultramafic magmatic system regarding $\mathrm{Ni}-\mathrm{Cu}(-$ PGE) sulfide ore formation.

$\mathrm{Ni}$-Cu sulfide mineralized intrusions of relatively small size have a high volume ratio of sulfide to silicate. This characteristic is considered to result from multiple magma pulses, as exemplified among others by Nebo-Babel (Seat et al., 2007), Noril'sk (Naldrett, 1992; Arndt et al., 2003), Voisey's Bay (Li and Naldrett, 1999) and Kalatongke (Gao et al., 2012). These intrusions are characterized by complex magmatic structures. These complex structures are likely to result from multiple magma pulses flowing through linear weaknesses in the country rocks. Due to the metamorphic-tectonic overprint, the interpretation of magmatic processes leading to the chonolithic geometry of the ultramafic intrusion that host the Limoeiro deposit needs to be considered with additional caution. A proposed model for the emplacement of the intrusive ultramafic body is presented in Figure 12 and discussed herein. This model, which was successfully applied for planning the drilling program by VM, is based on broad geological features, and will be tested further by studies of the Limoeiro deposit based upon lithogeochemical and isotopic data (Mota-e-Silva, in prep).

An obvious initial question regarding the chonolithic structure associated with the Limoeiro Deposit is to establish the original position of this conduit-type intrusion. This question derives from the possible dislocation of blocks during the regional tectonic event, which may lead to an actual location distinct from the original position of the intrusion. Based on the location of massive layers in the basal zone of the Upper Sequence in distinct tectonically sliced portions of the chonolith, including the better preserved Retiro and the tectonically disrupted Piçarra targets (Fig. 1.6), we propose that the base of the chonolithic intrusion was originally 
subhorizontal (Fig. 1.12). These thin layers of massive sulfides follow the elongate intrusive geometry and are broadly concordant with the lower contact of the Upper Sequence harzburgite, thus supporting a subhorizontal intrusion. The direction of the magma flow in a vertical conduit is assumed to be upwards as the result of magma ascending from the mantle to the crust, as illustrated by the intrusions associated with the Eagle deposit (Ripley and Li, 2011). Defining the direction of magma flow in sub-horizontal chonolithic structures, especially when the magmatic structure is not entirely exposed or preserved, is not so straightforward. As far as the ultramafic intrusion hosting the Limoeiro deposit is concerned, the direction of magma flow will be further assessed through lithogeochemical studies (Mota-e-Silva, in prep). At this stage we assume that the magma flowed eastward, from the unmineralized ultramafic rocks of the Upper Sequence in the western portion of the Parnazo target, to progressively sulfide-enriched rocks of the Upper Sequence in the eastern portion of the Parnazo and the Retiro targets (Fig. 1.12). This assumption of the direction of magma flow takes into account two geological features. Firstly, it considers that country rocks of the Parnazo target, where gneissic rocks with abundant sulfides were intersected by drilling (Fig. 1.7), may have provided an external source of sulfur that helped sulfide segregation when magma flowed through this part of the conduit system. An external source of $S$ is just constrained by geological features, with no sulfur isotope data yet available. Secondly, it considers that the transition from the smaller conduit structure of the Parnazo target, with cross sections just 100 to 200 meters in diameter, to the larger conduit structure of the Retiro target, with a cross section up to several hundreds of meters in diameter, are linked to the more robust concentration of sulfides in the latter. This enlargement in the conduit structure may have changed the flow dynamics of the magma, providing a better environment for sulfide deposition. When the magma that flows through a narrow chamber reaches a more enlarged space it will slow down and will be less capable of carrying the sulfide blebs. This process is similar that what was proposed for some $\mathrm{Ni}-\mathrm{Cu}$ sulfide deposits in the Voisey's Bay area (Li and Naldrett, 1999) as well as for offset dike mineralization in the Sudbury Igneous Complex (Lightfoot and Farrow, 2002). The massive sulfide layer, as indicated clearly in the Retiro target, is not located exactly at the base of the Upper Sequence but a few meters upwards. An explanation for the location of massive sulfides close the lowermost portion of the Upper Sequence, but not exactly at the bottom, is that the base of the Upper Sequence was a 
chilled margin where cooling is faster. Under these conditions the permeability would not remain open for sulfide migration, thus concentrating the sulfides percolating from the center of the intrusion at the upper part of this chilled margin.

The existence of two distinct sequences of ultramafic rocks, denominated Lower and Upper sequences, is a distinctive feature of the Limoeiro deposit (Fig. 1.6 and 12), that suggests a multi-pulse dynamic magma conduit. In the Parnazo and Retiro targets, where the primary magmatic structure is better preserved, each sequence consists of a core of harzburgite enveloped by orthopyroxenite, with an irregular and discontinuous outer shell of amphibolite (Fig. 1.6 and 12). The latter has metamorphic texture and minerals, but is nevertheless interpreted to be the outer contact zone of the intrusion, originally consisting of a chilled margin and/or a marginal breccia zone. A brecciated zone is indicated by closely associated amphibolite and gneiss, as well as gneiss xenoliths and feldspar xenocrysts within orthopyroxenite of the outer zone. The Upper and Lower sequences have similar thickness, magmatic structure, rock types, cumulus minerals and textures. These features suggest that they were formed by compositionally similar magmas within the same type of magmatic intrusion. In the Parnazo and Retiro targets, the Lower and Upper sequences have highly distinct $\mathrm{S}$ contents (Fig. 1.7), resulting from the presence of disseminated $\mathrm{Ni}-\mathrm{Cu}$ sulfide mineralization only in the latter (Fig. 1.5 and 12). This feature indicates that the events that led to sulfide saturation and segregation described in the Upper Sequence of the Parnazo and Retiro targets do not have an equivalent in the Lower Sequence of these targets. The combined geological features of the intrusions has lead to our interpretation that the Lower and Upper sequences evolved independently, with each being emplaced under open system conditions and developing their own chilled margin and/or border zone. Emplacement under open system conditions for both sequences is suggested by the constant composition of harzburgite $(\mathrm{OI}+$ Opx + Chr cumulate) over a strike length of a few $\mathrm{km}$. Even though large intrusions interpreted as closed systems may also have stratigraphic sections with constant compositions over several $\mathrm{km}$, they are distinct from the Limoeiro intrusion by the much larger variety of rock types throughout their stratigraphy. The Lower and Upper sequences are interpreted to be two major pulses of magma, the second one resulting in further inflation of the conduit. The rocks interpreted to represent the chilled margins of the Lower and Upper sequences consist of 
amphibolite, within which primary magmatic textures were obliterated by tectonics and associated metamorphic recrystallization. The use of chilled textures to establish the chronological order of emplacement of these two sequences is therefore compromised, and they are not used to indicate which sequence was emplaced first. In our model (Fig. 1.12) the Lower Sequence is assumed to be the first one to be emplaced, which is supported by the fact that the massive sulfide layers, interpreted to be the basal portion of the Upper Sequence, do not seem to be disturbed by a subsequent major emplacement of magma. Independently of the order of emplacement, it is important to stress that they result from distinct influxes of magma. The contact between the Lower and Upper sequences is different in the Parnazo and Retiro targets. In the Parnazo target the contact consists of an irregular layer of amphibolite associated with orthopyroxenite, while in the Retiro target it occurs within a sequence of orthopyroxenite (Fig. 1.6). In both targets the contact between these two sequences is also defined by the sharp increase in S contents in the Upper Sequence (Fig. 1.7). The probable explanation for such geological setting is that the emplacement of the Lower Sequence started with magma flowing through a linear weakness in the country rocks. This second impulse of magma (e.g. the Upper Sequence) was initially emplaced close to but slightly above the contact with the previously emplaced Lower Sequence structure, thus preserving the outer contact zone with country rocks in the Parnazo target (Fig. 1.12). When this second pulse of magma developed a larger conduit structure in the Retiro target it overlapped with the former structure of the Lower Sequence, resulting in further inflation of the conduit, such that no country rocks were preserved in the contact zone (Fig. 1.12).

It is worth mentioning that the tectonically disturbed Piçarra and Bofe targets, where the geological distinction between the Upper and Lower sequences is less precisely defined, were not considered so far in our model. Whenever we are able to define how the Upper and Lower sequences proceed to the east of the Retiro target, using lithogeochemical data (Mota-eSilva, in prep), our model will be enlarged to contemplate the eastern portion of the chonolithic structure. 


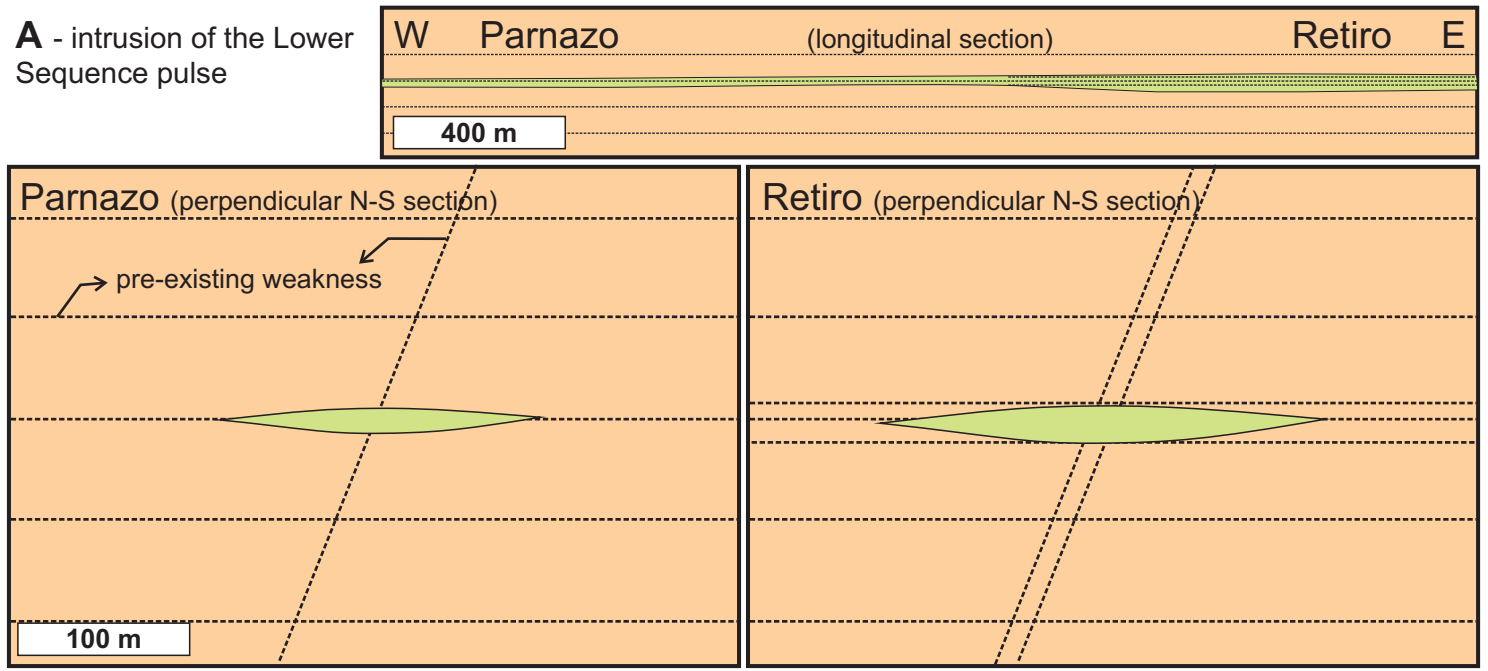

B - inflation of the Lower Sequence pulse
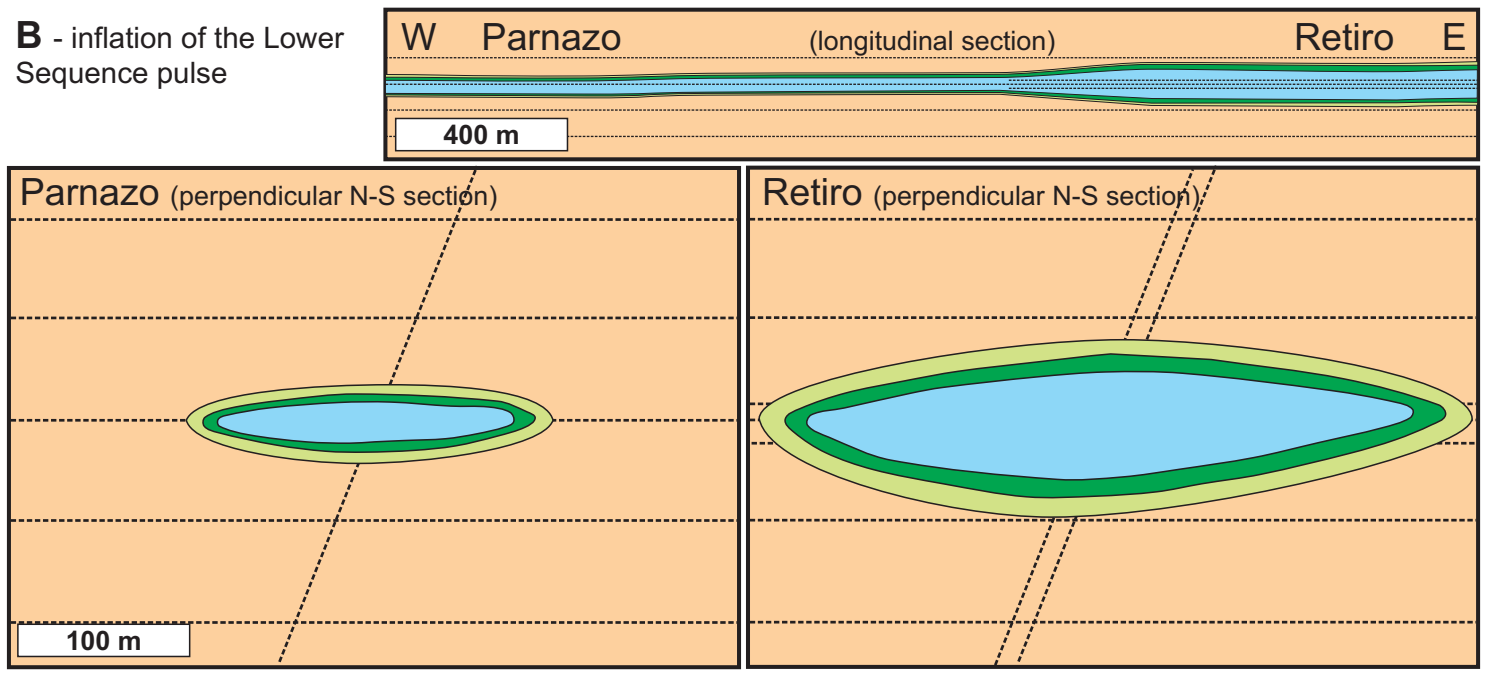

C - intrusion and inflation of the Upper Sequence pulse carrying sulfides droplets

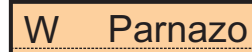

(longitudinal section)

Retiro E

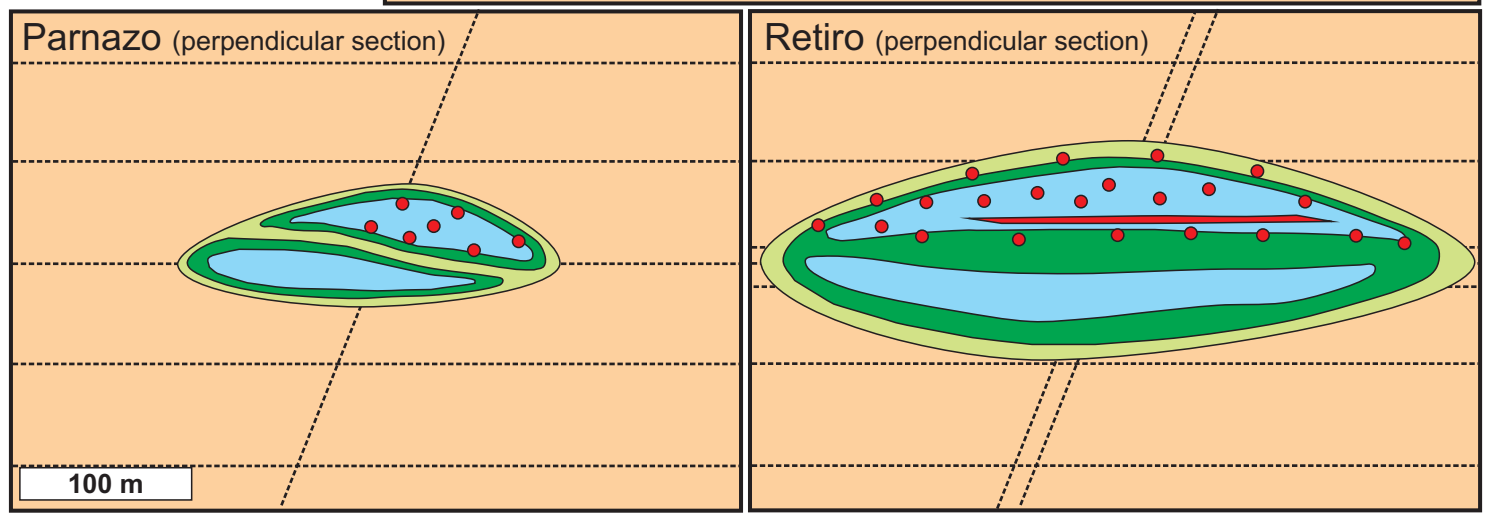

$\because$ Disseminated sulfides Amphibolite (chilled margin and/or marginal breccia zone)

Massive sulfides

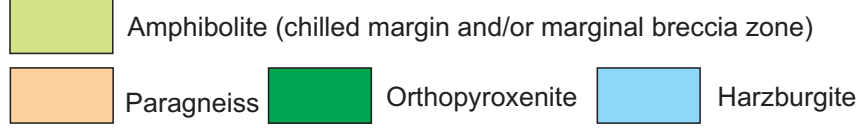

Fig. 1.12 Schematic geological sections showing the intrusive model for the ultramafic conduit that hosts the Limoeiro deposit. 
At this point it is not possible to conclude if the Limoeiro chonolithic conduit represents an open-system magma conduit connected to volcanic flows, as proposed for the mineralized sills in Noril'sk (Naldrett, 1992; Arndt et al., 2003), or a magma conduit located between two magma chambers, as proposed for the Voisey's Bay intrusion (Li and Naldrett, 1999; Ryan, 2000).

Further exploration for $\mathrm{Ni}$-Cu sulfide in the region should provide a broader view of this magmatic system, and constraints for the magmatic evolution away from the conduit structure investigated in this study.

\section{The ultramafic composition of the conduit}

The conduit intrusion that hosts the Limoeiro deposit is formed mainly by harzburgite and orthopyroxenite, with no significant amount of mafic rocks. A different type of conduit-type structure, consisting of dunite and/or peridotites, is frequently associated with komatiitic magmas (Arndt et al., 2008). Komatiitic magma systems do form Ni sulfide deposits in the conduit phase (a small component in these systems) of the magma ascent to the extensive flow fields (Arndt et al., 2008). The rocks formed in these small conduits of komatiite magmas are characterized by assemblages where olivine is the only cumulus mineral. The chonolith that hosts the Limoeiro deposit contrasts with these systems by two main reasons: (i) no volcanic rock that could represent remnants of an extensive flow fields of komatiite magma is known in the region; (ii) the rocks of the conduit consists mainly of harzburgite $(\mathrm{OI}+\mathrm{Opx}+\mathrm{Chr}$ cumulates) and orthopyroxenite (Opx \pm Chr cumulate). A komatititic composition for the rocks hosting the Limoeiro $\mathrm{Ni}$-Cu sulfide deposit is unlikely, based upon the geological and petrographic characteristics mentioned above and considering several geochemical lines of evidence, including the low $\mathrm{Ni} / \mathrm{Cu}$ content of the sulfide ore $(\sim 1)$, a subject to be addressed in the future studies (Mota-e-Silva, in prep). 
Conduit-type intrusions consisting solely of ultramafic rocks, as exemplified by the intrusions hosting the Jinchuan Ni-Cu sulfide deposit (Song et al., 2012) as well as several other small Ni-Cu-PGE mineralized intrusions in China (Song et al., 2003; Wang et al., 2010), are less common than conduits formed by mafic and ultramafic rocks [e.g. Kabanga North (Evans et al., 2000)] or even exclusively by mafic rocks [e.g. Noril'sk (Naldrett, 1992), Voisey's Bay (Li and Naldrett, 1999), Kalatongke (Gao et al., 2012)]. These ultramafic-only conduits are interpreted to result from mafic parental magmas within highly dynamic magma plumbing systems. The ultramafic rock assemblages and the presence of large amounts of $\mathrm{Ni}$-Cu sulfides suggest that the conduit-type structure of the Limoeiro deposit was also an open and very dynamic magma system.

\section{Tectonic-Metamorphic Overprint}

The Limoeiro deposit is located within a high-grade mobile belt formed during the Neoproterozoic Brasiliano/Pan-African orogenic cycle. The absolute age of the ultramafic intrusion that hosts the Limoeiro deposit is not known, but regional geological constraints suggest that both intrusion and host rocks belong to a terrain older than the orogenic cycle (see Regional Geology section).

The region where the Limoeiro deposit is located is strongly affected by the deformational, metamorphic, and magmatic episodes of the Brasiliano Orogenic Cycle (650 500 Ma; Brito Neves et al., 2000; Santos et al., 2010), and pre-orogenic structural or magmatic features are rarely preserved. Tectonic features developed during the Brasiliano orogeny in this area include two regional dextral shear zones, that internally consist in a network of several smaller sinistral NE-SW transcurrent shear zones that juxtapose different terrains (Fig. 1.1; Santos and Medeiros, 1999; Brito Neves et al., 2000). Despite the strong overprint of this deformational event throughout the Borborema Province, the intrusion hosting the Limoeiro deposit has its conduit structure largely preserved. Pervasively transformed rocks are restricted 
to the outer border contact of the intrusive body, as well as discrete shear zones that cut through the conduit structure. Several examples of partially to well-preserved mafic-ultramafic complexes that have been submitted to high-grade metamorphism occur within the Neoproterozoic mobile belts in Brazil. These examples include the Niquelândia and Barro Alto complexes in central Brazil (Ferreira Filho et al., 1992; 2010), the Ni-Cu sulfide mineralized Americano do Brasil (Mota-e-Silva et al., 2011) and Damolânida (DellaGiustina et al., 2011) intrusions in southern Goiás, and several layered intrusions in Tocantins (Lima et al., 2008). In all these examples the tectonism and associated metamorphic recrystallization is heterogeneous and mainly concentrated in the borders of the mafic-ultramafic intrusions or along discrete shear zones. The relatively well-preserved structure of the ultramafic chonolithic structure of the Limoeiro deposit, and mafic-ultramafic intrusions in general, compared to pervasively deformed high-grade gneissic country rocks, result from the widely known distinct rheological properties of rocks (Passchier et al., 1990). Considering the importance of magmatic structures for the development of magmatic $\mathrm{Ni}$-Cu sulfide deposits, the common preservation of primary features in intrusions submitted to high-grade tectonic-metamorphic events in mobile belts is particularly significant.

The country rocks of the chonolithic intrusion hosting the Limoeiro deposit are formed by paragneisses and schists of the Vertentes complex. These rocks have peak metamorphic assemblages consisting of garnet, sillimanite, quartz and k-feldspar, which indicate metamorphism at granulite facies. Ultramafic rocks of the Limoeiro intrusion were partially recrystallized under high-grade metamorphic conditions. According to experimental studies in the CMASH system, the ultramafic rocks have peak metamorphic assemblages that indicate conditions of the amphibolite-to-granulite facies transition, between the Opx-in $\left(\sim 700^{\circ} \mathrm{C}\right)$ and the Chl-out isograd $\left(850^{\circ} \mathrm{C}\right)$ under mid-crustal pressures (spinel stability field; Jenkins, 1981; Schmädicke, 2000). Peak metamorphic assemblages indicate that similar high-grade metamorphic conditions characterize both the ultramafic chonolithic intrusion and country rocks. A high-grade metamorphic event related to the 630 - 610 Ma period of the Brasiliano Orogenic Cycle was described in this part of the Borborema Province in several studies (Neves et al., 2006; Santos et al., 2010). 


\section{Implications for Exploration}

Small conduit-type mafic-ultramafic intrusions, like the one that hosts the Limoeiro deposit, are a common geological setting for magmatic $\mathrm{Ni}-\mathrm{Cu}$ sulfide deposits. This preferred association is now widely recognized as a key exploration guideline (Naldrett, 1997). The reasoning behind this geological association, as detailed by Barnes and Lightfoot (2005), is explained by a model whereby a sulfide liquid entrained in a flowing magma is precipitated in flow-dynamic traps within the magma conduits. Fingerprints of magma conduits hosting $\mathrm{Ni}-\mathrm{Cu}$ sulfide deposits are very small, thus representing a challenge to exploration. After location of the mafic-ultramafic body, detailed geological mapping supported by geochemical data and a high resolution geophysical survey should provide a preliminary delineation of the magmatic structure to support drilling of identified targets.

This exploration challenge may become harder when this small structure is affected by metamorphism, deformation and faults. This study indicates that the ultramafic chonolithic structure of the Limoeiro deposit is remarkably well-preserved contrasting with pervasively deformed high-grade gneissic country rocks. It is important to mention that the ultramafic chonolith that hosts the Limoeiro deposit was fully impacted by the high-grade metamorphism and associated tectonism of the Brasiliano Orogenic Cycle (ca 630-610 Ma; Neves et al., 2006). This is a different situation when compared to the Ni-Cu sulfide mineralized chonolith of the Nebo-Babel intrusion in Australia, intruded after the ca. 1.1 Ga Musgrave Orogeny (Seat et al., 2007), as well as the medium-sized layered intrusion that hosts the Santa Rita Ni-Cu sulfide deposit in Brazil, intruded shortly after peak metamorphism of the ca. 2.1 Ga Transamazonian Orogeny (Barnes et al., 2011; Lazarin, 2011). Therefore, the intrusion hosting the Limoeiro deposit is probably the best-preserved chonolith that has been overprinted by granulite facies metamorphism within an orogenic terrain. An important lesson from our study is that reconstruction of small magma conduits, an important tool for exploration for $\mathrm{Ni}-\mathrm{Cu}$ sulfide deposits, may be successfully achieved within high-grade orogenic terrains. 
The Limoeiro deposit is a key example to conclude that the Borborema Province and other deformed geological provinces in the World should not be overlooked during exploration for primary magmatic Ni-Cu ores.

\section{Conclusions}

The principal conclusions of this study are as follows:

1. The Limoeiro deposit is the first discovery of a nickel sulfide deposit in the Borborema Province, a high-grade mobile belt formed during the Neoproterozoic Brasiliano/Pan-African orogenic cycle.

2. Despite the high-grade metamorphism and the tectonic deformation, the primary magmatic structure of the intrusion hosting the Limoeiro deposit is remarkably well preserved. This intrusion forms a tube-like conduit (chonolith) with cross sections a few hundreds of meters in diameter and of the considerable length of more than 4 $\mathrm{km}$.

3. The tube-like conduit that hosts the Limoeiro deposit consists of two distinct sequences of ultramafic rocks, denominated Upper and Lower sequences. Each sequence consists of a core of harzburgite enveloped by orthopyroxenite, with an irregular and discontinuous outer shell of amphibolite.

4. The Upper and Lower sequences have similar thickness, magmatic structure, rock types, cumulus minerals and textures. These sequences have highly distinct $S$ contents resulting from the presence of disseminated $\mathrm{Ni}-\mathrm{Cu}$ sulfide mineralization in the former. 
5. The magmatic system of the Limoeiro deposit is considered to result from the input of two major pulses of magma with similar composition. Sulfide saturation and segregation is restricted to the second magma pulse (Upper Sequence).

6. Ni-Cu(-PGE) sulfide mineralization in the Limoeiro deposit is associated with the Upper Sequence of ultramafic rocks, and different ore bodies resulted from tectonic slicing of the originally continuous tube-like structure. The bulk of the mineralization in all ore bodies consists of thick (up to 150 meters) and elongated (up to $1 \mathrm{~km}$ ) masses of disseminated sulfides broadly concordant with the chonolithic structure. Massive ore occur in the lower portions of some of the ore bodies, and represents about 3 vol\% of the Limoeiro deposit.

7. The intrusion hosting the Limoeiro deposit is probably the best-preserved chonolith that has been overprinted by granulite facies metamorphism within an orogenic terrain. This study indicates that reconstruction of small magma conduits, an important tool for exploration for $\mathrm{Ni}$-Cu sulfide deposits, may be successfully achieved within high-grade orogenic terrains.

8. The discovery of the Limoeiro deposit opens a new window for exploration in the Borborema Province in Brazil, and remarks the possibility of finding primary Ni$\mathrm{Cu}(-\mathrm{PGE})$ deposits in high-grade mobile belts elsewhere.

\section{Acknowledgements}

This study was supported by Votorantim Metais Ltda (VM) and Universidade de Brasilia (UnB). We thank the field geologists of VM Limoeiro project for their stimulating interest and contributions for this study. The authors thank Paulo Pires, Lucio Molinari and Jones Belther from VM for their allowing the use of the company's private data and encouragement on publishing this part of the first author's Ph.D. thesis. The authors are grateful to the "Conselho 
Nacional de Ciência e Tecnologia" (CNPq) for continuous support to field and laboratory work through research grants. Cesar F. Ferreira Filho is a Research Fellow from CNPq. We thank the referees Tony Green and Joyashish Thakurta and associated editor Larry Meinert for providing constructive and helpful reviews.

\section{References}

Accioly, A.C.A., McReath, I., Santos, E.J., Guimarães, I.P., and Santos, A.C., 2003, The ages of crystallization and metamorphism of the Passira Anorthosite Complex, Borborema Province, Northeastern Brazil: Short Papers, IV South American Symposium on Isotope Geology, p. 487-490.

Almeida, F.F.M., Hasui, Y., Brito Neves, B.B., and Fuck, R.A., 1981, Brazilian structural provinces: an introduction: Earth Science Reviews, v. 17, p. 1-29.

Anglo American, 2011, Annual Report (http://www.angloamerican.com/ /media/Files/A/AngloAmerican-PIc/reports/aa-ar2011-new.pdf).

Arndt, N.T., Czamanske, G.K., Walker, R.J., Chauvel, C., and Fedorenko, V.A., 2003, Geochemistry and Origin of the Intrusive Hosts of the Noril'sk-Talnakh Cu-Ni-PGE Sulfide Deposits: Economic Geology, v. 98, p. 495-515.

Arndt, N.T., Lesher, C.M., and Barnes, S.J., 2008, Komatiite: Cambridge, Cambridge University Press, $467 \mathrm{p}$.

Barnes, S.-J., Lightfoot, P.C., 2005, Formation of magmatic nickel sulfide ore deposits and processes affecting their copper and platinum group element contents: Economic Geology, $\forall .100^{\text {th }}$ Anniversary Volume, p. 179-213.

Barnes, S.J., Osborne, G.A., Cook, D., Barnes, L., Maier, W.D. and Godel, B., 2011, The Santa Rita Nickel Sulfide Deposit in the Fazenda Mirabela Intrusion, Bahia, Brazil: Geology, Sulfide Geochemistry, and Genesis: Economic Geology, v. 106, p. 1083-1110.

Bates, R.L.; and Jackson, J.A.J. (ed.), 1987, Glossary of Geology: 3rd. Edition, American Geological Institute, Alexandria, USA, 788 p.

Brito Neves, B.B., Santos, E.J., and Van Schmus, W.R., 2000, Tectonic History of the Borborema Province, Northeast Brazil, in: Cordani, U.G., Milani, E. J., Thomaz Filho, A., 
and Campos, D.A., eds., Tectonic Evolution of South America: Rio de Janeiro, 31st International Geological Congress, 2000, p. 151-182.

De Waal, S.A., and Maier, W.D., 2001, Parental magma and emplacement of the stratiform Uitkomst complex, South Africa: The Canadian Mineralogist, v. 39, p. 557-571.

DellaGiustina, M.E.S., Pimentel, M.M., Ferreira Filho C.F., and Hollanda, M.H.B.M., 2011, Dating coeval mafic magmatism and ultrahigh-temperature metamorphism in the Anápolis-Itauçu Complex, Central Brazil: Lithos, v. 124, p. 82-102.

Evans, D.M., Boadi, I., Byemelwa, L., Gilligan, J., Kabete, J., and Marcet, P., 2000, Kabanga magmatic nickel sulphide deposits, Tanzania: morphology and geochemistry of associated intrusions: Journal of African Earth Sciences, v. 30, p. 651-674.

Ferreira Filho, C.F., Nilson, A.A., and Naldrett, A.J., 1992, The Niquelândia Mafic-Ultramafic Complex, Goias, Brazil: a contribution to the ophiolite X stratiform controversy based on new geological and structural data: Precambrian Research, v. 59, p. 125-143.

Ferreira Filho, C.F., Pimentel, M.M., Araujo, S.M., and Laux, J.H., 2010, Layered intrusions and volcanic sequences in Central Brazil: Geological and geochronological constraints for Mesoproterozoic (1.25 Ga) and Neoproterozoic (0.79 Ga) igneous associations: Precambrian Research, v. 183, p. 617-634.

Gao, J., Zhou, M., Lightfoot, P.C., Wang, C.Y., and Qi, L., 2012, Origin of PGE-Poor and CuRich Magmatic Sulfides from the Kalatongke Deposit, Xinjiang, Northwest China: Economic Geology, v. 107, p. 481-506.

Gauert, C.D.K., de Waal, S.A., and Wallmach, T., 1995, Geology of the ultrabasic to basic Uitkomst Complex, eastern Transvaal, South Africa: an overview: African Journal of Earth Sciences, v. 21, p. 553- 570.

Goodgame, V.R., Johnson J.R., MacTavish A.D., Stone W.E., Watkins, K.P., and Wilson, G.C., 2010, The Thunder Bay North Deposit: Chonolith-Hosted Pt-Pd-Cu-Ni Mineralization Related to the Midcontinent Rift: International Platinum Symposium, $11^{\text {th }}$, Canada, 2124 June 2010 (http://11ips.laurentian.ca/NR/rdonlyres/99202861-604D-4E34-A4600C3F11617066/0/Goodgameetal.pdf).

Jenkins, M.D., 1981, Experimental phase relations of hydrous peridotites modeled in the system $\mathrm{H}_{2} \mathrm{O}-\mathrm{CaO}-\mathrm{MgO}-\mathrm{Al}_{2} \mathrm{O}_{3}-\mathrm{SiO}_{2}$ : Contributions to Mineralogy and Petrology, v. 77 , p. 166176.

Kretz, R., 1983, Symbols for rock-forming minerals: American Mineralogist, v. 68, p. 277-279. 
Lazarin, F.A., 2011, Geologia, Petrologia e Estudos Isotópicos dos Depósitos de Níquel-Cobre Sulfetados Santa Rita e Peri-Peri, Nordeste do Brasil: MSc thesis, Brasilia, Brazil, Universidade de Brasilia, 69 p. (in Portuguese).

Li, C., and Naldrett, A.J., 1999, Geology and petrology of the Voisey's Bay intrusion: reaction of olivine with sulfide and silicate liquids: Lithos, v. 47, p. 1-31.

Li, C., Ripley, E.M., Maier, W.D., and Gomwe, T.E.S., 2002, Olivine and sulfur isotopic compositions of the Uitkomst $\mathrm{Ni}-\mathrm{Cu}$ sulfide ore-bearing complex, South Africa: evidence for sulfur contamination and multiple magma emplacements: Chemical Geology, v. 188, p. $149-159$.

Lightfoot, P.C., and Farrow, C.E.G., 2002, Geology, geochemistry, and mineralogy of the Worthington offset dike: A genetic model for offset dike mineralization in the Sudbury Igneous Complex: Economic Geology, v. 97, p. 1419-1445.

Lima, H.A.F., Ferreira Filho, C.F., Pimentel, M.M., Dantas, E.L., and Araújo, S.M., 2008, Geology, petrology and geochronology of the layered mafic-ultramafic intrusions in the Porto Nacional area, central Brazil: Journal of South American Earth Sciences, v. 26, p. 300-317.

Maier, W.D., Barnes, S., Arindam, S., Ripley, E., Li, C., and Livesey, T., 2010, The Kabanga Ni sulfide deposit, Tanzania: I. Geology, petrography, silicate rock geochemistry, and sulfur and oxygen isotopes: Mineralium Deposita, v. 45, p. 419-441.

Mota-e-Silva, J., Ferreira Filho, C.F., Bühn, B., and Dantas, E.L., 2011, Geology, petrology and geochemistry of the "Americano do Brasil" layered intrusion, central Brazil, and its $\mathrm{Ni}-$ Cu sulfide deposits: Mineralium Deposita, v. 46, p. 57-90.

Mota-e-Silva, J., in prep., Complexo Ultramáfico de Limoeiro: Mineralização Ni-Cu(-PGE) e Contextualização Regional: Ph.D. thesis, Universidade de Brasilia, Brazil, (in Portuguese).

Naldrett, A.J., 1992, A model for the Ni-Cu-PGE ores of the Noril'sk region and Its application to other areas of flood basalts: Economic Geology, v. 87, p. 1945-1962.

Naldrett, A.J., 1997, Key factors in the genesis of Noril'sk, Jinchuan, Voisey's Bay and other world-class Ni-Cu-PGE deposits: implications for exploration: Australian Journal of Earth Sciences, v. 44, p. 283-315.

Neves, S.P., and Alcantara, V.C., 2010, Geochemistry of orthogneisses and metasedimentary rocks across a proposed terrane boundary in the Central Domain of Borborema 
Province, NE Brazil: Geodynamic implications: Journal of South American Earth Sciences, v. 29, p. 498-511.

Neves, S.P., Bruguier, O., Vauchez, A., Bosch, D., Silva, J.M.R., and Maraino, G., 2006, Timing of crust formation, deposition of supracrustal sequences, and Transamazonian and Brasiliano metamorphism in the East Pernambuco belt (Borborema Province, NE Brazil): implications for western Gondwana assembly: Precambrian Research, v. 149, p. 197-216.

Neves, S.P., Bruguier, O., Silva, J.M.R., Bosch, D., Alcantara, V.C., and Lima, C.M., 2009, The age distributions of detrital zircons in metasedimentary sequences in eastern Borborema Province (NE Brazil): evidence for intracontinental sedimentation and orogenesis?: Precambrian Research, v. 175, p. 187-205.

Passchier, C.W., Myers, J.S., and Kroner, A., 1990, Field Geology of High-Grade Gneiss Terrains: Springer-Verlag, Berlin, $150 \mathrm{p}$.

Ripley, E.M., and Li, C., 2011, A Review of Conduit-Related Ni-Cu-(PGE) Sulfide Mineralization at the Voisey's Bay Deposit, Labrador, and the Eagle Deposit, Northern Michigan: Reviews in Economic Geology, v. 17, p. 181-197.

Ryan, B., 2000, The Nain-Churchill Boundary and the Nain Plutonic Suite: A Regional Perspective on the Geologic Setting of the Voisey's Bay Ni-Cu-Co Deposit: Economic Geology, v. 95, p. 703-724.

Sá, J.M., Bertrand, J.M., Leterrier, J., and Macedo, M.H.F., 2002, Geochemistry and geochronology of pre-Brasiliano rocks from the Transversal Zone, Borborema Province, Northeast Brazil: Journal of South American Earth Sciences, v. 14, p. 851 - 866.

Santos, E.J., and Medeiros, V.C., 1999, Constraints from granitic plutonism on Proterozoic crustal growth of the Transverse Zone, Borborema Province, Northeast Brazil: Revista Brasileira de Geociências, v. 29, p. 73-84.

Santos, E.J., Van Schmus, W.R., Kozuch, M., and Brito Neves, B.B., 2010, The Cariris Velhos tectonic event in northeast Brazil: Journal of South American Earth Sciences, v. 29, p. 61-76.

Schmädicke, E., 2000, Phase relations in peridotitic and pyroxenitic rocks in the model systems CMASH and NCMASH: Journal of Petrology, v. 41, p. 69-86.

Seat, Z., Beresford, S.W., Grguric, B.A., Waugh, R.S., Hronsky, J.M.A., Gee, M.A.M., Groves, D.I., and Mathison, C.I., 2007, Architecture and emplacement of the Nebo-Babel 
gabbronorite-hosted magmatic Ni-Cu-PGE sulphide deposit, West Musgrave, Western Australia: Mineralium Deposita, v. 42, p. 551-581.

Seat, Z., Gee, M., Grguric, B.A., Beresford, S.W., and Grassineau, N.V., 2011, The Nebo-Babel Ni-Cu-PGE Sulfide Deposit (West Musgrave, Australia): Pt. 1. U/Pb Zircon Ages, Whole-Rock and Mineral Chemistry, and O-Sr-Nd Isotope Compositions of the Intrusion, with Constraints on Petrogenesis: Economic Geology, v. 106, p. 527-556.

Song, X-Y., Zhou, M-F., Cao, Z-M., Sun, M., and Wang, Y-L., 2003, The Ni-Cu-(PGE) magmatic sulfide deposits in the Yangliuping Area within the Permian Emeishan Large Igneous Province, SW China: Mineralium Deposita, v. 38, p. 831-843.

Song, X-Y., Danyushevsky, L.V., Keays, R.R., Chen, L-M., Wang, Y-S., Tian, Y-L., and Xiao. JF., 2012, Structural, lithological, and geochemical constraints on the dynamic magma plumbing system of the Jinchuan $\mathrm{Ni}-\mathrm{Cu}$ sulfide deposit, NW China: Mineralium Deposita, v. 47, p. 277-297.

Van Schmus, W.R., Brito Neves, B.B., Hackspacher, P.C., and Babinski, M., 1995, U-Pb and Sm-Nd geochronological studies of the Eastern Borborema Province, Northeast Brazil: initial conclusions: Journal of South American Earth Sciences, v. 8, p. 267-288.

Van Schmus, W.R., Kozuch M., and Brito Neves B.B., 2011, Precambrian history of the Zona Transversal of the Borborema Province, NE Brazil: Insights from Sm-Nd and U-Pb geochronology: Journal of South American Earth Sciences, v. 31, p. 227-252.

Votorantim Metais Ltda, 2012, Relatório Parcial de Pesquisa - Projeto Limoeiro presented to DNPM in $25^{\text {th }}$ September 2012, 81 p. (in Portuguese).

Wang, C.Y., Zhou, M-F., and Qi, L., 2010, Origin of extremely PGE-rich mafic magma system: An example from the Jinbaoshan ultramafic sill, Emeishan large igneous province, SW China: Lithos, v. 119, p. 147-161. 


\section{CAPÍTULO 2}

Mineral and whole rock chemistry of the chonolith that hosts the Limoeiro $\mathrm{Ni}-\mathrm{Cu}-(\mathrm{PGE})$ deposit: evidence of magma flow direction, siderophile element depletion and sulfide fractionation 


\title{
Mineral and whole rock chemistry of the chonolith that hosts the Limoeiro Ni-Cu-(PGE) deposit: evidence of magma flow direction, siderophile element depletion and sulfide fractionation
}

\author{
Jonas Mota-e-Silva $^{1,2}$, Cesar Fonseca Ferreira Filho ${ }^{2}$ \\ ${ }^{1}$ Votorantim Metais, Exploration Division, Polo Industrial Multivias, Jundiai/SP, 13212-161, \\ Brazil \\ ${ }^{2}$ University of Brasilia, Geosciences Institute, Brasília/DF, 70900-970, Brazil
}

\section{Abstract}

The mineral chemistry and lithochemistry of the chonolith that hosts the Limoeiro NiCu-(PGE) sulfide deposit reveals a history of the intrusion mechanism of a mafic magma multipulse dynamic conduit system with special attention for ore formation. The Limoeiro deposit was recently discovered (2009) and the extensive drilling allows us to interpret a comprehensive history of igneous petrology and ore formation. In this study we show that Limoeiro is formed by four different magmatic sequences each representing a major magma pulse. The upper most sequence (Low-Cr) has relatively low MgO ( 21 wt\%) and $\mathrm{Cr}(\sim 400 \mathrm{ppm})$ contents, very high $\mathrm{Cu} / \mathrm{Pd}$ ratio $(\sim 7200)$ and low forsterite content in olivines $\left(\mathrm{Fo}_{82}\right)$, indicating a more fractionated magma that had segregated sulfide somewhere upstream. The Upper sequence is the most mineralized and its sulfides decrease in $\mathrm{Ni}, \mathrm{Cu}, \mathrm{Pt}$ and $\mathrm{Pd}$ tenors to the east, together with an increase of $\mathrm{Cu} / \mathrm{Pd}$ ratio (from 5200 to 5800 ). These patterns suggest progressively more evolved magma to the east, due to increasing contamination or fractionation of eastwards flowing magma. The Transition Zone and Lower sequences are the sequences forming the lower most part of stratigraphy. A primitive tholeiitic picrite type of magma has formed all sequences. This magma was formed by a high degree of partial melting of an E-MORB mantle source (given its parental magma rare-earth and trace elements composition) from a depth not

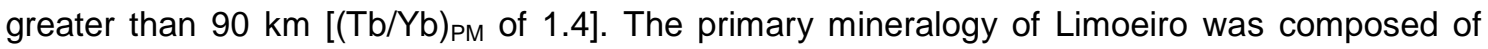
olivine phenocrysts, cumulus orthopyroxene and intercumulus clinopyroxene, plagioclase and 
amphibole. Subsequent metamorphism has totally transformed the primary mineral assemblage of the external parts of intrusion, and partly transformed it in the inner part. Finally the ore chemistry indicates that Cu-rich residual liquid has fractionated during the MSS crystallization, probably generating chalcopyrite-rich oreshoots (which have not been discovered yet). Rather than formed by vertical settling process, the massive sulfide liquid has flowed horizontally and has been injected into the silicate crystal mush to the east. These results have the potential to influence strategies that will guide the ongoing Limoeiro conduit system exploration, as well as to enhance the overall understanding of the geological setting, dynamics and potential in mafic magma conduit systems.

\section{Introduction}

Magmatic deposits are the main source of nickel and platinum group elements (PGE), and a significant producer of copper, generally as by-product. These deposits occur as sulfide concentrations associated with a variety of mafic and ultramafic magmatic rocks (Naldrett, 2004). It is known that the majority of known Ni resources are contained in laterite ores (Mudd, 2010). However, the cost and challenges related to processing this ore type drove the industry to produce nickel mostly from sulfide deposits, especially when metal commodities prices are relatively low. In recent years only a few major Ni sulfide deposit has been discovered [e.g., Nova-Bollinger deposits in Australia (Bennett et al., 2014)] and increasingly old sulfide mines are becoming exhausted. In this sense, to explore and discover a new world-class sulfide $\mathrm{Ni}$ deposit is strategic for the mining industry.

There are some classic key concepts that should be used during exploration for $\mathrm{Ni}$ $\mathrm{Cu}$-(PGE) sulfide ores: (i) the parental magma must contain sufficient concentrations of $\mathrm{Ni}, \mathrm{Cu}$ and PGE; (ii) the magma must reach sulfur saturation in order to segregate immiscible sulfide; (iii) the sulfides must interact with sufficient amount of silicate magma to capture chalcophile elements in high concentrations; (iv) the sulfides must be spatially restricted to constitute an economic and exploitable ore (Naldrett, 2004). Some authors (Naldrett, 1966, Keays, 1995 and 
Li et al., 2001a) documented the importance of assimilation of $S$ directly from country rocks to produce large sulfide deposits, although other authors (Lesher and Campbell, 1993; Arndt et al., 2005; Seat et al., 2009) interpret that the magma must be driven to sulfide saturation by contamination, with or without the addition of external S. This is a controversial discussion; however there is a general consensus that dynamic magmatic systems, such as a magma conduit, where sulfides blebs are continuously accumulated and upgraded in metals by a new fresh incoming magma, is a very fertile environment to form large Ni-Cu-(PGE) sulfide deposits (Li et al., 2001a; Naldrett, 2004; Arndt et al., 2005; Seat et al., 2009).

The Limoeiro Ni-Cu-(PGE) sulfide deposit (Mota-e-Silva et al., 2013), in northeastern Brazil, represents a relatively low-grade recent discovery, although the mafic magma conduit system related to it constitutes an extensive area for greenfield exploration with potential to host one or more World-class sulfide $\mathrm{Ni}$ deposits. In this study we characterize the geology, lithochemistry and mineral chemistry of the Limoeiro deposit and its host chonolith. This study is particularly interesting as it deals with a well preserved mafic magma multi-pulse dynamic conduit system, characterizing its mantle source for parental magma, emplacement dynamics, magma fractionation and sulfide liquid accumulation, sulfide liquid fractionation and later injection into crystal mush. These results have the potential to influence strategies that will guide the ongoing Limoeiro conduit system exploration, as well as to enhance the overall understanding of the geological setting, dynamics and potential in mafic magma conduit systems.

\section{Geological setting}

The ultramafic rocks that host the Limoeiro Ni-Cu-(PGE) sulfide deposit are located in northeastern Brazil, in a high grade mobile belt belonging to the Pan-African / Brasiliano orogenic cycle (650-500 Ma) known as the Borborema province (Almeida et al. 1981; Brito Neves et al. 2000; Santos et al. 2010) (Fig. 2.1). This intrusion has a chonolithic (tubular) 
geometry that represents a magma conduit hosted within high grade paragneiss and schist. The intrusion, which is elongated in an ENE-WSW direction, is disrupted by faults. The faults define the drilling target blocks from the west to the east as: Parnazo, Retiro, Piçarra and Bofe (Fig. 2.2). A previous study (Mota-e-Silva et al., 2013) recognized that the intrusion could be divided into two distinct sequences (Upper and Lower) of ultramafic rocks, each one consisting of a core of harzburgite enveloped by orthopyroxenite (olivine + orthopyroxene \pm chromite and orthopyroxene \pm olivine \pm chromite cumulates respectively), with an irregular and discontinuous metamorphic outer shell of amphibolite. The authors interpreted that each sequence represents a distinct major pulse of magma. Each magmatic sequence is defined by a gradational decrease of the $\mathrm{MgO}$ and $\mathrm{Cr}$ content towards the edges, opposed by a gradational increase of $\mathrm{Al}_{2} \mathrm{O}_{3}$. The authors also showed that the Upper sequence is sulfide mineralized whereas the Lower one is barren.
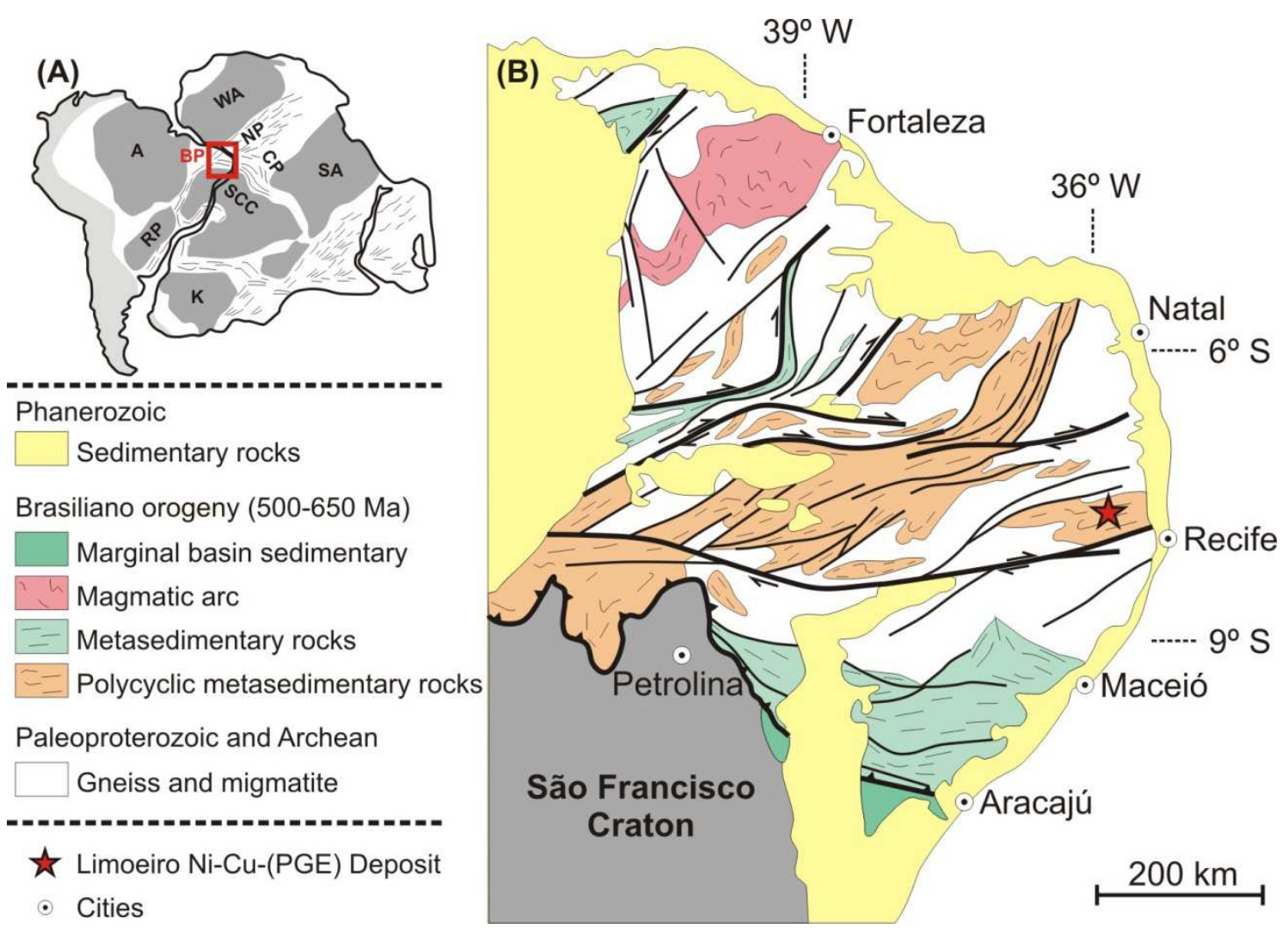

Fig. 2.1 - (A) Prerift reconstruction of western Gondwana showing the main cratons in dark grey, the Andean in light grey and the Brasiliano/Pan-African provinces are marked with dashes (modified from Neves and Alcantara, 2010). Abbreviations for cratons: A, Amazonia; K, Kalahari; RP, Rio de La Plata; AS, Sahara Metacraton; SCC, São Francisco/Congo; WA, West Africa. Abbreviations for provinces: BP, Borborema; CP, Cameroon; NP, Nigeria. (B) Simplified geological map showing the main geotectonic units, the major shear zones and the location of the Limoeiro $\mathrm{Ni}-\mathrm{Cu}$-(PGE) deposit (modified from Medeiros, 2004). 


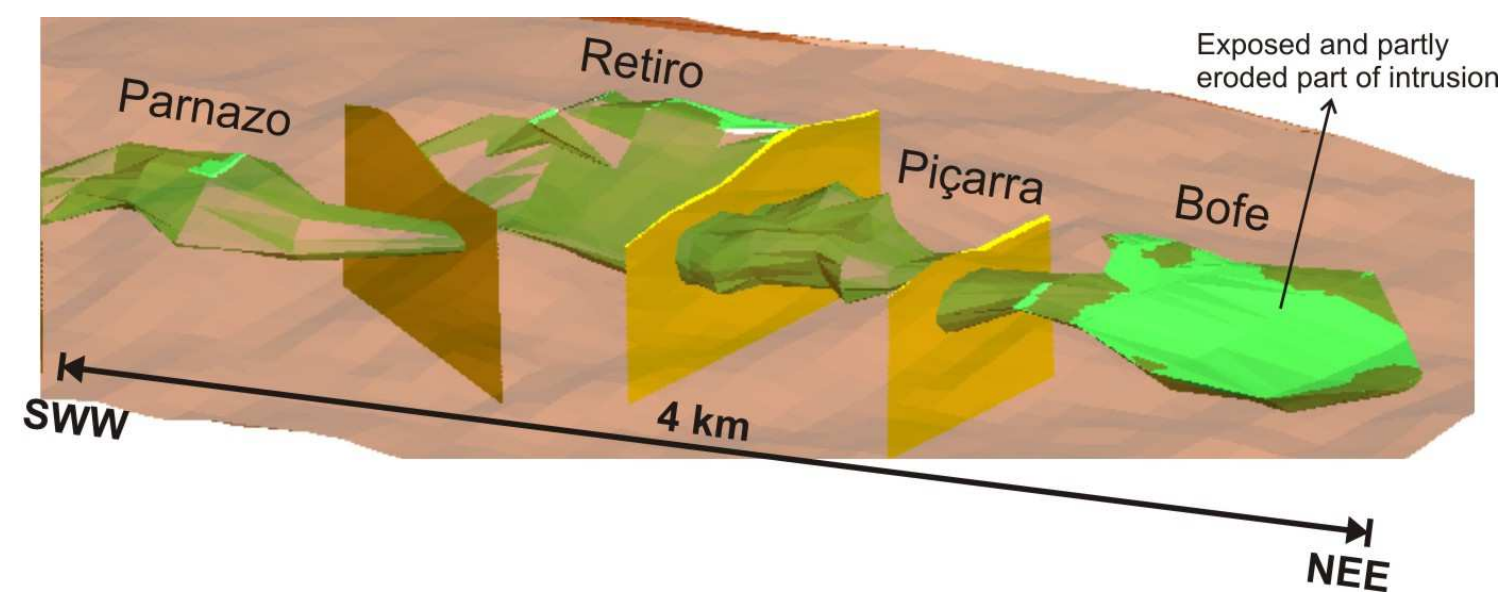

Fig. 2.2 - Schematic three-dimensional model of the chonolithic conduit of the ultramafic intrusion (taken from Mota-eSilva et al., 2013).

\section{Sampling and analytical procedures}

The cross sections of the Limoeiro deposit presented in this study are based upon extensive exploration data (including maps, drilling sections, geophysical surveys) developed by Votorantim Metais (VM).

The VM database (11,222 samples) used in this work includes whole rock assay results for 24 elements and oxides: $\mathrm{Ag}, \mathrm{Al}_{2} \mathrm{O}_{3}, \mathrm{As}, \mathrm{Au}, \mathrm{BaO}, \mathrm{CaO}, \mathrm{Co}, \mathrm{Cr}, \mathrm{Cu}, \mathrm{Fe}, \mathrm{K}_{2} \mathrm{O}, \mathrm{MgO}$, $\mathrm{MnO}, \mathrm{Na}_{2} \mathrm{O}, \mathrm{Ni}, \mathrm{P}_{2} \mathrm{O}_{5}, \mathrm{~Pb}, \mathrm{Pd}, \mathrm{Pt}, \mathrm{S}, \mathrm{TiO}_{2}, \mathrm{~V}, \mathrm{Zn}$ and $\mathrm{Zr}$. These samples were obtained from half drill cores that were sampled continuously at approximately $1 \mathrm{~m}$ intervals, and adjusted to respect geological contacts. Each sample weighed about $2 \mathrm{~kg}$ and analyses were carried out at ALS Chemex, Toronto, Canada, using an inductively coupled plasma atomic emission spectrometer (ICP-AES) after fine crushing $(70 \mathrm{wt} \%<2 \mathrm{~mm})$, pulverizing $\left(85 \mathrm{wt} \%<75 \mu \mathrm{m}^{2}\right)$ and four acid digestion. Gold, Pt and Pd were analyzed using an ICP-AES after standard lead oxide collection fire assay. Some samples were also assayed using the LECO induction furnacetitration method for $S$ concentration determinations aiming to validate the ICP-AES analyses and to determinate the $\mathrm{S}$ concentrations for samples that reached the maximum detection limit (10 wt\%). Seventeen pulps from half-drill core samples, with varied sulfide-contents, were 
selected for be assay for all six PGE (Os, Ir, Ru, Rh, Pt and Pd). The analyses were performed using fire assay with nickel sulfide collection and neutron activation analysis (NAA).

In order to properly characterize petrography and lithochemistry [major, trace and rare-earth elements (REE)] of the ultramafic rocks, 78 selected quarter drill core were sampled. The criteria was to select undeformed, less altered, low sulfide-content and typical ultramafic rocks taken from representative drill holes of each drilling target. All the analyses were performed at ALS Chemex using lithium borate fusion. The major elements and loss on ignition (LOI) were quantified by ICP-AES. The trace and REE were quantified using inductively coupled plasma mass spectrometer (ICP-MS). In addition the volatile elements $\mathrm{As}, \mathrm{Bi}, \mathrm{Hg}, \mathrm{Sb}, \mathrm{Se}$ and Te were assayed using aqua regia digestion followed by ICP-MS analysis; C and S were assayed using LECO induction furnace-titration method.

Mineral analyses (1,249 analyses) were performed on polished thin sections using a 5-spectrometer JEOL JXA-8230 SuperProbe at the Electron Microprobe Laboratory of the University of Brasília, Brazil. The wavelength dispersive (WDS) analyses were performed at an accelerating voltage of $15 \mathrm{kV}$ and a beam current of $10 \mathrm{nA}$. Both synthetic and natural mineral standards were used for the analyses and the same standards and procedure were used throughout the analytical work. Systematic WDS analyses were obtained for olivine and orthopyroxene.

\section{Results}

\section{Geology}

In this study it is revealed that within the deposit area, there are actually four different sequences from the top to the bottom named: Low Cr, Upper, Transition Zone and Lower sequences (Fig. 2.3 and 2.4). Recent additional drilling has shown that the model of a sulfide- 
bearing Upper sequence and a barren Lower sequence is only valid for the Parnazo and Retiro targets. Despite the structural complexity of the Piçarra block due to fault disruptions and deformation, the reconstruction of stratigraphy and sequences is not straightforward. Although stratigraphic interpretation in the light of lithological and lithochemical information suggested that the Lower sequence is also mineralized to the west of the Piçarra target.

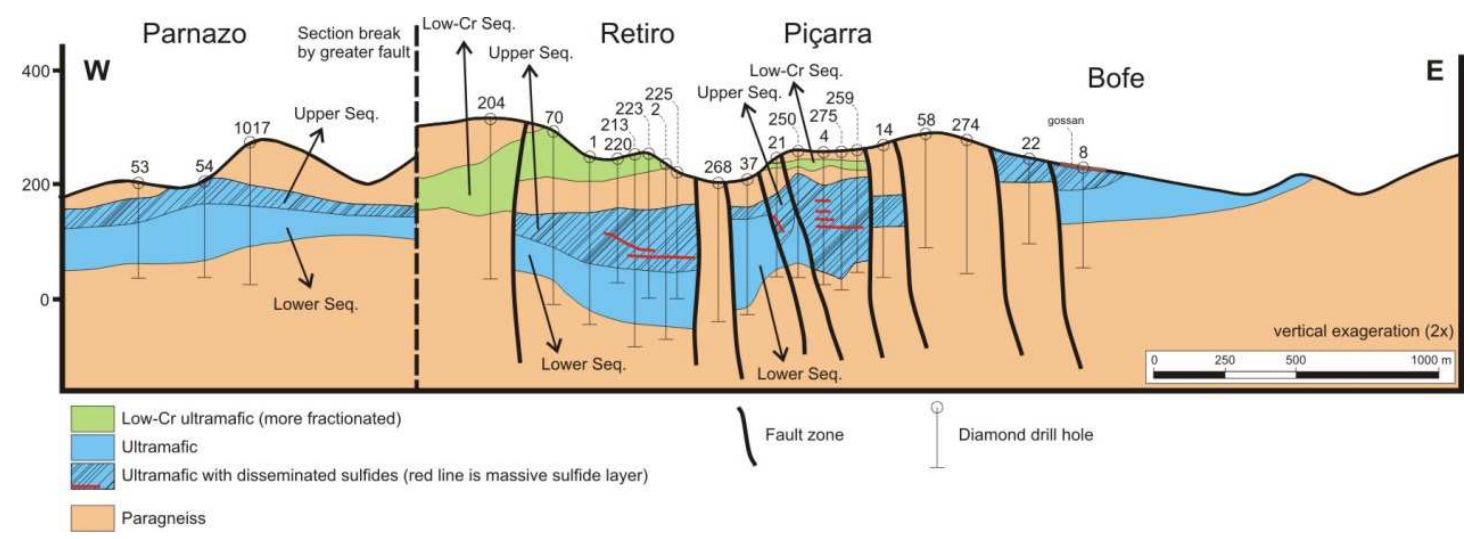

Fig. 2.3 - Longitudinal schematic section of the ultramafic intrusion, highlighting the major magmatic sequences and the disseminated and massive ore locations.

The Low-Cr is the uppermost sequence in the deposit area, and it is separated by 10 and $100 \mathrm{~m}$ of country paragneiss from the other three sequences (Fig. 2.4). This sequence is not mineralized, but it provides a stratigraphic reference, as it is located above the Upper sequence, which is the main target for the drilling programs. The recognition of the Low-Cr sequence has permitted, for example, conclusion that drill hole 204 in western Retiro did not reach the orebody as a fault has dislocated the whole block to a deeper position (Fig. 2.3). Distinguishing the Low-Cr from the other sequences in outcrops or drill core is not so straightforward, as it consists of the same lithologies (i.e., harzburgite and orthopyroxenite) and textures. However the lack of discrete chromite grains in the Low-Cr sequence rocks can work as a distinguishing feature in the deposit area. 

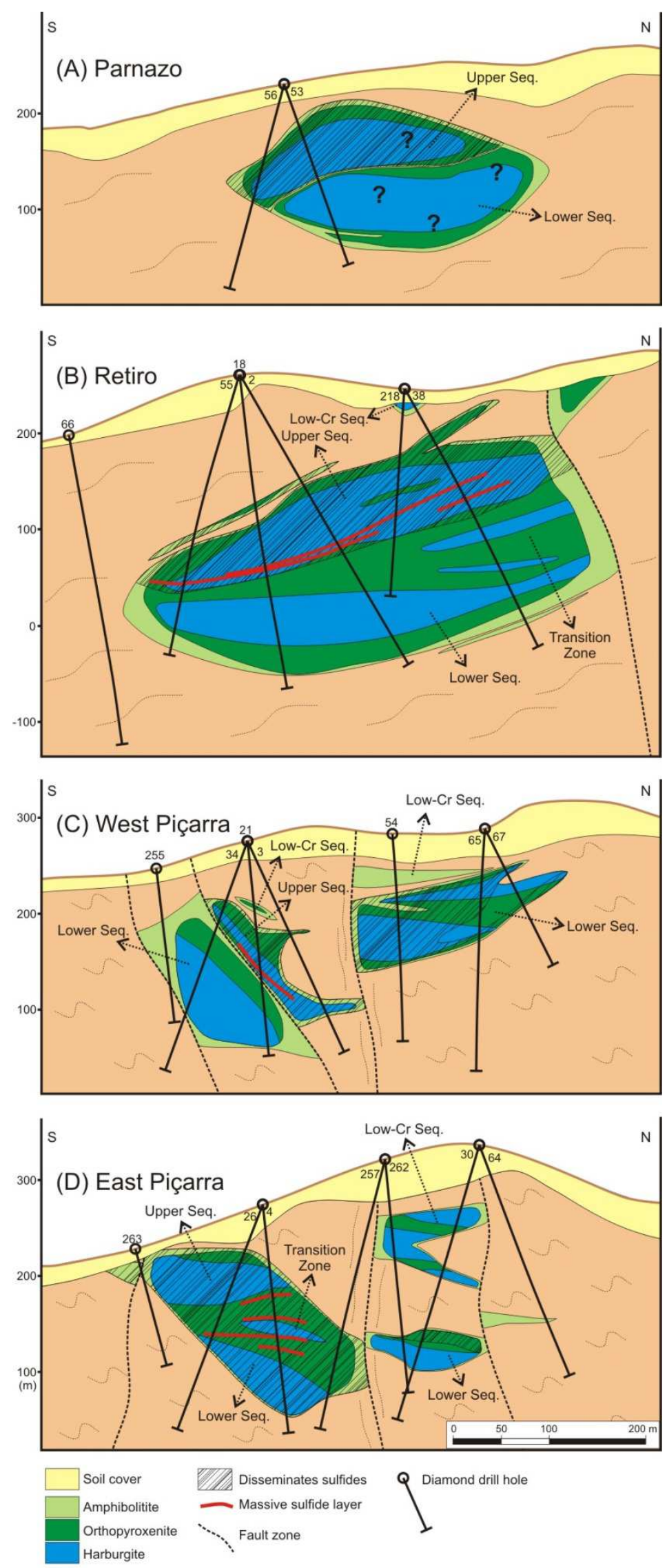

Paragneiss with indication of domiant foliation

Fig. 2.4 - Geologic cross sections of the (A) Parnazo, (B) Retiro, (C) West Piçarra and (D) East Piçarra targets. 
The Transition Zone sequence is located between the Upper and Lower sequences. This horizon is relatively thin $(<70 \mathrm{~m})$ and not continuous throughout the entire chonolithic structure. It is more consistent in the northern part of the Retiro target, however it is absent in most of the drill holes in the southern part of the Retiro and in a great part of Piçarra target. The sequence consists of the same previously described lithological concentrically zoned, but in this case the orthopyroxenite member has a larger extent than the harzburgite. The magnetic susceptibility in the orthopyroxenites of the Transition Zone is much higher than in the other sequences. The reason is the relatively high abundance ( $\sim 5 \mathrm{vol} \%)$ of magnetite, which may be related to primary accumulation of cumulus iron oxides or to metamorphic transformation of chromites. Sulfide mineralization occurs in parts of this sequence, especially the eastern part (Piçarra target), where it hosts massive sulfide layers (Fig. 2.4).

\title{
Mining database geochemistry
}

\author{
Magmatic sequences
}

The magmatic sequences that formed the Limoeiro ultramafic rocks have gentle lithochemical differences between them. These differences are probably due to the distinct sampling position along the magma conduit, reflecting within conduit fractionation and sulfide segregation.

Considering that the Retiro target has the least faulted geology, largest number of drill holes and the clearest stratigraphy of magmatic sequences, it was chosen as the sampling site to compare and chemically separate between the four magmatic sequences. The Low-Cr sequence differs from the other sequences in terms of $\mathrm{MgO}$ and $\mathrm{Cr}$ contents. It has a median of $20.6 \mathrm{wt} \% \mathrm{MgO}$ and $389 \mathrm{ppm} \mathrm{Cr}$, whereas the other three sequences have medians between 27.7 and 29.5 wt\% $\mathrm{MgO}$ and between 1880 and 2030 ppm Cr (Fig. 2.5A,B). Additionally the $\mathrm{Cu} / \mathrm{Pd}$ ratio, which is a geochemical proxy commonly used to identify levels of fractionation by previous sulfide removal in magmatic systems (e.g., Barnes et al. 1993; Maier et al., 1996; Li et 
al., 2001b; Barnes and Lightfoot, 2005), is significantly different compared to the other sequences. The Low-Cr sequence has a Cu/Pd median of 7200, which differs from 5522 of the Upper, 4407 of the Transition Zone and 2840 of the Lower sequence (Fig. 2.5D). Other elements and oxides such as $\mathrm{Zr}, \mathrm{TiO}_{2}, \mathrm{~V}, \mathrm{Zn}, \mathrm{K}_{2} \mathrm{O}, \mathrm{Na}_{2} \mathrm{O}, \mathrm{CaO}, \mathrm{BaO}, \mathrm{Al}_{2} \mathrm{O}_{3}$, and $\mathrm{P}_{2} \mathrm{O}_{5}$ that are relatively incompatible with the cumulus phases of Limoeiro (olivine, orthopyroxene and chromite), are also more enriched in the Low-Cr sequence compared to the other sequences. The S content clearly indicates that the Upper sequence is the most mineralized with a median of 0.68 wt $\% \mathrm{~S}$. The Transition Zone sequence, which also has mineralized portions, has a median of $0.16 \mathrm{wt} \% \mathrm{~S}$, however the Low-Cr and Lower sequences, that are strictly barren in the Retiro target, have medians of 0.03 and 0.04 wt\% S, respectively (Fig. 2.5C).
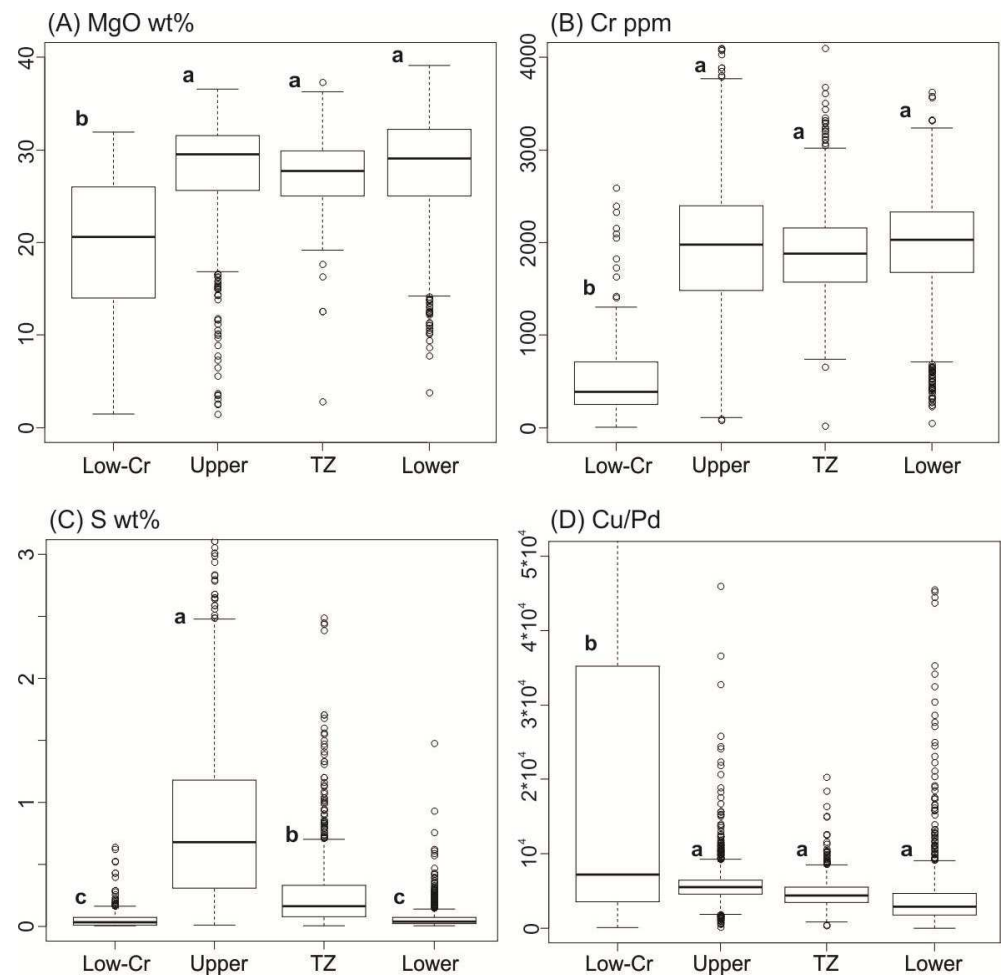

Fig. 2.5 - Box-and-Whisker plots of $\mathrm{MgO}, \mathrm{Cr}, \mathrm{S}$ and $\mathrm{Cu} / \mathrm{Pd}$ of four different magmatic sequences: Low $\mathrm{Cr}$, Upper, Transition Zone and Lower sequences. The center line is the median and the box is limited by upper and lower quartile. The dashed line comprises all data except the outliers that are shown in open circles. The letters exhibit the significant different groups of data according to Tukey's HSD test for $p<0.01$.

The Upper sequence in the three different drilling targets Parnazo, Retiro and Piçarra (ordered from the west to the east) was chosen as the sampling target to evaluate horizontal chemical variation longitudinal to the conduit. This technique has the potential to indicate the 
magma influx direction, and among other ideas also derive petrological inferences. The Upper sequence was chosen for this assessment due to its higher sulfide content, higher number of lithochemical analyses (as it is the main drilling target) and consistent spatial distribution throughout the chonolith structure. The eastern part of the Piçarra target was not included because of difficulties in recognizing the magmatic sequences in several of the drill holes that are close to fault zones.

From west to east there is a clear increase in the sulfide content in the Upper sequence, as it grows from a median of $0.27 \mathrm{wt} \%$, to $0.68 \mathrm{wt} \%$ and finally to $1.09 \mathrm{wt} \%$ of S (Fig. 2.6A). Moving along the same west to east vector, the $\mathrm{Cu} / \mathrm{Pd}$ ratio median increases from 5200 to 5522 and finally to 5802 (Fig. 2.6B). The Pt/Pd ratio is about the same in Parnazo and Retiro targets ( 0.385 and 0.382 respectively), but it is higher in the Piçarra target $(0.424)$.
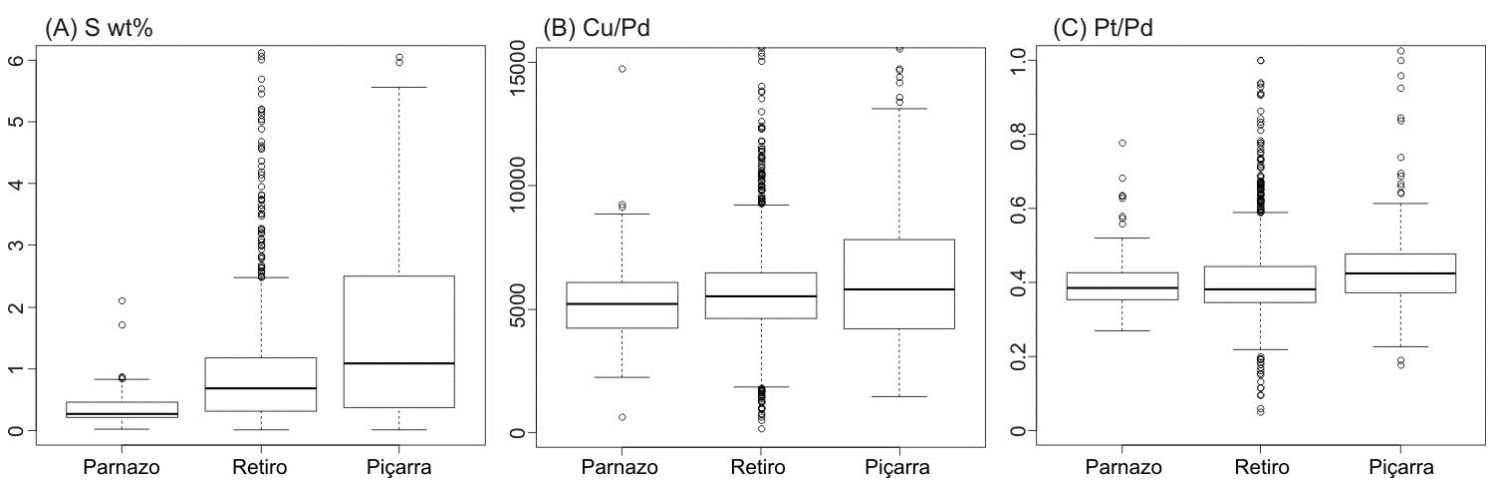

Fig. 2.6 - Box-and-Whisker plots of $\mathrm{S}, \mathrm{Cu} / \mathrm{Pd}$ and $\mathrm{Pt} / \mathrm{Pd}$ for the Upper sequence in three different targets from the west to the east: Parnazo, Retiro and Piçarra. The center line is the median and the box is limited by upper and lower quartile. The dashed line comprises all data except the outliers that are shown in open circles.

\section{Tenor calculation}

The Retiro and Piçarra targets concentrate $91 \%$ of the drill holes in the Limoeiro Ni$\mathrm{Cu}(-\mathrm{PGE})$ deposit area, as they are the only targets to have defined indicated and inferred resources and reserves. Additionally they are the only targets to contain high-grade disseminated sulfide (>10 vol\% sulfides) and massive sulfide (>60 vol\% sulfides) samples, and for that reason they are more reliable to utilise for tenor calculations. Given that the Limoeiro Ni$\mathrm{Cu}(-\mathrm{PGE})$ deposit is 97 vol\% composed of disseminated sulfide mineralization (Mota-e-Silva et 
al., 2013), within which sulfide content varies from 2 vol\% up to 55 vol\% it is a robust method to calculate tenors using a linear regression of metal data $(\mathrm{Ni}, \mathrm{Cu}, \mathrm{Pd}$ and $\mathrm{Pt})$ against sulfur (Kerr, 2001). It is assumed that 100 vol\% of sulfides would produce a rock with $37 \mathrm{wt} \% \mathrm{~S}$, which is approximately the expected grade for a rock containing 100 vol\% of magmatic sulfides at Limoeiro (i.e., pyrrhotite >> pentlandite chalcopyrite >> magnetite; for Limoeiro ore mineralogy description see Mota-e-Silva et al. 2013). All Cu and Ni were accomodated in chalcopyrite and pentlandite respectively and the remainder of the $S$ was included in pyrrhotite (e.g., Naldrett, 1981). The results of these calculations are given in Table 2.1, and the individual metals linear regressions against sulfur are shown in Fig. 2.7.
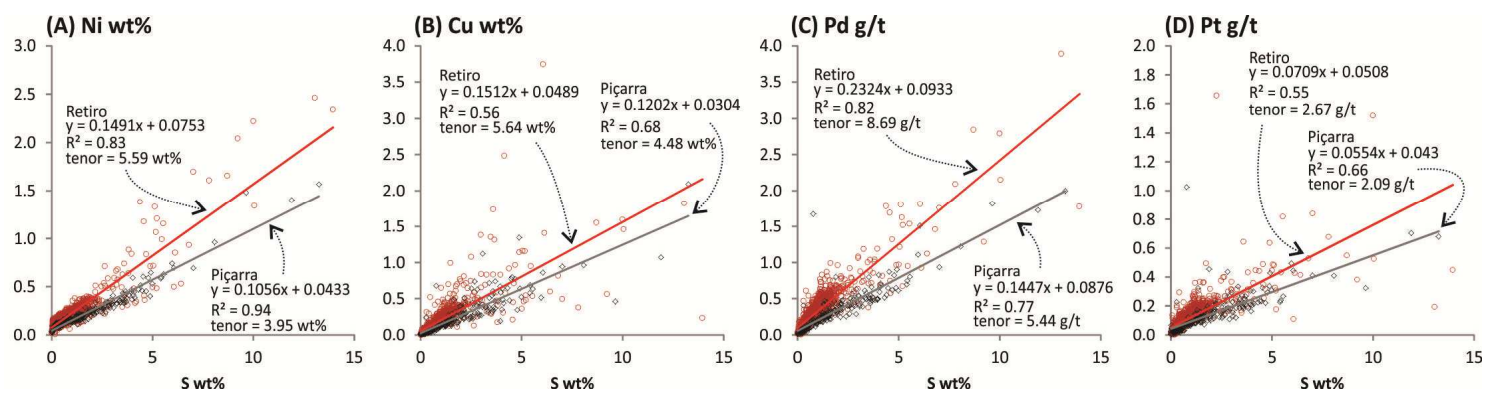

Fig. 2.7 - Biplots of the metals $\mathrm{Ni}, \mathrm{Cu}, \mathrm{Pd}$ and $\mathrm{Pt}$ versus $\mathrm{S}$. The text indicates the orebody name, line equation, correlation coefficient $\left(\mathrm{R}^{2}\right)$ and calculated tenor for $37 \mathrm{wt} \% \mathrm{~S}$.

Table 2.1 - Calculated $\mathrm{Ni}, \mathrm{Cu}, \mathrm{Pd}$ and Pt tenors for Retiro and Piçarra targets. Metal tenor ratios and relative proportions between the three BMS phases: pyrrhotite, chalcopyrite and pentlandite for each target are also illustrated.

\begin{tabular}{|c|c|c|c|}
\hline & \multicolumn{2}{|c|}{ Drilling target (from $\mathrm{W}$ to $\mathrm{E}$ ) } \\
\hline & & Retiro & Piçarra \\
\hline \multirow{4}{*}{ 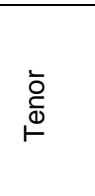 } & Ni wt\% & 5.59 & 3.95 \\
\hline & Cu wt\% & 5.64 & 4.48 \\
\hline & $\mathrm{Pd} g / \mathrm{t}$ & 8.69 & 5.44 \\
\hline & $\mathrm{Ptg} g / \mathrm{t}$ & 2.67 & 2.09 \\
\hline \multirow{3}{*}{ 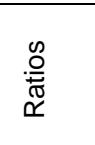 } & $\mathrm{Cu} / \mathrm{Pd}$ & 6488 & 8233 \\
\hline & $\mathrm{Ni} / \mathrm{Cu}$ & 0.99 & 0.88 \\
\hline & $\mathrm{Pt} / \mathrm{Pd}$ & 0.31 & 0.38 \\
\hline \multirow{3}{*}{ 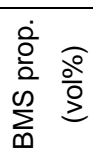 } & Pentlandite & 15.5 & 10.9 \\
\hline & Chalcopyrite & 15.4 & 12.2 \\
\hline & Pyrrhotite & 69.1 & 76.9 \\
\hline
\end{tabular}


The Retiro target has higher base and noble metal contents compared to Piçarra (Fig. 2.7; Table 2.1). The linear regression of $\mathrm{Ni}$ versus $\mathrm{S}$ generates an equation for whose component "b" (in $\mathrm{Ni}=\mathrm{a}^{*} \mathrm{~S}+\mathrm{b}$ ) represents the amount of $\mathrm{Ni}$ in non-sulfide mineral phases, which mainly represents $\mathrm{Ni}$ hosted by olivine and orthopyroxene. These Ni concentrations (753 ppm $\mathrm{Ni}$ for Retiro and $433 \mathrm{ppm} \mathrm{Ni}$ for Piçarra) are roughly compatible with the values obtained for $\mathrm{Ni}$ content in olivine and orthopyroxene using electron microprobe analyses (EMPA) as shown in the Mineral Chemistry section. All the correlations coefficients $\left(\mathrm{R}^{2}\right)$ in the $\mathrm{Ni}, \mathrm{Cu}, \mathrm{Pd}$ and $\mathrm{Pt}$ versus $\mathrm{S}$ regression are equal to or greater than 0.55 . Nickel and $\mathrm{Pd}$ in particular have quite high $R^{2}$ values between 0.77 and 0.94 . These numbers testify to the robustness of the method in calculating the metal tenors. The $\mathrm{Cu} / \mathrm{Pd}$ and $\mathrm{Pt} / \mathrm{Pd}$ ratios calculated over the tenor values (Table 2.1) corroborate with the tendency already illustrated in the previous magmatic sequences section (Fig. 2.6B,C), as in both cases the ratios increase to the east. The $\mathrm{Ni} / \mathrm{Cu}$ ratio, that was not calculated in the previous section in order to avoid influence of silicate $\mathrm{Ni}$ content in samples with very low sulfide content, shows a tendency to decrease to the east.

\section{Platinum-group elements}

Seventeen representative samples of the Limoeiro deposit were sampled in order to carry out complementary analyses for $\mathrm{Os}, \mathrm{Ir}, \mathrm{Ru}$ and Rh using Neutron Activation Analysis (NAA). These samples were collected from the Piçarra and Retiro targets, and include typical disseminated and massive sulfide ore from both targets (Table 2.2).

The Os, Ir and Rh concentrations have an excellent linear correlation (R2=0.87, 0.88 and 0.91 respectively) with $S$ (Fig. 2.8). No significant differences on such correlations were detected after separating samples from Retiro and Piçarra in individual plots, and for that reason the samples were kept together representing the bulk deposit. Most of the samples were below the detection limit, especially for $\mathrm{Ru}$, and for that reason this element's correlation with $\mathrm{S}$ had to be done based on two massive sulfide samples. 

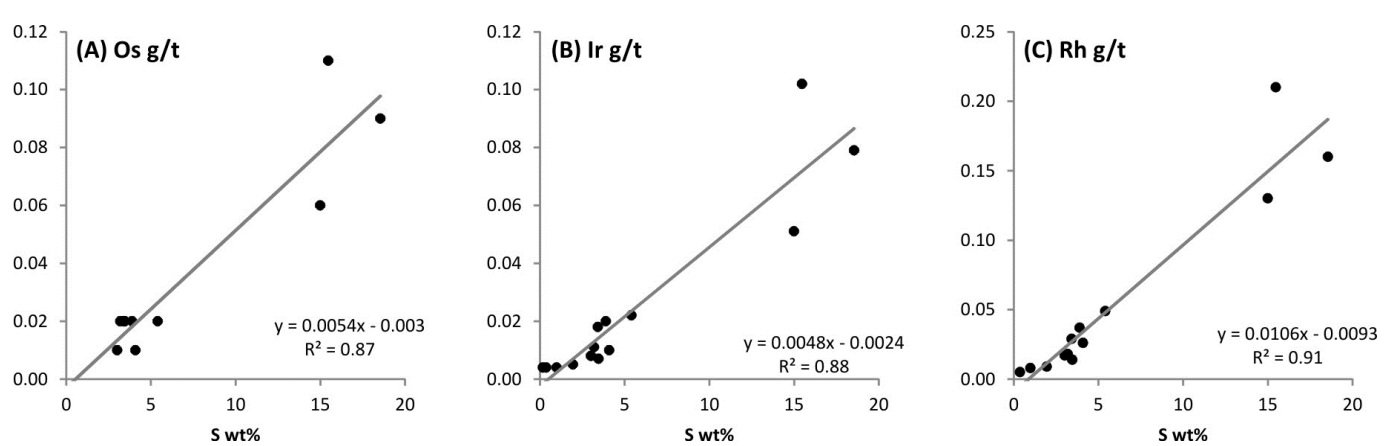

Fig. 2.8 - Biplots of the PGE Os, Ir and Rh versus $S$. The text indicates the line equation and the correlation coefficient $\left(R^{2}\right)$.

Table 2.2 - Metal concentrations of 17 selected samples for the determination of the all 6 PGE grades for different types of ore.

\begin{tabular}{|c|c|c|c|c|c|c|c|c|c|c|c|c|c|c|c|c|c|}
\hline Target & Piçarra & Piçarra & Piçarra & Piçarra & Piçarra & Piçarra & Piçarra & Piçarra & Retiro & Retiro & Retiro & Retiro & Retiro & Retiro & Retiro & Retiro & Retiro \\
\hline Drill hole & SLM0003 & SLM0004 & SLM0004 & SLM0004 & SLM0004 & SLM0004 & SLM0021 & SLM0021 & SLM0001 & SLM0001 & SLM0001 & SLM0002 & SLM0002 & SLM0002 & SLM0002 & SLM0018 & SLM0018 \\
\hline epth from & 182.70 & 138.15 & 61.91 & 116.90 & 101.74 & 177.72 & 124.90 & 136.81 & 211.51 & 287.14 & 282.18 & 170.91 & 199.50 & 203.35 & 194.33 & 134.12 & 165.23 \\
\hline depth to & 183.25 & 138.99 & 62.88 & 118.00 & 102.85 & 178.90 & 125.72 & 137.29 & 212.88 & 288.61 & 283.04 & 172.15 & 199.79 & 203.77 & 195.34 & 135.15 & 166.25 \\
\hline lithology & AT & MS & AT & PX & PX & $\mathrm{HZ}$ & $\mathrm{HZ}$ & MS & $\mathrm{HZ}$ & $\mathrm{HZ}$ & $\mathrm{HZ}$ & $\mathrm{HZ}$ & MS & $\mathrm{HZ}$ & $\mathrm{HZ}$ & PX & $\mathrm{HZ}$ \\
\hline sulf. (vol\%) & 30 & 65 & 30 & 10 & 35 & 10 & 25 & 75 & & & & 2 & 65 & 20 & 1 & 20 & 3 \\
\hline sample & 186990 & 187107 & 187029 & 187086 & 187070 & 187150 & 187839 & 187854 & 187274 & 187334 & 187330 & 187455 & 187486 & 187492 & 187481 & 187865 & 187889 \\
\hline Co_ppm & 204 & 1390 & 212 & 132 & 199 & 317 & 383 & 1615 & 114 & 141 & 146 & 129 & 1230 & 241 & 120 & 288 & 157 \\
\hline Cu_pct & 0.30 & 0.69 & 0.26 & 0.30 & 0.64 & 0.39 & 0.58 & 0.90 & 0.03 & 0.04 & 0.05 & 0.06 & 0.72 & 1.32 & 0.07 & 0.31 & 0.32 \\
\hline Ni_pct & 0.31 & 2.58 & 0.30 & 0.20 & 0.29 & 0.40 & 0.58 & 2.75 & 0.14 & 0.12 & 0.12 & 0.16 & 3.03 & 0.38 & 0.13 & 0.48 & 0.21 \\
\hline Ir_gt & 0.011 & 0.079 & 0.018 & 0.005 & 0.020 & 0.008 & 0.022 & 0.051 & 0.004 & $<0.004$ & $<0.004$ & 0.004 & 0.102 & 0.007 & $<0.004$ & 0.010 & 0.004 \\
\hline Os_gt & 0.020 & 0.090 & 0.020 & $<0.01$ & 0.020 & 0.010 & 0.020 & 0.060 & $<0.01$ & $<0.01$ & $<0.01$ & $<0.01$ & 0.110 & 0.020 & $<0.01$ & 0.010 & $<0.01$ \\
\hline Pd_gt & 0.479 & 3.165 & 0.438 & 0.675 & 0.695 & 0.462 & 0.704 & 3.035 & 0.096 & 0.090 & 0.090 & 0.110 & 4.000 & 0.674 & 0.091 & 0.819 & 0.466 \\
\hline Pt_gt & 0.257 & 0.891 & 0.200 & 0.285 & 0.227 & 0.159 & 0.218 & 1.128 & 0.057 & 0.034 & 0.038 & 0.057 & 1.085 & 0.223 & 0.043 & 0.419 & 0.232 \\
\hline Rh_gt & 0.018 & 0.160 & 0.029 & 0.009 & 0.037 & 0.017 & 0.049 & 0.130 & $<0.005$ & $<0.005$ & $<0.005$ & 0.005 & 0.210 & 0.014 & $<0.005$ & 0.026 & 0.008 \\
\hline Ru_gt & $<0.05$ & 0.060 & $<0.05$ & $<0.05$ & $<0.05$ & $<0.05$ & $<0.05$ & $<0.05$ & $<0.05$ & $<0.05$ & $<0.05$ & $<0.05$ & 0.070 & $<0.05$ & $<0.05$ & $<0.05$ & $<0.05$ \\
\hline
\end{tabular}

Abbreviations: $\mathrm{AT}=$ Amphibolite; $\mathrm{MS}=$ Massive sulfide; $\mathrm{PX}=$ Orthopyroxenite; $\mathrm{HZ}=$ Harzburgite 
The correlations of Os, Ir, and Rh versus $S$ allow the calculation of PGE tenor for the Limoeiro deposit normalizing the metals to $37 \mathrm{wt} \% \mathrm{~S}$ in the same way that was carried out in the previous section. The $\mathrm{Ni}, \mathrm{Co}, \mathrm{PGE}, \mathrm{Au}$ and $\mathrm{Cu}$ distribution normalized to primitive mantle gives clues on (i) the type of magma from which the magmatic sulfides have segregated, (ii) sulfide liquid fractionation and (iii) prior sulfide removal from magma (for a review see Naldrett, 2004). The Limoeiro sulfide deposit has a PGE distribution that is more primitive than the flood basaltrelated Ni-Cu-PGE sulfide deposit of Noril'sk, Russia; however it is more fractionated than the komatiitic sulfide Ni deposits of Kambalda, Australia (Fig. 2.9). Gold was not included in the Fig. 2.9 spidergram due to its very poor correlation with $S$ in the Limoeiro deposit, causing uncertainty in calculating its tenor. Gold tenor is commonly difficult to calculate in many magmatic deposits, as it is the most mobile noble metal and it can be easily re-distributed during metamorphism, hydrothermalism and tectonics (e.g., Naldrett, 2004).

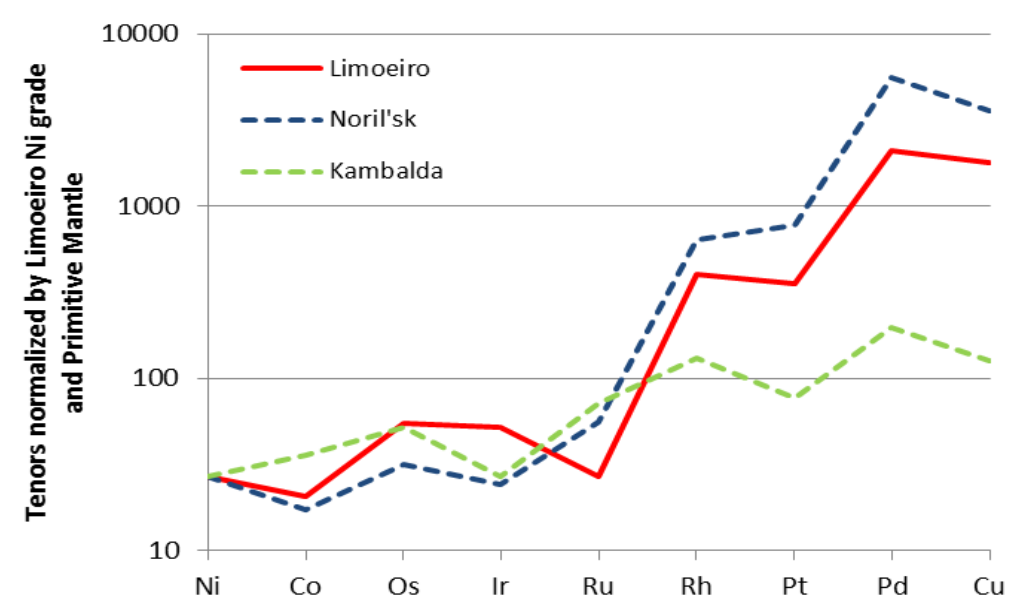

Fig. 2.9 - Spidergram of the 6 PGE plus Ni, Co and $\mathrm{Cu}$. The values are normalized to the Primitive Mantle (McDonough and Sun, 1995) and by the Limoeiro deposit $\mathrm{Ni}$ grade, in order to highlight the curve slope for direct comparison with the degree of fractionation of the Noril'sk and Kambalda deposits.

The degree of sulfide fractionation can be visualized in terms of base and noble metals ratios. The Limoeiro deposit has a Ni/Cu ratio of 0.99 (here represented by Retiro target), which is higher than the $\mathrm{Ni} / \mathrm{Cu}$ ratio of the Noril'sk deposit $(\mathrm{Ni} / \mathrm{Cu}=0.50)$, but is much lower compared to the $\mathrm{Ni} / \mathrm{Cu}$ ratio of the Kambalda deposit $(\mathrm{Ni} / \mathrm{Cu}=13.8)$ (Naldrett, 2004). The $\mathrm{Pd} / \mathrm{Ir}$ ratio of Limoeiro is also intermediate between Noril'sk and Kamblada (43, 281 and 9 respectively). Based on these two ratios Barnes and Lightfoot (2005) have delineated typical fields of occurrence of magmatic deposits and related them with magma types (Fig. 2.10). The 
Limoeiro deposit plots in the generic "Layered intrusion" field, between the more fractionated "Flood basalts" and the more primitive "High-MgO basalts" field.

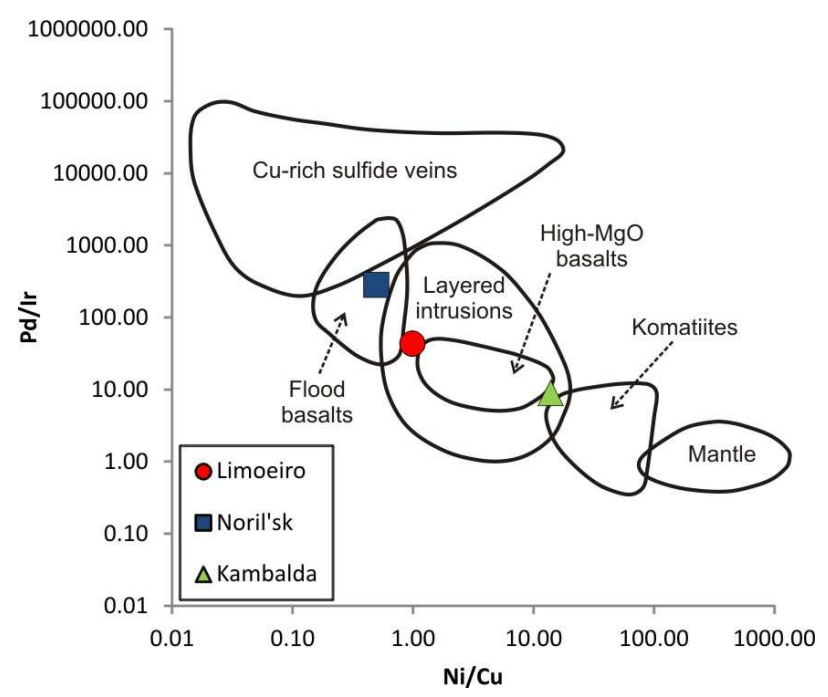

Fig. 2.10 - Biplot of $\mathrm{Pd} / \mathrm{Ir}$ versus $\mathrm{Ni} / \mathrm{Cu}$ aiming to show the intensity of the Limoeiro deposit fractionation. For comparison the Noril'sk and Kambalda deposits are also plotted. The field contours and the graphic concept were taken from Barnes and Lightfoot (2005).

\section{Base and noble metal distribution}

Nickel and Copper (base metals) have different relative concentrations when comparing the disseminated and massive sulfide ores. Using all samples from the VM Limoeiro project database it becomes clear that the Ni versus $\mathrm{Cu}$ biplot does not form a reasonable linear correlation trend (Fig. 2.11A). Actually the plot shows scattered results with several net-textured (between 5 and $15 \mathrm{wt} \% \mathrm{~S}$ ) and semi-massive to massive ore samples ( $\geq 15 \mathrm{wt} \% \mathrm{~S}$ ) concentrated either in the Cu-rich and Ni-poor part of the graph and in the Ni-rich and Cu-poor area of the plot. However the disseminated sulfide samples show a strong linear correlation between $\mathrm{Ni}$ and $\mathrm{Cu}(\mathrm{Ni} / \mathrm{Cu} \sim 0.75)$. This correlation is especially clear for samples with $\mathrm{Ni}$ and $\mathrm{Cu}$ grades $\leq 0.5 \mathrm{wt} \%$ (Fig. 2.11B). The related discrepancy of $\mathrm{Ni}$ and $\mathrm{Cu}$ correlations indicates that different processes are controlling base metal concentrations in the disseminated and massive sulfide ore in Limoeiro. 

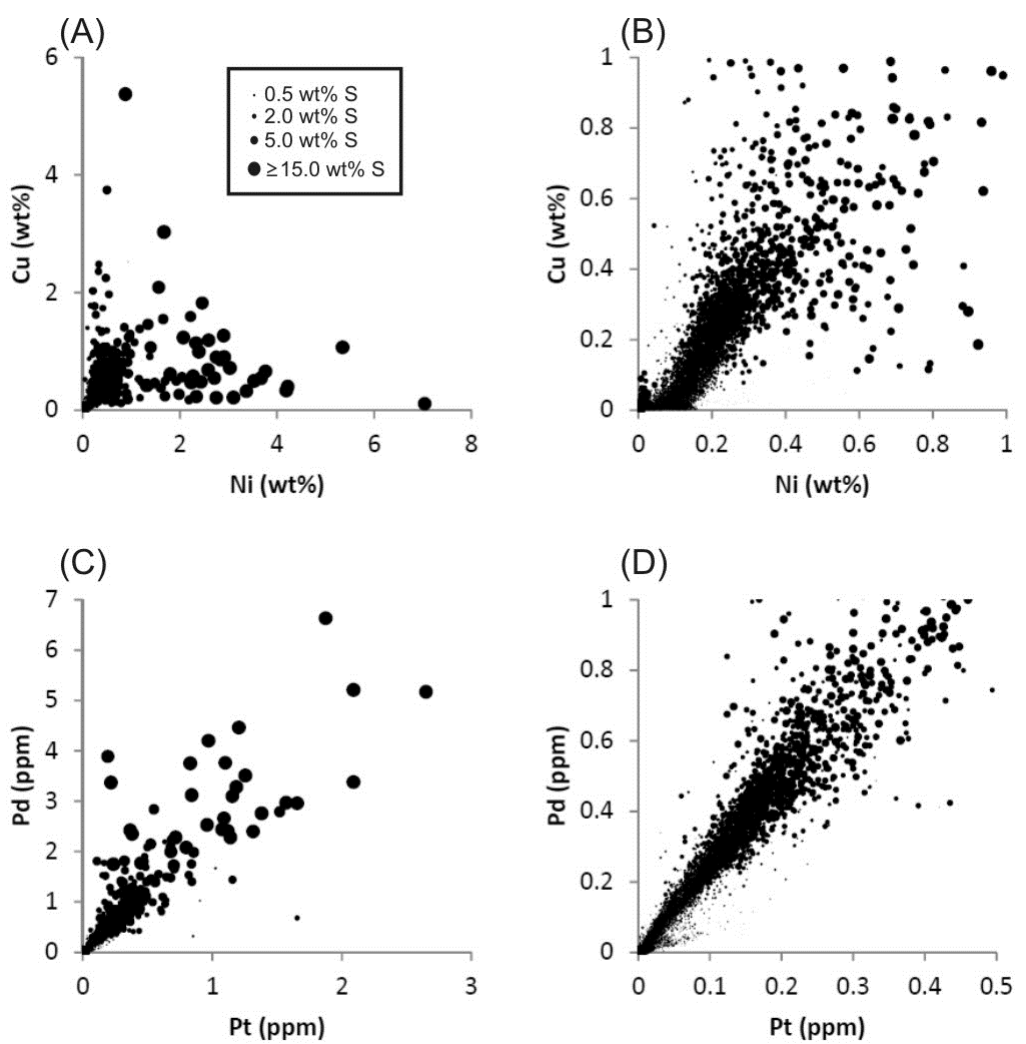

Fig. 2.11 - Biplots of Ni versus $\mathrm{Cu}(\mathrm{A}$ and $\mathrm{B})$ and $\mathrm{Pt}$ versus $\mathrm{Pd}(\mathrm{C}$ and $\mathrm{D})$. The figures $\mathrm{A}$ and $\mathrm{C}$ include all samples, but figures $B$ and $D$ are more representative of the disseminated sulfide ore.

The noble metals (i.e., Pt and Pd) do not have the same pattern as the base metals. Platinum and Pd display good linear correlation in all three ore types: disseminated and semimassive to massive sulfide (Fig. 2.11C-D). Only a few samples plot away from the correlation trend of $\mathrm{Pt} / \mathrm{Pd} \sim 0.37$. This pattern suggests that whatever process controlling the $\mathrm{Ni}$ and $\mathrm{Cu}$ concentrations in different ore types does not play a significant role for controlling $\mathrm{Pt}$ and $\mathrm{Pd}$.

The drill hole SLM0201 in Retiro target is a representative example to exhibit the variation of the $\mathrm{Ni}, \mathrm{Cu}$ and $\mathrm{S}$ concentrations along the mineralized Upper sequence, the poorly mineralized Transition zone and the barren Lower sequence (Fig. 2.12). The presence of massive to semi-massive ores at the base of the Upper sequence that has the dominance of disseminated sulfide ore is evident in the downhole $\mathrm{Ni}, \mathrm{Cu}$ and $\mathrm{S}$ variation graphs (Fig. 2.12). Looking in more detail at the base of the Upper sequence it becomes clear that the semimassive to massive sulfide layers have varied $\mathrm{Ni} / \mathrm{Cu}$ ratios (i.e., very high and very low); contrary to the disseminated sulfide ore that has a distinctive constant $\mathrm{Ni} / \mathrm{Cu}$ ratio of $\sim 0.8$ (Fig. 2.13A-C). There are four layers of sulfide-rich mineralization at the base of the Upper sequence 
in SLM0201 that contrast with the homogeneous disseminated sulfide envelope. The top most layer is net-textured ore with $\mathrm{Ni} / \mathrm{Cu}$ ratio of 3.64 , followed by one semi-massive chalcopyrite-rich layer with $\mathrm{Ni} / \mathrm{Cu}$ of 0.16 , and the bottom most part hosts two massive sulfide layers formed by four samples with Ni/Cu ratio of 3.22, 64.3, 5.00 and 0.23 (Fig. 2.13A). This underpins that the sulfide rich mineralization, especially the semi-massive to massive ore, has very different and heterogeneous $\mathrm{Ni} / \mathrm{Cu}$ ratios compared to the disseminated sulfide. In concordance with the graph in Fig. 2.11A, the drill hole SLM0201 has more Ni-rich semi-massive to massive sulfide layers than Cu-rich ones.

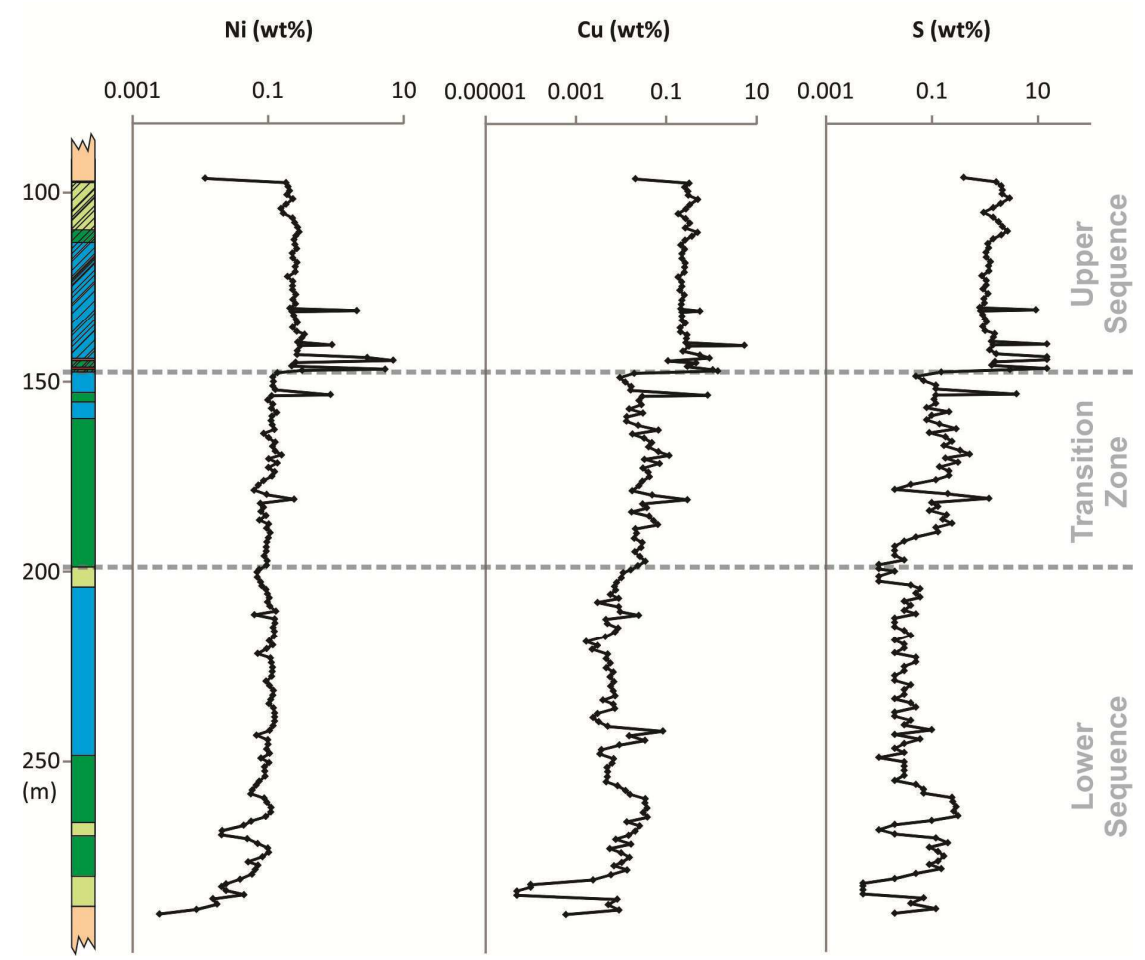

Fig. 2.12 - Drillhole SLM0201 log and its Ni, Cu and S concentrations. The topmost and the basal most samples are country rocks. The lithology codes are the same as those used in Fig. 2.4.

This strong base metal content variation in the semi-massive to massive sulfide ore located at the base of the Upper sequence is not observed in the Pt and Pd concentrations (Fig. 2.13B). These two noble metals have quite constant $\mathrm{Pt} / \mathrm{Pd}$ ratios, varying from 0.22 to 0.50 in the six samples representing the four sulfide-rich layers of the base of the Upper sequence. The sulfide-rich layer at the top of the Transition zone has a slightly lower $\mathrm{Pt} / \mathrm{Pd}$ ratio of 0.18 . Again, 
these constant $\mathrm{Pt} / \mathrm{Pd}$ values suggest that the process by which $\mathrm{Ni}$ and $\mathrm{Cu}$ were segregated from each other to form such variable sulfide-rich ores has not separated Pt from Pd.

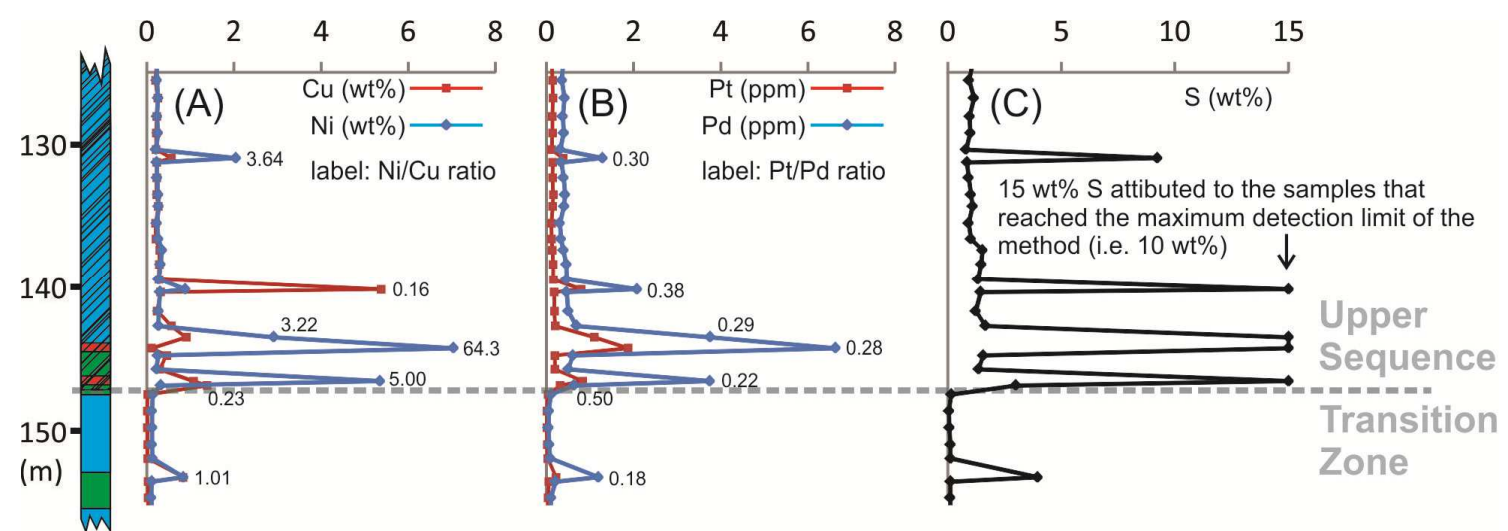

Fig. 2.13 - A detail of the base of the Upper sequence in drillhole SLM0201 shown in Fig. 2.12. The charts display the concentrations of $\mathrm{Ni}$ and $\mathrm{Cu}(\mathrm{A})$, the $\mathrm{Pt}$ and $\mathrm{Pd}(\mathrm{B})$ and $\mathrm{S}(\mathrm{C})$. The numbers labeled in the spikes represent metal ratios. The lithology codes are the same as those used in Fig. 2.4.

\section{Mineral chemistry}

Primary cumulus olivine $(n=529)$ and orthopyroxene $(n=604)$ crystals were systematically analyzed along several drill holes that are representative of different parts of the $4 \mathrm{~km}$ long chonolithic structure in the deposit area. Additionally a few metamorphic amphibole $(n=102)$ and spinel $(n=11)$ grains were analyzed aiming to gather information on their compositional variations and their influence on whole-rock geochemistry. Representative set of mineral chemistry results are shown in Table 2.3.

The forsterite $\left(\mathrm{Fo}, \mathrm{Mg}_{2} \mathrm{SiO}_{4}\right)$ component in the olivine varies from 79 to $87 \mathrm{~mol} \%$, which varies systematically vertically in each magmatic sequence. However some of the rocks are olivine-free, as the outer parts of each magmatic sequence are generally composed of orthopyroxenite and amphibolite. In this case the lower $\mathrm{Mg}$ content within cumulus minerals may be traced by the proportion of the enstatite $\left(\mathrm{En}, \mathrm{MgSiO}_{3}\right)$ component in the orthopyroxene. Orthopyroxene varies from 77 to $87 \mathrm{~mol} \%$ of En. The lower Fo (79-82 mol\%) and En contents (77-81 mol\%) are found at the edges of the magmatic sequence, especially on the top contact. The center of the magmatic sequence reaches the highest $\mathrm{Mg}$ contents within olivine and 
orthopyroxene, commonly forming D-shape curves for the Fo- and En-contents, and accompanying the whole-rock $\mathrm{MgO}$ concentration along stratigraphy (Fig. 2.14). Some of the drill holes (e.g., SLM0021) do not show the decrease of Fo- and En-contents on the lower contact of the magmatic sequences, as the orthopyroxenite and amphibolite outer shell is missing.

The Ni content in the orthopyroxene varies between $\sim 50$ and $\sim 500 \mathrm{ppm}$, but its high variability makes the confidence intervals too wide and no trend can be traced. The olivine $\mathrm{Ni}$ content has a direc relationship with mineralization. The Ni content in olivines varies from $\sim 1500$ to $\sim 2500 \mathrm{ppm}$ in the barren ultramafic and from $\sim 500$ to $\sim 1000 \mathrm{ppm}$ in the most mineralized zones (Fig. 2.14). The transition from the barren Lower sequence to the mineralized Upper sequence in the drill hole SLM0021 exhibits a reversal trend as Fo increases from 83.4 to 84.0 mol\%, simultaneously to the decrease of the Ni content from 1713 to $943 \mathrm{ppm}$. In the drill hole SLM0002 chemical profile it is evident that the $\mathrm{Ni}$ depletion in olivines is proportional to the intensity of the mineralization, as olivines $2 \mathrm{~m}$ below a massive sulfide layer have $809 \mathrm{ppm}$ of $\mathrm{Ni}$ ( $\mathrm{Fo}=84 \mathrm{~mol} \%)$, contrasting with $\sim 1300 \mathrm{ppm} \mathrm{Ni}$ in olivines $5 \mathrm{~m}$ above $(\mathrm{Fo}=84 \mathrm{~mol} \%)$ and $14 \mathrm{~m}$ below $(\mathrm{Fo}=81 \mathrm{~mol} \%)$ the same massive sulfide layer. All these three groups of olivine are within the Upper sequence, close to the basal contact with the Transition Zone (Fig. 2.14).

It was shown that the $\mathrm{S}$ content in whole-rock is progressively higher to the east as the mineralization abundance increases in the Upper sequence (Fig. 2.6). This pattern influences on the olivine Ni-content. In the Upper sequence the olivines have $\sim 1300 \mathrm{ppm} \mathrm{Ni}$ in the Parnazo target (west) and gradually drop to $\sim 700 \mathrm{ppm} \mathrm{Ni}$ in the eastern part of Piçarra target (east). Similarly, the Lower sequence olivines decrease from 2000 ppm Ni in the Parnazo and Retiro targets (west) to $~ 800 \mathrm{ppm}$ in the eastern part of Piçarra target (east) (Fig. 2.15). 
Table 2.3 - Representative microprobe analysis of olivine and orthopyroxene grains of the Limoeiro intrusion.

Drill hole SLM0002 SLM0002 SLM0002 SLM0002 SLM0002 SLM0002 SLM0002 SLM0002 SLM0002 SLM0002 SLM0002 SLM0002 SLM0002 SLM0002 SLM0002 SLM0002 SLM0002

\begin{tabular}{|c|c|c|c|c|c|c|c|c|c|c|c|c|c|c|c|c|c|}
\hline Depth $(m)$ & 140 & 158 & 180 & 195 & 202 & 214 & 224 & 234 & 242 & 257 & 272 & 272 & 285 & 300 & 307 & 125 & 140 \\
\hline Mineral & Ol & Ol & Ol & Ol & Ol & Ol & Ol & Ol & Ol & Ol & Ol & Ol & $\mathrm{Ol}$ & Ol & Ol & Opx & Opx \\
\hline $\mathrm{Na}$ & 0.01 & 0.00 & 0.00 & 0.00 & 0.00 & 0.00 & 0.00 & 0.00 & 0.00 & 0.00 & 0.00 & 0.01 & 0.00 & 0.00 & 0.00 & 0.00 & 0.00 \\
\hline $\mathrm{Mg}$ & 9.70 & 9.83 & 10.13 & 9.91 & 10.08 & 9.66 & 9.40 & 9.63 & 9.76 & 9.81 & 10.19 & 10.14 & 9.93 & 9.78 & 9.65 & 6.05 & 6.28 \\
\hline $\mathrm{Si}$ & 6.11 & 6.05 & 6.00 & 6.07 & 5.99 & 6.00 & 6.12 & 6.08 & 5.98 & 6.04 & 5.96 & 5.99 & 6.12 & 5.98 & 6.07 & 7.93 & 7.89 \\
\hline $\mathrm{K}$ & & 0.00 & 0.01 & & 0.00 & 0.00 & & & 0.00 & & 0.00 & 0.00 & & 0.00 & & 0.00 & \\
\hline $\mathrm{Ca}$ & 0.00 & 0.00 & 0.00 & 0.00 & 0.00 & 0.00 & 0.00 & 0.00 & 0.00 & 0.00 & 0.00 & 0.00 & 0.00 & 0.00 & 0.00 & 0.02 & 0.01 \\
\hline $\mathrm{Cl}$ & 0.00 & 0.00 & 0.01 & 0.00 & 0.00 & 0.00 & 0.00 & 0.00 & 0.00 & 0.00 & 0.00 & 0.00 & 0.00 & 0.00 & 0.01 & 0.00 & 0.00 \\
\hline $\mathrm{Ti}$ & 0.00 & 0.00 & 0.00 & 0.00 & 0.00 & 0.00 & 0.00 & 0.00 & 0.01 & 0.00 & 0.00 & 0.00 & 0.00 & 0.00 & 0.00 & 0.00 & 0.01 \\
\hline $\mathrm{Fe}$ & 2.03 & 2.02 & 1.81 & 1.89 & 1.87 & 2.27 & 2.29 & 2.14 & 2.21 & 2.04 & 1.80 & 1.81 & 1.77 & 2.19 & 2.15 & 1.82 & 1.31 \\
\hline $\mathrm{Mn}$ & 0.02 & 0.03 & 0.03 & 0.03 & 0.03 & 0.03 & 0.05 & 0.04 & 0.03 & 0.03 & 0.03 & 0.03 & 0.02 & 0.04 & 0.03 & 0.03 & 0.02 \\
\hline $\mathrm{Ni}$ & 0.03 & 0.02 & 0.03 & 0.02 & 0.01 & 0.02 & 0.01 & 0.02 & 0.03 & 0.03 & 0.04 & 0.02 & 0.02 & 0.02 & 0.02 & 0.00 & 0.01 \\
\hline v & 0.00 & 0.00 & 0.00 & 0.00 & 0.00 & 0.00 & 0.00 & 0.00 & 0.00 & 0.00 & 0.00 & 0.00 & 0.00 & 0.00 & 0.00 & 0.00 & 0.00 \\
\hline Total & 17.89 & 17.95 & 18.01 & 17.93 & 18.01 & 18.00 & 17.88 & 17.92 & 18.01 & 17.96 & 18.04 & 18.02 & 17.88 & 18.02 & 17.93 & 16.00 & 15.92 \\
\hline $\mathrm{Na}_{2} \mathrm{O}$ & 0.02 & 0.00 & 0.00 & 0.00 & 0.00 & 0.02 & 0.00 & 0.01 & 0.00 & 0.01 & 0.00 & 0.04 & 0.00 & 0.00 & 0.00 & 0.00 & 0.00 \\
\hline $\mathrm{MgO}$ & 42.63 & 43.45 & 45.12 & 43.92 & 44.81 & 42.71 & 41.57 & 42.59 & 42.55 & 43.52 & 44.99 & 45.54 & 44.52 & 42.78 & 42.74 & 28.33 & 29.84 \\
\hline $\mathrm{SiO}_{2}$ & 40.04 & 39.90 & 39.81 & 40.10 & 39.67 & 39.52 & 40.31 & 40.10 & 38.86 & 39.91 & 39.23 & 40.10 & 40.89 & 38.99 & 40.09 & 55.29 & 55.86 \\
\hline $\mathrm{Al}_{2} \mathrm{O}_{3}$ & 0.00 & 0.00 & 0.00 & 0.00 & 0.00 & 0.02 & 0.00 & 0.00 & 0.00 & 0.01 & 0.05 & 0.00 & 0.00 & 0.00 & 0.00 & 0.84 & 2.28 \\
\hline $\mathrm{CaO}$ & 0.00 & 0.00 & 0.00 & 0.02 & 0.03 & 0.00 & 0.01 & 0.02 & 0.01 & 0.03 & 0.03 & 0.02 & 0.01 & 0.02 & 0.00 & 0.10 & 0.09 \\
\hline$\frac{1}{5}$ & 0.00 & 0.01 & 0.04 & 0.00 & 0.00 & 0.00 & 0.00 & 0.00 & 0.00 & 0.00 & 0.00 & 0.00 & 0.01 & 0.01 & 0.02 & 0.01 & 0.00 \\
\hline $\mathrm{TiO}_{2}$ & 0.00 & 0.00 & 0.00 & 0.00 & 0.00 & 0.00 & 0.00 & 0.00 & 0.05 & 0.00 & 0.00 & 0.00 & 0.00 & 0.00 & 0.00 & 0.02 & 0.05 \\
\hline $\mathrm{Cr}_{2} \mathrm{O}_{3}$ & 0.00 & 0.00 & 0.00 & 0.02 & 0.04 & 0.02 & 0.00 & 0.01 & 0.00 & 0.02 & 0.05 & 0.00 & 0.00 & 0.01 & 0.00 & 0.06 & 0.08 \\
\hline $\mathrm{FeO}$ & 15.94 & 15.91 & 14.33 & 14.90 & 14.85 & 17.88 & 18.08 & 16.85 & 17.15 & 16.11 & 14.13 & 14.53 & 14.14 & 17.10 & 16.96 & 15.16 & 11.07 \\
\hline $\mathrm{MnO}$ & 0.16 & 0.25 & 0.23 & 0.26 & 0.26 & 0.27 & 0.43 & 0.28 & 0.23 & 0.23 & 0.23 & 0.23 & 0.18 & 0.29 & 0.23 & 0.24 & 0.17 \\
\hline $\mathrm{NiO}$ & 0.21 & 0.16 & 0.25 & 0.19 & 0.09 & 0.16 & 0.11 & 0.15 & 0.23 & 0.26 & 0.31 & 0.20 & 0.19 & 0.20 & 0.18 & 0.03 & 0.06 \\
\hline $\mathrm{V}_{2} \mathrm{O}_{3}$ & 0.00 & 0.00 & 0.01 & 0.04 & 0.03 & 0.02 & 0.00 & 0.01 & 0.03 & 0.04 & 0.00 & 0.04 & 0.03 & 0.02 & 0.01 & 0.01 & 0.00 \\
\hline Total & 99.02 & 99.67 & 99.82 & 99.45 & 99.78 & 100.62 & 100.50 & 100.02 & 99.13 & 100.14 & 99.05 & 100.70 & 99.97 & 99.42 & 100.23 & 100.08 & 99.51 \\
\hline $\begin{array}{l}\text { Fo or En } \\
\text { content }\end{array}$ & 0.83 & 0.83 & 0.85 & 0.84 & 0.84 & 0.81 & 0.80 & 0.82 & 0.82 & 0.83 & 0.85 & 0.85 & 0.85 & 0.82 & 0.82 & 0.77 & 0.83 \\
\hline
\end{tabular}


Drill hole SLM0002 SLM0002 SLM0002 SLM0002 SLM0002 SLM0002 SLM0002 SLM0002 SLM0002 SLM0002 SLM0002 SLM0002 SLM0002 SLM0002 SLM0004 SLM0004 SLM0004

\begin{tabular}{|c|c|c|c|c|c|c|c|c|c|c|c|c|c|c|c|c|c|c|}
\hline & Depth $(\mathrm{m})$ & 140 & 158 & 180 & 195 & 202 & 214 & 224 & 234 & 242 & 257 & 285 & 300 & 307 & 331 & 87 & 110 & 130 \\
\hline & Mineral & Opx & Opx & Opx & Opx & Opx & Opx & Opx & Opx & Opx & Opx & Opx & Opx & Opx & Opx & $\mathrm{Ol}$ & $\mathrm{OO}$ & 이 \\
\hline & $\mathrm{Na}$ & 0.00 & 0.00 & 0.00 & 0.00 & 0.00 & 0.00 & 0.00 & 0.00 & 0.00 & 0.00 & 0.00 & 0.00 & 0.03 & 0.00 & 0.00 & 0.00 & 0.01 \\
\hline & $\mathrm{Mg}$ & 6.34 & 6.69 & 6.75 & 6.54 & 6.67 & 6.58 & 6.29 & 6.41 & 6.40 & 6.55 & 6.62 & 6.74 & 6.34 & 6.21 & 9.95 & 9.89 & 9.95 \\
\hline & $\mathrm{Si}$ & 8.00 & 7.96 & 7.86 & 8.09 & 7.90 & 7.87 & 8.10 & 8.04 & 8.02 & 7.94 & 8.08 & 7.93 & 7.99 & 7.91 & 5.97 & 5.97 & 5.97 \\
\hline & Al & 0.24 & 0.09 & 0.20 & 0.06 & 0.20 & 0.15 & 0.02 & 0.04 & 0.06 & 0.14 & 0.05 & 0.03 & 0.16 & 0.19 & 0.00 & 0.00 & 0.00 \\
\hline & K & & 0.00 & 0.01 & & 0.00 & 0.00 & & & 0.00 & & & 0.00 & & 0.00 & 0.00 & 0.00 & 0.00 \\
\hline & $\mathrm{Ca}$ & 0.02 & 0.02 & 0.02 & 0.02 & 0.02 & 0.03 & 0.03 & 0.02 & 0.03 & 0.02 & 0.02 & 0.03 & 0.03 & 0.03 & 0.00 & 0.00 & 0.00 \\
\hline$\tilde{E}$ & $\mathrm{Cl}$ & 0.00 & 0.00 & 0.01 & 0.00 & 0.00 & 0.00 & 0.00 & 0.00 & 0.00 & 0.00 & 0.00 & 0.00 & 0.02 & 0.00 & 0.01 & 0.00 & 0.00 \\
\hline$\stackrel{0}{4}$ & $\mathrm{Ti}$ & 0.01 & 0.00 & 0.01 & 0.00 & 0.00 & 0.01 & 0.00 & 0.00 & 0.00 & 0.00 & 0.00 & 0.00 & 0.00 & 0.00 & 0.00 & 0.00 & 0.00 \\
\hline & $\mathrm{Cr}$ & 0.00 & 0.00 & 0.01 & 0.00 & 0.01 & 0.00 & 0.00 & 0.00 & 0.01 & 0.01 & 0.00 & 0.00 & 0.01 & 0.02 & 0.00 & 0.00 & 0.00 \\
\hline & $\mathrm{Fe}$ & 1.23 & 1.19 & 1.14 & 1.12 & 1.17 & 1.36 & 1.38 & 1.36 & 1.41 & 1.27 & 1.08 & 1.26 & 1.34 & 1.59 & 2.07 & 2.10 & 2.05 \\
\hline & $\mathrm{Mn}$ & 0.03 & 0.03 & 0.03 & 0.04 & 0.03 & 0.03 & 0.06 & 0.04 & 0.02 & 0.02 & 0.02 & 0.05 & 0.04 & 0.03 & 0.03 & 0.05 & 0.03 \\
\hline & $\mathrm{Ni}$ & 0.00 & 0.00 & 0.00 & 0.00 & 0.00 & 0.01 & 0.00 & 0.01 & 0.01 & 0.01 & 0.00 & 0.00 & 0.00 & 0.00 & 0.01 & 0.01 & 0.01 \\
\hline & v & 0.00 & 0.00 & 0.00 & 0.00 & 0.00 & 0.00 & 0.00 & 0.00 & 0.00 & 0.01 & 0.00 & 0.00 & 0.00 & 0.00 & 0.00 & 0.00 & 0.00 \\
\hline & Total & 15.87 & 16.00 & 16.04 & 15.88 & 16.00 & 16.04 & 15.89 & 15.93 & 15.95 & 15.98 & 15.89 & 16.06 & 15.95 & 15.99 & 18.04 & 18.03 & 18.04 \\
\hline & $\mathrm{Na}_{2} \mathrm{O}$ & 0.00 & 0.00 & 0.00 & 0.02 & 0.01 & 0.00 & 0.00 & 0.00 & 0.00 & 0.00 & 0.00 & 0.01 & 0.09 & 0.01 & 0.01 & 0.00 & 0.04 \\
\hline & $\mathrm{MgO}$ & 30.53 & 31.89 & 32.31 & 31.30 & 31.94 & 31.32 & 29.90 & 30.39 & 30.45 & 31.41 & 31.93 & 31.90 & 30.15 & 29.30 & 43.77 & 43.33 & 44.41 \\
\hline & $\mathrm{SiO}_{2}$ & 57.48 & 56.54 & 56.09 & 57.69 & 56.41 & 55.81 & 57.37 & 56.82 & 56.88 & 56.73 & 58.09 & 55.93 & 56.60 & 55.68 & 39.13 & 38.96 & 39.73 \\
\hline & $\mathrm{Al}_{2} \mathrm{O}_{3}$ & 1.44 & 0.52 & 1.23 & 0.36 & 1.22 & 0.92 & 0.11 & 0.21 & 0.35 & 0.87 & 0.32 & 0.20 & 0.94 & 1.14 & 0.01 & 0.02 & 0.00 \\
\hline & $\mathrm{K}_{2} \mathrm{O}$ & 0.00 & 0.01 & 0.03 & 0.00 & 0.01 & 0.00 & 0.00 & 0.00 & 0.01 & 0.00 & 0.00 & 0.01 & 0.00 & 0.02 & 0.02 & 0.01 & 0.01 \\
\hline å & $\mathrm{CaO}$ & 0.12 & 0.14 & 0.12 & 0.16 & 0.16 & 0.19 & 0.23 & 0.16 & 0.19 & 0.12 & 0.15 & 0.23 & 0.21 & 0.18 & 0.00 & 0.00 & 0.01 \\
\hline$\frac{t}{50}$ & $\mathrm{Cl}$ & 0.00 & 0.01 & 0.04 & 0.01 & 0.00 & 0.00 & 0.00 & 0.01 & 0.00 & 0.00 & 0.01 & 0.01 & 0.07 & 0.01 & 0.02 & 0.00 & 0.00 \\
\hline$\frac{2}{2}$ & $\mathrm{TiO}_{2}$ & 0.05 & 0.02 & 0.06 & 0.00 & 0.02 & 0.06 & 0.02 & 0.04 & 0.00 & 0.02 & 0.00 & 0.00 & 0.05 & 0.00 & 0.00 & 0.00 & 0.00 \\
\hline & $\mathrm{Cr}_{2} \mathrm{O}_{3}$ & 0.03 & 0.04 & 0.09 & 0.03 & 0.10 & 0.03 & 0.03 & 0.04 & 0.05 & 0.08 & 0.02 & 0.00 & 0.09 & 0.14 & 0.00 & 0.04 & 0.00 \\
\hline & $\mathrm{FeO}$ & 10.54 & 10.11 & 9.74 & 9.51 & 9.96 & 11.57 & 11.67 & 11.52 & 11.98 & 10.87 & 9.30 & 10.59 & 11.33 & 13.42 & 16.19 & 16.39 & 16.32 \\
\hline & $\mathrm{MnO}$ & 0.25 & 0.25 & 0.27 & 0.31 & 0.21 & 0.23 & 0.47 & 0.30 & 0.20 & 0.17 & 0.16 & 0.41 & 0.31 & 0.23 & 0.24 & 0.40 & 0.27 \\
\hline & $\mathrm{NiO}$ & 0.03 & 0.04 & 0.00 & 0.02 & 0.00 & 0.05 & 0.03 & 0.06 & 0.06 & 0.08 & 0.00 & 0.03 & 0.03 & 0.03 & 0.06 & 0.07 & 0.12 \\
\hline & $\mathrm{V}_{2} \mathrm{O}_{3}$ & 0.02 & 0.00 & 0.00 & 0.00 & 0.00 & 0.02 & 0.02 & 0.00 & 0.00 & 0.05 & 0.03 & 0.00 & 0.00 & 0.00 & 0.01 & 0.02 & 0.00 \\
\hline & Total & 100.49 & 99.57 & 99.98 & 99.41 & 100.05 & 100.18 & 99.86 & 99.54 & 100.17 & 100.40 & 100.00 & 99.31 & 99.87 & 100.14 & 99.45 & 99.24 & 100.90 \\
\hline & Fo or En & 0.84 & 0.85 & 0.86 & 0.85 & 0.85 & 0.83 & 0.82 & 0.82 & 0.82 & 0.84 & 0.86 & 0.84 & 0.83 & 0.80 & 0.83 & 0.82 & 0.83 \\
\hline
\end{tabular}


Drill hole SLM0004 SLM0004 SLM0004 SLM0004 SLM0004 SLM0004 SLM0004 SLM0004 SLM0004 SLM0004 SLM0004 SLM0004 SLM0021 SLM0021 SLM0021 SLM0021 SLM0021

\begin{tabular}{|c|c|c|c|c|c|c|c|c|c|c|c|c|c|c|c|c|c|c|}
\hline \multicolumn{2}{|c|}{ Depth $(\mathrm{m})$} & 170 & 188 & 209 & 221 & 87 & 110 & 130 & 159 & 170 & 188 & 209 & 221 & 113 & 121 & 132 & 137 & 143 \\
\hline & Mineral & Ol & Ol & Ol & Ol & Opx & Opx & Opx & Opx & Opx & Opx & Opx & Opx & $\mathrm{Ol}$ & $\mathrm{Ol}$ & Ol & Ol & $\mathrm{Ol}$ \\
\hline \multirow{14}{*}{$\begin{array}{l}\tilde{D} \\
\frac{1}{\alpha}\end{array}$} & $\mathrm{Na}$ & 0.00 & 0.00 & 0.00 & 0.00 & 0.00 & 0.00 & 0.00 & 0.00 & 0.00 & 0.00 & 0.00 & 0.00 & 0.00 & 0.00 & 0.00 & 0.01 & 0.01 \\
\hline & $\mathrm{Mg}$ & 10.14 & 10.12 & 9.99 & 9.98 & 6.63 & 6.54 & 6.74 & 6.32 & 6.77 & 6.67 & 6.83 & 6.71 & 9.86 & 10.02 & 9.95 & 9.97 & 10.02 \\
\hline & Si & 5.96 & 5.98 & 5.96 & 6.01 & 7.82 & 7.92 & 7.91 & 7.87 & 7.87 & 7.84 & 7.96 & 8.00 & 6.03 & 6.00 & 6.04 & 6.00 & 6.01 \\
\hline & Al & 0.00 & 0.00 & 0.00 & 0.00 & 0.26 & 0.15 & 0.09 & 0.21 & 0.17 & 0.30 & 0.03 & 0.05 & 0.00 & 0.00 & 0.00 & 0.00 & 0.00 \\
\hline & K & 0.00 & 0.00 & 0.00 & 0.00 & 0.00 & 0.00 & 0.00 & 0.00 & 0.00 & 0.00 & 0.00 & 0.00 & 0.00 & 0.00 & 0.00 & 0.00 & 0.00 \\
\hline & $\mathrm{Ca}$ & 0.00 & 0.01 & 0.00 & 0.00 & 0.02 & 0.04 & 0.02 & 0.02 & 0.02 & 0.02 & 0.02 & 0.02 & 0.00 & 0.00 & 0.00 & 0.00 & 0.00 \\
\hline & $\mathrm{Cl}$ & 0.00 & 0.00 & 0.00 & 0.00 & 0.00 & 0.00 & 0.00 & 0.01 & 0.00 & 0.00 & 0.00 & 0.00 & 0.00 & 0.00 & 0.00 & 0.00 & 0.00 \\
\hline & $\mathrm{Ti}$ & 0.00 & 0.00 & 0.00 & 0.00 & 0.00 & 0.00 & 0.00 & 0.00 & 0.01 & 0.00 & 0.00 & 0.00 & 0.01 & 0.00 & 0.00 & 0.00 & 0.00 \\
\hline & $\mathrm{Cr}$ & 0.00 & 0.00 & 0.00 & 0.00 & 0.01 & 0.01 & 0.00 & 0.01 & 0.00 & 0.00 & 0.00 & 0.00 & 0.00 & 0.00 & 0.00 & 0.00 & 0.00 \\
\hline & $\mathrm{Fe}$ & 1.89 & 1.87 & 2.04 & 1.94 & 1.26 & 1.29 & 1.24 & 1.56 & 1.14 & 1.14 & 1.14 & 1.14 & 2.01 & 1.94 & 1.92 & 1.98 & 1.91 \\
\hline & $\mathrm{Mn}$ & 0.03 & 0.03 & 0.04 & 0.03 & 0.04 & 0.05 & 0.03 & 0.03 & 0.03 & 0.02 & 0.03 & 0.03 & 0.03 & 0.02 & 0.03 & 0.02 & 0.02 \\
\hline & $\mathrm{Ni}$ & 0.01 & 0.01 & 0.02 & 0.02 & 0.00 & 0.00 & 0.00 & 0.00 & 0.00 & 0.00 & 0.00 & 0.00 & 0.01 & 0.01 & 0.02 & 0.01 & 0.02 \\
\hline & v & 0.01 & 0.00 & 0.00 & 0.00 & 0.00 & 0.00 & 0.00 & 0.00 & 0.01 & 0.00 & 0.00 & 0.00 & 0.00 & 0.00 & 0.00 & 0.00 & 0.00 \\
\hline & Total & 18.04 & 18.02 & 18.04 & 17.99 & 16.04 & 16.01 & 16.05 & 16.03 & 16.04 & 16.01 & 16.03 & 15.98 & 17.96 & 18.00 & 17.96 & 18.00 & 18.00 \\
\hline \multirow{15}{*}{ 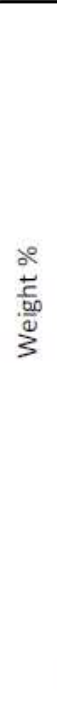 } & $\mathrm{Na}_{2} \mathrm{O}$ & 0.00 & 0.01 & 0.00 & 0.00 & 0.01 & 0.02 & 0.01 & 0.00 & 0.01 & 0.00 & 0.00 & 0.00 & 0.00 & 0.00 & 0.00 & 0.03 & 0.05 \\
\hline & $\mathrm{MgO}$ & 45.25 & 44.72 & 44.62 & 44.56 & 31.65 & 30.89 & 32.14 & 29.93 & 32.73 & 31.69 & 32.70 & 32.10 & 43.64 & 44.35 & 44.27 & 44.26 & 44.77 \\
\hline & $\mathrm{SiO}_{2}$ & 39.65 & 39.40 & 39.67 & 39.97 & 55.61 & 55.71 & 56.21 & 55.55 & 56.71 & 55.56 & 56.77 & 57.03 & 39.82 & 39.59 & 40.04 & 39.72 & 40.03 \\
\hline & $\mathrm{Al}_{2} \mathrm{O}_{3}$ & 0.00 & 0.00 & 0.00 & 0.00 & 1.57 & 0.89 & 0.56 & 1.24 & 1.06 & 1.82 & 0.18 & 0.30 & 0.00 & 0.00 & 0.00 & 0.00 & 0.00 \\
\hline & $\mathrm{K}_{2} \mathrm{O}$ & 0.01 & 0.00 & 0.00 & 0.00 & 0.01 & 0.01 & 0.00 & 0.00 & 0.02 & 0.00 & 0.00 & 0.02 & 0.01 & 0.00 & 0.01 & 0.00 & 0.01 \\
\hline & $\mathrm{CaO}$ & 0.02 & 0.03 & 0.00 & 0.02 & 0.12 & 0.26 & 0.12 & 0.13 & 0.13 & 0.11 & 0.13 & 0.15 & 0.02 & 0.00 & 0.00 & 0.00 & 0.01 \\
\hline & $\mathrm{Cl}$ & 0.00 & 0.00 & 0.00 & 0.00 & 0.00 & 0.01 & 0.00 & 0.03 & 0.01 & 0.02 & 0.01 & 0.02 & 0.01 & 0.00 & 0.01 & 0.01 & 0.00 \\
\hline & $\mathrm{TiO}_{2}$ & 0.00 & 0.00 & 0.00 & 0.02 & 0.04 & 0.03 & 0.00 & 0.02 & 0.06 & 0.02 & 0.00 & 0.02 & 0.05 & 0.00 & 0.00 & 0.00 & 0.00 \\
\hline & $\mathrm{Cr}_{2} \mathrm{O}_{3}$ & 0.01 & 0.03 & 0.03 & 0.03 & 0.11 & 0.07 & 0.00 & 0.06 & 0.04 & 0.03 & 0.03 & 0.01 & 0.01 & 0.00 & 0.00 & 0.02 & 0.01 \\
\hline & $\mathrm{FeO}$ & 15.05 & 14.71 & 16.22 & 15.48 & 10.70 & 10.87 & 10.53 & 13.15 & 9.86 & 9.66 & 9.74 & 9.75 & 15.89 & 15.26 & 15.22 & 15.70 & 15.20 \\
\hline & $\mathrm{MnO}$ & 0.24 & 0.23 & 0.29 & 0.26 & 0.31 & 0.43 & 0.29 & 0.26 & 0.26 & 0.21 & 0.28 & 0.26 & 0.26 & 0.19 & 0.24 & 0.15 & 0.17 \\
\hline & $\mathrm{NiO}$ & 0.08 & 0.07 & 0.13 & 0.14 & 0.00 & 0.00 & 0.00 & 0.03 & 0.00 & 0.04 & 0.00 & 0.01 & 0.06 & 0.06 & 0.13 & 0.09 & 0.15 \\
\hline & $\mathrm{V}_{2} \mathrm{O}_{3}$ & 0.05 & 0.00 & 0.00 & 0.00 & 0.03 & 0.00 & 0.02 & 0.01 & 0.08 & 0.00 & 0.03 & 0.00 & 0.00 & 0.02 & 0.01 & 0.00 & 0.00 \\
\hline & Total & 100.36 & 99.21 & 100.96 & 100.47 & 100.16 & 99.17 & 99.89 & 100.41 & 100.96 & 99.14 & 99.87 & 99.67 & 99.78 & 99.46 & 99.92 & 99.97 & 100.38 \\
\hline & Fo or En & 0.84 & 0.84 & 0.83 & 0.84 & 0.84 & 0.84 & 0.84 & 0.80 & 0.86 & 0.85 & 0.86 & 0.85 & 0.83 & 0.84 & 0.84 & 0.83 & 0.84 \\
\hline
\end{tabular}


Drill hole SLM0021 SLM0021 SLM0021 SLM0021 SLM0021 SLM0021 SLM0021 SLM0021 SLM0021 SLM0021 SLM0021 SLM0021 SLM0021 SLM0021 SLM0021 SLM0021 SLM0021

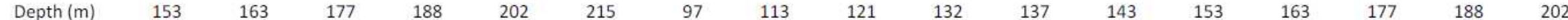

\begin{tabular}{|c|c|c|c|c|c|c|c|c|c|c|c|c|c|c|c|c|c|c|}
\hline & Mineral & Ol & Ol & Ol & Ol & Ol & Ol & Opx & Opx & Opx & Opx & Opx & Opx & Opx & Opx & Opx & Opx & Opx \\
\hline \multirow{14}{*}{$\begin{array}{l}\frac{n}{E} \\
\frac{0}{\&}\end{array}$} & $\mathrm{Na}$ & 0.00 & 0.00 & 0.01 & 0.00 & 0.00 & 0.00 & 0.00 & 0.00 & 0.00 & 0.00 & 0.01 & 0.00 & 0.00 & 0.01 & 0.00 & 0.00 & $\overline{0.00}$ \\
\hline & $\mathrm{Mg}$ & 9.95 & 9.90 & 9.96 & 10.09 & 10.20 & 10.18 & 6.56 & 6.65 & 6.75 & 6.61 & 6.60 & 6.78 & 6.62 & 6.51 & 6.78 & 6.76 & 6.77 \\
\hline & $\mathrm{Si}$ & 6.01 & 6.05 & 5.98 & 6.05 & 6.00 & 6.03 & 7.88 & 7.88 & 7.78 & 7.89 & 8.01 & 7.97 & 7.86 & 7.81 & 7.96 & 7.96 & 8.05 \\
\hline & Al & 0.00 & 0.00 & 0.00 & 0.00 & 0.00 & 0.00 & 0.17 & 0.17 & 0.26 & 0.21 & 0.05 & 0.05 & 0.25 & 0.37 & 0.03 & 0.11 & 0.01 \\
\hline & K & 0.00 & 0.00 & 0.00 & 0.00 & 0.00 & 0.00 & 0.00 & 0.00 & 0.00 & 0.00 & 0.01 & 0.00 & 0.01 & 0.00 & 0.00 & 0.00 & 0.00 \\
\hline & $\mathrm{Ca}$ & 0.00 & 0.00 & 0.00 & 0.00 & 0.00 & 0.01 & 0.03 & 0.02 & 0.01 & 0.02 & 0.03 & 0.02 & 0.03 & 0.03 & 0.02 & 0.02 & 0.03 \\
\hline & $\mathrm{Cl}$ & 0.00 & 0.00 & 0.00 & 0.00 & 0.00 & 0.00 & 0.00 & 0.00 & 0.00 & 0.00 & 0.00 & 0.00 & 0.00 & 0.00 & 0.00 & 0.00 & 0.00 \\
\hline & $\mathrm{Ti}$ & 0.00 & 0.00 & 0.00 & 0.00 & 0.00 & 0.00 & 0.00 & 0.00 & 0.00 & 0.01 & 0.00 & 0.00 & 0.00 & 0.00 & 0.01 & 0.00 & 0.00 \\
\hline & $\mathrm{Cr}$ & 0.00 & 0.00 & 0.01 & 0.00 & 0.00 & 0.01 & 0.01 & 0.02 & 0.01 & 0.01 & 0.00 & 0.00 & 0.00 & 0.01 & 0.00 & 0.01 & 0.00 \\
\hline & $\mathrm{Fe}$ & 1.96 & 1.92 & 1.98 & 1.73 & 1.73 & 1.69 & 1.34 & 1.27 & 1.23 & 1.21 & 1.23 & 1.13 & 1.19 & 1.24 & 1.17 & 1.09 & 1.04 \\
\hline & $\mathrm{Mn}$ & 0.03 & 0.03 & 0.03 & 0.03 & 0.03 & 0.02 & 0.03 & 0.04 & 0.02 & 0.03 & 0.04 & 0.02 & 0.04 & 0.02 & 0.04 & 0.03 & 0.04 \\
\hline & $\mathrm{Ni}$ & 0.03 & 0.03 & 0.04 & 0.04 & 0.03 & 0.04 & 0.01 & 0.00 & 0.00 & 0.00 & 0.00 & 0.00 & 0.00 & 0.00 & 0.00 & 0.01 & 0.00 \\
\hline & V & 0.00 & 0.00 & 0.00 & 0.00 & 0.00 & 0.00 & 0.00 & 0.00 & 0.00 & 0.00 & 0.00 & 0.00 & 0.00 & 0.00 & 0.00 & 0.00 & 0.00 \\
\hline & Total & 17.99 & 17.95 & 18.02 & 17.95 & 18.00 & 17.97 & 16.03 & 16.03 & 16.08 & 16.00 & 15.98 & 16.00 & 16.01 & 16.01 & 16.02 & 15.99 & 15.95 \\
\hline \multirow{15}{*}{$\begin{array}{l}\frac{a}{2} \\
\frac{c}{00} \\
\frac{0}{0} \\
3\end{array}$} & $\mathrm{Na}_{2} \mathrm{O}$ & 0.00 & 0.01 & 0.03 & 0.01 & 0.00 & 0.00 & 0.00 & 0.00 & 0.00 & 0.01 & 0.04 & 0.01 & 0.01 & 0.03 & 0.00 & 0.01 & 0.01 \\
\hline & $\mathrm{MgO}$ & 44.27 & 43.75 & 44.44 & 45.15 & 45.76 & 45.20 & 31.21 & 31.43 & 32.28 & 31.59 & 31.53 & 32.33 & 31.56 & 30.90 & 32.59 & 32.45 & 32.51 \\
\hline & $\mathrm{SiO}_{2}$ & 39.84 & 39.89 & 39.77 & 40.34 & 40.16 & 39.87 & 55.91 & 55.53 & 55.46 & 56.17 & 57.03 & 56.70 & 55.86 & 55.28 & 57.03 & 56.93 & 57.63 \\
\hline & $\mathrm{Al}_{2} \mathrm{O}_{3}$ & 0.02 & 0.00 & 0.00 & 0.00 & 0.00 & 0.00 & 1.03 & 1.00 & 1.56 & 1.29 & 0.33 & 0.29 & 1.51 & 2.19 & 0.17 & 0.64 & 0.08 \\
\hline & $\mathrm{K}_{2} \mathrm{O}$ & 0.00 & 0.01 & 0.00 & 0.02 & 0.01 & 0.00 & 0.02 & 0.00 & 0.00 & 0.00 & 0.03 & 0.01 & 0.03 & 0.00 & 0.01 & 0.01 & 0.02 \\
\hline & $\mathrm{CaO}$ & 0.02 & 0.00 & 0.02 & 0.00 & 0.00 & 0.03 & 0.17 & 0.10 & 0.09 & 0.13 & 0.17 & 0.15 & 0.18 & 0.22 & 0.15 & 0.11 & 0.20 \\
\hline & $\mathrm{Cl}$ & 0.02 & 0.00 & 0.01 & 0.00 & 0.01 & 0.01 & 0.00 & 0.00 & 0.00 & 0.00 & 0.02 & 0.01 & 0.00 & 0.02 & 0.00 & 0.01 & 0.00 \\
\hline & $\mathrm{TiO}_{2}$ & 0.00 & 0.00 & 0.00 & 0.02 & 0.00 & 0.03 & 0.04 & 0.00 & 0.04 & 0.06 & 0.00 & 0.03 & 0.02 & 0.02 & 0.08 & 0.03 & 0.04 \\
\hline & $\mathrm{Cr}_{2} \mathrm{O}_{3}$ & 0.00 & 0.01 & 0.07 & 0.00 & 0.00 & 0.05 & 0.10 & 0.17 & 0.11 & 0.06 & 0.00 & 0.04 & 0.04 & 0.09 & 0.01 & 0.09 & 0.00 \\
\hline & $\mathrm{FeO}$ & 15.52 & 15.15 & 15.74 & 13.81 & 13.86 & 13.41 & 11.40 & 10.69 & 10.50 & 10.33 & 10.49 & 9.64 & 10.13 & 10.46 & 10.03 & 9.35 & 8.90 \\
\hline & $\mathrm{MnO}$ & 0.20 & 0.25 & 0.26 & 0.21 & 0.22 & 0.14 & 0.27 & 0.30 & 0.20 & 0.23 & 0.30 & 0.21 & 0.30 & 0.18 & 0.30 & 0.21 & 0.32 \\
\hline & $\mathrm{NiO}$ & 0.24 & 0.26 & 0.37 & 0.30 & 0.25 & 0.30 & 0.06 & 0.01 & 0.02 & 0.02 & 0.00 & 0.00 & 0.04 & 0.02 & 0.04 & 0.09 & 0.02 \\
\hline & $\mathrm{V}_{2} \mathrm{O}_{3}$ & 0.04 & 0.00 & 0.03 & 0.00 & 0.02 & 0.00 & 0.02 & 0.00 & 0.00 & 0.00 & 0.00 & 0.04 & 0.04 & 0.00 & 0.04 & 0.00 & 0.00 \\
\hline & Total & 100.17 & 99.33 & 100.76 & 99.86 & 100.29 & 99.04 & 100.22 & 99.23 & 100.27 & 99.88 & 99.93 & 99.44 & 99.72 & 99.40 & 100.45 & 99.94 & 99.71 \\
\hline & or En & 0.84 & 0.84 & 0.83 & 0.85 & 0.85 & 0.86 & 0.83 & 0.84 & 0.85 & 0.85 & 0.84 & 0.86 & 0.85 & 0.84 & 0.85 & 0.86 & 0.87 \\
\hline
\end{tabular}


Drill hole SLM0021 SLM0053 SLM0053 SLM0053 SLM0053 SLM0053 SLM0053 SLM0053 SLM0053 SLM0053 SLM0053 SLM0053 SLM0053 SLM0053 SLM0053 SLM0053 SLM0053

\begin{tabular}{|c|c|c|c|c|c|c|c|c|c|c|c|c|c|c|c|c|c|c|}
\hline & Depth $(\mathrm{m})$ & 215 & 48 & 67 & 78 & 90 & 102 & 106 & 114 & 129 & 143 & 155 & 48 & 67 & 78 & 102 & 106 & 11 \\
\hline & Mineral & Opx & Ol & Ol & Ol & Ol & Ol & Ol & Ol & Ol & $\mathrm{Ol}$ & Ol & Opx & Opx & Opx & Opx & Opx & Opx \\
\hline & $\mathrm{Na}$ & 0.00 & 0.05 & 0.00 & 0.00 & 0.00 & 0.00 & 0.00 & 0.00 & 0.00 & 0.00 & 0.01 & 0.01 & 0.00 & 0.00 & 0.00 & 0.00 & 0.00 \\
\hline & $\mathrm{Mg}$ & 6.81 & 9.43 & 9.70 & 9.36 & 9.78 & 9.82 & 9.70 & 10.36 & 10.45 & 10.23 & 10.03 & 6.42 & 6.50 & 6.20 & 6.61 & 6.39 & 6.9 \\
\hline & $\mathrm{Si}$ & 8.02 & 6.02 & 5.98 & 6.20 & 6.02 & 5.96 & 6.12 & 5.99 & 5.94 & 6.01 & 6.01 & 7.83 & 7.73 & 8.08 & 7.90 & 8.07 & \\
\hline & Al & 0.02 & 0.00 & 0.00 & 0.00 & 0.00 & 0.00 & 0.00 & 0.00 & 0.00 & 0.00 & 0.00 & 0.24 & 0.41 & 0.17 & 0.14 & 0.13 & \\
\hline & $\mathrm{K}$ & 0.00 & & 0.00 & 0.00 & 0.00 & & 0.00 & 0.00 & & 0.00 & & & 0.00 & 0.00 & & 0.00 & \\
\hline & $\mathrm{Ca}$ & 0.03 & 0.01 & 0.00 & 0.00 & 0.00 & 0.00 & 0.00 & 0.00 & 0.00 & 0.00 & 0.00 & 0.03 & 0.03 & 0.03 & 0.03 & 0.02 & \\
\hline है & $\mathrm{Cl}$ & 0.00 & 0.03 & 0.00 & 0.01 & 0.00 & 0.00 & 0.00 & 0.00 & 0.00 & 0.01 & 0.00 & 0.00 & 0.00 & 0.00 & 0.00 & 0.00 & \\
\hline 并 & $\mathrm{Ti}$ & 0.00 & 0.00 & 0.00 & 0.00 & 0.00 & 0.00 & 0.00 & 0.00 & 0.00 & 0.00 & 0.00 & 0.01 & 0.00 & 0.00 & 0.00 & 0.00 & \\
\hline & $\mathrm{Cr}$ & 0.01 & 0.00 & 0.00 & 0.00 & 0.00 & 0.00 & 0.00 & 0.00 & 0.00 & 0.00 & 0.00 & 0.01 & 0.01 & 0.01 & 0.00 & 0.00 & \\
\hline & $\mathrm{Fe}$ & 1.03 & 2.44 & 2.29 & 2.18 & 2.13 & 2.18 & 2.00 & 1.60 & 1.61 & 1.67 & 1.90 & 1.46 & 1.33 & 1.29 & 1.31 & 1.21 & \\
\hline & $\mathrm{Mn}$ & 0.04 & 0.02 & 0.03 & 0.03 & 0.03 & 0.04 & 0.02 & 0.03 & 0.02 & 0.04 & 0.02 & 0.03 & 0.03 & 0.03 & 0.04 & 0.03 & \\
\hline & $\mathrm{Ni}$ & 0.00 & 0.02 & 0.02 & 0.01 & 0.02 & 0.03 & 0.03 & 0.02 & 0.02 & 0.03 & 0.02 & 0.00 & 0.00 & 0.00 & 0.00 & 0.01 & \\
\hline & v & 0.00 & 0.00 & 0.00 & 0.00 & 0.00 & 0.00 & 0.00 & 0.00 & 0.00 & 0.00 & 0.00 & 0.00 & 0.00 & 0.00 & 0.00 & 0.00 & \\
\hline & Total & 15.97 & 18.03 & 18.02 & 17.81 & 17.98 & 18.04 & 17.88 & 18.01 & 18.06 & 17.99 & 18.00 & 16.04 & 16.05 & 15.83 & 16.03 & 15.86 & 16. \\
\hline & $\mathrm{Na}_{2} \mathrm{O}$ & 0.01 & 0.19 & 0.00 & 0.02 & 0.00 & 0.02 & 0.00 & 0.00 & 0.01 & 0.01 & 0.05 & 0.02 & 0.00 & 0.00 & 0.01 & 0.00 & \\
\hline & $\mathrm{MgO}$ & 32.66 & 41.38 & 42.28 & 41.12 & 43.12 & 43.10 & 42.98 & 46.62 & 46.79 & 45.89 & 44.77 & 30.40 & 30.91 & 29.74 & 31.47 & 30.75 & 33. \\
\hline & $\mathrm{SiO}_{2}$ & 57.35 & 39.37 & 38.86 & 40.59 & 39.52 & 39.03 & 40.46 & 40.16 & 39.66 & 40.21 & 39.98 & 55.28 & 54.81 & 57.82 & 56.09 & 57.91 & \\
\hline & $\mathrm{Al}_{2} \mathrm{O}_{3}$ & 0.13 & 0.00 & 0.00 & 0.00 & 0.00 & 0.00 & 0.00 & 0.00 & 0.01 & 0.00 & 0.00 & 1.45 & 2.49 & 1.02 & 0.81 & 0.77 & \\
\hline & $\mathrm{K}_{2} \mathrm{O}$ & 0.01 & 0.00 & 0.00 & 0.02 & 0.00 & 0.00 & 0.00 & 0.00 & 0.00 & 0.00 & 0.00 & 0.00 & 0.00 & 0.03 & 0.00 & 0.00 & \\
\hline$\alpha^{\circ}$ & $\mathrm{CaO}$ & 0.20 & 0.06 & 0.00 & 0.03 & 0.00 & 0.00 & 0.02 & 0.01 & 0.00 & 0.01 & 0.01 & 0.18 & 0.21 & 0.22 & 0.21 & 0.16 & \\
\hline$\frac{t}{\frac{\pi}{00}}$ & $\mathrm{Cl}$ & 0.01 & 0.11 & 0.00 & 0.02 & 0.00 & 0.00 & 0.01 & 0.00 & 0.00 & 0.03 & 0.01 & 0.00 & 0.01 & 0.01 & 0.02 & 0.00 & \\
\hline & $\mathrm{TiO}_{2}$ & 0.01 & 0.00 & 0.00 & 0.01 & 0.00 & 0.00 & 0.00 & 0.00 & 0.00 & 0.00 & 0.00 & 0.08 & 0.03 & 0.05 & 0.00 & 0.02 & \\
\hline & $\mathrm{Cr}_{2} \mathrm{O}_{3}$ & 0.05 & 0.02 & 0.00 & 0.00 & 0.03 & 0.00 & 0.03 & 0.00 & 0.04 & 0.00 & 0.00 & 0.07 & 0.11 & 0.10 & 0.04 & 0.01 & \\
\hline & $\mathrm{FeO}$ & 8.85 & 19.04 & 17.76 & 17.04 & 16.72 & 17.06 & 15.79 & 12.85 & 12.87 & 13.32 & 15.09 & 12.33 & 11.23 & 11.06 & 11.10 & 10.37 & \\
\hline & $\mathrm{MnO}$ & 0.36 & 0.17 & 0.25 & 0.22 & 0.23 & 0.31 & 0.16 & 0.23 & 0.19 & 0.28 & 0.18 & 0.28 & 0.25 & 0.27 & 0.31 & 0.25 & \\
\hline & $\mathrm{NiO}$ & 0.00 & 0.16 & 0.12 & 0.10 & 0.12 & 0.21 & 0.26 & 0.20 & 0.18 & 0.26 & 0.17 & 0.00 & 0.00 & 0.00 & 0.03 & 0.07 & \\
\hline & $\mathrm{V}_{2} \mathrm{O}_{3}$ & 0.01 & 0.00 & 0.01 & 0.02 & 0.02 & 0.01 & 0.00 & 0.00 & 0.00 & 0.04 & 0.00 & 0.00 & 0.00 & 0.02 & 0.01 & 0.00 & \\
\hline & Total & 99.65 & 100.50 & 99.29 & 99.19 & 99.76 & 99.74 & 99.71 & 100.08 & 99.74 & 100.05 & 100.26 & 100.09 & 100.06 & 100.33 & 100.10 & 100.31 & \\
\hline & Fo or En & 0.87 & 0.79 & 0.81 & 0.81 & 0.82 & 0.82 & 0.83 & 0.87 & 0.87 & 0.86 & 0.84 & 0.81 & 0.83 & 0.83 & 0.83 & 0.84 & 0.87 \\
\hline
\end{tabular}


Drill hole SLM0053 SLM0053 SLM0053 SLM0053 SLM0053 SLM0070 SLM0070 SLM0070 SLM0070 SLM0070 SLM0070 SLM0070 SLM0070 SLM0070 SLM0070 SLM0251 SLM0251

\begin{tabular}{|c|c|c|c|c|c|c|c|c|c|c|c|c|c|c|c|c|c|c|}
\hline & Depth (m) & 129 & 143 & 155 & 168 & 168 & 67 & 163 & 193 & 219 & 245 & 67 & 163 & 193 & 219 & 245 & 61 & 71 \\
\hline & Mineral & Opx & Opx & Opx & Opx & Opx & Ol & $\mathrm{Ol}$ & $\mathrm{Ol}$ & $\mathrm{Ol}$ & 이 & Opx & Opx & Opx & Opx & Opx & Ol & Ol \\
\hline \multirow{14}{*}{ है } & $\mathrm{Na}$ & 0.00 & 0.00 & 0.00 & 0.00 & 0.00 & 0.00 & 0.02 & 0.00 & 0.00 & 0.00 & 0.00 & 0.00 & 0.00 & 0.00 & 0.00 & 0.00 & 0.00 \\
\hline & Mg & 6.89 & 6.74 & 6.76 & 6.22 & 6.30 & 9.80 & 10.27 & 10.40 & 10.15 & 10.22 & 6.58 & 6.77 & 6.89 & 6.90 & 6.86 & 9.70 & 9.61 \\
\hline & $\mathrm{Si}$ & 7.90 & 7.95 & 7.86 & 7.76 & 7.72 & 6.00 & 5.98 & 5.99 & 6.01 & 6.04 & 7.94 & 7.84 & 8.01 & 8.00 & 8.00 & 5.88 & 6.07 \\
\hline & Al & 0.14 & 0.17 & 0.20 & 0.42 & 0.41 & 0.00 & 0.00 & 0.00 & 0.00 & 0.00 & 0.13 & 0.29 & 0.00 & 0.04 & 0.01 & 0.00 & 0.00 \\
\hline & K & & 0.00 & & 0.00 & 0.00 & 0.00 & 0.00 & 0.00 & 0.00 & 0.00 & 0.00 & 0.00 & 0.00 & 0.00 & 0.00 & & 0.00 \\
\hline & $\mathrm{Ca}$ & 0.03 & 0.03 & 0.02 & 0.02 & 0.01 & 0.00 & 0.01 & 0.00 & 0.00 & 0.00 & 0.02 & 0.02 & 0.02 & 0.02 & 0.02 & 0.00 & 0.00 \\
\hline & $\mathrm{Cl}$ & 0.00 & 0.00 & 0.00 & 0.00 & 0.00 & 0.00 & 0.00 & 0.00 & 0.00 & 0.00 & 0.00 & 0.00 & 0.00 & 0.00 & 0.00 & 0.00 & 0.00 \\
\hline & $\mathrm{Ti}$ & 0.00 & 0.00 & 0.00 & 0.00 & 0.00 & 0.00 & 0.00 & 0.00 & 0.00 & 0.00 & 0.00 & 0.00 & 0.00 & 0.00 & 0.00 & 0.00 & 0.00 \\
\hline & $\mathrm{Cr}$ & 0.00 & 0.00 & 0.00 & 0.04 & 0.04 & 0.00 & 0.00 & 0.00 & 0.00 & 0.00 & 0.01 & 0.01 & 0.00 & 0.00 & 0.01 & 0.00 & 0.00 \\
\hline & $\mathrm{Fe}$ & 1.03 & 1.02 & 1.15 & 1.53 & 1.54 & 2.15 & 1.69 & 1.57 & 1.75 & 1.61 & 1.27 & 1.05 & 1.03 & 0.97 & 1.03 & 2.07 & 2.22 \\
\hline & $\mathrm{Mn}$ & 0.03 & 0.03 & 0.03 & 0.02 & 0.02 & 0.04 & 0.03 & 0.03 & 0.02 & 0.03 & 0.03 & 0.02 & 0.04 & 0.02 & 0.04 & 0.05 & 0.01 \\
\hline & $\mathrm{Ni}$ & 0.00 & 0.00 & 0.01 & 0.01 & 0.01 & 0.01 & 0.02 & 0.02 & 0.03 & 0.04 & 0.00 & 0.01 & 0.00 & 0.00 & 0.01 & 0.01 & 0.03 \\
\hline & V & 0.00 & 0.00 & 0.00 & 0.00 & 0.00 & 0.00 & 0.00 & 0.00 & 0.00 & 0.01 & 0.00 & 0.01 & 0.00 & 0.00 & 0.00 & 0.00 & 0.00 \\
\hline & Total & 16.03 & 15.96 & 16.04 & 16.02 & 16.05 & 18.00 & 18.03 & 18.02 & 17.99 & 17.95 & 15.99 & 16.02 & 15.99 & 15.97 & 15.99 & 18.51 & 17.94 \\
\hline \multirow{15}{*}{$\begin{array}{l}\frac{d}{2} \\
\frac{7}{50} \\
\frac{000}{3} \\
3\end{array}$} & $\mathrm{Na}_{2} \mathrm{O}$ & 0.00 & 0.00 & 0.00 & 0.00 & 0.00 & 0.01 & 0.07 & 0.00 & 0.00 & 0.00 & 0.00 & 0.01 & 0.00 & 0.00 & 0.00 & 0.00 & 0.01 \\
\hline & $\mathrm{MgO}$ & 33.30 & 32.55 & 32.39 & 29.42 & 29.87 & 43.19 & 46.14 & 46.74 & 45.28 & 45.59 & 31.17 & 32.32 & 33.17 & 33.07 & 32.81 & 43.17 & 42.47 \\
\hline & $\mathrm{SiO}_{2}$ & 56.96 & 57.22 & 56.17 & 54.68 & 54.57 & 39.39 & 40.06 & 40.10 & 39.97 & 40.17 & 56.07 & 55.73 & 57.52 & 57.13 & 57.03 & 39,02 & 39.96 \\
\hline & $\mathrm{Al}_{2} \mathrm{O}_{3}$ & 0.85 & 1.03 & 1.20 & 2.51 & 2.44 & 0.00 & 0.00 & 0.00 & 0.00 & 0.00 & 0.79 & 1.74 & 0.01 & 0.27 & 0.08 & 0.02 & 0.00 \\
\hline & $\mathrm{K}_{2} \mathrm{O}$ & & 0.00 & 0.00 & 0.02 & 0.01 & 0.00 & 0.00 & 0.00 & 0.00 & 0.00 & 0.01 & 0.02 & 0.00 & 0.00 & 0.00 & & 0.02 \\
\hline & $\mathrm{CaO}$ & 0.18 & 0.20 & 0.16 & 0.11 & 0.09 & 0.00 & 0.04 & 0.02 & 0.03 & 0.00 & 0.11 & 0.13 & 0.14 & 0.11 & 0.16 & 0.00 & 0.00 \\
\hline & $\mathrm{Cl}$ & 0.02 & 0.02 & 0.01 & 0.00 & 0.00 & 0.00 & 0.00 & 0.01 & 0.00 & 0.00 & 0.00 & 0.00 & 0.00 & 0.00 & 0.01 & 0.00 & 0.01 \\
\hline & $\mathrm{TiO}_{2}$ & 0.00 & 0.04 & 0.00 & 0.01 & 0.00 & 0.00 & 0.00 & 0.00 & 0.00 & 0.00 & 0.00 & 0.00 & 0.00 & 0.00 & 0.01 & 0.03 & 0.00 \\
\hline & $\mathrm{Cr}_{2} \mathrm{O}_{3}$ & 0.01 & 0.03 & 0.04 & 0.32 & 0.39 & 0.03 & 0.00 & 0.01 & 0.03 & 0.00 & 0.08 & 0.08 & 0.00 & 0.03 & 0.07 & 0.00 & 0.00 \\
\hline & $\mathrm{FeO}$ & 8.91 & 8.80 & 9.83 & 12.88 & 12.97 & 16.90 & 13.54 & 12.60 & 13.95 & 12.78 & 10.76 & 8.90 & 8.81 & 8.32 & 8.80 & 16.46 & 17.53 \\
\hline & $\mathrm{MnO}$ & 0.28 & 0.24 & 0.27 & 0.19 & 0.14 & 0.30 & 0.22 & 0.23 & 0.19 & 0.24 & 0.23 & 0.19 & 0.32 & 0.17 & 0.31 & 0.40 & 0.05 \\
\hline & $\mathrm{NiO}$ & 0.01 & 0.04 & 0.08 & 0.06 & 0.08 & 0.05 & 0.17 & 0.18 & 0.28 & 0.33 & 0.03 & 0.06 & 0.00 & 0.04 & 0.05 & 0.10 & 0.20 \\
\hline & $\mathrm{V}_{2} \mathrm{O}_{3}$ & 0.01 & 0.00 & 0.02 & 0.00 & 0.02 & 0.00 & 0.03 & 0.00 & 0.01 & 0.06 & 0.00 & 0.05 & 0.00 & 0.01 & 0.00 & 0.02 & 0.00 \\
\hline & Total & 100.53 & 100.17 & 100.17 & 100.20 & 100.59 & 99.87 & 100.28 & 99.89 & 99.72 & 99.17 & 99.24 & 99.24 & 99.98 & 99.15 & 99.33 & 99.21 & 100.24 \\
\hline & $\begin{array}{l}\text { Fo or En } \\
\text { content }\end{array}$ & 0.87 & 0.87 & 0.85 & 0.80 & 0.80 & 0.82 & 0.86 & 0.87 & 0.85 & 0.86 & 0.84 & 0.87 & 0.87 & 0.88 & 0.87 & 0.82 & 0.81 \\
\hline
\end{tabular}


Drill hole SLM0251 SLM0251 SLM0251 SLM0251 SLM0251 SLM0251 SLM0251 SLM0251 SLM0251 SLM0251 SLM0251 SLM0251 SLM0251

\begin{tabular}{|c|c|c|c|c|c|c|c|c|c|c|c|c|c|c|}
\hline \multicolumn{2}{|c|}{ Depth (m) } & 80 & 89 & 99 & 109 & 119 & 61 & 71 & 80 & 89 & 99 & 109 & 119 & 129 \\
\hline & Mineral & $\mathrm{Ol}$ & $\mathrm{Ol}$ & OI & $\mathrm{Ol}$ & OI & Opx & Opx & Opx & Opx & Opx & Opx & Opx & Opx \\
\hline \multirow{14}{*}{$\begin{array}{l}\tilde{E} \\
\text { है } \\
\dot{z}\end{array}$} & $\mathrm{Na}$ & 0.00 & 0.00 & 0.01 & 0.02 & 0.00 & 0.00 & 0.00 & 0.00 & 0.00 & 0.00 & 0.00 & 0.00 & 0.01 \\
\hline & $\mathrm{Mg}$ & 10.14 & 9.77 & 10.12 & 10.22 & 9.92 & 6.29 & 6.59 & 6.81 & 6.49 & 6.59 & 6.75 & 6.79 & 6.39 \\
\hline & $\mathrm{Si}$ & 5.99 & 6.19 & 6.02 & 6.00 & 6.03 & 7.93 & 7.94 & 7.97 & 8.16 & 8.10 & 8.11 & 7.90 & 7.94 \\
\hline & Al & 0.00 & 0.00 & 0.00 & 0.00 & 0.00 & 0.11 & 0.08 & 0.05 & 0.02 & 0.06 & 0.01 & 0.11 & 0.08 \\
\hline & K & 0.00 & 0.00 & 0.00 & 0.00 & 0.00 & & 0.00 & 0.00 & 0.00 & 0.00 & 0.00 & 0.00 & 0.00 \\
\hline & $\mathrm{Ca}$ & 0.00 & 0.00 & 0.00 & 0.01 & 0.00 & 0.03 & 0.02 & 0.02 & 0.03 & 0.02 & 0.01 & 0.02 & 0.02 \\
\hline & $\mathrm{Cl}$ & 0.00 & 0.00 & 0.00 & 0.01 & 0.00 & 0.00 & 0.00 & 0.00 & 0.00 & 0.00 & 0.00 & 0.00 & 0.00 \\
\hline & $\mathrm{Ti}$ & 0.00 & 0.00 & 0.00 & 0.00 & 0.00 & 0.00 & 0.00 & 0.00 & 0.00 & 0.00 & 0.00 & 0.00 & 0.00 \\
\hline & $\mathrm{Cr}$ & 0.00 & 0.00 & 0.00 & 0.01 & 0.01 & 0.01 & 0.01 & 0.00 & 0.01 & 0.00 & 0.00 & 0.00 & 0.01 \\
\hline & $\mathrm{Fe}$ & 1.83 & 1.78 & 1.78 & 1.69 & 1.96 & 1.40 & 1.35 & 1.12 & 1.09 & 1.04 & 0.95 & 1.17 & 1.50 \\
\hline & $\mathrm{Mn}$ & 0.02 & 0.03 & 0.03 & 0.03 & 0.02 & 0.06 & 0.00 & 0.00 & 0.04 & 0.03 & 0.04 & 0.00 & 0.01 \\
\hline & $\mathrm{Ni}$ & 0.02 & 0.02 & 0.02 & 0.03 & 0.03 & 0.00 & 0.02 & 0.03 & 0.00 & 0.01 & 0.01 & 0.04 & 0.05 \\
\hline & V & 0.00 & 0.00 & 0.00 & 0.00 & 0.00 & 0.00 & 0.00 & 0.00 & 0.00 & 0.00 & 0.00 & 0.00 & 0.00 \\
\hline & Total & 18.01 & 17.81 & 17.98 & 18.01 & 17.97 & 16.17 & 16.02 & 16.00 & 15.83 & 15.87 & 15.89 & 16.04 & 16.02 \\
\hline \multirow{15}{*}{$\begin{array}{l}\stackrel{0}{2} \\
\frac{1}{20} \\
\frac{.00}{2} \\
3\end{array}$} & $\mathrm{Na}_{2} \mathrm{O}$ & 0.00 & 0.00 & 0.02 & 0.05 & 0.00 & 0.01 & 0.00 & 0.00 & 0.01 & 0.00 & 0.00 & 0.01 & 0.02 \\
\hline & $\mathrm{MgO}$ & 44.93 & 43.42 & 44.95 & 45.72 & 44.49 & 29.94 & 31.15 & 32.84 & 31.10 & 31.85 & 32.45 & 32.29 & 30.18 \\
\hline & $\mathrm{SiO}_{2}$ & 39.57 & 41.02 & 39.90 & 40.02 & 40.34 & 56.30 & 55.93 & 57.35 & 58.31 & 58.34 & 58.11 & 56.02 & 55.88 \\
\hline & $\mathrm{Al}_{2} \mathrm{O}_{3}$ & 0.00 & 0.00 & 0.00 & 0.00 & 0.00 & 0.66 & 0.47 & 0.28 & 0.13 & 0.38 & 0.05 & 0.67 & 0.50 \\
\hline & $\mathrm{K}_{2} \mathrm{O}$ & 0.00 & 0.00 & 0.00 & 0.01 & 0.01 & & 0.00 & 0.01 & 0.01 & 0.00 & 0.00 & 0.00 & 0.00 \\
\hline & $\mathrm{CaO}$ & 0.00 & 0.00 & 0.00 & 0.05 & 0.03 & 0.20 & 0.15 & 0.16 & 0.18 & 0.17 & 0.10 & 0.11 & 0.13 \\
\hline & $\mathrm{Cl}$ & 0.00 & 0.00 & 0.00 & 0.02 & 0.01 & 0.00 & 0.01 & 0.00 & 0.00 & 0.00 & 0.00 & 0.02 & 0.01 \\
\hline & $\mathrm{TiO}_{2}$ & 0.00 & 0.00 & 0.00 & 0.02 & 0.00 & 0.00 & 0.00 & 0.01 & 0.00 & 0.02 & 0.00 & 0.01 & 0.00 \\
\hline & $\mathrm{Cr}_{2} \mathrm{O}_{3}$ & 0.00 & 0.02 & 0.00 & 0.06 & 0.05 & 0.07 & 0.05 & 0.04 & 0.07 & 0.02 & 0.03 & 0.04 & 0.06 \\
\hline & $\mathrm{FeO}$ & 14.44 & 14.13 & 14.11 & 13.50 & 15.64 & 11.91 & 11.41 & 9.61 & 9.32 & 8.94 & 8.18 & 9.91 & 12.63 \\
\hline & $\mathrm{MnO}$ & 0.18 & 0.23 & 0.21 & 0.22 & 0.17 & 0.51 & 0.16 & 0.22 & 0.31 & 0.30 & 0.36 & 0.31 & 0.41 \\
\hline & $\mathrm{NiO}$ & 0.19 & 0.20 & 0.16 & 0.29 & 0.21 & 0.02 & 0.00 & 0.00 & 0.03 & 0.05 & 0.06 & 0.00 & 0.09 \\
\hline & $\mathrm{V}_{2} \mathrm{O}_{3}$ & 0.03 & 0.00 & 0.01 & 0.00 & 0.01 & 0.03 & 0.02 & 0.03 & 0.00 & 0.00 & 0.04 & 0.02 & 0.00 \\
\hline & Total & 99.34 & 99.01 & 99.35 & 99.95 & 100.97 & 99.66 & 99.35 & 100.53 & 99.45 & 100.08 & 99.39 & 99.40 & 99.92 \\
\hline & $\begin{array}{l}\text { Fo or En } \\
\text { content }\end{array}$ & 0.85 & 0.85 & 0.85 & 0.86 & 0.84 & 0.82 & 0.83 & 0.86 & 0.86 & 0.86 & 0.88 & 0.85 & 0.81 \\
\hline
\end{tabular}

Abbreviations: $\mathrm{OI}$ = Olivine; Opx = Orthopyroxene; Fo = Forsterite; En = Enstatite; fields in blank are not detectable elements. 


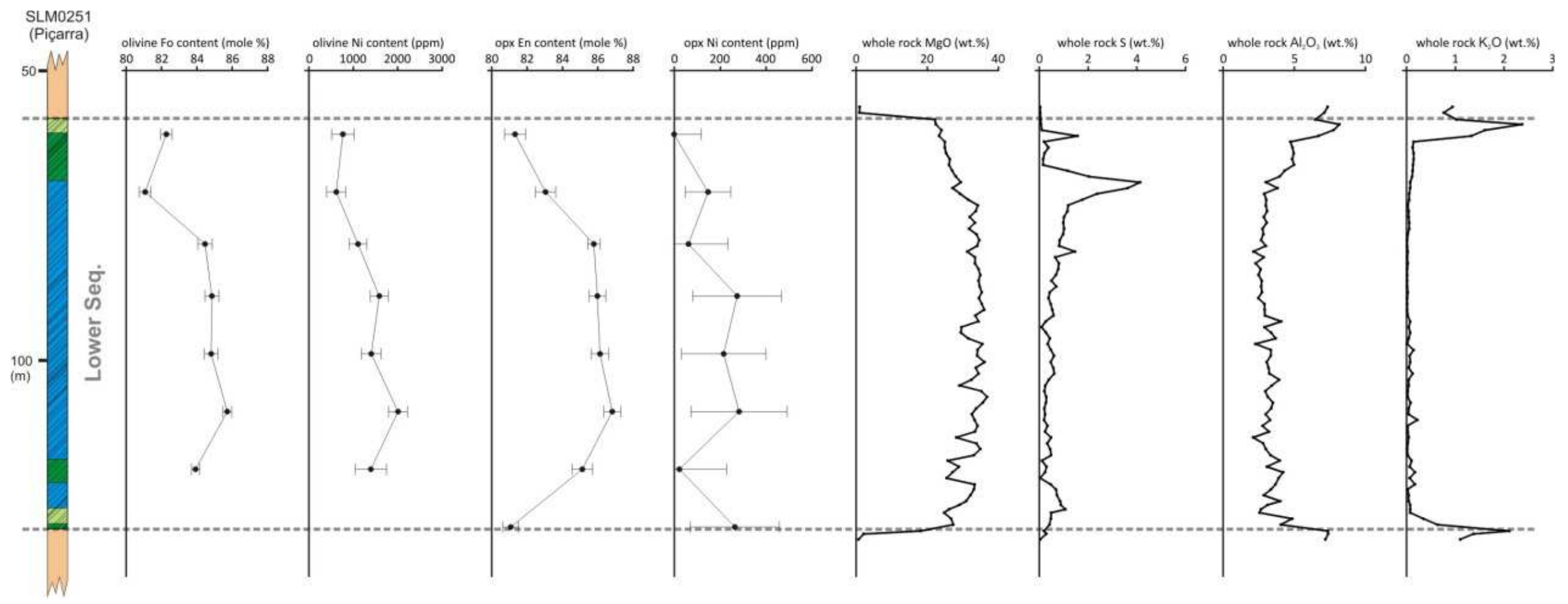




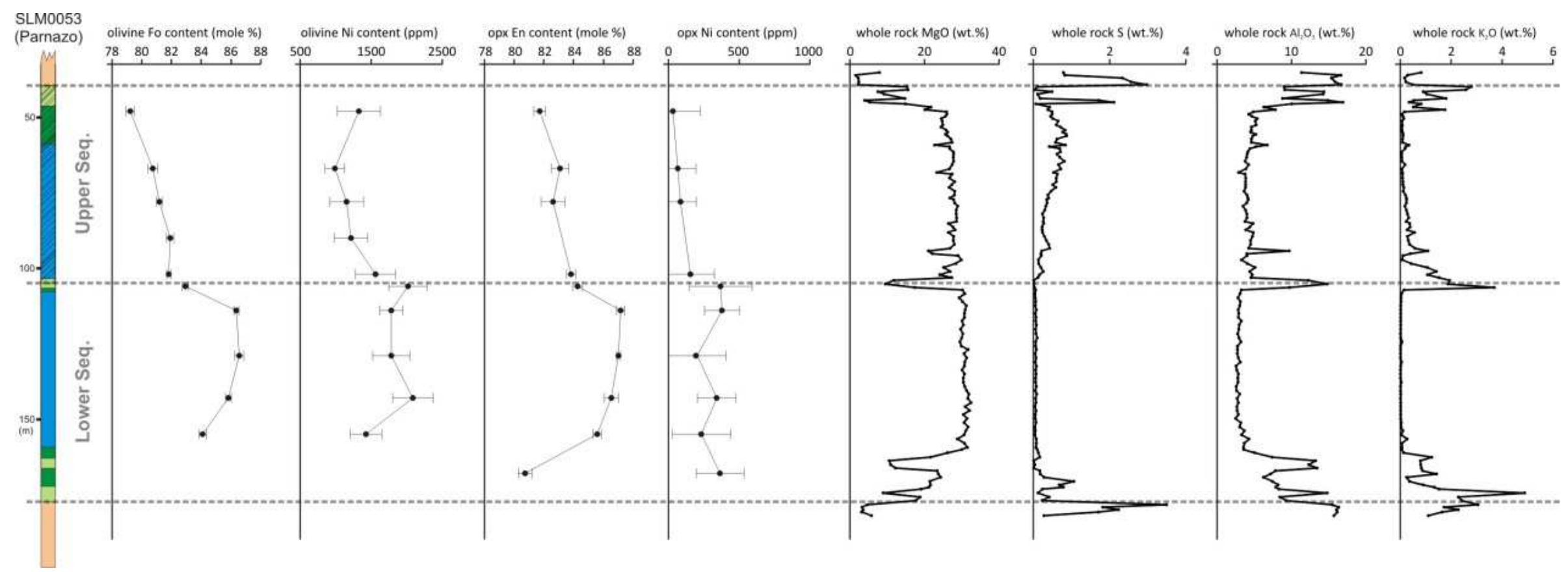

82 


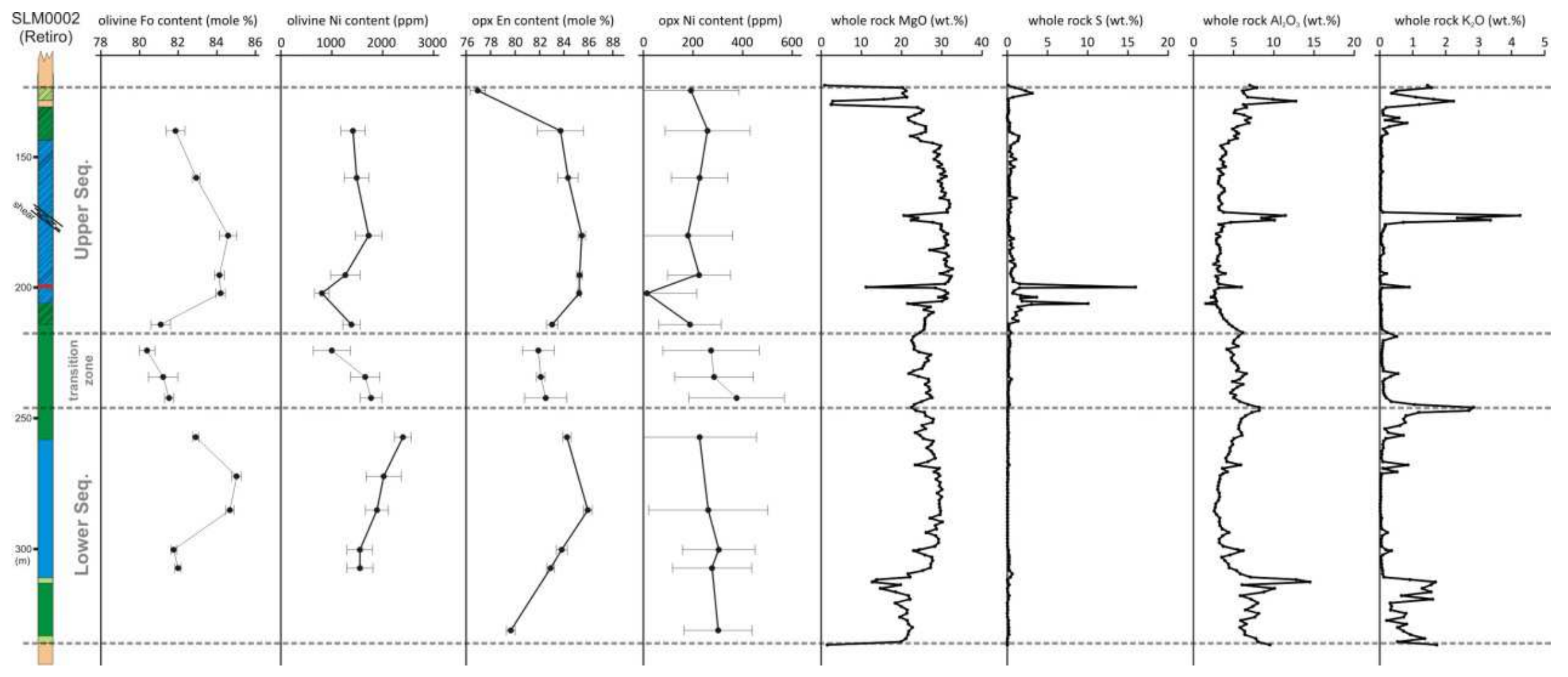




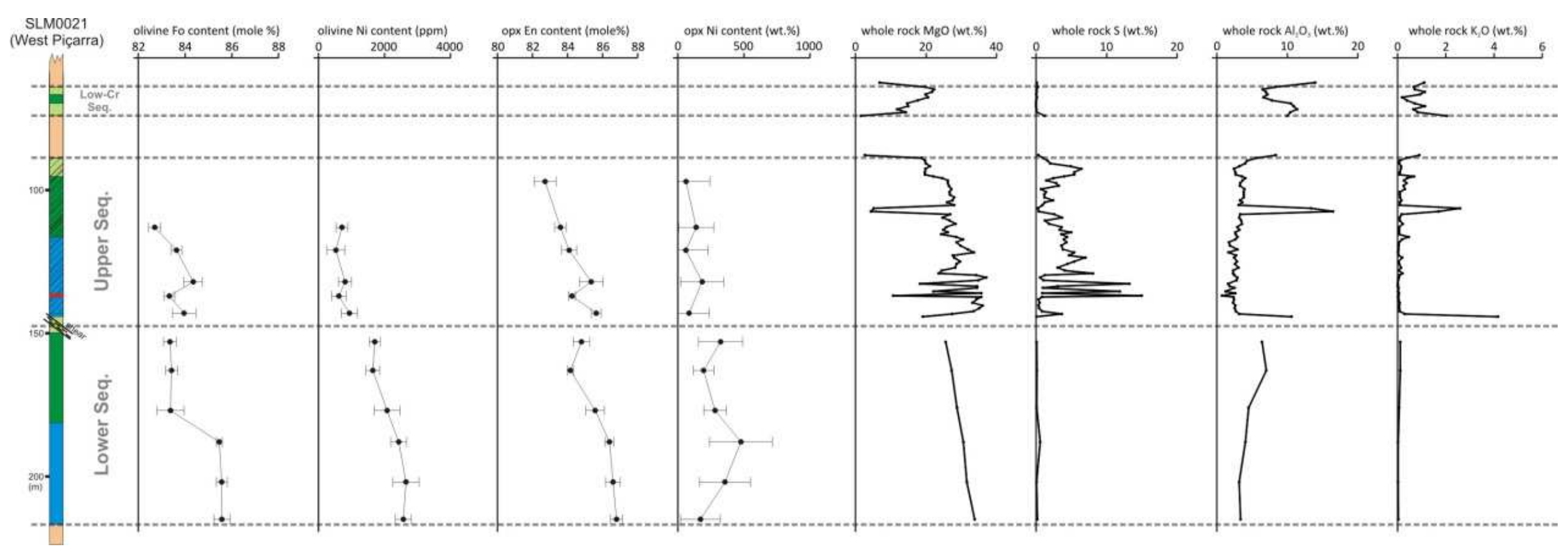




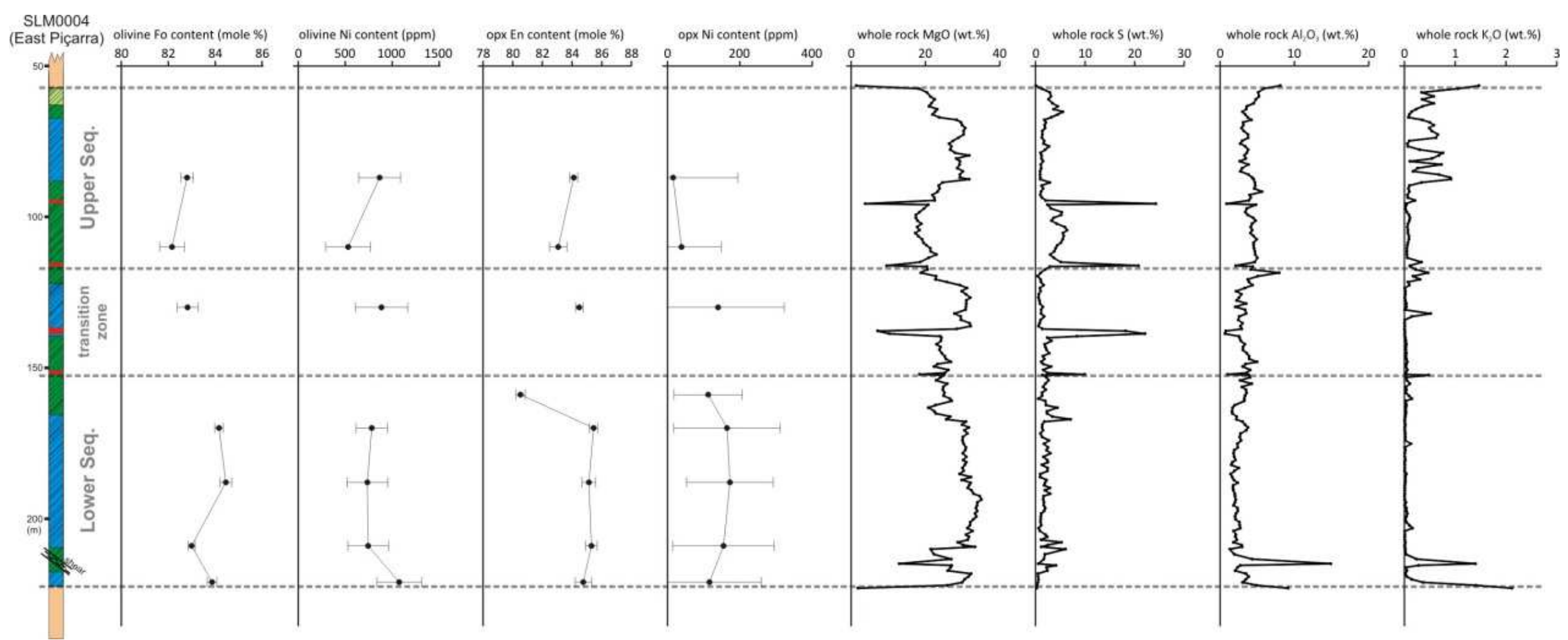

Fig. 2.14 - The forsterite and Ni content in olivines, the enstatite and Ni contents in orthopyroxenes, the whole rock MgO, S, Al2O3 and K2O concentrations for the drillholes SLM0251, 53, 2, 21 and 4. The plotted mineral analyses are averages and error bars were calculated as plus and minus one standard deviation. The lithology codes are the same as those used in Fig. 2.4 

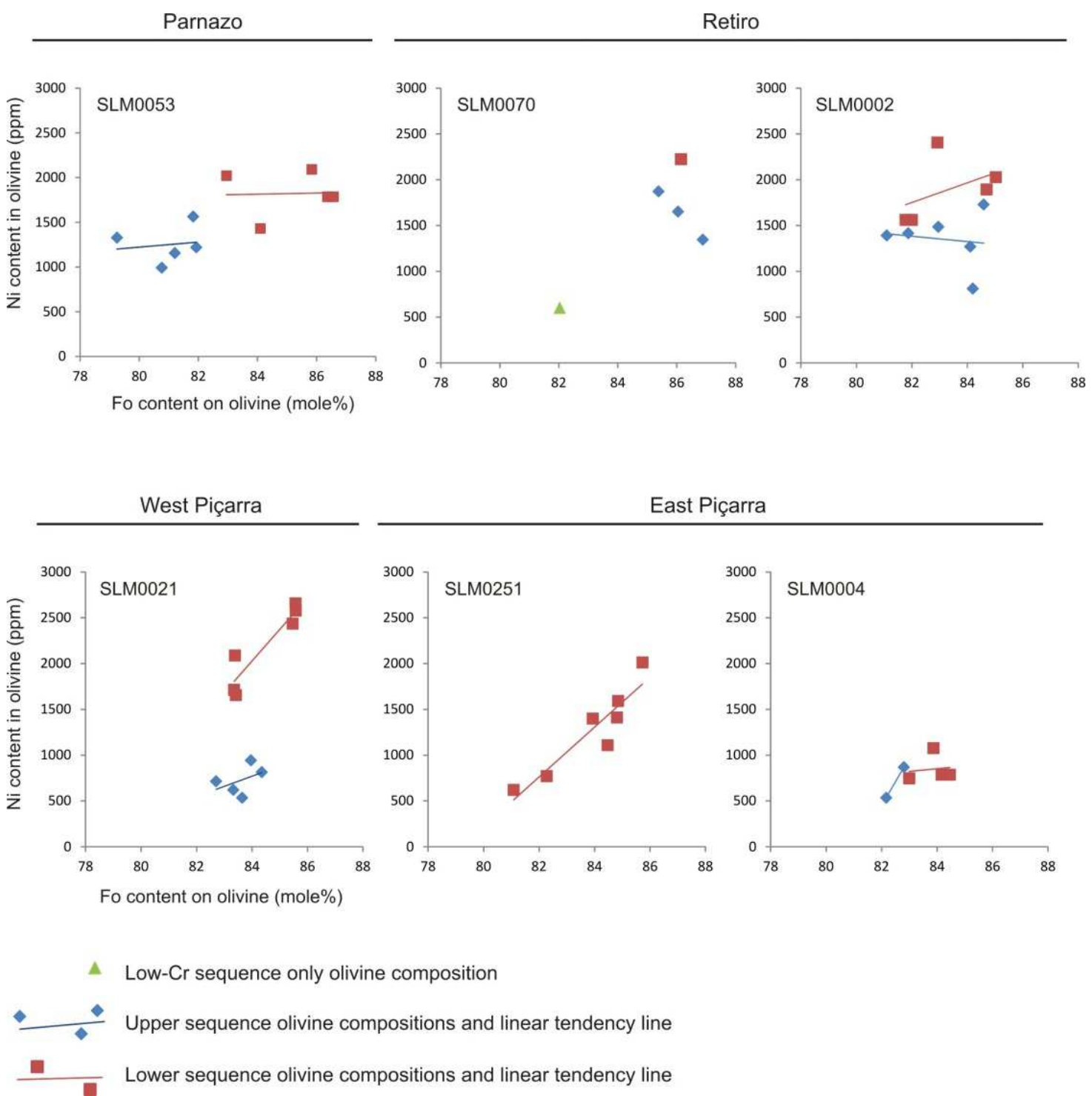

Fig. 2.15 - Average olivine Fo and Ni contents, in drillholes SLM0053, 70, 2, 21, 251, and 4. From the top left to the bottom right the charts are respectively moving from the west to the east portion of the intrusion 


\section{Whole rock geochemistry}

\section{Major elements}

Seventy eight whole rock samples were collected and analyzed to provide a complete geochemical characterization (Table 2.4). The samples are representative of typical harzburgite and orthopyroxenite, purposely collected from the portions with less metamorphic, hydrothermal and tectonic alteration and also with the lowest possible sulfide content. The three central most drilling targets (Parnazo, Retiro and Piçarra) were sampled.

In the Limoeiro intrusion, the major element distribution (expressed as oxides) is mainly controlled by the fractionation trend from the most primitive harzburgite core to the most evolved orthopyroxenite/amphibolite outer shell of the magmatic sequence. The main distribution trend of $\mathrm{SiO}_{2}$ (from 38.8 to $52.8 \mathrm{wt} \%$ ), $\mathrm{CaO}$ (from 0.16 to $7.62 \mathrm{wt} \%$ ) and $\mathrm{Na}_{2} \mathrm{O}$ (from 0.02 to $1.07 \mathrm{wt} \%$ ) increases as the $\mathrm{MgO}$ concentration decreases (Fig. 2.16A,D,E). The $\mathrm{SiO}_{2}$ versus $\mathrm{MgO}$ trend has $\sim 10 \mathrm{wt} \%$ less $\mathrm{MgO}$ than the mixing line between the two main primary cumulus silicate minerals (i.e., olivine and orthopyroxene). This observation added to the occurrence of $\mathrm{CaO}$ and $\mathrm{Na}_{2} \mathrm{O}$ in a rock formed by $\mathrm{CaO}$ - and $\mathrm{Na}_{2} \mathrm{O}$-free primary minerals indicate that there were also one or more unknown primary minerals that were totally metamorphosed to form amphibole and other metamorphic minerals. This debate will be detailed in the Discussion section. 

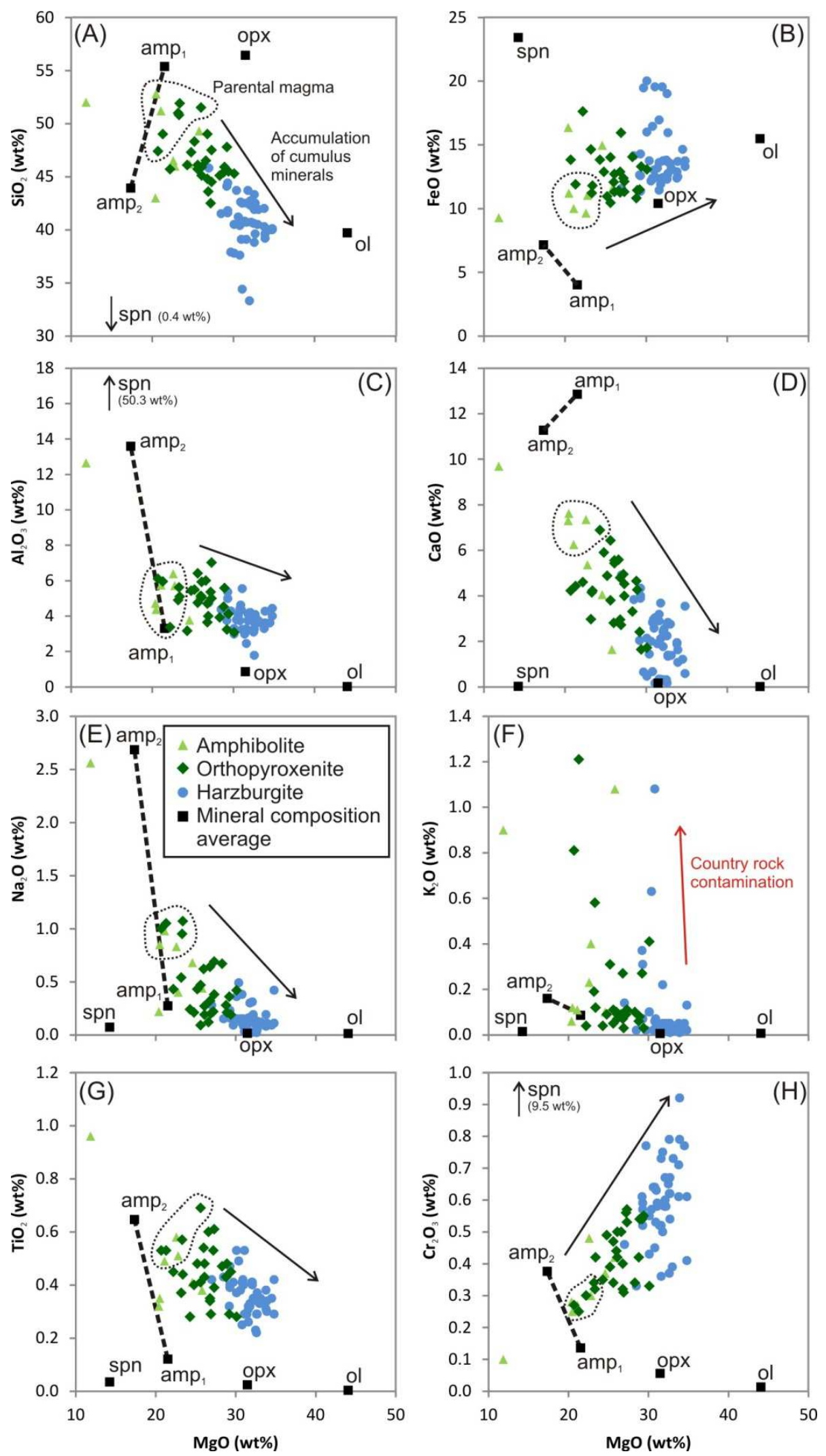

Fig. 2.16 - Biplots of the major oxides $\mathrm{SiO}_{2}, \mathrm{FeO}, \mathrm{Al}_{2} \mathrm{O}_{3}, \mathrm{CaO}, \mathrm{Na}_{2} \mathrm{O}, \mathrm{K} 2 \mathrm{O}, \mathrm{TiO}_{2}, \mathrm{Cr}_{2} \mathrm{O}_{3}$ versus $\mathrm{MgO}$ for 78 whole rock samples of ultramafic rocks of the Limoeiro intrusion. The dashed line includes the samples potentially representative of the intrusion parental magma (liquid) and the black arrow points towards the samples with the dominance of cumulus minerals (more cumulus minerals and less liquid or intercumulus minerals). The red arrow points towards higher levels of localized country rock contamination. 
Iron oxide has higher concentrations as $\mathrm{MgO}$ values also increase. The main trend formed (between 9.6 and $16.9 \mathrm{wt} \% \mathrm{FeO}$ ) in this biplot is 2 wt\% $\mathrm{FeO}$ above the mixing line connecting olivine, orthopyroxene and amphibole compositions (Fig. 2.16B). This upward shift indicates varied proportions of oxides (metamorphic spinel and primary chromite) and magmatic sulfides, both very common components of the Limoeiro chonolith (Mota-e-Silva et al., 2013). Aluminum oxide has an opposite tendency compared to $\mathrm{MgO}$ as the former is higher towards the edges and the latter is more concentrated within the core of the intrusion. The main trend in the $\mathrm{Al}_{2} \mathrm{O}_{3}$ versus $\mathrm{MgO}$ biplot varies from 2.44 to 7.02 wt\% $\mathrm{Al}_{2} \mathrm{O}_{3}$ (Fig. 2.16C), which is consistent with the already reported chemical variation within the magmatic sequence (Mota-e-Silva et al., 2013). Aluminum oxide concentrations should be mainly proportional to the abundance of the amphibole, chlorite and spinel metamorphic phases.

Potassium oxide concentration has a positive correlation with phlogopite abundance identified by petrography. The $\mathrm{K}_{2} \mathrm{O}$ versus $\mathrm{MgO}$ biplot defines a main trend where $\mathrm{K}_{2} \mathrm{O}$ increases with fractionation but the concentrations are not higher than $0.14 \mathrm{wt} \% \mathrm{~K}_{2} \mathrm{O}$. However, several samples, which included the three different lithologies, have much higher values, reaching a maximum of $1.21 \mathrm{wt} \% \mathrm{~K}_{2} \mathrm{O}$ (Fig. $2.16 \mathrm{~F}$ ). This pattern may be (i) an indication of heterogeneous country rock assimilation and contamination; or due to (ii) large-ions lithophile element (LILE) mobility during metamorphic/hydrothermal alteration. These hypotheses will be discussed further within the Elements Mobility section of the Discussion.

Titanium oxide and $\mathrm{Cr}_{2} \mathrm{O}_{3}$ have opposite tendencies, as $\mathrm{TiO}_{2}$ increases with fractionation whereas $\mathrm{Cr}_{2} \mathrm{O}_{3}$ decreases (Fig. 2.16G,H). The $\mathrm{TiO}_{2}$ main trend varies from 0.22 to 0.69 wt\% and its whole-rock content may be the sum of $\mathrm{TiO}_{2}$ hosted by amphibole with some amount also present in trace minerals such as titanite. Chromium oxide is related to the abundance of chromite, a mineral that was partly transformed to Al-Mg- $\mathrm{Cr}$ spinel during metamorphism. Chromite is a mineral crystalized at high temperatures and for that reason, the $\mathrm{Cr}_{2} \mathrm{O}_{3}$ main trend decreases from $0.92 \mathrm{wt} \%$ in harzburgite to $0.25 \mathrm{wt} \%$ in amphibolite. Part of the $\mathrm{Cr}_{2} \mathrm{O}_{3}$ whole rock content is hosted as solid solution in amphibole (Fig. 2.16H). 
One outlier sample (070-271) with 11.85 wt\% $\mathrm{MgO}, 12.65$ wt\% $\mathrm{Al}_{2} \mathrm{O}_{3}, 2.56$ wt\% $\mathrm{Na}_{2} \mathrm{O}$, 11.85 wt $\% \mathrm{CaO}, 0.96$ wt $\% \mathrm{TiO}_{2}$ and $0.10 \mathrm{wt} \% \mathrm{Cr}_{2} \mathrm{O}_{3}$ may indicate a different process rather than simple magmatic fractionation (Fig. 2.16A-H). This sample is a nematoblastic amphibolite formed by 60 vol\% hornblende, 36 vol\% plagioclase and 4 vol\% phlogopite, thus this is the only known sample containing plagioclase within the Limoeiro intrusion. Using a $\mathrm{MgO}, \mathrm{Cr}_{2} \mathrm{O}_{3}, \mathrm{Al}_{2} \mathrm{O}_{3}$ and S drill hole chemical log, Mota-e-Silva et-al (2013) have shown that sheared samples form $\mathrm{Al}_{2} \mathrm{O}_{3}$ concentration spikes. In the previous section (Mineral Chemistry) it was shown that the shear zones are associated with elevated $\mathrm{Al}_{2} \mathrm{O}_{3}$ and $\mathrm{K}_{2} \mathrm{O}$ (Fig. 2.14). Given the nematoblastic texture of this sample, it is suggestive that it was affected by deformation and is within a shear zone, therefore its original chemistry was probably modified.

Mota-e-Silva et al., (2013) have shown that the external shell of the Limoeiro intrusion is mainly composed of metamorphic amphibolite. This originally consisted of a chilled margin and/or marginal breccia zone. The above discussion outlines that the main distribution trends of the major element biplots varies with fractionation, thus displaying compositions between the primitive harzburgite core and the more fractionated edge formed by amphibolite and orthopyroxenite mineralogy. The harzburgite core is interpreted to have formed by cumulus mineral accumulation, whereas the samples from the intrusion edge that plot within the main fractionation trend in the biplots (Fig. $2.16 \mathrm{~A}-\mathrm{H}$ ) are representative of the chilled intruded magma. Thus, the rocks from the outer parts of the intrusion are henceforward interpreted to be representative of the intrusion parental magma as already displayed by the Fig. 2.16 plots. Note that this group of samples does not include outliers (e.g., $\mathrm{K}_{2} \mathrm{O}$ higher than $0.14 \mathrm{wt} \%$ ) that can represent products of country rock contamination or metamorphic/metasomatic modification. There were calculated and tabulated in Table 2.4 as averages for all elements of these samples in order to represent the parental magma composition. 
Table 2.4 - Lithochemistry of 78 selected samples from the Limoeiro intrusion.

\begin{tabular}{|c|c|c|c|c|c|c|c|c|c|c|c|c|}
\hline & & \multirow{2}{*}{$\begin{array}{r}\text { Retiro } \\
002-158\end{array}$} & \multirow{2}{*}{$\begin{array}{r}\text { Retiro } \\
002-180\end{array}$} & \multirow{2}{*}{$\begin{array}{r}\text { Retiro } \\
002-202\end{array}$} & \multirow{2}{*}{$\begin{array}{r}\text { Retiro } \\
002-214\end{array}$} & \multirow{2}{*}{$\begin{array}{r}\text { Retiro } \\
002-242\end{array}$} & \multirow{2}{*}{$\begin{array}{r}\text { Retiro } \\
002-272\end{array}$} & \multirow{2}{*}{$\begin{array}{r}\text { Aletiro } \\
002-300\end{array}$} & \multirow{2}{*}{$\begin{array}{r}\text { Retiro } \\
002-331^{*}\end{array}$} & \multirow{2}{*}{$\begin{array}{l}\text { Piçarra } \\
004-067^{*}\end{array}$} & \multirow{2}{*}{$\begin{array}{r}\text { Piçarra } \\
004-087\end{array}$} & \multirow{2}{*}{$\begin{array}{c}\text { Piçarra } \\
004-110\end{array}$} \\
\hline & Sample $002-125^{\circ}$ & & & & & & & & & & & \\
\hline Lithology & PX & $\mathrm{Hz}$ & $\mathrm{HZ}$ & $\mathrm{HZ}$ & PX & PX & $\mathrm{HZ}$ & $\mathrm{Hz}$ & PX & AT & $\mathrm{Hz}$ & AT \\
\hline $\mathrm{SiO}_{2}$ & 47,4 & 39.1 & 40.7 & 40.8 & 45.9 & 48.3 & 40.4 & 45.8 & 50.8 & 46.2 & 37.6 & 43.0 \\
\hline $\mathrm{Al}_{2} \mathrm{O}_{3}$ & 6.10 & 4.34 & 3.74 & 2.98 & 5.93 & 5.49 & 3.73 & 4.75 & 5.61 & 3.77 & 4.38 & 4.71 \\
\hline $\mathrm{Fe}_{2} \mathrm{O}_{3}$ & 15.35 & 14.45 & 13.65 & 14.60 & 12.55 & 12.15 & 13.75 & 12.85 & 12.45 & 16.60 & 18.25 & 18.15 \\
\hline $\mathrm{CaO}$ & 4.22 & 2.57 & 2.53 & 1.89 & 5.55 & 4.88 & 2.83 & 4.91 & 4.15 & 4.05 & 0.67 & 7.30 \\
\hline $\mathrm{MgO}$ & 20.70 & 31.00 & 32.20 & 31.40 & 26.10 & 25.20 & 30.80 & 27.00 & 23.30 & 24.60 & 30.80 & 20.40 \\
\hline $\mathrm{Na}_{2} \mathrm{O}$ & 1.00 & 0.08 & 0.19 & 0.07 & 0.19 & 0.43 & 0.11 & 0.28 & 0.95 & 0.68 & 0.38 & 0.22 \\
\hline $\mathrm{K}_{2} \mathrm{O}$ & 0.81 & 0.04 & 0.04 & 0.04 & 0.07 & 0.31 & 0.06 & 0.14 & 0.58 & 0.10 & 1.08 & 0.06 \\
\hline $\mathrm{Cr}_{2} \mathrm{O}_{3}$ & 0.27 & 0.53 & 0.58 & 0.52 & 0.50 & 0.39 & 0.64 & 0.46 & 0.32 & 0.37 & 0.45 & 0.28 \\
\hline $\mathrm{TiO}_{2}$ & 0.53 & 0.40 & 0.35 & 0.29 & 0.43 & 0.48 & 0.41 & 0.42 & 0.57 & 0.41 & 0.25 & 0.32 \\
\hline Mno & 0.17 & 0.17 & 0,19 & 0.18 & 0.18 & 0.19 & 0.17 & 0.20 & 0.20 & 0.20 & 0.19 & 0.20 \\
\hline $\mathrm{P}_{2} \mathrm{O}_{3}$ & 0.01 & 0.01 & 0.03 & 0.08 & 0.01 & 0.04 & 0.04 & 0.03 & 0.06 & $<0.01$ & 0.01 & 0.01 \\
\hline sro. & 0.02 & $<0.01$ & 0.01 & $<0.01$ & $\infty 0.01$ & 0.01 & $\infty 0.01$ & 0.01 & $<0.01$ & 0.01 & 0.01 & $\varnothing 0.01$ \\
\hline $\mathrm{BaO}$ & 0.02 & $<0.01$ & $<0.01$ & $<0.01$ & $\times 0.01$ & 0.01 & $<0.01$ & $<0.01$ & 0.01 & $<0.01$ & $<0.01$ & 40.01 \\
\hline c & 0.12 & 0.54 & 0.48 & 0.52 & 0.48 & 0.24 & 0.68 & 0.18 & 0.06 & 0.16 & 0.21 & 0.04 \\
\hline 5 & 1.49 & 0.33 & 0.23 & 0.56 & 0.13 & 0.11 & 0.04 & 0.03 & 0.17 & 2.57 & 0.69 & 3.94 \\
\hline Ba & 151 & 2 & 2 & 2 & 3 & 62 & 4 & 9 & 66 & 11 & 29 & 2 \\
\hline $\mathrm{Ce}$ & 7 & 7 & 7 & 17 & 9 & 17 & 8 & 10 & 15 & 10 & 3 & 9 \\
\hline cr & 1880 & 4420 & 4260 & 3600 & 3460 & 2660 & 4440 & 3120 & 2250 & 2510 & 3010 & 2010 \\
\hline Cs & 31.80 & 0.17 & 0.13 & 0.16 & 0.12 & 1.85 & 0.31 & 0.63 & 10.55 & 1.56 & 94.10 & 0.43 \\
\hline Dy & 1.61 & 1.01 & 1.16 & 0.91 & 1.48 & 1.59 & 1.23 & 1.64 & 1.79 & 1.23 & 0.24 & 1.12 \\
\hline Er & 0.86 & 0.66 & 0.68 & 0.53 & 0.75 & 1.02 & 0.85 & 0.77 & 0.98 & 0.87 & 0.14 & 0.65 \\
\hline Eu & 0.30 & 0.29 & 0.37 & 0.31 & 0.37 & 0.50 & 0.36 & 0.55 & 0.40 & 0.23 & 0.05 & 0.36 \\
\hline Ga & 8.60 & 6.60 & 6.00 & 5.00 & 7.90 & 7.10 & 5.60 & 7.00 & 8.30 & 5.30 & 6.40 & 6.00 \\
\hline Gd & 1.46 & 0.84 & 1.28 & 1.11 & 1.37 & 1.69 & 1.11 & 1.71 & 1.81 & 1.31 & 0.17 & 1.11 \\
\hline $\mathrm{Hf}$ & 0.90 & 0.70 & 1.00 & 0.90 & 0.80 & 1.60 & 1.00 & 1.20 & 1.40 & 1.00 & 0.60 & 0.90 \\
\hline Ho & 0.35 & 0.17 & 0.23 & 0.18 & 0.27 & 0.29 & 0.25 & 0.30 & 0.32 & 0.28 & 0.06 & 0.22 \\
\hline La & 2.90 & 3.00 & 2.60 & 10.40 & 3.90 & 8.00 & 3.20 & 4.20 & 6.80 & 5.00 & 1.90 & 4.10 \\
\hline Lu & 0.10 & 0.10 & 0.11 & 0.07 & 0.08 & 0.10 & 0.07 & 0.07 & 0.11 & 0.09 & 0.02 & 0.09 \\
\hline $\mathrm{Nb}$ & 3.60 & 3.00 & 2.40 & 2.30 & 2.90 & 3.80 & 3.10 & 3.10 & 4.50 & 3.30 & 1.50 & 1.80 \\
\hline Nd & 4.80 & 3.70 & 4.40 & 7.10 & 4.70 & 8.40 & 4.80 & 6.30 & 7.70 & 5.30 & 1.20 & 4.60 \\
\hline Pr & 0.92 & 0.83 & 0.94 & 1.74 & 1.04 & 1.97 & 1.07 & 1.39 & 1.71 & 1.19 & 0.33 & 1.12 \\
\hline $\mathrm{Rb}$ & 40.40 & 0.80 & 0.70 & 0.80 & 1.10 & 9.60 & 1.20 & 2.80 & 27.30 & 2.00 & 93.70 & 1.10 \\
\hline $\mathrm{Sm}$ & 1.28 & 0.86 & 1.12 & 1.03 & 1.23 & 1.88 & 1.40 & 1.59 & 1.70 & 1.20 & 0.34 & 1.06 \\
\hline Sn & 1.00 & 1.00 & 1.00 & 1.00 & 1.00 & 1.00 & 1.00 & 1.00 & 1.00 & 1.00 & 1.00 & 1.00 \\
\hline Sr & 186.50 & 38.30 & 36.50 & 25.30 & 57.80 & 74.70 & 44.20 & 78.40 & 28.10 & 93.00 & 70.40 & 73.30 \\
\hline $\mathrm{Ta}$ & 0.20 & 0.20 & 0.20 & 0.20 & 0.20 & 0.20 & 0.20 & 0.20 & 0.30 & 0.20 & 0.10 & 0.10 \\
\hline $\mathrm{Tb}$ & 0.22 & 0.16 & 0.19 & 0.17 & 0.23 & 0.28 & 0.23 & 0.28 & 0.31 & 0.22 & 0.06 & 0.16 \\
\hline Th & 0.90 & 0.71 & 0.51 & 2.25 & 0.86 & 2.45 & 0.78 & 1.07 & 1.27 & 1.25 & 0.79 & 1.00 \\
\hline$\pi$ & $=0.5$ & $<0.5$ & $<0.5$ & $<0.5$ & $<0.5$ & $<0.5$ & $<0.5$ & $<0.5$ & $<0.5$ & $<0.5$ & $<0.5$ & $\infty .5$ \\
\hline Im & 0.10 & 0.09 & 0.10 & 0.06 & 0.11 & 0.11 & 0.09 & 0.14 & 0.11 & 0.10 & 0.03 & 0.09 \\
\hline$u$ & 0.24 & 0.17 & 0.21 & 0.24 & 0.21 & 0.28 & 0.31 & 0.36 & 0.36 & 0.27 & 0.09 & 0.13 \\
\hline$v$ & 138.00 & 80.00 & $<5$ & 45.00 & 85.00 & 92.00 & 69.00 & 81.00 & 116.00 & 78.00 & 23.00 & 52.00 \\
\hline w & 2.00 & 1.00 & 1.00 & 1.00 & 1.00 & 1.00 & 1.00 & 1.00 & 1.00 & $<1$ & 1.00 & 1.00 \\
\hline Y & 7.60 & 5.30 & 6.80 & 4.90 & 6.90 & 8.30 & 6.60 & 8.60 & 9.20 & 7.00 & 1.60 & 6.10 \\
\hline $\mathrm{Yb}$ & 0.87 & 0.66 & 0.64 & 0.56 & 0.92 & 0.96 & 0.57 & 0.81 & 1.06 & 0.77 & 0.37 & 0.59 \\
\hline $\mathrm{Zr}$ & 33.00 & 30.00 & 37.00 & 36.00 & 34.00 & 63.00 & 38.00 & 50.00 & 51.00 & 46.00 & 26.00 & 36.00 \\
\hline
\end{tabular}




\begin{tabular}{|c|c|c|c|c|c|c|c|c|c|c|c|c|}
\hline Target & Retiro & Retiro & Retiro & Retiro & Retiro & Retiro & Retiro & Retiro & Retiro & Piçarra & Piçarra & Piçarra \\
\hline Sample & $002-125^{*}$ & $002-158$ & $002-180$ & $002-202$ & $002-214$ & $002-242$ & $002-272$ & $002-300$ & $002-331^{*}$ & $004-067^{*}$ & 004-087 & $004-110$ \\
\hline Lithology & PX & $\mathrm{HZ}$ & $\mathrm{HZ}$ & $\mathrm{HZ}$ & PX & PX & $\mathrm{HZ}$ & $\mathrm{HZ}$ & PX & AT & $\mathrm{HZ}$ & AT \\
\hline As & 0.10 & 0.10 & 0.20 & 0.20 & 0.10 & $<0.1$ & 0.60 & $<0.1$ & 0.10 & 0.20 & 0.20 & 0.20 \\
\hline $\mathrm{Bi}$ & 0.15 & 0.14 & 0.34 & 0.18 & 0.17 & 0.09 & 0.04 & 0.02 & 0.02 & 0.53 & 0.20 & 0.47 \\
\hline $\mathrm{Hg}$ & $<0.005$ & $<0.005$ & $<0.005$ & $<0.005$ & $<0.005$ & $<0.005$ & $<0.005$ & $<0.005$ & $<0.005$ & $<0.005$ & $<0.005$ & $<0.005$ \\
\hline $\mathrm{Sb}$ & $<0.05$ & $<0.05$ & 0.15 & $<0.05$ & $<0.05$ & 0.11 & 0.07 & $<0.05$ & 0.07 & $<0.05$ & $<0.05$ & 0.06 \\
\hline $\mathrm{Se}$ & 4.20 & 0.90 & 0.90 & 1.90 & 0.60 & 0.30 & 0.30 & 0.20 & 0.50 & 5.30 & 1.90 & 8.80 \\
\hline $\mathrm{Te}$ & 0.66 & 0.30 & 0.21 & 0.30 & 0.15 & 0.05 & 0.02 & 0.01 & 0.03 & 0.87 & 0.42 & 1.29 \\
\hline LOI & 1.46 & 5.21 & 5.00 & 5.60 & 3.11 & 1.20 & 7.13 & 3.14 & 0.56 & 2.56 & 5.99 & 3.34 \\
\hline Total & 98.06 & 98.00 & 99.20 & 98.45 & 100.52 & 99.08 & 100.07 & 99.99 & 99.56 & 99.55 & 100.06 & 98.00 \\
\hline $\mathrm{Ag}$ & $<0.5$ & $<0.5$ & $<0.5$ & $<0.5$ & $<0.5$ & $<0.5$ & $<0.5$ & $<0.5$ & $<0.5$ & 1 & 0.5 & 1.5 \\
\hline $\mathrm{Cd}$ & $<0.5$ & $<0.5$ & $<0.5$ & $<0.5$ & $<0.5$ & $<0.5$ & $<0.5$ & $<0.5$ & $<0.5$ & $<0.5$ & $<0.5$ & 0.9 \\
\hline Co & 129 & 140 & 129 & 135 & 81 & 98 & 122 & 97 & 92 & 172 & 170 & 234 \\
\hline $\mathrm{Cu}$ & 1810 & 612 & 873 & 980 & 340 & 197 & 45 & 47 & 177 & 3450 & 1020 & 4900 \\
\hline Mo & 1 & 1 & $<1$ & $<1$ & 1 & 1 & $<1$ & $<1$ & $<1$ & 1 & $<1$ & 1 \\
\hline $\mathrm{Ni}$ & 1680 & 1810 & 1470 & 1530 & 833 & 850 & 1290 & 739 & 499 & 2100 & 1590 & 3350 \\
\hline $\mathrm{Pb}$ & 8 & 3 & $<2$ & $<2$ & 5 & 4 & 2 & 2 & 5 & 3 & 18 & 7 \\
\hline $\mathrm{Zn}$ & 104 & 58 & 64 & 71 & 56 & 64 & 72 & 66 & 90 & 88 & 139 & 122 \\
\hline
\end{tabular}




\begin{tabular}{|c|c|c|c|c|c|c|c|c|c|c|c|c|}
\hline Target & Piçarra & Piçarra & Piçarra & Piçarra & Piçarra & Piçarra & Retiro & Retiro & Retiro & Retiro & Retiro & Retiro \\
\hline Sample & $004-130$ & $004-159^{*}$ & $004-170$ & $004-188$ & $.004-209$ & $004-221$ & $018-155$ & 018-186 & 018-205 & $018-220$ & $018-235$ & $018-257$ \\
\hline hology & $\mathrm{HZ}$ & $P X$ & $\mathrm{HZ}$ & $\mathrm{HZ}$ & $\mathrm{HZ}$ & $\mathrm{HZ}$ & $P X$ & $\mathrm{~Hz}$ & $\mathrm{HZ}$ & $\mathrm{HZ}$ & $\mathrm{HZ}$ & $\mathrm{HZ}$ \\
\hline $\mathrm{SiO}_{2}$ & 39.1 & 46.1 & 33.3 & 38.8 & 34,4 & 44.1 & 47.3 & 41.5 & 40.0 & 42.5 & 42.5 & 42.0 \\
\hline $\mathrm{Al}_{2} \mathrm{O}_{3}$ & 2.44 & 3.16 & 4.18 & 1.77 & 3.23 & 3.75 & 5.43 & 4.37 & 3.61 & 4.12 & 5.54 & 3.28 \\
\hline $\mathrm{Fe}_{2} \mathrm{O}_{3}$ & 18.80 & 15.35 & 21.70 & 21.10 & 21.70 & 14.00 & 14.30 & 15.70 & 16.25 & 13.20 & 13.85 & 14.30 \\
\hline $\mathrm{CaO}$ & 0.34 & 6.88 & 0.32 & 0.16 & 0.15 & 2.03 & 5.90 & 3.83 & 1.21 & 3.67 & 3.03 & 1.88 \\
\hline Mgo & 31.60 & 24.30 & 32.00 & 32.60 & 31.10 & 29.20 & 24.80 & 28.50 & 34.50 & 31.80 & 31.10 & 33.80 \\
\hline $\mathrm{Na}_{2} \mathrm{O}$ & 0.02 & 0.24 & 0.02 & 0.02 & 0.03 & 0.19 & 0.21 & 0.15 & 0.09 & 0.12 & 0.11 & 0.08 \\
\hline $\mathrm{K}_{2} \mathrm{O}$ & 0.01 & 0.04 & 0.03 & 0.03 & 0.04 & 0.37 & 0.09 & 0.02 & 0.05 & 0.05 & 0.05 & 0.05 \\
\hline $\mathrm{Cr}_{2} \mathrm{O}_{3}$ & 0.36 & 0.35 & 0.58 & 0.37 & 0.58 & 0.61 & 0.49 & 0.33 & 0.77 & 0.50 & 0.59 & 0.61 \\
\hline $\mathrm{TiO}_{2}$ & 0.26 & 0.28 & 0.41 & 0.22 & 0.29 & 0.32 & 0.40 & 0.43 & 0.35 & 0.33 & 0.53 & 0.38 \\
\hline Mno & 0.21 & 0.20 & 0.18 & 0.19 & 0.21 & 0.18 & 0.19 & 0.21 & 0.18 & 0.21 & 0.21 & 0.20 \\
\hline $\mathrm{P}_{2} \mathrm{O}_{3}$ & 0.21 & 0.03 & 0.16 & 0.02 & 0.02 & $<0.01$ & 0.01 & 0.05 & 0.02 & 0.40 & 0.07 & 0.05 \\
\hline Sro & $<0.01$ & $<0.01$ & $<0.01$ & $<0.01$ & $<0.01$ & $<0.01$ & $<0.01$ & $<0.01$ & $<0.01$ & 0.01 & $<0.01$ & $\varnothing 0.01$ \\
\hline $\mathrm{BaO}$ & $<0.01$ & $<0.01$ & $<0.01$ & $<0.01$ & $<0.01$ & $<0.01$ & $<0.01$ & $<0.01$ & $<0.01$ & $<0.01$ & $<0.01$ & $\infty 0.01$ \\
\hline C & 0.16 & 0.05 & 0.12 & 0.16 & 0.14 & 0.09 & 0.11 & 0.26 & 0.26 & 0.28 & 0.29 & 0.53 \\
\hline 5 & 1.47 & 1.37 & 1.21 & 1.76 & 2.83 & 0.54 & 1.33 & 0.11 & 0.68 & 0.09 & 0.03 & 0.04 \\
\hline Ba & 1 & 2 & 1 & 1 & 1 & 26 & 2 & 1 & 2 & 3 & 6 & 3 \\
\hline $\mathrm{Ce}$ & 6 & 7 & 34 & 13 & 3 & 7 & 12 & 20 & 6 & 20 & 9 & 8 \\
\hline Cr & 2530 & 2480 & 4010 & 2570 & 3960 & 4240 & 3460 & 2350 & 5430 & 3690 & 4630 & 4200 \\
\hline Cs & 0.14 & 0.19 & 0.59 & 0.11 & 0.45 & 3.55 & 1.15 & 0.07 & 0.08 & 0.14 & 0.05 & 0.09 \\
\hline Dy & 1.10 & 1.37 & 1.29 & 0.29 & 0.17 & 0.94 & 1.85 & 1.13 & 0.61 & 3.30 & 1.24 & 0.85 \\
\hline Er & 0.62 & 0.83 & 0.66 & 0.24 & 0.12 & 0.56 & 1.02 & 0.69 & 0.29 & 1.69 & 0.74 & 0.73 \\
\hline Eu & 0.11 & 0.45 & 0.37 & 0.07 & 0.05 & 0.19 & 0.49 & 0.41 & 0.15 & 0.70 & 0.38 & 0.24 \\
\hline Ga & 4.80 & 4.60 & 6.50 & 3.90 & 5.30 & 5.80 & 7.90 & 6.30 & 5.70 & 6.30 & 7.80 & 5.40 \\
\hline Gd & 1.36 & 1.27 & 2.00 & 0.44 & 0.13 & 0.91 & 1.65 & 1.34 & 0.66 & 4.10 & 1.26 & 0.87 \\
\hline $\mathrm{Hf}$ & 0.50 & 0.80 & 1.40 & 0.60 & 0.60 & 0.60 & 1.00 & 1.00 & 0.60 & 1.00 & 1.50 & 1.10 \\
\hline Ho & 0.21 & 0.26 & 0.25 & 0.07 & 0.02 & 0.19 & 0.41 & 0.23 & 0.11 & 0.65 & 0.25 & 0.14 \\
\hline La & 2.50 & 3.00 & 18.20 & 8.00 & 2.00 & 3.10 & 5.70 & 11.80 & 2.80 & 7.50 & 3.80 & 4.30 \\
\hline Lu & 0.08 & 0.10 & 0.06 & 0.01 & 0.01 & 0.07 & 0.10 & 0.10 & 0.04 & 0.19 & 0.11 & 0.04 \\
\hline $\mathrm{Nb}$ & 2.10 & 1.50 & 4,70 & 0.70 & 1.50 & 2.80 & 2.60 & 3.00 & 3.10 & 2.90 & 4.30 & 3.30 \\
\hline Nd & 4.20 & 4.40 & 14,70 & 4,40 & 1.20 & 3.50 & 7.10 & 7.60 & 3.10 & 14.20 & 5.10 & 3.80 \\
\hline Pr & 0.82 & 0.97 & 3.83 & 1.30 & 0.32 & 0.80 & 1.59 & 2.02 & 0.60 & 2.81 & 1.17 & 0.83 \\
\hline $\mathrm{Rb}$ & 0.80 & 1.10 & 1.10 & 0.30 & 0.60 & 12.70 & 1.50 & 0.70 & 0.30 & 0.90 & 1.50 & 0.30 \\
\hline $5 m$ & 1.15 & 1.20 & 2.80 & 0.61 & 0.27 & 0.97 & 1.66 & 1.33 & 0.68 & 3.96 & 1.22 & 0.84 \\
\hline Sn & 1.00 & 2.00 & 1.00 & 1.00 & 1.00 & 2.00 & 1.00 & 1.00 & 1.00 & 1.00 & $<1$ & $<1$ \\
\hline Sr & 9.10 & 63.80 & 9.60 & 3.40 & 3.60 & 16.80 & 48.00 & 56.00 & 1890 & 55.60 & 47,70 & 28.20 \\
\hline $\mathrm{Ta}$ & 0.10 & 0.10 & 0.40 & $<0.1$ & 0.10 & 0.60 & 0.20 & 0.20 & 0.20 & 0.20 & 0.30 & 0.20 \\
\hline Tb & 0.17 & 0.21 & 0.29 & 0.06 & 0.05 & 0.15 & 0.31 & 0.18 & 0.12 & 0.59 & 0.19 & 0.17 \\
\hline Th & 0.44 & 1.41 & 8.35 & 0.98 & 0.64 & 0.69 & 1.44 & 2.92 & 0.50 & 1.02 & 1.62 & 0.83 \\
\hline$\pi$ & $<0.5$ & $<0.5$ & $<0.5$ & $<0.5$ & $<0.5$ & $e 0.5$ & $<0.5$ & $<0.5$ & $<0.5$ & $<0,5$ & $<0.5$ & $\infty .5$ \\
\hline $\mathrm{Tm}$ & 0.07 & 0.11 & 0.10 & 0.03 & 0.02 & 0.06 & 0.14 & 0.10 & 0.06 & 0.23 & 0.10 & 0.07 \\
\hline$u$ & 0.35 & 0.16 & 0.35 & 0.13 & 0.13 & 0.24 & 0.32 & 0.20 & 0.16 & 0.66 & 0.27 & 0.26 \\
\hline v & $<5$ & $<5$ & 57,00 & 66.00 & 64.00 & 61.00 & 88.00 & 34.00 & 39.00 & $<5$ & $<5$ & 39.00 \\
\hline$w$ & 1.00 & 1.00 & 1.00 & 1.00 & 1.00 & 1.00 & 1.00 & 1.00 & 1.00 & 1.00 & 2.00 & 2.00 \\
\hline Y & 5.50 & 7.80 & 6.20 & 1.80 & 0.90 & 5.10 & 9.80 & 6.50 & 3.50 & 16.20 & 6.60 & 5.40 \\
\hline $\mathrm{Yb}$ & 0.45 & 0.72 & 0.45 & 0.29 & 0.27 & 0.67 & 0.86 & 0.60 & 0.43 & 1.33 & 0.70 & 0.54 \\
\hline $2 r$ & 18.00 & 24.00 & 60.00 & 22.00 & 18.00 & 23.00 & 35.00 & 37.00 & 26.00 & 34,00 & 50.00 & 41,00 \\
\hline
\end{tabular}




\begin{tabular}{|c|c|c|c|c|c|c|c|c|c|c|c|c|}
\hline Target & Piçarra & Piçarra & Piçarra & Piçarra & Piçarra & Piçarra & Retiro: & Retiro. & Retiro & Retiro & Retiro & Retiro \\
\hline Sample & $004-130$ & $004-159^{\circ}$ & $004-170$ & $004-188$ & $004-209$ & $004-221$ & $018-155$ & $018-186$ & $018-205$ & $018-220$ & $018-235$ & $018-257$ \\
\hline Lthology & $\mathrm{HZ}$ & PX & $\mathrm{HZ}$ & $\mathrm{HZ}$ & $\mathrm{HZ}$ & $H z$ & PX & $\mathrm{HZ}$ & $\mathrm{HZ}$ & $\mathrm{HZ}$ & $\mathrm{HZ}$ & $\mathrm{HZ}$ \\
\hline As & 0.30 & 0.20 & 0.10 & 0.30 & 0.30 & 0.10 & 0.20 & 0.30 & 0.20 & 0.10 & 0.10 & 0.10 \\
\hline$B i$ & 0.32 & 0.30 & 0.26 & 0.37 & 0.65 & 0.21 & 0.29 & 0.09 & 0.52 & 0.51 & 0.06 & 0.05 \\
\hline $\mathrm{Hg}$ & $<0.005$ & $<0.005$ & $<0.005$ & $<0.005$ & $\varnothing 0.005$ & $<0.005$ & $<0.005$ & $<0.005$ & $<0.005$ & $<0.005$ & $<0,005$ & $\infty .005$ \\
\hline$S b$ & $<0.05$ & $<0.05$ & $<0.05$ & $<0.05$ & $\infty .05$ & 00.05 & $<0.05$ & $<0.05$ & 0.05 & $<0.05$ & $<0.05$ & $\infty .05$ \\
\hline $\mathrm{Se}$ & 4.50 & 4.00 & 3.80 & 4.90 & 7.40 & 1.60 & 4.00 & 0.50 & 2.60 & 0.60 & 0.20 & $\varnothing 0.2$ \\
\hline $\mathrm{Te}$ & 0.71 & 0.65 & 0.44 & 0.71 & 1.11 & 0.27 & 0.46 & 0.09 & 0.54 & 0.13 & $<0.01$ & 0.01 \\
\hline tol & 7.00 & 2.61 & 7.84 & 4.41 & 7.29 & 5.76 & 2.30 & 3.70 & 3.38 & 4.10 & 3.14 & 3.12 \\
\hline Total & 100.35 & 99.50 & 100.72 & 99.69 & 99.04 & 100.51 & 101.42 & 98.80 & 100.41 & 101.01 & 100.72 & 99.75 \\
\hline $\mathrm{Ag}$ & $<0.5$ & 0.5 & 0.7 & 1.1 & 2.3 & $<0.5$ & 0.5 & $<0.5$ & 0.7 & 0.8 & $<0.5$ & $<0.5$ \\
\hline $\mathrm{Cd}$ & $<0.5$ & 13 & $<0.5$ & $<0.5$ & $<0.5$ & $<0.5$ & $c 0.5$ & $<0.5$ & $<0.5$ & $<0.5$ & $<0.5$ & $<0.5$ \\
\hline Co & 227 & 158 & 183 & 220 & 272 & 146 & 153 & 126 & 173 & 116 & 114 & 137 \\
\hline $\mathrm{Cu}$ & 2300 & 1830 & 1880 & 2980 & 6640 & 842 & 2220 & 354 & 1740 & 588 & 74 & 34 \\
\hline Mo & 1 & $<1$ & 1 & 1 & 1 & 1 & 1 & $<1$ & 1 & 1 & $<1$ & 1 \\
\hline $\mathrm{Ni}$ & 2280 & 2060 & 2040 & 2230 & 3540 & 1400 & 2330 & 743 & 2450 & 1260 & 1270 & 1210 \\
\hline $\mathrm{Pb}$ & $<2$ & 3 & 3 & 2 & $<2$ & $<2$ & 5 & 3 & 3 & $<2$ & 2 & 5 \\
\hline $\mathrm{Zn}$ & 117 & 72 & 126 & 92 & 116 & 106 & 60 & 81 & 81 & 60 & 64 & 69 \\
\hline
\end{tabular}




\begin{tabular}{|c|c|c|c|c|c|c|c|c|c|c|c|c|}
\hline Target & Retiro & Retiro & Piçarra & Piçarra & Piçarra & Piçarra & Piçarra & Piçarra & Piçarra & Piçarra & Piçarra & Piçarra \\
\hline Sample & $018-280$ & $018-307$ & $021-090^{*}$ & $021-100$ & $021-121$ & $021-132$ & $021-143$ & $021-153$ & $021-163$ & $021-176$ & $021-188$ & $021-202$ \\
\hline thology & $\mathrm{Hz}$ & $\mathrm{PX}$ & AT & $P X$ & $\mathrm{HZ}$ & $\mathrm{HZ}$ & $H z$ & PX & $p X$ & $\mathrm{PX}$ & $\mathrm{HZ}$ & $\mathrm{H}_{2}$ \\
\hline $\mathrm{SiO}_{2}$ & 39.6 & 51.5 & 52.8 & 49.0 & 37.8 & 42.7 & 40.6 & 45.7 & 44.5 & 45.4 & 41.2 & 40.7 \\
\hline $\mathrm{Al}_{2} \mathrm{O}_{3}$ & 4.08 & 5.13 & 4.37 & 3.65 & 2.98 & 3.97 & 3.09 & 6.41 & 7.02 & 4.52 & 4.06 & 3.18 \\
\hline $\mathrm{Fe}_{2} \mathrm{O}_{3}$ & 14.15 & 13.40 & 12.45 & 14.30 & 22.20 & 15.25 & 15.30 & 11.60 & 12.55 & 12.00 & 13.50 & 12.70 \\
\hline $\mathrm{CaO}$ & 1.34 & 2.81 & 7,62 & 2.95 & 0.46 & 2.42 & 0.31 & 6.43 & 4.52 & 4.65 & 2.00 & 3.18 \\
\hline MgO & 32.70 & 26.00 & 20.50 & 26.80 & 30.10 & 32.10 & 32.50 & 25.60 & 27.30 & 28.80 & 30.60 & 31.60 \\
\hline $\mathrm{Na}_{2} \mathrm{O}$ & 0.06 & 0.62 & 0.85 & 0.64 & 0.36 & 0.18 & 0.10 & 0.47 & 0.38 & 0.28 & 0.15 & 0.16 \\
\hline $\mathrm{K}_{2} \mathrm{O}$ & 0.01 & 0.10 & 0.12 & 0.27 & 0.10 & 0.05 & 0.05 & 0.11 & 0.11 & 0.06 & 0.02 & 0.02 \\
\hline $\mathrm{Cr}_{2} \mathrm{O}_{3}$ & 0.67 & 0.44 & 0.25 & 0.32 & 0.43 & 0.67 & 0.65 & 0.47 & 0.57 & 0.42 & 0.64 & 0.52 \\
\hline $\mathrm{TiO}_{2}$ & 0.29 & 0.54 & 0.35 & 0.34 & 0.53 & 0.40 & 0.23 & 0.69 & 0.61 & 0.43 & 0.38 & 0.31 \\
\hline Mno & 0.22 & 0.21 & 0.14 & 0.19 & 0.20 & 0.22 & 0.25 & 0.22 & 0.22 & 0.20 & 0.24 & 0.26 \\
\hline $\mathrm{P}_{2} \mathrm{O}_{3}$ & 0.01 & 0.02 & 0.02 & $<0.01$ & 0.02 & 0.05 & 0.07 & 0.05 & 0.03 & 0.02 & 0.06 & 0.22 \\
\hline Sro & $<0.01$ & $<0.01$ & 0.01 & 0.01 & 8.01 & 0.01 & 0.01 & 0.01 & 0.02 & 0.01 & 0.01 & $<0.01$ \\
\hline Bao & $<0.01$ & $<0.01$ & $<0.01$ & $<0.01$ & 8.01 & $<0.01$ & $<0.01$ & $<0.01$ & $<0.01$ & 0.03 & $<0.01$ & $<0.01$ \\
\hline c & 0.38 & 0.01 & 0.03 & 0.08 & 0.12 & 0.16 & 0.18 & 0.20 & 0.18 & 0.14 & 0.26 & 0.21 \\
\hline 5 & 0.02 & 0.16 & 1.13 & 0.63 & 2.97 & 0.46 & 0.65 & 0.09 & 0.12 & 0.09 & 0.58 & 0.07 \\
\hline $\mathrm{Ba}$ & 1 & 2 & 3 & 20 & 2 & 2 & 2 & 3 & 4 & 1 & 1 & 1 \\
\hline $\mathrm{Ce}$ & 5 & 12 & 4 & 9 & 8 & 11 & 5 & 19 & 16 & 14 & 8 & 22 \\
\hline cr & 5620 & 3030 & 1680 & 2260 & 2940 & 5640 & 5260 & 3550 & 4470 & 3460 & 4910 & 4130 \\
\hline cs & 0.03 & 0.57 & 0.76 & 10.10 & 1.28 & 0.20 & 0.85 & 0.22 & 0.62 & 0.29 & 0.18 & 0.52 \\
\hline Dy & 0.62 & 1.31 & 0.84 & 0.91 & 0.51 & 1.01 & 0.53 & 2.17 & 1.49 & 1.65 & 0.84 & 1.68 \\
\hline Er & 0.42 & 0.82 & 0.45 & 0.56 & 0.38 & 0.62 & 0.32 & 1.17 & 0.78 & 0.88 & 0.50 & 0.89 \\
\hline Eu & 0.14 & 0.21 & 0.59 & 0.23 & 0.10 & 0.29 & 0.12 & 0.67 & 0.38 & 0.48 & 0.22 & 0.48 \\
\hline Ga & 6.40 & 8.30 & 6.50 & 5,30 & 5,30 & 6.10 & 5.40 & 8.60 & 9.60 & 7.00 & 6.30 & 5.40 \\
\hline Gd & 0.70 & 1.30 & 0.71 & 0.88 & 0.48 & 1.12 & 0.64 & 2.42 & 1.53 & 1.71 & 0.89 & 2.02 \\
\hline $\mathrm{Hf}$ & 1.00 & 1.20 & 0.80 & 0.80 & 1.00 & 1.00 & 0.50 & 1.90 & 1.80 & 1.30 & 1.10 & 1.00 \\
\hline Ho & 0.14 & 0.24 & 0.15 & 0.20 & 0.12 & 0.21 & 0.10 & 0.43 & 0.28 & 0.31 & 0.17 & 0.32 \\
\hline ta & 1.90 & 5.70 & 1.70 & 4.00 & 3.40 & 5.50 & 1.90 & 8.20 & 7.60 & 5.90 & 4.00 & 12.00 \\
\hline Lu & 0.07 & 0.09 & 0.04 & 0.04 & 0.03 & 0.09 & 0.05 & 0.15 & 0.11 & 0.13 & 0.08 & 0.10 \\
\hline $\mathrm{Nb}$ & 2.10 & 4.40 & 5.50 & 2.40 & 4.20 & 3.30 & 1.60 & 5.90 & 4.80 & 2.50 & 2.50 & 2.30 \\
\hline Nd & 2.90 & 6.10 & 2.10 & 4.50 & 4.30 & 5.50 & 2.60 & 10.40 & 7.70 & 7.50 & 3.90 & 9.70 \\
\hline Pr & 0.64 & 1.42 & 0.39 & 0.99 & 0.99 & 1.35 & 0.58 & 2.46 & 1.89 & 1.78 & 0.98 & 2.49 \\
\hline $\mathrm{Rb}$ & 0.50 & 1.00 & 1,40 & 11.30 & 2.50 & 1.10 & 2.80 & 1.40 & 1.80 & 1.40 & 1.20 & 1.10 \\
\hline $5 m$ & 0.65 & 1.25 & 0.67 & 0.92 & 0.70 & 1.13 & 0.54 & 2.38 & 1.59 & 1.69 & 0.81 & 2.04 \\
\hline Sn & $<1$ & $<1$ & 1.00 & 1.00 & 1.00 & 1.00 & 1.00 & $<1$ & 1.00 & 1.00 & $<1$ & $<1$ \\
\hline Sr & 20.60 & 12.90 & 87.40 & 92.20 & 6.70 & 27.60 & 6.00 & 78.90 & 60.80 & 59,90 & 29.50 & 42.00 \\
\hline $\mathrm{Ta}$ & 0.20 & 0.30 & 0.20 & 0.20 & 0.30 & 0.20 & 0.10 & 0.50 & 0.30 & 0.20 & 0.20 & 0.20 \\
\hline $\mathrm{Tb}$ & 0.09 & 0.22 & 0.14 & 0.15 & 0.10 & 0.16 & 0.08 & 0.34 & 0.22 & 0.26 & 0.14 & 0.27 \\
\hline Th & 0.49 & 1.18 & 0.22 & 0.66 & 0.56 & 1.51 & 0.51 & 2.31 & 1.70 & 1.01 & 1.37 & 3.47 \\
\hline$\pi$ & $<0.5$ & $<0.5$ & $<0.5$ & $<0.5$ & $<0.5$ & $<0.5$ & $<0.5$ & $<0.5$ & $<0.5$ & $<0.5$ & $<0.5$ & $\infty .5$ \\
\hline $\mathrm{Im}$ & 0.06 & 0.10 & 0.07 & 0.04 & 0.03 & 0.08 & 0.05 & 0.17 & 0.12 & 0.12 & 0.07 & 0.12 \\
\hline$u$ & 0.19 & 0.32 & 0.10 & 0.25 & 0.11 & 0.32 & 0.24 & 0.38 & 0.31 & 0.31 & 0.34 & 0.60 \\
\hline$v$ & $<5$ & 86.00 & 51.00 & 67.00 & 80.00 & $<5$ & $<5$ & 37.00 & 18.00 & 12.00 & $<5$ & es \\
\hline$w$ & 1.00 & 1.00 & 1.00 & 1.00 & $<1$ & 1.00 & 2.00 & 1.00 & 2.00 & 2.00 & 2.00 & 3.00 \\
\hline$\gamma$ & 3.50 & 7.00 & 4.20 & 4.70 & 2.70 & 5.30 & 2.70 & 11.20 & 7.50 & 8.40 & 4.60 & 8.30 \\
\hline$Y b$ & 0.42 & 0.73 & 0.46 & 0.59 & 0.49 & 0.55 & 0.33 & 1.06 & 0.78 & 0.79 & 0.50 & 0.72 \\
\hline $\mathrm{Zr}$ & 33.00 & 49.00 & 30.00 & 26.00 & 39.00 & 32.00 & 15.00 & 60.00 & 60.00 & 42.00 & 32.00 & 32.00 \\
\hline
\end{tabular}




\begin{tabular}{|c|c|c|c|c|c|c|c|c|c|c|c|c|}
\hline Target & Retiro & Retiro & Piçarra & Piçarra & Piçarra & içarra & Piçarra & Piçarra & Piçarra & Piçarra & Piçarra & Piçarra \\
\hline Sample & $018-280$ & $018-307$ & $021-090^{*}$ & $21-100$ & $021-121$ & $021-132$ & $021-143$ & $021-153$ & $021-163$ & $021-176$ & $021-188$ & $021-202$ \\
\hline hology & $\mathrm{HZ}$ & PX & AT & PX & $\mathrm{HZ}$ & $\mathrm{HZ}$ & $\mathrm{HZ}$ & $P X$ & $P X$ & $P X$ & $\mathrm{HZ}$ & $\mathrm{Hz}$ \\
\hline As & $<0.1$ & $<0.1$ & 0.10 & 0.10 & 0.30 & 0.20 & 0.20 & 0.10 & 0.10 & 0.20 & 0.30 & 0.20 \\
\hline$B i$ & 0.05 & 0.01 & 1.90 & 0.22 & 0.76 & 0.16 & 0.22 & 0.04 & 0.09 & 0.07 & 0.62 & 0.04 \\
\hline $\mathrm{Hg}$ & $<0.005$ & $<0.005$ & $<0.005$ & $<0.005$ & $\varnothing 0.005$ & $<0.005$ & $<0.005$ & $<0.005$ & $<0.005$ & $<0.005$ & $<0.005$ & 0.01 \\
\hline sb & $<0.05$ & $<0.05$ & $<0.05$ & $<0.05$ & $<0.05$ & $<0.05$ & -0.05 & $<0.05$ & $<0.05$ & $<0.05$ & $<0.05$ & $<0.05$ \\
\hline Se & $<0.2$ & 0.40 & 2.40 & 1.40 & 7.60 & 1.30 & 1.80 & 0.30 & 0.30 & 0.30 & 2.60 & 0.30 \\
\hline $\mathrm{Te}$ & $<0.01$ & 0.03 & 0.63 & 0.28 & 1.10 & 0.22 & 0.35 & 0.06 & 0.07 & 0.06 & 0.50 & 0.03 \\
\hline LOI & 5.54 & -0.44 & 1.44 & 0.69 & 3.55 & 3.84 & 6.51 & 3.02 & 3.78 & 3.44 & 6.11 & 8.76 \\
\hline Total & 98.70 & 100.33 & 100.92 & 99.16 & 98.73 & 101.86 & 99.70 & 100.78 & 10161 & 100.26 & 99.00 & 101.61 \\
\hline $\mathrm{Ag}$ & $<0.5$ & $<0.5$ & 1.1 & $<0.5$ & 1.3 & $<0.5$ & $<0.5$ & $<0.5$ & $<0.5$ & $<0.5$ & 1.1 & $<0.5$ \\
\hline cd & $<0.5$ & $<0.5$ & 1.1 & 0.6 & $<0.5$ & $<0.5$ & $<0.5$ & $<0.5$ & $<0.5$ & $<0.5$ & $<0.5$ & $\infty .5$ \\
\hline co & 126 & 110 & 128 & 108 & 262 & 138 & 156 & 93 & 101 & 105 & 164 & 128 \\
\hline $\mathrm{Cu}$ & 38 & 133 & 2780 & 808 & 4250 & 673 & 904 & 161 & 150 & 147 & 1850 & 60 \\
\hline Mo & 1 & $<1$ & 1 & 1 & 1 & 1 & $<1$ & $<1$ & $<1$ & $<1$ & 1 & $<1$ \\
\hline $\mathrm{Ni}$ & 1180 & 779 & 1640 & 1140 & 3630 & 1520 & 1670 & 1040 & 1150 & 1090 & 3000 & 1220 \\
\hline $\mathrm{Pb}$ & $<2$ & $<2$ & 4 & 3 & 3 & 3 & $<2$ & 3 & 3 & 2 & 3 & 2 \\
\hline $\mathrm{Zn}$ & 82 & 99 & 75 & 107 & 104 & 104 & 91 & 64 & 81 & 78 & 79 & 81 \\
\hline
\end{tabular}




\begin{tabular}{|c|c|c|c|c|c|c|c|c|c|c|c|c|}
\hline Target & Piçarra & Piçarra & Piçarra & Piçarra & Piçarra & Piçarra & Piçarra & Piçarra & Piçarra & Piçarra & Retiro & Retiro \\
\hline Sample & $021-215$ & $036-056$ & $036-087$ & $036-116$ & $036-130$ & $036-146^{*}$ & $036-162$ & $036-175$ & $036-188$ & $036-202$ & $038-054$ & $038-074^{*}$ \\
\hline thology & $\mathrm{Hz}$ & PX & $P X$ & $\mathrm{HZ}$ & PX & PX & PX & $\mathrm{Hz}$ & $\mathrm{HZ}$ & PX & PXX & PX \\
\hline $\mathrm{SiO}_{2}$ & 40.3 & 47.5 & 45.5 & 37.9 & 43.6 & 45.7 & 45,1 & 42.3 & 43.7 & 45,3 & $\$ 1.0$ & 49.0 \\
\hline $\mathrm{Al}_{2} \mathrm{O}_{3}$ & 3.37 & 5.00 & 4.11 & 4.28 & 3.99 & 3.37 & 3.92 & 4.19 & 3.78 & 3.07 & 4.90 & 5.95 \\
\hline $\mathrm{Fe}_{2} \mathrm{O}_{3}$ & 13.75 & 13.45 & 14.75 & 21.60 & 17.70 & 19.55 & 15.60 & 13.80 & 15.25 & 14.50 & 16.25 & 13.20 \\
\hline $\mathrm{CaO}$ & 1.94 & 3.99 & 1.64 & 0.65 & 2,72 & 4.60 & 3.31 & 1.76 & 1.44 & 1.72 & 2.97 & 4.43 \\
\hline $\mathrm{MgO}$ & 33.80 & 27.30 & 29.40 & 29.70 & 26.90 & 22.20 & 28.30 & 32.10 & 30.40 & 30.10 & 23.20 & 21.30 \\
\hline $\mathrm{Na}_{2} \mathrm{O}$ & 0.19 & 0.69 & 0.19 & 0.09 & 0.20 & 0.43 & 0.67 & 0.31 & 0.49 & 0.42 & 0.54 & 1.05 \\
\hline $\mathrm{K}_{2} \mathrm{O}$ & 0.03 & 0.11 & 0.03 & 0.02 & 0.03 & 0.04 & 0.10 & 0.05 & 0.63 & 0.41 & 0.19 & 1.21 \\
\hline $\mathrm{Cr}_{2} \mathrm{O}_{3}$ & 0.71 & 0.53 & 0.55 & 0.77 & 0.31 & 0.30 & 0.34 & 0.60 & 0.57 & 0.33 & 0.34 & 0.25 \\
\hline $\mathrm{TiO}_{2}$ & 0.31 & 0.39 & 0.45 & 0.41 & 0.29 & 0.45 & 0.47 & 0.41 & 0.49 & 0.28 & 0.37 & 0.53 \\
\hline Mno & 0.24 & 0.24 & 0.25 & 0.23 & 0.22 & 0.26 & 0.19 & 0.19 & 0.24 & 0.22 & 0.22 & 0.25 \\
\hline $\mathrm{P}_{2} \mathrm{O}_{3}$ & 0.02 & $<0.01$ & 0.01 & 0.02 & 0.04 & 0.02 & 0.08 & 0.04 & 0.03 & 0.16 & $<0.01$ & 0.01 \\
\hline Sro & $<0.01$ & 0.02 & $<0.01$ & $<0.01$ & $<0.01$ & 0.01 & 0.01 & 0.01 & 0.02 & 0.02 & 0.01 & 0.01 \\
\hline $\mathrm{BaO}$ & $<0.01$ & $<0.01$ & $<0.01$ & $<0.01$ & $<0.01$ & $<0.01$ & $<0.01$ & $<0.01$ & 0.01 & 0.01 & $<0.01$ & 0.04 \\
\hline c & 0.33 & 0.09 & 0.13 & 0.13 & 0.21 & 0,05 & 0.15 & 0.26 & 0.11 & 0.16 & 0.09 & 0.01 \\
\hline 5 & 0.19 & 0.59 & 0.63 & 0.73 & 1.48 & 2.37 & 0.91 & 0.21 & 0.50 & 0.43 & 0.79 & 0.79 \\
\hline Ba & 3 & 9 & 1 & 1 & 1 & 3 & 3 & 4 & 108 & 69 & 13 & 480 \\
\hline $\mathrm{Ce}$ & 7 & 12 & 12 & 2 & 8 & 9 & 10 & 10 & 9 & 10 & 8 & 14 \\
\hline$C_{r}$ & 5650 & 4030 & 4430 & 5900 & 2480 & 2080 & 2330 & 4450 & 3820 & 2520 & 2290 & 1750 \\
\hline Cs & 0.19 & 1.22 & 0.30 & 0.08 & 0.22 & 0.27 & 0.43 & 0.51 & 39.80 & 25.10 & 1.90 & 80.10 \\
\hline Dy & 0.81 & 1.47 & 0.94 & 0.30 & 0.58 & 0,94 & 1.17 & 0.89 & 0.77 & 0.78 & 0.51 & 1.54 \\
\hline Er & 0.47 & 0.85 & 0.51 & 0.19 & 0.32 & 0.54 & 0.71 & 0.51 & 0.36 & 0.40 & 0.32 & 0.86 \\
\hline Eu & 0.29 & 0.39 & 0.22 & 0.06 & 0.17 & 0.34 & 0,41 & 0.27 & 0.13 & 0.16 & 0.11 & 0.46 \\
\hline Ga & 5.70 & 7.70 & 7.70 & 7.60 & 6.40 & 5.40 & 6.00 & 7.30 & 6.90 & 5.80 & 7.60 & 7.20 \\
\hline Gd & 0.87 & 1.52 & 0.97 & 0.33 & 0.65 & 0.95 & 1.14 & 1.04 & 0.87 & 0.87 & 0.51 & 1.86 \\
\hline $\mathrm{Hf}$ & 0.60 & 0.90 & 1.10 & 0.90 & 0.70 & 0.70 & 0.70 & 1.10 & 1.00 & 0.50 & 0.70 & 1.00 \\
\hline Ho & 0.16 & 0.30 & 0.18 & 0.06 & 0.12 & 0.20 & 0.23 & 0.19 & 0.15 & 0.16 & 0.11 & 0.31 \\
\hline La & 2.80 & 5.80 & 6.20 & 0.80 & 4.80 & 3.70 & 5.00 & 4.60 & 3.90 & 5.60 & 3.50 & 6.00 \\
\hline Lu & 0.07 & 0.12 & 0.09 & 0.04 & 0.05 & 0,09 & 0.05 & 0.11 & 0.08 & 0.07 & 0.03 & 0.14 \\
\hline $\mathrm{Nb}$ & 2.00 & 3.00 & 3.50 & 1.30 & 1.60 & 3.00 & 4.10 & 3.80 & 3.10 & 1.80 & 2.30 & 3.00 \\
\hline Nd & 3.80 & 6.60 & 5.70 & 1.20 & 3,60 & 4.60 & 5.00 & 5.00 & 4.40 & 4.70 & 3.40 & 7.20 \\
\hline $\mathrm{Pr}$ & 0.91 & 154 & 1.46 & 0.24 & 0.93 & 1,10 & 1.22 & 1.27 & 1.07 & 1.17 & 0.88 & 1.70 \\
\hline $\mathrm{Rb}$ & 1.00 & 2.40 & 1.40 & 0.70 & 1.00 & 0.70 & 1.30 & 1.50 & 41.10 & 27,70 & 5.40 & 56.80 \\
\hline Sm & 0.88 & 1.47 & 1.12 & 0.27 & 0.62 & 1.06 & 1.18 & 1.09 & 0.89 & 0.94 & 0.85 & 1.72 \\
\hline Sn & 1.00 & 100 & 1.00 & 1.00 & 1.00 & 1.00 & 2.00 & 1.00 & 1.00 & 1.00 & 1.00 & 1.00 \\
\hline Sr & 19.70 & 174.00 & 18.80 & 12.30 & 35.40 & 72.00 & 59.10 & 52.00 & 96.30 & 112.00 & 65.20 & 136.00 \\
\hline $\mathrm{Ta}$ & 0.20 & 0.20 & 0.30 & 0.10 & 0.10 & 0.20 & 0.30 & 0.30 & 0.20 & 0.10 & 0.20 & 0.20 \\
\hline $\mathrm{Tb}$ & 0.13 & 0.21 & 0.14 & 0.04 & 0.09 & 0.15 & 0.22 & 0.16 & 0.12 & 0.13 & 0.10 & 0.26 \\
\hline Th & 0.83 & 1.16 & 2.06 & 0.42 & 1.01 & 0.86 & 0.74 & 0.75 & 0.79 & 1.33 & 0.60 & 1.10 \\
\hline$\pi$ & $<0.5$ & $<0.5$ & $<0.5$ & $<0.5$ & $<0.5$ & $<0.5$ & $<0.5$ & $<0.5$ & $<0.5$ & $<0.5$ & $<0.5$ & $\infty .5$ \\
\hline Tm & 0.07 & 0.12 & 0.08 & 0.02 & 0.05 & 0,09 & 0.08 & 0.10 & 0.07 & 0.06 & 0.04 & 0.14 \\
\hline u & 0.24 & 0.28 & 0.22 & 0.17 & 0.15 & 0.24 & 0.36 & 0.25 & 0.16 & 0.59 & 0.27 & 0.20 \\
\hline v & $<5$ & 6.00 & $<5$ & $<5$ & 51.00 & 58.00 & 92.00 & $<5$ & 18.00 & 22.00 & 79.00 & 98.00 \\
\hline$w$ & 6.00 & 2.00 & 2.00 & 3.00 & 1.00 & 1.00 & $<1$ & 1.00 & 1.00 & 1.00 & $<1$ & 1.00 \\
\hline$Y$ & 4.20 & 7.90 & 4.80 & 1.70 & 3,30 & 5,00 & 6.50 & 4.90 & 3.90 & 3.90 & 3.40 & $6.4 \mathrm{C}$ \\
\hline$Y_{b}$ & 0.44 & 0.75 & 0.58 & 0.24 & 0.34 & 0,61 & 0.68 & 0.60 & 0.49 & 0.45 & 0.32 & 0.92 \\
\hline $\mathrm{Zr}$ & 22.00 & 27.00 & 35.00 & 31.00 & 21.00 & 25.00 & 29.00 & 37.00 & 33.00 & 18.00 & 27.00 & 34.00 \\
\hline
\end{tabular}




\begin{tabular}{|c|c|c|c|c|c|c|c|c|c|c|c|c|}
\hline Target & Piçarra & Piçarra & Piçarra & Piçarra & Piçarra & Piçarra & Piçarra & Piçarra & Piçarra & Piçarra & Retiro & Retiro \\
\hline Sample & $021-215$ & $036-056$ & $036-087$ & $036-116$ & $036-130$ & $036-146^{\circ}$ & $036-162$ & $036-175$ & $036-188$ & $036-202$ & $038-054$ & $038-074^{*}$ \\
\hline Lthology & $\mathrm{HZ}$ & PX & $p x$ & $\mathrm{HZ}$ & px & $P X$ & PX & $\mathrm{HZ}$ & $\mathrm{HZ}$ & $p X$ & $P X$ & $\mathrm{PX}$ \\
\hline As & 0.40 & 0.30 & 0.30 & 0.40 & 0.40 & 0.50 & 0.50 & 0.20 & 0.40 & 0.30 & 0.20 & 0.30 \\
\hline Bi & 0.13 & 0.28 & 0.14 & 1.75 & 0.14 & 0.47 & 0.30 & 1.05 & 2.65 & 0.44 & 0.19 & 0.16 \\
\hline $\mathrm{Hg}$ & $<0.005$ & $<0.005$ & $<0.005$ & $<0.005$ & $<0.005$ & $<0.005$ & $<0.005$ & 0.01 & $<0.005$ & 0.01 & 0.01 & $\infty .005$ \\
\hline Sb & 0.05 & $<0.05$ & $<0.05$ & $<0.05$ & $<0.05$ & $<0.05$ & $<0.05$ & $<0.05$ & $<0.05$ & $<0.05$ & $<0.05$ & $<0.05$ \\
\hline Se & 0.50 & 1.30 & 1.50 & 3.30 & 5.10 & 8.10 & 2.90 & 0.80 & 1.70 & 1.20 & 1.80 & 2.20 \\
\hline $\mathrm{Te}$ & 0.09 & 0.37 & 0.25 & 0.86 & 0.48 & 1.06 & 0.42 & 0.27 & 0.48 & 0.25 & 0.39 & 0.34 \\
\hline $\mathrm{LOI}$ & 5.67 & 1.92 & 2.40 & 4.31 & 2.22 & 1.27 & 2.28 & 4.30 & 3.00 & 1.97 & 0.38 & 1.24 \\
\hline Total & 100.33 & 101.14 & 99.30 & 100.00 & 98.20 & 98.20 & 100.37 & 100.00 & 100.00 & 98.50 & 100.37 & 98.50 \\
\hline $\mathrm{Ag}$ & $<0.5$ & $<0.5$ & $<0.5$ & 1.9 & $<0.5$ & 1.6 & $<0.5$ & 0.6 & 1.9 & $<0.5$ & $<0.5$ & 0.5 \\
\hline $\mathrm{Cd}$ & $<0.5$ & $<0.5$ & $<0.5$ & $<0.5$ & $<0.5$ & 1 & $<0.5$ & $<0.5$ & $<0.5$ & $<0.5$ & $<0.5$ & $\infty .5$ \\
\hline Co & 139 & 122 & 132 & 205 & 203 & 223 & 152 & 133 & 151 & 134 & 134 & 115 \\
\hline $\mathrm{Cu}$ & 166 & 844 & 694 & 2750 & 2140 & 4790 & 1520 & 693 & 1360 & 758 & 832 & 1520 \\
\hline Mo & 1 & $<1$ & $\Leftrightarrow 1$ & 1 & 1 & 1 & $<1$ & $<1$ & 1 & $<1$ & 1 & $<1$ \\
\hline $\mathrm{Ni}$ & 1580 & 1110 & 1060 & 2280 & 2090 & 3400 & 1350 & 1340 & 1640 & 1180 & 1270 & 1280 \\
\hline $\mathrm{Pb}$ & $<2$ & 3 & $<2$ & $<2$ & 4 & 4 & 3 & 3 & 12 & 7 & $<2$ & 12 \\
\hline $\mathrm{Zn}$ & 89 & 81 & 83 & 113 & 63 & 106 & 76 & 86 & 98 & 99 & 91 & 84 \\
\hline
\end{tabular}




\begin{tabular}{|c|c|c|c|c|c|c|c|c|c|c|c|c|}
\hline Target & Retiro. & Retiro & Retiro & Retiro & Retiro & Retiro & Retiro & Retiro & Retiro & Parnazo & Parnazo & Parnazo \\
\hline Sample & $038-093$ & $038-110$ & $038-128$ & 038-151 & $038-176$ & $038-202$ & $038-231$ & $038-253$ & $038-273^{\circ}$ & $053-049$ & $053-067$ & $053-090$ \\
\hline iology & $\mathrm{HZ}$ & $\mathrm{Hz}$ & $\mathrm{HZ}$ & $p x$ & $\mathrm{HZ}$ & $P X$ & $\mathrm{HZ}$ & PX & AT & $P X$ & $\mathrm{HZ}$ & $\mathrm{HZ}$ \\
\hline $\mathrm{SiO}_{2}$ & 41.9 & 39.2 & 40,5 & 45.9 & 40,1 & 42.5 & 39.6. & 44.8 & 512 & 45.1 & 41.6 & 41.8 \\
\hline $\mathrm{Al}_{2} \mathrm{O}_{3}$ & 3.73 & 3.61 & 3.29 & 5.58 & 4.43 & 5.36 & 4.27 & 4.70 & 5.75 & 5.04 & 4.09 & 4.98 \\
\hline $\mathrm{Fe}_{2} \mathrm{O}_{3}$ & 14.60 & 15.20 & 17.75 & 12.70 & 15.25 & 13.75 & 13.85 & 12,50 & 11.10 & 14.10 & 15.85 & 13.95 \\
\hline $\mathrm{CaO}$ & 1.38 & 1.07 & 2.13 & 4.26 & 0.58 & 4.95 & 1.62 & 4.79 & 6.25 & 5.43 & 4.33 & 4.00 \\
\hline $\mathrm{MgO}$ & 33.10 & 33.90 & 30.10 & 28.90 & 34.80 & 27.20 & 33.90 & 26.80 & 21.10 & 26.10 & 29.30 & 29.30 \\
\hline $\mathrm{Na}_{2} \mathrm{O}$ & 0.12 & 0.10 & 0.15 & 0.21 & 0.11 & 0.22 & 0.11 & 0.32 & 0.98 & 0.27 & 0.16 & 0.16 \\
\hline $\mathrm{K}_{2} \mathrm{O}$ & 0.02 & 0.01 & 0.10 & 0.08 & 0.02 & 0.09 & 0.02 & 0.07 & 0.11 & 0.09 & 0.07 & 0.31 \\
\hline $\mathrm{Cr}_{2} \mathrm{O}_{3}$ & 0.73 & 0.92 & 0.55 & 0.54 & 0.41 & 0.56 & 0.79 & 0.40 & 0.27 & 0.42 & 0.52 & 0.57 \\
\hline $\mathrm{TiO}_{2}$ & 0.35 & 0.30 & 0.37 & 0.48 & 0.29 & 0.53 & 0.34 & 0.35 & 0.49 & 0.48 & 0.39 & 0.40 \\
\hline Mno & 0.24 & 0.23 & 0.25 & 0.18 & 0.25 & 0.24 & 0.24 & 0.26 & 0.22 & 0.17 & 0.25 & 0.24 \\
\hline $\mathrm{P}_{2} \mathrm{O}_{3}$ & 0.04 & 0.01 & $<0.01$ & 0.03 & $\infty 0.01$ & $<0.01$ & $<0.01$ & 0.01 & 0.05 & 0.06 & 0.07 & $<0.01$ \\
\hline Sro & $<0.01$ & $<0.01$ & 0.01 & 0.01 & 0.01 & 0.01 & 0.01 & $<0.01$ & 0.01 & 0.01 & 0.01 & $\infty 0.01$ \\
\hline $\mathrm{BaO}$ & $<0.01$ & $<0.01$ & $<0.01$ & $<0.01$ & $\infty 0.01$ & $<0.01$ & $<0.01$ & $<0.01$ & $<0.01$ & $<0.01$ & $<0.01$ & 0.01 \\
\hline c & 0.24 & 0.21 & 0.17 & 0.19 & 0.29 & 0.21 & 0.15 & 0.05 & $<0.01$ & 0.18 & 0.17 & 0.18 \\
\hline s & 0.40 & 0.39 & 1.06 & 0.14 & 0.22 & 0.10 & 0.03 & 0.10 & 0.01 & 0.59 & 0.93 & 0.31 \\
\hline $\mathrm{Ba}$ & 1 & 1 & 25 & 3 & 2 & 13 & $<0.5$ & 2 & 4 & 4 & 19 & 113 \\
\hline $\mathrm{Ce}$ & 9 & 6 & 10 & 13 & 6 & 16 & 5 & 10 & 15 & 16 & 14 & 11 \\
\hline Cr & 5330 & 6720 & 3940 & 3810 & 2930 & 4060 & 5930 & 2960 & 2060 & 2820 & 3650 & 4030 \\
\hline Cs & 0.19 & 0.04 & 0.94 & $<0.01$ & 0.18 & 0.14 & 0.04 & 0.64 & 1.81 & 0.21 & 0.03 & 1.90 \\
\hline Dy & 0.76 & 0.56 & 0.81 & 1.31 & 0.22 & 1.82 & 0.60 & 1.17 & 1.66 & 1.98 & 1.77 & 1.33 \\
\hline Er & 0.44 & 0.31 & 0.42 & 0.92 & 0.13 & 0.98 & 0.34 & 0.64 & 0.89 & 1.32 & 0.94 & 0.72 \\
\hline Eu & 0.19 & 0.17 & 0.27 & 0.41 & 0.05 & 0.61 & 0.18 & 0.30 & 0.54 & 0.64 & 0.51 & 0.41 \\
\hline Ga & 5.70 & 6.40 & 6.30 & 7.60 & 7.10 & 9.10 & 7.30 & 7.90 & 9.50 & 7.70 & 6.80 & 7.90 \\
\hline Gd & 0.83 & 0.54 & 0.92 & 1.48 & 0.23 & 2.00 & 0.64 & 1.22 & 1.67 & 2.17 & 1.87 & 1.39 \\
\hline $\mathrm{Hf}$ & 0.90 & 0.60 & 1.30 & 1.00 & 0.70 & 1.40 & 0.60 & 0.70 & 1.30 & 1.20 & 1.00 & 1.10 \\
\hline Ho & 0.16 & 0.11 & 0.17 & 0.29 & 0.05 & 0.37 & 0.12 & 0.23 & 0.32 & 0.42 & 0.37 & 0.29 \\
\hline La & 4.30 & 2.50 & 4.60 & 6.10 & 3.10 & 6.90 & 1.70 & 4.00 & 6.80 & 8.20 & 5.80 & 4.30 \\
\hline Lu & 0.08 & 0.07 & 0.08 & 0.07 & 0.07 & 0.13 & 0.06 & 0.10 & 0.13 & 0.15 & 0.13 & 0.11 \\
\hline $\mathrm{Nb}$ & 2.70 & 2.20 & 3.20 & 4.10 & 2.40 & 3.50 & 3.10 & 2.60 & 4.20 & 4.20 & 3.40 & 3.70 \\
\hline Nd & 4.00 & 3.10 & 5.00 & 6.60 & 1.80 & 9.40 & 2.60 & 5.10 & 7.70 & 9.50 & 7.60 & 6.00 \\
\hline Pr & 1.04 & 0.76 & 1.25 & 1.53 & 0.54 & 2.18 & 0.61 & 1.22 & 1.81 & 2.02 & 1.78 & 1.46 \\
\hline $\mathrm{Rb}$ & 0.30 & 0.20 & 5.00 & 0.60 & 0.50 & 1.30 & 0.30 & 1.30 & 3.80 & 1.90 & 1.20 & 28.30 \\
\hline Sm & 0.90 & 0.62 & 0.99 & 1.56 & 0.25 & 2.16 & 0.62 & 1.20 & 1.74 & 1.75 & 1.83 & 1.39 \\
\hline Sn & 1.00 & 100 & 1.00 & 1.00 & $<1$ & 1.00 & 1.00 & 1.00 & 1.00 & 1.00 & 1.00 & 1.00 \\
\hline $\mathrm{sr}$ & 23.00 & 15.90 & 25.90 & 65.00 & 13.40 & 92.80 & 25.70 & 61.30 & 57.60 & 65.90 & 65.10 & 59.00 \\
\hline $\mathrm{Ta}$ & 0.20 & 0.20 & 0.20 & 0.30 & 0.10 & 0.20 & 0.20 & 0.20 & 0.30 & 0.20 & 0.20 & 0.30 \\
\hline $\mathrm{Tb}$ & 0.13 & 0.08 & 0.13 & 0.24 & 0.03 & 0.32 & 0.09 & 0.19 & 0.27 & 0.39 & 0.30 & 0.22 \\
\hline Th & 0.83 & 0.55 & 1.18 & 3.28 & 0.56 & 1.42 & 0.61 & 1.13 & 1.51 & 2.92 & 1.69 & 1.46 \\
\hline$\pi$ & $<0.5$ & $<0.5$ & $<0.5$ & $<0.5$ & $<0.5$ & $<0.5$ & $<0.5$ & $<0.5$ & $<0.5$ & $<0.5$ & $<0.5$ & $\infty 0.5$ \\
\hline $\mathrm{Tm}$ & 0.07 & 0.05 & 0.07 & 0.12 & 0.03 & 0.16 & 0.05 & 0.11 & 0.14 & 0.14 & 0.15 & 0.12 \\
\hline u & 0.19 & 0.12 & 0.21 & 0.28 & 0.06 & 0.35 & 0.37 & 0.16 & 0.44 & 0.51 & 0.64 & 0.39 \\
\hline v & 32.00 & $<5$ & 20.00 & 70.00 & $<5$ & 37.00 & 33.00 & 18.00 & 68.00 & 107.00 & 6.00 & $<5$ \\
\hline w & 1.00 & 100 & 1.00 & 1.00 & 1.00 & 1.00 & 1.00 & 1.00 & 2.00 & 1.00 & 1.00 & 1.00 \\
\hline$Y$ & 3.10 & 3.00 & 4.10 & 7.20 & 1.30 & 9.90 & 3.30 & 6.40 & 8.70 & 10.10 & 8.90 & 7.20 \\
\hline $\mathrm{Yb}_{\mathrm{b}}$ & 0.47 & 0.39 & 0.49 & 0.85 & 0.27 & 0.93 & 0.39 & 0.65 & 0.92 & 1.10 & 0.92 & 0.75 \\
\hline $\mathrm{Zr}$ & 31.00 & 21.00 & 48.00 & 39.00 & 26.00 & 51.00 & 22.00 & 25.00 & 49.00 & 48.00 & 39.00 & 39.00 \\
\hline
\end{tabular}




$\begin{array}{rrrrrrrrrrrrr}\text { Target } & \text { Retiro } & \text { Retiro } & \text { Retiro } & \text { Retiro } & \text { Retiro } & \text { Retiro } & \text { Retiro } & \text { Retiro } & \text { Retiro } & \text { Parnazo } & \text { Parnazo } & \text { Parnazo } \\ \text { Sample } & 038-093 & 038-110 & 038-128 & 038-151 & 038-176 & 038-202 & 038-231 & 038-253 & 038-273 & 053-049 & 053-067 & 053-090 \\ \text { Lithology } & \mathrm{HZ} & \mathrm{HZ} & \mathrm{HZ} & \mathrm{PX} & \mathrm{HZ} & \mathrm{PX} & \mathrm{HZ} & \mathrm{PX} & \mathrm{AT} & \mathrm{PX} & \mathrm{HZ} & \mathrm{HZ} \\ \mathrm{AS} & 0.40 & 0.40 & 0.40 & 0.30 & 0.20 & 0.30 & 0.30 & 0.30 & 0.10 & 0.30 & 0.20 & 0.30 \\ \mathrm{Bi} & 0.17 & 0.29 & 0.41 & 0.06 & 0.07 & 0.05 & 0.04 & 0.02 & 0.02 & 0.21 & 0.15 & 0.08 \\ \mathrm{Hg} & <0.005 & <0.005 & <0.005 & <0.005 & <0.005 & <0.005 & <0.005 & <0.005 & <0.005 & <0.005 & 0.01 & <.005 \\ \mathrm{Sb} & <0.05 & <0.05 & <0.05 & <0.05 & <0.05 & <0.05 & <0.05 & <0.05 & <0.05 & <0.05 & <0.05 & <0.05 \\ \mathrm{Se} & 1.20 & 1.40 & 2.90 & 0.50 & 0.60 & 0.40 & <0.2 & 0.40 & <0.2 & 1.90 & 2.60 & 0.90 \\ \mathrm{Te} & 0.20 & 0.29 & 0.48 & 0.08 & 0.09 & 0.03 & 0.02 & 0.03 & 0.02 & 0.27 & 0.22 & 0.11 \\ \mathrm{LOI} & 3.96 & 3.65 & 3.59 & 2.57 & 4.11 & 3.00 & 4.84 & 3.64 & 0.97 & 4.11 & 4.87 & 6.05 \\ \mathrm{Total} & 100.00 & 98.20 & 98.80 & 101.44 & 100.36 & 98.40 & 99.60 & 98.60 & 98.50 & 101.38 & 101.51 & 101.77 \\ \mathrm{Ag} & <0.5 & <0.5 & <0.5 & <0.5 & <0.5 & <0.5 & <0.5 & <0.5 & <0.5 & 0.5 & <0.5 & <0.5 \\ \mathrm{Cd} & <0.5 & <0.5 & <0.5 & <0.5 & <0.5 & <0.5 & <0.5 & <0.5 & <0.5 & <0.5 & <0.5 & <0.5 \\ \mathrm{Co} & 142 & 157 & 189 & 104 & 150 & 104 & 130 & 99 & 76 & 132 & 162 & 130 \\ \mathrm{Cu} & 818 & 821 & 1970 & 276 & 338 & 168 & 64 & 135 & 2 & 1080 & 1260 & 574 \\ \mathrm{Mo} & 1 & 1 & 1 & 1 & <1 & 1 & 1 & <1 & 1 & <1 & <1 & 1 \\ \mathrm{Ni} & 1600 & 2170 & 2760 & 1130 & 1380 & 1150 & 1320 & 721 & 374 & 1380 & 1580 & 1220 \\ \mathrm{~Pb} & <2 & <2 & 3 & 3 & <2 & 2 & <2 & <2 & 3 & <2 & <2 & 2 \\ \mathrm{Zn} & 65 & 75 & 72 & 63 & 72 & 58 & 89 & 89 & 86 & 57 & 51 & 82\end{array}$




\begin{tabular}{|c|c|c|c|c|c|c|c|c|c|c|c|c|}
\hline Target & Parnazo & Parnazo & Parnazo & Retiro & Retiro & Retiro & Retiro & Retiro & Retiro. & Retiro & Retiro & Retiro \\
\hline Sample & $053-114$ & $053-143$ & $053-168$ & $055-182$ & $055-208$ & $055-228$ & $055-235$ & $055-245$ & $055-257$ & $055-266$ & $055-272$ & $055-282$ \\
\hline Lithology & $\mathrm{HZ}$ & $\mathrm{HZ}$ & AT & AT & $P X$ & $\mathrm{HZ}$ & PX & $\mathrm{HZ}$ & $\mathrm{HZ}$ & $\mathrm{HZ}$ & PX & PX \\
\hline $\mathrm{SiO}_{7}$ & 42.1 & 40.5 & 49.3 & 46.5 & 46.1 & 42.5 & 46.5 & 43.3 & 40.0 & 43.7 & 47.8 & 51.9 \\
\hline $\mathrm{Al}_{2} \mathrm{O}_{3}$ & 3.95 & 3.62 & 5.24 & 6.39 & 4.75 & 3.52 & 6.00 & 3.85 & 399 & 3.75 & 3.24 & 5.09 \\
\hline $\mathrm{Fe}_{2} \mathrm{O}_{3}$ & 15.15 & 15.00 & 12.75 & 10.70 & 15.55 & 17.70 & 12.65 & 13.65 & 14.75 & 13.70 & 12.75 & 13.10 \\
\hline $\mathrm{CaO}$ & 2.83 & 2.75 & 1.64 & 7.35 & 3.80 & 1.39 & 5.58 & 2.77 & 3.54 & 2.11 & 2.41 & 4.22 \\
\hline $\mathrm{MgO}$ & 32.70 & 33.00 & 25.80 & 22.60 & 25.60 & 32.70 & 26.60 & 32.60 & 34.80 & 31.80 & 29.20 & 23.40 \\
\hline $\mathrm{Na}_{2} \mathrm{O}$ & 0.08 & 0.10 & 0.44 & 0.83 & 0.09 & 0.05 & 0.12 & 0.13 & 0.42 & 0.30 & 0.36 & 1.07 \\
\hline $\mathrm{K}_{2} \mathrm{O}$ & 0.05 & 0.04 & 1.08 & 0.23 & 0.05 & 0.02 & 0.09 & 0.05 & 0.13 & 0.22 & 0.27 & 0.12 \\
\hline $\mathrm{Cr}_{2} \mathrm{O}_{1}$ & 0.54 & 0.39 & 0.42 & 0.48 & 0.34 & 0.62 & 0.50 & 0.62 & 0.61 & 0.75 & 0.54 & 0.42 \\
\hline $\mathrm{TiO}_{2}$ & 0.34 & 0.33 & 0.38 & 0.58 & 0.41 & 0.37 & 0.60 & 0.34 & 0.42 & 0.32 & 0.29 & 0.44 \\
\hline Mno & 0.19 & 0.26 & 0.21 & 0.17 & 0.24 & 0.21 & 0.21 & 0.19 & 0.22 & 0.22 & 0.24 & 0.24 \\
\hline $\mathrm{P}_{2} \mathrm{O}_{5}$ & 0.02 & 0.02 & $<0.01$ & 0.13 & 0.10 & 0.02 & 0.04 & 0.10 & 0.26 & 0.01 & $<0.01$ & $\infty 0.01$ \\
\hline Sro & $<0.01$ & $<0.01$ & 0.01 & 0.02 & 0.01 & $<0.01$ & 0.01 & 0.01 & 0.01 & 0.01 & 0.01 & 0.01 \\
\hline $\mathrm{BaO}$ & $<0.01$ & $<0.01$ & 0.01 & $<0.01$ & $\varangle 0.01$ & $<0.01$ & $<0.01$ & $<0.01$ & $<0.01$ & $<0.01$ & 0.01 & $<0.01$ \\
\hline C & 0.08 & 0.11 & 0.07 & 0.29 & 0.15 & 0.33 & 0.55 & 0.44 & 0.22 & 0.20 & 0.21 & 0.08 \\
\hline 5 & 0.06 & 0.06 & 0.21 & 0.17 & 1.16 & 1.45 & 0.06 & 0.04 & 0.03 & 0.14 & 0.14 & 0.17 \\
\hline $\mathrm{Ba}$ & 1 & 1 & 116 & 16 & 3 & 1 & 4 & 3 & 6 & 25 & 78 & 5 \\
\hline $\mathrm{Ce}$ & 8 & 14 & 7 & 17 & 15 & 9 & 23 & 15 & 20 & 8 & 5 & 14 \\
\hline cr & 3710 & 2770 & 3290 & 3720 & 2460 & 4310 & 3670 & 4310 & 4250 & 5270 & 4070 & 3020 \\
\hline Cs & $<0.01$ & 0.02 & 4.25 & 1.62 & 0.12 & 0.01 & 0.01 & 0.03 & 0.11 & 3.28 & 5.12 & 2.39 \\
\hline Dy & 1.21 & 1.03 & 0.48 & 2.60 & 1.34 & 0.98 & 1.97 & 1.39 & 1.66 & 0.92 & 0.54 & 1.32 \\
\hline Er & 0.65 & 0.58 & 0.28 & 1.41 & 0.67 & 0.52 & 0.97 & 0.89 & 0.83 & 0.55 & 0.42 & 0.73 \\
\hline Eu & 0.37 & 0.31 & 0.14 & 0.41 & 0.37 & 0.24 & 0.56 & 0.47 & 0.63 & 0.29 & 0.17 & 0.30 \\
\hline Ga & 6.10 & 5.80 & 11.20 & 10.00 & 7.30 & 6.20 & 9.20 & 6.20 & 5.70 & 7.10 & 7.10 & 8.40 \\
\hline Gd & 1.17 & 1.10 & 0.62 & 2.72 & 1.57 & 1.08 & 2.06 & 1.56 & 1.94 & 1.00 & 0.47 & 1.51 \\
\hline $\mathrm{HF}$ & 1.10 & 1.00 & 1.20 & 1.60 & 1.40 & 1.10 & 1.40 & 0.70 & 1.10 & 1.00 & 0.80 & 1.10 \\
\hline Ho & 0.22 & 0.22 & 0.10 & 0.52 & 0.26 & 0.20 & 0.37 & 0.30 & 0.33 & 0.19 & 0.13 & 0.26 \\
\hline La & 3.60 & 6.80 & 3.40 & 7.50 & 6.70 & 3.90 & 11.90 & 7.50 & 9.50 & 3.20 & 2.50 & 5.70 \\
\hline Lu & 0.08 & 0.09 & 0.06 & 0.19 & 0.10 & 0.09 & 0.13 & 0.12 & 0.10 & 0.09 & 0.11 & 0.11 \\
\hline $\mathrm{Nb}$ & 3.10 & 3.30 & 3.80 & 5.70 & 3.70 & 3.00 & 4.90 & 2.80 & 3.60 & 2.50 & 2.30 & 3.20 \\
\hline Nd & 4.10 & 6.00 & 3.20 & 10.00 & 7.50 & 4.70 & 10.10 & 7.50 & 9.20 & 4.30 & 2.30 & 7.40 \\
\hline Pr & 0.97 & 1.56 & 0.84 & 2.27 & 1.82 & 1.12 & 2.66 & 1.73 & 2.32 & 1.06 & 0.58 & 1.79 \\
\hline $\mathrm{Rb}$ & 0.20 & 0.20 & 44.10 & 4.30 & 0.70 & 0.30 & 0.60 & 0.30 & 1.20 & 11.50 & 15.90 & 3.40 \\
\hline $5 m$ & 1.08 & 1.15 & 0.62 & 2.49 & 1.52 & 1.01 & 2.17 & 1.81 & 2.02 & 0.98 & 0.42 & 1.51 \\
\hline Sn & $<1$ & 1.00 & 1.00 & 1.00 & 1.00 & 1.00 & 1.00 & 1.00 & 1.00 & 1.00 & 1.00 & $<1$ \\
\hline St & 31.20 & 32.30 & 32.70 & 152.00 & 71.50 & 27.80 & 95.20 & 59.80 & 77.40 & 49.30 & 54.60 & 97.30 \\
\hline $\mathrm{Ta}$ & 0.20 & 0.20 & 0.30 & 0.40 & 0.20 & 0.20 & 0.30 & 0.20 & 0.20 & 0.20 & 0.20 & 0.20 \\
\hline Tb & 0.22 & 0.16 & 0.08 & 0.41 & 0.23 & 0.16 & 0.31 & 0.27 & 0.29 & 0.15 & 0.08 & 0.23 \\
\hline Th & 1.26 & 1.91 & 1.27 & 1.26 & 1.94 & 1.01 & 2.20 & 1.90 & 1.64 & 1.03 & 0.75 & 1.34 \\
\hline$\pi$ & $<0.5$ & $<0.5$ & $<0.5$ & $<0.5$ & $<0.5$ & $<0.5$ & $<0.5$ & $<0.5$ & $<0.5$ & $<0.5$ & $<0.5$ & 0.5 \\
\hline $\operatorname{Tm}$ & 0.09 & 0.08 & 0.05 & 0.21 & 0.11 & 0.09 & 0.16 & 0.12 & 0.13 & 0.09 & 0.08 & 0.12 \\
\hline u & 0.25 & 0.25 & 0.84 & 0.57 & 0.43 & 0.27 & 0.28 & 0.63 & 0.63 & 0.26 & 0.20 & 0.28 \\
\hline v & 71.00 & $<5$ & $<5$ & 55.00 & 33.00 & $<5$ & 39.00 & 52.00 & $<5$ & 40.00 & $<5$ & 30.00 \\
\hline w & 1.00 & 1.00 & 1.00 & 1.00 & 1.00 & 1.00 & 1.00 & 2.00 & 1.00 & 1.00 & 1.00 & 1.00 \\
\hline$Y$ & 6.00 & 5.30 & 2.70 & 13.10 & 6.70 & 4.90 & 9.50 & 7.80 & 8.40 & 5.00 & 3.50 & 6.60 \\
\hline $\mathrm{Yb}$ & 0.70 & 0.58 & 0.34 & 1.28 & 0.70 & 0.56 & 0.97 & 0.85 & 0.74 & 0.59 & 0.61 & 0.73 \\
\hline $\mathrm{Zr}$ & 43.00 & 34.00 & 42.00 & 56.00 & 50.00 & 39.00 & 50.00 & 30.00 & 36.00 & 37.00 & 28.00 & 38.00 \\
\hline
\end{tabular}




\begin{tabular}{|c|c|c|c|c|c|c|c|c|c|c|c|c|}
\hline Target & Parnazo & Parnazo & Parnazo & Retiro & Retiro & Retiro & Retiro & Retiro & Retiro. & Retiro & Retiro & Retiro \\
\hline Sample & $053-114$ & $053-143$ & $053-168$ & $055-182$ & $055-208$ & $055-228$ & $055-235$ & $055-245$ & $055-257$ & $055-266$ & $055-272$ & $055-282$ \\
\hline Lithology & $\mathrm{Hz}$ & $\mathrm{Hz}$ & AT & AT & $P X$ & $\mathrm{HZ}$ & PX & $\mathrm{HZ}$ & $\mathrm{Hz}$ & $\mathrm{HZ}$ & PX & PX \\
\hline As & 0.20 & 0.20 & 0.30 & 0.60 & 0.30 & 0.30 & 0.30 & 0.50 & 0.40 & 0.30 & 0.20 & $<0.1$ \\
\hline $\mathrm{Bi}$ & 0.01 & 0.09 & 0.08 & 0.08 & 0.24 & 0.56 & 0.04 & 0.03 & 0.04 & 0.09 & 0.10 & 0.03 \\
\hline $\mathrm{Hg}$ & 0.01 & $<0.005$ & $<0.005$ & $<0.005$ & $\infty .005$ & 0.01 & 0.01 & $<0.005$ & $<0.005$ & $<0.005$ & 0.01 & $\infty .005$ \\
\hline Sb & $<0.05$ & $<0.05$ & $<0.05$ & $<0.05$ & $\infty 0.05$ & $<0.05$ & $c 0.05$ & $<0.05$ & $<0.05$ & $<0.05$ & $<0.05$ & $\infty .05$ \\
\hline $\mathrm{Se}$ & 0.20 & 0.30 & 0.50 & 0.40 & 2.90 & 3.90 & 0.20 & $<0.2$ & 0.20 & 0.80 & 0.50 & 0.30 \\
\hline $\mathrm{Te}$ & 0.02 & 0.05 & 0.18 & 0.11 & 0.43 & 0.71 & 0.02 & 0.03 & 0.02 & 0.13 & 0.25 & 0.06 \\
\hline LOI & 3.07 & 2.65 & 1.04 & 1.97 & 1.69 & 2.90 & 2.94 & 4.26 & 2.95 & 2.99 & 2.15 & 0.66 \\
\hline Total & 101.02 & 98.70 & 98.30 & 98.00 & 98.70 & 102.00 & 101.84 & 101.87 & 102.10 & 99.90 & 99.30 & 100.67 \\
\hline Ag & $<0.5$ & $<0.5$ & $<0.5$ & $<0.5$ & 0.7 & 1 & $<0.5$ & $<0.5$ & $<0.5$ & $<0.5$ & $<0.5$ & $<0.5$ \\
\hline Cd & $<0.5$ & $<0.5$ & $<0.5$ & $<0.5$ & $<0.5$ & $<0.5$ & $<0.5$ & $<0.5$ & $<0.5$ & $<0.5$ & $<0.5$ & $>0.5$ \\
\hline Co & 130 & 134 & 114 & 88 & 156 & 193 & 94 & 126 & 135 & 122 & 122 & 104 \\
\hline $\mathrm{Cu}$ & 71 & 167 & 106 & 193 & 2140 & 2840 & 71 & 50 & 25 & 122 & 92 & 214 \\
\hline Mo & $<1$ & $<1$ & $<1$ & 1 & 1 & 1 & 1 & $<1$ & $<1$ & $<1$ & $<1$ & $<1$ \\
\hline $\mathrm{Ni}$ & 1100 & 1280 & 1110 & 1070 & 1450 & 2850 & 1060 & 1220 & 1190 & 1260 & 1080 & 752 \\
\hline $\mathrm{Pb}$ & $<2$ & $<2$ & 6 & 5 & 6 & 3 & 7 & 2 & 3 & $<2$ & 2 & $<2$ \\
\hline $\mathrm{Zn}$ & 54 & 55 & 94 & 68 & 58 & 59 & 58 & 70 & 73 & 110 & 122 & 98 \\
\hline
\end{tabular}




\begin{tabular}{|c|c|c|c|c|c|c|c|}
\hline Target & Retiro & Retiro & Retiro & Retiro & Retiro & Retiro & \\
\hline Sample & 070-149 & $070-163$ & $070-193$ & $070-219$ & $070-245$ & $070-271$ & parental \\
\hline Lthology & AT & $\mathrm{Hz}$ & $\mathrm{HZ}$ & $\mathrm{HZ}$ & $H Z$ & AT & magma \\
\hline $\mathrm{SiO}_{2}$ & 46.0 & 42.5 & 42.6 & 41.9 & 44.4 & 52.0 & 48.7 \\
\hline $\mathrm{Al}_{2} \mathrm{O}_{3}$ & 5.72 & 3.27 & 4.61 & 3.25 & 5.36 & 12.65 & 4.76 \\
\hline $\mathrm{Fe}_{2} \mathrm{O}_{3}$ & 12.25 & 15.10 & 13.70 & 13.85 & 12.60 & 10.30 & 14.51 \\
\hline $\mathrm{CaO}$ & 5.36 & 2.89 & 2.95 & 2.24 & 3.89 & 9.69 & 5.28 \\
\hline $\mathrm{MgO}$ & 22.80 & 31.60 & 30.90 & 32.60 & 29.30 & 11.85 & 22.25 \\
\hline $\mathrm{Na}_{2} \mathrm{O}$ & 0.40 & 0.12 & 0.15 & 0.08 & 0.23 & 2.56 & 0.77 \\
\hline $\mathrm{K}_{2} \mathrm{O}$ & 0.40 & 0.03 & 0.07 & 0.02 & 0.07 & 0.90 & 0.38 \\
\hline $\mathrm{Cr}_{3} \mathrm{O}_{3}$ & 0.30 & 0.73 & 0.53 & 0.79 & 0.59 & 0.10 & 0.30 \\
\hline $\mathrm{THO}_{2}$ & 0.51 & 032 & 0.42 & 0.29 & 0.47 & 0.96 & 0.45 \\
\hline Mno & 0.18 & 0.19 & 0.17 & 0.21 & 0.16 & 0.17 & 0.21 \\
\hline $\mathrm{P}_{2} \mathrm{O}_{3}$ & $<0.01$ & 0.03 & 0.05 & 0.03 & 0.05 & 0.07 & 0.03 \\
\hline sro & 0.01 & 0.01 & $<0,01$ & 0.01 & $<0.01$ & 0.02 & 0.01 \\
\hline $\mathrm{BaO}$ & 0.01 & 0.03 & $<0.01$ & $<0.01$ & $<0.01$ & 0.05 & 0.02 \\
\hline c & 0.33 & 0.28 & 0.25 & 0.49 & 0.28 & 0.06 & 0.07 \\
\hline$s$ & 0.02 & 0.40 & 0.17 & 0.08 & 0.05 & 0.02 & 1.24 \\
\hline $8 \mathrm{a}$ & 61 & 1 & 1 & 1 & 1 & 171 & 90 \\
\hline $\mathrm{Ce}$ & 14 & 5 & 10 & 8 & 13 & 21 & 10 \\
\hline $\mathrm{Cr}$ & 2170 & 5780 & 3820 & 6110 & 4410 & 710 & 2086 \\
\hline Cs & 7.91 & 0.08 & 0.03 & 0.09 & 0.10 & 0.73 & 15.88 \\
\hline Dy & 1.26 & 107 & 1.33 & 0.66 & 1.33 & 2.72 & 1,37 \\
\hline Er & 0.65 & 0.52 & 0.57 & 0.37 & 0.71 & 1.42 & 0.79 \\
\hline Eu & 0.38 & 0.29 & 0.39 & 0.24 & 0.37 & 0.88 & 0.41 \\
\hline $\mathrm{Ga}$ & 7.30 & 6.80 & 7.20 & 5.00 & 6.90 & 14.40 & 6.93 \\
\hline Gd & 138 & 1.11 & 1.21 & 0.70 & 1.45 & 2.89 & 1,38 \\
\hline $\mathrm{Hf}$ & 1.00 & 0.80 & 0.90 & 0.60 & 1,30 & 2.30 & 0.99 \\
\hline Ho & 0.25 & 0.22 & 0.22 & 0.13 & 0.25 & 0.53 & 0.27 \\
\hline La & 7.40 & 170 & 4.90 & 3.70 & 5.70 & 8.80 & 4.49 \\
\hline Lu & 0.10 & 0.08 & 0.08 & 0.06 & 0.11 & 0.22 & 0.10 \\
\hline $\mathrm{Nb}$ & 3.90 & 2.10 & 3.50 & 2.00 & 4.00 & 6.20 & 3.58 \\
\hline Nd & 6.40 & 3.20 & 5.50 & 3.60 & 6.90 & 11.70 & 5.48 \\
\hline $\mathrm{Pr}$ & 1.63 & 0.71 & 1.16 & 0.91 & 1.68 & 2.79 & 1.22 \\
\hline $\mathrm{Rb}$ & 22.30 & 0.60 & 0.50 & 0.60 & 1.10 & 19.10 & 16.69 \\
\hline Sm & 139 & 0.90 & 1.37 & 0.79 & 1.52 & 2.90 & 1,32 \\
\hline Sn & 1.00 & 100 & 1.00 & 1.00 & 1.00 & 1.00 & 1.13 \\
\hline Sr & 68.60 & 40.10 & 37.80 & 62.40 & 30.70 & 119.50 & 90.55 \\
\hline $\mathrm{Ta}$ & 0.20 & 0.10 & 0.20 & 0.10 & 0.30 & 0.40 & 0.21 \\
\hline $\mathrm{Tb}$ & 0.21 & 0.17 & 0.24 & 0.11 & 0.24 & 0.48 & 0.22 \\
\hline Th & 1.13 & 0.50 & 1.91 & 0.88 & 1.32 & 2.58 & 1.07 \\
\hline$\pi$ & $\infty .5$ & $<0.5$ & $<0.5$ & $<0.5$ & $<0.5$ & $<0.5$ & \\
\hline $\mathrm{Tm}$ & 0.11 & 0.09 & 0.12 & 0.07 & 0.12 & 0.25 & 0.11 \\
\hline u & 0.26 & 0.39 & 0.23 & 0.15 & 0.28 & 0.55 & 0.25 \\
\hline$v$ & 99.00 & 100.00 & 57.00 & 84.00 & 18.00 & 222.00 & 86.71 \\
\hline W & 1.00 & 100 & 1.00 & 1.00 & 1.00 & 1.00 & 1.29 \\
\hline Y & 5.80 & 5.40 & 6.80 & 3.60 & 6.90 & 14.10 & 6.99 \\
\hline $\mathrm{Yb}$ & 0.65 & 0.55 & 0.83 & 0.40 & 0.73 & 1.39 & 0.79 \\
\hline $\mathrm{Zr}$ & 35.00 & 29.00 & 32.00 & 21,00 & 48.00 & 83.00 & 36.50 \\
\hline
\end{tabular}




$\begin{array}{rrrrrrrrr}\text { Target } & \text { Retiro } & \text { Retiro } & \text { Retiro } & \text { Retiro } & \text { Retiro } & \text { Retiro } & \text { calc. } \\ \text { Sample } & 070-149 & 070-163 & 070-193 & 070-219 & 070-245 & 070-271 & \text { parental } \\ \text { Lithology } & \text { AT } & \mathrm{HZ} & \mathrm{HZ} & \mathrm{HZ} & \mathrm{HZ} & \mathrm{AT} & \text { magma } \\ \mathrm{As} & 0.10 & 0.20 & <0.1 & 0.10 & 0.10 & 0.30 & 0.20 \\ \mathrm{Bi} & 0.10 & 0.23 & 0.03 & 0.16 & 0.05 & 0.23 & 0.44 \\ \mathrm{Hg} & 0.01 & <0.005 & <0.005 & <0.005 & <0.005 & 0.01 & \\ \mathrm{Sb} & <0.05 & <0.05 & <0.05 & <0.05 & <0.05 & <0.05 & 0.07 \\ \mathrm{Se} & <0.2 & 1.20 & 0.70 & 0.50 & <0.2 & 0.20 & 3.81 \\ \mathrm{Te} & 0.02 & 0.22 & 0.09 & 0.07 & 0.04 & 0.05 & 0.53 \\ \mathrm{LOl} & 4.76 & 4.70 & 3.64 & 6.44 & 4.35 & 0.70 & 1.51 \\ \text { Total } & 98.70 & 101.52 & 99.79 & 101.71 & 101.47 & 102.02 & 99.10 \\ \mathrm{Ag} & <0.5 & <0.5 & <0.5 & <0.5 & <0.5 & <0.5 & 1.1 \\ \mathrm{Cd} & <0.5 & <0.5 & <0.5 & <0.5 & <0.5 & <0.5 & 1.1 \\ \mathrm{Co} & 80 & 130 & 114 & 122 & 102 & 47 & 137 \\ \mathrm{Cu} & 76 & 875 & 360 & 305 & 73 & 189 & 2045 \\ \mathrm{Mo} & <1 & <1 & <1 & <1 & <1 & <1 & 1 \\ \mathrm{Ni} & 332 & 1610 & 1270 & 1280 & 1170 & 173 & 1629 \\ \mathrm{~Pb} & 3 & <2 & <2 & <2 & <2 & 8 & 5 \\ \mathrm{Zn} & 83 & 74 & 53 & 63 & 62 & 70 & 88\end{array}$

Abbreviation: $\mathrm{AT}=$ Amphibolite; $\mathrm{OX}=$ Orthopyroxenite $\mathrm{HZ}=$ Harzburgite Note: Samples marked with $\left({ }^{*}\right)$ were used to calculate the parental magma 
Trace elements (including the REE)

Trace and Rare-Earth Elements (REE) concentrations and ratios can be used as proxies for the identification and classification of magmas. The aim is to identify the potential mantle source where the Limoeiro magma was generated and whether or not crustal contamination has played an important role in the Limoeiro magmatic evolution and on the $\mathrm{Ni}$ $\mathrm{Cu}$-(PGE) sulfide deposit formation. There are no significant differences between the trace and REE concentrations and distribution patterns between the magmatic sequences (i.e., Upper and Lower) and between the three drilling targets (i.e., Parnazo, Piçarra and Retiro). For that reason the Limoeiro intrusion data are grouped and only the parental magma composition is plotted individually.

The REE pattern for Limoeiro intrusion rocks forms a wide envelope, which is the result of very distinct lithologies such as harzburgite and amphibolite being included in the same group (Fig. 2.17). The Limoeiro parental magma has an almost flat curve in the Heavy RareEarth Elements (HREE); however it shows a positive slope towards the Light Rare-Earth Elements (LREE). Visually comparing this pattern with basalts commonly formed in Earth (i.e., N-MORB, Normal Mid-Oceanic Ridge Basalts; E-MORB, Enriched Mid-Oceanic Ridge Basalts; OIB, Ocean Island Basalt) it becomes clear that the E-MORB has the most similar curve. The negative Eu anomaly is present in the Limoeiro intrusion envelope, although it cannot be recognized in the Limoeiro parental magma curve (Fig. 2.17).

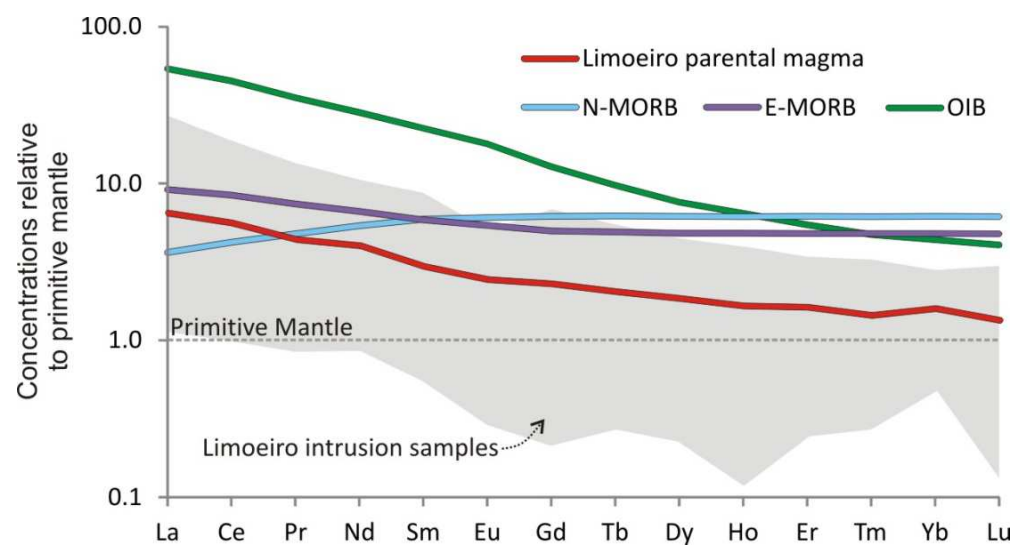

Fig. 2.17 - Primitive mantle-normalized REE patterns for the calculated Limoeiro parental magma and for the Limoeiro intrusion ultramafic rocks. For comparison are shown N-MORB, E-MORB and OIB typical REE values (Sun and McDonough, 1989). The normalization values are from Sun and McDonough (1989). 
The $(\mathrm{La} / \mathrm{Yb})_{\mathrm{PM}}(\mathrm{PM}$, Primitive Mantle) ratio is commonly used to quantify the slope of the REE distribution in a given rock. This slope is influenced by crustal contamination in the parental magma and mantle composition, degree of partial fusion and the melting depth where such magma was generated (Pearce, 2008). The Fig. 2.18 displays $(\mathrm{La} / \mathrm{Yb})_{\mathrm{PM}}$ versus $(\mathrm{Eu} / \mathrm{Yb})_{\mathrm{PM}}$ ratios. The latter reflects the slope of the HREE distribution, and a biplot containing both ratios elucidates the comparison between magmas in terms of their REE contents. The Limoeiro parental magma plots close to the E-MORB, but with higher $(\mathrm{La} / \mathrm{Yb})_{\mathrm{PM}}$ and $(\mathrm{Eu} / \mathrm{Yb})_{\mathrm{PM}}$ ratios, just over a hypothetical mixing line with OIB (Fig. 2.18). The $(\mathrm{Tb} / \mathrm{Yb})_{\mathrm{PM}}$ ratio is even more specific than $(E u / Y b)_{P M}$ of the HREE distribution pattern and its value reflects the depth where the magma was generated. Wang et al. (2002) have defined that $(\mathrm{Tb} / \mathrm{Yb})_{\mathrm{PM}}$ ratios higher than 1.8 are indicative of garnet-bearing peridotite mantle source $(>90 \mathrm{~km})$, whereas lower than 1.8 indicates spinel-bearing peridotite mantle $(<90 \mathrm{~km})$. The Limoeiro parental magma has a $(\mathrm{Tb} / \mathrm{Yb})_{\mathrm{PM}}$ of 1.4 , thus suggestive of generating from partial melting of a mantle source shallower than $90 \mathrm{~km}$ depth, within the spinel-bearing peridotite zone.

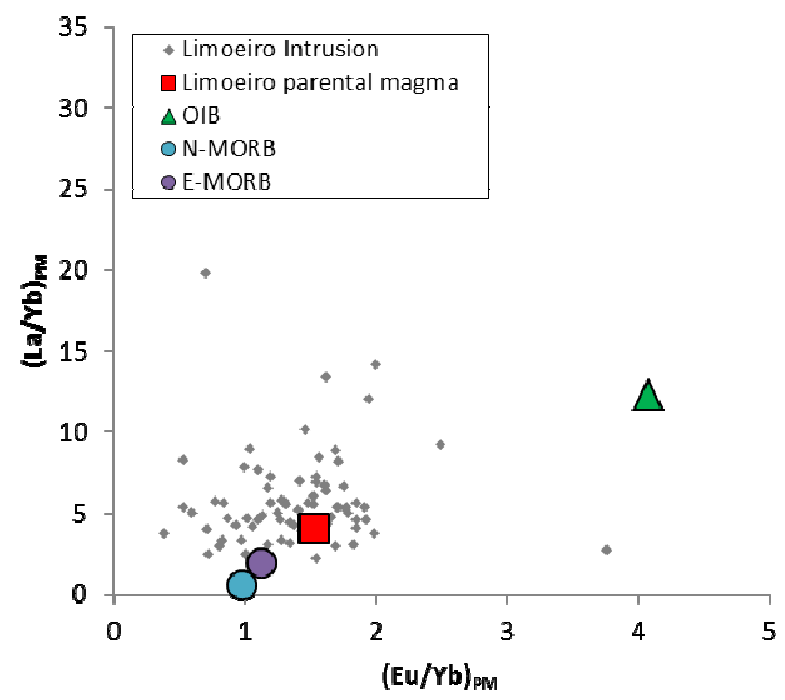

Fig. 2.18 - Diagram showing variations in the primitive mantle-normalized $\mathrm{Eu} / \mathrm{Yb}$ and $\mathrm{La} / \mathrm{Yb}$ ratios for the the calculated Limoeiro parental magma and for the Limoeiro intrusion ultramafic rocks. For comparison are shown N-MORB, E-MORB and OIB typical values (Sun and McDonough, 1989). Normalizing values are from Sun and McDonough (1989).

Selected trace element combined with REE spidergrams again shows that the Limoeiro parental magma curve is more similar to E-MORB than any other typical basaltic magma (Fig. 2.19). The Limoeiro intrusion envelope displays a larger variability towards the left 
side of the spidergram, where the most incompatible and mobile elements (LILE) are plotted. The Limoeiro parental magma has very irregular LILE content, as it shows much lower Ba and higher Cs contents compared to common basaltic magmas. The only chalcophile element on the spidergram is $\mathrm{Pb}$, which has a distinctive positive spike in the Limoeiro parental magma trace element distribution and a negative one for the other magmas (Fig. 2.19).

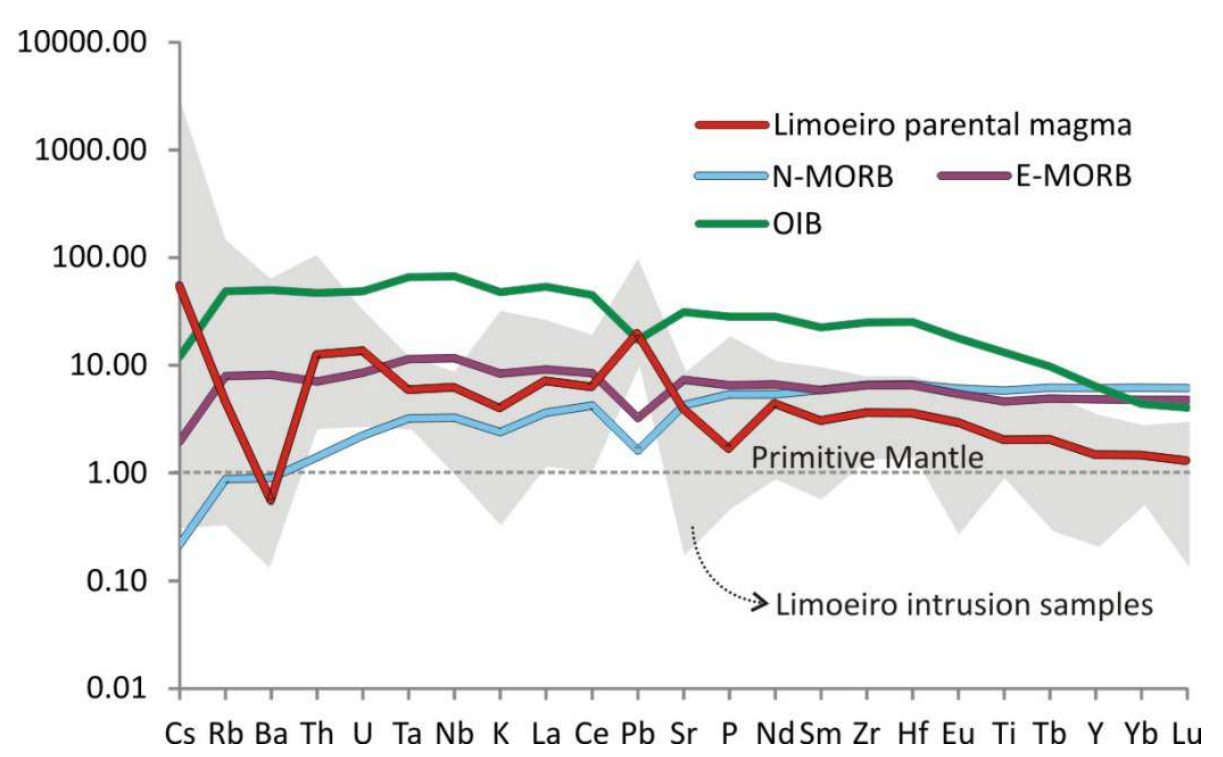

Fig. 2.19 - Primitive mantle-normalized lithophile element patterns for the calculated Limoeiro parental magma and for the Limoeiro intrusion ultramafic rocks. For comparison are shown N-MORB, E-MORB and OIB typical REE values (Sun and McDonough, 1989). The normalization values are from Sun and McDonough (1989).

The Th-Nb proxy is important for the identification and classification of geotectonic environment for basalt generation as it indicates crustal input and hence for demonstrating an oceanic, non-subduction setting. Normalizing both elements by $\mathrm{Yb}$ the effects of fractional crystallization and crystal accumulation is reduced, whereas the $\mathrm{Nb}$ and Th positive or negative anomaly is highlighted, which distinguish between basalts erupted at continental margins and in subduction zones (which involves magma-crust interaction) and oceanic basalts (MORB or OIB) (Pearce, 2008). The Limoeiro parental magma plots over the MORB-OIB array, very well aligned with the arrows that suggest magma-crust interaction from a magma generated in an enriched mantle (Fig. 2.20). The Limoeiro magma plot is also coincident with 70 to $80 \%$ of fractional crystallization of a magma generated in an enriched mantle source, according to the assimilation-fractional crystallization model (AFC) of DePaolo (1981). The model uses an 
arbitrarily-chosen value of 0.3 for the rate of assimilation relative to the rate of crystallization. Another sensitive indicator of crustal contamination is the $(\mathrm{Th} / \mathrm{Yb})_{\mathrm{PM}}$ versus $(\mathrm{Nb} / \mathrm{Th})_{\mathrm{PM}}$ biplot (Fig. 2.21). In this case, the Limoeiro parental magma composition is coincident with the crustal contaminated sulfide-bearing intrusions field of the Emeishan large igneous province, China (Zhou et al., 2008). The Limoeiro intrusion rocks plot in a trend with (Th/Yb) $)_{\mathrm{PM}}$ varying from 4.6 to 28.2 and with $(\mathrm{Nb} / \mathrm{Th})_{\mathrm{PM}}$ ratios between 0.5 and 0.1 . This trend is roughly within a mixing line from E-MORB to crust compositions.

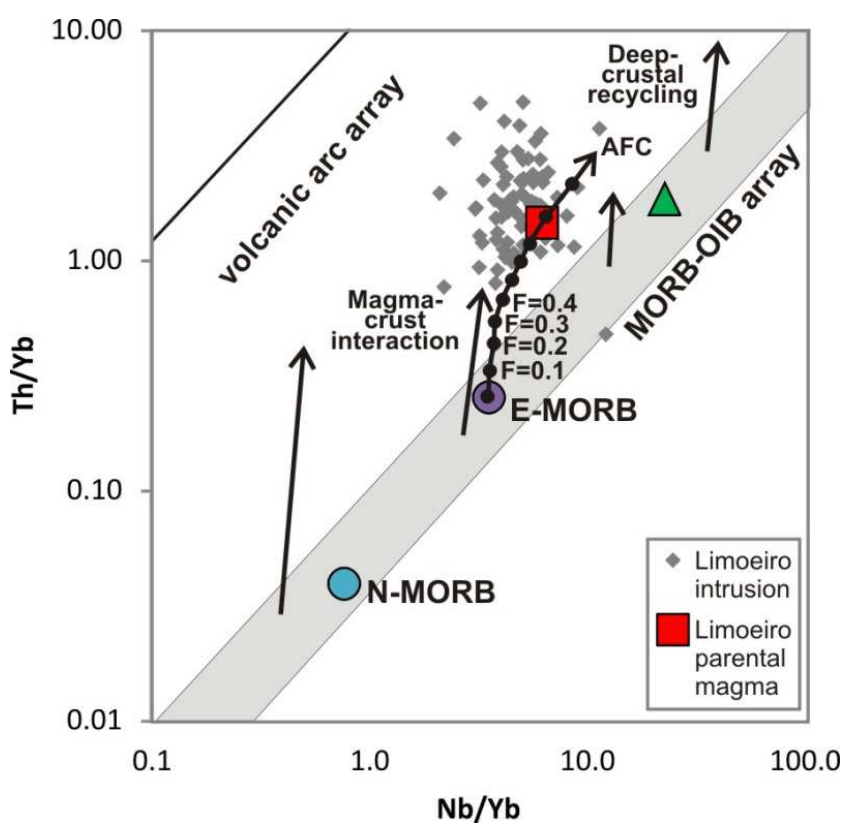

Fig. 2.20 - Diagram showing variations in the $\mathrm{Th} / \mathrm{Yb}$ and $\mathrm{Nb} / \mathrm{Yb}$ ratios for the calculated Limoeiro parental magma and for the Limoeiro intrusion ultramafic rocks. The diagram was originally designed to discriminate basalts (Pearce, 2008) with the MORB-OIB array shaded while volcanic arc basalts or crustally-contaminated basalts and alkalic basalts containing a large recycled crustal component plot above the array. The curved AFC arrow indicates magma formed in an enriched mantle source that has passed through assimilation and fractional crystallization processes (DePaolo, 1981). The F number indicates different levels of fractionation (for a review see Pearce, 2008 and DePaolo, 1981).

The Ti-Yb proxy indicates melting depth and hence allows interpretation of mantle temperature and thickness of the conductive lithosphere. The proxy works as a discriminant boundary between low $\mathrm{Ti} / \mathrm{Yb}$ MORB and high $\mathrm{Ti} / \mathrm{Yb}$ OIB, reflecting the fact that OIB originates by melting beneath thicker lithosphere, with lower degrees of melting, leaving residual garnet (Pearce, 2008). In the $\mathrm{TiO}_{2} / \mathrm{Yb}$ versus $\mathrm{Nb} / \mathrm{Yb}$ biplot (Fig. 2.22), the Limoeiro parental magma plots within the MORB array (shallow melting), and more specifically within the E-MORB field. 
The Limoeiro magma composition plots over the "plume-ridge interaction" arrow, which according to Pearce (2008) is indicative of volcanic-rifted margins, where hot mantle flows toward progressively thinner lithosphere (often becoming more depleted in the process).

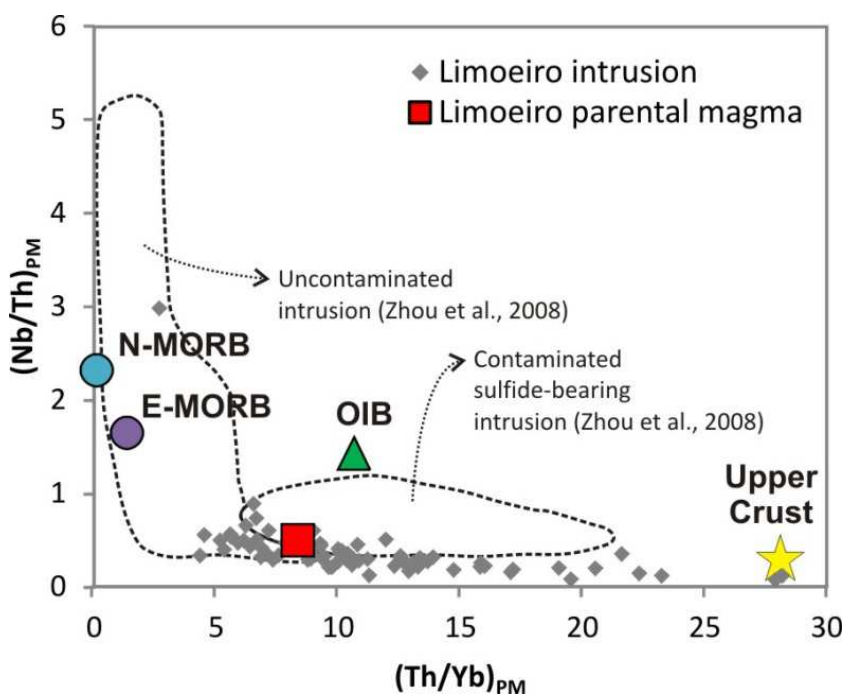

Fig. 2.21 - Diagram showing variations in the primitive mantle-normalized $\mathrm{Nb} / \mathrm{Th}$ and $\mathrm{Th} / \mathrm{Yb}$ ratios for the calculated Limoeiro parental magma and for the Limoeiro intrusion ultramafic rocks. For comparison are shown N-MORB, EMORB, OIB (Sun and McDonough, 1989) and Upper Crust (Rudnick and Gao, 2004) typical values. The dashed lines related to two different magmatic complexes documented by Zhou et al. (2008) in the Emeishan large igneous province, China. Normalizing values are from Sun and McDonough (1989).

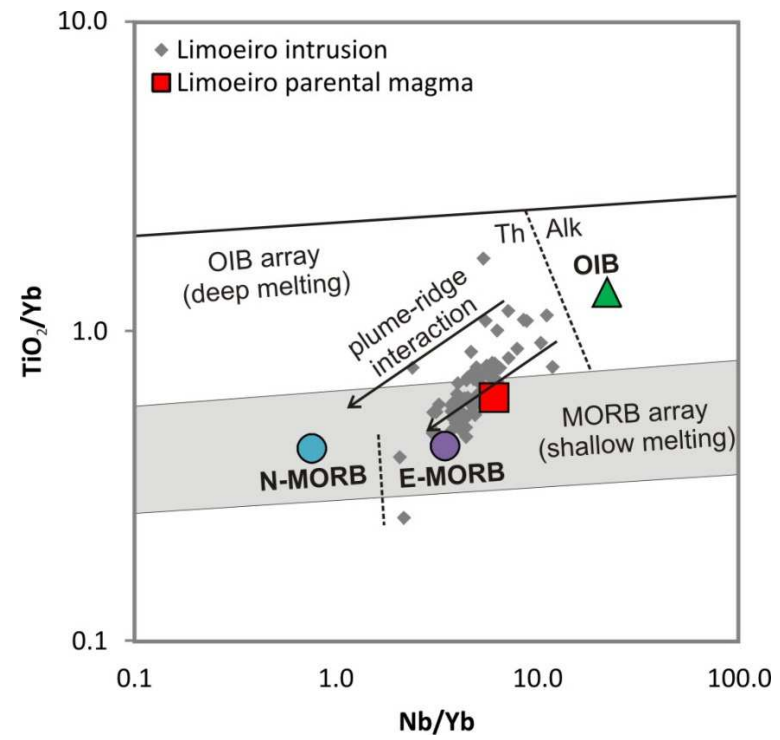

Fig. 2.22 - Diagram showing variations in the $\mathrm{TiO}_{2} / \mathrm{Yb}$ and $\mathrm{Nb} / \mathrm{Yb}$ ratios for the the calculated Limoeiro parental magma and for the Limoeiro intrusion ultramafic rocks. For comparison are shown N-MORB, E-MORB and OIB typical values (Sun and McDonough, 1989). The diagram was originally designed by Pearce (2008) to discriminate geotectonic setting 
where the oceanic islands basalts plot predictably in the OIB field (the alkalic lavas have the highest $\mathrm{Ti} / \mathrm{Yb}$ and $\mathrm{Nb} / \mathrm{Yb}$ ratios, whereas the tholeiitic basalts have the lowest) and the plume-distal ridges plot in the MORB field (shaded).

\section{Discussion}

\section{Metamorphism and elements mobility}

High grade metamorphism, hydrothermalism (associated with later low grade metamorphism) and tectonics affected the Limoeiro ultramafic rocks. Potentially these processes can affect the original composition of the major, trace and REE and lead to misinterpretation of the magmatic (primary) history of the rocks. The LILE (e.g., $\mathrm{Rb}, \mathrm{Ba}, \mathrm{K}, \mathrm{Sr}$ ) are more mobile than the high field strength elements (HFSE; e.g., $\mathrm{Ti}, \mathrm{Zr}, \mathrm{Y}, \mathrm{P}, \mathrm{Nb}$ ) and the REE during low grade metamorphism (Rollinson, 1993). The Limoeiro ultramafic rocks have a positive linear correlation between $\mathrm{Ti}$ and $\mathrm{Zr}$ (Fig. 2.23A). The loss on ignition (LOI) content, which is usually taken as an alteration proxy, has no correlation at all with the Ti/Zr ratio (Fig. 2.23B). This is an indication that the low grade metamorphism which forms the hydrated secondary phases (e.g., serpentine, talc) has not affected the less mobile elements such as $\mathrm{Ti}$ and $\mathrm{Zr}$. The LREE (here represented by $\mathrm{Ce}$ ) are the most mobile elements among the REE. Cerium shows a good positive linear correlation with $\mathrm{Zr}$ (Fig. 2.23C) with the most primitive internal part of the intrusion (harzburgite) containing the lowest concentrations of $\mathrm{Ce}$ and $\mathrm{Zr}$ ( $\sim 5$ and $\sim 20$ ppm respectively) and the most evolved external part of the intrusion (orthopyroxenite and amphibolite) having the highest concentrations of $\mathrm{Ce}$ and $\operatorname{Zr}(\sim 20$ and $\sim 65 \mathrm{ppm}$ respectively). These elements are not compatible with any of the Limoeiro cumulus phases (i.e., olivine, orthopyroxene and chromite), as they would be mostly concentrated in the intercumulus minerals that are now converted to metamorphic phases (mainly amphibole). This preserved magmatic association of $\mathrm{Ce}$ concentration variation, considered with its good positive correlation with the immobile $\mathrm{Zr}$, suggests that this element was immobile during the hydrothermal or metamorphic processes at Limoeiro. The same assumption can be deduced to the actinide Th, which also shows positive linear correlation with Zr (Fig. 2.23D). 

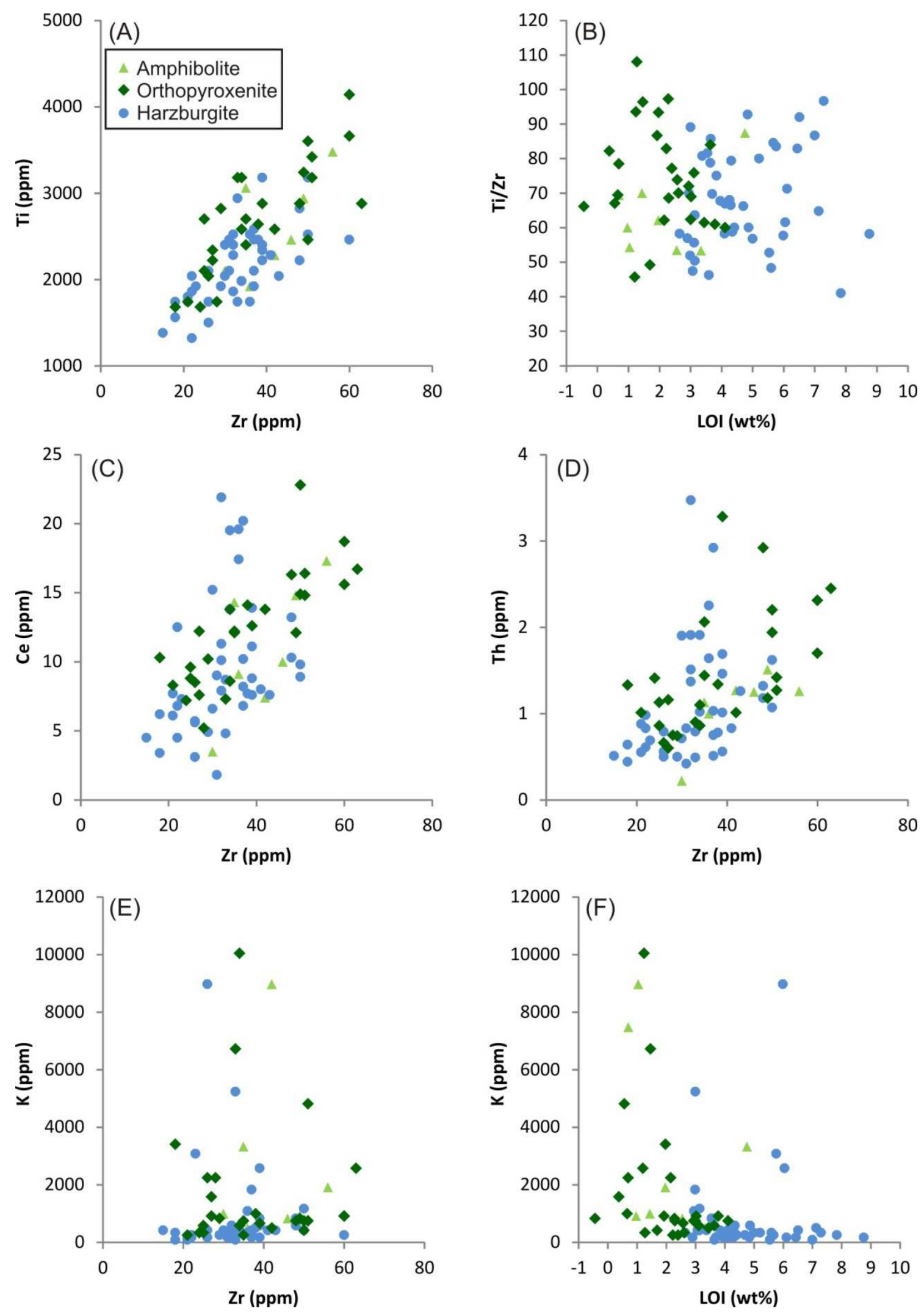

Fig. 2.23 - Biplots of $\mathrm{Ti}, \mathrm{Ce}$, Th and $\mathrm{K}$ versus $\mathrm{Zr}$ and $\mathrm{Ti} / \mathrm{Zr}$ and $\mathrm{K}$ versus loss on ignition for 78 whole rock samples of ultramafic rocks of the Limoeiro intrusion. 
Potassium, which is a mobile LILE, exhibits a highly variable concentration in the sampled rocks (from 80 to 10,000 ppm), forming a scatter pattern in a biplot with $\mathrm{Zr}$ (Fig. 2.23E). The downhole chemical variation graphs generated from the mining geochemical database (Fig. 2.14) show increasing concentration of $K$ towards the edge of each magmatic sequence. Locally, metric-scale shear zones host high concentrations of $\mathrm{K}\left(\sim 4 \mathrm{wt} \% \mathrm{~K}_{2} \mathrm{O}\right)$ within the internal parts of the intrusion. The shear zones at Limoeiro are usually composed of a variable phyllosilicate-rich metamorphic assemblage. Other lower $\mathrm{K}$ anomalies (1-2 wt $\left.\% \mathrm{~K}_{2} \mathrm{O}\right)$ within the intrusion are related to undeformed ultramafic rocks containing phlogopite (Fig. 2.14). In the sample dataset the $\mathrm{K}$ concentration has a poor negative correlation with LOI (Fig. 2.23F), thus $\mathrm{K}$ is clearly not related to the low grade metamorphic/hydrothermal alteration assemblage (i.e., typically this assemblage is composed of serpentine + talc \pm carbonate and accounts for 5 vol\% of the Limoeiro ultramafic rocks). It is likely that the localized high $\mathrm{K}$ concentrations in the undeformed ultramafic rocks within the intrusion are related to local and heterogeneous country rock assimilation, as they do not have a relationship with shear zones, hydrothermal alteration or lithological variation (Fig. 2.14 and 16E). The samples collected for whole rock geochemical analyses were meticulously selected based on petrographic criteria, such that no sheared zone or anomalously deformed rock containing post magmatic concentration of mobile elements (e.g., LILE) was included in the set of samples. The element concentrations observed in Figs. 16-23 are related to magmatic primary processes, which include the interaction between the parental magma composition, regional crustal contamination, fractionation and local heterogeneous country rock assimilation.

\section{Primary assemblage}

Mota-e-Silva et al., (2013) documented that the primary mineral assemblage of Limoeiro intrusion is composed of olivine + orthopyroxene \pm chromite and that it typically accounts for $\sim 65$ vol\% of the intrusion. The other $35 \mathrm{vol} \%$ is formed by low-grade metamorphic/hydrothermal minerals (5 vol\%) and high grade metamorphic phases (30 vol\%). The magmatic plus the metamorphic modal mineralogy is compatible with the lithochemical 
plots of Fig. 2.16A-H. As outlined in the later section, significant metasomatic alteration associated with metamorphic and hydrothermal processes is confined to shear zones only. For this reason no widespread post-magmatic event has played a role in the lithochemical composition of the Limoeiro ultramafic rocks. A different primary assemblage is needed to ideal explain lithochemical plots with lower $\mathrm{MgO}$ and higher $\mathrm{SiO}_{2}, \mathrm{Al}_{2} \mathrm{O}_{3}, \mathrm{CaO}$ and $\mathrm{Na}_{2} \mathrm{O}$ than the mixing lines between the three primary cumulus minerals compositions. The high grade metamorphic assemblage has totally altered the fine grained chilled margin and probably also altered the more reactive primary intercumulus phases in the internal parts of intrusion. Rocks with immature textures such as dolerites (e.g., aphanitic textures or the presence of skeletal crystals) are more prone to alteration (Gélinas et al., 1982). Given the whole rock composition of the Limoeiro intrusion (Fig. $2.16 \mathrm{~A}-\mathrm{H}$ ) it is considered that the primary mineralogy should contain clinopyroxene, plagioclase and amphibole to compensate for the excess of water, $\mathrm{SiO}_{2}$, $\mathrm{Al}_{2} \mathrm{O}_{3}, \mathrm{CaO}$ and $\mathrm{Na}_{2} \mathrm{O}$ and the lack of $\mathrm{MgO}$ over the mixing line between the three primary cumulus minerals. As amphibole, clinopyroxene and plagioclase were probably intercumulus phases (crystalized directly from trapped liquid in the cumulus crystal mush), the commonly used rock names harzburgite and orthopyroxene are still valid from a petrological point of view. The interpretation that amphibole, clinopyroxene and plagioclase were also primary intercumulus phases would also explain why the most external part of the intrusion, interpreted to have formed through rapid crystallization of the initial magma injection prior to the inflation of the chonolith (Mota-e-Silva et al., 2013); is composed of amphibolite (almost totally formed by metamorphic hornblende and anthophyllite). Additionally the REE lithochemistry for the Limoeiro intrusion ultramafic rocks shows that a few samples have a negative Eu anomaly (Fig. 2.17), suggesting localized prior crystallization of feldspar. The lithochemistry of outermost part of the intrusion, spatially coincident with the most evolved rocks, provides the best representative of the chemical composition of the Limoeiro parental magma. Note that the term parental magma used here refers to a product formed by flowing contaminated silicate liquid containing suspended tiny sulfide blebs and silicate crystals that rapidly solidified in contact with cool wall rocks during the initial sill-shaped intrusion. 


\section{Magmatic sequences and magma flow direction}

This study describes two additional magmatic sequences (Low-Cr and Transition Zone sequences) to the already documented Upper and Lower sequences within the Limoeiro intrusion. Using Tukey's HSD (Honestly Significant Difference) test with $p<0.01$ it is shown that the Low-Cr sequence is the most dissimilar with significantly lower $\mathrm{MgO}$ and $\mathrm{Cr}$ concentrations and higher $\mathrm{Cu} / \mathrm{Pd}$ ratios (Fig. $2.5 \mathrm{~A}, \mathrm{~B}, \mathrm{D})$. The $\mathrm{MgO}$ concentration is only slightly lower ( 21 versus $\sim 28 \mathrm{wt} \%$ ) compared to the other sequences, however the $\mathrm{Cr}$ content is much lower ( $\sim 400$ versus $\sim 2000 \mathrm{ppm}$ ), suggesting that the ultramafic rocks that form the Low-Cr sequence are chromite-free, contrasting with the ultramafic rocks in the other sequences that usually contain between 1 and 6 vol\% of chromite (Mota-e-Silva et al., 2013). Chromite is a common accessory mineral in ultramafic rocks and it usually appears as one of the first cumulus phase to crystallize in primitive mafic and ultramafic magmas. Tholeiitic and high-Mg magmas generally host between 300 and 1000 ppm of $\mathrm{Cr}$ in their composition (Barnes and Maier, 2002), and for that reason chromite crystallization generally ceases as pyroxene (which are able to concentrate hundreds of $\mathrm{ppm}$ of $\mathrm{Cr}$ in solid solution) starts to crystallize as fractionation proceeds during the cooling of the magmatic system. The only group of olivines analyzed in the Low-Cr sequence display one of the lowest Mg\# ( 82 mole\% Fo) and Ni contents ( $\sim 500 \mathrm{ppm}$ ) in the entire set of olivines analyzed at Limoeiro (Fig. 2.15 and Table 2.3). These characteristics suggest that the Low-Cr sequence formed from a more evolved parental magma, which was depleted in $\mathrm{Cr}, \mathrm{Ni}$ and with a relatively low $\mathrm{Mg \#}$. The $\mathrm{Cu} / \mathrm{Pd}$ ratio of the Low-Cr sequence is also the highest within the Limoeiro deposit area with a median of 7200. The S content of the Low-Cr sequence rocks, however, is the lowest with a median of $0.03 \mathrm{wt} \% \mathrm{~S}$ (Fig. 2.5C). This is an indication that the magma that formed the Low-Cr sequence in the Limoeiro deposit area was depleted in PGE compared to base metals due to prior sulfide segregation somewhere upstream within the magma conduit. This geochemical evidence can be used as a tool to explore for Ni-Cu-PGE sulfide orebodies in a magmatic system formed by multiple influxes of magma. A necessary key to better guide the exploration target is the identification of the magma flow direction. 
To approach the magma flow direction problem, the Upper sequence samples were selected for the reasons already discussed. From the west (Parnazo) to the east (Piçarra) the Upper sequence $\mathrm{Cu} / \mathrm{Pd}$ ratio gradually increases from $\sim 5200$ to $\sim 5800$ suggesting a progressively more evolved magma to the east (Fig. 2.6B), due to increasing contamination or fractionation. This observation is also consistent with the higher metal tenors ( $\mathrm{Ni}, \mathrm{Cu}, \mathrm{Pt}$ and $\mathrm{Pd})$ observed in the west (Retiro) compared to the ones calculated for the east (Piçarra) (Fig. 2.7 and Table 2.1). One could argue that higher $\mathrm{R}$ - or $\mathrm{N}$-factor (i.e., proportion between silicate magma and sulfide liquid, and their degree of interaction; see review by Naldrett, 2004) occurring within the Retiro orebody could also produce such pattern, however we prefer to assume similar factors for the Piçarra and Retiro orebodies, simply because they are adjacent portions of the same dynamic magma conduit. Additionally the Low-Cr sequence has a clear more fractionated lithochemical signature, revealed by relatively low forsterite content in olivine (Fig. 2.15), low $\mathrm{Cr}$, low $\mathrm{MgO}$ and the highest $\mathrm{Cu} / \mathrm{Pd}$ ratio in the whole rock (Fig. 2.5), reinforcing the validity of this last parameter. It was interpreted that the magma pulse that formed the Upper sequence flowed from the west to the east, but what about the other magma pulses that have formed the other sequences? There is no such sampling support or favorable geological setting (presence of disseminated mineralization throughout the sequence) to undertake a similar assessment to the other sequences. However other geological and lithochemical observations may enable a workable interpretation: (i) the Lower sequence that is barren of sulfide mineralization in the Parnazo, Retiro and west part of Piçarra targets is sulfide-bearing in the eastern part of Piçarra (Fig. 2.4D); (ii) the Lower sequence has a $\mathrm{Pd} / \mathrm{Cu}$ ratio of $\sim 3000$ (Fig. $2.5 \mathrm{D}$ ), which is the lowest number among all the four sequences, indicating that the magma that formed the Lower sequence in the Limoeiro deposit area has not experienced a prior sulfide segregation. Summarizing the above observations it is plausible to speculate that the magma pulse, which formed the Lower sequence also flowed to the east and its sulfide saturation event is recorded in the Limoeiro deposit area. The most debatable point in this conclusion is that the eastern part of Piçarra target is an area where the chonolith has a complex primary geometry strongly overprinted by brittle-ductile fault jogs (Fig. 2.4D), and the interpretation of sequence boundaries is problematic. Subsequent drilling programes in the eastern part of Piçarra target 
will enable a better interpretation of the fault jogging and sequence definition that may clarify this interpretation.

The Transition Zone sequence lies between the Upper and Lower sequences, however it is generally thinner than the adjacent sequences. The volume of magma that has passed through the Transition Zone sequence was probably lower and cooler than in Upper and Lower sequences in the Limoeiro deposit area. This assumption is supported by the predominance of orthopyroxenite in the Transition Zone sequence, contrary to the other two major sequences where harzburgite dominates. The slightly lower $\mathrm{MgO}$ content of this sequence compared to the Upper and Lower sequences (Fig. 2.5A) also corroborates with this conclusion. Furthermore the olivine forsterite-content in the core of the Transition Zone sequence varies from 80 to 83 mole\%, whereas it ranges from 83 to 85 mole\% (Fig. 2.14C,E) in other sequences located in the same part of the chonolith. The Transition Zone sequence works as a stratigraphic marker as it generally has a much higher abundance of magnetite within orthopyroxene, which can be easily traceable by the magnetic susceptibility core logging.

\section{Parental magma}

The outer part of the Limoeiro intrusion represent a chilled margin and/or marginal breccia zone (Mota-e-Silva et al., 2013) and it is the best representative of the parental magma to the intrusion. The intrusion margins were probably formed by a fine-grained rock that was later converted to a 100 vol\% metamorphic mineralogy composed essentially of amphibole (i.e., anthophyllite and hornblende). Aphanitic or fine-grained rocks are more suitable to metamorphic transformation than a rock with coarse fabric (Gélinas et al., 1982). The downhole chemical profiles show that the intrusion margins have a lithochemically sharp contact with the country rocks (Fig. 2.12 and 2.14), evidencing no major hydrothermal or metamorphic metasomatism of major (represented by $\mathrm{MgO}$ and $\mathrm{Al}_{2} \mathrm{O}_{3}$ ), trace (represented by $\mathrm{Ni}, \mathrm{Cu}$ and $\mathrm{S}$ ) or even LILE (represented by $\mathrm{K}_{2} \mathrm{O}$ ). However, the sporadic presence of country rock xenoliths within the intrusion (Mota-e-Silva et al., 2013), and the variable thickness or even the absence of 
amphibolite are evidence that the magma was able to erode and partly assimilate the wall rocks during the intrusion inflation stage. The amphibolite rocks of the Upper and more rarely the Lower sequence are mineralized. They commonly are more sulfide-rich than the adjacent orthopyroxenite and harzburgite rocks (Fig. 2.14). This may suggest that there is a temporal gap between these sequences formation: (i) the first magma pulse formed a precursor sill (later converted to amphibolite during metamorphism); (ii) this magma was sulfur-saturated and carried sulfide droplets in suspension; (iii) the continuous ascent of magma (plumbing system) coming from the mantle promoted the sill inflation and consolidated the magma conduit structure. Based on the above interpretation samples were selected from the intrusion margins that have contents of $\mathrm{MgO}, \mathrm{SiO}_{2}, \mathrm{FeO}, \mathrm{Al}_{2} \mathrm{O}_{3}, \mathrm{CaO}, \mathrm{NaO}, \mathrm{TiO}_{2}$, and $\mathrm{Cr}_{2} \mathrm{O}_{3}$ compatible with the most evolved part of the trend defined by the biplots on Fig. 2.16. Averages for each chemical element of these samples $(n=7)$ were taken as the parental magma composition and shown in Table 2.4. This calculated parental magma includes everything that solidified together within the chilled precursor sills, including: (i) contaminated magma; (ii) absorbed xenoliths; (iii) sulfide droplets; and (iv) phenocrysts transported in suspension. The calculated value reveals a primitive tholeiitic picrite magma type with $\sim 49 \mathrm{wt} \% \mathrm{SiO}_{2}, \sim 22 \mathrm{wt} \% \mathrm{MgO}, \sim 15 \mathrm{wt} \% \mathrm{Fe}_{2} \mathrm{O}_{3}$ and $\sim 5$ wt $\% \mathrm{CaO}$. These values are in accordance with the abundance of olivine cumulates and high forsterite content of olivine $\left(\mathrm{FO}_{79}-87\right)$ found in the intrusion. The composition of the most primitive cumulus olivine in the Limoeiro intrusion is comparable with those reported for ultramafic rocks of Bushveld complex, South Africa $\left(\mathrm{Fo}_{88}\right.$; Eales and Cawthorn, 1996) and the Stillwater complex, USA ( $\mathrm{Fo}_{87}$; Campbell and Murck, 1993). The tholeiitic picrite type of magma is roughly compatible with the $\mathrm{Ni} / \mathrm{Cu}$ ratio of 0.99 and $\mathrm{Pd} / \mathrm{Ir}$ ratio of 43 found in the mineralization of the Retiro target (most primitive orebody). These values are intermediate between Noril'sk ( $\mathrm{Ni} / \mathrm{Cu}=0.50$ and $\mathrm{Pd} / \mathrm{Ir}=281$; Naldrett, 2004) and Kambalda (Ni/Cu=13.9 and Pd//r=9; Naldrett, 2004), suggesting that the magma that segregated the sulfide liquid that formed the Retiro target orebody was not evolved as the Noril'sk flood basalts but not primitive as the Kambalda komatiites. According to the Barnes and Lightfoot's (2005) diagram these ratios plot within the generic "Layered intrusion" field, between the more fractionated "Flood basalts" and the more primitive "High-MgO basalts" field. This last field would be the most appropriate to classify the Limoeiro parental magma according to the other evidences described. There are two 
possibilities to explain this shift: (i) It is possible that more primitive mineralization with a higher $\mathrm{Ni} / \mathrm{Cu}$ ratio ( 2 for example) can be found somewhere upstream from the Retiro target orebody; or (ii) the magma from which the sulfide liquid has exsolved and interacted was Ni-depleted due to strong previous crystallization of olivine phenocrysts [olivine/melt $\mathrm{D}^{\mathrm{Ni}}$ value of 7 for $\mathrm{S}$-bearing basaltic magmas (Li et al., 2003)].

\section{Emplacement and source of the parental magma}

The Limoeiro chonolith has formed in a multi-pulse dynamic magmatic system, with several intrusion and inflation sequences for each new magma batch (Mota-e-Silva et al., 2013). We have demonstrated that the amphibolite metamorphosed outer shell generally was a precursor sill that initiated the magma pathway prior to the following inflation phases that occurred for each new magma pulse. Mafic high-MgO primitive magmas (like Limoeiro) have low viscosity, thus they flow rapidly and if the conduit is sufficiently large, the flow regime will be turbulent. Under these conditions the magma thermally erodes and rapidly assimilates its wall rocks (Huppert and Sparks, 1985). At very high flow rates the contaminants may be diluted, but at moderate flow rates the amount of contamination can be up to $\sim 30$ vol\% for a basaltic magma and up to $\sim 50$ vol\% for a komatiitic magma (Lesher and Arndt, 1995). The Limoeiro parental magma is clearly very crustal contaminated. The presence of phlogopite $\left[\mathrm{KMg}_{3} \mathrm{AlSi}_{3} \mathrm{O}_{10}(\mathrm{~F}, \mathrm{OH})_{2}\right]$ in different parts of the intrusion, with no relation to parts that are particularly deformed, hydrothermally or metamorphically altered, is an indication of heterogeneous localized country rock contamination (Fig. 2.16F). The parental magma contamination in broader scale can be traced by the high Th content relative to $\mathrm{Yb}$ or $\mathrm{Nb}$ (Fig. 2.19, 2.20 and 2.21). This contamination signature can be identified in any of the lithologies in all parts of the intrusion. This suggests that contamination processes have played a role in all magma pulses that were emplaced at Limoeiro deposit area, thus indicating that contamination took place regionally during magma ascent from mantle to crust. The Limoeiro parental magma has trace element patterns compatible with an E-MORB type of mantle reservoir (Fig. 2.17 and 2.19). DePaolo (1981) established an assimilation-fractional crystallization model (AFC; 
assimilation of wall rocks assisted by latent heat of crystallization) curve for a magma coming from an E-MORB source that interacted with Archean felsic crust with an arbitrarily-chosen value of $r=0.3$ (the rate of assimilation relative to the rate of crystallization). This curve matches perfectly with the Limoeiro parental magma composition in the position where the E-MORB has between $70-80 \%$ of fractionation rate and strong crustal contamination (Fig. 2.20). The same extensive crustal contamination can be seem in the low $(\mathrm{Nb} / \mathrm{Th})_{\mathrm{PM}}$ ratio and high and variable $(\mathrm{Th} / \mathrm{Yb})_{\mathrm{PM}}$ ratio (Fig. 2.21), showing coincidence of the Limoeiro ultramafic rocks with the contaminated and mineralized intrusion in the Emeishan LIP (large igneous province), China (Zhou et al, 2008) and with the upper crust typical signature (Rudnick and Gao, 2004).

The parental magma of Limoeiro has been generated from a relatively shallow EMORB mantle source (Fig. 2.22). The $(\mathrm{Tb} / \mathrm{Yb})_{\mathrm{PM}}$ of Limoeiro parental magma is 1.4 , which according to Wang et al. (2002) is indicative of magma generated in the spinel-bearing peridotite mantle $(<90 \mathrm{~km})$, rather than deeper garnet-bearing peridotite mantle sources $(>90 \mathrm{~km})$. Typically, the lithosphere is between 80 and $200 \mathrm{~km}$ in thickness, whereas asthenosphere that separates Upper and Lower Mantle lies between $200 \mathrm{in} 400 \mathrm{~km}$ of depth (Marone and Romanowicz, 2007). Recently a $900 \mathrm{~km}$ long deep seismic refraction line was acquired in an NW-SE direction across the Borborema Province. The eastern part of the survey crosses the Rio Capibaribe Terrane (location of the Limoeiro chonolith). The Moho depth was estimated to be $33.50 \pm 0.50 \mathrm{~km}$ (Soares et al., 2009; Pavão et al, 2013). Based on the above discussion it is proposed that the Limoeiro parental magma was formed from an E-MORB source, within the Upper Mantle. 


\section{Ore genesis}

Mota-e-Silva et al. (2013) have shown that the Limoeiro Ni-Cu-(PGE) deposit has a magmatic origin and its mineralization comprises disseminated sulfides confined within the Upper sequence with a few submeter-scale massive sulfide layers located close to the base of the same magmatic sequence. Previously these massive sulfide layers were interpreted to be products of accumulation in traps of the same sulfide droplets that formed the disseminated sulfide, by a more static and in-situ process. However recent additional drilling has enable derivation of a more complete interpretation of the deposit formation. As previously outlined, the outer amphibolite shell is commonly more sulfide-rich than the adjacent ultramafic rocks (Fig. 2.14). Moreover, the disseminated sulfide orebody hosted in the harzburgite shows a preference to be either more concentrated in association with orthopyroxene (Fig. 2.24A) or olivine (Fig. 2.24B). This evidence shows that this is a dynamic magmatic system; (i) first there is the intrusion of a very contaminated sulfide-bearing parental magma quenched in the external parts of the intrusion as a precursor sill; (ii) second, there is the establishment of a dynamic plumbing system that promotes the intrusion inflation. This last magma may have interacted less with the country rocks, resulting in fewer sulfide blebs carried in suspension due to lower rates of local country rock contamination. (iii) Most olivines crystallized in a deeper and hotter position of the magmatic system, compared to orthopyroxene. The crystals that form the intrusion were crystallized at unrelated locations in the chonolith, and they were sorted by fluid dynamics. Following deposition, the cumulates have been modified by sub-solidus reactions. The main evidence for sub-solidus reaction is optically continuous olivine inclusions within large orthopyroxene grains, suggesting a reaction of destruction of olivine and crystallization of orthopyroxene (Mota-e-Silva et al., 2013). 

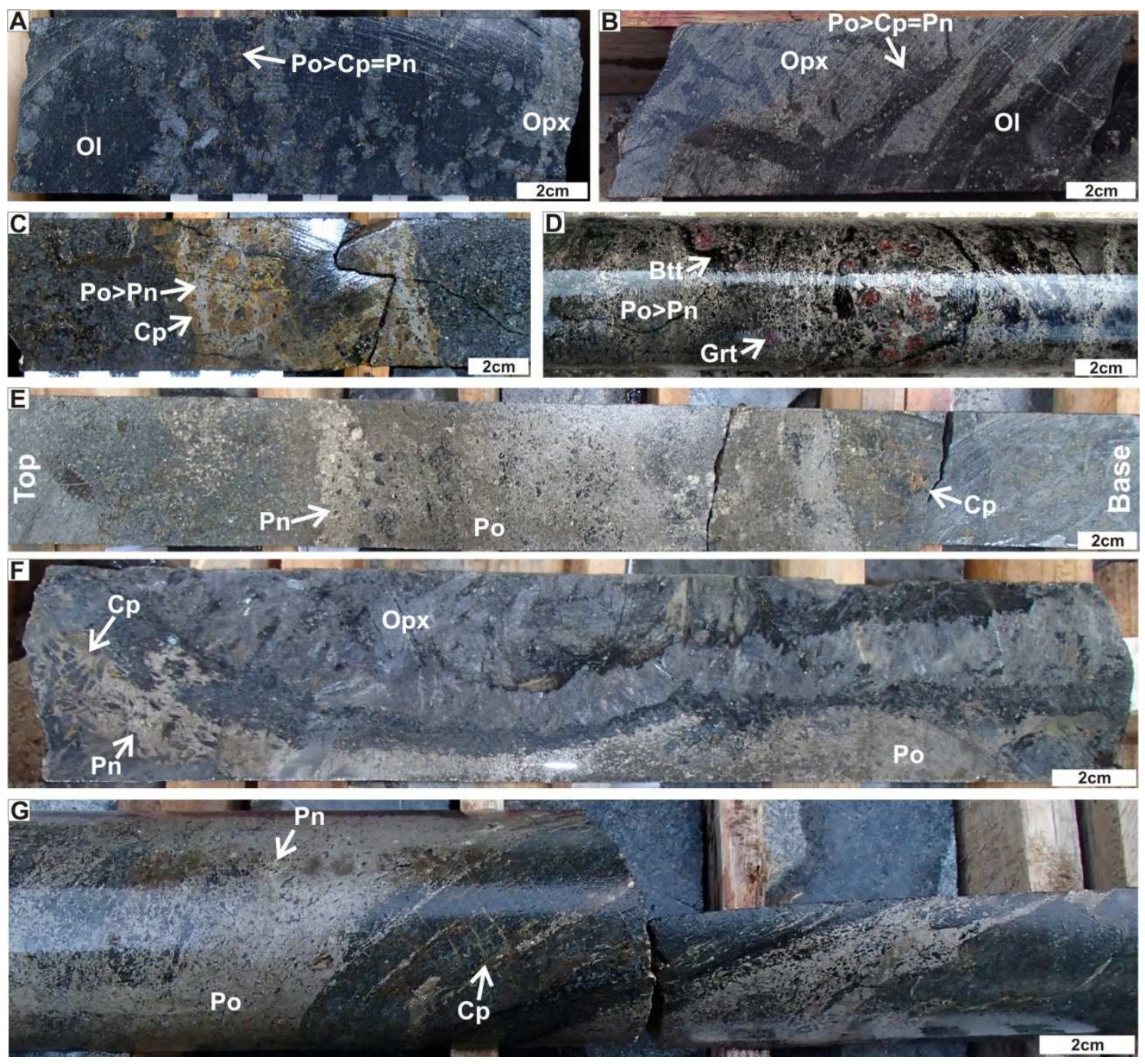

Fig. 2.24 - Drill core pictures showing critical aspects of the Limoeiro ore. (A) Disseminated sulfide ore with sulfides dominantly associated with orthopyroxenes. Drill hole SLM0201 at the depth of $\sim 144 \mathrm{~m}$. (B) Disseminated sulfide ore with sulfides dominantly associated with olivines. Drill hole SLM0004 at the depth of $\sim 70 \mathrm{~m}$. (C) Sharp contact between massive sulfide layer and host rock. Note ultramafic autoliths within the massive ore and the segregation of chalcopyrite from the other BMS to the most external part of the massive ore. Drill hole SLM0201 at the depth of $140.35 \mathrm{~m}$. (D) Garnet and biotite (xenolith remnants) patches within a massive sulfide ore. Drill hole SLM0002 at the depth of 199.60m. (E) Massive sulfide layer with pentlandite segregated to the most external parts, pyrrhotite in the core and chalcopyrite displaced to the ultramafics in the footwall. Drill hole SLM0201 at the depth of $146.85 \mathrm{~m}$. (F) Discordant, vertical and winding sulfide vein with alteration halo in the orthopyroxenite. Drill core SLM0108 at the depth of 50.50m.

(G) Massive sulfide and stringer ore with a tectonic fabric parallel to metamorphic amphiboles. Drill hole SLM0004 at the depth of $115.85 \mathrm{~m}$.

The massive sulfide layers occasionally have angled autolith clasts of ultramafic rocks (Fig. 2.24C), and partly assimilated country rocks (paragneiss) represented by garnet and biotite xenolith remnants within the massive sulfide (Fig. 2.24D). Moreover the massive sulfide layer usually has a sharp contact with the disseminated-sulfide bearing adjacent ultramafic rock, 
showing no progressive gradation of the sulfide abundance (Fig. 2.24C). These features are likely to be related to massive sulfide flow and injection into the crystal mush or the hot and malleable recently-crystallized ultramafic rock. Other authors interpreted a similar process for the Jinchuan deposit, China (Tang, 1995), Aguablanca deposit, Spain (Tornos et al., 2001), Vammala deposit, Finland (Papunen and Vorma, 1985), Noril'sk (Kunilov, 1994; Stekhin, 1994), and Voisey's Bay, Canada (Li and Naldrett, 1999). The processes outlined involved injection as separate pulses of massive liquid sulfide or as sulfide-rich breccias, into their positions within, above, or near the bases of the host intrusions. The first stage in the formation of massive sulfide ore may be related to accumulation of sulfide droplets in a physical trap on the bottom of the flowing magma, in a similar way to the documented processes within komatiite lava flows (e.g., Hill, 2001). Sulfide droplets grow slowly and continually in sulfur-saturated mafic magma, but coarse sulfide droplets $(>1 \mathrm{~cm})$ are unable to be transported in suspension by a horizontally flowing magma. Coarse sulfide blebs tend to settle downwards rather than travel horizontally even within rapidly flowing magmas (Lesher and Groves, 1986). The smaller sulfide droplets remained in suspension in the flowing magma and were later entrapped by growing silicate phases within the Limoeiro intrusion. This feature is compatible with the kind of textures observed in the Limoeiro disseminated sulfide mineralization (Fig. 2.24A-B).

Segregation between Fe-rich sulfide (MSS - monosulfide solid solution) and Cu-rich sulfide (ISS - intermediate solid solution) has been predicted theorically (e.g. Naldrett, 2004), and documented at a number of magmatic deposits, for example: Sudbury, Canada (Li et al. 1992; Naldrett et al. 1999), Noril'sk (Naldrett et al. 1994), and Americano do Brasil, Brazil (Motae-Silva et al., 2011). This segregation between two distinct ores is attributed to the fact that during cooling of a sulfide liquid, MSS crystallizes first $\left(1000-1200^{\circ} \mathrm{C}\right)$ whereas a Cu-Ni-rich sulfide remains liquid until temperatures lower than $900^{\circ} \mathrm{C}$ are reached (Kullerud et al., 1969; Ebel and Naldrett, 1997). Nickel behaves differently from $\mathrm{Fe}$ and $\mathrm{Cu}$, which have clear preferences respectively for MSS and ISS, it has a coefficient partition between MSS and ISS of close to 1 . This means that Ni will concentrate more in one or another phase depending on the sulfur fugacity (Li et al., 1996; Barnes et al., 1997; Makovicky, 2002). The most recent drilling at Limoeiro has shown that some of the massive sulfide layers display segregation between pyrrhotite, pentlandite and chalcopyrite (Fig. 2.24E). Pentlandite forms aggregates of relatively 
coarse grains $(\sim 5 \mathrm{~mm})$ at the edges of the pyrrhotite domain. Chalcopyrite, however, seems to be displaced from the pyrrhotite and pentlandite, forming net-textured sulfides in the host ultramafic at the base of the massive sulfide layer (Fig. 2.24E).

The correlation between $\mathrm{Ni}$ and $\mathrm{Cu}$ is very good in samples with $\mathrm{Ni}$ and $\mathrm{Cu}$ grades lower than $0.5 \mathrm{wt} \%$ (Fig. 2.11B), showing that no separation between MSS and ISS took place in the disseminated sulfide mineralization. However, for the massive and semi-massive ore, defined to samples with $\mathrm{S}$ equal or greater than $15 \mathrm{wt} \%$, the graph shows a domination of $\mathrm{Ni}$ rich and Cu-poor grades and to a lesser extent Ni-poor and Cu-rich concentrations (Fig. 2.11A). This indicates a different control than for the disseminated mineralization. In the Upper sequence, the semi massive and massive sulfide layers can be separated into two groups: (i) the Ni-rich mineralization, where Ni/Cu ratio normally varies from 3 to 5 (Fig. 2.13); and (ii) the Cu-rich mineralization, where $\mathrm{Ni} / \mathrm{Cu}$ ratios are $\sim 0.2$ (Fig. 2.13). This suggests that $\mathrm{Ni}$ and $\mathrm{Cu}$ have separated from each other during the genesis of the semi-massive and massive ore at Limoeiro. This is probably due to segregation between MSS and the residual Cu-rich sulfide liquid. Additionally within dynamic plumbing magmatic systems such as Limoeiro, the intrusion remains hot for longer periods of time as new hot magma pulses intrude periodically, allowing the sulfide liquid to fractionate and segregate efficiently during cooling.

Discordant, vertical, winding sulfide veins with associated alteration halos through the host ultramafic may result from the dense sulfide liquid migrating downwards through the crystal mush (Fig. 2.24F). One could argue that this separation could be due to tectonic sulfide mobilization. However the tectonic influence in the Limoeiro intrusion is easy to recognize through formation of biotite-rich zones in the shear fabric (Fig. 2.24G). The sulfide veins show no deformation. The downhole lithochemical variation logs show clear positive $\mathrm{Al}_{2} \mathrm{O}_{3}$ and $\mathrm{K}_{2} \mathrm{O}$ anomalies in sheared zones. These zones are localized in the intrusion and they do not have the same scale of $\mathrm{Ni} / \mathrm{Cu}$ ratio variation as observed in the samples shown in Fig. 2.13. As the disseminated mineralization has not passed through the sulfide liquid segregation process, its $\mathrm{Ni} / \mathrm{Cu}$ ratio ( $\sim .8$ according to Fig. $2.11 \mathrm{~B})$ can be assumed to be an approximation of the expected bulk composition of the sulfide fraction. Given this bulk composition, the Ni/Cu biplot in Fig. 2.11A clearly has a lack of Cu-rich and Ni-poor data points that would define the 
segregated ISS. Targeting chalcopyrite-rich and pyrrhotite-poor orebodies should be one of the strategies in the following exploration activities at Limoeiro and in other conduits that are part of the same magmatic system. This type of ore may be hosted within barren ultramafics (e.g., Lower sequence) or even within the country rocks (paragneiss). This is a great challenge to explorers, as the geophysical response of chalcopyrite-rich massive ore is not as obvious as pyrrhotite-rich ore, due to mineral assemblage different magnetic, polarization and conductive properties.

Contrary to the base metals $\mathrm{Ni}$ and $\mathrm{Cu}$, the noble metals $\mathrm{Pt}$ and $\mathrm{Pd}$ do not have a different correlation when comparing the disseminated and the massive sulfide ores. Both types of mineralization show exactly the same trend of $\mathrm{Pt} / \mathrm{Pd} \sim 0.40$, with only a few outliers. This is an indication that $\mathrm{Pt}$ and $\mathrm{Pd}$ have similar behaviour during sulfide segregation between MSS and Cu-rich liquids. Mota-e-Silva et al. (in review) have documented that most of the Pd and all Pt are hosted by discrete PGM (platinum-group minerals) grains. The majority of the Pd is hosted by merenskyite, whereas $\mathrm{Pt}$ is divided between sperrylite and merenskyite [the merenskyite at Limoeiro has melonite and moncheite components in solid solution, and on average it has the composition of $\left.\left(\mathrm{Pd}_{0.64}, \mathrm{Pt}_{0.18}, \mathrm{Ni}_{0.18}\right)\left(\mathrm{Te}_{1.30}, \mathrm{Bi}_{0.70}\right)\right]$. The BMS hosts only a minor amount of $\mathrm{Pd}$ (between $12-16 \%$ of total $\mathrm{Pd}$, which is mainly within pentlandite) and close to zero Pt. Relative to the BMS abundances, the PGM have a slightly preference for association with chalcopyrite and pentlandite rather than with pyrrhotite [(Mota-e-Silva et al. (in review)]. This reported PGM assemblage is based upon general samples from the Limoeiro Ni-Cu-(PGE) deposit and it does not include a specific study of the segregated Cu-rich sulfide liquid, as this type of mineralization is poorly known in the deposit so far. The main conclusion from the above discussion is that $\mathrm{Pt}$ and Pd have similar partition coefficients between MSS and the Cu-rich sulfide liquid, which would suggest potential participation of semimetal-rich residual liquid (as illustrated by Holwell and McDonald, 2010). The three samples with higher concentrations of base metals at the base of the Upper sequence in the borehole SLM0201 have the following $\mathrm{Ni}+\mathrm{Cu}+\mathrm{Fe}, \mathrm{Ni} / \mathrm{Cu}$ and $\mathrm{Pt}+\mathrm{Pd}$ values from the top to the base: (i) $28.9 \mathrm{wt} \%, 0.16$ and $2.88 \mathrm{~g} / \mathrm{t}$; (ii) $56.7 \mathrm{wt} \%, 64.3$ and $8.51 \mathrm{~g} / \mathrm{t}$; (iii) $41.2 \mathrm{wt} \%, 5.00$ and $4.58 \mathrm{~g} / \mathrm{t}$. If the $\mathrm{Ni}+\mathrm{Cu}+\mathrm{Fe}$ can be roughly used as amount of BMS (as the S content is limited to $10 \mathrm{wt} \%$, being the maximum detection limit; Fig. 2.13) the $(\mathrm{Ni}+\mathrm{Cu}+\mathrm{Fe}) /(\mathrm{Pt}+\mathrm{Pd})$ ratio will be inversely proportional to the $(\mathrm{Pt}+\mathrm{Pd})$ content associated with 
the magmatic sulfides. The chalcopyrite-rich semi-massive to massive ore (ISS) has the highest $(\mathrm{Ni}+\mathrm{Cu}+\mathrm{Fe}) /(\mathrm{Pt}+\mathrm{Pd})$ ratio with 10.0 , whereas the other two samples which represents pyrrhotiterich ore-types (MSS) have values of 6.6 and 9.0. The best methodology for this assumption would be use whole-rock S-content measured by LECO, however as this data is not available this result should be used carefully. The achieved results allow interpretation that the Cu-rich mineralization of Limoeiro deposit is not more Pt- and Pd-enriched than the pyrrhotite-rich semimassive to massive ore. Li et al. (1992) concluded that much of the Pt, Pd, and Au fractionated into the Cu-rich liquid, which resulted in the highest abundances of $\mathrm{PGE}$ and $(\mathrm{Pt}+\mathrm{Pd}) / \mathrm{Ir}$ ratio in the chalcopyrite-rich massive sulfide ore in the footwall of the Sudbury Complex. Similar compositions were documented for Cu-rich mineralization at Noril'sk (Naldrett et al. 1994), and the Americano do Brasil deposit (Mota-e-Silva et al., 2011). The question needs to be considered why at Limoeiro no such enrichment of PGE and especially of PPGE (palladiumgroup platinum-group elements) present within the Cu-rich residual sulfide liquid? This question demands specific study of the PGM assemblage and PGE concentrations in the Cu-rich offshoots of Limoeiro, which will be addressed by upcoming work.

The most relevant debate and conclusions drawn in the Discussion section are illustrated by Fig. 2.25 . 

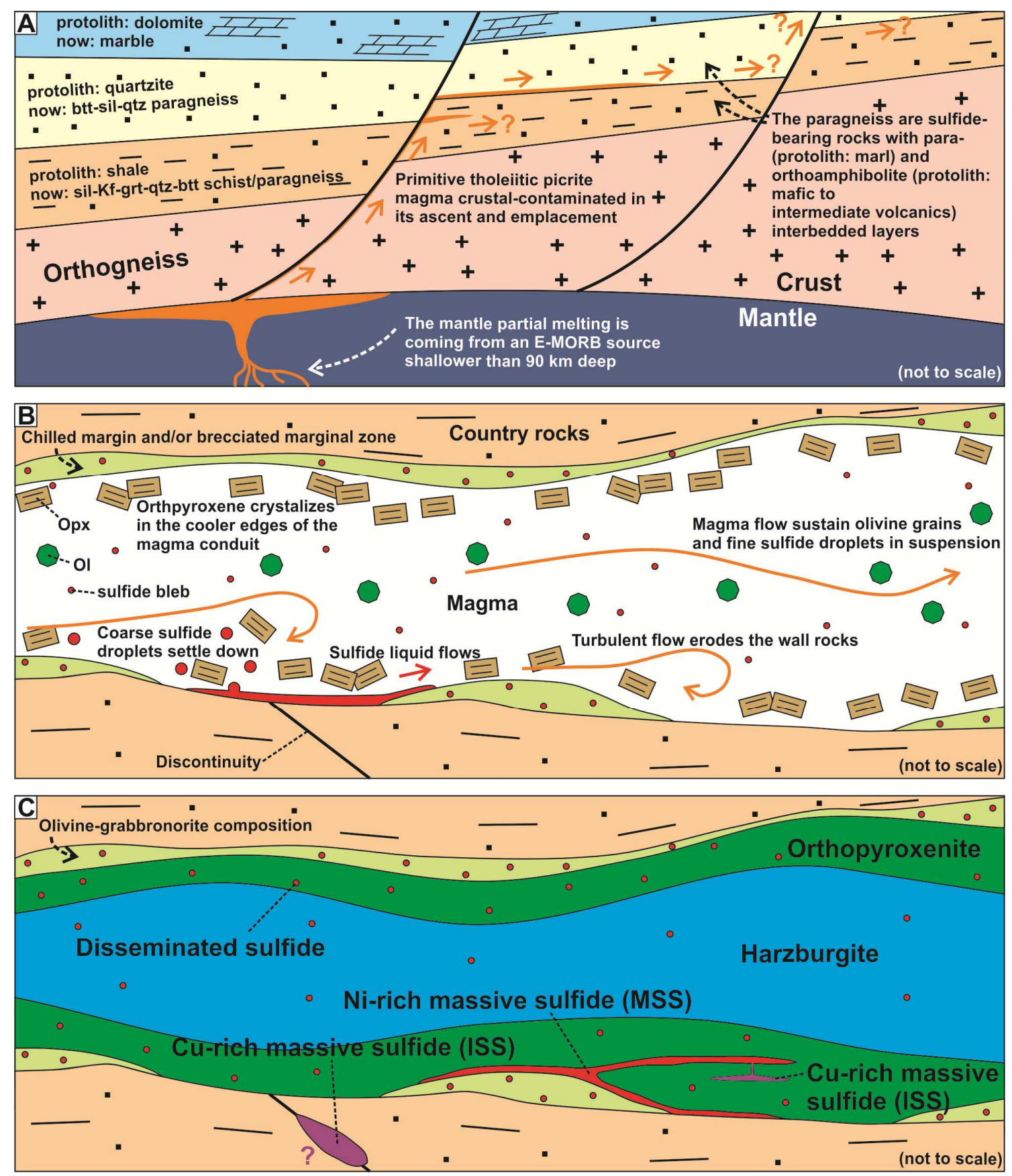

Fig. 2.25 - Schematic intrusive model for Limoeiro complex containing lithospheric- and intrusion-scale sketches. (A) A regional view showing partial melting in the shallow parts of an enriched mantle source and migration of the magma to the upper crust. (B) A longitudinal conduit view in the final stage of the inflation phase. (C) A longitudinal conduit view after crystallization.

\section{Conclusion}

The principal conclusions of this work are as follows: 
1. The Limoeiro intrusion includes at least four different magmatic sequences from the top to the base: (i) Low-Cr, which was formed by the most fractionated parental magma that had segregated sulfide upstream. This sequence overlies the others separated by tens of meters of country rock. (ii) Upper sequence, which is the most sulfide-bearing. (iii) Transition Zone sequence, which is partly mineralized and was formed by a minor magma pulse. (iv) Lower sequence, which is barren in most of the targets but might be mineralized in the eastern most part of the conduit.

2. The Upper sequence parental magma flowed from the west to the east, indicated by the progressive increase of the $\mathrm{Pd} / \mathrm{Cu}$ ratio and the drop in metal tenors to the east.

3. The primary mineral assemblage of the harzburgite and orthopyroxenite at Limoeiro may have included clinopyroxene and plagioclase as intercumulus phases. This primary mineralogy was later converted to a metamorphic assemblage.

4. The parental magma that formed all the magmatic sequences was similar. This magma came from an E-MORB mantle source from a depth shallower than 90 $\mathrm{km}$. The magma was intensely contaminated during its ascent through the crust. Sulfide droplets and olivine crystals were carried in suspension by the rapid magma flow. The bulk parental magma emplaced in to the chonolith is now preserved as the external amphibolite rocks, which have a composition compatible with a primitive high-MgO tholeiitic picrite magma.

5. The massive sulfide ore was formed from a sulfide liquid accumulated in a trap in the bottom of the Upper sequence in a similar manner to komatiite systems. This sulfide liquid remained hot for a long period of time and it has locally flowed as discrete entity, and has locally been injected into silicate crystal mush or into malleable ultramafic rock. Fractional crystallization of MSS from 
the initial magmatic sulfide liquid has locally generated a Cu-rich residual liquid that has formed discrete chalcopyrite-rich oreshoots.

\section{Acknowledgment}

We would like to thank Votorantim Metais for their permission, encouragement and financial support to sample the Limoeiro deposit and publish the results. We are glad to Richard Hornsey and Katherine Smuk from MMG for drill core photos and their crucial contribution and discussion on ore genesis and intrusion mechanisms in chonolithic systems.

\section{References}

Almeida FFM, Hasui Y, Brito Neves BB, Fuck RA (1981) Brazilian structural provinces: an introduction: Earth Sci Rev 17:1-29

Arndt N., Lesher CM, Czamanske GK (2005) Mantle-derived magmas and magmatic Ni-Cu(PGE) deposits. Econ Geol 100th Anniversary Vol: 5-24

Barnes SJ, Maier WD (2002) Platinum-group element distributions in the Rustenburg layered suite of the Bushveld Complex, South Africa. The geology, geochemistry, mineralogy and mineral beneficiation of platinum-group elements 54: 431-458

Barnes S-J, Lightfoot PC (2005) Formation of magmatic nickel sulfide ore deposits and processes affecting their copper and platinum group element contents. Econ Geol 100:179-213

Barnes S-J, Couture JF, Sawyer EW, Bouchaib C (1993) Nickel-copper occurrences in the Belleterre-Angliers Belt of the Pontiac Subprovince and the use of $\mathrm{Cu}-\mathrm{Pd}$ ratios in interpreting platinum-group element distributions. Econ Geol 88(6): 1402-1418

Barnes S-J, Makovicky E, Makovicky M, Rose-Hansen J, Karup-Moller S (1997) Partition coefficients for $\mathrm{Ni}, \mathrm{Cu}, \mathrm{Pd}, \mathrm{Pt}, \mathrm{Rh}$, and Ir between monosulphide solid solution and sulphide liquid and the formation of compositionally zoned $\mathrm{Ni}-\mathrm{Cu}$ sulphide bodies by fractional crystallization of sulphide liquid. Can J Earth Sci 34: 366-374 
Bennett M, Gollan M, Staubmann M, Bartlett J (2014) Motive, Means, and Opportunity: Key Factors in the Discovery of the Nova-Bollinger Magmatic Nickel-Copper Sulide Deposits in Western Australia. In: Kelley KD, Golden HC. Special Publication Number 18, Building Exploration Capability for the $21^{\text {st }}$ Century, Society of Economic Geologists

Brito Neves BB, Santos EJ, Van Schmus WR (2000) Tectonic History of the Borborema Province, Northeast Brazil. In: Cordani UG, Milani EJ, Thomaz Filho A, Campos DA (eds) Tectonic Evolution of South America, 31st International Geological Congress, Rio de Janeiro, pp 151-182

Campbell IH, Murck BW (1993) Petrology of the G and H chromitite zones in the Mountain View area of the Stillwater Complex, Montana. J Petrol 34: 291-316

DePaolo DJ (1981) Neodymium isotopes in the Colorado Front Range and crust-mantle evolution in the Proterozoic. Nature 291: 193-196

Eales HV, Cawthorn RG (1996) The Bushveld complex. In: Cawthorn RG (ed) Layered intrusions. Elsevier Science, Amsterdam, 181-229

Ebel DS, Naldrett AJ (1997) Crystallization of sulfide liquids and the interpretation of ore composition: Can J Earth Sci 34: 352-365

Gélinas L, Mellinger M, Trudel P. (1982) Archean mafic metavolcanics from the Rouyn-Noranda district, Abitibi Greenstone Belt, Quebec. 1. Mobility of the major elements. Can J Earth Sci 19(12): 2258-2275

Hill RET (2001) Komatiite volcanology, volcanological setting and primary geochemical properties of komatiite-associated nickel deposits. Geochemistry: Exploration, Environment, Analysis 1(4): 365-381

Holwell DA, McDonald I (2010) A review of the behaviour of platinum group elements within natural magmatic sulfide ore systems. Platinum Metals Review 54(1): 26-36

Huppert HE, Stephen R, Sparks J (1985) Cooling and contamination of mafic and ultramafic magmas during ascent through continental crust. Earth and Planetary Science Letters, 74(4): $371-386$

Keays RR (1995) The role of komatiitic and picritic magmatism and S-saturation in the formation of ore deposits. Lithos 34: 1-18

Kerr A (2001) The calculation and use of sulfide metal contents in the study of magmatic ore deposits: A methodological analysis. Exploration and Mining Geology, 10(4): 289-301 
Kullerud G, Yund RA, Moh GH (1969) Phase relations in the Cu-Fe-S, Cu-Ni-S, and Fe-Ni-S systems. Econo Geol Monograph 4: 323-343

Kunilov VY (1994) Geology of the Noril'sk region: The history of the discovery, prospecting, exploration and mining of the Noril'sk deposits: Ontario Geological Survey Special Volume 5: 203-216

Lesher CM, Groves DI (1986) Controls on the formation of komatiite-associated nickel-copper sulfide deposits. In Geology and metallogeny of copper deposits (pp. 43-62). Springer Berlin Heidelberg

Lesher CM, Campbell IH (1993) Geochemical and fluid dynamic modeling of compositional variations in Archean komatiite-hosted nickel sulfide ores in Western Australia. Econ Geol 88: 804-816

Lesher CM, Arndt NT (1995) REE and Nd isotope geochemistry, petrogenesis and volcanic evolution of contaminated komatiites at Kambalda, Western Australia. Lithos 34: 127158

Li C., Naldrett AJ (1999) Geology and petrology of the Voisey's Bay intrusion: reaction of olivine with sulfide and silicate liquids. Lithos 47: 1-31

Li C, Naldrett AJ, Coats CJA, Johannessen P (1992) Platinum, palladium, gold and cooper-rich stringers at Strathcona mine, Sudbury: their enrichment by fractionation of a sulfide liquid. Econ Geol 87: 1584-1598

Li C, Barnes SJ, Makovicky E, Karup-Moller S, Makovicky M, Rose-Hansen J (1996) Partitioning of $\mathrm{Ni}, \mathrm{Cu}, \mathrm{Ir}, \mathrm{Rh}, \mathrm{Pt}$ and $\mathrm{Pd}$ between monosulfide solid solution and sulfide liquid: Effects of composition and temperature. Geochim Cosmochim Acta 60: 12311238

Li C., Naldrett AJ, Ripley EM (2001a) Critical factors for the formation of a nickel-copper deposit in an evolved magma system: lessons from a comparison of the Pants Lake and Voisey's Bay sulfide occurrences in Labrador, Canada. Miner Deposita 36(1): 85-92

Li C., Maier WD, De Waal SA (2001b) Magmatic Ni-Cu versus PGE deposits: Contrasting genetic controls and exploration implications. S Afr J Geol 104(4): 309-318

Li C, Ripley EM, Mathez EA (2003) The effect of S on the partitioning of Ni between olivine and silicate melt in MORB. Chem Geol 201: 295-306

Maier WD, Barnes SJ, De Klerk WJ, Teigler B, Mitchell AA (1996) Cu/Pd and Cu/Pt of silicate rocks in the Bushveld Complex; implications for platinum-group element exploration. Econ Geol 91(6): 1151-1158 
Makovicky E (2002) Ternary and Quaternary phase systems with PGE, in Cabri, L. J., ed., The geology, geochemistry, mineralogy and mineral beneficiation of platinum-group elements: Can Inst Min Met Special Volume 54: 131-175

Marone F, Romanowicz B (2007). The depth distribution of azimuthal anisotropy in the continental upper mantle. Nature 447(7141): 198-201

McDonough WF, Sun SS (1995) The composition of the Earth. Chem geo 120(3): 223-253

Medeiros VC (2004) Evolução Geodinâmica e Condicionamento Estrutural dos Terrenos Piancó-Alto Brígida e Alto Pajeú, Domínio da Zona Transversal, NE do Brasil (Doctoral dissertation, Universidade Federal do Rio Grande do Norte)

Mota e Silva J, Ferreira Filho CF, Buhn B, Dantas EL (2011) Geology, petrology and geochemistry of the" Americano do Brasil" layered intrusion, central Brazil, and its $\mathrm{Ni}-\mathrm{Cu}$ sulfide deposits. Mineralium Deposita 46(1): 57-90

Mota-e-Silva J, Ferreira Filho CF, Della Giustina MES (2013) The Limoeiro Deposit: Ni-Cu-PGE Sulfide Mineralization Hosted Within an Ultramafic Tubular Magma Conduit in the Borborema Province, Northeastern Brazil. Econ Geol 108(7): 1753-1771

Mota-e-Silva J, Prichard HM, Ferreira Filho CF, Fisher PC, McDonald I (in review) Platinumgroup minerals in the Limoeiro Ni-Cu-(PGE) sulfide deposit, Brazil: the effect of magmatic and upper amphibolite to granulite metamorphic processes on PGM formation. Miner Deposita

Mudd GM (2010) Global trends and environmental issues in nickel mining: Sulfides versus laterites. Ore Geol Rev 38(1): 9-26

Naldrett AJ (1966) The role of sulphurization in the gneiss of iron-nickel sulphide deposit of the porcupine district, Ontario. Transactions LXIX: 147-155

Naldrett AJ (1981). Nickel sulphide deposits: classification, composition and genesis. Econ Geol, 75: 628-687

Naldrett AJ (2004). Magmatic sulfide deposits - geology, geochemistry and exploration. Springer, Berlin, p 724

Naldrett AJ, Asif M, Gorbachev NS, Kunilov VY, Stekhin Al, Fedorenko VA, Lightfoot PC (1994) The composition of the $\mathrm{Ni}-\mathrm{Cu}$ ores of the Oktyabr'sky deposit, Noril'sk region. In: Lightfoot, P. C., Naldrett, A. J. (eds) Proceedings of Sudbury-Noril'sk symposium, Ontario Geological Survey Spec Vol 5: 357-373 
Naldrett AJ, Asif M, Schandl E, Searcy T, Morrison GG, Binney WP, Moore C (1999) Platinumgroup elements in the Sudbury ores: significance with respect to the origin of different ore zones and to the exploration for footwall orebodies. Econ Geol 94: 185-210

Neves SP, Alcantara VC (2010) Geochemistry of orthogneisses and metasedimentary rocks across a proposed terrane boundary in the Central Domain of Borborema Province, NE Brazil: Geodynamic implications: J South Am Earth Sci 29: 498-511

Papunen H, Vorma A (1985) Nickel Deposits in Finland, a Review, in Papunen, H. and Gorbunov, G. I., Eds., Nickel-Copper Deposits of the Baltic Shield and Scandinavian Caledonides. Geological Survey of Finland, Bulletin 333: 123-139

Pavão CG, França GS, Bianchi M, de Almeida T, Von Huelsen MG (2013) Upper-lower crust thickness of the Borborema Province, NE Brazil, using Receiver Function. J South Am Earth Sci 42: 242-249

Pearce JA (2008) Geochemical fingerprinting of oceanic basalts with applications to ophiolite classification and the search for Archean oceanic crust. Lithos 100(1): 14-48

Rollinson H (1993) Using geochemical data: Evaluation, presentation and interpretation. Pearson Education Limited, 352 p.

Rudnick RL, Gao S, Ling WL, Liu YS, McDonough WF (2004) Petrology and geochemistry of spinel peridotite xenoliths from Hannuoba and Qixia, North China craton. Lithos 77(1): 609-637

Santos EJ, Van Schmus WR, Kozuch M, Brito Neves BB (2010) The Cariris Velhos tectonic event in northeast Brazil. J South Am Earth Sci 29: 61-76

Seat Z, Beresford SW, Grguric BA, Gee MM, Grassineau NV (2009) Reevaluation of the role of external sulfur addition in the genesis of Ni-Cu-PGE deposits: Evidence from the NeboBabel Ni-Cu-PGE deposit, West Musgrave, Western Australia. Econ Geol 104(4): 521538

Soares JEP, Fuck RA, Mejia NIM, Tavares EJ, Schmidt K, Monteiro LR, Custódio M, Guimarães VOM (2009) Características sísmicas da litosfera do estado do Ceará resultados preliminares de experimento de refração sísmica profunda, XXIII Geology Northeast Symposium 2009, Ceará, Brasil (in Portuguese)

Stekhin Al (1994) Mineralogy and geochemical characteristics of the Cu-Ni ores of the Oktyabr'sky and Talnakh deposits. Ontario Geological Survey Special Volume 5: 217230 
Sun SS, McDonough W (1989) Chemical and isotopic systematics of oceanic basalts: implications for mantle composition and processes. Geol Soc, London, Spec Pub 42(1): 313-345

Tang Z (1995) Ore-forming model and geological correlation of the Jinchuan Cu-Ni-(PGEbearing) sulfide deposit. Beijing, Geological Publishing House, 208 pp

Tornos F, Casquet C, Galindo C, Velasco F, Canales A (2001) A new style of $\mathrm{Ni}-\mathrm{Cu}$ mineralization related to magmatic breccia pipes ina transpressional magmatic arc, Aguablanca, Spain. Miner Deposita 36(7): 700-706

Zhou MF, Arndt NT, Malpas J, Wang CY, Kennedy AK (2008) Two magma series and associated ore deposit types in the Permian Emeishan large igneous province, SW China. Lithos 103(3): 352-368 
Platinum-group minerals in the Limoeiro $\mathrm{Ni}-\mathrm{Cu}-(\mathrm{PGE})$ sulfide deposit, Brazil: the effect of magmatic and upper amphibolite to granulite metamorphic processes on PGM formation 


\title{
Platinum-group minerals in the Limoeiro Ni-Cu-(PGE) sulfide deposit, Brazil: the effect of magmatic and upper amphibolite to granulite metamorphic processes on PGM formation
}

\author{
Jonas Mota-e-Silva ${ }^{1,2}$, Hazel M Prichard ${ }^{3}$, Cesar F Ferreira Filho ${ }^{2}$, Peter C Fisher \\ ${ }^{3}$, lain McDonald ${ }^{3}$ \\ ${ }^{1}$ Votorantim Metais, Exploration Division, Polo Industrial Multivias, Jundiai/SP, 13212-161, \\ Brazil \\ ${ }^{2}$ University of Brasilia, Geosciences Institute, Brasília/DF, 70900-970, Brazil \\ ${ }^{3}$ School of Earth and Ocean Science, Cardiff University, Main Building, Park Place, Cardiff, \\ CF10 3AT, UK
}

\section{Abstract}

The Limoeiro Ni-Cu-(PGE) deposit is a recent discovery (2009) associated with an igneous chonolith in northeastern Brazil. Using representative ore from the deposit; platinumgroup minerals (PGM) have been identified and platinum-group elements (PGE) analyzed in solid solution in base metal sulfides (BMS). $98 \%$ of the PGM in the massive sulfide ore is homogeneous Pt-Ni-Bi-bearing merenskyite $\left(\mathrm{PdTe}_{2}\right)$ enclosed primarily by pyrrhotite, suggesting that it formed by exsolution from monosulfide solid solution (MSS). Merenskyite gradually but systematically becomes poorer in Pt and Ni with increasing fractionation, which is interpreted to reflect a transition to a more evolved sulfide liquid that segregated within the eastern parts of the intrusion. In massive sulfide ores merenskyite forms unusually large (up to $5000 \mathrm{~m}^{2}$ ) euhedral grains, commonly in contact with spherical silicate inclusions. BMS hosts $12-16 \%$ of the $\mathrm{Pd}$, with the remainder hosted by PGM, which is interpreted to indicate that merenskyite recrystallized from a PGE-bearing bismuthotelluride metamorphic melt formed during high grade metamorphism. Sperrylite $\left(\mathrm{PtAs}_{2}\right)$ is the second most abundant PGM (18\% of PGM in disseminated ore) and in contrast to merenskyite occurs mainly as very small (median of $25 \mu^{2}$ ) inclusions in high-temperature silicates and oxides, interpreted to have crystallized at 
high temperatures directly from sulfide blebs that formed and were transported within the Limoeiro chonolith.

\section{Keywords}

Platinum-group-minerals; Merenskyite; Upper amphibolite to granulite facies metamorphism; Sperrylite; Ni-Cu-PGE sulfide deposit; Platinum-group elements

\section{Introduction}

Magmatic nickel-copper-platinum-group element (Ni-Cu-PGE) sulfide deposits form as a result of the segregation and concentration of droplets of sulfide liquid from a silicate mafic or ultramafic magma, and the partitioning of chalcophile elements into this phase (Naldrett 2004). Platinum-group element dominated deposits are more commonly associated with sulfide-poor reefs such as the Merensky Reef and Platreef in the Bushveld complex in the Republic of South Africa (e.g., Naldrett et al. 2008), the Great Dyke in Zimbabwe (e.g., Wilson et al. 2000) and the Stillwater complex in the USA (e.g., Godel and Barnes 2008). In contrast, the major base metal (i.e., $\mathrm{Ni}$ and $\mathrm{Cu}$ ) sulfide (BMS) deposits are characterized by sulfide-rich rocks, such as in the Noril'sk-Talnakh deposits (e.g., Lightfoot et al. 1990) in Russia, Sudbury in Canada (e.g., Lightfoot and Farrow, 2002), and Jinchuan in China (e.g., Li et al. 2004), and in these cases PGE are by-products. However these PGE by-products in Ni-Cu sulfide deposits can be crucial for the economic viability of smaller low grade Ni-Cu-(PGE) sulfide deposits, such as the Limoeiro Ni-Cu-(PGE) sulfide deposit in Brazil.

The Limoeiro Ni-Cu-(PGE) deposit is located in NE Brazil and hosts 35Mt @ 0.25\% $\mathrm{Ni}, 0.27 \% \mathrm{Cu}, 0.40 \mathrm{ppm} \mathrm{Pd}$ and $0.16 \mathrm{ppm} \mathrm{Pt}$ with flotation tests resulting in 60 and $90 \%$ recoverable $\mathrm{Ni}$ and $\mathrm{Cu}$, respectively (Votorantim Metais, 2013). It was discovered during 2009 
and is located within a complex, concentrically zoned, tube-like (chonolithic) subhorizontal orthopyroxenite-harzburgite intrusion, interpreted to have formed in the geological setting of a dynamic multi-pulse mafic magma conduit (Mota-e-Silva et al. 2013). The absolute age of this intrusion is not yet known, but regional geological constraints suggest that both the intrusion and host rocks belong to a terrain older than the Brasiliano/Pan-African orogenic cycle (650 $500 \mathrm{Ma}$ ). During this orogeny the intrusion and its country rock were metamorphosed to upper amphibolite to granulite facies with a temperature range of between 700 and $850^{\circ} \mathrm{C}$ according to the CMASH system (Opx-in and Chl-out isograd). The ultramafic rocks are also affected by a later low-temperature hydrothermal alteration (Mota-e-Silva et al. 2013). Studies from other deposits worldwide have shown that during hydrothermal alteration and greenschist facies metamorphism, base metal (i.e., $\mathrm{Ni}$ and $\mathrm{Cu}$ ) sulfides (BMS) recrystallize to a different mineral assemblage and Pd-bearing PGM can be mobilized from the BMS into the surrounding silicates (e.g., Fuchs and Rose, 1974; Dillon-Leitch et al. 1986; Prichard et al. 2001; Seabrook et al. 2004; Wang et al. 2008). However the effects of upper amphibolite to granulite facies metamorphism on PGM and PGE mobility are poorly understood.

This study is particularly interesting as there is an opportunity to investigate the role of both magmatic and high grade metamorphic processes on the formation and distribution of the PGM. The combination of the use of scanning electron microscope (SEM) and laser-ablation inductively-coupled-plasma mass spectrometry (LA-ICP-MS) analyses enables us to examine the behavior of the PGE during the geological history of these ores, whether hosted by BMS or in discrete PGM grains. These results have the potential to influence future metallurgical assessments that will be necessary to exploit the deposit, as well as to enhance the overall understanding of PGE and PGM in magmatic and metamorphic systems, especially during upper amphibolite to granulite facies metamorphism. 


\section{Geological setting}

\section{The Limoeiro Ni-Cu-(PGE) sulfide deposit}

The Limoeiro Ni-Cu-(PGE) sulfide deposit is located in northeastern Brazil, in a high grade mobile belt belonging to the Brasiliano orogenic cycle (650 - $500 \mathrm{Ma}$ ) known as the Borborema province (e.g., Almeida et al. 1981; Brito Neves et al. 2000; Santos et al. 2010) (Fig. 3.1). This intrusion has a chonolithic (tubular) form that potentially represents a magma conduit hosted within high grade paragneiss and schist (Fig. 3.2). The conduit consists of two main distinct sequences of ultramafic rocks (Upper and Lower sequences), each consisting of a core of harzburgite (olivine-orthopyroxene +/- chromite cumulates) enveloped by orthopyroxenite (orthopyroxene-olivine +/- chromite cumulates), with an irregular and discontinuous outer shell of amphibolite (Fig. 3.3). A granoblastic texture consisting of equigranular medium-grained amphibole crystals with polygonal contacts evidences the metamorphic alteration of the primary assemblage of the intrusion outer rim. The ultramafic sequences, otherwise characterized by a similar composition and structure, have distinctly different $S$ contents resulting from the presence of disseminated $\mathrm{Ni}-\mathrm{Cu}$ sulfide mineralization only in the Upper Sequence. These sequences are believed to have been formed from the input of two major pulses of magma with similar compositions (Mota-e-Silva et al. 2013) but different sulfide saturation histories. Geological evidence and the variation of whole rock $\mathrm{Ni} / \mathrm{Cu}$ and $\mathrm{Cu} / \mathrm{Pd}$ ratios along the conduit (Mota-e-Silva and Ferreira Filho, 2013) suggest that the direction of the magma flux into the Limoeiro intrusion was from the west to the east. Therefore, the intrusion appears to record a more primitive signature in the western ores and a more fractionated signature in the eastern ores. 

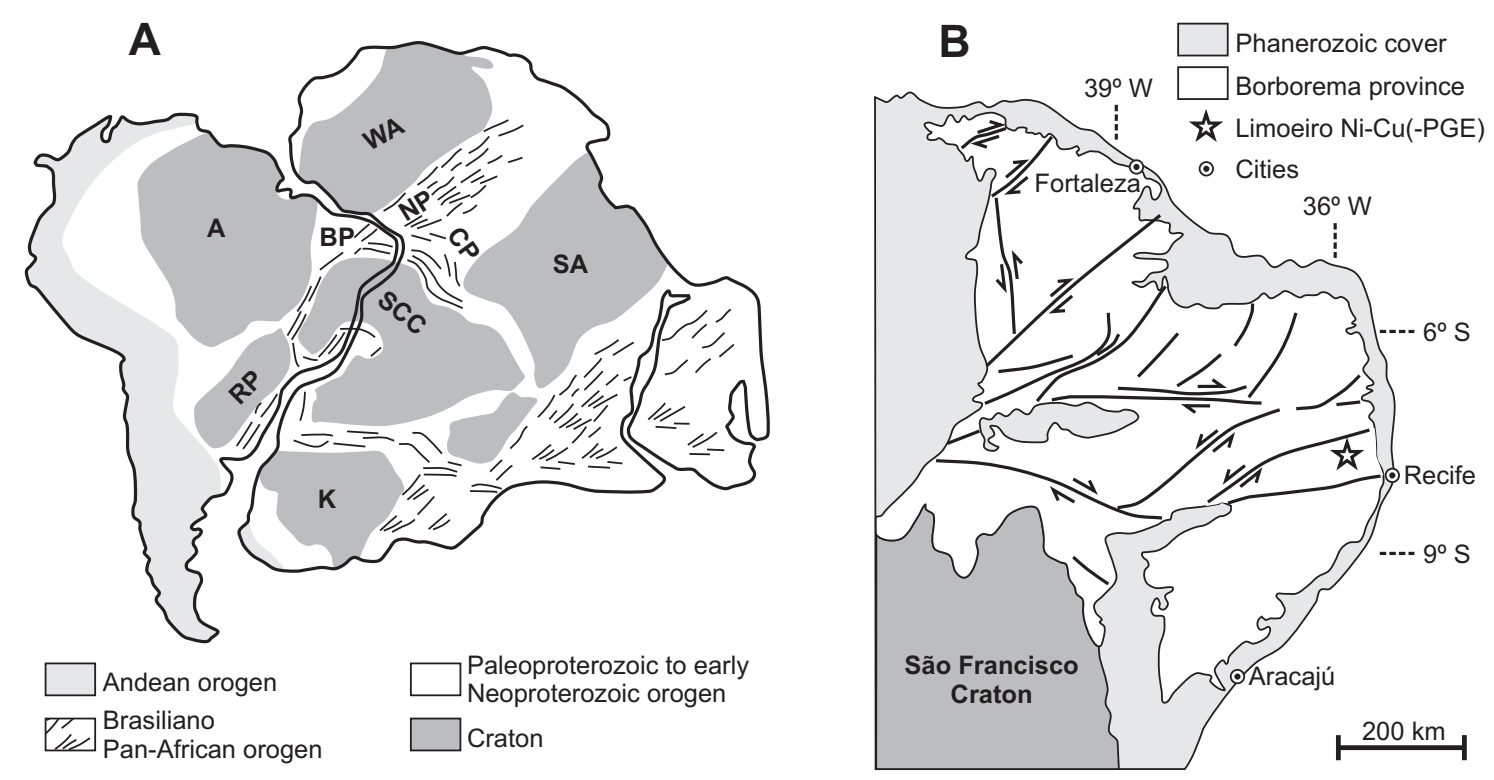

Fig. 3.1 (A) Pre-rift reconstruction of western Gondwana showing the main cratons and Brasiliano/Pan-African provinces (modified from Neves and Alcantara, 2010). Abbreviations: A, Amazonia; BP, Borborema; CP, Cameroon; NP, Nigeria; K, Kalahari; RP, Rio de La Plata; SA, Sahara Metacraton; SCC, São Francisco/Congo; WA, West Africa. (B) Map showing the position of the Limoeiro Ni-Cu(-PGE) sulfide deposit in the Borborema province (modified from Mota-e-Silva et al., 2013)

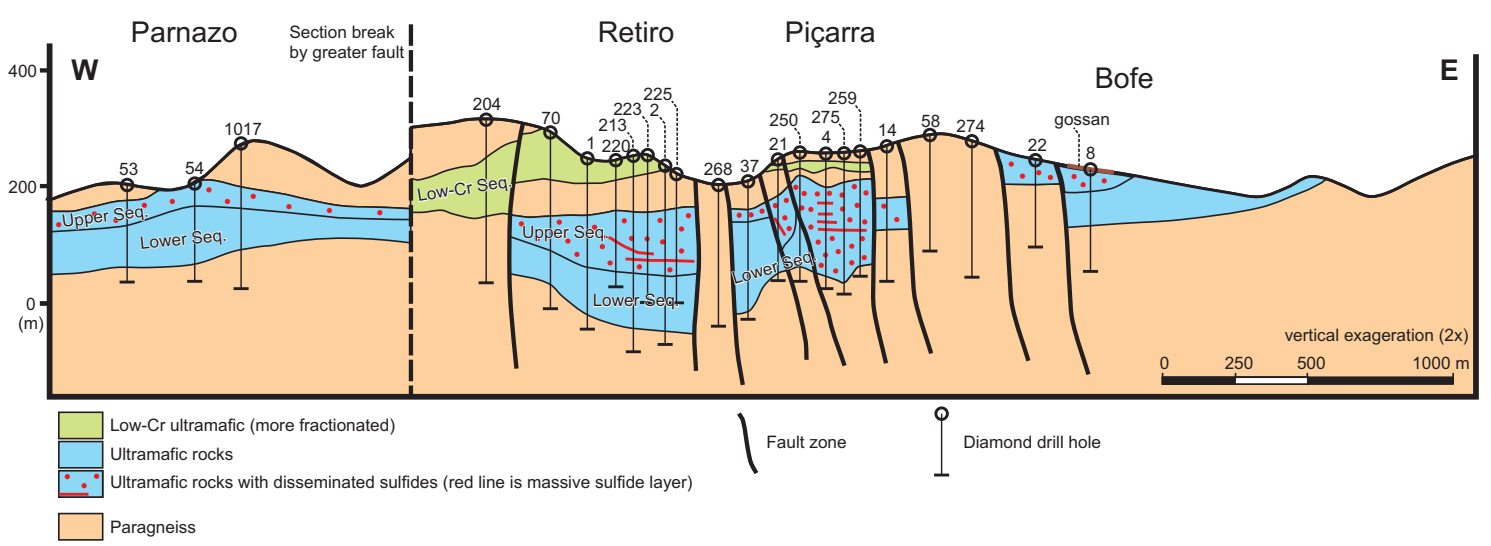

Fig. 3.2 Representative longitudinal section along the chonolith. Note that the Upper sequence is the only sulfidebearing unit in the Parnazo and Retiro targets. However this feature is not clear in the very tectonically-disrupted Piçarra target to the east. The density of red circles is proportional to sulfide abundance

The complex is metamorphosed and partly deformed. Peak metamorphic paragenesis for the ultramafic intrusion and country rocks indicates upper amphibolite to granulite facies metamorphism represented by a metamorphic assemblage of anthophyllite, hornblende, phlogopite, chlorite, Al-Fe-Mg-Cr spinel coexisting with deformed and partially recrystallized relicts of larger orthopyroxene and olivine crystals that are occasionally surrounded by fine- 
grained polygonal aggregates (produced by metamorphic recrystallization to sub-grains). The ultramafic rocks are also affected by a later low-temperature hydrothermal alteration, which is characterized by formation of antigorite with magnetite, talc, chlorite, and calcite (Mota-e-Silva et al. 2013). Deformed rocks, locally transformed into phlogopitite in extreme cases, and tectonically remobilized sulfide stringers represent the products of tectonism and deformation throughout the complex. Such deformation is confined to shear zones and some parts of the outer contact of the intrusion with its country rocks.
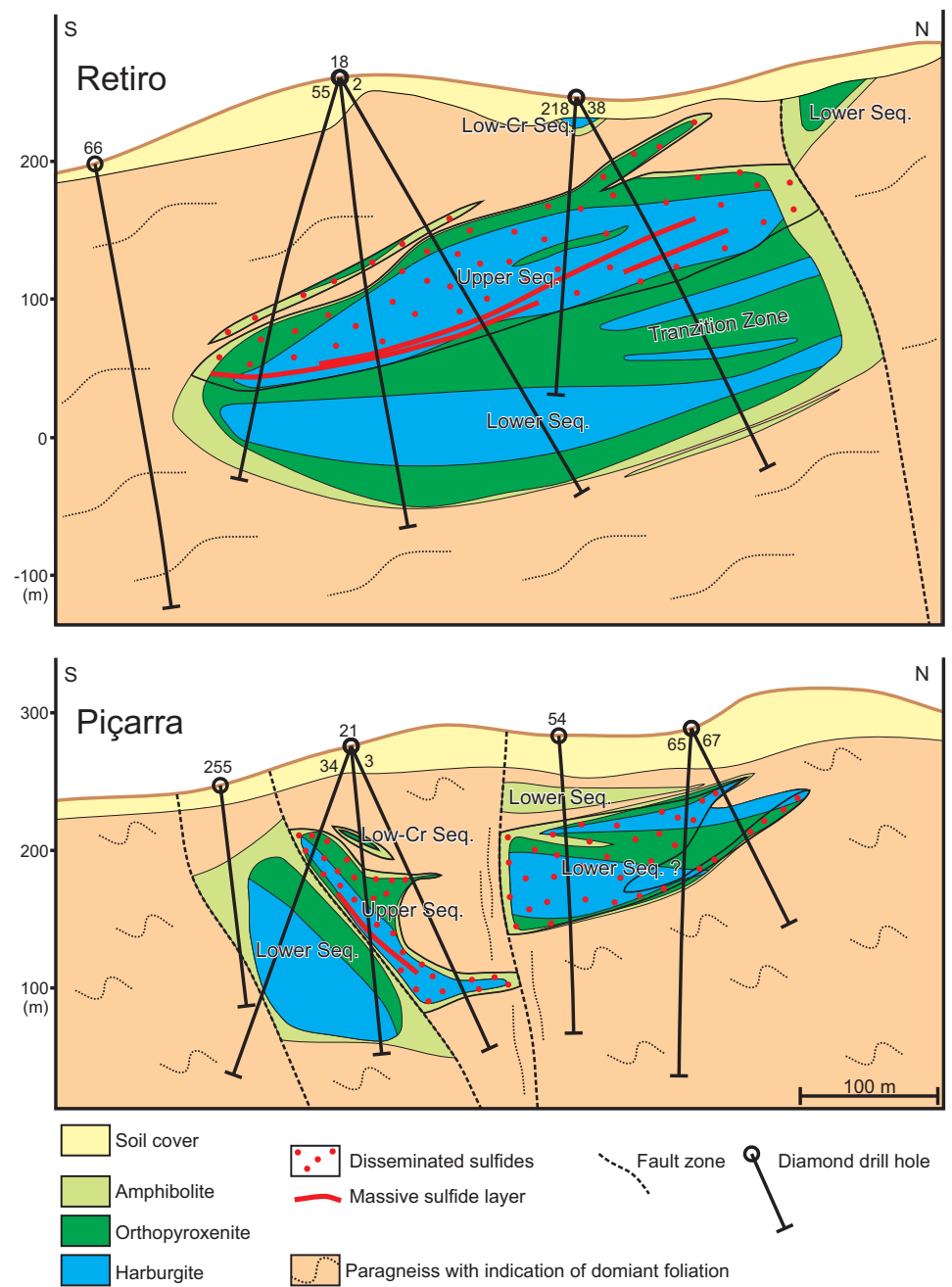

Fig. 3.3 Representative cross-sections of the two main drilling targets in the Limoeiro Ni-Cu(-PGE) sulfide deposit

On a broad scale the mineralization still preserves its primary magmatic geometry, consisting of thick (up to 150 meters) and elongated (up to $1 \mathrm{~km}$ ) masses of disseminated sulfides (2-10 vol\%; Fig. 3.4A) broadly concordant with the chonolith geometry. Massive ore 
(Fig. 3.4B and C) occurs just in the Retiro and Piçarra targets (Fig. 3.2) and represents about 3 vol\% of the Limoeiro deposit (Mota-e-Silva, et al. 2013). Locally tectonically mobilized sulfide stringers form narrower massive sulfide layers (Fig. 3.4D).
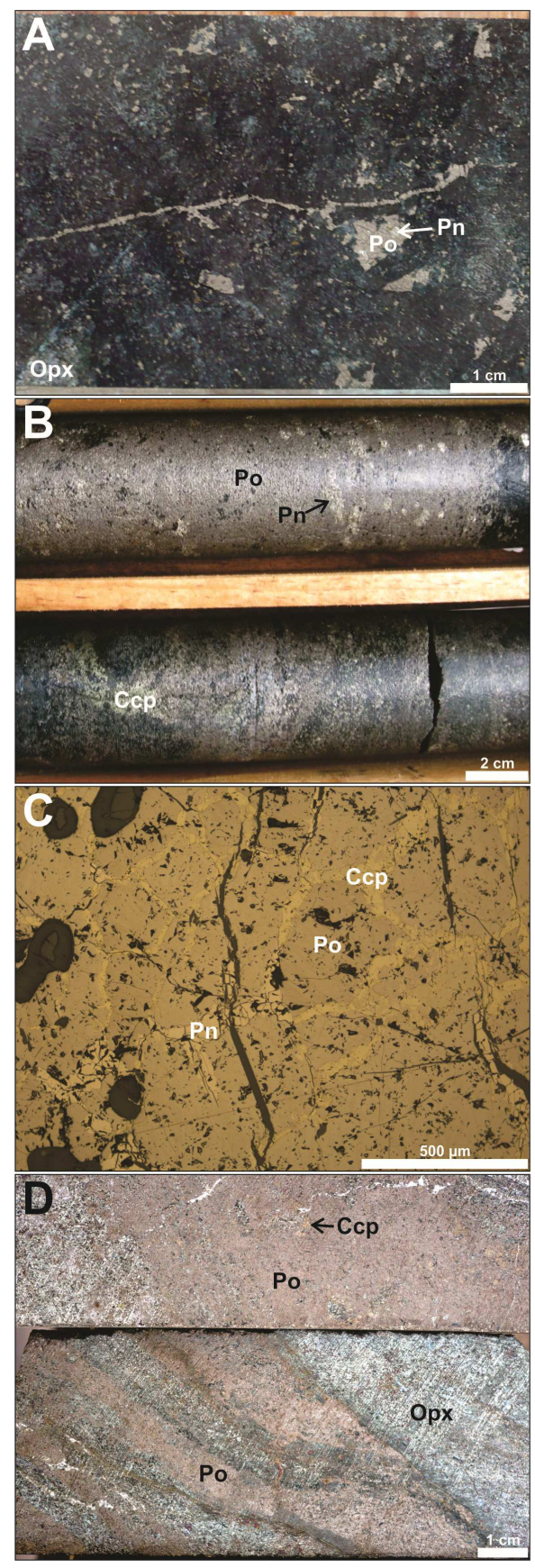

Fig. 3.4 Examples of ore types from the Limoeiro Ni-Cu(-PGE) deposit. (A) Drill core of a typical disseminated sulfide ore [pyrrhotite (Po), pentlandite $(\mathrm{Pn})$ and chalcopyrite (Ccp)] hosted in orthopyroxenite. (B) Drill core of massive sulfide. (C) The honey-comb-like-texture showing chalcopyrite and pentlandite ribbons surrounding polygonal pyrrhotite grains in $120^{\circ}$ triple junctions. (D) Drill core of sample 004-115.80, an example of tectonically mobilized and sheared massive sulfide. In this case the massive sulfide has numerous ellipsoidal elongated silicate inclusions forming a typical "Durchbewegung" texture (term coined by Vokes, 1969) suggesting mechanical deformation involving milling of country rock inclusions 


\section{Drilling targets and recently recognized magmatic sequences}

This section provides an update on new information concerning current understanding of the mineralization targets and magmatic sequences in the Limoeiro intrusion, which is critical for placing into context some of the samples used in this study. From west to east, the Limoeiro intrusion hosts mineralization at the following fault-block defined targets: Parnazo, Retiro, Piçarra, and Bofe. The Retiro and Piçarra targets are the most extensively drilled, as they contain the only known economic mineralization within the Limoeiro intrusion (Fig. 3.2). The Retiro target has a more continuous, less faulted and less deformed structure, compared to the Piçarra target at which the distinction between igneous stratigraphic boundaries is not so well defined. Recent information obtained from additional drilling has revealed that the Upper sequence is located below a Low-Cr sequence (Figs. 3 and 4). This latter sequence is formed of the same rocks as the Upper and Lower sequences, however lithochemical results indicate a consistently low $\mathrm{Cr}$ content (150 to $850 \mathrm{ppm}$ ) versus 1120 to $2310 \mathrm{ppm}$ that is typical of both the Upper and Lower sequences (Mota-e-Silva and Ferreira Filho, in prep). Furthermore between the Upper and Lower sequence a narrower but continuous Transition Zone layer (Figs. 5 and 6), that is generally sulfide-bearing, has been identified. A better description and understanding of the significance of the Low-Cr sequence and this Transition Zone is not the focus of this study. These will be the subject of a future paper that will deal with subjects such as the mechanism of intrusion, stratigraphy and magma fractionation, based on variations in silicate mineral compositions. 


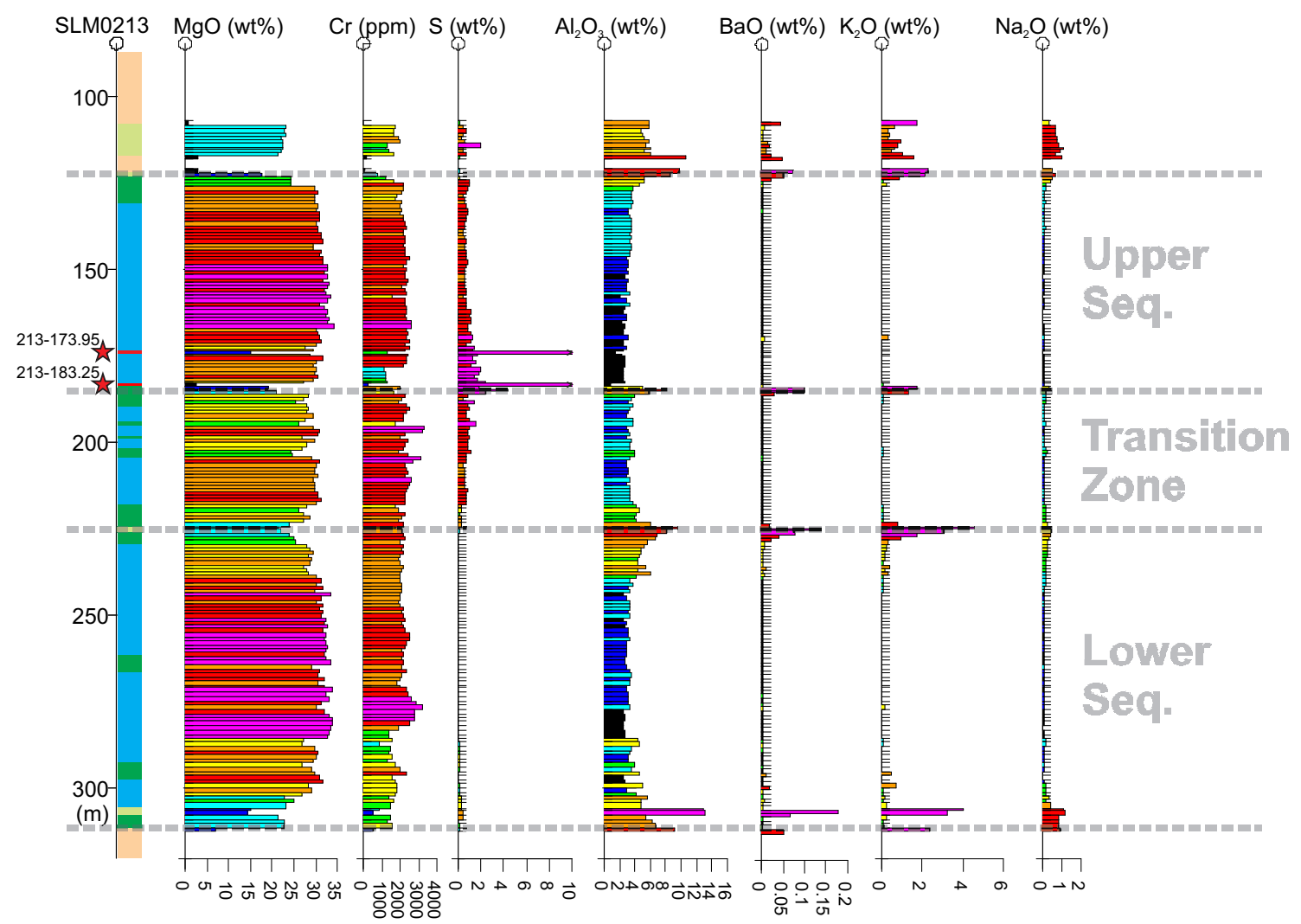

Fig. 3.5 Representative bore hole strip log of the Retiro target. The massive sulfide horizons sampled are marked with a red star and labeled with the sample name. The colors for the lithologies are the same as those used in Fig. 3.3

\section{Sampling and analytical methods}

The cross sections of the Limoeiro deposit presented in this study are based upon extensive exploration data (including maps, drilling sections, and geophysical surveys) developed by Votorantim Metais (VM). Their whole rock assay results were obtained from half drill cores that were sampled continuously at approximately $1 \mathrm{~m}$ intervals, and adjusted to respect geological contacts. Each sample weighed about $2 \mathrm{~kg}$ and analyses for 21 elements were carried out at ALS Chemex, Toronto, Canada, by inductively-coupled plasma atomic emission spectrometry (ICP-AES) after fine crushing $(70 \mathrm{wt} \%<2 \mathrm{~mm})$ with a Cr-steel jaw crusher, pulverizing $\left(85 \mathrm{wt} \%<75 \mu \mathrm{m}^{2}\right)$ with a "ring and puck" style low-chrome steel grinding mill, followed by open beaker four-acid ( $\left.\mathrm{HF}, \mathrm{HClO}_{4}, \mathrm{HCl}, \mathrm{HNO}_{3}\right)$ digestion. Platinum, $\mathrm{Pd}$ and $\mathrm{Au}$ were analyzed by ICP-AES after standard lead oxide fire assay preconcentration. 


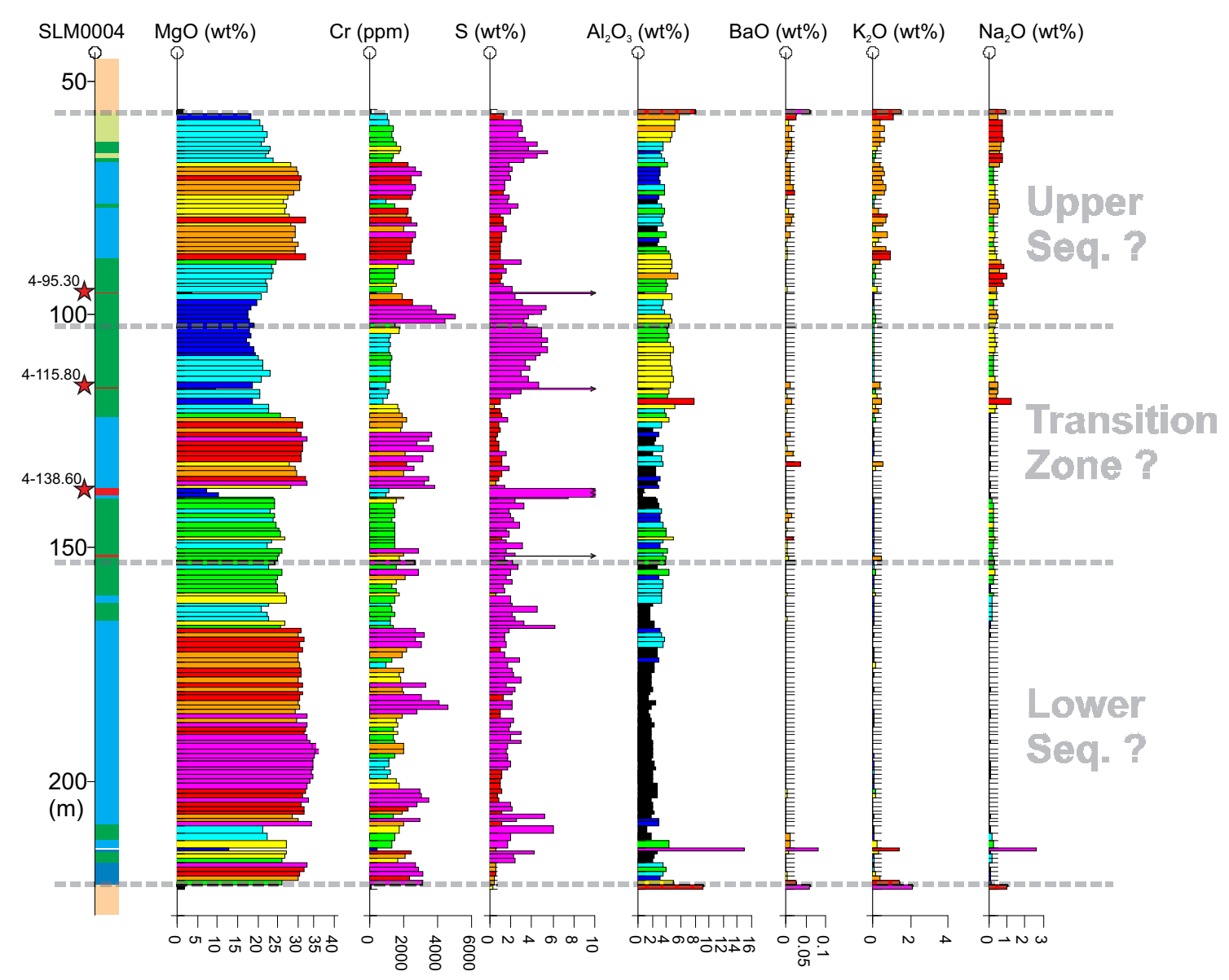

Fig. 3.6 Representative bore hole strip log of the east part of the Piçarra target. The massive sulfide horizons sampled are marked with a red star and labeled with the sample name. The colors for the lithologies are the same as those used in Fig. 3.3

Fifteen half drill cores of PGM mineralization were studied. These included the disseminated sulfide ore hosted within three different rock types (amphibolite, orthopyroxenite, and harzburgite) and also massive sulfide, in both primary and remobilized ores, from different parts of the chonolith. Samples were analyzed from the western Retiro drilling target, the most primitive part of the intrusion to be sampled, and from the eastern Piçarra target, which consists of more fractionated rocks and ore bodies. Polished thin-sections were produced from the material collected. PGM were identified using a four-quadrant back-scattered electron detector (4QBSD) on a Zeiss NTS S360 SEM at Cardiff University. The samples were searched systematically for PGM using the SEM set at 50x magnification for massive sulfide samples and 200x for disseminated sulfide samples. Quantitative analyses of the larger PGM (>5x5 $\mu \mathrm{m})$ were obtained by X-ray emission spectrometry using an Oxford Instruments INCA Energy Dispersive 
X-ray spectrometer attached to the SEM. Operating conditions for the analyses were $20 \mathrm{keV}$ accelerating voltage, with a beam current of $\sim 1 \mathrm{nA}$, and a working distance of $25 \mathrm{~mm}$ (this is important to give a suitable efficient dead time for the detector between 40 and $45 \%$ ). A cobalt reference standard was regularly analyzed in order to check for any drift in the analytical conditions. A wide-ranging set of standards obtained from MicroAnalysis Consultants Ltd (St Ives, Cambridgeshire) was used to calibrate the EDX analyzer. Precision and accuracy values have been determined using repeated analyses of standards, which guarantee a reasonable stoichiometry and good totals between 98.5 and $101.5 \%$ in the analyses presented. Images taken with more than $1000 x$ magnification were acquired using a working distance of $13 \mathrm{~mm}$ to achieve a better resolution. For a few images, where even higher magnifications were necessary (>10000x), a Veeco FEI/Philips XL30 field emission environmental scanning electron microscope was used.

In order to measure the PGE and other trace element contents in the BMS, 26 different BMS grains from 4 different polished thin sections were analyzed, representing massive sulfide orebodies from distinct parts of the intrusion.

Laser ablation ICP-MS analyses were carried out using a New Wave Research UP213 Nd:YAG 213nm UV laser system coupled to a Thermo X Series 2 ICP-MS. The relative abundances of PGE and other elements were recorded in time-resolved analysis mode (time slices of $\sim 250 \mathrm{~ms}$ ) as the laser beam followed a line designed to sample single or multiple sulfide phases. The laser beam diameter was $30 \mu \mathrm{m}$, with a frequency of $10 \mathrm{~Hz}$ and a power of $\sim 6 \mathrm{~J} \mathrm{~cm}^{-2}$. The sample was moved at $6 \mu \mathrm{m} \mathrm{sec}^{-1}$ relative to the laser along a pre-determined line pattern. Ablations were carried out under a pure helium atmosphere (flow $\sim 0.7 \mathrm{~L} \mathrm{~min}^{-1}$ ) and the resulting vapor combined with argon (flow rate $0.65-0.75 \mathrm{~L} \mathrm{~min}^{-1}$ ) before delivery into the ICPMS. Acquisitions lasted between 80 and 400 seconds, including a 20 second gas blank prior to the start of the analysis and a 10 second washout at the end. Signals within the time spectra that could be attributed to PGM included in the sulfides were not selected for integration so the data reflect concentrations in the sulfide minerals alone. Sulfur concentrations were measured prior to LA-ICP-MS using SEM and ${ }^{33} \mathrm{~S}$ was used as internal standard. Subtraction of gas blanks and internal standard corrections were performed using Thermo Plasmalab software. 
Calibration was performed using a series of 5 synthetic Ni-Fe-S standards prepared from quenched sulfides. The standards incorporate $\mathrm{S}, \mathrm{Ni}, \mathrm{Fe}$ and $\mathrm{Cu}$ as major elements and $\mathrm{Co}$, $\mathrm{Zn}, \mathrm{As}, \mathrm{Se}, \mathrm{Ru}, \mathrm{Rh}, \mathrm{Pd}, \mathrm{Ag}, \mathrm{Cd}, \mathrm{Sb}, \mathrm{Te}, \mathrm{Re}, \mathrm{Os}, \mathrm{Ir}, \mathrm{Pt}, \mathrm{Au}$ and $\mathrm{Bi}$ as trace elements. The compositions of the 5 standards are given in Prichard et al. (2013). The standards produce fivepoint calibration curves for $\mathrm{S}, \mathrm{Ni}$ and Fe and three-point calibration curves for PGE, $\mathrm{Ag}, \mathrm{Re}, \mathrm{Au}$, and semi-metals. Standards 1-3 produce three-point calibration curves for $\mathrm{Cu}, \mathrm{Co}$, and $\mathrm{Zn}$ and matrix-matched corrections for argide species $\left({ }^{59} \mathrm{Co}^{40} \mathrm{Ar},{ }^{61} \mathrm{Ni}^{40} \mathrm{Ar},{ }^{63} \mathrm{Cu}{ }^{40} \mathrm{Ar},{ }^{65} \mathrm{Cu} 40 \mathrm{Ar},{ }^{66} \mathrm{Zn}{ }^{40} \mathrm{Ar}\right.$ ) that interfere with ${ }^{99} \mathrm{Ru},{ }^{101} \mathrm{Ru},{ }^{103} \mathrm{Rh},{ }^{105} \mathrm{Pd}$ and ${ }^{106} \mathrm{Pd}$. Corrections for ${ }^{106} \mathrm{Cd}$ on ${ }^{106} \mathrm{Pd}$ and ${ }^{108} \mathrm{Cd}$ on ${ }^{108} \mathrm{Pd}$ were determined using Cd-bearing Standard 1, but Cd concentrations in the sulfides were $<10 \mathrm{ppm}$, producing only very small corrections in most unknowns. Argide and isobariccorrected data are indicated by ${ }^{101} \mathrm{Ru}^{*},{ }^{103} \mathrm{Rh}^{*}$, and ${ }^{108} \mathrm{Pd}^{*}$ in Tables $\mathrm{X}$ and $\mathrm{Y}$. Where independent corrections have been applied to different isotopes of the same element (e.g., ${ }^{66} \mathrm{Zn}{ }^{40} \mathrm{Ar}$ and ${ }^{106} \mathrm{Cd}$ on ${ }^{106} \mathrm{Pd}$ and ${ }^{108} \mathrm{Cd}$ on ${ }^{108} \mathrm{Pd}$ ) the independently corrected values typically vary by less than $20 \%$ (and commonly $<5 \%$ ) indicating that the corrections are robust. The accuracy and precision of the LA-ICP-MS procedure for PGE was checked by analysis of the Laflamme-Po724 pyrrhotite standard run as an unknown against the Cardiff sulfide standards at the start and end of each day (Table 3.1). Elements $\mathrm{Ru}, \mathrm{Rh}, \mathrm{Pd}$, Os, ir and Pt have shown precisions between 0.0 and 2.5\%, and accuracies between 1.0 and $4.5 \%$. Elements As, Se, Cd, $\mathrm{Sb}, \mathrm{Te}, \mathrm{Re}$ and $\mathrm{Bi}$ are not certified in the Po724 standard and their concentrations in the Po724 are generally as low as the detection limit lower limit of the equipment. 
Table 3.1 - Summary of trace element concentrations (in ppm) in LA-ICP-MS analyses of the Po724 standard. The (*) indicates the isotopes that were corrected for interferences. Certified values and 1 sigma uncertainties are shown.

\begin{tabular}{|c|c|c|c|c|c|}
\hline \multirow{2}{*}{ Isotope } & \multicolumn{2}{|c|}{ Analyzed } & \multirow{2}{*}{ Po724 certified } & \multirow{2}{*}{$\begin{array}{l}\text { Precision } \\
(\%)\end{array}$} & \multirow{2}{*}{$\begin{array}{c}\text { Accuracy } \\
(\%)\end{array}$} \\
\hline & Po724-1 & Po724-2 & & & \\
\hline${ }^{15}$ As & $<9$ & $<9$ & $\mathrm{n} / \mathrm{a}$ & - & - \\
\hline${ }^{82} \mathrm{Se}$ & $<40$ & $<40$ & $\mathrm{n} / \mathrm{a}$ & - & - \\
\hline${ }^{101} \mathrm{Ru}^{*}$ & 38.7 & 38.2 & $37.0 \pm 1.0$ & 1.3 & 3.9 \\
\hline${ }^{103} \mathrm{Rh}^{*}$ & 38.8 & 38.4 & $37.0 \pm 1.7$ & 1.0 & 4.3 \\
\hline${ }^{106} \mathrm{Pd}^{*}$ & 44 & 43.8 & $45.0 \pm 0.8$ & 0.5 & 2.4 \\
\hline${ }^{108} \mathrm{Pd}^{*}$ & 43.9 & 43.9 & $45.0 \pm 0.8$ & 0.0 & 2.4 \\
\hline${ }^{111} \mathrm{Cd}$ & $<0.7$ & $<0.7$ & $\mathrm{n} / \mathrm{a}$ & - & - \\
\hline${ }^{121} \mathrm{Sb}$ & $<0.8$ & $<0.8$ & $\mathrm{n} / \mathrm{a}$ & - & - \\
\hline${ }^{125} \mathrm{Te}$ & $<0.8$ & 0.82 & $\mathrm{n} / \mathrm{a}$ & - & - \\
\hline${ }^{185} \mathrm{Re}$ & 0.09 & 0.07 & $\mathrm{n} / \mathrm{a}$ & 28.6 & - \\
\hline${ }^{189}$ Os & 36.4 & 36.9 & $35.2 \pm 1.9$ & 1.4 & 1.0 \\
\hline${ }^{193} \mathrm{Ir}$ & 36.4 & 37.2 & $36.2 \pm 0.5$ & 2.2 & 1.7 \\
\hline${ }^{19 b} \mathrm{Pt}$ & 37.1 & 36.4 & $35.9 \pm 0.7$ & 1.9 & 2.4 \\
\hline${ }^{19 /} \mathrm{Au}$ & 40.2 & 45.5 & $47.3 \pm 2.4$ & 11.5 & 9.4 \\
\hline${ }^{205} \mathrm{Bi}$ & $<0.05$ & $<0.05$ & $n / a$ & - & - \\
\hline
\end{tabular}

Po724-1 and Po724-2 are duplicates of the Memorial University pyrrhotite standard Po-724 that were run at the start and at the end of the analytical run to check the precision and accuracy of the analyses

\section{Results}

\section{Platinum-group mineralogy}

The Limoeiro Ni-Cu-(PGE) sulfide deposit PGM assemblage comprises mostly bismuthotelluride minerals, dominated by Pt-Ni-bearing merenskyite $\left[(\mathrm{Pd}, \mathrm{Pt}, \mathrm{Ni})(\mathrm{Te}, \mathrm{Bi})_{2}\right]$. The massive sulfide ore is dominated by merenskyite which accounts for 98\% of PGM grains observed whereas the disseminated sulfide ore has a more diverse PGM assemblage (Table 3.2). Other common PGM are sperrylite $\left(\mathrm{PtAs}_{2}\right)$, kotulskite $[\mathrm{Pd}(\mathrm{Te}, \mathrm{Bi})]$, moncheite $\left[\mathrm{Pt}(\mathrm{Te}, \mathrm{Bi})_{2}\right]$, Pt-Pd-bearing melonite $\left[(\mathrm{Ni}, \mathrm{Pt}, \mathrm{Pd})(\mathrm{Te}, \mathrm{Bi})_{2}\right]$, an unknown $\mathrm{Pd}-\mathrm{Pb}$ telluride, hollingworthite [(Rh,Pt,Pd)AsS], an unknown Pd-Ag bismuthotelluride, and cooperite (PtS). The total PGM assemblage identified (Table 3.2) is composed of $87 \%$ bismuthotelluride, $8 \%$ arsenide, $1.5 \%$ telluride, $1.5 \%$ sulfarsenide, and a combined $2 \%$ of sulfide, bismuthide, and Sn-PGM. Quantitative analyses of some of these phases are presented in Table 3.3. Merenskyite accounts for $50 \%$ of the total number of PGM grains in the disseminated sulfide ore, but represents only $45 \%$ by area, mainly because sperrylite and kotulskite have a slightly larger average grain size (Fig. 3.7). The largest grain is a $5000 \mu \mathrm{m}^{2}$ merenskyite in massive sulfide ore 
and the smallest PGM found in this study is a $0.1 \mu \mathrm{m}^{2}$ cooperite that occurs together with a sperrylite as a composite grain. The median PGM grain size is $6.4 \mu \mathrm{m}^{2}$ in 9 samples of disseminated ore (200x search parameter) and $88 \mu \mathrm{m}^{2}$ in 6 samples of massive ore (50x search parameter). As merenskyite and sperrylite are the most abundant PGM identified (84\%), their mineralogical characteristics are described in individual sections as follows.

number of grains

(frequency)

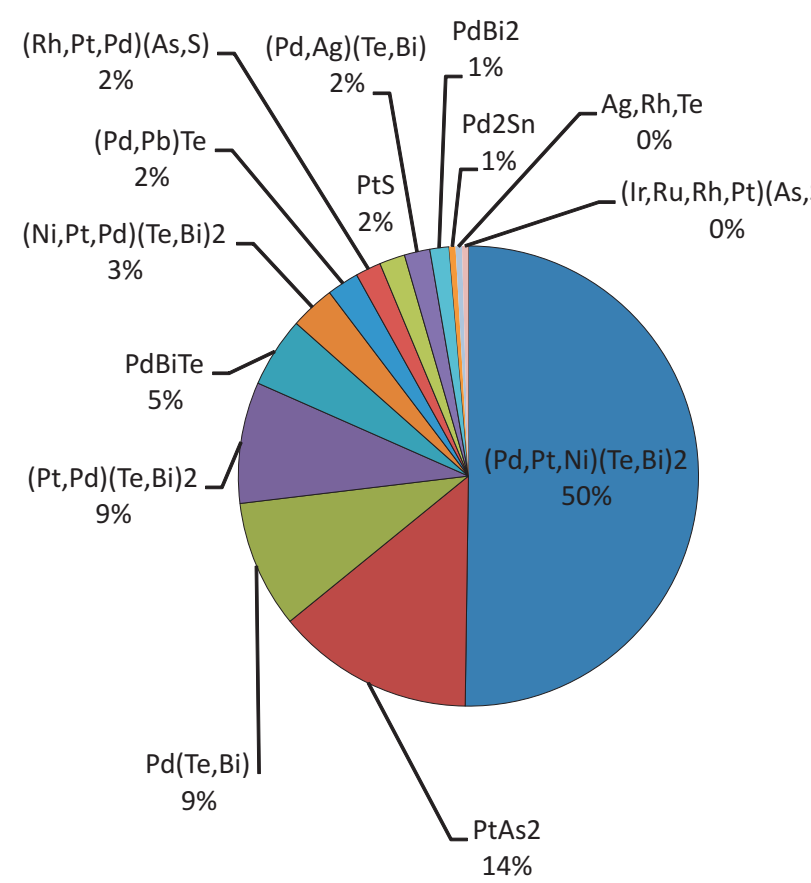

total area

$\left(\mu \mathrm{m}^{2}\right)$

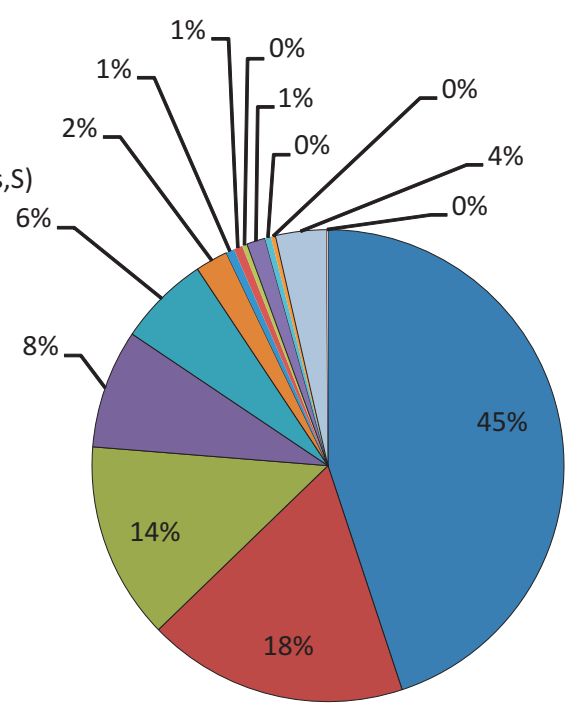

Fig. 3.7 Pie charts showing the PGM frequency and area abundances in the disseminated ore from the Limoeiro Ni-Cu(PGE) sulfide deposit 


\section{Merenskyite, $(\mathrm{Pd}, \mathrm{Pt}, \mathrm{Ni})(\mathrm{Te}, \mathrm{Bi})_{2}$}

Merenskyite has a wide range of compositions with varying $\mathrm{Pt}$ and $\mathrm{Ni}$ contents and distinct $\mathrm{Te} / \mathrm{Bi}$ weight ratios (Table 3.3). It usually displays euhedral to subhedral forms, occasionally with conspicuous cleavage parallel to the longer crystal axis (Figs. 8A, C and D). The grains have a dominantly homogeneous composition and can occur as composite grains together with hessite $\left(\mathrm{Ag}_{2} \mathrm{Te}\right)$, altaite $(\mathrm{PbTe})$, and moncheite. The association with hessite is especially frequent in sample $004-115.80$ with $\sim 85 \%$ of the merenskyite grains associated with hessite. This sample is a narrow mobilized and sheared massive sulfide layer composed of sulfide stringers aligned parallel to the deformation fabric, marked by the elongation of amphibole and phlogopite (Fig. 3.4D). In contrast, non-sheared massive sulfide samples (Fig. 3.4B) have only $~ 2 \%$ of the merenskyite grains associated with hessite.
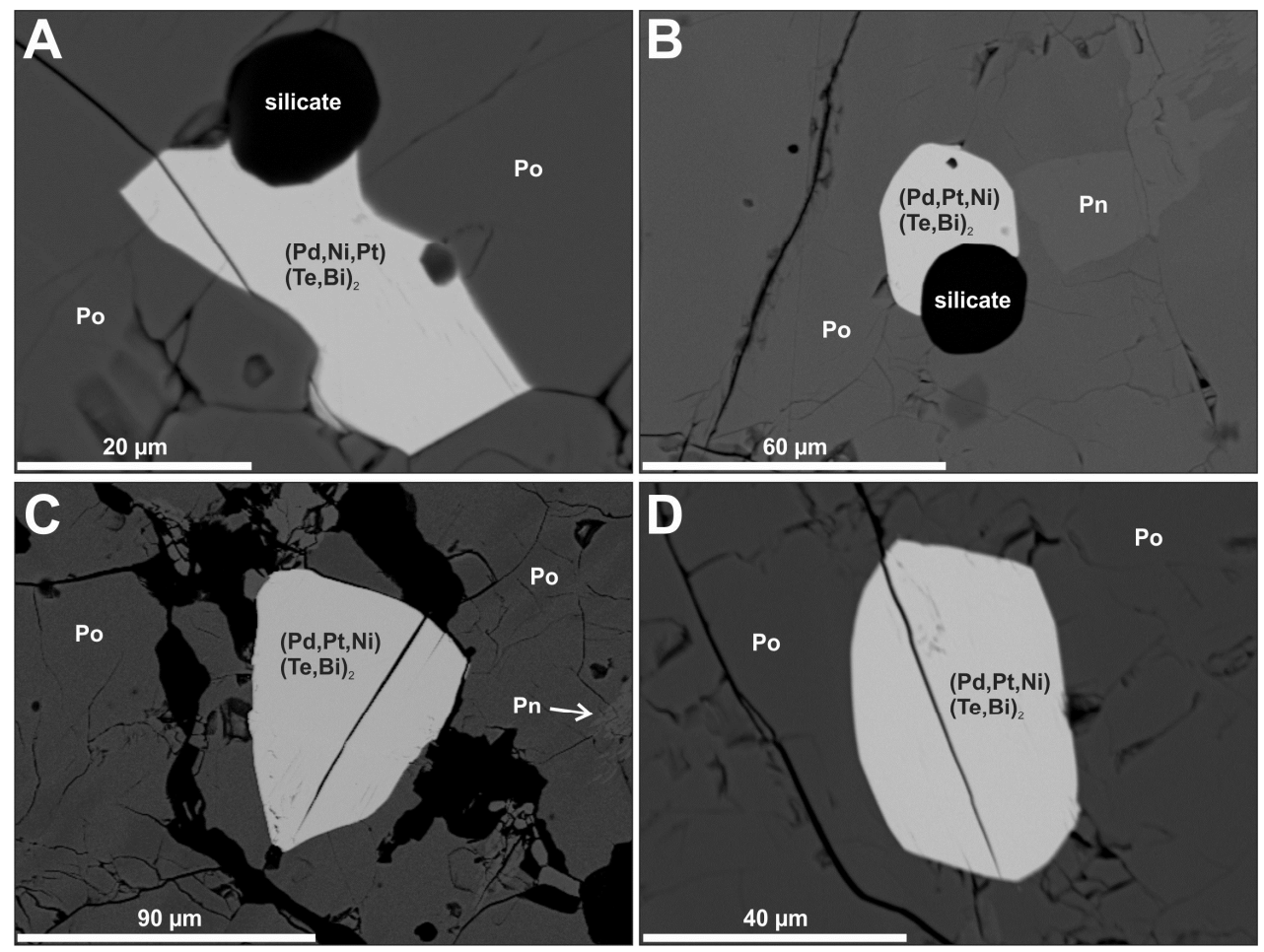

Fig. 3.8 Back scattered electron images of: (A) Subhedral merenskyite grain with discrete cleavage, enclosed by pyrrhotite (Po), and attached to a rounded silicate in massive sulfide ore, sample 213-173.95, grain \# 3. (B) Euhedral merenskyite grain enclosed by pyrrhotite and pentlandite $(\mathrm{Pn})$, and attached to a rounded silicate in massive sulfide ore, sample 213-183.25, grain \# 6. (C) Subhedral merenskyite grain with clear cleavage parallel to the longer crystal axis, enclosed by pyrrhotite, surrounded by open fractures in massive sulfide ore, sample 213-183.25, grain \# 12. (D) Subhedral merenskyite grain with discrete cleavage parallel to the longer crystal axis, enclosed by pyrrhotite, and affected by a fracture through the massive sulfide ore, sample 213-173.95, grain \# 10. Mineral symbols based on Whitney and Evans (2010) listing 
Table 3.2 - Platinum-group mineral frequency in the Limoeiro Ni-Cu-(PGE) deposit.

\begin{tabular}{|c|c|c|c|c|c|c|c|c|c|c|c|c|c|c|c|c|}
\hline Target & Sample & Litho & Mrk & Spy & $\mathrm{Kt}$ & Mon & Mch & Mlt & $(\mathrm{Pd}-\mathrm{Pb})(\mathrm{Te})$ & HIw & Cpr & $(\mathrm{Ag}-\mathrm{Pd})(\mathrm{Bi}-\mathrm{Te})$ & Fro & Plv & $(\mathrm{Ag}-\mathrm{Rh})(\mathrm{Te})$ & Irs \\
\hline Piçarra & 021-090 & AT & 5 & 2 & & & 11 & & & & 1 & & 2 & & & \\
\hline Piçarra & 004-110 & AT & 2 & & 2 & 2 & & 1 & & & & & & & & \\
\hline Piçarra & $004-067$ & AT & 4 & 1 & & & & & & & & & & & & \\
\hline Piçarra & $004-087$ & $\mathrm{HZ}$ & 11 & & & 2 & & & 1 & & & & & & & \\
\hline Parnazo & $053-067$ & $\mathrm{HZ}$ & 2 & 2 & 2 & & & & 2 & & & & & & & \\
\hline Retiro & $055-228$ & $\mathrm{HZ}$ & 23 & 2 & 4 & 1 & & & 1 & & & 1 & 1 & & & \\
\hline Retiro & 018-155 & PX & 33 & 1 & 1 & & & & & & & & & & & \\
\hline Retiro & $002-125$ & $\mathrm{PX}$ & 10 & 4 & 4 & 11 & & & & & 1 & & & & & \\
\hline Retiro & $213-185.00$ & $\mathrm{PX}$ & 22 & 19 & 7 & 3 & & 6 & 1 & 4 & 2 & 3 & & 1 & 1 & 1 \\
\hline Piçarra & $004-115.80$ & MS & 14 & & & & & & & & & & & 1 & & \\
\hline Piçarra & 004-095.30 & MS & 22 & & & & & & & & & & & & & \\
\hline Piçarra & 004-138.60 & MS & 55 & & & & & & & & & & & & & \\
\hline Piçarra & $021-137$ & MS & 16 & & & & & & & & & & & & & \\
\hline Retiro & 213-173.95 & MS & 19 & & & & & 3 & & & & & & & & \\
\hline Retiro & 213-183.25 & MS & 45 & & & & & & & & & & & & & \\
\hline
\end{tabular}

PGM abbreviations: Mrk, Merenskyite; Spy, Sperrylite; Kt, Kotulskite; Mon, Moncheite; Mch, Michenerite; Mlt, Melonite; (Pd-Pb)(Te), unknown Pd-Pb telluride; HIw, Hollingworthite; Cpr, Cooperite; (Ag-Pd)(Bi-Te), unknown Ag-Pd bismuthotelluride; Fro, Frodite; Plv, Paolovite; (Ag-Rh)(Te), Ag-Rh telluride; Irs, Irarsite.

Lithological unit abbreviations: AT, amphibolite; PX, orthopyroxenite; HZ, harzburgite; and MS, massive sulfide. 
Table 3.3 - Selective representative quantitative analyses of the PGM found in the Limoeiro deposit.

\begin{tabular}{|c|c|c|c|c|c|c|c|c|c|c|c|c|c|c|c|}
\hline Sample & Litho & Grain \# & Mineral & $\begin{array}{c}\mathrm{Fe} \\
(\mathbf{w t} \%)\end{array}$ & $\begin{array}{c}\mathrm{Ni} \\
(w t \%)\end{array}$ & $\underset{(w t \%)}{\mathrm{Cu}}$ & $\underset{(\mathbf{w t} \%)}{\mathbf{R h}}$ & $\begin{array}{c}\mathbf{P t} \\
(w t \%)\end{array}$ & $\underset{(w t \%)}{P d}$ & $\underset{(w t \%)}{A u}$ & $\underset{(w t \%)}{S}$ & $\underset{(w t \%)}{\text { As }}$ & $\begin{array}{c}\mathrm{Te} \\
\text { (wt\%) }\end{array}$ & $\begin{array}{c}\mathbf{B i} \\
(\mathbf{w t} \%)\end{array}$ & $\begin{array}{l}\text { Total } \\
\text { (wt\%) }\end{array}$ \\
\hline $055-228$ & $\mathrm{HZ}$ & 5.1 & kotulskite & 0.78 & 4.79 & & & 0.89 & 30.80 & & & & 40.84 & 21.71 & 99.80 \\
\hline $002-125$ & $\mathrm{PX}$ & 20 & kotulskite & & & & & & 43.55 & & & & 45.54 & 10.86 & 99.95 \\
\hline $213-185.00$ & $P X$ & 7 & melonite & 3.37 & 12.88 & & & 3.54 & 7.05 & & & & 63.94 & 10.07 & 100.85 \\
\hline $055-228$ & $\mathrm{HZ}$ & 2 & merenskyite & 1.39 & 4.46 & & & 5.85 & 22.63 & & & & 43.23 & 22.47 & 100.04 \\
\hline $055-228$ & $\mathrm{HZ}$ & $\overline{6}$ & merenskyite & & 8.06 & & & 4.31 & 19.32 & & & & 44.95 & 23.77 & 100.41 \\
\hline $055-228$ & $H Z$ & 5.2 & merenskyite & & 0.49 & & & & 24.83 & & & & 32.67 & 41.88 & 99.87 \\
\hline $004-115.80$ & MS & 3 & merenskyite & & & & & & 25.09 & & & & 33.77 & 40.07 & 98.93 \\
\hline $004-115.80$ & MS & 4 & merenskyite & & & & & & 24.97 & & & & 33.42 & 40.98 & 99.37 \\
\hline 004-138.60 & MS & 51 & merenskyite & 1.38 & 3.82 & & & 3.86 & 18.43 & & & & 54.44 & 17.90 & 99.83 \\
\hline $004-138.60$ & MS & 18 & merenskyite & 0.44 & 3.74 & & & 4.11 & 18.82 & & & & 53.39 & 19.12 & 99.62 \\
\hline $004-95.30$ & MS & 10 & merenskyite & & 0.64 & & & 7.34 & 22.11 & & & & 52.10 & 17.73 & 99.91 \\
\hline 004-95.30 & MS & 18 & merenskyite & & 0.79 & & & 6.92 & 21.84 & & & & 51.18 & 18.57 & 99.29 \\
\hline $021-137$ & MS & 19 & merenskyite & & 2.15 & & & 8.74 & 17.39 & & & & 47.73 & 23.00 & 99.00 \\
\hline $021-137$ & MS & 6 & merenskyite & & 2.74 & & & 7.29 & 17.91 & & & & 50.31 & 22.34 & 100.59 \\
\hline $213-173.95$ & MS & 7 & merenskyite & 0.72 & 4.68 & & & 10.26 & 12.20 & & & & 52.78 & 11.79 & 99.47 \\
\hline $213-173.95$ & MS & 6 & merenskyite & 0.85 & 5.22 & & & 10.84 & 11.94 & & & & 53.59 & 18.07 & 100.51 \\
\hline $213-183.25$ & MS & 11 & merenskyite & & 3.23 & & & 8.87 & 15.83 & & & & 48.28 & 23.98 & 100.19 \\
\hline $213-183.25$ & MS & 32 & merenskyite & & 3.25 & & & 10.56 & 15.74 & & & & 49.17 & 22.11 & 100.83 \\
\hline $002-125$ & PX & 4 & merenskyite & & & & & 1.62 & 27.66 & & & & 62.09 & 8.00 & 99.37 \\
\hline 021-090 & AT & 22 & michenerite & 0.90 & 0.62 & & & & 23.88 & & & & 28.16 & 46.34 & 99.90 \\
\hline $021-090$ & AT & 20 & michenerite & 0.74 & & & & & 24.30 & & & & 27.55 & 47.32 & 99.91 \\
\hline $004-110$ & AT & 3 & moncheite & 0.87 & & & & 26.31 & 10.64 & & & & 55.26 & 6.80 & 99.88 \\
\hline $002-125$ & PX & 5 & moncheite & & & & & 39.57 & 2.37 & & & & 54.52 & 3.72 & 100.17 \\
\hline $002-125$ & $P X$ & 6 & moncheite & & & & & 43.27 & & & & & 55.41 & & 98.67 \\
\hline $213-185.00$ & $P X$ & 67 & moncheite & 0.69 & 0.82 & & & 40.98 & & & & & 54.49 & 3.39 & 100.38 \\
\hline $055-228$ & $\mathrm{HZ}$ & 24 & sperrylite & & & 0.71 & & 55.92 & & & 0.43 & 41.98 & & & 99.03 \\
\hline $002-125$ & $P X$ & 1 & sperrylite & & & & & 57.57 & & & & 43.41 & & & 100.97 \\
\hline $213-185.00$ & PX & 3 & sperrylite & & & & 0.78 & 57.06 & & & & 42.45 & & & 100.29 \\
\hline $213-185.00$ & PX & 4 & sperrylite & & & & 1.41 & 56.53 & & & & 42.41 & & & 100.35 \\
\hline $213-185.00$ & $P X$ & 29 & sperrylite & & & & & 56.16 & & 1.75 & 1.14 & 40.92 & & & 99.96 \\
\hline
\end{tabular}

Lithological unit abbreviations: AT, amphibolite; PX, orthopyroxenite; HZ, harzburgite; and MS, massive sulfide. 


\section{Sperrylite, PtAs 2}

The second most abundant mineral phase, sperrylite, occurs as small (median of $25 \mu \mathrm{m}^{2}$ in area) homogeneous grains. The sperrylite varies in form from euhedral diamond shapes to subhedral and more rarely as almost rounded grains (Fig. 3.9). These sperrylites occasionally contain small amounts of $\mathrm{Rh}, \mathrm{Cu}, \mathrm{Au}$, and $\mathrm{S}$ (Table 3.3). Rhodium, $\mathrm{S}$ and $\mathrm{Cu}$ have been documented in low concentrations in sperrylite elsewhere (Cabri, 2002), however the presence of these elements in the analyses presented here may also be related to other phases located below the section. This possibility is particularly feasible for $S$ and $\mathrm{Rh}$ as sperrylite occasionally forms composite grains with cooperite (Fig. 3.9B) and hollingworthite at Limoeiro. Pt-bearing melonite also occurs in composite grains with sperrylite (Fig. 3.9E). Sperrylite commonly occurs in clusters, and never close to the most abundant PGM, merenskyite.

\section{Platinum-group mineral associations and textures}

The PGM in the massive sulfide ores occur mainly associated with pyrrhotite, but associations with silicates are also very common (Fig. 3.10). This association with silicates reflects the preference of PGM to crystallize at BMS margins or enclosed in BMS but attached to inclusions of rounded (probably spherical) grains composed of serpentine, hornblende, carbonate, chlorite, and other silicates (Fig. 3.8A and B). One of these silicates either completely fills the spherical inclusion (as observed in 2 dimensions) or several silicates occur within a single inclusion. Chalcopyrite, pentlandite, and oxides contain far fewer PGM. Sample 004-115.80, which is from a mobilized narrow stringer sulfide layer, is different from the primary massive sulfide samples because the PGM are located in contact with chalcopyrite, pyrrhotite, and silicates, but not with pentlandite or oxides. 

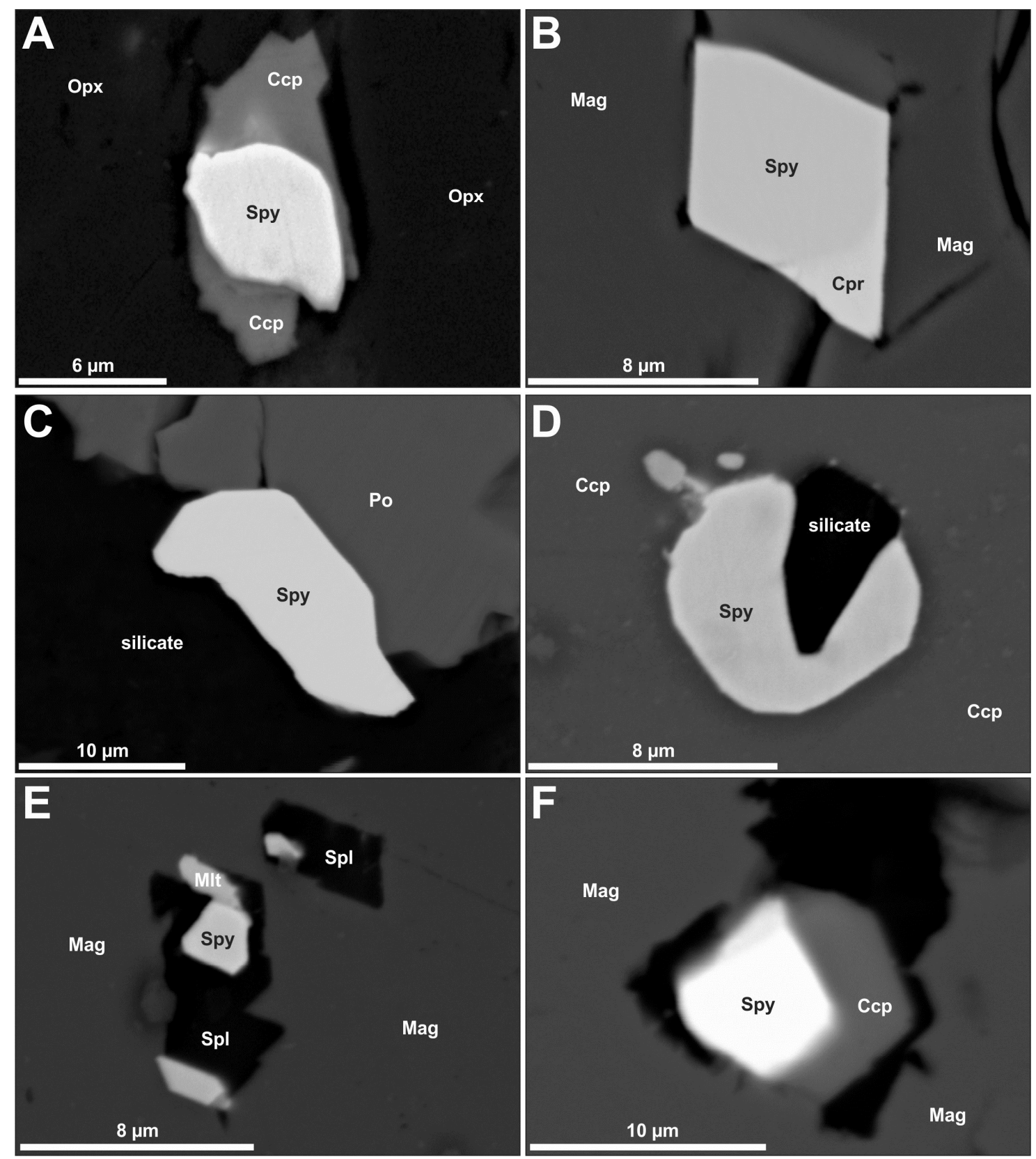

Fig.3.9 Back scattered electron images of: (A) Subhedral sperrylite (Spy) in contact with and partially surrounded by chalcopyrite (Ccp), both enclosed by silicate forming an orthopyroxenite containing disseminated sulfides, sample 213185.00, grain \# 35. (B) Euhedral sperrylite with a typical diamond shape, forming a composite grain with cooperite (Cpr), both enclosed by magnetite (Mag) in an orthopyroxenite containing disseminated sulfides, sample 213-185.00, grain \# 3. (C) Subhedral sperrylite at the contact between BMS and a silicate in an orthopyroxenite containing disseminated sulfides, sample 002-125, grain \# 1. (D) Anhedral to subhedral sperrylite in contact with a silicate, both enclosed by chalcopyrite in an orthopyroxenite containing disseminated sulfides, sample 213-185.00, grain \# 29. (E) Euhedral sperrylite forming a composite grain with melonite (Mlt), both included in a spinel (Spl) grain (probably derived during metamorphism of chromite) in an orthopyroxenite containing disseminated sulfides, sample 213-185.00, grain \# 21. (F) Euhedral sperrylite in contact with chalcopyrite, both enclosed by magnetite in an orthopyroxenite, sample 213-185.00, grain \# 11. Mineral symbols mostly from Whitney and Evans (2010) and alternatively based on Kretz (1983) and Spear (1993) when not found in the first listing 

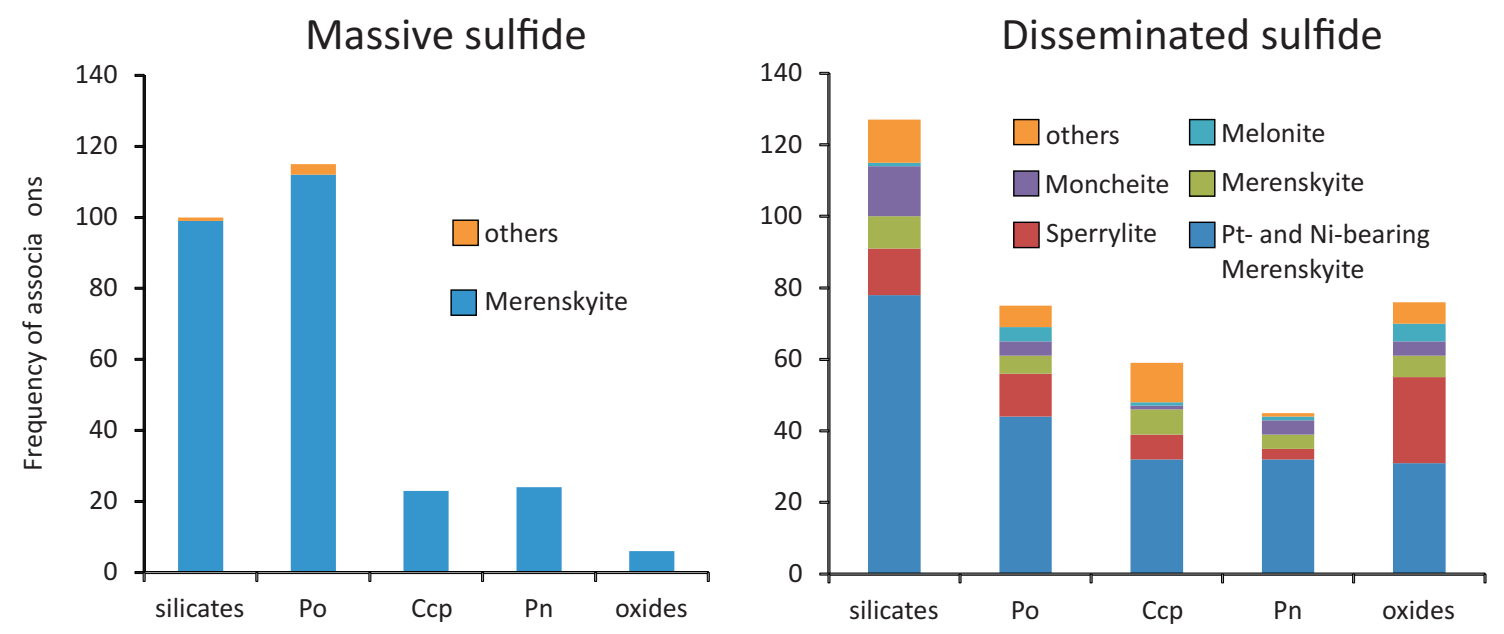

Fig.3.10 Bar charts showing the frequency of each mineral phase in contact with the PGM from the Limoeiro Ni-Cu(PGE) sulfide deposit

In contrast, the silicate minerals in disseminated sulfide ores are the most common host for the PGM. This preference is followed by the occurrence of PGM in order of decreasing abundance in oxides, pyrrhotite, chalcopyrite, and pentlandite (Fig. 3.10). This pattern underpins the observation that the PGM, despite having a close spatial relationship with BMS, are commonly situated in contact with other phases. Sperrylite is preferentially hosted by oxides (Fig. 3.10), partly because the most sperrylite-rich sample $213-185.00$ is a magnetite-rich orthopyroxenite (Table 3.2). It is also clear that the group of less common PGM (classified as "others" in Fig. 3.10) has a preferential association with chalcopyrite.

These patterns of association of the PGM described above are related to different textures and fabrics. The most common textures identified are i) PGM on the margin of BMS, ii) enclosed by the BMS, and iii) enclosed by silicate or oxide minerals. Less common textures are iv) PGM in sulfide veinlets, v) on the edge of BMS but where PGM show irregular reaction boundaries with the adjacent mineral phase, and vi) elongate PGM associated with sulfides within silicate cleavages (Fig. 3.11). Compared to disseminated ores, massive sulfides have more abundant PGM enclosed by BMS. In contrast PGM enclosed by silicates or oxides are much more frequent in disseminated ores (Fig. 3.11). 


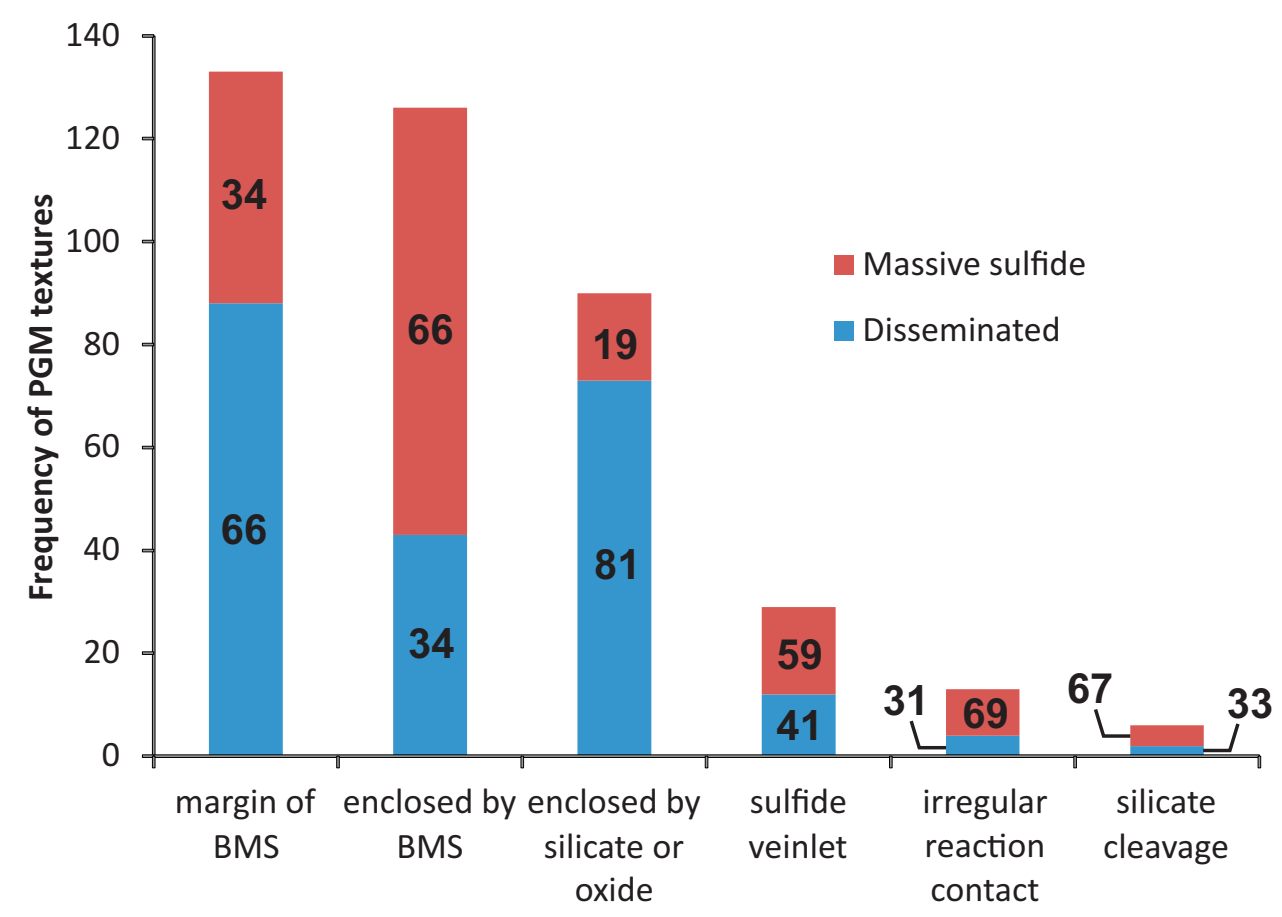

Fig.3.11 Bar chart showing the frequency of PGM in different textural sites in the Limoeiro Ni-Cu-(PGE) deposit. The numbers on the bars refer to the proportions (in \%) of massive and disseminated sulfide ore for each texture

The distributions of merenskyite and sperrylite in each of the distinct textural types also show a pattern (Fig. 3.12). Sperrylite occurs mainly enclosed by silicate or oxide and less frequently at the margin of BMS or more occasionally enclosed by BMS. Merenskyite occurs in all these textual settings but is most frequently enclosed by BMS and unlike sperrylite also occurs in sulfide veinlets, with irregular reaction boundaries and as elongate crystals associated with sulfides within silicate cleavages (Fig. 3.12).

BMS that enclose PGM occur either as sulfide blebs included within primary silicate minerals (Fig. 3.13A), or as interstitial minerals between cumulus silicates (Fig. 3.13B). Although it is common to find PGM enclosed by BMS in massive sulfide ores in the Retiro target, they are also commonly in contact with rounded silicate inclusions (Fig. 3.8A and B). The PGM that are situated on the edges of BMS grains have euhedral to subhedral forms and their grains commonly cross BMS boundaries and extend into adjacent mineral phases (silicates of magmatic or high grade metamorphic origin; Fig. 3.9C and Fig. 3.13C and D). PGMs on the margins of BMS grains frequently have an irregular contact with the adjacent mineral phase, which suggests a reaction relationship between the phases. In such cases it is common for the 
PGM to be associated with hessite, forming composite grains. This texture commonly occurs where the PGM is in direct contact with low grade metamorphic or hydrothermal minerals, such as antigorite (Fig. 3.13E). It also occurs where primary sulfide blebs within orthopyroxene grains have been affected by late-magmatic or hydrothermal sulfide remobilization (Fig. 3.13F). The PGM located within chalcopyrite or pentlandite veinlets generally occupy the whole width of the veinlet, and generally have irregular forms and crosscut the primary pyrrhotite and silicate grains (Fig. 3.13G) or take the place of pre-existing fractures in magnetite (Fig. 3.13H). PGM within sulfides filling spaces in silicate cleavages occur hosted in primary orthopyroxene grains (Fig. 3.13I) whether they are deformed or not, and also in high grade metamorphic amphibole (Fig. 3.13J). PGM enclosed by silicates or oxides can be surrounded by primary mineral phases (Fig. 3.9E; Fig. 3.13K) or by low grade metamorphic or hydrothermal minerals, such as antigorite (Fig. 3.13L). In these cases the PGM are not in direct contact with the BMS but are still in close proximity.

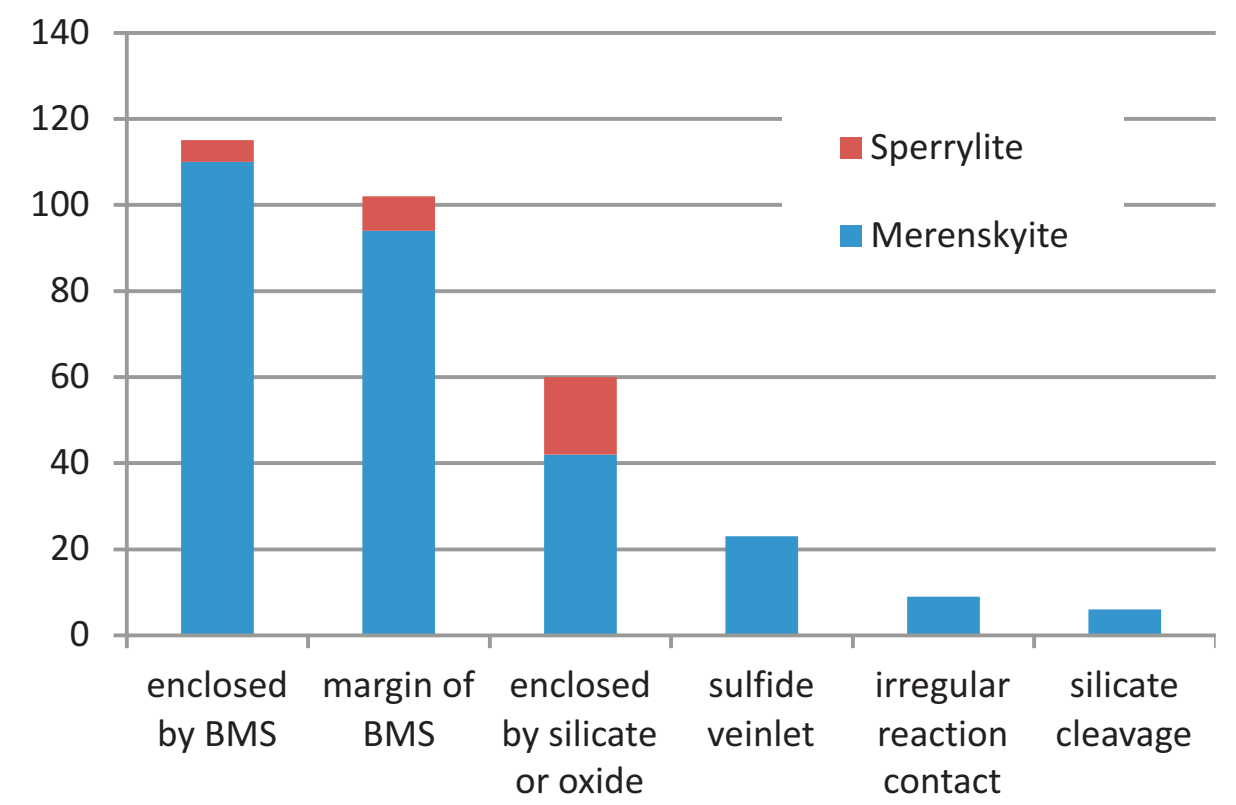

Fig.3.12 Bar chart showing merenskyite and sperrylite abundances for each texture in the Limoeiro Ni-Cu-(PGE) deposit. These minerals are the two most abundant PGM phases in the Limoeiro deposit 

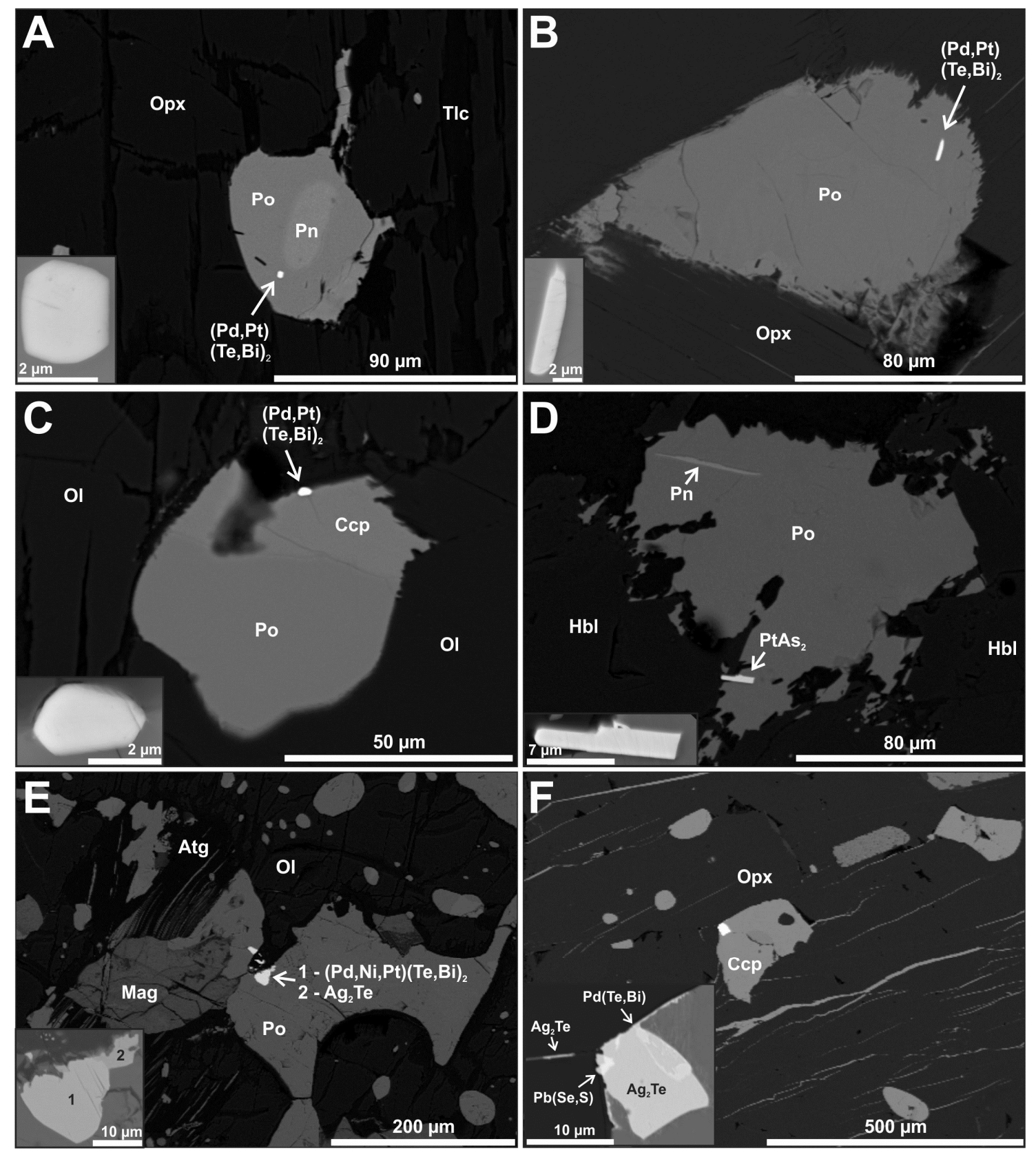

Fig.3.13 Back scattered electron images of: (A) An euhedral merenskyite enclosed by a BMS bleb included in an orthopyroxene (Opx), itself partly altered to talc (Tlc), in sample 018-155, grain \# 9. (B) An elongate merenskyite enclosed by a partly remobilized intercumulus BMS surrounded by orthopyroxene grains in sample 004-087, grain \# 14 . (C) A subhedral merenskyite located between a BMS bleb surrounded by olivine that is partly serpentinized in sample 018-155, grain \# 17. (D) A subhedral elongate sperrylite (Spy) crystallized on the edge of a pyrrhotite (Po) and in contact with metamorphic hornblende $(\mathrm{Hbl})$ in sample 002-125, grain \# 25. (E) A composite grain (merenskyite + hessite) at the edge of a pyrrhotite showing an irregular corroded contact with antigorite (Atg) in sample 021-137, grain \# 6. (F) A composite grain (merenskyite + hessite) at the edge of a chalcopyrite (Ccp) bleb showing an irregular corroded contact with the host orthopyroxenite that is itself crosscut by several veinlets containing remobilized sulfide in sample 213-185.00, grain \# 30. Mineral symbols mostly from Whitney and Evans (2010) and alternatively based on Kretz (1983) and Spear (1993) when not found in the first listing 

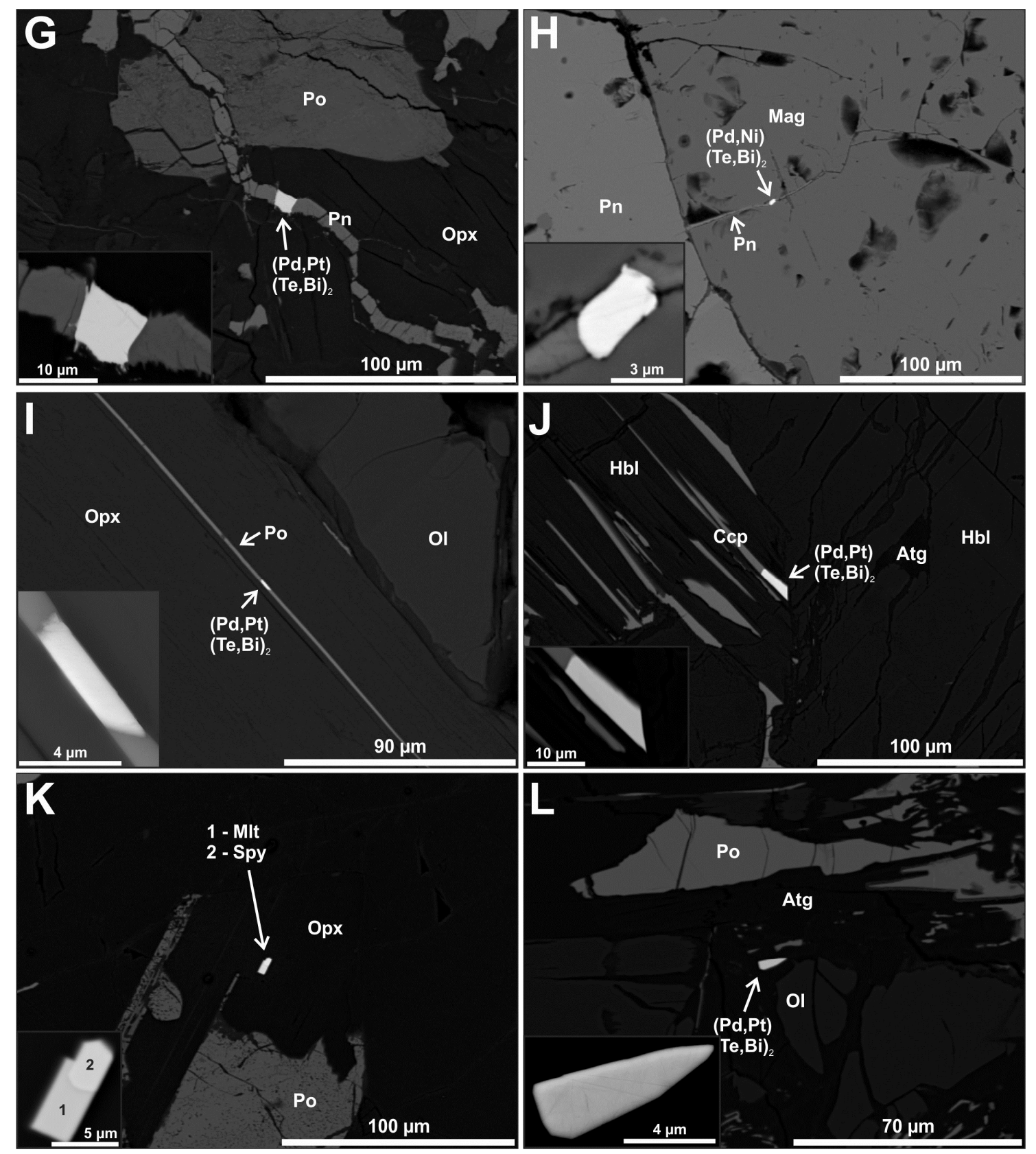

Fig.3.13 cont. (G) A merenskyite grain within a pentlandite (Pn)-filled veinlet in sample 021-137, grain \# 1. (H) A merenskyite grain within a pentlandite-filled veinlet that occupies a fracture crosscutting a magnetite (Mag) grain in sample 213-185, grain \# 66. (I) An elongate merenskyite grain within pyrrhotite (Po) situated in orthopyroxene (Opx) cleavage in sample 004-087, grain \# 12. (J) An elongate merenskyite grain with chalcopyrite (Ccp) located in a metamorphic hornblende ( $\mathrm{Hbl}$ ) cleavage in sample 004-067, grain \# 1. (K) An euhedral composite grain [sperrylite (Spy) + melonite (Mlt)] enclosed by orthopyroxene in sample 213-185, grain \# 33. (L) An elongate merenskyite grain enclosed by antigorite (Atg) in sample 055-228, grain \# 10 


\section{Merenskyite cryptic variation}

Merenskyite $\left(\mathrm{PdTe}_{2}\right)$ occurs in continuous solid solution with melonite $\left(\mathrm{NiTe}_{2}\right)$ and moncheite ( $\mathrm{PtTe}_{2}$; Barkov et al. 2002; Cabri, 2002). Merenskyite grains within any individual massive sulfide ore sample have a very similar, homogeneous composition, but merenskyite in massive sulfide ores shows a systematic variation throughout the chonolith that hosts the Limoeiro deposit. Merenskyite within the mineralized Upper sequence is richer in $\mathrm{Pt}$ and $\mathrm{Ni}$ in the west (Retiro; most primitive), but is richer in Pd in the east (Piçarra; most fractionated), ranging from $\left(\mathrm{Pd}_{0.42}, \mathrm{Ni}_{0.33}, \mathrm{Pt}_{0.21}, \mathrm{Fe}_{0.06}\right)\left(\mathrm{Te}_{1.64}, \mathrm{Bi}_{0.33}\right)$ to $\left[\left(\mathrm{Pd}_{0.84}, \mathrm{Pt}_{0.15}, \mathrm{Ni}_{0.03}\right)\left(\mathrm{Te}_{1.65}, \mathrm{Bi}_{0.33}\right)\right.$ (Fig. 3.14). A different composition, poorer in $\mathrm{Pt}$ and/or $\mathrm{Ni}$, occurs in mobilized massive sulfide in the Transition Zone in the Piçarra target, ranging from $\left(\mathrm{Pd}_{1.02}\right)\left(\mathrm{Te}_{1.14}, \mathrm{Bi}_{0.84}\right)$ to $\left(\mathrm{Pd}_{0.90}, \mathrm{Fe}_{0.13}, \mathrm{Ni}_{0.07}\right)\left(\mathrm{Te}_{1.46}, \mathrm{Bi}_{0.44}\right)$ (Fig. 3.4D; Fig. 3.14).

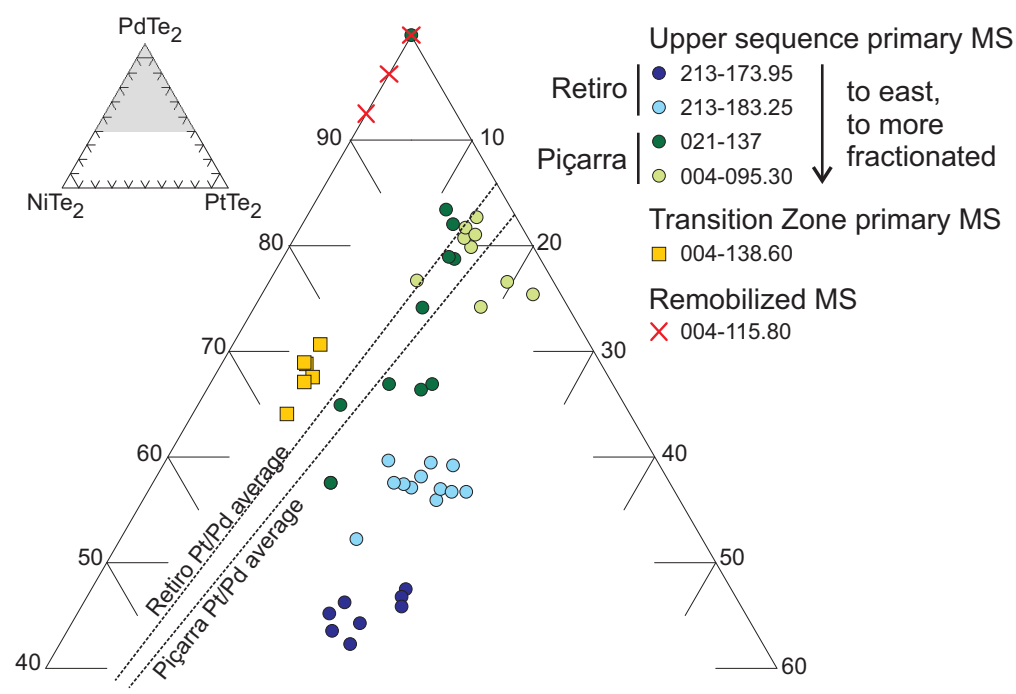

Fig.3.14 Compositional variation of PGM belonging to the solid solution series of melonite, merenskyite and moncheite in the Limoeiro $\mathrm{Ni}-\mathrm{Cu}(\mathrm{PGE})$ sulfide deposit. Results of 60 analyses are projected onto the Ni-Pd-Pt ternary diagram (atomic proportions). The dashed line indicates the average $\mathrm{Pt} / \mathrm{Pd}$ atomic ratio for the two main Limoeiro deposit targets. "MS" = massive sulfide

The $\mathrm{Te} / \mathrm{Bi}$ atomic ratio does not show a change between the most primitive and most fractionated primary massive sulfide samples, although the merenskyite analyses from the sheared massive sulfide sample (004-115.80) are considerably more Bi-rich and form a separate cluster of plots on the Te/Bi biplot (Fig. 3.15). 
Two merenskyite grains in primary massive sulfide sample 021-137 have similar compositions to the merenskyite grains in the sheared massive sulfide sample 004-115.80. These two particular grains are hosted within a chalcopyrite veinlet that crosscuts silicates.

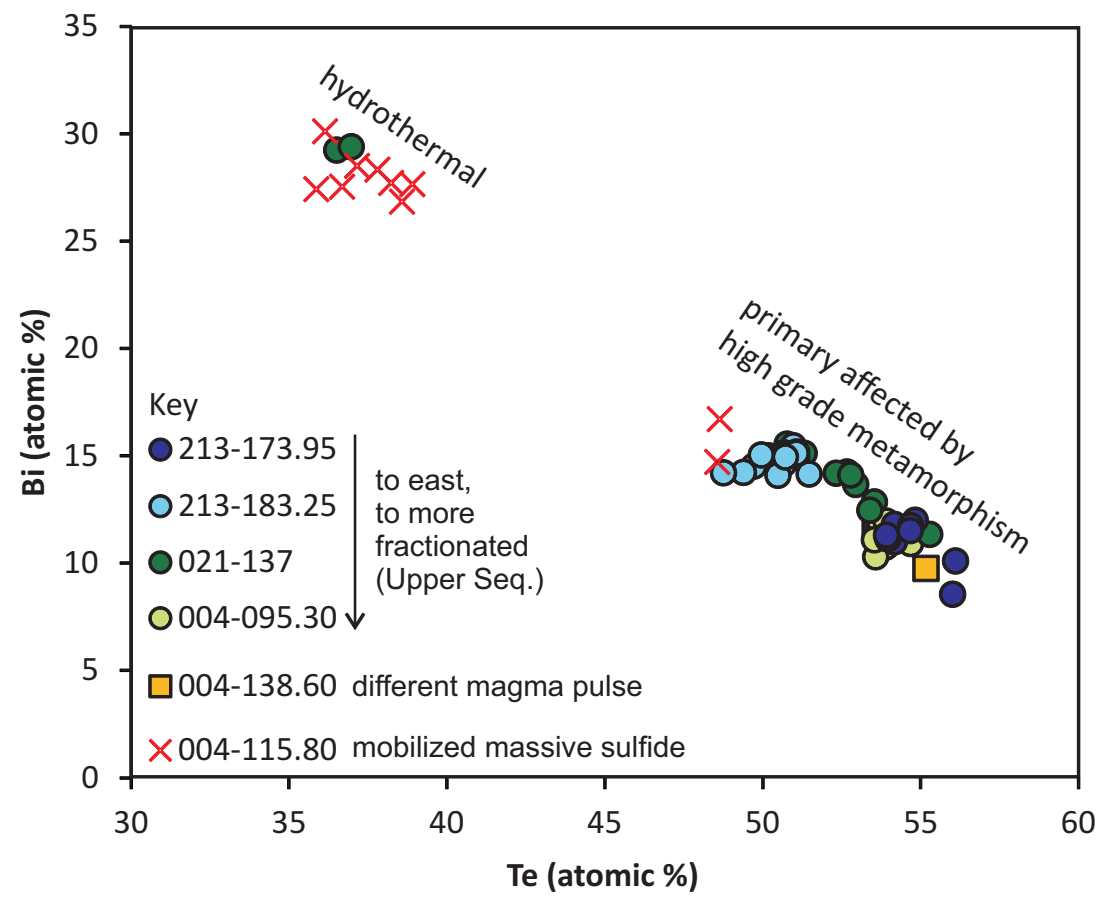

Fig.3.15 Compositional Te and Bi variation of 60 merenskyite grains in the Limoeiro Ni-Cu(PGE) sulfide deposit. "MS" = massive sulfide

Merenskyite in disseminated sulfides is compositionally very variable within any individual sample and no trends or systematic changes in compositions could be identified between different parts of the chonolith.

\section{PGE in the base metal sulfide}

PGE, other associated metals and their most important ligands (e.g., Te, Bi, As, S, Sb, Se) were analyzed in pyrrhotite, pentlandite, and chalcopyrite in the massive sulfide samples from the Limoeiro deposit. Several elements were shown to have concentrations below the lower limits of detection (LLD) of the analytical method and some others show great variability 
between analyses, so only some analyses are interpretable (Table 3.4). Palladium and Co appear to be concentrated in pentlandite where they have concentrations in the order of $\sim 6 \mathrm{ppm}$ and $\sim 1.2 \mathrm{wt} \%$, respectively. Zinc, Ag, and Cd appear to be most concentrated in chalcopyrite > pentlandite pyrrhotite. Concentrations of $\mathrm{Pt}, \mathrm{Ir}$, Os, Ru and Rh are mainly below LLD. Based on the few analyses above the LLD, it appears that the little Ru and Rh are present in solid solution, as micronuggets or nanonclusters (see Helmy et al., 2013) in BMS, mostly in pentlandite. The little $\mathrm{Pt}$, Ir and Os that are present occur in pyrrhotite and pentlandite, but not in chalcopyrite. Cobalt, Pd, Zn, Ag, Cd, Pt, Ir, Os, Ru and Rh appear to be more concentrated in the Piçarra BMS rather than in Retiro BMS. Selenium has similar values for all three BMS and constant concentrations in the two different drilling targets. Bismuth is more concentrated in chalcopyrite, and it seems to be the only trace element that is more concentrated in the Retiro BMS compared to the Piçarra BMS. Tellurium does not show a clear pattern, except that chalcopyrite is the only BMS with detectable amounts of Te for both drilling targets.

Table 3.4 - Summary of average and 1 standard deviation of PGE and other metal and semimetal concentrations (in ppm) in the BMS.

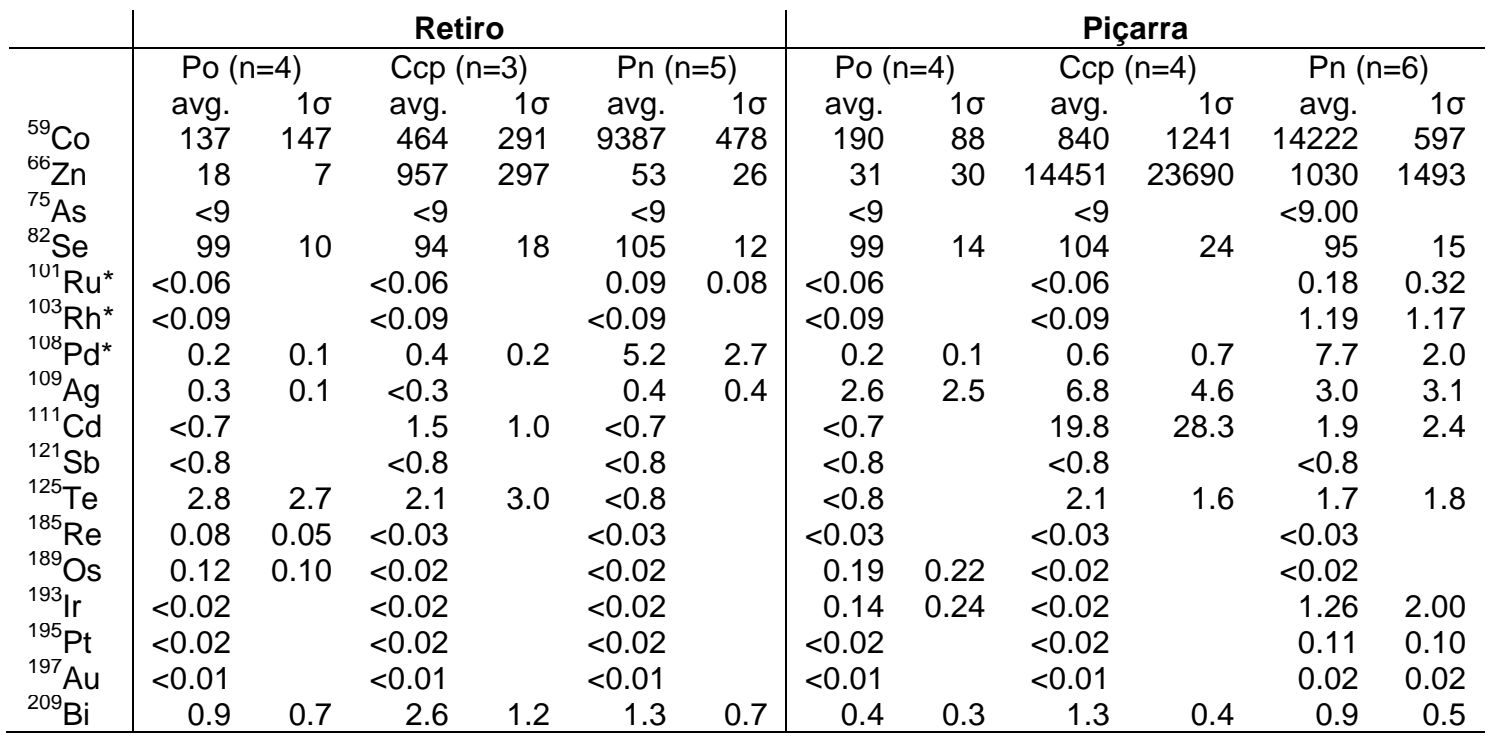

The BMS: Po, pyrrhotite; Ccp, chalcopyrite; Pn, pentlandite. The $\left(^{*}\right)$ indicates the isotopes that were corrected for interferences. 


\section{Mass balance calculation}

A mass balance calculation was carried out to determine which of the BMS concentrates each of the PGE and to determine the total amount of PGE in BMS. This mass balance must be regarded as an approximation because of the doubtful representativeness of the small sample contained in the thin sections relative to the bulk deposit mineralogy, relatively large analytical uncertainties, and high variability of metal content in each of the BMS minerals.

The relative abundances of the BMS are essential to the mass balance calculation, as each of them has a distinct PGE content. Using the VM half drill core assay database, Mota-eSilva and Ferreira Filho (unpublished) calculated the tenors (grades normalized to 100 vol\% sulfides) for the Piçarra and Retiro targets, extending the linear correlation line of $\mathrm{Ni}, \mathrm{Cu}, \mathrm{Pd}$ and Pt versus S up to $37 \mathrm{wt} \% \mathrm{~S}$, which is approximately the expected grade for a rock containing 100 vol\% of magmatic sulfides in Limoeiro (i.e., pyrrhotite $>>$ pentlandite $\sim$ chalcopyrite $>>$ magnetite; for Limoeiro ore mineralogy description see Mota-e-Silva et al. 2013). The Limoeiro deposit is 97 vol\% composed of a disseminated sulfide orebody (Mota-e-Silva et al. 2013), in which the sulfide content varies from 2 to 55 vol\%. Thus using a linear regression of metal data $(\mathrm{Ni}, \mathrm{Cu}, \mathrm{Pd}$ and $\mathrm{Pt}$ ) versus $\mathrm{S}$ is a robust method to calculate tenors (Kerr, 2001). Typical and generic compositions for BMS were used, as the Limoeiro BMS compositions were not determined. All $\mathrm{Cu}$ and $\mathrm{Ni}$ were allocated in chalcopyrite and pentlandite respectively and the remainder of the $\mathrm{S}$ was admitted as pyrrhotite (e.g., Naldrett, 1981). Therefore tenor and proportions of pyrrhotite, chalcopyrite and pentlandite were calculated for the Retiro and Piçarra targets and are given in Table 3.5. Multiplying the BMS abundances by the Pd content within the BMS recorded in the LA-ICPMS analyses, it is possible to calculate how much Pd should be in each of the BMS in a hypothetical rock composed of 100 vol\% magmatic sulfides. This value can be compared with the Pd tenor calculated by Mota-e-Silva and Ferreira Filho (unpublished; Table 3.5). The difference between the two values should be related to the amount of Pd accommodated in discrete PGM grains. The result is that $84-88 \%$ of the Pd is in PGM, and $12-$ $16 \%$ of the Pd is in the BMS (Table 3.5). 
Table 3.5 - Calculated Ni, $\mathrm{Cu}, \mathrm{Pd}$ and Pt tenors (from Mota-e-Silva and Ferreira Filho, unpublished), estimation of BMS proportions in the sulfide fraction, concentration of Pd for each BMS in a 100 vol\% sulfide rock and the partitioning of $\mathrm{Pd}$ between BMS and PGM.

\begin{tabular}{r|rr}
\multicolumn{1}{c|}{ Tenor } & \multicolumn{2}{|c}{ Drilling target } \\
& Retiro & Piçarra \\
\hline Ni wt\% & 5.6 & 3.0 \\
Cu wt\% & 5.7 & 4.5 \\
Pd ppm & 8.7 & 5.5 \\
Pt ppm & 2.7 & 2.1 \\
\hline Po (vol.) & $67 \%$ & $78 \%$ \\
Ccp (vol.) & $16 \%$ & $13 \%$ \\
Pn (vol.) & $16 \%$ & $9 \%$ \\
\hline Pd (ppm) in Po & 0.1 & 0.1 \\
Pd (ppm) in Ccp & 0.1 & 0.1 \\
Pd (ppm) in Pn & 0.9 & 0.7 \\
Pd (ppm) in BMS & 1.1 & 0.9 \\
\hline Pd in BMS & $12 \%$ & $16 \%$ \\
Pd in PGM & $88 \%$ & $84 \%$ \\
\hline
\end{tabular}

The BMS: Po, pyrrhotite; Ccp, chalcopyrite; Pn, pentlandite.

\section{Whole rock chemistry}

The Piçarra sulfide mineralization has lower tenors and higher $\mathrm{Cu} / \mathrm{Pd}$ and $\mathrm{Ni} / \mathrm{Cu}$ ratios than Retiro (Table 3.5), which indicates that it formed from a more fractionated silicate magma (Mota-e-Silva and Ferreira Filho, 2013). The whole rock Pt/Pd weight ratio for Piçarra (0.38) is slightly but consistently higher than for the Retiro target (0.33; Fig. 3.16). Pt and Pd are strongly correlated in both the Retiro $\left(R^{2}=0.78\right)$ and Piçarra orebodies $\left(R^{2}=0.88\right)($ Fig. 3.16).

To investigate the samples that fall away from the linear trend line shown in Fig. 3.16, a plot of $\mathrm{MgO}$ versus $\mathrm{Pt} / \mathrm{Pd}$ ratio has been constructed separating the four different lithologies in the Limoeiro Ni-Cu-(PGE) sulfide deposit (Fig. 3.17). The vast majority of the whole rock samples plot generally close to the average $\mathrm{Pt} / \mathrm{Pd}$ ratio for the deposit $(0.35)$, but the amphibolite deviates from most of the other lithologies (higher $\mathrm{Pt} / \mathrm{Pd}$ ratio). The two samples with the highest $\mathrm{Pt} / \mathrm{Pd}$ ratios are phlogopite-bearing rocks affected by tectonic deformation. 

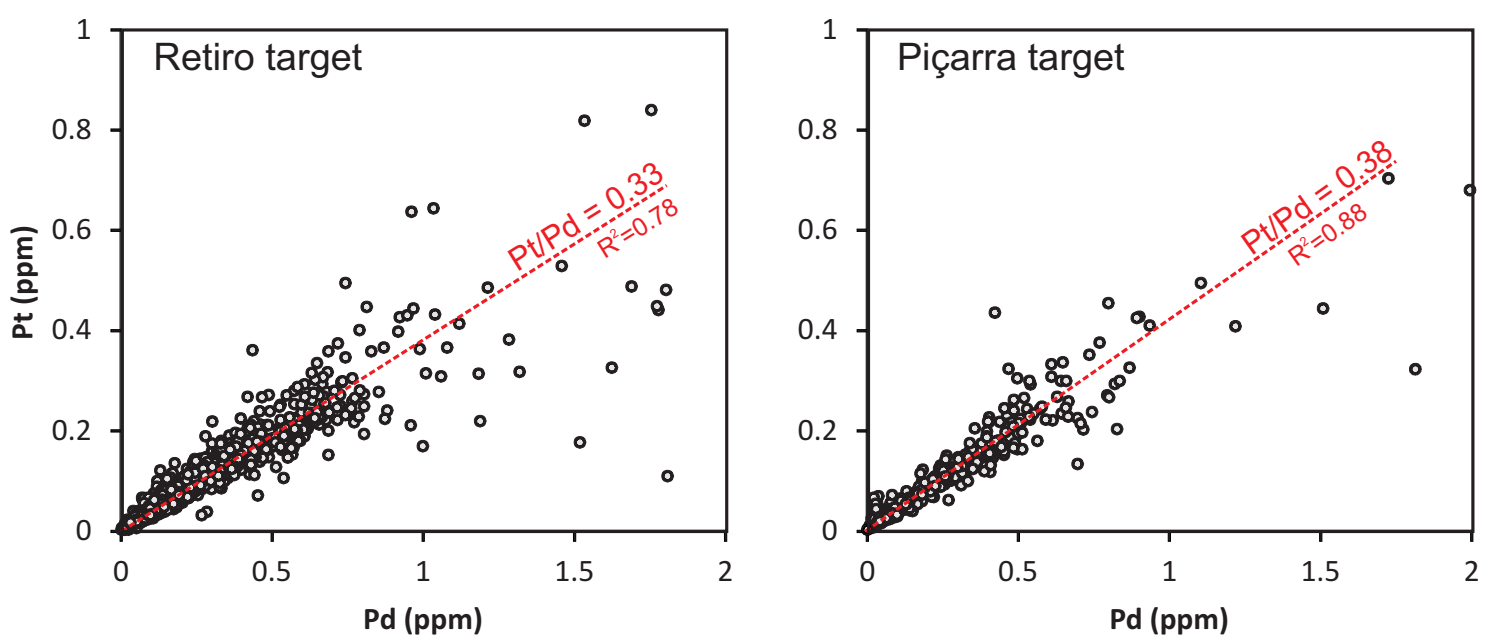

Fig.3.16 Whole rock Pt and Pd contents of 2006 samples from the two main targets in the mineralized Upper sequence of the Limoeiro Ni-Cu-(PGE) deposit. The linear trend (red dashed line) indicates the average Pt/Pd ratio. Data from the VM drilling assay database

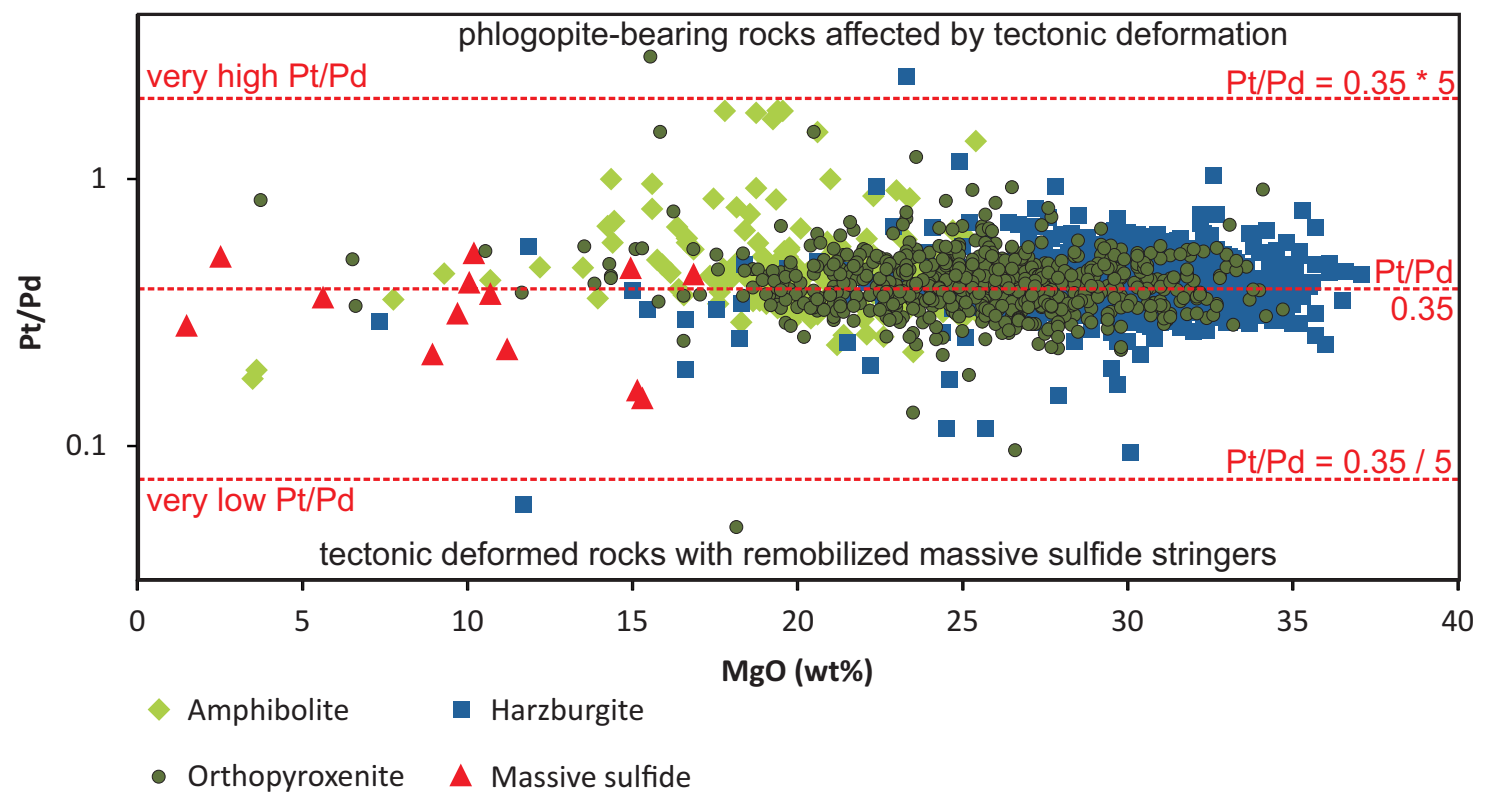

Fig.3.17 Whole rock $\mathrm{MgO}$ content versus Pt/Pd weight ratio biplot of 2006 samples from different lithologies from the mineralized Upper sequence of the Retiro and Piçarra targets in the Limoeiro Ni-Cu-(PGE) deposit. The central red dashed line represents the bulk deposit average $\mathrm{Pt} / \mathrm{Pd}$ weight ratio. The top and bottom red dashed lines are respectively 5 times and a fifth of the average $\mathrm{Pt} / \mathrm{Pd}$ weight ratio and are plotted as a reference for the identification of the samples with relatively high and low Pt/Pd weight ratios. The text in black refers to the four samples (two at the top and two at the bottom) that are outside the red dashed lines. The Pt/Pd weight ratio values are plotted on a base 10 logarithmic scale. Data from the VM drilling assay database

In contrast, but showing a less clear pattern, most of massive sulfides have lower $\mathrm{Pt} / \mathrm{Pd}$ ratios. The two samples that plot below the bottom line (5 times less than the average 
$\mathrm{Pt} / \mathrm{Pd}$ ratio) are tectonically deformed rocks with mobilized massive sulfide stringers. Sample 004-115.80, which is a typical mobilized massive sulfide (Fig. 3.4D), has grades of $3.4 \mathrm{Pd} \mathrm{ppm}$ and $0.22 \mathrm{ppm} \mathrm{Pt}$ with a $\mathrm{Pt} / \mathrm{Pd}$ ratio of 0.06 , similar to the two tectonically deformed rocks with mobilized massive sulfide stringers noted above. Sample 004-115.80 is not plotted on Fig. 3.17, due to its stratigraphic position in the Transition Zone.

\section{Discussion}

\section{The role of the primary magma in formation of the PGM}

The processes by which PGE are transferred from a magma to a sulfide liquid and subsequently incorporated into monosulfide solid solution (MSS) and/or intermediate solid solution (ISS) have been discussed by Li et al. (1996), Naldrett et al. (2004), Sinyakova and Kosyakov (2007), Helmy et al. (2010), Holwell and McDonald (2010), and Liu and Brenan (2012). PGE-bearing bismuthotellurides in Limoeiro ores are strongly associated with BMS (Fig. 3.10) mainly situated at the edge of sulfide blebs and intercumulus BMS, or completely enclosed by the BMS (Fig. 3.11). Many other deposits with similar PGM textures have been interpreted to have formed through exsolution of the PGE from BMS during cooling at temperatures $<650^{\circ} \mathrm{C}$ (e.g., Barnes et al. 2008; Prichard et al. 2013). Such a process has been confirmed experimentally (e.g., Makovicky et al. 1990; Helmy et al. 2007).

The Limoeiro parental magma was relatively enriched in $\mathrm{Te}$ and $\mathrm{Bi}$ compared to the other typical PGE ligands (Sb, As, S, and Se), given the strong dominance of bismuthotellurides $(87 \%)$ in the PGM assemblage. This interpretation relies on the fact that the BMS are essentially composed of the common magmatic assemblage (pyrrhotite, chalcopyrite, and pentlandite; Mota-e-Silva et al. 2013), and the strong correlations between Pt and Pd (Fig. 3.16) are suggestive of a magmatic geochemical signature characterizing the mineralization. Additionally the S/Se ratio varies between 3200 and 3800 (Table 3.4) in the Limoeiro BMS, which is within the normal mantle range variation (Lorand et al. 2003). This shows that no post- 
magmatic S-loss or S-gain occurred throughout the Limoeiro deposit. The high grade metamorphism did not mobilize the chalcogenes, semimetals or metals in Limoeiro deposit. Thus the ore geochemical characteristics must be interpreted in the light of magmatic processes. It is known that country rock contamination has an influence on the semimetal and metal content in mafic magmas (e.g., Ames and Farrow, 2007; Hutchinson and McDonald, 2008; Godel et al. 2012). In Sudbury, Canada, for example, the PGM assemblage is influenced by the semimetal content in the underlying source rock with As being more abundant on the south side of the complex compared to the northern ranges (Cabri and Laflamme, 1976; Ames et al. 2008; Dare et al. 2010a). It has been speculated that the country rock associated with the Limoeiro deposit, a sulfide-bearing paragneiss, could have provided an external source of $S$ for the Limoeiro mafic magma, which is supported by the occurrence of xenoliths of paragneiss at the base of some massive sulfide layers (Mota-e-Silva et al. 2013). It is known that $\mathrm{Te}$ and $\mathrm{Bi}$ occur in the order of 1-10 ppb in basalts; in sedimentary rocks, however, especially those derived from carbonaceous sediments, $\mathrm{Te}$ and $\mathrm{Bi}$ concentrations have a background of tens of ppm (Santoliquido and Ehmann, 1972; Beaty and Manuel, 1973). We hypothesize that the paragneiss country rock, which contains several calc-silicate layers (high grade metamorphic product of carbonaceous sediments; Mota-e-Silva et al. 2013), has contaminated the Limoeiro mafic magma with a significant input of $\mathrm{Te}$ and $\mathrm{Bi}$, which were later hosted by bismuthotelluride PGM formed by exsolution from BMS at temperatures $<650^{\circ} \mathrm{C}$.

At Limoeiro, the interpreted fractionation vector is eastwards (from the Retiro target in the west to the Piçarra target in the east; Mota-e-Silva and Ferreira Filho, 2013). Thus the sulfides in samples 213-183.25 and 213-173.95 from Retiro segregated from more primitive silicate magma than those in sample 021-137 from the west part of Piçarra, which is more primitive than sample 004-095.30 from the central part of Piçarra. The orebodies in the most fractionated part to the east have lower tenors of $\mathrm{Ni}, \mathrm{Cu}, \mathrm{Pd}$ and $\mathrm{Pt}$ compared to those to the west (Table 3.5).This geochemical contrast is also recorded by typical geochemical proxies $(\mathrm{Ni} / \mathrm{Cu}$ and $\mathrm{Cu} / \mathrm{Pd})$ used to identify levels of previous sulfide segregation in magmatic systems (e.g., Barnes et al. 1993; Barnes and Lightfoot, 2005). The Ni/Cu ratio decreases from 0.99 to 0.66 and the $\mathrm{Cu} / \mathrm{Pd}$ ratio increases from $\sim 6500$ to $\sim 8200$ to the east (Table 3.5). It is possible to assume similar R- and $\mathrm{N}$-factors (i.e., proportions between silicate magma and sulfide liquid, 
and their degree of interaction; see review by Naldrett, 2004) for the Piçarra and Retiro orebodies, because they are adjacent portions of the same magma conduit (Fig. 3.2).

Previous work has shown the existence of a continuous solid-solution series between merenskyite and melonite, and between merenskyite and moncheite (e.g., Garuti and Rinaldi 1986, Hudson 1986, Harney and Merkle 1990). Compositions containing all three members (merenskyite, melonite, and moncheite), including one analysis with exactly equal proportions of each have been observed in the Wellgreen Ni-Cu-PGE deposit, Canada (Barkov et al. 2002). The minerals in that study consist of members of the merenskyite-moncheite series, which are relatively enriched in melonite (10 to $30 \mathrm{~mol} . \%$ ). In contrast, at Limoeiro the grains have compositions lying completely within the merenskyite field, but varying from a zone relatively close to the center of the triangle ( $\sim 33 \mathrm{~mol} . \%$ melonite, $\sim 42 \mathrm{~mol} . \%$ merenskyite, and $\sim 21 \mathrm{~mol} . \%$ moncheite) to the merenskyite apex but still containing some Pt ( 3 mol.\% melonite, 84 mol.\% merenskyite and $\sim 15$ mol.\% moncheite) (Fig. 3.14). Thus, the analyses presented in this study occupy an area of the triangle where there have been no previous compositions published. This extends the field for the merenskyite-melonite-moncheite solid solution system beyond that which was previously known. As merenskyite appears to have exsolved from BMS, its compositional variation along the fractionation trend reflects the variation that was in the sulfide melt. The sharp decrease of $\mathrm{Ni}$ content in the merenskyite towards the eastern parts of the chonolith (Fig. 3.14) is expected as the sulfide liquid segregated from a more fractionated Ssaturated magma containing lower base metals tenors (assuming that $\mathrm{R}$ - and $\mathrm{N}$-factors are constant). This Ni-depletion in the sulfide liquid segregated to the east is expressed by a lower pentlandite content (Table 3.5).

The massive sulfide ore sample $004-138.60$ represents a different magma pulse as it is situated in the Transition Zone (Fig. 3.6) rather than in the Upper sequence. The composition of merenskyite in this zone plots in a distinct field that is clearly Pt and/or Ni depleted compared to merenskyite in massive sulfide ore in the Upper sequence (Fig. 3.14). The Limoeiro deposit is considered to result from the input of two major pulses of magma with similar compositions that formed the Upper and Lower sequences (Mota-e-Silva et al. 2013). Considering the compositional differences in merenskyite, it is likely that the magma that formed the Transition 
Zone of the Limoeiro deposit was slightly depleted in Pt and/or Ni. If the Transition Zone was depleted in $\mathrm{Pt}$, it is possible that sperrylite may have segregated from the silicate magma (Ballhaus and Sylvester, 2000; McDonald, 2008) or from the sulfide liquid (Dare et al. 2010a). Alternatively, the Transition Zone could be Ni-depleted due to later-stage sulfide saturation after segregation of Ni-bearing silicate minerals (mainly olivine). The different timing of sulfide saturation between the Upper sequence and the Transition Zone could be related to different levels of S-bearing host rock assimilation. The Upper sequence is generally thicker than the Transition Zone (Fig. 3.5), which responds to a more voluminous magma passing through that part of the conduit. More voluminous magma is more likely to promote higher heat conduction into the substrate and achieve turbulent flow conditions, which favors thermal erosion (Lesher et al, 2001).

The disseminated sulfide ore has a more diverse PGM assemblage with merenskyite accounting for $50 \%$ of the PGM grains, accompanied by appreciable amounts of sperrylite, kotulskite, and moncheite (Fig. 3.7; Table 3.2). The merenskyite grains located in the disseminated sulfide ore do not show the same compositional homogeneity within the same sample as the massive sulfide ore (Table 3.3). Fine sulfide droplets are more easily able to be transported than coarse sulfide droplets or blebs of massive sulfide melt (Lesher and Groves, 1986). The disseminated sulfide in the Limoeiro deposit is mainly formed by fine sulfide blebs between 50 and $400 \mu \mathrm{m}$ in size (Mota-e-Silva et al. 2013), which were probably transported by magma fluxing through relatively long horizontal distances in the dynamic and sub-horizontal conduit system until finally they were trapped as inclusions in the settling and crystallizing silicates. Thus, the disseminated sulfide ore is composed of sulfide blebs crystallized in diverse parts of the magma conduit that have interacted with different magma compositions. This magmatic origin for disseminated sulfide heterogeneity relies on the fact that disseminated sulfide blebs at Limoeiro still preserve their primary rounded geometry and mineralogy, which is composed of pyrrhotite ( 70vol\%), chalcopyrite ( 15vol\%) and pentlandite (15vol\%) (Mota-eSilva et al. 2013). On a larger scale however, the disseminated sulfide is chemically homogeneous, showing strong correlations $\left(\mathrm{R}^{2} \sim 0.9\right)$ of $\mathrm{S}$ versus $\mathrm{Ni}, \mathrm{Cu}$, Pd and Pt (Mota-eSilva and Ferreira Filho, unpublished), which also favors the dominance of magmatic processes. 
Arsenide is present in $8 \%$ of the PGM in the Limoeiro deposit. In contrast to the bismuthotellurides, the arsenides are rarely found enclosed by the BMS, but are more frequently found as euhedral to subhedral grains enclosed by silicate and oxide minerals or at the edge of BMS phases (Fig. 3.10 and Fig. 3.12). The phases that enclose the As-bearing sperrylite are primary magmatic orthopyroxene (Fig. 3.9A), magnetite crystals in sample 213185.00 (Fig. 3.9B and F) and euhedral spinel, which is believed to represent a metamorphic transformation from chromite (Fig. 3.9E; Mota-e-Silva, et al. 2013).

Inclusions of Pt-minerals in olivine and chromite were proposed to have formed by direct crystallization of PGM from the magma in the Merensky Reef (Ballhaus and Sylvester, 2000). However in the Limoeiro deposit the sperrylite included in such phases is generally accompanied by a small chalcopyrite grain (Fig. 3.9A and F). Dare et al. (2010b) working at the Creighton Ni-Cu-PGE sulfide deposit, Sudbury, Canada, suggested that sperrylite and other sulfarsenides crystallized directly from the sulfide melt at temperatures above $1000{ }^{\circ} \mathrm{C}$. Similar processes have also been proposed for part of the arsenide assemblage in the Great Dyke of Zimbabwe (Coghill and Wilson, 1993), for arsenide and sulfarsenide minerals in the $\mathrm{Ni}-\mathrm{Cu}$ mineralizations at Dundonald Beach South, Abitibi Subprovince, in Canada (Hanley, 2007), formation of PGM in an As-rich magmatic sulfide system from the Talnotry diorite intrusion in Scotland (Power et al. 2004), and for the low sulfide, PGE-bearing rocks in the ultramafic complexes of Western Andriamena, Madagascar (McDonald, 2008). This last author suggested that the high As content in the initial sulfide melt promoted early crystallization of $\mathrm{Pt}$, Ir and $\mathrm{Rh}$ arsenide and sulfarsenide PGM, some of which segregated from the sulfide and were incorporated into growing olivine crystals. Examples of similar situations found elsewhere in the world and the textural associations at the Limoeiro deposit point towards the development of sperrylite predominantly by direct crystallization from sulfide melt. Sperrylite is the only arsenide identified at Limoeiro, and all LA-ICPMS analyses showed As to be below the LLD of 9ppm in the BMS (Table 3.4). This suggests that all the As was incorporated into sperrylite, whereas Pt was abundant enough to remain in the sulfide liquid and enter into the merenskyite composition at the point in time that it exsolved from the BMS at $<650^{\circ} \mathrm{C}$. The crystallization of sperrylite at high temperatures $\left(>1000^{\circ} \mathrm{C}\right)$ directly from sulfide melt has occasionally permitted sperrylite to form individual grains separated from sulfides by magma flow dynamics. The tiny sperrylite 
grains were kept in suspension within the magma as the flow dynamics can preferentially retain tiny grains compared with coarser sulfide liquid blebs that were partially accumulating at the bottom of the conduit to form the massive sulfide ore. This assumption possibly explains why no sperrylite was identified in the massive sulfide ore (Table 3.2). Alternatively, the massive sulfide layers represent MSS cumulates rather than the bulk sulfide liquid, and in this case, sperrylite may be included within the segregated intermediate solid solution (ISS). This possibility is supported by the observation that the massive sulfide ore of the Limoeiro deposit has high $\mathrm{Ni} / \mathrm{Cu}$ ratios (between 3 and 5 ) compared to the disseminated sulfide ( 0.75), suggesting that it represents MSS cumulates that segregated Cu-rich residual sulfide liquid (Mota-e-Silva and Ferreira Filho, unpublished). Whether sperrylite is concentrated within undiscovered Cu-rich ISS offshoots or is indeed restricted to disseminated sulfide due to magma flow dynamics, does not change the interpretation that the sperrylite crystallization conditions resulted in segregation from the sulfide blebs.

However, there are exceptions with a minority of the sperrylite grains present as anhedral rounded forms enclosed by BMS and in contact with an included silicate mineral (Fig. 3.9D), in a similar way to many of the merenskyite grains (Fig. 3.8A and B). These grains may represent a distinctly different generation of sperrylite and they might have been formed at a later-stage through exsolution from MSS that accounts for accommodation of the small amount of As and Pt that partitioned into MSS.

The bulk Pt/Pd ratio is 0.33 in the western ore body (Retiro), whereas it is 0.38 in the eastern ore body (Piçarra; Fig. 3.16) indicating an overall increase in Pt relative to $\mathrm{Pd}$ to the east. By contrast, merenskyite becomes poorer in Pt content to the east suggesting that the sulfide melt was relatively Pt-depleted in the eastern part of the intrusion (Fig. 3.14). The conduit narrows from Retiro (west) to Piçarra (east) and we suggest that the mafic magma assimilated considerable amounts of As-rich country rock as it travelled eastwards along the conduit. As the country rocks are basically the same at Piçarra and Retiro and the metamorphic alteration is also similar in both targets, it is likely the Piçarra rocks record a higher degree of country rock contamination relating to the presence of greater amounts of sulfide (Mota-e-Silva et al. 2013) and higher concentrations of $\mathrm{Zn}, \mathrm{Cd}$ and Ag in the BMS (Table 3.4). Thus, it seems 
likely that: i) during the magma flow from Retiro to Piçarra a significant amount of As was introduced from assimilation of the country rocks; ii) the As was then incorporated into the sulfide melts that were present in the S-saturated magma flow; and iii) the sulfide blebs crystallized early sperrylite due to As incompatibility in MSS (Hattori et al. 2002) and an affinity for Pt (Hutchinson and McDonald, 2008). Almost all the As was expended to produce the crystallization of sperrylite, but this was not enough to consume all the Pt from the sulfide liquid. The remaining $\mathrm{Pt}$ was later incorporated into the merenskyite as the system cooled to temperatures of $<650^{\circ} \mathrm{C}$. The higher $\mathrm{Pt} / \mathrm{Pd}$ ratio of $\mathrm{P}$ içarra compared to Retiro, is probably related to the greater abundance of sperrylite at Piçarra.

The magmatic processes described in the preceding sections and the metamorphic processes discussed in the sections that follow, are summarized in Fig. 3.18.

Intrusion scale

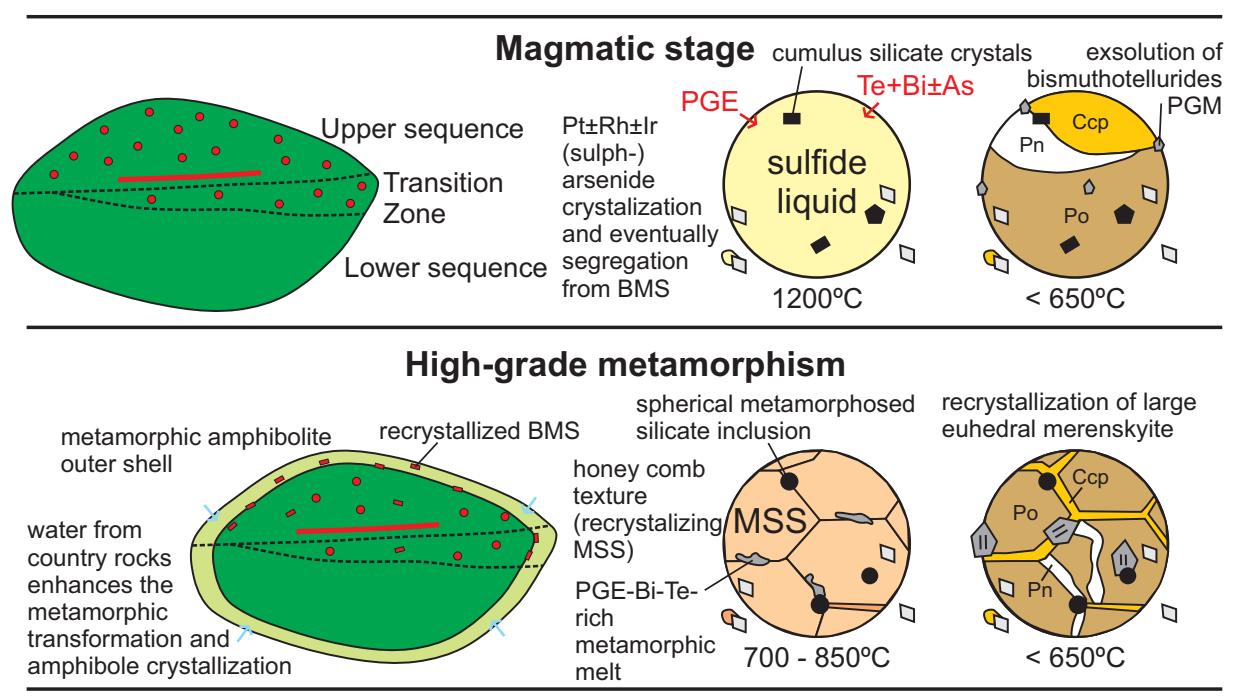

Low-grade metamorphism + hydrothermalism + tectonism

leached sulfides and PGM

(removal of $\mathrm{BMS}+\mathrm{Pd}+\mathrm{Te} \pm \mathrm{Bi}$ )

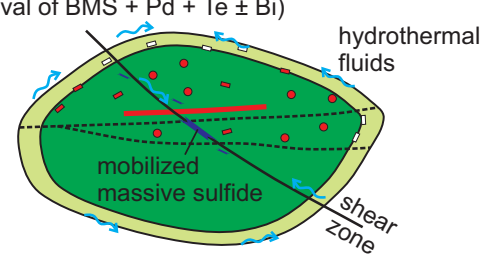

hydrothermal sulfide and PGM assemblage (chalcopyrite + Bi-rich meresnkyite + hessite)

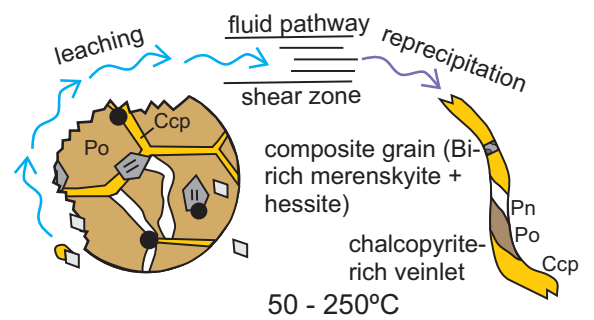

Fig. 3.18 Schematic model representing the Limoeiro chonolith showing an intrusion scale cross section and small scale chart of magmatic sulfide blebs showing the main geological phases that occurred during the formation of the primary, high grade metamorphic and lower temperature alteration secondary sulfide and PGM assemblages at the Limoeiro NiCu(-PGE) sulfide deposit 


\section{High grade metamorphism}

The Limoeiro Ni-Cu-(PGE) ore is strongly dominated by pyrrhotite with minor concentrations of chalcopyrite, pentlandite and trace amounts of magnetite and pyrite (Mota-eSilva et al., 2013). However although it was metamorphosed to upper amphibolite to granulite facies conditions $\left(700-850^{\circ} \mathrm{C}\right)$, it has a typical magmatic sulfide ore deposit mineralogy, which would not melt under metamorphic facies below ultrahigh-temperature (UHT) metamorphism (Tomkins et al., 2007). However, during the cooling of the magmatic system a residual liquid enriched in $\mathrm{Cu}, \mathrm{Pt}, \mathrm{Pd}, \mathrm{Au}, \mathrm{Ag}, \mathrm{As}, \mathrm{Bi}, \mathrm{Cd}, \mathrm{Sb}, \mathrm{Sn}, \mathrm{Te}, \mathrm{Pb}$, and $\mathrm{Zn}$ can segregate from the MSS (Li et al. 1992 and 1996; Naldrett, 2004; Helmy et al., 2010). The crystallization product of this residual sulfide liquid (ISS) is prone to remelt during amphibolite to granulite facies metamorphism (subject to degree of sulfide liquid fractionation) (Tomkins et al., 2007). The Limoeiro massive sulfide layers represent the solid phase (MSS) that has been separated from a residual sulfide liquid and therefore is unlikely to have melted during this metamorphism.

For the PGM experimental evidence indicates that merenskyite melts congruently at $740^{\circ} \mathrm{C}$ (Medvedeva et al., 1961) and that it is unsta ble at temperatures above $500^{\circ}$ to $540{ }^{\circ} \mathrm{C}$ (Hoffman and MacLean, 1976). Sulfosalts or tellurides may start to melt at conditions ranging from lowest greenschist facies to amphibolite facies, well below conditions required for partial melting of common silicate rocks. Thus, a complex PGE-bearing bismuthotelluride melt was probably generated at Limoeiro during the high grade metamorphism peak. Because of the rarity of PGM, the proportion of melt produced by their decomposition is minuscule (with a tenor of $9 \mathrm{ppm} \mathrm{Pd}$, as at Limoeiro, $0.004 \%$ of the massive sulfide would be melted). This trace melt could sequestrate PGE during its fluxing through the volumetrically dominant sulfide (Tomkins et al., 2007). Arsenic, $\mathrm{Pt}, \mathrm{Pd}, \mathrm{Au}, \mathrm{Ag}, \mathrm{Bi}, \mathrm{Te}, \mathrm{Sb}, \mathrm{Pb}$ are strongly incompatible with MSS (e.g., Holwell and McDonald, 2010; Helmy et al., 2010) and have partition coefficients in the hundreds into sulfide, arsenide or telluride liquids (e.g., Wood, 2003; Hanley, 2007; Helmy et al., 2007; Godel et al., 2012; Piña et al., 2013). However, the high grade metamorphism was not hot enough to remelt sperrylite, which crystallized at temperatures $>1000^{\circ} \mathrm{C}$ at Limoeiro (Fig. 3.18). 
A high grade metamorphic state commonly exists for a period of tens of millions of years (Mezger et al. 1991; Rubatto et al. 2001), whereas a small mafic pluton (such as Limoeiro) cools to wall rock temperatures in a time span between 0.1 and 1 million years (Paterson and Tobisch, 1992). Barnes et al. (2008) demonstrated that the slower cooling rate in a layered intrusion and possibly the presence of late magmatic fluids can produce a greater degree of exsolution of the PGM than in the case of subvolcanic sills. Thus, the length of time available for exsolution of the PGE from the MSS is proportional to the amount of PGE that are able to diffuse and exsolve as PGM instead of staying trapped within the structure of the BMS minerals. Neves et al. (2012) using a combination of $\mathrm{U} / \mathrm{Pb}$ and $\mathrm{Ar} / \mathrm{Ar}$ isotopic methods identified that the metamorphic regional temperatures in the Limoeiro deposit region remained near the closing temperature of amphibole $\left(\sim 500^{\circ} \mathrm{C}\right)$ for a long time (ca. $\left.40 \mathrm{Ma}\right)$ after the peak of metamorphism. Comparing the Limoeiro deposit with magmatic deposits at Noril'sk, Merensky Reef, Great Dyke, Sudbury, Penikat, in Finland, and the Santa Rita deposit, in Brazil it becomes clear that the Limoeiro deposit has the lowest proportion of Pd housed within BMS (12-16\%) and one of the coarsest PGM assemblages despite its relatively low grades of Pt and Pd in a small and shallow intrusion (Table 3.6). The relatively long timeframe of the metamorphic conditions that the deposit was exposed to has permitted the trace bismuthotelluride melt to efficiently interact with the BMS and scavenge most of PGE and their typical ligands to form discrete PGM phases after the metamorphic peak. It is likely that i) the large grain size of merenskyite, ii) high dominance of Pd in PGM rather than hosted by BMS, and iii) compositional homogeneity among the dispersed merenskyite grains within any individual massive sulfide sample, are consequences of a metamorphic origin for the Limoeiro bismuthotellurides (Fig. 3.18). As an alternative hypothesis the bismuthotellurides may have been absorbed in solid solution by the metamorphic MSS and later re-exsolved slowly after the high grade metamorphism peak. Both, the main and the alternative hypotheses, consider a long timeframe for the PGM formation during metamorphism.

In the disseminated sulfide ore various mineral phases were in contact with sulfide blebs forming a more appropriate environment for metamorphic reactions and metal exchanges, and for this reason, the high grade metamorphic event was unable to produce the same homogeneous results in the PGM compositions observed in the massive sulfide ores. 
Table 3.6 - Compilation of several mineralized intrusions listing characteristics with potential to influence PGM size and Pd distribution between BMS and PGM.

\begin{tabular}{|c|c|c|c|c|c|c|c|}
\hline $\begin{array}{l}\text { Intrusion } \\
\text { (site) }\end{array}$ & $\begin{array}{l}\text { Grades } \\
\text { in } \\
\text { deposit } \\
(g / t)\end{array}$ & $\begin{array}{l}\text { Depth of } \\
\text { emplacement }\end{array}$ & $\begin{array}{l}\text { Dimensions } \\
\text { of intrusion } \\
(\mathrm{km})\end{array}$ & $\begin{array}{l}\text { Metamorphic } \\
\text { facies }\end{array}$ & $\begin{array}{l}\text { Median } \\
\text { PGM size } \\
\text { (largest } \\
\text { grain) in } \\
\mu^{2}\end{array}$ & $\begin{array}{l}\% \text { of } \\
\text { Pd in } \\
\text { BMS }\end{array}$ & Ref. \\
\hline Limoeiro & $\begin{array}{l}0.2 \mathrm{Pt} \\
0.4 \mathrm{Pd}\end{array}$ & Upper crust & $0.2 \times 0.5 \times 4$ & $\begin{array}{l}\text { Upper } \\
\text { amphibolite to } \\
\text { granulite }\end{array}$ & $\begin{array}{l}6.4 / 88 \\
(5000)\end{array}$ & $12-16$ & $1 ; 2$ \\
\hline $\begin{array}{l}\text { Noril'sk } \\
\text { (Medvesky } \\
\text { creek) }\end{array}$ & $\begin{array}{l}\text { 1.8 Pt; } \\
\text { 7.3 Pd }\end{array}$ & Sub-volcanic & $0.2 \times 8 \times 18$ & none & 1.5 & 100 & $3 ; 4$ \\
\hline $\begin{array}{l}\text { Buskveld } \\
\text { (Merensky } \\
\text { reef) }\end{array}$ & $\begin{array}{l}\text { 3.6 Pt; } \\
1.8 \mathrm{Pd}\end{array}$ & Upper crust & $7 \times 280 \times 450$ & none & 620 & $30-60$ & $3 ; 4$ \\
\hline $\begin{array}{l}\text { Great Dyke } \\
\text { (MSZ) }\end{array}$ & $\begin{array}{l}2.8 \mathrm{Pt} \\
2.1 \mathrm{Pd}\end{array}$ & Upper crust & $3.5 \times 7 \times 400$ & none & 4.5 & $30-60$ & $3 ; 4$ \\
\hline $\begin{array}{l}\text { Sudbury } \\
\text { (Creighton } \\
\text { deposit) }\end{array}$ & $\begin{array}{l}0.5 \mathrm{Pt} \\
0.6 \mathrm{Pd}\end{array}$ & Impact melt & $2 \times 30 \times 60$ & Amphibolite & $11(3400)$ & $40-90$ & $\begin{array}{l}4 ; 5 \\
6 ; 7\end{array}$ \\
\hline Penikat & $\begin{array}{l}\text { 1.7 Pt; } \\
\text { 6.2 Pd }\end{array}$ & $?$ & $2 \times 3 \times 20$ & Greenschist & 35 & $\sim 50$ & 3 \\
\hline $\begin{array}{l}\text { Mirabela } \\
\text { (Santa Rita) }\end{array}$ & $\begin{array}{l}0.1 \mathrm{Pt} \\
0.05 \mathrm{Pd}\end{array}$ & Lower crust & $2 \times 2 \times 3$ & none & $8(690)$ & $>50$ & $8 ; 9$ \\
\hline
\end{tabular}

References: ${ }^{1}$ this study; ${ }^{2}$ Mota-e-Silva et al. (2013); ${ }^{3}$ Barnes et al. (2008); ${ }^{4}$ Naldrett (2004); ${ }^{5}$ Dare et al. (2010a); ${ }^{6}$ Dare et al. (2010b); ${ }^{7}$ Mukwakwami et al. (2012); ${ }^{8}$ Knight et al. (2011); ${ }^{9}$ C.F. Ferreira Filho, personal communication, August 25, 2014.

The upper amphibolite to granulite metamorphic re-crystallization of the sulfide phases has not produced a distinct metamorphic mineralogy but one typical of magmatic ores. In contrast, other sulfide deposits worldwide, metamorphosed to lower grade sub-greenschist and greenshcist grades, display extensive alteration of the BMS assemblage forming magnetitebearing pentlandite-rich sulfide aggregates, millerite, pyrite and monoclinic pyrrhotite (e.g., Dillon-Leitch et al. 1986; Wang et al. 2008; Barnes et al. 2009; Smith et al. 2011; Djon and Barnes 2012). The reason why the Limoeiro ore has not changed its primary compositions (i.e. no major $\mathrm{S}$ loss or gain, or $\mathrm{Ni}$, etc) is likely to be related to the absence of significant fluid infiltration during higher grade metamorphism. The same process applies for igneous rocks submitted to higher versus lower grade metamorphism. However, the ores exhibit distinctive metamorphic textures. Under thermal metamorphism massive sulfide bodies recrystallize with 
the development of $120^{\circ}$ triple junctions characteristic of equilibrated annealed textures (Craig, 1983). The upper amphibolite to granulite facies metamorphism $\left(700-850^{\circ} \mathrm{C}\right)$ at Limoeiro was probably hot enough to drive the BMS back into the MSS stability field. After the metamorphic peak, as the intrusion cooled down, recrystallization of BMS generated a metamorphic honeycomb texture (Fig. 3.4C) with hexagons of pyrrhotite surrounded by chalcopyrite and pentlandite ribbons forming a $120^{\circ}$ triple junction fabric. As the high grade metamorphism in the Limoeiro deposit was essentially thermal with a lack of coeval deformation, the sulfide did not move plastically to generate pseudobreccias ("Durchbewegung" texture as described by Vokes, 1969). Additionally the merenskyite in Retiro's massive sulfide ore is commonly found in contact with spherical silicate minerals composed of serpentine +/- hornblende +/- carbonate +/chlorite. These minerals are a combination of high and low grade metamorphic minerals. Abundant rounded (certainly spherical in 3D) silicate inclusions are present in the massive sulfide at Tati and Selebi-Phikwe, in eastern Botswana (Fiorentini et al, 2012). Similar to the Limoeiro deposit, these intrusions are also overprinted by granulite-facies metamorphism. It is possible that during the high grade metamorphism the silicate inclusions were re-crystallized under lithospheric pressure in a deforming MSS driving them to assume a spherical geometry. Subsequently metamorphic bismuthotelluride PGM crystallized at the edges of the BMS, which includes the contacts with included spherical silicates (Fig. 3.18).

\section{Low grade metamorphism, hydrothermalism and tectonism}

Some PGM found in the Limoeiro deposit are affected by hydrothermal remobilization.

This is shown by different textures including PGM within sulfide veinlets that crosscut the primary fabric (Fig. 3.13G and H), PGM within orthpyroxene (magmatic) and hornblende (metamorphic) cleavages (Fig. 3.13I and J), PGM enclosed by antigorite and apparently separated from the BMS (Fig. 3.13L), and PGM with irregular corroded contacts with the adjacent antigorite (Fig. 3.13E) or adjacent sulfide (Fig. 3.13F). The PGM that are associated with these late alteration textures are exclusively Pd-bearing minerals, essentially merenskyite (Fig. 3.12). No Pt-bearing PGM have been identified in these altered areas. Chloride and bisulfide are the most important ligands for Pd and Pt transport in hydrothermal fluid (Wood et 
al., 1989). Gammons and Bloom (1993) and Pan and Wood's (1994) experimental studies predict higher PdS solubility than PtS solubility as bisulfide complexes, and suggest Pd and Pt bisulfide complexes are important for Pd transport in hydrothermal fluids. Working with modelling and field-based evidence Barnes and Liu (2012) found Pd to have higher solubility than Pt in hydrothermal systems operating in sulfide-rich environments. The removal of Pd by hydrothermal fluids can decouple $\mathrm{Pd}$ from $\mathrm{Pt}$ leaving behind rocks with relatively high $\mathrm{Pt} / \mathrm{Pd}$ ratios (Fuchs and Rose, 1974; Prichard et al. 2001). Coupling between deformation processes and rock permeability is a major factor influencing fluid migration in hydrothermal systems. Localization of deformation in faults and shear zones leads to flow localization, with large scale flow systems forming when active faults and shear zones link to create percolation networks. (Cox 1999). The external part is the most deformed zone of the Limoeiro intrusion. Hydrothermal fluids have percolated through this zone leaching bismuthotellurides, which are richer in $\mathrm{Pd}$ (abundant merenskyite) rather than $\mathrm{Pt}$ (rare moncheite). The extraction of metals produced a signature of a high $\mathrm{Pt} / \mathrm{Pd}$ ratio in the amphibolite rocks in the most external part of intrusion (Fig. 3.17). Coevally, tectonic activity developed shear zones cross cutting the inner parts of the intrusion. These shear zones partly mobilized massive sulfide orebodies in plastic deformation allowing mobilization to produce distinctive "Durchbewegung" texture ores (Fig. 3.4D). Hydrothermal fluids infiltrated from the outside through these shear zones losing their ability to alter the rock as they changed their composition progressively in response to elemental exchanges with the rock. The hydrothermal fluids have deposited metals preferentially into the sheared massive sulfide orebodies, which have produced a distinctive assemblage consisting of hessite, Bi-rich merenskyite (Fig. 3.14 and 15) and chalcopyrite. The chemical signature is also peculiar as sample 004-115.80 (the only tectonically mobilized sample examined in this study) has a bulk $\mathrm{Pt} / \mathrm{Pd}$ weight ratio of 0.06 that is noticeably lower than the 0.33 and 0.38 ratios that represent the bulk values of the Retiro and Piçarra orebodies respectively (Fig. 3.16). In this case the merenskyite composition is also different as it has no Pt, very low Ni (Fig. 3.14) and the Te/Bi ratio is much lower (Fig. 3.15). Hoffman and MacLean (1976) have shown that thermal stability of Merenskyite decreases significantly with increasing Bi content. Consequently, hydrothermally mobilized ores should contain merenskyite that is richest in $\mathrm{Bi}$. 
The hydrothermal activity has not affected the Limoeiro deposit extensively, but it has played a role locally in certain parts of the intrusion, especially in the outer shell and through the internal shear zones (Fig. 3.18). However its identification and characterization described above are important as they enhance the general understanding of PGE mobility and PGM formation during low grade metamorphism and hydrothermal alteration. Such characterization also has the potential to identify more elements that need to be considered during beneficiation and metallurgical studies as the hydrothermally altered parts of the intrusion would potentially also be mined.

\section{Conclusions}

The principal conclusions of this study are:

1. The Limoeiro intrusion parental magma was probably enriched in $\mathrm{Te}$ and $\mathrm{Bi}$ relative to other typical PGE ligands (As, Se, Sb, S), as shown by the extensive dominance of bismuthtellurides ( 87\%) in the PGM assemblage.

2. Sperrylite crystallized early at high temperatures directly from sulfide blebs that were present in the Limoeiro magma conduit. The sperrylite grains are interpreted to have separated from the sulfide blebs and were captured as inclusions by high temperature silicates and oxides. Sperrylite was not identified in the massive sulfide PGM assemblage, but only within the disseminated sulfide ore.

3. Bi-Pt-Ni-bearing merenskyite is by far the dominant mineral phase in the Limoeiro PGM assemblage and is interpreted to have formed from crystallization from a diminutive PGE-bearing bismuthotelluride metamorphic melt or by exsolution from MSS during slow cooling. The merenskyite composition is controlled by the surrounding BMS composition, as the bismuthotelluride metamorphic melt sequestrated PGE and their typical ligands from BMS. 
4. The longer timeframe related to metamorphism compared to a magmatic system, has permitted very efficient diffusion of PGE through the BMS and the partition of Pd into the metamorphic bismuthotelluride melt. For this reason $\mathrm{Pd}$ is much more concentrated in PGM (84-88\%) rather than BMS (12-16\%).

5. With increasing fractionation the $\mathrm{Pt} / \mathrm{Pd}$ ratio of the orebodies slightly increases, but the merenskyite becomes Pt- and $\mathrm{Ni}$-poor. A decrease of $\mathrm{Ni}$ in the merenskyite composition reflects the composition of the sulfide liquid segregated from more fractionated magma to the east (Piçarra). The lower abundance of $\mathrm{Pt}$ in merenskyite is a consequence of Pt entering into sperrylite, which segregated in greater amounts from the sulfide liquid in that part of the intrusion during the magmatic stage.

6. Merenskyites in the Transition Zone have distinctly different compositions from those in the Upper Sequence. Merenskyite compositions vary with sulfide liquid composition, which depends on where the sulfide liquid segregated in terms of i) magmatic stratigraphy and ii) position in the fractionation trend from the west to the east of the complex.

7. Merenskyite grains at Limoeiro have different amounts of the melonite and moncheite end members present in solid solution. In this study we report previously naturally unknown proportions between these three minerals, demonstrating the existence of an even larger field of solid solution for the merenskyite-melonite-moncheite system in nature;

8. During low grade metamorphism, localized hydrothermal alteration promoted a heterogeneous removal of $\mathrm{BMS}, \mathrm{Pd}, \mathrm{Te}$ and $\mathrm{Bi}$ from the outer parts of the chonolith. These fluids reprecipitated the metals as a BMS, Bi-rich merenskyite and hessite assemblage in remobilized sulfide stringers in the inner parts of intrusion. 


\section{Acknowledgments}

We would like to thank the technical support from the Limoeiro Project team (headed by Rafael Freitas) for their assistance and cooperation. We are grateful to Jones Belther (Votorantim Metais' Minerals Exploration Division director) for permission to sample the Limoeiro deposit and publish the results. We are immensely glad with the very detailed corrections and suggestion of improvement carried out by the associated editor Mike Lesher and reviewer Belinda Godel. This paper is part of first author's PhD thesis (Geosciences Institute, University of Brasilia), which was partly funded by CAPES Foundation, Ministry of Education of Brazil, fellowship (process BEX 3603/13-0).

\section{References}

Almeida FFM, Hasui Y, Brito Neves BB, Fuck RA (1981) Brazilian structural provinces: an introduction. Earth Sci Rev 17:1-29

Ames DE, Farrow CEG (2007) Metallogeny of the Sudbury mining camp, Ontario: Mineral Deposits Division, Geological Association of Canada Special Publication 5, p. 329-350.

Ballhaus C, Sylvester P (2000) Noble metal enrichment processes in the Merensky Reef, Bushveld Complex. J Petrol 41: 545-561

Barkov A, Laflamme G, Cabri LJ, Martin RF (2002) Platinum-group minerals from the Wellgreen Ni-Cu-PGE Deposit, Yukon, Canada. Can Mineral 40: 651-669

Barnes S-J, Lightfoot PC (2005) Formation of magmatic nickel sulfide ore deposits and processes affecting their copper and platinum group element contents. Econ Geol 100: $179-213$

Barnes S-J, Couture JF, Sawyer EW, Bouchaib C (1993) Nickel-copper occurrences in the Belleterre-Angliers Belt of the Pontiac Subprovince and the use of $\mathrm{Cu}-\mathrm{Pd}$ ratios in interpreting platinum-group element distributions. Econ Geol 88(6): 1402-1418

Barnes S-J, Prichard HM, Cox RA, Fisher PC, Godel B (2008) The location of the chalcophile and siderophile elements in platinum-group element ore deposits (a textural, microbeam 
and whole rock geochemical study): implications for the formation of the deposits. Chem Geol 248: 295-317

Barnes S-J, Wells MA., Verrall MR (2009) Effects of magmatic processes, serpentinization, and talc-carbonate alteration on sulfide mineralogy and ore textures in the Black Swan disseminated nickel sulfide deposit, Yilgarn Craton. Econ Geol 104(4): 539-562

Beaty RD, Manuel OK (1973) Tellurium in rocks. Chem Geol 12(2): 155-159

Brito Neves BB, Santos EJ, Van Schmus WR (2000) Tectonic History of the Borborema Province, Northeast Brazil. In: Cordani UG, Milani EJ, Thomaz Filho A, Campos DA (eds) Tectonic Evolution of South America, 31st International Geological Congress, Rio de Janeiro, pp 151-182

Cabri LJ, Laflamme G (1976) The mineralogy of the platinumgroup elements from some copper-nickel deposits of the Sudbury area, Ontario. Econ Geol 71: 1159-1195

Cabri LJ (2002) The Platinum-Group Minerals. In: Cabri LJ (ed) The Geology, Geochemistry, Mineralogy and Mineral Beneficiation of Platinum-Group Elements, Canadian Institute of Minning, Metallurgy and Petroleum, Special Volume 54: 483-506

Coghill BM, Wilson, AH (1993) Platinum-group minerals in the Selukwe Subchamber, Great Dyke, Zimbabwe: implications for PGE collection mechanisms and post-formational redistribution. Mineral Mag 57(389): 613-634

Cox SF (1999) Deformational controls on the dynamics of fluid flow in mesothermal gold systems. Geol Soc, London, Spec Pub 155(1): 123-140

Craig JR (1983) Metamorphic features in Appalachian massive sulphides. Min Mag 47(345): $515-525$

Dare SA, Barnes SJ, Prichard HM, Fisher PC (2010a) The timing and formation of platinumgroup minerals from the Creighton $\mathrm{Ni}$-Cu-platinum-group element sulfide deposit, Sudbury, Canada: early crystallization of PGE-rich sulfarsenides. Econ Geol 105(6): 1071-1096

Dare SA, Barnes SJ, Prichard HM (2010b) The distribution of platinum group elements (PGE) and other chalcophile elements among sulfides from the Creighton $\mathrm{Ni}-\mathrm{Cu}-\mathrm{PGE}$ sulfide deposit, Sudbury, Canada, and the origin of palladium in pentlandite. Miner Deposita 45(8): 765-793

Dillon-Leitch HCH, Watkinson DH, Coats CJA (1986). Distribution of platinum-group elements in the Donaldson West deposit, Cape Smith belt, Quebec. Econ Geol 81(5): 1147-1158 
Djon MLN, Barnes SJ (2012). Changes in sulfides and platinum-group minerals with the degree of alteration in the Roby, Twilight, and High Grade Zones of the Lac des Iles Complex, Ontario, Canada. Miner Deposita 47(8): 875-896

Ebel DS, Naldrett AJ (1996) Fractional crystallization of sulfide ore liquids at high temperature. Econ Geol 91(3): 607-621

Farrow CE, Watkinson DH (1997) Diversity of precious-metal mineralization in footwall Cu-NiPGE deposits, Sudbury, Ontario: implications for hydrothermal models of formation. Can Mineral 35: 817-840

Fiorentini ML, Bekker A, Rouxel O, Wing BA, Maier W, Rumble D (2012) Multiple sulfur and iron isotope composition of magmatic $\mathrm{Ni}-\mathrm{Cu}$-(PGE) sulfide mineralization from eastern Botswana. Econ Geol 107(1): 105-116

Fuchs WA, Rose AW (1974) The geochemical behavior of platinum and palladium in the weathering cycle in the Stillwater Complex, Montana. Econ Geol 69(3): 332-346

Gammons CH, Yu Y, Bloom MS (1993) Experimental investigation of the hydrothermal geochemistry of platinum and palladium: II. The solubility of PtS and PdS in aqueous sulfide solutions to $300^{\circ} \mathrm{C}$. Geochim Cosmochim Acta 57: 2451-2467

Garuti G, Rinaldi R (1986) Mineralogy of Melonitc-Group and Other Tellurides from the IvreaVerbano Basic Complex, Western Italian Alps. Econ Geol 81: 1213-1217

Godel B, Barnes S-J (2008) Platinum-group elements in sulfide minerals and the whole rocks of the J-M Reef (Stillwater Complex): Implication for the formation of the reef. Chem Geol 248: $272-294$

Godel B, González-Álvarez I, Barnes SJ, Barnes SJ, Parker P, Day J (2012) Sulfides and sulfarsenides from the rosie nickel prospect, Duketon Greenstone Belt, Western Australia. Econ Geol 107(2): 275-294

Hanley JJ (2007) The role of arsenic-rich melts and mineral phases in the development of highgrade Pt-Pd mineralization within komatiite-associated magmatic $\mathrm{Ni}-\mathrm{Cu}$ sulfide horizons at Dundonald Beach South, Abitibi Subprovince, Ontario, Canada. Econ Geol 102(2): 305-317

Harney DMW, Merkle RKW (1990) Pt-Pd Minerals from the Upper zone of the Eastern Busheveld Complex, South Africa. Can Mineral 28: 619-628

Hattori KH, Arai S, Clarke DB (2002) Selenium, tellurium, arsenic and antimony contents of primary mantle sulfides. Can Mineral 40(2): 637-650 
Helmy HM, Ballhaus C, Berndt J, Bockrath C, Wohlgemuth-Ueberwasser C. (2007) Formation of $\mathrm{Pt}, \mathrm{Pd}$ and $\mathrm{Ni}$ tellurides: experiments in sulfide-telluride systems. Contrib Mineral Petrol 153(5): 577-591

Helmy HM, Ballhaus C, Wohlgemuth-Ueberwasser C, Fonseca RO, Laurenz V (2010) Partitioning of $\mathrm{Se}, \mathrm{As}, \mathrm{Sb}, \mathrm{Te}$ and $\mathrm{Bi}$ between monosulfide solid solution and sulfide melt-Application to magmatic sulfide deposits. Geochim Cosmochim Acta 74(21): 61746179

Helmy HM, Ballhaus C, Fonseca RO, Wirth R, Nagel T, Tredoux M (2013) Noble metal nanoclusters and nanoparticles precede mineral formation in magmatic sulphide melts. Nature communications 4: 2405

Hoffman EL, MacLean WH (1976) Phase relations of michenerite and merenskyite in the Pd-BiTe system. Econ Geol 71(7): 1461-1468

Holwell DA, McDonald I (2010) A review of the behaviour of platinum group elements within natural magmatic sulfide ore systems. Platinum Metals Review 54(1): 26-36

Hudson DR (1986) Platinum-Group Minerals from the Kambalda Nickel Deposits, Western Australia. Econ Geol 81: 1218-1225

Hutchinson D, McDonald I. (2008) Laser ablation ICP-MS study of platinum-group elements in sulfides from the Platreef at Turfspruit, northern limb of the Bushveld Complex, South Africa. Miner Deposita 43(6): 695-711

Kelly DP, Vaughan DJ (1983) Pyrrhotine-pentlandite ore textures: a mechanistic approach. Mineral Mag 47(4): 453-463

Kerr A (2001) The calculation and use of sulfide metal contents in the study of magmatic ore deposits: A methodological analysis. Explor Min Geol 10(4): 289-301

Kitakaze A, Sugaki A, Itoh H, Komatsu R (2011) A revision of the phase relations in the system Fe-Ni-S from $650^{\circ}$ to $450^{\circ} \mathrm{C}$. Can Mineral 49(6): 1687-1710

Knight RD, Prichard HM, McDonald I, Ferreira, CFF (2011) Platinum-group mineralogy of the Fazenda Mirabela intrusion, Brazil: the role of high temperature liquids and sulfur loss. Trans Inst Min Metall B 120(4): 211-224

Kretz R (1983) Symbols for rock-forming minerals. Am Mineral 68: 277-279

Lesher CM, Groves DI (1986) Controls on the formation of komatiite-associated nickel-copper sulfide deposits. In Geology and metallogeny of copper deposits (pp. 43-62). Springer Berlin Heidelberg 
Lesher CM, Burnham OM, Keays RR, Barnes SJ, Hulbert L (2001) Trace-element geochemistry and petrogenesis of barren and ore-associated komatiites. Can Mineral 39(2): 673-696

Li C, Naldrett AJ, Coats CJA, Johannessen P (1992) Platinum, palladium, gold, copper-rich stringers at the Strathcona Mine, Sudbury; their enrichment by fractionation of a sulfide liquid. Econ Geol 87(6): 1584-1598

Li C, Barnes SJ, Makovicky E, Rose-Hansen J, Makovicky M (1996) Partitioning of nickel, copper, iridium, rhenium, platinum, and palladium between monosulfide solid solution and sulfide liquid: effects of composition and temperature. Geochim Cosmochim Acta 60(7): 1231-1238

Li C, Xu Z, de Waal SA, Ripley EM, Maier WD (2004) Compositional variations of olivine from the Jinchuan $\mathrm{Ni}-\mathrm{Cu}$ sulfide deposit, western China: implications for ore genesis. Miner Deposita 39: 159-172

Lightfoot PC, Farrow CEG (2002) Geology, geochemistry, and mineralogy of the Worthington offset dike: A genetic model for offset dike mineralization in the Sudbury Igneous Complex. Econ Geol 97: 1419-1445

Lightfoot PC, Naldrett AJ, Gorbachev NS, Doherty W, Fedorenko VA (1990) Geochemistry of the Siberian Trap of the Noril'sk with implications for the relative contributions of crust and mantle to flood basalt magmatism. Contrib Mineral Petrol 104: 631-644

Liu Y-N, Brenan J (2012) Experimental measurement of PGE and semi-metal partitioning during sulfide melt crystallization at controlled fO2-fS2 conditions. Chinese Academy of Sciences, International Ni-Cu-(PGE) Symposium, 12th, China, 16-21 June 2012, Proceedings, p. 36-39

Lorand JP, Alard O, Luguet A, Keays RR (2003) Sulfur and selenium systematics of the subcontinental lithospheric mantle: inferences from the Massif Central xenolith suite (France). Geochim Cosmochim Acta 67(21): 4137-4151

Makovicky E, Karup-Moller S, Makovicky M, Rose-Hansen J (1990) Experimental studies on the phase systems Fe-Ni-Pd-S and Fe-Pt-Pd-As-S applied to PGE deposits. Mineral Petrol 42:307-319

McDonald I (2008) Platinum-group element and sulfide mineralogy in ultramafic complexes at western Andriamena, Madagascar. Trans Inst Min Metall B 117(1): 1-10

Medvedeva ZS, Klochko MA, Kuznetsov VG, Andreeva SN (1961) Structural diagram of the PdTe alloy system. Zhurnal Neorganicheskoi Khimii 6: 1737-1739. 
Mezger K, Rawnsley CM, Bohlen SR, Hanson GN (1991) U-Pb garnet, sphene, monazite, and rutile ages: Implications for the duration of high grade metamorphism and cooling histories, Adirondack Mts., New York. J Geol 415-428

Mota-e-Silva J, Ferreira Filho CF (2013) Architecture and emplacement of the Limoeiro Ni-CuPGE sulfide deposit, Northeastern Brazil. Gramado, Brazil, III Brazilian Symposium of Metallogeny

Mota-e-Silva J, Ferreira Filho CF (unpublished) Mineral and whole rock chemistry of the chonolith that hosts the Limoeiro Ni-Cu-(PGE) deposit: evidences of magma flow direction, siderophile elements depletion and sulfide fractionation

Mota-e-Silva J, Ferreira Filho CF, Giustina MESD (2013) The Limoeiro Deposit: Ni-Cu-PGE Sulfide Mineralization Hosted Within an Ultramafic Tubular Magma Conduit in the Borborema Province, Northeastern Brazil. Econ Geol 108: 1753-1771

Mukwakwami J, Lafrance B, Lesher CM (2012) Back-thrusting and overturning of the southern margin of the $1.85 \mathrm{Ga}$ Sudbury Igneous Complex at the Garson mine, Sudbury, Ontario. Prec Res 196: 81-105

Naldrett AJ (1981) Nickel sulphide deposits: classification, composition and genesis. Econ Geol 75: 628-687

Naldrett AJ (2004) Magmatic Sulfide Deposits - Geology, Geochemistry and Exploration: Germany, Springer Berlin, 724 pp

Naldrett T, Kinnaird J, Wilson A, Chunnett G (2008) Concentration of PGE in the Earth's Crust with Special Reference to the Bushveld Complex. Earth Sci Front 15(5): 264-297

Neves SP, Alcantara VC (2010) Geochemistry of orthognelSSes and metasedimentary rocks across a proposed terrane boundary in the Central Domain of Borborema Province, NE Brazil: geodynamic implications. J South Am Earth Sci 29(2): 498-511

Pan P, Wood SA (1994) Solubility of Pt and Pd sulfides and Au metal in aqueous bisulfide solutions; II, Results at 200 degrees $C$ to 350 degrees $C$ and saturated vapor pressure. Miner Deposita 29: 373-390

Paterson SR, Tobisch OT (1992) Rates of processes in magmatic arcs: implications for the timing and nature of pluton emplacement and wall rock deformation. Journal of Structural Geology 14(3): 291-300

Piña R, Gervilla F, Barnes SJ, Ortega L, Lunar R (2013) Partition Coefficients of Platinum Group and Chalcophile Elements Between Arsenide and Sulfide Phases as Determined in the Beni Bousera Cr-Ni Mineralization (North Morocco). Economic Geology 108(5): 935-951 
Power MR, Pirrie D, Jedwab J, Stanley CJ (2004) Platinum-group element mineralization in an As-rich magmatic sulfide system, Talnotry, southwest Scotland. Mineral Mag 68(2): 395411

Prichard HM, Sá JHS, Fisher PC (2001) Platinum-group mineral assemblages and chromite composition in the altered and deformed Bacuri complex, Amapa, Northeastern Brazil. Can Mineral 39: 377-396

Prichard HM, Hutchinson D, Fisher PC (2004) Petrology and crystallization history of multiphase sulfide droplets in a mafic dyke from Uruguay: Implications for the origin of $\mathrm{Cu}-\mathrm{Ni}$ PGE-sulfide deposits. Econ Geol 99: 365-376

Prichard HM, Knight RD, Fisher PC, McDonald I, Zhou MF, Wang CY (2013) Distribution of platinum-group elements in magmatic and altered ores in the Jinchuan intrusion, China: an example of selenium remobilization by postmagmatic fluids. Miner Deposita 1-20

Rowell WF, Edgar AD (1986) Platinum-group element mineralisation in hydrothermal Cu-Ni sulfide occurrence, Rathbun Lake, northeastern Ontario. Econ Geol 81: 1272-1277

Rubatto D, Williams IS, Buick IS (2001) Zircon and monazite response to prograde metamorphism in the Reynolds Range, central Australia. Contrib Mineral Petrol 140(4): 458-468

Sinyakova EF, Kosyakov VI (2007) Experimental Modeling of Zoning in Copper-Nickel Sulfide Ores. Dokl Earth Sci 417A(9): 1380-1385

Santoliquido PM, Ehmann WD (1972) Bismuth in stony meteorites and standard rocks. Geochim Cosmochim Acta 36(8): 897-902

Santos EJ, Van Schmus WR, Kozuch M, Brito Neves BB (2010) The Cariris Velhos tectonic event in northeast Brazil. J South Am Earth Sci 29: 61-76

Seabrook CL, Prichard HM, Fisher PC (2004) Platinum-group minerals in the Raglan Ni-Cu(PGE) sulfide deposit, Cape Smith, Quebec, Canada. Can Mineral 42(2): 485-497

Smith JW, Holwell DA, McDonald I (2011) The mineralogy and petrology of platinum-group element-bearing sulfide mineralization within the Grasvally Norite-PyroxeniteAnorthosite (GNPA) member, south of Mokopane, northern Bushveld Complex, South Africa. Trans Inst Min Metall B 120: 158-174

Spear FS (1993) Metamorphic phase-equilibria and Pressure - Temperature - Time Paths. Mineral Society of America, Washington, D.C. 
Vokes FM (1969) A review of the metamorphism of sulphide deposits. Earth Sci Rev 5(2): 99143

Votorantim Metais (2013) Limoeiro Project Scopying Study - internal unpublished report, December 2013, 160p. (in Portuguese)

Wang CY, Prichard HM, Zhou MF, Fisher PC (2008) Platinum-group minerals from the Jinbaoshan Pd-Pt deposit, SW China: evidence for magmatic origin and hydrothermal alteration. Miner Deposita 43(7): 791-803

Whitney DL, Evans BW (2010) Abbreviations for names of rock-forming minerals. American mineralogist 95(1): 185

Wilson AH, Murahwv CZ, Coghill B (2000) Stratigraphy, geochemistry and platinum group element mineralisation of the central zone of the Selukwe Subchamber of the Great Dyke, Zimbabwe. J Afr Earth Sci 30(4): 633-653

Wood SA, Mountain BW, Fenlon BJ (1989) Thermodynamic constraints on the solubility of platinum and palladium in hydrothermal solutions; reassessment of hydroxide, bisulfide, and ammonia complexing. Econ Geol 84: 2020-2028

Wood M (2003) Arsenic in igneous systems: An experimental investigation: Unpublished BA Sc thesis, Toronto, Canada, University of Toronto, $32 \mathrm{p}$. 
Platinum-group minerals formed during weathering of the Limoeiro Ni-Cu(-PGE) deposit, northeastern Brazil: supergene dispersion of PGE and formation of $\mathrm{Pd}-\mathrm{Cu}$ alloy and

Pd iodide 


\title{
Platinum-group minerals formed during weathering of the Limoeiro $\mathrm{Ni}-\mathrm{Cu}(-\mathrm{PGE})$ deposit, northeastern Brazil: supergene dispersion of PGE and formation of Pd-Cu alloy and Pd iodide
}

\author{
Jonas Mota-e-Silva ${ }^{1,2}$, Hazel M Prichard ${ }^{3}$, Saioa Suárez ${ }^{4}$, Cesar F Ferreira Filho \\ ${ }^{2}$, Peter C Fisher ${ }^{3}$ \\ ${ }^{1}$ Votorantim Metais, Exploration Division, Polo Industrial Multivias, Jundiai/SP, 13212-161, \\ Brazil \\ ${ }^{2}$ University of Brasilia, Geosciences Institute, Brasília/DF, 70900-970, Brazil \\ ${ }^{3}$ School of Earth and Ocean Science, Cardiff University, Main Building, Park Place, Cardiff, \\ CF10 3AT, UK \\ ${ }^{4}$ UPV/EHU, Department of Mineralogy and Petrology 48940 Lejona \& Ikerbasque 48011 Bilbao, \\ Spain
}

\section{Abstract}

The effects of weathering over platinum-group minerals (PGM) in the Limoeiro nickel, copper and platinum-group elements [Ni-Cu-(PGE)] deposit reveal the progressive alteration of primary merenskyite, which includes the history of formation of rare iodine-PGM. Pyrrhotite >> chalcopyrite $=$ pentlandite with trace PGM is the typical fresh ore assemblage in the primary deposit. Weathering has produced $\sim 4 \mathrm{~m}$ thick gossan cap over the sulfide-rich part of Limoeiro primary ore. Different metal mobility was recorded as $\mathrm{Pt}$ and $\mathrm{Pd}$ have shown to be $7 \mathrm{x}$ relatively more concentrated in the gossans than $\mathrm{Ni}$ and $\mathrm{Cu}$ do. Apparently Pt and Pd have shown similar mobilities between them as the $\mathrm{Pt} / \mathrm{Pd}$ of $\sim 0.4$ is roughly constant from the fresh ore at tens of meters deep up to the gossan in surface. The mobility of Pt is very dependent on whether it is in arsenide (sperrylite) or in bismuthotelluride (solid solution merenskyite-moncheite) structures. In the first case the element's mobility in Limoeiro is: $\mid r<\mathrm{Rh}<\mathrm{Pt}<\mathrm{Pd}<\mathrm{Bi}<\mathrm{Cu}<\mathrm{Ni}$. However the $\mathrm{Pt}$ hosted in bismuthotellurides is much more mobile giving: $\mathrm{I}<\mathrm{Rh}<\mathrm{Pd}<\mathrm{Bi}<\mathrm{Pt}<\mathrm{Cu}<\mathrm{Ni}$. The weathering effects over the deposit starts at $\sim 50 \mathrm{~m}$ deep with oxidation of pentlandite and pyrrhotite to produce violarite and pyrite respectively. Chalcopyrite is much more stable as it 
alters around a depth of $20 \mathrm{~m}$. The PGM starts to be altered at the depth of $\sim 25 \mathrm{~m}$ as merenskyite becomes Pd-rich since much of the $\mathrm{Bi}$ and especially Te have been released to the adjacent goethite. With progressive weathering towards the surface merenskyite appears partially dissolved and pseudomorphed by goethite, which is often coated with newly formed $\mathrm{Pd}-\mathrm{Cu} \pm \mathrm{Bi}$ rosettes. Part of the remobilized $\mathrm{Pd}$ has also precipitated as small $(<4 \mu \mathrm{m}$ across), euhedral to subhedral grains of $\mathrm{Pd}$ iodide that are located close to the merenskyite pseudomorphs. These abundant Pd-I-rich minerals are consequence of the dominant saline groundwaters in the Limoeiro deposit area.

\section{Introduction}

Magmatic nickel-copper-platinum-group element (Ni-Cu-PGE) sulfide deposits are one of the most well understood types of mineral deposits. However few of these studies focus on characterizing how these deposits are transformed by weathering. It is known that weathering above massive sulfide Ni-Cu-PGE mineralization generates gossans, but distinguishing them from other ironstones is not so straightforward (Taylor and Thornber, 1992; Taylor, 2011). Generally, assay results can specifically identify high concentrations of $\mathrm{Ni}, \mathrm{Cu}$ and PGE or they may be recorded as part of multivariate discriminant analysis (e.g. Ni-Cu-Co-Cr-Zn, Ni-Cu-ZnPb-Mn-Cr; Travis et al., 1976). Compared to the primary sulfide mineralization gossans generally have less $\mathrm{Ni}$ and $\mathrm{Co}$, similar $\mathrm{Cu}$ and, at times, higher PGE contents, due to the different resistance of the host minerals to weathering. PGE and base metal mobility in the supergene zone (Taufen \& Marchetto, 1989) may change with aqueous geochemical conditions, such as pH and Eh (Brookins, 1987). PGE in gossans can occur in platinum-group minerals (PGM) inherited from fresh ores or in new minerals formed in the supergene environment. The latter involves remobilization of PGE at low temperatures, has been disputed in the past, but several studies have shown conclusive evidence of this process (e.g., Bowles 1986; Kwitko et al., 2002; Oberthür et al. 2003; Cabral and Kwitko-Ribeiro, 2004). Alloys, such as Os-Ir-Ru and Pt-Fe, are among the most common types of PGM argued to have formed in surface zones either by weathering or later precipitation in streams, where they commonly form 
PGE placer deposits (Tolstykh et al., 2002). Recently experimental and empirical studies have confirmed that PGE-oxides and hydroxides can be formed also as a result of weathering processes (Brookins, 1987; Augé \& Legendre, 1994; Jedwab, 1995; Locmelis et al., 2010; Suárez et al., 2010).

The Limoeiro Ni-Cu(-PGE) sulfide deposit, in northeastern Brazil, was discovered in 2009 by Votorantim Metals' (VM) geologists, as they identified a PGE-Cu-Ni-rich gossan within a $1 \mathrm{~km}$ wide area containing several ultramafic rock outcrops. This was achieved by investigation of a geophysical anomaly that consisted of coincident high magnetic and low gamma spectrometry responses (Mota-e-Silva et al., 2013). Initially the gossan was classified as generic ironstone, but the interpretation changed after an assay result of $3990 \mathrm{ppm} \mathrm{Cu}$ and $2290 \mathrm{ppm} \mathrm{Ni}$. Later chip samples of the same gossan were also assayed for Pt and Pd, and these returned values of up to $3.08 \mathrm{ppm}$ Pd and $1.15 \mathrm{ppm}$ Pt (Votorantim Metais unpublished internal reports).

This paper reports on the weathering of the sulfide ores and gossan formation in the Limoeiro Ni-Cu(-PGE) deposit. It traces the progressive dissolution of base metal sulfides (BMS) and PGM present in the unweathered ore, as they alter to new PGM phases. The objectives were to produce a survey of the PGM mineralogy in the gossan, to identify the different weathering fronts and the alteration sequences, to relate the PGM in the gossan to those in the fresh sulfide deposit, and so gather evidence for the remobilization of PGE and base metals (i.e. $\mathrm{Ni}$ and $\mathrm{Cu}$ ) during supergene alteration.

\section{The PGE and PGM in the Limoeiro sulfide deposit}

The Limoeiro Ni-Cu(-PGE) sulfide deposit is located in a high grade mobile belt belonging to the Brasiliano orogenic cycle $(650-500 \mathrm{Ma})$ known as the Borborema province (Almeida et al., 1981; Brito Neves et al., 2000; Santos et al., 2010) (Fig. 4.1). The deposit is hosted by a tubular sub-horizontal and concentrically zoned intrusion (chonolith) interpreted as 
a multi-pulse magma conduit (Fig. 4.2). The intrusion is formed by several sequences (mineralized and barren), each representing a magma pulse (Mota-e-Silva et al., 2013). In the Limoeiro primary sulfide deposit most of the PGE occur as discrete PGM. They are dominantly $\mathrm{Pd}(-\mathrm{Pt}-\mathrm{Ni})$-bearing bismuthotellurides (mainly Bi-Pt-Ni-bearing merenskyite), followed by Pt(-RhIr)-bearing arsenide and sulfarsenide (dominantly sperrylite) (Mota-e-Silva et al., in review). The mineralization hosting these PGM consists of massive sulfide layers less than a meter thick surrounded by an envelope of tens to hundreds of meters of disseminated sulfide (Mota-e-Silva et al., 2013) (Fig. 4.2).
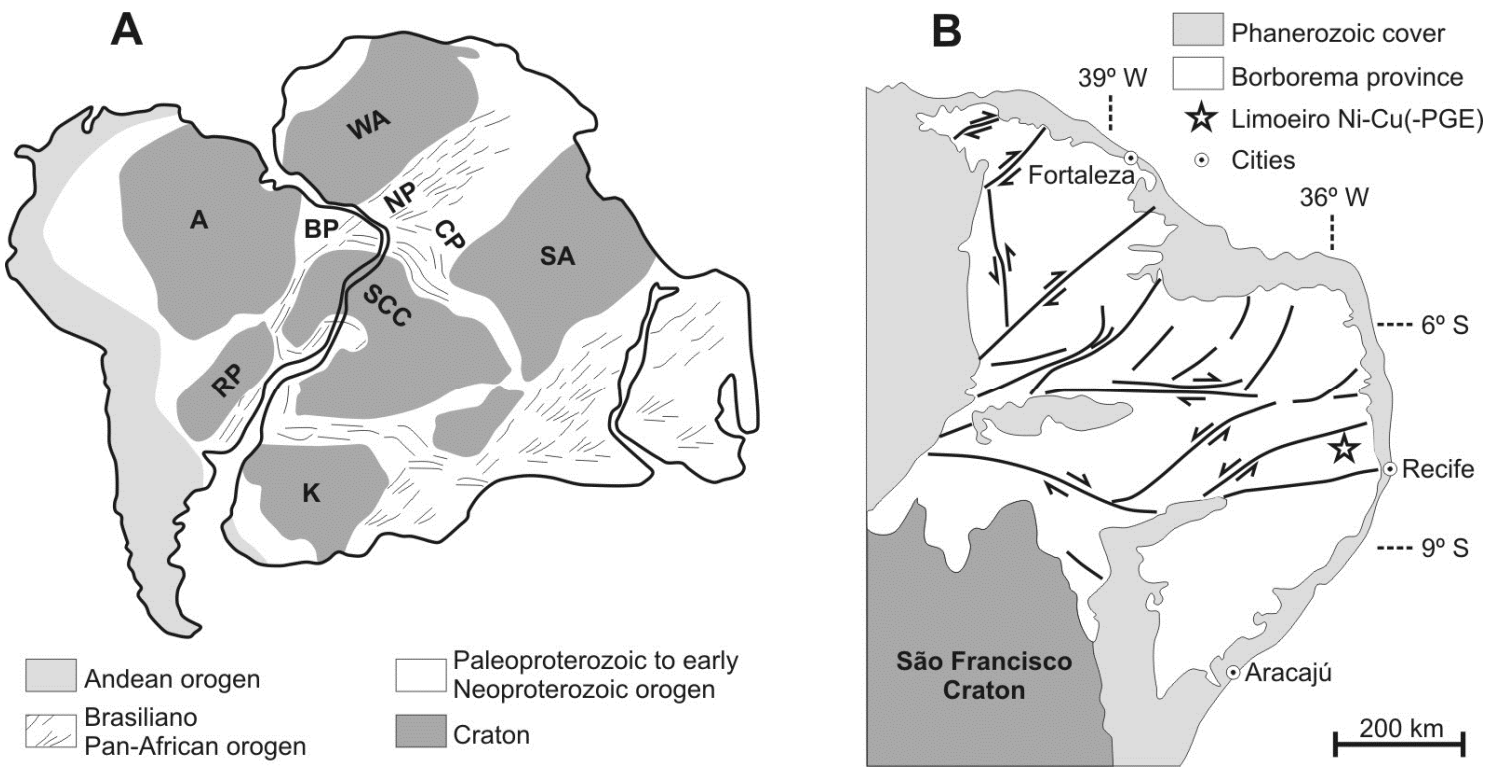

Fig. 4.1 (A) Pre-rift reconstruction of western Gondwana showing the main cratons and Brasiliano/Pan-African provinces (modified from Neves and Alcantara, 2010). Craton abbreviations: A, Amazonia; SCC, São Francisco/Congo; WA, West Africa; RP, Rio de La Plata; SA, Sahara; and K, Kalahari. Provinces of the Brasiliano/Pan-African orogeny abbreviations: BP, Borborema; NP, Nigeria; and CP, Cameroon. (B) Sketch showing the position of the Limoeiro Ni-Cu(PGE) sulfide deposit in the Borborema province (modified from Mota-e-Silva et al., 2013).

\section{Sampling and analytical methods}

The map of the Limoeiro deposit and gossans (Fig. 4.2) is a simplification from previous studies (e.g. Mota-e-Silva et al., 2013) with the addition of gossan locations defining its areal extent. The map was generated with the support of exploration data (including maps and geophysical surveys) developed by VM. 


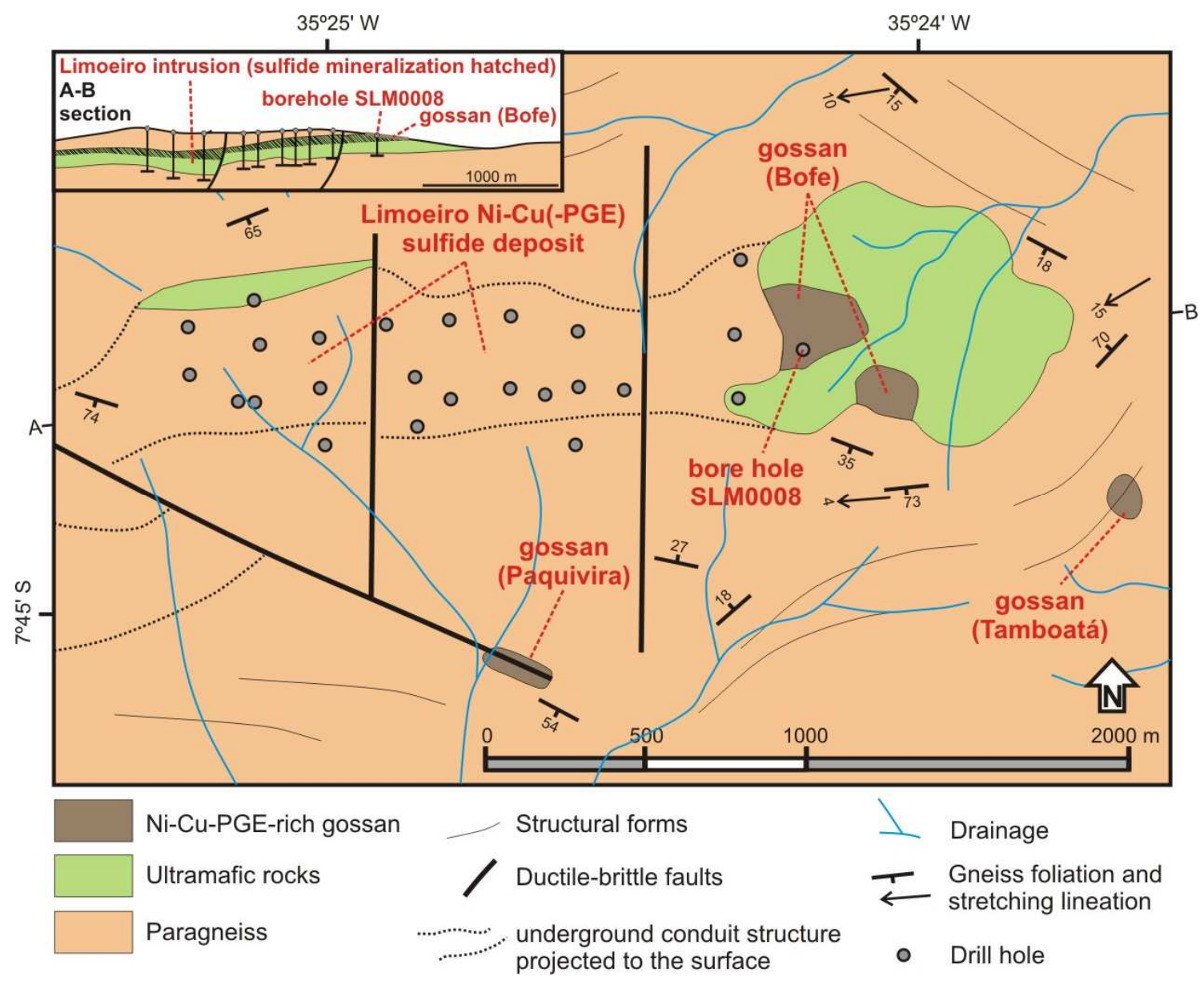

Fig. 4.2 Simplified geological map of the Limoeiro intrusion showing the locations of the gossan occurrences and bore hole SLM0008. A simplified cross section is presented in the upper-left corner. The coordinates are from the SAD-69 geographic projection.

The drill log presented here was obtained from half drill cores that were sampled continuously at approximately $1 \mathrm{~m}$ intervals, and adjusted accordingly to geological contacts. Each sample weighed about 2-kg and analyses of 21 elements were carried out at ALS Chemex, Toronto, Canada, using an inductively coupled plasma atomic emission spectrometer (ICP-AES) after fine crushing $(70 \mathrm{wt} \%<2 \mathrm{~mm})$, pulverizing $\left(85 \mathrm{wt} \%<75 \mu \mathrm{m}^{2}\right)$ and four acid digestion. Platinum and Pd were analyzed using an ICP-AES after standard lead oxide collection fire assay.

For PGM characterization 4 gossan grab samples from the surface and 5 half drill cores were sampled and polished thin sections were produced. The gossan samples came from two different locations: Bofe and Paquivira. The drill core samples were taken from different depths in bore hole SLM0008 that is located at the margin of the Bofe gossan. The PGM were 
identified using a four quadrant back scatter detector (4QBSD) on a Zeiss NTS S360 SEM at Cardiff University. The samples were searched systematically for PGM using the SEM set at a magnification of $\times 200$. Quantitative analyses of the larger PGM $(>3 \times 3 \mu \mathrm{m})$ were obtained using an Oxford Instruments INCA Energy X-ray analyzer (EDX) attached to the SEM. Operating conditions for the quantitative analyses were $20 \mathrm{kV}$, with a probe current of $\sim 1 \mathrm{nA}$ and a working distance of $25 \mathrm{~mm}$. A cobalt reference standard was regularly analyzed in order to check for any drift in the analytical conditions. A wide-ranging set of standards obtained from MicroAnalysis Consultants Ltd (St Ives, Cambridgeshire) was used to calibrate the EDX analyzer.

\section{Results}

The gossans

In the region of the Limoeiro deposit at least 4 gossan occurrences are known: Bofe, Paquivira, Tamboatá and Passassunga (the first three are close to each other and shown in Fig. 4.2). The Bofe gossan is the only one which overlies the known economic sulfide deposit. It is formed predominantly of goethite, limonite (a dusty orange mineral aggregate dominated by goethite and with minor amounts of hematite, fine grained quartz and aluminum hydroxide, as identified in the SEM) and veins of dark grey cement made up of amorphous/poorly crystallized silica and goethite (Fig. 4.3). The gossan samples have fine to coarse cellular boxwork and botryoidal textures that occasionally preserve tiny greenish, iridescent minerals (possibly bornite altered to malachite).

The Bofe gossan crops out in-situ and as scattered clasts within clayey soil comprising a total area of 250 by $500 \mathrm{~m}$. It crops out discontinuously as locally the drainage has dissected the terrain to the depth of the ultramafic saprolite (Fig. 4.3). Vertical exposure is not complete and the best depth estimate based on drill hole SLM0008 and on the local topography is from 2 
to $6 \mathrm{~m}$ (Fig. 4.4). This gossan is therefore a little thicker than the submeter-scale thickness of the primary massive sulfide ore.
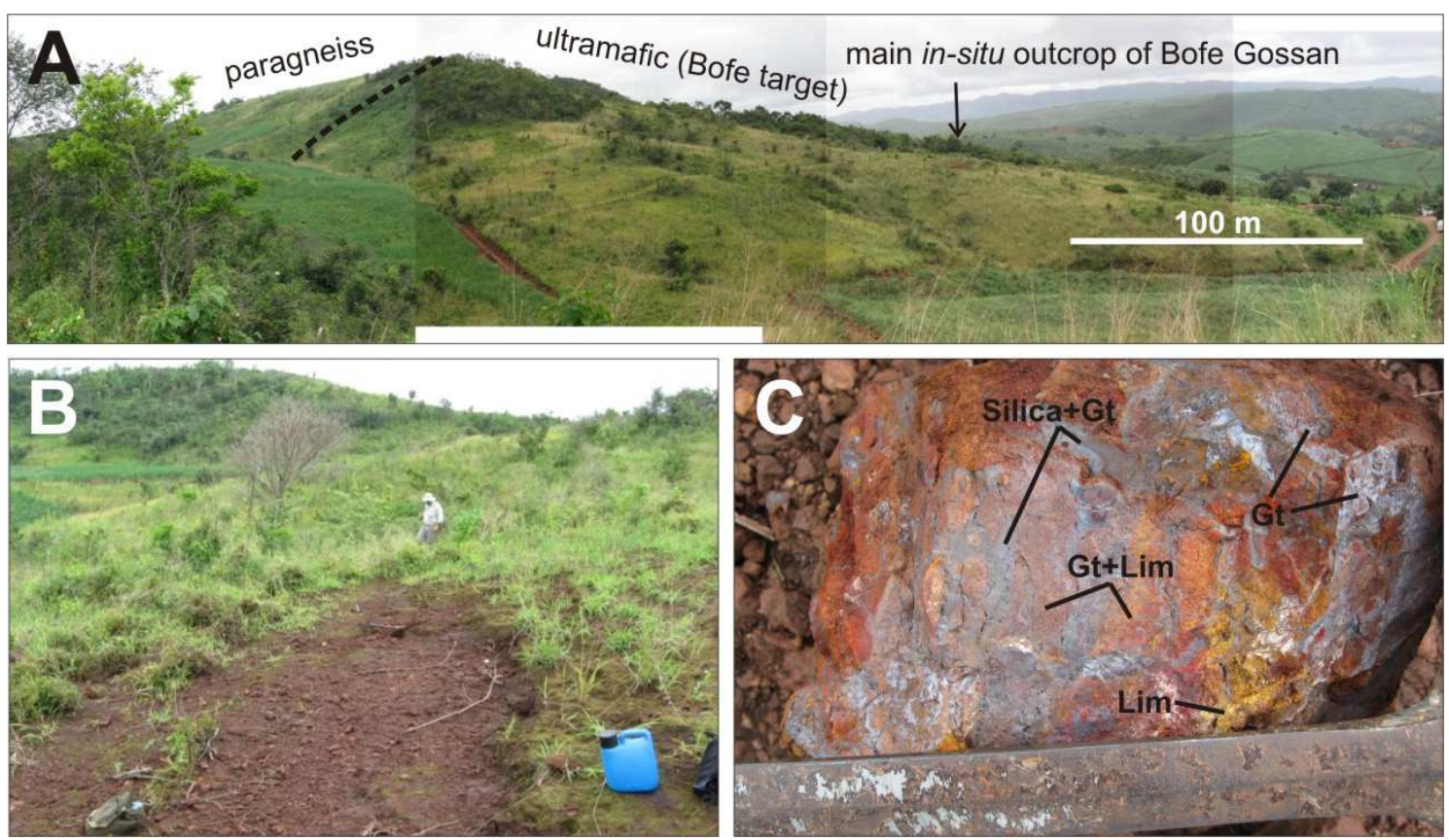

Fig. 4.3 (A) Panoramic view looking north towards the ultramafic rocks and the Bofe gossan. (B) Detail of the main insitu Bofe gossan outcrop looking towards the south. Note that vegetation shows retarded growth where the gossan outcrops. (C) Sample of PGE-Cu-Ni-rich Bofe gossan (2 cm wide hammer handle shows the scale). Mineral symbols: Gt, goethite; Lim, limonite.

The Paquivira gossan overlies a shear zone (Fig. 4.2). Outcrops are scarce in the vicinity of the gossan, such that the size and structure of associated mafic-ultramafic bodies are not well constrained. The Paquivira gossan is more goethite-rich compared to the Bofe gossan. The Pd and Pt grades are also higher reaching up to $8.28 \mathrm{ppm} \mathrm{Pd}$ and $5.84 \mathrm{ppm} \mathrm{Pt}$ in chip samples, whereas the $\mathrm{Ni}$ and $\mathrm{Cu}$ grades are similar to the $\mathrm{NI}$ and $\mathrm{Cu}$ grades in the Bofe gossan reaching up to 3030 and 4090 ppm respectively (Votorantim Metais' unpublished internal reports). 


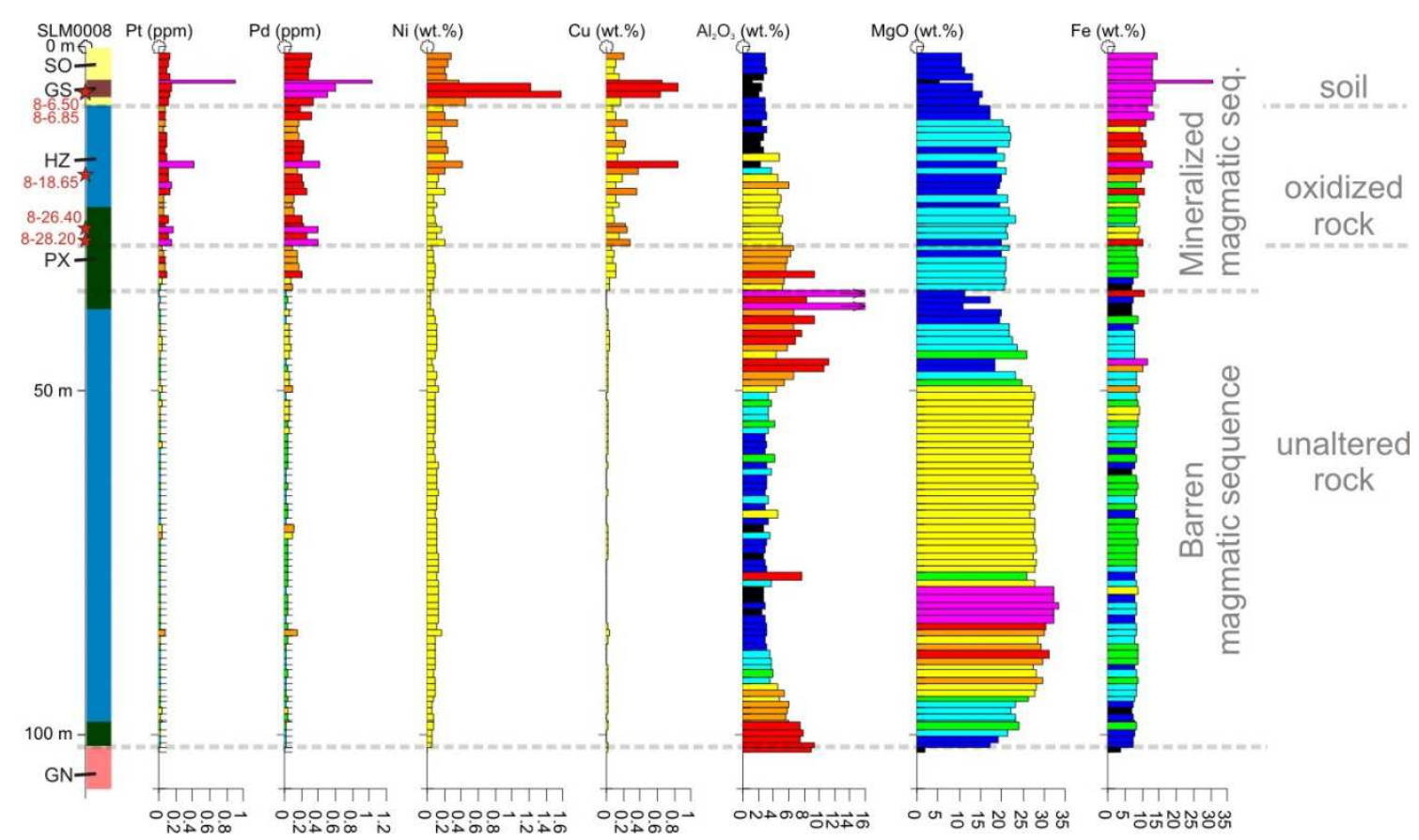

Fig. 4.4 The SLM0008 log containing depth marks, lithology, and assay results for $\mathrm{Pt}, \mathrm{Pd}, \mathrm{Ni}, \mathrm{Cu}_{2} \mathrm{Al}_{2} \mathrm{O}_{3}, \mathrm{MgO}$ and $\mathrm{Fe}$ represented as bar plots. The bar colors vary according to concentrations to distinguish between similar values and the interpretation of trends. Lithological abbreviations: SO, soil with a few gossan clasts; GS, gossan; HZ, harzburgite; PX, orthopyroxenite; GN, paragneiss.

\section{The weathering profile and its mineralogical changes}

Interpreting the geochemical changes in weathering profiles is not straightforward in the Limoeiro deposit, as the underlying fresh rocks are variable. Such variation is controlled by the several magmatic sequences that form the intrusion. Each sequence is defined by a gradational decrease of the $\mathrm{MgO}$ and $\mathrm{Cr}$ content towards the edge of the intrusion, accompanied by a gradational increase of $\mathrm{Al}_{2} \mathrm{O}_{3}$, where there is a zone with anomalously high values of $\mathrm{BaO}, \mathrm{K}_{2} \mathrm{O}$ and $\mathrm{Na}_{2} \mathrm{O}$ (Mota-e-Silva et al., 2013; Fig. 4.4). These variation trends must be taken into account when interpreting the mobile and immobile behavior of elements throughout the weathering profile.

An average thickness of $11.93 \mathrm{~m}$ [one standard deviation $(1 \sigma)=9.29 \mathrm{~m}$ ] for the soil layer (including soft saprolite) and an average depth limit of $37.48 \mathrm{~m}(1 \sigma=11.73 \mathrm{~m})$ for weathered rock were calculated using 35 drill hole logs from the VM's database. The drill hole SLM0008 exhibits slightly lower depth values than the averages calculated above. The 
geochemical profile of this drill core shows that above the soil/rock boundary the $\mathrm{MgO}$ decreases from 20 to $10 \mathrm{wt} \%$ due to alteration of orthopyroxene and olivine to limonite (Fig. 4.4). The Fe shows a flat pattern of $\sim 8 w t \%$ throughout the fresh rocks, and this gradually increases above the oxidized/fresh rock boundary reaching up to $14 \mathrm{wt} \%$ at the surface. The drill hole SLM0008 intercepted a gossan layer $5 \mathrm{~m}$ below the surface. This has $31 \mathrm{wt} \% \mathrm{Fe}$ and the highest values of $\mathrm{Pt}$ and $\mathrm{Pd}(0.9$ and $1.0 \mathrm{ppm}$ respectively) in the drill hole. The highest values of the base metals $\mathrm{Ni}$ and $\mathrm{Cu}$ occur immediately under this gossan layer, in a zone where clayey soil is dominant, but gossan clasts are also present (Fig. 4.4).

The deepest signs of weathering can be seen in sample 8-28.20 (labeled by drill hole number - depth in meters), where magmatic sulfide blebs included in silicates are altered and oxidized (Fig. 4.5A). At this depth pentlandite is altered to violarite, which is oxidized, and pyrrhotite is altered to pyrite, which is also oxidized but to a lesser extent. The EDX qualitative analyses (hydrogen cannot be analyzed by such method) shows that the oxididation of violarite generates a product with a composition of $\sim 46 \mathrm{wt} \% \mathrm{O}, \sim 27 \mathrm{wt} \% \mathrm{~S}, \sim 20 \mathrm{wt} \% \mathrm{Ni}, \sim 3 \mathrm{wt} \% \mathrm{Fe}, \sim 3$ $\mathrm{wt} \%$ Co and $\sim 1 \mathrm{wt} \% \mathrm{Mg}$. The oxidation of pyrite is not as intense as for violarite at this depth and is marked by its alteration to iron hydroxides that preferentially precipitate along the conchoidal fractures within the grain (Fig. 4.5B). The altered pyrite at this depth has $\sim 43 \mathrm{wt} \% \mathrm{~S}$, $\sim 41 \mathrm{wt} \% \mathrm{Fe}, \sim 14 \mathrm{wt} \% \mathrm{O}$ and $\sim 2 \mathrm{wt} \% \mathrm{Si}$. Contrary to the aforementioned BMS, chalcopyrite is still fresh at this depth (Fig. 4.5A). The two most abundant PGM (i.e. merenskyite and sperrylite) are also preserved, even where included in oxidized sulfides (Fig. 4.5B). The merenskyite however has a diffuse contour that differs from that found in the fresh sulfide mineralization (Mota-e-Silva et al., in review). At a slightly shallower depth of $26.40 \mathrm{~m}$ there is little change, as chalcopyrite and merenskyite remain fresh, whereas pyrite and violarite are even more oxidized (Fig. 4.5C).

At a depth of $18.65 \mathrm{~m}$ violarite, pyrite and chalcopyrite are oxidized, and their oxidation products are not visually or chemically distinguishable from each other (Figs. 5D and E). Such products are not homogeneous, as they form patches with different levels of oxidation and incorporation of $\mathrm{Si}$. On average their composition is $\sim 44 \mathrm{wt} \% \mathrm{Fe}, \sim 39 \mathrm{wt} \% \mathrm{O}, \sim 11 \mathrm{wt} \% \mathrm{Si}, \sim 3$ $\mathrm{wt} \% \mathrm{Cu}, \sim 1 \mathrm{wt} \% \mathrm{Mg}, \sim 1 \mathrm{wt} \% \mathrm{Al}$ with only trace amounts of S. Given the composition, this is 
probably goethite with minor amounts of silicates. Some of the olivine and orthopyroxene grains are also altered at this depth. They have lost $\mathrm{Mg}$ and incorporated Fe compared to the fresh minerals. The altered minerals are surrounded by goethite veinlets that have preferentially crystallized along boundaries, fractures and cleavage. The hornblende is still fresh at this depth (Fig. 4.5E) and among the PGM, sperrylite is still preserved (Fig. 4.5D). No merenskyite grains could be identified, although a partly oxidized Pd-Te \pm Bi PGM was identified (Fig. 4.5D). The PGM grains are mainly located at the edge of the oxidized sulfide grains, in a very similar way to the merenskyite occurrences in the fresh sulfide mineralization (Mota-e-Silva et al., in prep). The PGM contain variable minor amounts of $\mathrm{Cu}$ and Pt. (Fig. 4.5D).

Closer to the surface, at a depth of $6.50 \mathrm{~m}$, weathered rock and gossan clasts occur in the soft saprolite. All the silicates are altered through Mg loss and incorporation of Fe. Veinlets of goethite and poorly crystalized silica with voids are dominant and the ultramafic mineralogy is partly replaced by the typical gossan mineral assemblage (Fig. 4.5F). The goethite commonly has an appreciable base metal content, and eventually it occurs mixed with manganese hydroxide and hydrosilicate minerals (e.g. garnierite) making a compound phase that reaches up to $20 \mathrm{wt} \% \mathrm{Ni}$ and $14 \mathrm{wt} \% \mathrm{Cu}$. The oxidized sulfide is rarely found in its original position and shape especially where the goethite and silica veinlets are more abundant. The PGM identified at this depth include three Pd-Cu alloys and one Pt-Fe alloy. Such a mineralogical assemblage is similar to the typical gossan association, which is described in the following section.

A summary of the mineral alteration and precipitation through the weathering profile of the Limoeiro Ni-Cu(-PGE) sulfide deposit is shown in Fig. 4.6. This shows the reactivity of the BMS and platinum-group bimuthotellurides, and the stability of oxides and platinum-group arsenides and sulfarsenides during weathering. 

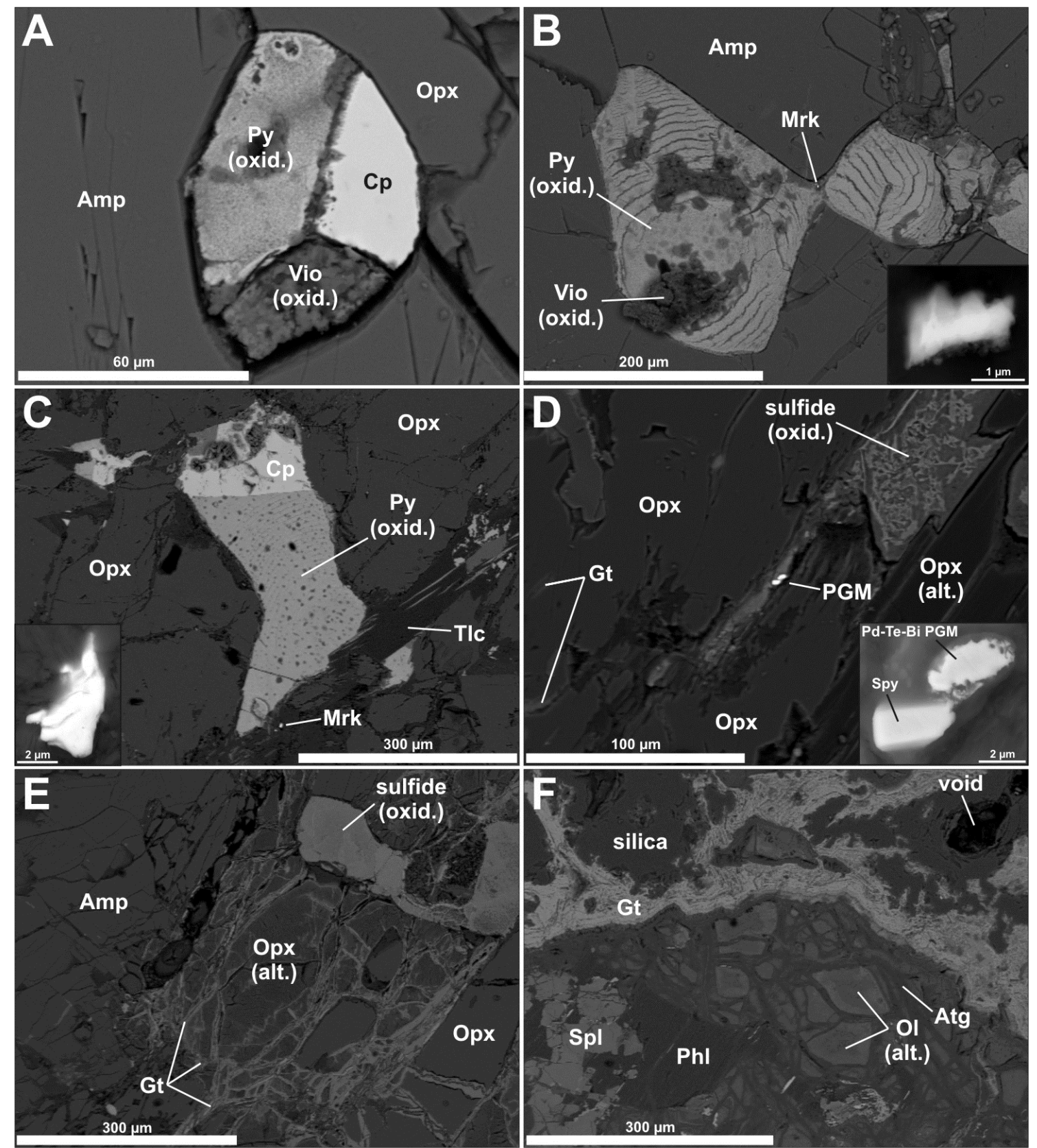

Fig. 4.5 Back scattered electron images of: (A) Sulfide bleb hosted by amphibole (Amp) and orthopyroxene (Opx) grains showing the distinct oxidation state of the base metal sulfides (BMS). Violarite (Vio) is the most oxidized BMS, whereas pyrite is slightly oxidized and chalcopyrite $(\mathrm{Cp})$ is still fresh. This is a mineralized orthopyroxenite sample from a depth of $28.20 \mathrm{~m}$. (B) Partly oxidized pyrite with goethite crystallized in circular concentric fractures. Violarite is completely oxidized, whereas merenskyite (Mrk; detail in the bottom right inset) is still preserved but exhibits a diffuse outline hosted in a mineralized orthopyroxenite from a depth of $28.20 \mathrm{~m}$. (C) Partly oxidized pyrite, with fresh chalcopyrite and merenskyite, the latter showing a diffuse outline and oxidized fractures (detail in the bottom left inset). This is a mineralized orthopyroxenite sampled at a depth of $26.40 \mathrm{~m}$. (D) Oxidized sulfide (mostly replaced by goethite) included in partly altered orthopyroxene. Sperrylite (Spy) is still preserved whereas merenskyite (detail of these two PGM in the bottom right inset) is altered to a Pd-Te-Bi PGM that shows an irregular outline, in a mineralized harzburgite at a depth of $18.65 \mathrm{~m}$. (E) Oxidized sulfide included in a fresh amphibole and partly altered orthopyroxene. The oxidation of these mineral phases occurs by gradual replacement of them by veinlets of goethite (Gt). This sample is a mineralized ultramafic-derived saprolite in the transition zone to gossan at a depth of $6.50 \mathrm{~m}$. (F) A partly altered ultramafic rock; altered olivine, antigorite (Atg), phlogopite (Phl) and Cr-spinel (Spl) occur in the lower part of the image, whereas a typical gossan mineralogy and texture (goethite, fine grained quartz and voids) dominate in the upper portion of the 
image. The sample consists of a mineralized ultramafic-derived saprolite in the transition zone to gossan at the depth of 6.50m. Mineral symbols are used in accordance with Kretz (1983).

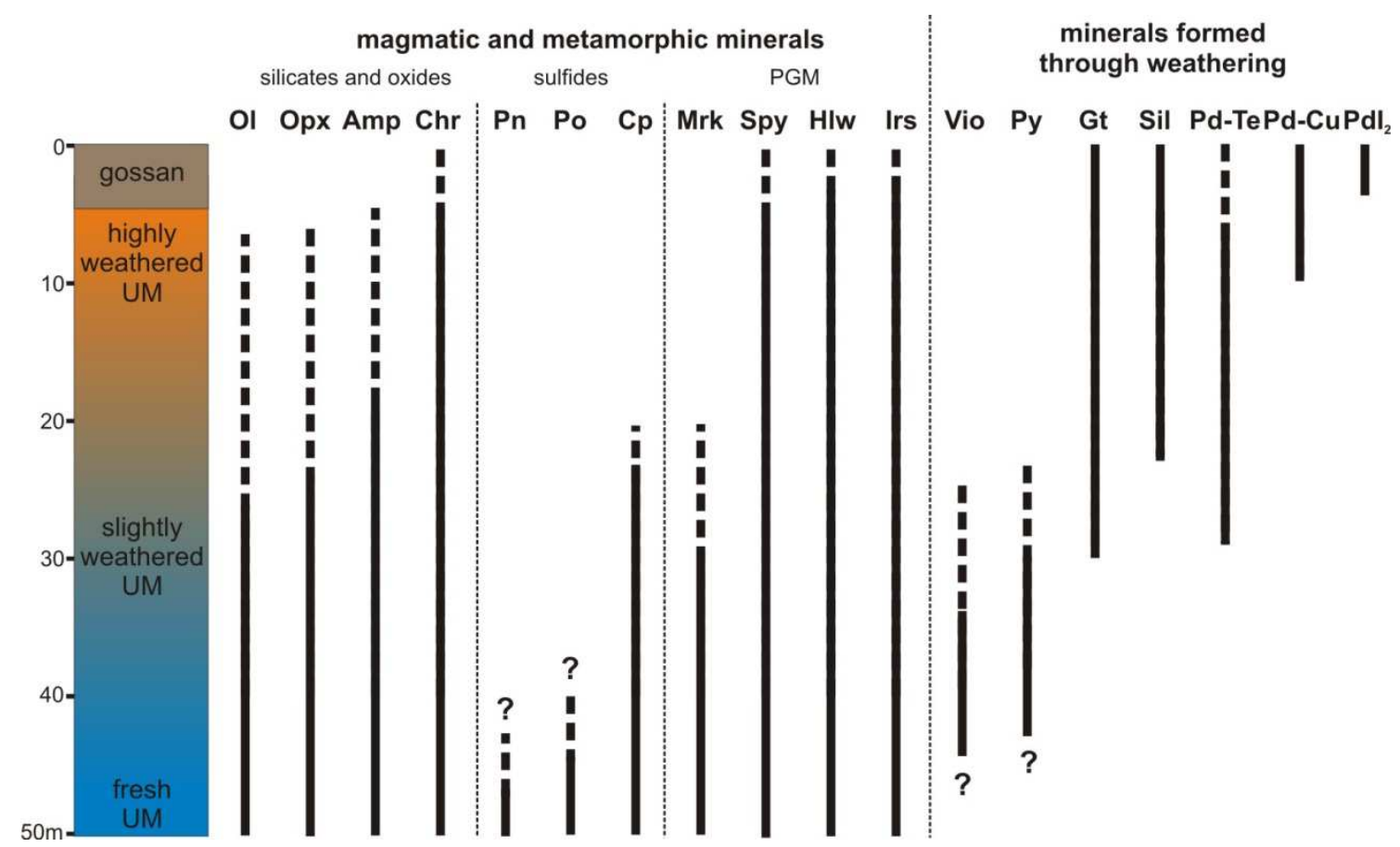

Fig. 4.6 Schematic chart showing (solid black lines) the range of occurrence of each specific mineral phase along the weathering profile in the Limoeiro $\mathrm{Ni}-\mathrm{Cu}(-\mathrm{PGE})$ sulfide deposit. The dashed line indicates the zone where the mineral is altered. The question marks note uncertainties on the depth of alteration of pentlandite and pyrrhotite to violarite and pyrite. Mineral symbols are used in accordance with Kretz (1983) when available: olivine (OI), orthpyroxene (Opx), amphibole (Amp), chromite ( $\mathrm{Chr}$ ), pentlandite $(\mathrm{Pn})$, pyrrhotite $(\mathrm{Po})$, chalcopyrite $(\mathrm{Cp})$, merenskyite (Mrk), sperrylite (Spy), hollingworthite (HIw), irarsite (Irs), violarite (Vio), pyrite (Py), goethite (Gt), silica (Sil), Pd-Te (Pd-Te $\pm B i P G M), P d-$ $\mathrm{Cu}$ (Pd-Cu alloy) and $\mathrm{Pdl}_{2}$ (Pd iodide).

\section{Platinum-group minerals}

Eighty nine discrete PGM grains have been identified in the gossans and oxidized rock samples (Table 4.1$)$. Some of them are large enough $(>5 \times 5 \mu \mathrm{m})$ to be quantitatively analyzed, and a selection of these analyses are shown in Table 4.2. The PGM assemblage identified in the gossans consists of Pd-Cu alloy (52\%), Pd iodide (21\%), Pd-Te PGM (11\%) and Rh- (9\%), Ir- (5\%) and Pt- (2\%) arsenide and sulfarsenide (Fig. 4.7). These arsenide and sulfarsenide minerals are also found in the fresh sulfide mineralization (Mota-e-Silva et al., in prep), and thus may represent relicts of former PGM. The other PGM only occur in the weathered mineralization, $\mathrm{Pd}-\mathrm{Cu}$ alloy is only detected in the saprolite-gossan section and Pd- 
iodide specifically is only detected in the gossans. Considering grain area, instead of frequency, the PGM assemblage in the gossans is strongly dominated by Pd-Cu and Pd-Te PGM $(70 \%$ and 29\% respectively) (Fig. 4.7). The Pd-Cu and Pd-Te PGM, as well as the Pd iodide form partly oxidized grains. This oxidation affects most of the grains, and so the non-oxidized portion is rarely large enough to be analyzed quantitatively.
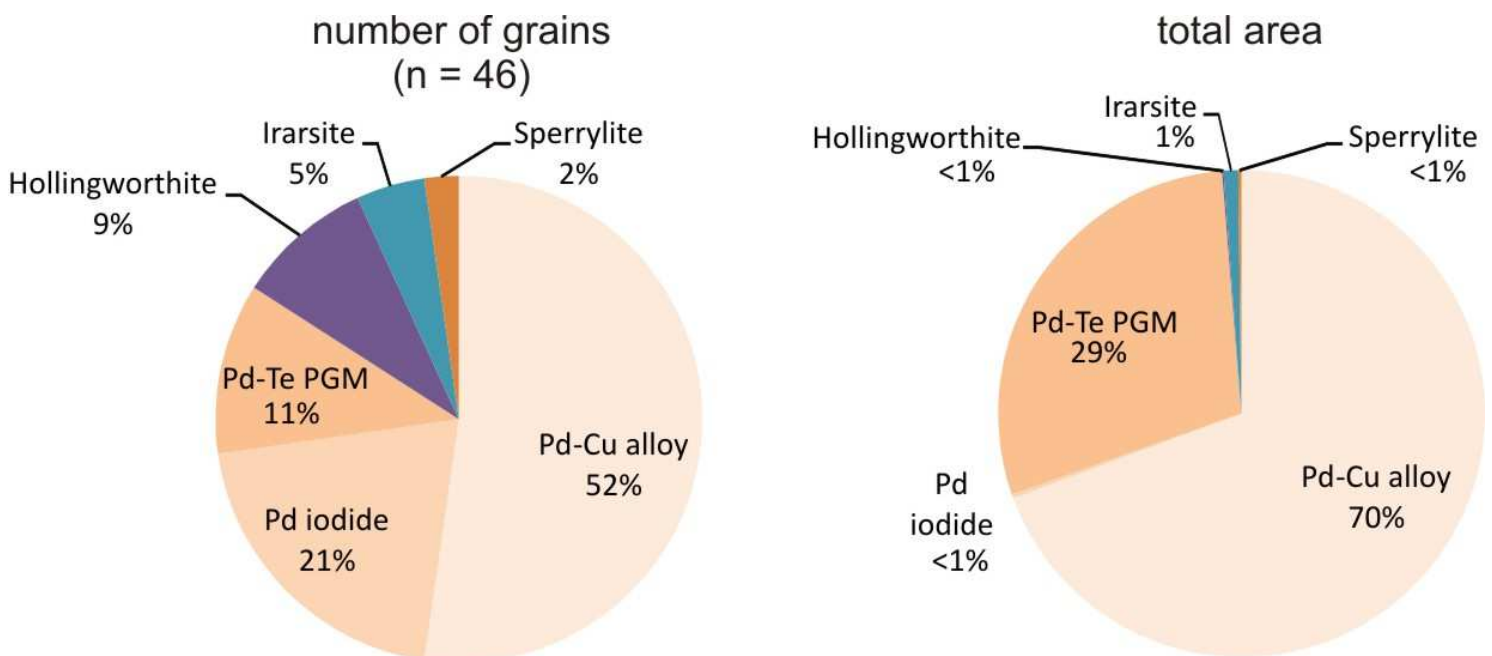

Fig. 4.7 Pie charts showing the PGM frequency and area abundances in the Bofe and Paquivira gossans in the Limoeiro Ni-Cu(-PGE) sulfide deposit.

\section{Arsenide and sulfarsenide}

Within this group of PGM sperrylite $\left(\mathrm{PtAs}_{2}\right)$, irarsite $[(\mathrm{Ir}, \mathrm{Pt}, \mathrm{Rh}) \mathrm{AsS}]$ and hollingworthite $[(\mathrm{Rh}, \mathrm{Ir}, \mathrm{Co}, \mathrm{Pt}) \mathrm{AsS}]$ minerals were identified in the Limoeiro gossan. They form euhedral relicts derived from the sulfide mineralization. These relicts are not totally preserved and show different degrees of weathering. Sperrylite is partly oxidized on its edges (Fig. 4.8A), but its original shape is still recognizable. Amongst the arsenides and sulfarsenides, sperrylite is the PGM most frequently chemically altered. Hollingworthite appears fragmented into pieces suggesting physical disintegration of the mineral (Figs. 8C, D, E and F). This feature may have caused hollingworthite to be partly eroded in most cases and its original form is still represented by voids in the host goethite. Irarsite is also affected by partial fragmentation (Fig. 4.8C), but to a lesser extent than for hollingworthite. In most cases irarsite is present as perfectly preserved euhedral crystals (Fig. 4.8B and E). Locally both hollingworthite and irarsite are partly oxidized 
(Fig. 4.8C). These PGM occurrences described above suggest a decreasing order of susceptibility to alteration during weathering as follows: sperrylite, hollingworthite and irarsite.
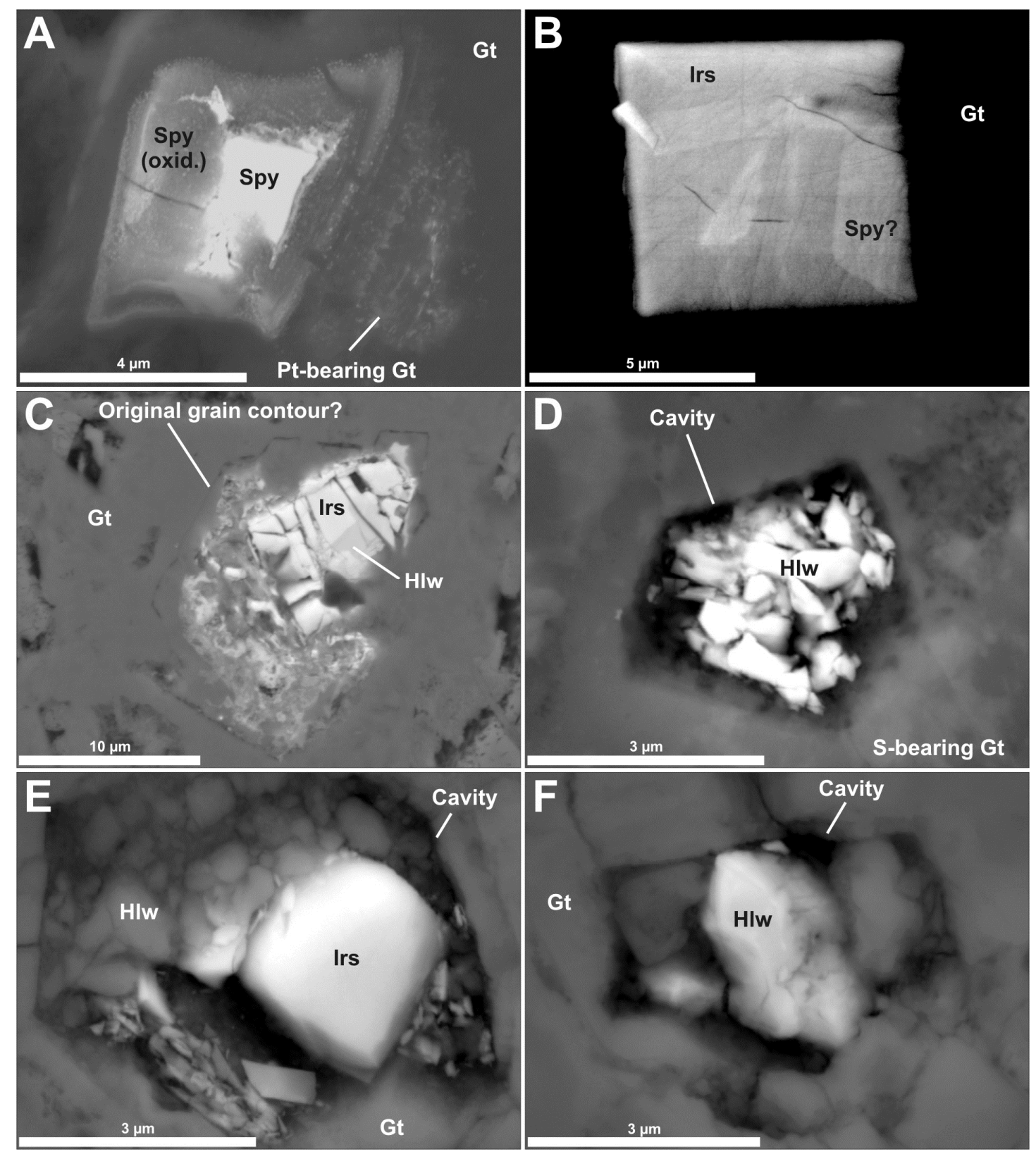

Fig. 4.8 Back scattered electron images of arsenide and sulfarsenide PGM in the gossan: (A) A sperrylite (Spy) with an oxidized rim preserving the original grain boundary. The sperrylite is hosted by goethite (Gt) which contains Pt-rich goethite patches adjacent to the sperrylite. Sample GS-BF-2, grain 3. (B) A fresh irarsite (Irs) associated with a brighter (more dense) phase possibly sperrylite. This mineral is hosted by goethite. Sample GS-PQ-1, grain 9. (C) A partly altered and corroded irarsite and hollingworthite $(\mathrm{HIw})$ composite crystal hosted by goethite. A faceted dark line surrounding the PGM probably represents the original grain boundary of the irarsite and hollingworthite composite grain. Sample GS-PQ-1, grain 6. (D) A broken and partly corroded hollingworthite grain hosted by goethite. The cavity around the PGM is suggestive of the original hollingworthite grain boundary. Sample GS-PQ-2, grain 5. (E) A preserved cubic irarsite crystal and a broken and partly corroded hollingworthite forming a composite grain within goethite. A cavity around the PGM is suggestive of the original composite grain boundary. Sample GS-PQ-2, grain 3. (F) A broken and partly corroded hollingworthite grain hosted by goethite. A cavity around the PGM is suggestive of the original grain boundary. Sample GS-PQ-2, grain 2. Mineral symbols are used in accordance with Kretz (1983). 
Table 4.1 Platinum-group mineral abundances. The sample names have Bofe (BF) and Paquivira (PQ) gossans as abbreviations. Gossans were sampled on surface and the other samples from drill hole 8 at the depth mentioned on the number after the dash.

\begin{tabular}{|c|c|c|c|c|c|c|c|c|c|c|c|}
\hline Sample & Litho & $\begin{array}{c}\mathrm{Pd}(\mathrm{Te}, \mathrm{Bi})_{2} \\
\text { Mrk }\end{array}$ & $\begin{array}{l}\mathrm{PtAs}_{2} \\
\text { Spy }\end{array}$ & $(\mathrm{Pd}, \mathrm{Ag})(\mathrm{Te}, \mathrm{Bi})_{2}$ & $(\mathrm{Pd}, \mathrm{Pb}) 2(\mathrm{Te}, \mathrm{Bi})_{3}$ & $\begin{array}{c}(\mathrm{Rh}, \mathrm{Ir}, \mathrm{Co}, \mathrm{Pt})(\mathrm{As}, \mathrm{S})_{2} \\
\mathrm{HIw}\end{array}$ & $\begin{array}{c}(\mathrm{Ir}, \mathrm{Pt}, \mathrm{Rh}) \mathrm{As}_{2} \\
\mathrm{Irs}\end{array}$ & Pd-Te alloy & Pt-Fe alloy & Pd-Cu alloy & Pd lodide \\
\hline GS-BF-1 & GS & & & & & & & & & 1 & 8 \\
\hline GS-PQ-2 & GS & & & & & 3 & & & & 15 & \\
\hline GS-PQ-1 & GS & & & & & 1 & 2 & 6 & & 5 & 1 \\
\hline GS-BF-2 & GS & & 1 & & & & & 1 & & 2 & \\
\hline $8-6.85$ & SAP & & & & & & & & 1 & 3 & \\
\hline $8-18.65$ & $\mathrm{oxHZ}$ & & 2 & & & & & 4 & & & \\
\hline $8-26.40$ & oxPX & 8 & 1 & 3 & 1 & & & & & & \\
\hline $8-28.20$ & oxPX & 20 & & & & & & & & & \\
\hline
\end{tabular}

Lithological unit abbreviations: GS, gossan; SAP, saprolite; oxHZ, oxidized harzburgite; oxPX, oxidized orthopyroxenite.

Minerals abbreviations: Mrk, merenskyite; Spy, sperrylite; HIw, hollingworthite; Irs, irarsite. 
Table 4.2 Selective representative quantitative analyses [in wt\% and atomic proportion (norm. to 100\%)] of the PGM and associated minerals found in the gossans of the Limoeiro deposit. The sample names have Bofe (BF) and Paquivira (PQ) gossans as abbreviations.

\begin{tabular}{|c|c|c|c|c|c|c|c|c|c|c|c|c|c|c|c|c|c|c|c|c|c|c|c|}
\hline Mineralogy & $\begin{array}{l}\text { Ob } \\
s\end{array}$ & Sample & Grain & Fig. & $\begin{array}{l}\text { No } \\
\text {. }\end{array}$ & $\begin{array}{l}\text { (wt. \%) } \\
\text { o }\end{array}$ & Al & $\mathrm{Si}$ & $\mathbf{s}$ & K & $\mathrm{Fe}$ & Co & $\mathrm{Ni}$ & $\mathrm{Cu}$ & As & Rh & Pd & Te & 1 & Ir & Pt & $\mathrm{Bi}$ & Total \\
\hline \multicolumn{24}{|l|}{ PGM } \\
\hline Spy & po & GS-BF-2 & 3 & $8 \mathrm{~A}$ & 1 & 28.44 & & & 30.9 & & 22.1 & & & & 14.8 & 3.44 & & & & & & & 99.86 \\
\hline Irs & rg & GS-PQ-1 & 9 & $8 B$ & 2 & & & & 8.95 & & 4.11 & 0.5 & & & 29.7 & & 2.03 & & & 4 & 14.9 & & 100.57 \\
\hline Irs & $\mathrm{rg}$ & GS-PQ-1 & 6 & $8 C$ & 3 & & & & 12.6 & & 4.14 & 4.1 & 0.91 & & 30.7 & 9.64 & 0.90 & & & 3 & 4.25 & & 100.75 \\
\hline$P d-T e \pm B i$ & rc & GS-PQ-1 & 10 & $9 B-C$ & 4 & & & & & & 1.46 & & & & & & 68.5 & 22.1 & & & & 8.34 & 100.44 \\
\hline $\mathrm{Pd}-\mathrm{Te} \pm \mathrm{Bi}$ & po & GS-PQ-1 & 1 & - & 5 & 20.79 & & & & & & & & & & & 62.5 & 10.1 & & & & 5.89 & 99.30 \\
\hline $\mathrm{Pd}-\mathrm{Te} \pm \mathrm{Bi}$ & po & GS-BF-2 & 2 & - & 6 & 15.44 & & & & & 10.1 & & 0.61 & 1.94 & & & 54.8 & 12.3 & & & 4.29 & 2.99 & 102.57 \\
\hline$P d-T e \pm B i$ & ho & GS-BF-2 & 4 & $9 \mathrm{E}$ & 7 & 34.31 & & 1.17 & 0.28 & & 31.7 & & 0.73 & 3.08 & & & 19.3 & & & & 10.7 & & 101.38 \\
\hline $\mathrm{Pd}-\mathrm{Cu}$ & a & GS-PQ-2 & 10 & $10 \mathrm{~A}$ & 8 & 22.09 & 0.96 & 0.43 & 0.18 & & 2.10 & & & 7.88 & & & 61.3 & & & & & & 94.96 \\
\hline $\mathrm{Pd}-\mathrm{Cu}$ & a & GS-PQ-2 & 21 & $10 \mathrm{~B}$ & 9 & 17.93 & 0.22 & & & 0.31 & 4.01 & & & 10.9 & & & 67.3 & & & & & & 100.75 \\
\hline $\mathrm{Pd}-\mathrm{Cu}$ & a & GS-PQ-2 & 21 & $10 \mathrm{~B}$ & 10 & 19.38 & & & & & 4.02 & & & 11.0 & & & 67.4 & & & & & & 101.85 \\
\hline $\mathrm{Pd}-\mathrm{Cu}$ & a & GS-PQ-2 & 11 & $10 \mathrm{C}$ & 11 & 18.51 & & & & & 2.61 & & & 12.8 & & & 67.5 & & & & & 0.87 & 102.38 \\
\hline Pd-lodide & & GS-PQ-1 & 1 & $11 \mathrm{E}$ & 12 & & & & & & 2.27 & & & & & & 35.3 & & 6 & & & & 98.80 \\
\hline Pd-lodide & po & GS-BF-1 & 12 & $11 \mathrm{~A}$ & 13 & 13.20 & & & & & 16.8 & & & & & & 21.5 & & 5 & & & & 101.54 \\
\hline Pd-lodide & po & GS-BF-1 & 13 & 11D & 14 & 17.26 & & & 0.31 & & 21.9 & & & 2.78 & & & 27.1 & & 3 & & & & 99.81 \\
\hline Pd-lodide & po & GS-PQ-1 & 1 & $11 \mathrm{~F}$ & 15 & 18.40 & & & & & & & & & & & 41.5 & & 3 & & & & 98.20 \\
\hline \multicolumn{24}{|l|}{ Goethite } \\
\hline & & GS-PQ-1 & 4 & - & 16 & 34.0 & & 0.78 & 0.26 & & 65.8 & & & & & & & & & & & & 100.9 \\
\hline & & GS-PQ-1 & 10 & $9 \mathrm{~B}-\mathrm{C}$ & 17 & 39.2 & & 1.21 & & & 59.9 & & & & & & & & & & & & 100.4 \\
\hline & & GS-PQ-2 & 11 & - & 18 & 38.0 & 0.56 & 1.07 & 0.14 & & 59.5 & & & & & & & & & & & & 99.37 \\
\hline & & GS-PQ-2 & 12 & - & 19 & 33.1 & & 1.13 & & & 64.8 & & & & & & & & & & & & 99.03 \\
\hline with $\mathrm{Cu}$ & & GS-BF-1 & 6 & - & 21 & 37.6 & & 1.66 & 0.21 & & 59.1 & & & 0.38 & & & & & & & & & 99.08 \\
\hline with $\mathrm{Cu}$ & & GS-PQ-2 & 21 & $10 \mathrm{~B}$ & 22 & 31.4 & 0.20 & 1.01 & 0.20 & & 66.6 & & & 0.34 & & & & & & & & & 99.88 \\
\hline with $\mathrm{Cu}, \mathrm{Te}$ & & GS-PQ-2 & 10 & $10 \mathrm{~A}$ & 23 & 38.0 & 0.70 & 0.56 & 0.39 & & 59.4 & & & 0.68 & & & & 0.65 & & & & & 100.4 \\
\hline with $\mathrm{Cu}, \mathrm{Te}$ & & GS-PQ-2 & 11 & $10 \mathrm{C}$ & 24 & 33.1 & 0.27 & 0.98 & & & 64.9 & & & 0.41 & & & & 0.87 & & & & & 100.6 \\
\hline with $\mathrm{Cu}, \mathrm{Te}$ & & GS-PQ-1 & 7 & $10 \mathrm{G}$ & 25 & 33.5 & 0.49 & & & & 61.9 & & & 0.41 & & & & 3.72 & & & & & 100.0 \\
\hline with $\mathrm{Cu}, \mathrm{Te}, \mathrm{Pd}$ & & GS-PQ-2 & 11 & $10 \mathrm{C}$ & 26 & 36.6 & 0.80 & 0.57 & 0.14 & & 44.5 & & & 4.09 & & & 14.6 & 0.59 & & & & & 102.0 \\
\hline
\end{tabular}

PGM abbreviations: Spy, sperrylite; Irs, irarsite

Abbreviations in Obs field: po, partly oxidized; rg, relict grain; rc, relict core; ho, highly oxidized; a, aggregates 
Table 4.2 (cont.)

\begin{tabular}{|c|c|c|c|c|c|c|c|c|c|c|c|c|c|c|c|c|c|}
\hline No. & $\begin{array}{l}\text { (at. \%) } \\
\text { o }\end{array}$ & Al & $\mathrm{Si}$ & $S$ & $\mathrm{~K}$ & $\mathrm{Fe}$ & Co & $\mathrm{Ni}$ & $\mathrm{Cu}$ & As & Rh & $\mathbf{P d}$ & $\mathrm{Te}$ & I & Ir & $\mathrm{Pt}$ & $\mathrm{Bi}$ \\
\hline 1 & 69.32 & & & 6.19 & & 15.46 & & & & & 1.30 & & 7.75 & & & & \\
\hline 2 & & & & 26.22 & & 6.92 & 0.81 & & & 37.30 & 1.85 & & & & 19.70 & 7.20 & \\
\hline 3 & & & & 31.20 & & 5.88 & 5.54 & 1.22 & & 32.57 & 7.42 & 0.67 & & & 13.77 & 1.73 & \\
\hline 4 & & & & & & 2.95 & & & & & & 72.91 & 19.63 & & & & 4.52 \\
\hline 5 & 65.16 & & & & & & & & & & & 29.45 & 3.98 & & & & 1.41 \\
\hline 6 & 52.56 & & & & & 9.90 & & 0.57 & 1.67 & & & 28.07 & 5.25 & & & 1.20 & 0.78 \\
\hline 7 & 70.07 & & 1.36 & 0.29 & & 18.54 & & 0.41 & 1.58 & & & 5.96 & & & & 1.80 & \\
\hline 8 & 63.48 & 1.63 & 0.71 & 0.26 & & 1.73 & & & 5.70 & & & 26.49 & & & & & \\
\hline 9 & 55.65 & 0.40 & & & 0.39 & 3.57 & & & 8.58 & & & 31.41 & & & & & \\
\hline 10 & 57.95 & & & & & 3.44 & & & 8.29 & & & 30.32 & & & & & \\
\hline 11 & 56.58 & & & & & 2.29 & & & 9.91 & & & 31.02 & & & & & 0.20 \\
\hline 12 & & & & & & 4.76 & & & & & & 38.88 & & 56.36 & & & \\
\hline 13 & 47.89 & & & & & 17.50 & & & & & & 11.74 & & 22.87 & & & \\
\hline 14 & 53.42 & & & 0.48 & & 19.47 & & & 2.17 & & & 12.62 & & 11.85 & & & \\
\hline 15 & 62.44 & & & & & & & & & & & 21.18 & & 16.38 & & & \\
\hline 16 & 63.69 & & 0.83 & 0.24 & & 35.24 & & & & & & & & & & & \\
\hline 17 & 68.71 & & 1.20 & & & 30.09 & & & & & & & & & & & \\
\hline 18 & 67.82 & 0.60 & 1.09 & 0.12 & & 30.38 & & & & & & & & & & & \\
\hline 19 & 63.28 & & 1.23 & & & 35.49 & & & & & & & & & & & \\
\hline 21 & 67.56 & & 1.70 & 0.19 & & 30.38 & & & 0.17 & & & & & & & & \\
\hline 22 & 61.18 & 0.23 & 1.12 & 0.20 & & 37.11 & & & 0.17 & & & & & & & & \\
\hline 23 & 67.64 & 0.74 & 0.56 & 0.35 & & 30.26 & & & 0.30 & & & & 0.15 & & & & \\
\hline 24 & 62.90 & 0.30 & 1.06 & & & 35.33 & & & 0.20 & & & & 0.21 & & & & \\
\hline 25 & 64.35 & & 0.54 & & & 34.01 & & & 0.20 & & & & 0.90 & & & & \\
\hline 26 & 68.37 & 0.88 & 0.61 & 0.13 & & 23.83 & & & 1.92 & & & 4.12 & 0.14 & & & & \\
\hline
\end{tabular}


The sperrylite grain size varies from 1 to $33 \mu \mathrm{m}^{2}$, hollingworthite ranges from 3 to $6 \mu \mathrm{m}^{2}$ and irarsite from 6 to $110 \mu \mathrm{m}^{2}$. These arsenides and sulfarsenides are hosted by goethite free of base metals. In the previous section it was shown that goethite directly transformed from BMS has variable concentrations of $\mathrm{Ni}$ and $\mathrm{Cu}$. Mota-e-Silva et al. (in prep) have demonstrated that in the fresh sulfide mineralization at Limoeiro the PGM arsenides and sulfarsenides are mostly hosted by cumulus orthopyroxene and oxides (spinel, magnetite). These latter mineral phases are likely to be the precursors of the goethite that hosts these PGM in the gossan, and these precursor minerals also have no $\mathrm{Ni}$ and $\mathrm{Cu}$ content.

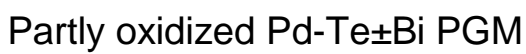

As demonstrated in the previous section the Pd-Te \pm Bi PGM was only identified at shallow depths $(<19 \mathrm{~m})$ coincident with the absence of merenskyite. This Pd-Te \pm Bi PGM phase occurs as pseudomorphs after merenskyite (Fig. 4.9), assuming the same euhedral primastic shape and size as the merenskyite described in the fresh sulfide mineralization (Mota-e-Silva et al., in prep). The $\mathrm{Pd}-\mathrm{Te} \pm \mathrm{Bi}$ forms a patchy PGM phase as it is partly oxidized and partly replaced by goethite. The rate of oxidation of the original merenskyite is variable (Fig. 4.9B, D and E). The whole area of individual merenskyite pseudomorphs (non-oxidized relict cores + oxidized parts + goethite) varies from $4 \mu \mathrm{m}^{2}$ to $4400 \mu \mathrm{m}^{2}$, with an average of $475 \mu \mathrm{m}^{2}$. This size range and average are very similar to the dimensions of the merenskyite grains described in the fresh massive sulfide ore (Mota-e-Silva et al., in prep).

The Pd-Te \pm Bi PGM are usually hosted by $\mathrm{Cu}$ - and S-bearing goethite, which indicates a derivation from the oxidation of BMS. The non-oxidized portion of this mineral phase is generally too small $(<5 \mu \mathrm{m})$ to be analyzed quantitatively, however one of the identified grains provided a good quantitative analysis (Fig. 4.9C, Table 4.2). This quantitative analysis indicates that the Pd-Te $\pm \mathrm{Bi}$ PGM is relatively enriched in $\mathrm{Pd}$ up to $69 \mathrm{wt} \%$ and has much less $\mathrm{Te}$ and $\mathrm{Bi}$ (Table 4.2) compared to the precursor merenskyite which, accordingly to Mota-e-Silva et al. (in review), typically has $20 \mathrm{wt} \% \mathrm{Pd}, 48 \mathrm{wt} \% \mathrm{Te}$ and $23 \mathrm{wt} \% \mathrm{Bi}$. The oxidized part of the $\mathrm{Pd}-\mathrm{Te} \pm \mathrm{Bi}$ 
PGM (Fig. 4.9A-C) contains elevated Pd (50-67 wt\%) and O (15-33 wt\%) in its composition

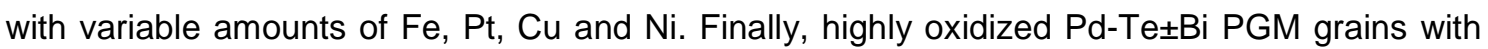
rare relict PGM cores (Fig. 4.9D-E) develop Pd-Cu-bearing Fe-oxides containing lower Pd $(<44$ wt.\%) but higher Pt and base metals, especially $\mathrm{Cu}(\leq 4$ wt.\%).
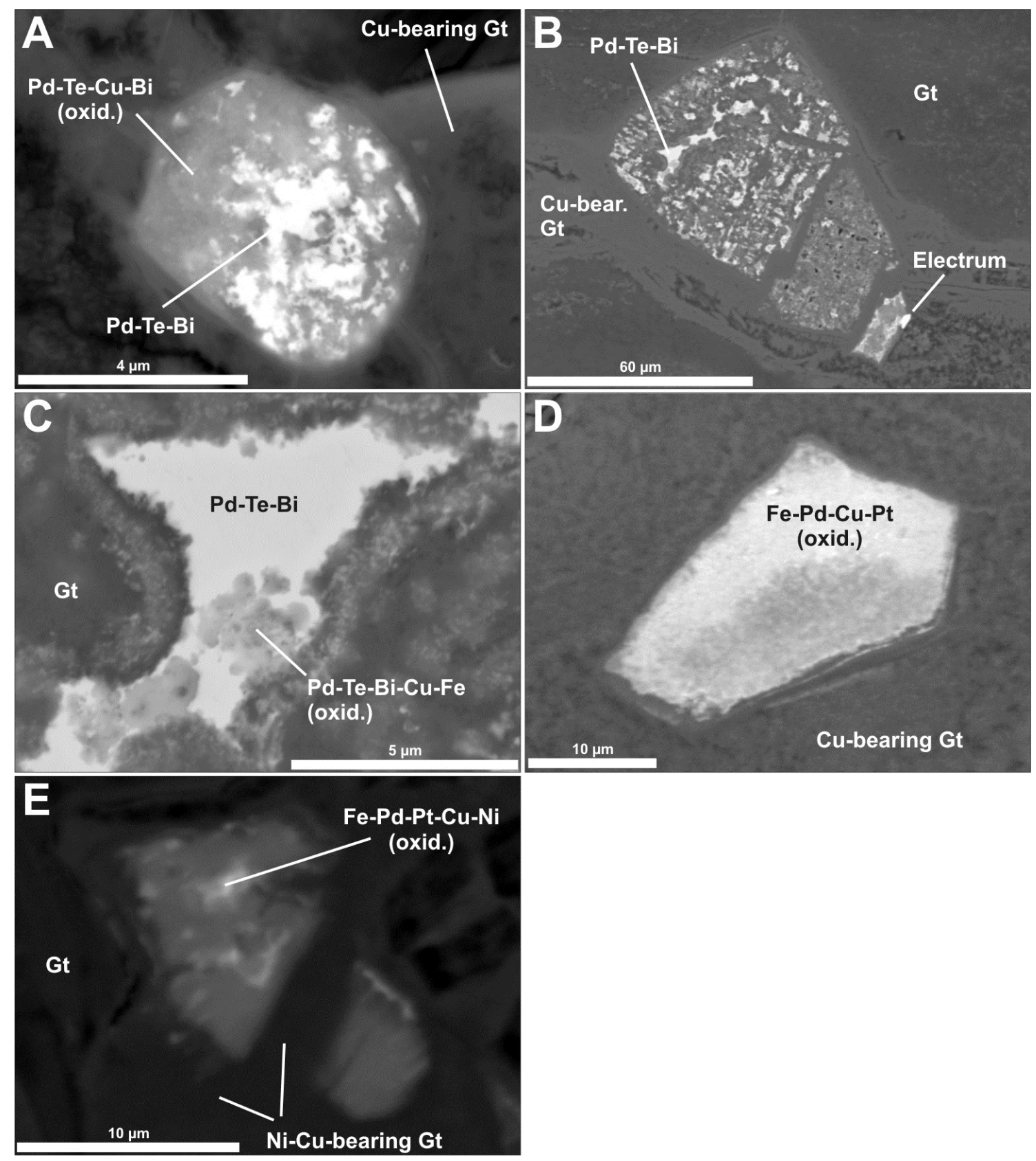

Fig. 4.9 Back scattered electron images of partly oxidized Pd-Te $\pm B i$ PGM: (A) Palladium-Te-Bi PGM (brightest) with oxidized parts (less bright) hosted by Cu-bearing goethite (Gt). Sample 8-18.65 (mineralized weathered harzburgite), grain 1. (B) A pseudomorph of merenskyite filled with Pd-Te-Bi PGM (detail in Fig. 4.9C) and Cu-bearing goethite. A small electrum grain occurs on the boundary of the pseudomorph with the host goethite. Sample GS-PQ-1 (Paquivira gossan), grain 10. (C) Detail of the Pd-Te-Bi PGM exhibited in Fig. 4.9B. The oxidation of the Pd-Te-Bi PGM forms rounded alteration fronts crossing from the external limits of the grain towards the inner parts. Sample GS-PQ-1, grain 10. (D) Oxidized Fe-Pd-Cu-Pt phase hosted by Cu-bearing goethite. The difference in the grain brightness reflects compositional variation (Pd-rich in the top and Fe-rich in the bottom). Sample GS-BF-2, grain 1. (E) Preserved core of 
oxidized Fe-Pd-Pt-Cu-Ni phase partly replaced by Ni-Cu bearing goethite. Sample GS-BF-2, grain 4. Mineral symbols are used in accordance with Kretz (1983).

\section{Pd-Cu alloy}

Both saprolite and gossan host partly oxidized Pd-Cu alloy in the shallow environment (<7m, Fig. 4.10). This Pd-Cu phase replaces the partially oxidized Pd-Te $\pm B i$ PGM suggesting a continuum of alteration from the pristine merenskyite to $\mathrm{Pd}$-Cu alloy in the Limoeiro supergene zone. Analogous to the Pd-Te $\pm B i$ PGM (Fig. 4.9), the Pd-Cu alloy occurs mixed with goethite that is pseudomorphing merenskyite. The whole merenskyite pseudomorph area including the $\mathrm{Pd}-\mathrm{Cu}$ alloy, voids and goethite, ranges from $2 \mu \mathrm{m}^{2}$ to $2330 \mu \mathrm{m}^{2}$ with an average of $435 \mu \mathrm{m}^{2}$. These dimensions are very similar to those reported for merenskyite grains in the fresh massive

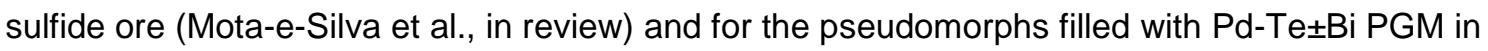
the gossans (as described in the previous section).

The degree of $\mathrm{Pd}-\mathrm{Te} \pm \mathrm{Bi}$ PGM replacement by $\mathrm{Pd}-\mathrm{Cu}$ alloy is variable. Relict tellurides partially replaced by Pd-Cu alloy and Fe-oxides appear strongly leached in open spaces or very porous areas of the samples (Fig. 4.10A). A less advanced replacement is proposed for smaller grains better protected by the enclosing goethite. These have patchy $\mathrm{Pd}$-Cu-alloys occupying larger areas of the grains along with more consolidated masses of goethite (Fig. 4.10B). In most cases however, goethite largely pseudomorphs precursor merenskyite and $\mathrm{Pd}-\mathrm{Cu}$ aggregates are sparse (Fig. 4.10C-E). 

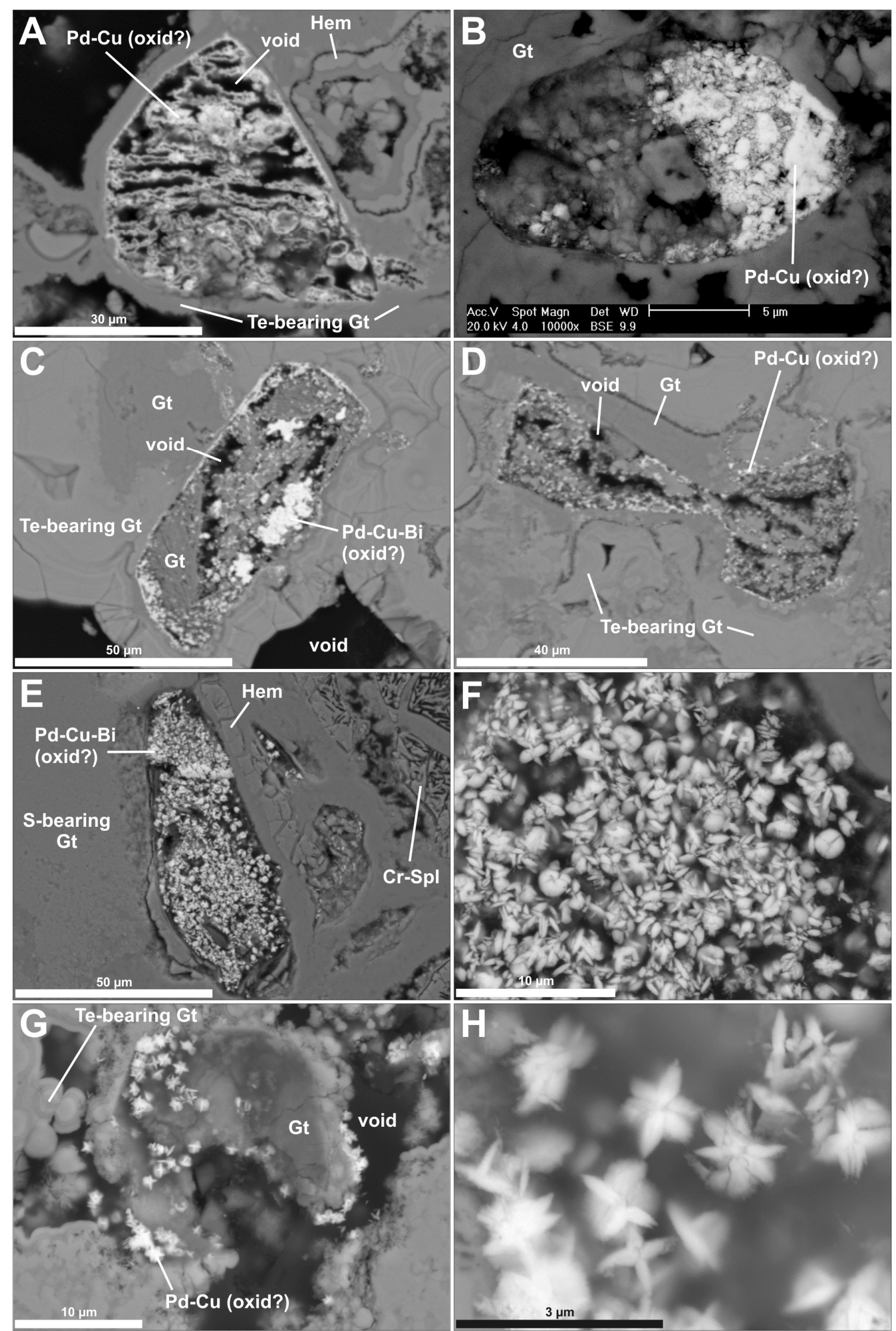

Fig. 4.10 Back scattered electron images of the Pd-Cu rich phases in the gossan: (A) Strongly dissolved and leached merenskyite enclosed in Te-bearing goethite. Relict PGM appears partially replaced by goethite and Pd-Cu-alloy masses (brightest in figure). Sample GS-PQ-2, grain 10. (B) Merenskyite pseudomorph composed of goethite and patches of Pd-Cu alloy. Sample GS-PQ-2, grain 21.(C) Merenskyite pseudomorph composed of goethite including 
micrometric patches of Pd-Cu-Bi alloys and sparse Pd-Cu-rosettes on the surface. Sample GS-PQ-2, grain 11. (D) Merenskyite pseudomorph composed of goethite and very fine grains of $\mathrm{Pd}-\mathrm{Cu}$ alloy locally crystalized outside the pseudomorph outline. Sample GS-PQ-2, grain 13. (E) Merenskyite pseudomorph with extensive development of Pd-Cu rosettes on the surface hosted by goethite and hematite $(\mathrm{Hem})$ and close to $\mathrm{Cr}$-spinel (Cr-Spl) crystals. Sample GS-PQ1, grain 11. (F) Detail of the Pd-Cu-Bi grain exhibited in Fig. 4.10E. The brightest grains are tiny rosette-like crystals of $\mathrm{Pd}-\mathrm{Cu}$-Bi alloy coating goethite. (G) Goethite partly coated by tiny rosette-like Pd-Cu crystals. Sample GS-PQ-2, grain 7. $(\mathrm{H})$ Detail of the Pd-Cu grain exhibited in Fig. 4.10G. The rosette-like crystals form an orthogonal-disc-like framework. Mineral symbols are used in accordance with Kretz (1983).

In detail, these goethite crusts are coated by tiny Pd-Cu crystals (Fig. 4.10C-F) able to coalesce and eventually form an almost continuous crystal surface (Fig. 4.10E). Under high magnification, these Pd-Cu crystals show diverse habits suggesting a sequential crystal growth (Fig. 4.10F-H). They occur (i) in a globular habit, as Pd-Cu microspheres displaying a central axis, (ii) in a radial habit, with crystals diverging from the center, and (iii) in a rosette-like habit, with tabular crystals often in an "X" shape or as a combination of several forms (Fig. 4.10H). Pd$\mathrm{Cu}$ rosettes mainly coat the goethite in merenskyite pseudomorphs but they are also located around them, along contacts between crystals or fissures (Fig. 4.10C-E). Less often, they occur

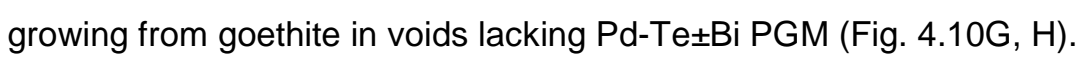

Each individual rosette has a diametrer of about $2 \mu \mathrm{m}$ and crystal surfaces formed by accreted rosettes are less than $5 \mu \mathrm{m}$ in length. None of them were large or uniform enough to obtain quantitative analysis clear of interference from their goethite substrate (Table 4.2). The patchy Pd-Cu aggregates are also irregular but sometimes reach sizes up to $10 \times 10 \mu \mathrm{m}$ (Fig. 4.10B, C). The analyses achieved on these grains show a rather uniform composition close to "(Pd,Cu,Fe)O" (Table 4.2), with elevated Pd and Cu [61-70 wt\% Pd, 8-14 wt\% Cu], moderate oxygen [18-22 wt\%] and low Fe [0-4 wt\%] and Bi [0-1 wt\%]. Compared to precursor Pd-TePGM, Pd-Cu grains contain similar or even higher Pd values but reflect a sharp increase in $\mathrm{Cu}$ up to $16 \mathrm{wt} \%$ and almost a complete loss of Te and $\mathrm{Bi}$. 


\section{Pd iodide}

The Pd iodide occurs as small euhedral crystals varying in area from 0.4 to $8.8 \mu \mathrm{m}^{2}$, (Fig. 4.11A-D) and less commonly partly replacing merenskyite pseudomorphs of $40 \mu \mathrm{m}$ in diameter (Fig. 4.11E-F). Quantitative analyses of the largest grain $(\sim 5 \mu \mathrm{m}$ in the longest dimension) reveal a composition of $35 \mathrm{wt} \% \mathrm{Pd}, 2 \mathrm{wt} \% \mathrm{Fe}$, and $61 \mathrm{wt} \% \mathrm{I}$, that would imply in an empirical formula of $\left.(\mathrm{Pd}, \mathrm{Fe})_{9}\right|_{11}$. The euhedral grains are too tiny to be properly analyzed quantitatively and moreover they do not show a continuous homogenous surface as they have oxidized portions intergrown throughout them (Fig. 4.11A-F). However qualitative analyses of these grains (taking out the $\mathrm{Fe}$ and $\mathrm{O}$ signals to minimize the influence of the oxidized parts and surrounding goethite) show dominantly a composition of $\mathrm{Pdl}_{2}$. Some of the tiny euhedral $\mathrm{Pd}$ iodide grains exhibit corroded crystal faces (Fig. 4.11A, B and C) suggesting that this mineral is unstable and has been partly modified during the evolution of the gossan. 

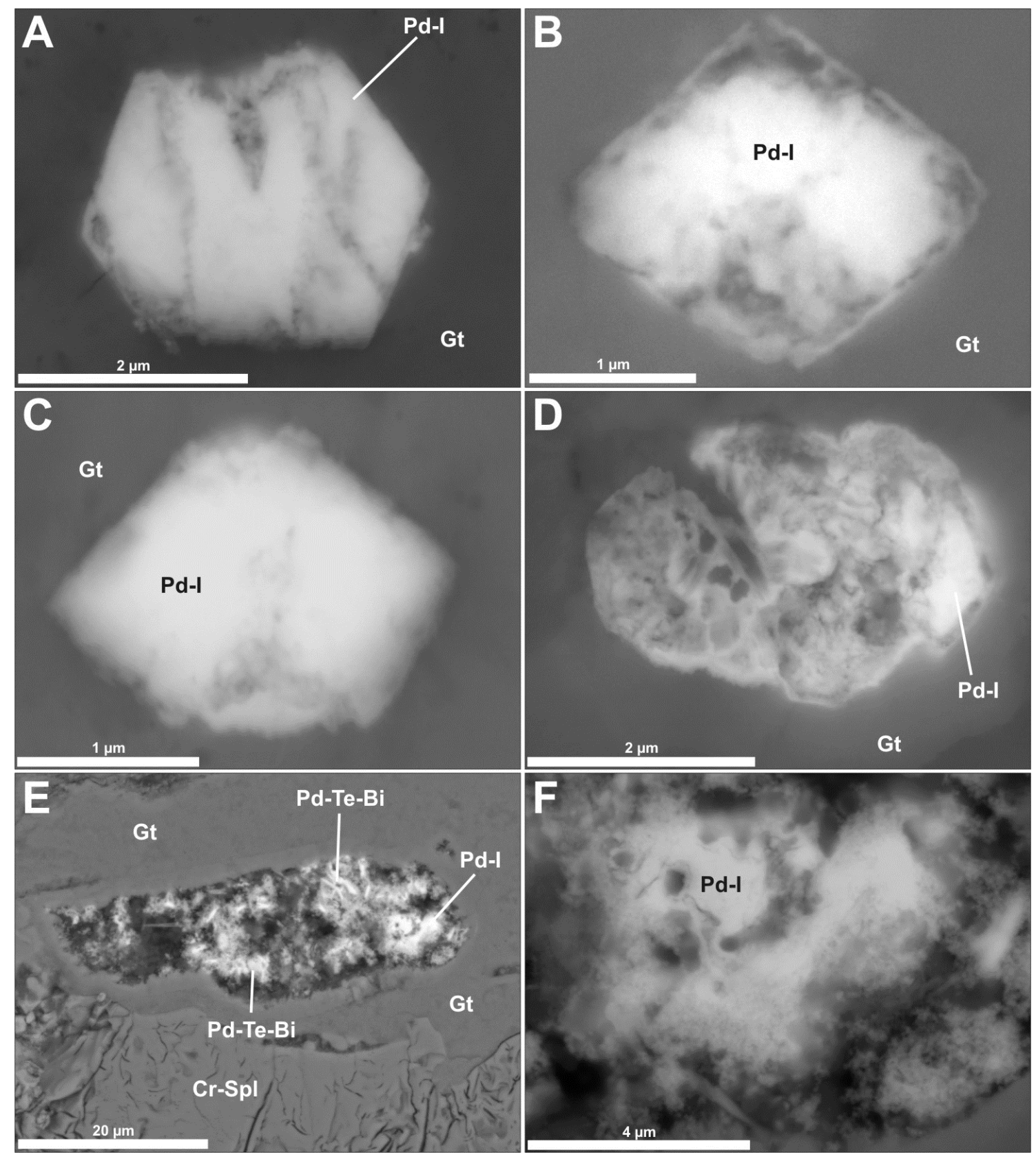

Fig. 4.11 Back scattered electron images of Pd iodide in the gossan: (A) Euhedral crystal of Pd iodide (Pd-I) hosted by goethite (Gt). Small veinlets of less bright material, probably represent oxidized areas, that crosscut parts of the $\mathrm{Pd}$ iodide. Sample GS-BF-1, grain 12. (B) Euhedral crystal of Pd iodide hosted by goethite. Less bright patches, concentrated in the outer parts of the grain, probably represent oxidized areas. Sample GS-BF-1, grain 3. (C) Partially corroded euhedral crystal of Pd iodide hosted by goethite. Less bright patches within the grain, concentrated in the outer parts, probably represent oxidized areas. Sample GS-BF-1, grain 6. (D) Partly corroded and rounded crystal of Pd iodide hosted by goethite. Less bright patches within the grain probably represent oxidized areas. Sample GS-BF-1, grain 13. (E) Pseudomorph of merenskyite containing voids (dark areas), goethite, Pd-Te-Bi PGM and Pd iodide (detail in Fig. 4.11F). The pseudomorph is hosted by goethite and has spatial proximity to Cr-spinel (Cr-Spl). Sample GS-PQ-1, grain 1. (F) Detail of the Pd iodide exhibited in Fig. 4.11E, with less bright areas probably representing oxidized portions of the mineral. Sample GS-PQ-1, grain 1. Mineral symbols are used in accordance with Kretz (1983). 


\section{Accessory minerals}

Other noble metals, heavy metals or semimetal-bearing phases are named here as accessory minerals. One hundred and fifty grains of accessory minerals have been identified (Table 4.3), and the most abundant phase is native $\mathrm{Zn}$, sometimes forming an alloy with $\mathrm{Cu}$. In the gossans, specifically, the most common phases are bismoclite (BiOCl), $\mathrm{Sn}-\mathrm{Fe}$ alloy and electrum. This latter mineral consists of tiny $\sim 4 \mu \mathrm{m}^{2}$ grains with irregular diffuse outlines and irregularities (e.g. cavities) (Fig. 4.12A). Bismoclite is commonly included in goethite as suhedral grains of 10 to $100 \mu \mathrm{m}^{2}$ in size (Fig. 4.12B). The native $\mathrm{Zn}$ and $\mathrm{Zn}-\mathrm{Cu}$ alloy form anhedral crystals and they are especially abundant within microfractures in the saprolite horizon that is overlain by the gossan (Fig. 4.12C and D). Apatite, galena and barite mainly occur as euhedral minerals commonly included in oxidized silicates in the saprolitic horizon under the gossan domain.

Table 4.3 Common accessory mineral abundances. The lithological codes are: GS, gossan; SAP, saprolite; oxHZ, oxidized harzburgite; oxPX, oxidized orthopyroxenite. The sample names have Bofe (BF) and Paquivira (PQ) gossans as abbreviations.

\begin{tabular}{llllllll} 
Sample & Litho & $\begin{array}{l}\mathrm{Zn} \pm(\mathrm{Cu}) \\
\text { Native } \mathrm{Zn}\end{array}$ & $\begin{array}{l}\mathrm{BiOCl} \\
\text { Bismoclite }\end{array}$ & $\begin{array}{l}\text { BaSO4 } \\
\text { Barite }\end{array}$ & $\begin{array}{l}\mathrm{PbS} \\
\text { Galena }\end{array}$ & $\begin{array}{l}\mathrm{Au}-\mathrm{Ag} \\
\text { Electrum }\end{array}$ & Apatite \\
\hline GS-BF-1 & GS & & 2 & & & 1 & \\
GS-PQ-2 & GS & & & & 1 & \\
GS-PQ-1 & GS & & 3 & & 1 & & 2 \\
GS-BF-2 & GS & 3 & & & & 2 & 1 \\
\hline $8-6.50$ & SAP & 5 & 1 & 5 & 3 & & 3 \\
$8-6.85$ & SAP & 3 & 1 & 4 & 1 & 1 & \\
$8-18.65$ & oxHZ & 26 & 2 & 6 & 5 & & \\
$8-26.40$ & oxPX & 3 & 5 & 2 & 11 & &
\end{tabular}




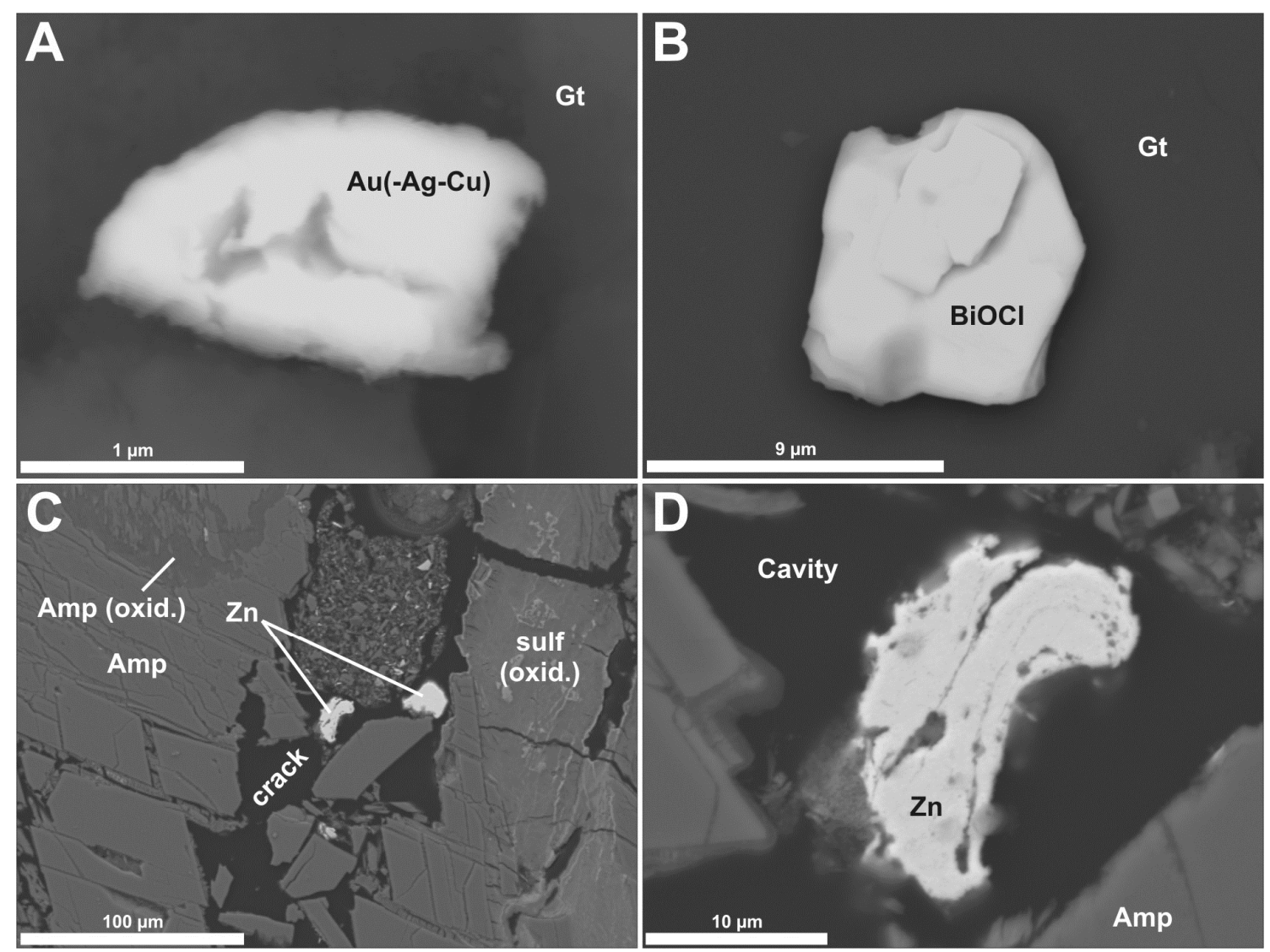

Fig. 4.12 Back scattered electron images of common accessory minerals found in the weathered portions of the Limoeiro Ni-Cu(-PGE) sulfide deposit: (A) Tiny electrum grain with a diffuse outline and irregular surface hosted by goethite (Gt). Sample GS-BF-1 (Bofe gossan), grain 8. (B) A subhedral bismoclite grain hosted in goethite. Sample 826.40 (weathered mineralized orthopyroxenite), grain 15. (C) Zn alloy (detail on Fig. 4.12D) in a crack which crosscuts a partly oxidized amphibole (Amp) grain and oxidized sulfide. The crack also contains broken pieces of amphibole and tiny mineral fragment aggregates. Sample 8-18.65 (weathered mineralized harzburgite), grain Zn10. (D) Detail of the Zn alloy showing an irregular diffuse outline in some parts of the grain, and growth lines in the internal structure. Sample 818.65, grain Zn10.

\section{Discussion}

\section{The progression of base metal sulfide during weathering}

Large scale alteration caused by weathering in the Limoeiro $\mathrm{Ni}-\mathrm{Cu}(-\mathrm{PGE})$ sulfide deposit is evident down to a depth of $\sim 38 \mathrm{~m}$, although pentlandite alteration to violarite and pyrrhotite alteration to pyrite occur as deep as somewhere between 67 and $38 \mathrm{~m}$. The lowest depth for the occurrence of violarite/pyrite was established by Mota-e-Silva et al. (in review), as they reported fresh sulfide mineralization composed of pyrrhotite, chalcopyrite and pentlandite 
occurring at depths as shallow as $67 \mathrm{~m}$. In this study we show that at $\sim 30 \mathrm{~m}$ the violarite and pyrite are oxidized. In the Limoeiro deposit the BMS are the mineral phases most prone to alter under the weathering conditions. Pentlandite is most vulnerable, followed by pyrrhotite and finally chalcopyrite. This later mineral is the most stable BMS, as it is found in its pristine condition at depths as shallow as $25 \mathrm{~m}$. The same stable behavior of chalcopyrite facing weathering was reported in the O'Toole sulfide Ni deposit, Brazil (Taufen and Marchetto, 1989). Chalcopyrite is even more stable than violarite and pyrite, which are formed in supergene conditions. At $\sim 30 \mathrm{~m}$ deep the altered violarite is partially oxidized hosting $\sim 46 \mathrm{wt} \% \mathrm{O}$ and pyrite is also partially oxidized hosting $\sim 14 \mathrm{wt} \% \mathrm{O}$, whereas the chalcopyrite is still unaltered (Fig. $4.5 \mathrm{~A})$.

The chalcopyrite in the Limoeiro sulfide deposit hosts up to $\sim 1.4 \mathrm{wt} \% \mathrm{Zn}$ in solid solution (Mota-e-Silva et al., in review). At $\sim 20 \mathrm{~m}$ and shallower all three BMS are altered to impure goethite, and are $\mathrm{Zn}$ free. Coincidently at this depth native $\mathrm{Zn}$, occasionally combined with $\mathrm{Cu}(\mathrm{Zn} \pm \mathrm{Cu}$ alloy), is amongst the most abundant of the accessory minerals (Table 4.3). The oxidation of sulfide drives the oxidation front to conditions of very low $\mathrm{pH}(<3)$, as stoichiometrically, this process generates eight acid ions for each oxidized sulfur atom (Taufen and Marchetto, 1989). This process promotes the immediate break down of the crystal lattice of sulfides and the release of the metals (including $\mathrm{Cu}$ and $\mathrm{Zn}$ ). One of the most important factors controlling $\mathrm{Zn}$ solubility is variation in $\mathrm{pH}$. Acidic environments ( $\mathrm{pH}$ values below 6.2) have been documented to enhance Zn mobility (Levinson, 1980; Martínez and Motto, 2000). It is likely that $\mathrm{Zn}$ contained in chalcopyrite has been mobilized as $\mathrm{Zn}^{+2}$ in solution due to the localized acidic conditions formed by the oxidation of chalcopyrite. Zinc was reprecipitated later, millimeters away as native $\mathrm{Zn}$ and $\mathrm{Zn} \pm \mathrm{Cu}$ alloys in fracture zones (Fig. 4.12C and D). Previously the natural occurrence of native zinc was argued as being dubious (Mason, 1949). In fact native $\mathrm{Zn}$ seems to be uncommon; however it has been identified in other locations, as documented in the oxidized zones in the Pb-Zn-Ag deposits in the Keno Hill, Yukon, Canada (Boyle, 1961) and as alteration products of sphalerite and djurleite in the Dulcinea Cu deposit, northern Chile (Clarke and Sillitoe, 1970). The preservation of native $\mathrm{Zn}$ in a geological environment demands neutral or slightly alkaline conditions associated with oxidizing solutions (Boyle, 1961). This may explain the occurrence of native $\mathrm{Zn}$ being restricted to fractures within the oxidized part of Limoeiro 
deposit, as these structures represent permeable zones which allow the interaction of the acidic water containing $\mathrm{Zn}^{+2}$ with close to neutral groundwater and rain water migrating downwards.

The Limoeiro fresh sulfide mineralization in the Piçarra target (closest to the Bofe gossan) has tenors of 3.74 wt\% Ni, 4.24 wt\% Cu, 5.15 ppm Pd and 1.98 ppm Pt (Mota-e-Silva, in review). Comparing these values with the concentrations of these metals in the gossan described in the introduction, it becomes evident that the $\mathrm{Ni} / \mathrm{Cu}$ and the $\mathrm{Pt} / \mathrm{Pd}$ ratios do not vary much from the fresh sulfide mineralization into the gossan. However the $(\mathrm{Ni}+\mathrm{Cu}) /(\mathrm{Pt}+\mathrm{Pd})$ ratio is $7 x$ lower in the gossans compared to the underlying fresh sulfide mineralization, quantitatively detailing the petrographic observation that $\mathrm{Ni}$ and $\mathrm{Cu}$ mobility is greater than that of $\mathrm{Pt}$ and $\mathrm{Pd}$ (Fig. 4.5). The mobility of both, $\mathrm{Ni}$ and $\mathrm{Cu}$ is increased by a decrease of $\mathrm{pH}$ (McLean and Bledsoe, 1996), by the presence of dissolved organic matter and the presence of high salt concentrations, which facilitates the formation of chloride complexes (Amrhein et al., 1992). Weathering conditions during gossan formation in Limoeiro were probably acidic due to oxidation of the sulfides. The groundwater was most likely saline, a characteristic currently present in of the region of the deposit (CPRM, 2005). These conditions have dispersed $\mathrm{Ni}$ and $\mathrm{Cu}$ in the supergene environment for tens of meters, forming a large dispersion halo. In the gossan horizon $\mathrm{Ni}$ and $\mathrm{Cu}$ are hosted by goethite in concentrations of up to $20 \mathrm{wt} \%$ and $14 \mathrm{wt} \%$ respectively. In contrast the mobility of the PGE seems to be limited to only a few $\mu \mathrm{m}$, a subject that will be addressed in the following section.

\section{Weathering of merenskyite}

Meresnkyite is by far the most abundant PGM in the Limoeiro Ni-Cu(-PGE) sulfide deposit, accounting for 98 vol\% of PGM in the massive sulfide ore (Mota-e-Silva et al., in review). In the results presented here it is shown that at $\sim 20 \mathrm{~m}$ depth merenskyite $\left[(\mathrm{Pd}, \mathrm{Pt}, \mathrm{Ni})(\mathrm{Te}, \mathrm{Bi})_{2}\right]$ is not found, as it is altered to Pd-Te-Bi PGM. This interpretation is supported by similarities between the two phases regarding abundance, grain size, textural characteristics and mineral association. Compared to the typical compositions of the Limoeiro's 
merenskyite (20 wt\% Pd, 48 wt\% Te and 23 wt\% Bi according to Mota-e-Silva et al., in review), the Pd-Te-Bi PGM has much more Pd ( 68 wt\%) and less Te and $\mathrm{Bi}$. It is suggested that during the weathering conditions that promoted the first signs of PGM alteration in Limoeiro, $\mathrm{Te}$ and $\mathrm{Bi}$ were very mobile, as was $\mathrm{Pt}$, whereas $\mathrm{Pd}$ was concentrated reflecting higher stability. The PdTe-Bi PGM occurs as pseudomorphs of merenskyite and it is commonly partly oxidized (Fig. 4.9).

Moving to shallower sections of the Limoeiro weathering profile the pseudomorphs of merenskyite evolve into a heterogeneous compound containing a bulk composition of, from the most to the least abundant (in atomic proportion): $\mathrm{Fe}, \mathrm{O}, \mathrm{Pd}, \mathrm{Pt}, \mathrm{Cu}$ and $\mathrm{Ni}$ (Fig. 4.9E and Table 4.2). This progressive alteration shows a tendency for leaching of all the metals and semimetals away from the merenskyite pseudomorphs producing a composition that becomes gradually closer to that of goethite. Tellurium is the most leached element, as it decreases from $52 \mathrm{wt} \%$ in the original merenskyite to zero in the most altered examples. At this point the surrounding goethite is Te-bearing reaching up to $\sim 4 \mathrm{wt} \% \mathrm{Te}$ (Table 4.2). This characteristic underpins the mobility of $\mathrm{Te}$ that has been intensively leached from merenskyite and later from the $\mathrm{Pd}-\mathrm{Te}-\mathrm{Bi}$ PGM into the surrounding goethite. The mobility of Te is particularly well shown in Fig. 4.10A-D where the Te-bearing goethite dominates the surrounding areas a few $\mu \mathrm{m}$ away from the source PGM.

One step further in the weathering process of merenskyite is represented by a pseudomorph formed of goethite, voids and a Pd-Cu士Bi alloy (Fig. 4.10A, B and C). The newly formed Pd-Cu士Bi alloys are more abundant in the Paquivira than in the Bofe gossan (Table 4.1). The Paquivira gossan was developed over a main transcurrent fault, and such a location must favor stronger dissolution of the PGM and leaching of the PGE. As shown in Fig. 4.10A, weathering of merenskyite is apparently more advanced in the Paquivira than in the Bofe gossan. The $\mathrm{Pd}-\mathrm{Cu} \pm \mathrm{Bi}$ alloy forms irregular grain aggregates that pseudomorph relict $\mathrm{Pd}-\mathrm{Te} \pm \mathrm{Bi}$ PGM along with goethite crusts (Fig. 4.10A-D), and tiny rosette-like crystals ( 2 $\mu \mathrm{m})$ coating Feoxyhydroxides (Fig.10C, D, E and G). In detail, the small Pd-Cu crystals show several habits from globular to tabular in the rosette-like forms. These habits all suggest a late nucleation of Pd and $\mathrm{Cu}$ as well as a sequential, but rapid crystal growth of the alloys on goethite (London, 2008 
and references therein). These $\mathrm{Pd}-\mathrm{Cu}$ rosettes formed in supergene oxidizing conditions possibly at the expense of the $\mathrm{Pd}-\mathrm{Cu}$ grains replacing the preexisting merenskyite, as they mainly coat the goethite crusts in situ or right around the grains. The rosettes located in areas lacking a precursor PGM may reflect either a complete dissolution of the Pd-PGM or, more likely, further mobility and reprecipitation of $\mathrm{Pd}$ away from its main source.

Similar rosette-like crystals, between 1 and $5 \mu \mathrm{m}$ diameter, with an orthogonal-disclike framework have been documented previously in Au-Pd-Pt veins (locally known as jacutinga type mineralization), at Itabira, Brazil (Kwitko et al., 2002; Cabral \& Lehmann, 2003; Cabral \& Kwitko-Ribeiro, 2004). These authors observed that the rosettes have a compositional range from PdO-like stoichiometry to native $\mathrm{Pd}$. They speculated that this compositional range associated with the rosette forms is a consequence of dehydration of a hydrated $\mathrm{Pd}$ oxide through recurrent heating during the tropical dry season, in an analogous way to gypsum efflorescences ("desert roses") formed by evaporation in a dry climate. A similar mechanism of dehydration of secondary $\mathrm{Pt}, \mathrm{Pd}$ - oxyde or hydroxy compounds was suggested for the crystallization of Pd-Cu-bearing alloys in ferralitic soils at low T conditions (Salpeteur et al. 1995, McDonald et al. 1999a). Dehydration of PtOH species to form PtO and Pt-Pd alloy was also documented at higher $\mathrm{T}$ as consequence of an epithermal-like alteration in the Waterberg deposit/district, South Africa (McDonald et al., 1999b).

The composition of the Pd-Cu rosettes in the Limoeiro gossans is uncertain. They do not form a large continuous crystalline surface and it is unknown whether the $O$ identified in the analyses is part of the PGM or due to the influence of the surrounding Fe-oxides. Considering the "PdO" composition obtained for the largest Pd-Cu aggregates, a $\mathrm{Pd}-\mathrm{Cu}-\mathrm{O}$ phase could be a feasible precursor of the rosettes. It is possible that partial dessication or transformation to more stable Fe-oxides during aging of the substrate (goethite-hematite, Fig. 4.10E) may represent mechanisms able to release Pd and $\mathrm{Cu}$ and form stable alloys at the PGM grain scale. The proposed hypothesis of rosettes being produced from dehydration of Pd-bearing phases also applies in Limoeiro, as the deposit is located in a transition zone to the semi-arid Brazilian climate where the water table strongly fluctuates seasonally (CPRM, 2005). Thus, lowering of the water table during dry periods would promote the formation of the Limoeiro Pd-Cu-rosettes. 
Whatever the case, this study provides evidence that $\mathrm{Pd}$ reprecipitates with $\mathrm{Cu}$ and $\mathrm{Bi}$ after being released from the original merenskyite. A graphical representation of the merenskyite as it weathers and alters; culminating in the precipitation of the $\mathrm{Pd}-\mathrm{Cu} \pm \mathrm{Bi}$ alloy, is shown in Fig. 4.13.

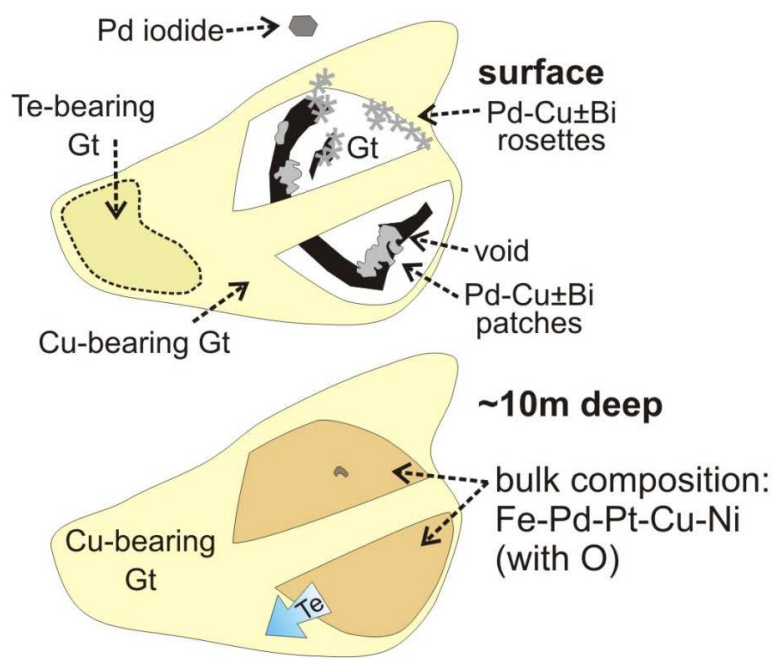

(1) $70 w t \% P d$ $22 \mathrm{wt} \% \mathrm{Te}$ $8 \mathrm{wt} \% \mathrm{Bi}$ Cu-bearing Gt $\therefore$

Most leached element

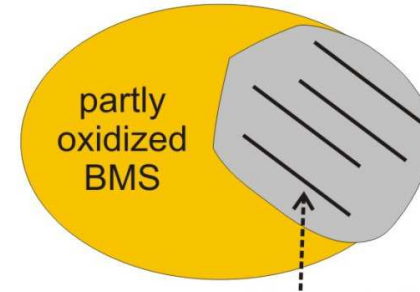

Merenskyite with prominent cleavage

\section{$\sim 30 \mathrm{~m}$ deep}

Fresh merenskyite:

$22 \mathrm{wt} \% \mathrm{Pd}$

$7 \mathrm{wt} \% \mathrm{Pt}$

$52 \mathrm{wt} \% \mathrm{Te}$

$19 \mathrm{wt} \% \mathrm{Bi}$

Fig. 4.13 Schematic diagram illustrating how the weathering process transformed the original merenskyite in the Limoeiro Ni-Cu(-PGE) sulfide deposit in stages from a depth of $30 \mathrm{~m}$ to the surface. The original merenskyite composition at the depth of $30 \mathrm{~m}$ deep is representative of the mineralogy of an example taken from Mota-e-Silva et al. (in review). The mineralogy and compositions at a depth of $20 \mathrm{~m}$ are from examples taken from Table 4.2 (this study).

It is known that each PGE has a distinct mobility and defined stability field, which is very dependent on pH-Eh conditions (Brookins, 1987; Wood, 2002), but not much is known about Te mobility. Empirical observations show that there are few reported occurrences of tellurides in placer deposits except for inclusions in other minerals (e.g. Hattori and Cabri, 
1992), suggesting that these minerals are not stable in the weathering environment. In the Limoeiro sulfide deposit 87 vol\% of the PGM are bismuthotellurides. The Te in these minerals is the most abundant element (from 35 to 60 wt\% according to Mota-e-Silva et al., in review). In this study it is shown that Te is the first element to be lost from the PGM, confirming the pronounced mobile behavior for this element during weathering in Limoeiro. This immediately raises the idea that Te could be used as a mineralization pathfinder as it may form a relatively large geochemical halo around deposits. This element generally occurs in very low concentrations $(<0.5 \mathrm{ppm})$ in most rocks and soils (Beaty and Manuel, 1973; Hattori and Cameron, 2004). This low background favors the identification of Te geochemical anomalies associated with Te-bearing mineralization, including telluride-dominant PGE mineralization as in the Limoeiro example. The study of Te in stream sediment surveys would be particularly interesting, as Hayes et al. (2012) observed in mining tailings material that Te concentrations are often elevated in areas enriched in clay-sized fractions, suggesting that sorption onto clay minerals is a likely controller of Te mobility. From another point of view, anomalous sources of Te such as the Limoeiro gossan or any other exposed Te-rich mineralization or mining stockpile and tailings requires additional attention regarding human health, as ingestion of high concentrations of this element is considered potentially toxic and might cause cancer and embryo and fetus malformation (Smith and Huyck, 1999). Knight (2013) studying a mining tailings in a semi-arid region (Lincoln County, Nevada, US) has identified only the less toxic form of $\mathrm{Te}$ : the $\mathrm{Te}(\mathrm{VI})$. This subject addressing the medical geology of Te is poorly documented and more effort is needed to properly understand the risks.

That $\mathrm{Pd}$ is much more mobile than $\mathrm{Pt}$ in weathering conditions is commonly documented (Fuchs and Rose, 1974; Prichard and Lord, 1994; Suaréz et al., 2010). In the Bacuri Complex, Brazilian Amazon rain forest, low Pd/Pt ratio in weathered ore was interpreted as consequence of the dissolution of Pd by surface waters (Prichard et al., 2001). In Limoeiro the higher mobility of $\mathrm{Pd}$ rather than $\mathrm{Pt}$ is not clear. The fresh sulfide mineralization has a $\mathrm{Pt} / \mathrm{Pd}$ ratio between 0.3 and 0.4 , that is compatible with the reported grades for the Bofe gossan described in the introduction (3.08 ppm Pd and $1.15 \mathrm{ppm} \mathrm{Pt;} \mathrm{Pt} / \mathrm{Pd}=0.37$ ). The drill hole SLM0008 log shown in Fig. 4.4 has consistently, from the bottom of the mineralized horizon to the surface, much higher Pd grades than Pt. Fuchs and Rose (1974) documented that the 
transport of $\mathrm{Pd}$ is favored in acid soils such as those found in a relatively humid forested environment. The Limoeiro deposit is located close to the Brazilian semi-arid climatic zone and the ground water in the region is predominantly saline (up to $4500 \mathrm{mg} / \mathrm{l}$ of dissolved solids; CPRM, 2005). High salinity water regularly contains relatively high $\mathrm{Cl}^{-}$amongst other dissolved salt ions. The mobility of $\mathrm{Pt}$ and $\mathrm{Pd}$ in solution as $\mathrm{PdCl}_{4}{ }^{2-}$ and $\mathrm{PtCl}_{4}{ }^{2-}$ would be accentuated in areas where the water has high chloride content (Fuchs and Rose, 1974). In Limoeiro, it is proposed that the $\mathrm{Pt}$ and $\mathrm{Pd}$ present in the bismuthotelluride were liberated and entered in solution as chloride complexes; however Pd partly reprecipitated in the form of $\mathrm{Pd}-\mathrm{Cu} \pm \mathrm{Bi}$ alloy. This balance favoring the stability of $\mathrm{Pd}$ in the weathering profile may be compensated for by sperrylite $\left(\mathrm{PtAs}_{2}\right)$, which accounts for 18 vol\% of PGM in the Limoeiro disseminated sulfide mineralization (Mota-e-Silva, et al., in review) and is preserved in the gossans (Fig. 4.6). Thus the contrast of the poorer stability of bismuthoteluride compared to the greater stability of arsenide PGM during the weathering in the Limoeiro region is likely to be a more critical factor in controlling the distribution of PGE in the weathering profile than the differences between Pd and Pt mobility.

\section{The weathering of PGM arsenides and sulfarsenides}

Arsenide and sulfarsenide PGM are absent in the Limoeiro massive sulfide mineralization. However $16 \%$ of the PGM identified in the disseminated sulfide mineralization are arsenides and sulfarsenides including sperrylite $\left(\mathrm{PtAs}_{2}\right)$, irarsite $[(\mathrm{Ir}, \mathrm{Pt}, \mathrm{Rh}) \mathrm{AsS}]$ and hollingworthite [(Rh,Ir,Co,Pt)AsS] (Mota-e-Silva et al., in review). This is the same as for the gossans which also have $16 \%$ of exactly the same arsenide and sulfarsenide PGM as identified in the fresh disseminated ores (Fig. 4.7). Arsenide and sulfarsenide PGM are not found in the fresh massive sulfide ore (Mota-e-Silva et al., in review). We have shown that the gossan represents relicts (Fig. 4.6) of sulfide mineralization given the similarities in the mineralogy, crystal habit, size and association. Therefore the similarity of the PGM in the gossan with the disseminated sulfide assemblage suggests that the gossan is not an in-situ product of simple oxidation of the massive sulfide layers, but that disseminated sulfide mineralization is also a 
precursor of the gossan. The Limoeiro disseminated sulfide mineralization has between 3 and 20 vol\% sulfides (Mota-e-Silva et al., 2013), which is probably not enough to generate a proper gossan such as shown in Fig. 4.3. The Limoeiro gossan is most probably a consequence of weathering of one or more massive sulfide orebody and its adjacent sulfide-rich disseminated sulfide mineralization that generated enough acid to promote intense leaching and compaction.

Taufen and Marchetto (1989) working with mass balance and systematic sampling calculated the relative mobility of following elements for the O'Toole sulfide $\mathrm{Ni}$ deposit: $(\mathrm{Rh}, \mathrm{Ir})<\mathrm{Ru}<\mathrm{Pt}<\mathrm{Pd}<\mathrm{Cu}<\mathrm{Co}<\mathrm{Ni}$. In Limoeiro the mobility/stability patterns for PGE and base metals are slightly different. The semimetals in the PGM have a crucial influence on understanding PGE mobility in Limoeiro. The arsenides and sulfarsenides are the least mobile PGM. Within this PGM group irarsite (Ir-PGM) is the most preserved (and probably least mobile), followed by hollingworthite (Rh-PGM) and finally sperrylite (Pt-PGM), which represents the most altered of the arsenide and sulfarsenide PGM. The merenskyite (bismuthotelluride) is more stable than BMS. Among the elements that form merenskyite $\mathrm{Te}$ is the most mobile followed by $\mathrm{Pt}, \mathrm{Bi}$ and $\mathrm{Pd}$. Pentlandite is the least stable BMS, and $\mathrm{Ni}$ was released much earlier and more intensively than $\mathrm{Cu}$. All these conclusions produce a mobility order of: $\mathrm{Ir}<\mathrm{Rh}<\mathrm{Pd}<\mathrm{Bi}<\mathrm{Cu}<\mathrm{Ni}$. The position of $\mathrm{Pt}$ in this sequence depends on whether it is associated with $\mathrm{Pd}, \mathrm{Te}$ and $\mathrm{Bi}$ as Pt-bearing merenskyite or whether it is associated with $\mathrm{As}$ in the form of sperrylite. In the first case Pt would be placed between $\mathrm{Bi}$ and $\mathrm{Cu}$ in the mobility sequence, but in the second situation Pt would be placed between $\mathrm{Rh}$ and $\mathrm{Pd}$.

\section{The significance of the Pd iodide mineral}

lodine is rarely found in PGM, but $\mathrm{Au}-\mathrm{Pd}-\mathrm{Hg}-\mathrm{TI}-\mathrm{I}$ and $\mathrm{Pd}-\mathrm{Pt}-\mathrm{Fe}-\mathrm{I}-\mathrm{Ag}$ phases have been documented in gossans from Egypt and southwest Spain (Jedwab, 1992; Suárez et al., 2010), $\mathrm{Pd}_{2} \mathrm{Fel}$ was identified in goethites from the Niquelandia Complex, Brazil (Milliotti and Stumpfl, 1996), and alluvial Pt-Pd-Hg intermetallic compounds with 10 to $120 \mathrm{ppm}$ of I have been found in Brazil (Cabral et al., 2011). There is a close link between iodine and organic 
matter, in the sense that iodine is a relatively abundant trace element in minerals formed in environments of intense microbial activity, as in peatlands for example (Keppler et al., 2004; Cabral et al., 2011). However working with samples recovered by the Luna-16 mission, Bogatikov et al. (2004) have identified $\mathrm{Rhl}_{3}$ in the lunar regolith, a place where intense microbial activity is unknown. Twenty one \% of the identified PGM in the Limoeiro gossan are Pd iodide (probably $\mathrm{Pdl}_{2}$ ) crystals. The gossan is located in the transition zone between the Atlantic rainforest and a semi-arid area, in hilly topography and far from any evidence of recent or fossil peatlands. However, its groundwater is predominantly saline (up to $4500 \mathrm{mg} / \mathrm{l}$ of dissolved solids; CPRM, 2005) that possibly accounts for relatively high concentrations of $\mathrm{Cl}^{-}, \mathrm{Br}^{-}$and $\mathrm{I}^{-}$. Commonly, $\mathrm{Cl}^{-}$is a much more abundant component of groundwater than $\mathrm{Br}^{-}$and, in particular, $\mathrm{I}^{-}$, however specific geochemical conditions can promote the preferential precipitation of iodide rather than the other halides (Boyle 1997; Gołębiowska et al., 2010). Precipitation of iodagyrite (Agl) in gold-bearing glacial sediments in the Chibougamau-Chapais area of Quebec, Canada, has been argued as consequence of a past arid climate in this region (Boyle 1997). In a similar way the iodargyrite identified in Zalas, in the Cracow area of Poland was interpreted as a result of periods of aridity where the primary mineralization was leached by saline, I-rich deeply sourced waters (Gołębiowska et al., 2010). lodargyrite in gossans of the lberian Pyrite Belt also support climatic shifts between arid and warm conditions that are coincident with late episodes of gossan reactivation (Velasco et al. 2013). The climate in the Limoeiro deposit area, at least in the past 210,000 years, has probably varied several times from semi-arid to tropical humid as geographical shifts in rainforest boundaries have been identified through the isotopic study of speleothems in the region (Wang et al., 2004). These sequential shifts may have generated arid and warm situations favorable to the precipitation of $\mathrm{Pd}$ iodide, followed by others with the dominance of a more humid environment which destabilized the Pd iodide and began a process of resolubilization. The destabilization of the Pd iodide is marked in the corroded crystal faces (Fig. 4.11A, B and C). 


\section{Conclusion}

The principal conclusions of this study are as follows:

1. Pentlandite and pyrrhotite are the first minerals to alter in the weathering profile. They are recrystallized as violarite and pyrite respectively somewhere between a depth of 67 and $38 \mathrm{~m}$. Chalcopyrite is much more stable as it alters around a depth of $20 \mathrm{~m}$. Zinc is present as a trace element in chalcopyrite and transported by acidic aqueous solutions during chalcopyrite oxidation; finally it reprecipitates as native $\mathrm{Zn}$ in fractures. Nickel and $\mathrm{Cu}$ are absorbed by goethite reaching concentrations up to 20 and 14 wt\% respectively.

2. The platinum-group mineralogy of the gossan that overlies the Limoeiro Ni-Cu-

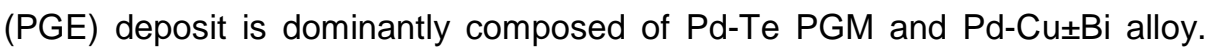
These phases are formed in the supergene environment and they are products of merenskyite alteration and element mobilization and reprecipitation during weathering.

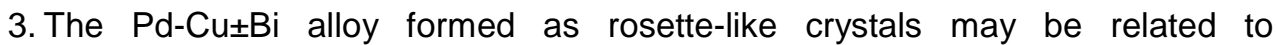
deoxygenation and possibly dewatering of $\mathrm{Pd}-\mathrm{Cu}-\mathrm{O}$ phases formed during weathering.

4. Tellurium is the most and first element to be leached from PGM. The adjacent goethite retains the Te forming patches with concentrations up to $4 \mathrm{wt} \% \mathrm{Te}$. This empirical observation raises the possibility of using Te as a pathfinder to explore for PGE using stream sediment survey.

5. During the weathering of the Limoeiro deposit Pt and Pd had similar mobilities as did $\mathrm{Ni}$ and $\mathrm{Cu}$. However $\mathrm{Pt}$ and $\mathrm{Pd}$ were much more stable than $\mathrm{Ni}$ and $\mathrm{Cu}$, as they are relatively much more concentrated $(7 \mathrm{x})$ in the gossans and weathered rocks. 
6. The Limoeiro gossan is most probably a consequence of weathering of one or more massive sulfide orebodies and their adjacent sulfide-rich disseminated sulfide mineralization.

7. Arsenide and sulfarsenide PGM present in the gossans are probably inherited from the fresh underlying disseminated sulfide mineralization.

8. The mobility of Pt depends on whether it is in arsenide (sperrylite) or in bismuthotelluride (solid solution merenskyite-moncheite) structures. In the first case the element's mobility in Limoeiro is: $\mathrm{Ir}<\mathrm{Rh}<\mathrm{Pt}<\mathrm{Pd}<\mathrm{Bi}<\mathrm{Cu}<\mathrm{Ni}$. However the $\mathrm{Pt}$ hosted in bismuthotellurides is much more mobile giving: $I r<R h<$ $\mathrm{Pd}<\mathrm{Bi}<\mathrm{Pt}<\mathrm{Cu}<\mathrm{Ni}$

9. The Pd iodide found in this study is probably $\mathrm{Pdl}_{2}$. This mineral, formed in the supergene environment, indicates that $\mathrm{Pd}$ has been mobilized and reprecipitated in arid and hot climatic conditions surrounded by saline groundwater. Corroded crystal faces suggest shifts in the past climate conditions between arid and more humid.

\section{Acknowledgments}

We are grateful to Votorantim Metais for permission to sample the Limoeiro deposit and publish the results. This paper is part of the sandwich doctorate research developed by the first author using the cooperation between research groups from Univesity of Brasilia and Cardiff University. The sandwich doctorate was funded by CAPES Foundation, Ministry of Education of Brazil, fellowship (process BEX 3603/13-0). 


\section{References}

Almeida FFM, Hasui Y, Brito Neves BB, Fuck RA (1981) Brazilian structural provinces: an introduction. Earth-Science Reviews, 17(1): 1-29.

Amrhein C, Strong JE, Mosher PA (1992) Effect of deicing salts on metal and organic matter mobilization in roadside soils. Environmental Science \& Technology, 26(4): 703-709.

Beaty RD, Manuel OK (1973) Tellurium in rocks. Chemical Geology, 12(2): 155-159.

Bogatikov OA, Mokhov AV, Kartashov PM, Gorshkov Al, Magazina LO, Ashikhmina NA, Koporulina EV (2004) Microparticles of ore minerals in the lunar regolith from Mare Fecundidatis: (Cu,Au,Ag)4Zn, Ag, Au, Sn, Pb, Sb, Re, MoS2, CdS, AuS, and Rhl3. Doklady Earth Science, 395A: 445-452.

Bowles, JF (1986) The development of platinum-group minerals in laterites. Economic Geology, 81(5): 1278-1285.

Boyle RW (1961) Native zinc at Keno Hill. The Canadian Mineralogist, 6(5): 692-694.

Boyle DR (1997) lodargyrite as an indicator of arid climatic conditions and its association with gold-bearing glacial tills of the Chibougamau-Chapais Area Ouebec. The Canadian Mineralogist, 35: 23-34.

Brito Neves BB., Santos EJ, Van Schmus WR (2000) Tectonic history of the Borborema Province, northeastern Brazil. In Tectonic evolution of South America: 31 st International Geological Congress, Rio de Janeiro, Brazil (pp. 151-182).

Brookins DG (1987) Platinoid element Eh-pH diagrams (25 $\mathrm{C}, 1$ bar) in the systems M-O-H-S with geochemical applications. Chemical Geology, 64(1): 17-24.

Cabral AR, Lehmann B (2003) A two-stage process of native palladium formation at low temperatures: evidence from a palladian gold nugget (Gongo Soco iron ore mine, Minas Gerais, Brazil). Mineralogical Magazine, 67(3): 453-463.

Cabral AR, Kwitko-Ribeiro R (2004) On the rosettes of "native palladium" from Minas Gerais, Brazil: evidence from Gongo Soco. The Canadian Mineralogist, 42(2): 683-687.

Cabral AR, Radtke M, Munnik F, Lehmann B, Reinholz U, Riesemeier H, Tupinambá M, KwitkoRibeiro R. (2011) lodine in alluvial platinum-palladium nuggets: Evidence for biogenic precious-metal fixation. Chemical Geology, 281(1): 125-132. 
CPRM (2005) Projeto Cadastro de Fontes de Abastecimento por Água Subterrânea: Município de Limoeiro, Pernambuco. Ministério de Minas e Energia, Brazil, 20 pp. Avaiable in http://www.cprm.gov.br/rehi/atlas/pernambuco/relatorios/LIMO098.pdf (in Portuguese).

Gołębiowska B, Pieczka A, Rzepa G, Matyszkiewicz J, Krajewski M (2010) lodargyrite from Zalas (Cracow area, Poland) as an indicator of Oligocene-Miocene aridity in Central Europe. Palaeogeography, Palaeoclimatology, Palaeoecology, 296(1): 130-137.

Hattori K, Cabri LJ (1992) Origin of platinum group mineral nuggets inferred from osmiumisotope study. The Canadian Mineralogist, 30: 289-301.

Hattori KH, Cameron EM (2004) Using the high mobility of palladium in surface media in exploration for platinum group element deposits: evidence from the Lac des lles region, northwestern Ontario. Economic Geology, 99(1): 157-171.

Hayes SM, Foster A, Balistrieri L (2012) Tellurium speciation in surficial weathering environments. In 2012 GSA Annual Meeting in Charlotte.

Jedwab J (1992) Platinum group minerals in ultrabasic rocks and nickeliferous veins from Zabargad Island (Egypt). Comptes rendus de l'Académie des sciences. Série 2, Mécanique, Physique, Chimie, Sciences de l'univers, Sciences de la Terre, 314(2): 157163.

Jedwab J (1995) Oxygenated platinum-group-elements and transition metal (Ti, Cr, Mn, Fe, Co, $\mathrm{Ce}$ )-compounds in the supergene domain. Chronicle of Mineral Research and Exploration 520: 47-53.

Knight N (2013) Tellurium Speciation and Distribution as a Function of Depth in Semi-arid Mine Tailings. In Geological Society of America Abstracts with Programs, v. 45 (7).

Kretz R (1983) Symbols for rock-forming minerals. American Mineralogist 68: 277-279.

Levinson AA (1980) Introduction to Exploration Geochemistry. 2nd edition. Applied Publishing Ltd., Wilmette, Illinois, 924 pp.

Locmelis M, Melcher F, Oberthür T (2010) Platinum-group element distribution in the oxidized Main Sulfide Zone, Great Dyke, Zimbabwe. Mineralium Deposita 45: 93-109.

Mason B (1949). Oxidation and reduction in geochemistry. The Journal of Geology, 62-72.

McDonald I, Ohnenstetter D, Ohnenstetter M, Vaughan DJ (1999a) Palladium oxides in ultramafic complexes near Lavatrafo,Western Andriamena, Madagascar. Mineralogical Magazine 63(3): 345-352. 
McDonald I, Ohnenstetter D, Rowe JP, Tredoux M, Pattrick RAD, Vaughan DJ (1999b) Platinum precipitation in the Waterberg Deposit, Naboomspruit, South Africa. South African Journal of Geology 102(3): 184-191.

McLean JE, Bledsoe BE (1996). Behavior of Metals in Soils. EPA Environmental Assessment Sourcebook, 19.

Mota-e-Silva J, Ferreira Filho CF, Della Giustina MES (2013) The Limoeiro Deposit: Ni-Cu-PGE Sulfide Mineralization Hosted Within an Ultramafic Tubular Magma Conduit in the Borborema Province, Northeastern Brazil. Economic Geology, 108(7): 1753-1771.

Neves SP, Alcantara VC (2010) Geochemistry of orthogneisses and metasedimentary rocks across a proposed terrane boundary in the Central Domain of Borborema Province, NE Brazil: geodynamic implications. Journal of South American Earth Sciences, 29(2): 498511.

Oberthür T, Weiser TW, Gast L, Kojonen K (2003) Geochemistry and mineralogy of platinumgroup elements at Hartley Platinum Mine, Zimbabwe. Mineralium Deposita, 38(3): 327343.

Prichard HM, Lord RA (1994) Evidence for differential mobility of platinum-group elements in the secondary environment in Shetland ophiolite complex. Transaction of the Institution of Mining and Metallurgy, 103: B79-86.

Prichard HM, Sá JHS, Fisher PC (2001) Platinum-group mineral assemblages and chromite composition in the altered and deformed Bacuri complex, Amapa, northeastern Brazil. The Canadian Mineralogist, 39(2): 377-396.

Santos EJ, Van Schmus WR, Kozuch M, Brito Neves BB (2010) The Cariris Velhos tectonic event in northeast Brazil. Journal of South American Earth Sciences, 29(1): 61-76.

Smith KS, Huyck HL (1999) An overview of the abundance, relative mobility, bioavailability, and human toxicity of metals. The Environmental Geochemistry of Mineral Deposits, 6: 2970.

Suárez S, Prichard HM, Velasco F, Fisher PC, McDonald I (2010) Alteration of platinum-group minerals and dispersion of platinum-group elements during progressive weathering of the Aguablanca Ni-Cu deposit, SW Spain. Mineralium Deposita, 45(4): 331-350.

Taufen PM, Marchetto CM (1989) Tropical weathering control of Ni, Cu, Co, and platinum group element distributions at the O'Toole Ni-Cu sulphide deposit, Minas Gerais, Brazil. Journal of Geochemical Exploration, 32(1): 185-197. 
Taylor GF, Thornber MR (1992) Gossan and ironstone surveys. In: Butt CRM, Zeegers H (Eds.), Regolith exploration geochemistry in tropical and subtropical terrains. Handbook of Exploration Geochemistry, 4. Elsevier, Amsterdam, pp. 139-202.

Taylor R (2011) Gossans and Leached Cappings. Field Assessment. Springer, Berlin, 146 pp.

Tolstykh N, Krivenko A, Sidorov E, Laajoki K, Podlipsky M (2002) Ore mineralogy of PGM placers in Siberia and the Russian Far East. Ore Geology Reviews, 20(1): 1-25.

Travis GA, Keays RR, Davison RM (1976) Palladium and iridium in the evaluation of nickel gossans in Western Australia. Economic Geology, 71(7): 1229-1243.

Velasco F, Herrero JM, Suárez S, Alvaro A, Tornos F (2013) Supergene features and evolution of gossans capping massive sulphide deposits in the lberian Pyrite Belt. Ore Geology Reviews, 53: 181-203.

Wang X, Auler AS, Edwards RL, Cheng H, Cristalli PS, Smart PL, Richards DA, Shen CC (2004) Wet periods in northeastern Brazil over the past 210 kyr linked to distant climate anomalies. Nature, 432(7018): 740-743.

Wood SA (2002) The aqueous geochemistry of the platinum-group elements with applications to ore deposits. In The Geology, Geochemistry, Mineralogy and Mineral Beneficiation of Platinum-Group Elements (L.J. Cabri, ed.). Canadian Institute of Mining, Metallurgy and Petroleum, Special Volume, 54: 211-249. 
The ultramafic conduit system of the Limoeiro $\mathrm{Ni}-\mathrm{Cu}-(\mathrm{PGE})$ deposit: implications for the magmatic and tectonic evolution of the eastern part of Borborema Province, northeastern Brazil 


\title{
The ultramafic conduit system of the Limoeiro $\mathrm{Ni}-\mathrm{Cu}-(\mathrm{PGE})$ deposit: implications for the magmatic and tectonic evolution of the eastern part of Borborema Province, northeastern Brazil
}

\author{
Jonas Mota-e-Silva ${ }^{1,2}$, Cesar F Ferreira Filho ${ }^{2}$, Edilton J Santos ${ }^{3}$, Maria E \\ Schutesky DellaGiustina ${ }^{2}$, Rafael F de Freitas ${ }^{1}$, Leonardo Aguiar ${ }^{4}$ \\ ${ }^{1}$ Votorantim Metais, Exploration Division, Polo Industrial Multivias, Jundiai/SP, 13212-161, \\ Brazil \\ ${ }^{2}$ University of Brasilia, Geosciences Institute, Brasília/DF, 70900-970, Brazil \\ ${ }^{3}$ CPRM Geological Survey of Brazil, Recife Branch, Recife-PE, Brazil. \\ ${ }^{4}$ CPRM Geological Survey of Brazil, Manaus Branch, Manaus-AM, Brazil.
}

\section{Abstract}

Mafic and ultramafic chonoliths are one of the most fertile types of intrusions for magmatic Ni sulfide deposits; additionally they have geotectonic significance as they intrude relatively shallow crustal levels commonly associated with compressional tectonic setting. This paper reveals the Limoeiro magmatism to be formed by at least $46 \mathrm{~km}$ long array of saucershaped subhorizontal intrusions (interpreted to be magma conduits) oriented WSW-ENE. An extra 108 kilometers of conduits are interpreted to exist based on magnetometric surveys. Limoeiro is part of a new discovery of a conduit swarm possibly related to a large igneous province. The intrusions are overprinted by a $634 \pm 6$ Ma lower granulite facies metamorphism (750-800 ${ }^{\circ} \mathrm{C}$ and $\left.5-8 \mathrm{kbar}\right)$. The metamorphic age was obtained after laser ablation $\mathrm{U}-\mathrm{Pb}$ dating of metamorphic zircons (ovoid- to rounded-shape and soccer ball habits). No pristine magmatic zircon was found in the intrusions, however progressive increase of the Th/U together with $\mathrm{U}-\mathrm{Pb}$ age on metamorphosed zircons suggest a crystallization age of ca.800 Ma for the intrusions. This age is the same as recorded in Niquelandia Complex, in Brazil, and in the magmatic system that hosts the Jinchuan sulfide Ni deposit, in China. The primitive mafic magmatism at 
ca. 800 Ma may be favored by the existence of global-scale superplume coeval to the Rodinia superconetinent break-up.

\section{Introduction}

The Borborema Province is part of the Brasiliano/Pan-African orogeny (650-500 Ma) and its position in NE Brazil lies in a central position in the western Gondwana. Until a few years ago the Borborema Province was usually considered barren by explorers of Ni-Cu-PGE deposits, probably due to the dominance of gneiss, mylonite, and migmatite rocks in an intensely deformed and faulted terrane. However, the recent discovery of the Limoeiro Ni-Cu(PGE) sulfide deposit (Mota-e-Silva et al., 2013) has opened a new window for exploration in the Borborema Province in Brazil. The ultramafic intrusion hosting the Limoeiro deposit is probably the best preserved conduit system described within an orogenic terrain, and provide new insights for discovering primary Ni-Cu-PGE sulfide deposits in high-grade mobile belts elsewhere.

The Limoeiro Ni-Cu(-PGE) sulfide deposit is hosted by subhorizontal ultramafic chonolith, which is interpreted to be a mafic magma conduit (Mota-e-Silva et al., 2013). Mafic and ultramafic chonoliths are the most fertile type of intrusions for magmatic deposits, hosting a large number of Ni-Cu-PGE and chromite deposits worldwide (e.g., Gauert et al., 1995; Evans et al., 2000; Seat et al., 2007; Goodgame et al., 2010; Ripley and Li, 2011; Lightfoot and EvansLamswood, 2015). Apart from their economic importance, these intrusions are related to a space generation in horizontal compressional stress regime (Gretener, 1969; Hornsey, 1999) and their emplacement is related to relatively shallow crustal levels (Park, 1989; Polteau et al., 2008; Horsman et al., 2000). Thus, fitting them in space and time delivers valuable information to the geological evolution of a certain province.

This study provides detailed geological and structural data for the ultramafic conduit system associated with the Limoeiro deposit. The regional setting of the conduits, together with 
new $\mathrm{U}-\mathrm{Pb}$ zircon ages, are used to constrain the tectonic environment of the intrusions emplacement. Finally, tectonic, magmatic and metamorphic events in this portion of the Borborema Province are reviewed based on the results discussed in this paper. The present study contributes to understanding the Mesoproterozoic and Neoproterozoic geotectonic evolution of western Gondwana, and can guide explorers to expand the Ni-Cu-PGE sulfide resources in the Borborema Province and in the Central African Fold Belt.

\section{Geological Framework}

\section{Borborema Province}

The Borborema Province, in northeastern Brazil, is branch of the Neoproterozoic Brasiliano/Pan-African orogenic system (650-500 Ma), which lies between the São FranciscoCongo and the West African cratons in the Gondwana reconstruction picture (Fig. 5.1). The Neoproterozoic age in Borborema is mainly constrained by the convergent magmatism in the northwest margin of the province (Fetter et al., 2003; Santos et al., 2008), the abundant sintectonic granitic intrusions (Leite et al., 2000; Guimarães et al, 2005), and by the continentalscale shear zones and related parasitic shear zones that juxtapose the assorted domains and terranes of the province (Brito Neves et al., 2000). Even though the Brasiliano/Pan-African tectonic and magmatic features largely prevail in the Borborema Province recent studies are progressively showing preserved tectonic features and geochronological evidences of former stages of continental amalgamation during the Mesoproterozoic, Paleoproterozoic and Archaean in the province (e.g., Van Schmus et al., 1995, 2003; Dantas et al., 2004; Santos et al., 2010). These older rocks, in the most of cases, were reworked by the Brasiliano/Pan-African tectonics and metamorphism.

The established mosaic-like structural setting combined with recent advances in geological, geophysical and geochronological studies led researches (e.g., Brito Neves et al., 2000) to divide the Borborema Province into five tectonic domains. The recently discovered 
Limoeiro Ni-Cu-(PGE) sulfide deposit and its related mafic conduits system, which is the focus of this study, lies in the Zona Transversal Domain (Fig. 5.1).
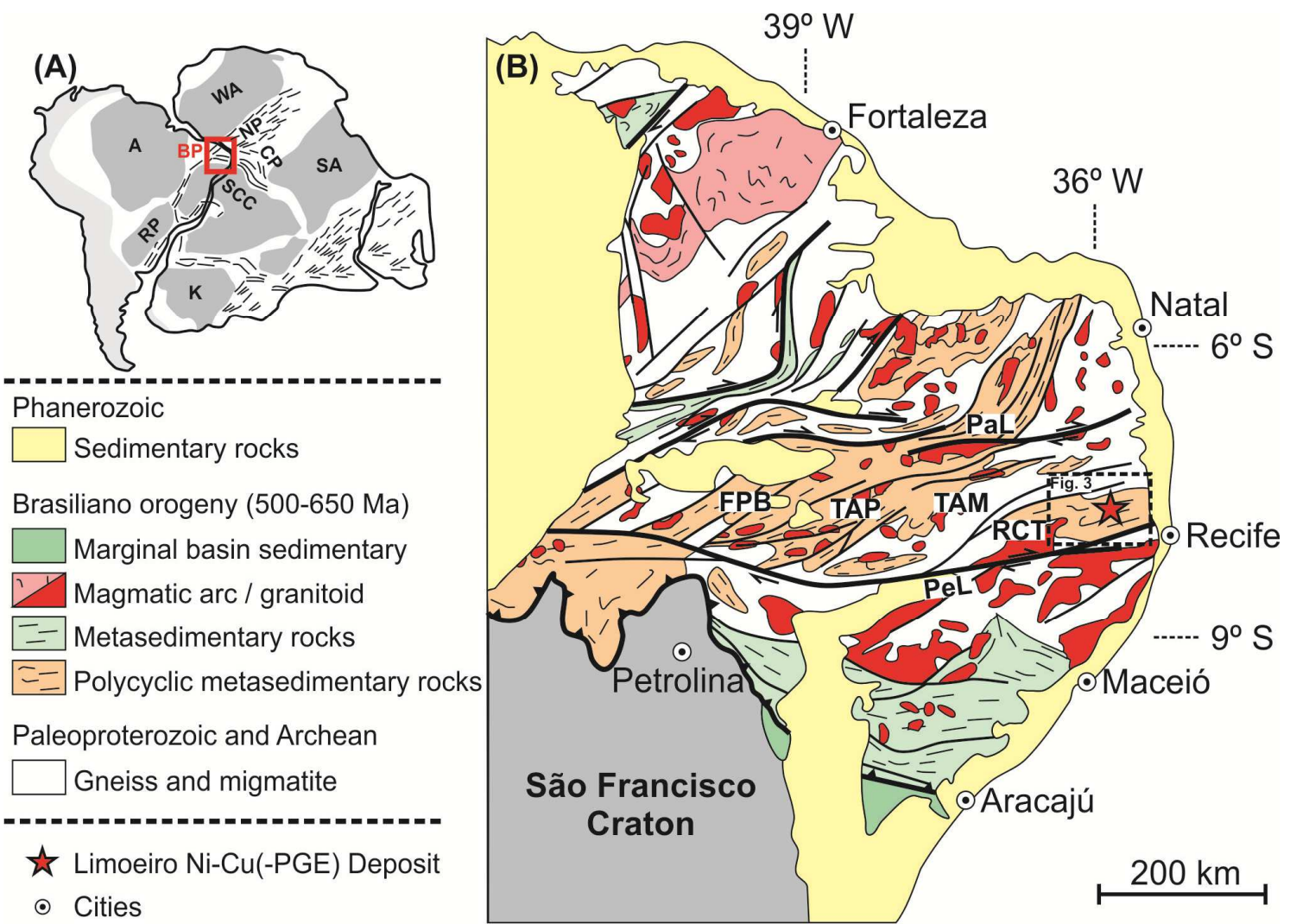

Fig. 5.1 - (A) Prerift reconstruction of western Gondwana showing the main cratons in dark grey, the Andean in light grey and the Brasiliano/Pan-African provinces are marked by dashes (modified from Neves and Alcantara, 2010). Abbreviations for cratons: A, Amazonia; K, Kalahari; RP, Rio de La Plata; AS, Sahara Metacraton; SCC, São Francisco/Congo; WA, West Africa. Abbreviations for provinces: BP, Borborema; CP, Cameroon; NP, Nigeria. (B) Simplified geological map showing the main geotectonic units, the major shear zones and the location of the Limoeiro Ni-Cu-(PGE) deposit (modified from Medeiros, 2004). The Zona Transversal Domain is delimited by the Patos Lineament $(\mathrm{PaL})$ to the north and Pernambuco Lineament $(\mathrm{PeL})$ to the south. Internally this domain is subdivided into the terranes: "Faixa Piancó-Alto Brígida" (FPB), "Terreno Alto Pajeú" (TAP), "Terreno Alto Moxotó" (TAM) and Rio Capibaribe Terrane (RCT). 


\section{Zona Transversal Domain}

The Zona Transversal Domain was named to dexcribe the proeminent E-W trending structures. The domain is delimited by two major Brasiliano/Pan-African continental-scale shear zones: the Patos Lineament to the north and Pernambuco Lineament to the south (Fig. 5.1). Within the Zona Transversal Domain there are four different subparallel lithotectonic terranes named from the west to the east as (mostly in Portuguese): "Faixa Piancó-Alto Brígida" (FPB), "Terreno Alto Pajeú" (TAP), "Terreno Alto Moxotó" (TAM) and Rio Capibaribe Terrane (RCT) (Santos and Medeiros, 1999; Brito Neves et al., 2000). Note that other authors (e.g., Neves et al, 2006) prefer to refer to FPB as "Cachoeirinha Belt" and to RCT as "East Pernambuco Belt". These terranes were probably amalgamated during the $\sim 1 \mathrm{Ga}$ Cariris Velhos orogeny (Santos and Medeiros, 1999) and deformed and rotated clockwise during the Brasiliano Orogeny (following the coupled dextral movement of the Patos and Pernambuco lineaments, which result in conjugate dextral and sinistral shear zones striking E-W and NE-SW respectively) (Fig. 5.1). The FPB and RCT consist of metavolcano-sedimentary sequences interpreted to have been deposited during the Neoproterozoic and metamorphosed during the Brasiliano Orogeny (Neves et al., 2006). Brasiliano plutons ranging from ca. 640-540 Ma intruded throughout the Transversal Zone Domain. The TAP is mostly related to the Tonian Cariris Velhos orogeny represented by $1000-920 \mathrm{Ma}(\mathrm{U}-\mathrm{Pb}$ ages in zircon) metavolcanic, metasedimentary, and metaplutonic rocks (Brito Neves et al., 2000; Santos et al., 2010). The oldest rocks known in the Zona Transversal are Paleoproterozoic gneisses with ages of 2.0 to $2.2 \mathrm{Ga}$, which are more abundant in the TAM (Van Schmus et al., 2011).

The Zona Transversal Domain is probably related to and continues into the Adamawa-Yadé Domain in the Central African Fold Belt, as the Patos Lineament matches perfectly with the Central Cameroonian Shear Zone (also known as Garoua Shear Zone) and the Pernambuco Lineament has a controversial, but probable, correlation with the Sanaga Fault (also known as Adamaoua Shear Zone) in a continental drift reconstruction (e.g., Trompette, 1997; Toteu et al., 2006; Njonfang et al., 2008; Neves and Alcantara, 2010). The Central African Fold Belt U-Pb zircon ages on plutonic rocks enable constrain the collisional and post- 
collisional magmatic events within the age period from 640-570 Ma. Additionally, the Neoproterozoic sedimentary basins in that area host detrital zircons with Archean to Paleoproterozoic, late Mesoproterozoic to early Neoproterozoic (1100-950 Ma), and Neoproterozoic U-Pb ages (Toteu et al., 2006). The focus of this study is located in the easternmost, spatially closer to the African equivalent, part of the Zona Transversal Domain, in the RCT (Fig. 5.1).

\section{Rio Capibaribe Terrane (RCT)}

The RCT is limited by the Congo-Cruzeiro do Nordeste Shear Zone to the north and by the Pernambuco Lineament to the south. Brasiliano syn-tectonic granites (640-540 Ma) are abundant in this part of the Borborema Province, showing essentially shoshonitic and high- $\mathrm{K}$ calc-alkalic affinities (Santos and Medeiros, 1999). The Brasiliano/Pan-African orogeny is also responsible for the $632 \pm 17$ Ma upper amphibolite facies metamorphism and the majority of the structural framework overprint in the RCT region (Neves et al., 2006; Neves et al., 2012). The only Cariris Velhos age (i.e., Tonian) reported for the RCT is a $961 \pm 11 \mathrm{Ma}(\mathrm{U}-\mathrm{Pb}$ in prismatic zircon) metarhyodacite layer sampled from a metavolcano-sedimentary complex interpreted to have a geochemical signature of a magmatic arc formed from crustally contaminated mantlederived magma (Accioly et al., 2010). The Mesoproterozoic and early Paleoproterozoic events are represented by the ca. $1.52 \mathrm{Ga}$ Taquaritinga A-type metagranitoid batholith (also termed as augen gneiss; Sá et al., 2002), and the 1,718 \pm 20 Ma gabbro-anorthosite Passira intrusion (Accioly et al., 2003). All the above mentioned units crosscut or overlie a predominantly Paleoproterozoic basement, which includes many high-grade, strongly deformed orthogneisses, paragneisses, and migmatites (Van Schmus et al., 2011). These basement rocks, and particularly the paragneisses are also described under different names [Sertânia Complex in TAM, Vertentes Complex (Santos et al., 2000; Gomes, 2001) and Surubim-Caroalina Complex (Kosin et al., 2004) both in RCT] in various papers and/or mapping projects. In addition, their depositional ages are controversial, as it is described that the Sertânia and Surubim-Caroalina complexes have samples with the youngest detrital zircon population ranging from 1.95-2.15 
Ga (i.e., Paleoproterozoic or younger deposition) (Neves et al., 2009), whereas other samples from the same units contain zircons as young as 870-680 Ma (i.e., Neoproterozoic or younger deposition) (Neves et al., 2009). It is likely that the available geological cartography has not properly distinguished the sedimentary and volcano-sedimentary basins developed during the Paleoproterozoic from the younger Neoproterozoic basins.

\section{The paragneisses in RCT}

The last section briefly outlined existing complexities and problems with respect to the geology and classification of the high-grade metamorphosed supracrustal rocks of the RCT (generally named as Vertentes and/or Surubim-Caroalina complexes). Because the Limoeiro deposit and its related intrusions are hosted by paragneisses and schists in the RCT, this section reviews all the available descriptions of these units, such that readers may place our study into context with other different unit names previously published.

Santos et al. (2000), Brito Neves et al. (2000) and Santos et al. (2010) considered the Vertentes Complex to be a metavolcano-sedimentary sequence, while Neves et al. (2006) describe this same sequence as two distinct supracrustal units, known as the Surubim and Vertentes complexes, mainly based on the occurrence of metavolcanic rocks in the latter. The metasedimentary rocks described in these studies consist of biotite gneiss, biotite schist, quartz-feldspar paragneiss, quartzite and marble, locally with small lenses of para-amphibolite and calcsilicate rocks. The abundance of accessory sillimanite and garnet in metasediments, together with local migmatization, were interpreted to attest the high-temperature metamorphism in the area (Neves et al., 2006). These lithologies and mineral associations are very similar to the country rocks of Limoeiro described later in this study. Differently, the Surubim-Caroalina Complex samples (interpreted by Neves et al., 2009 to be a Neoproterozoic unit), consist of medium-grained muscovite-garnet-bearing feldspathic quartzite and finegrained ultramylonite derived from a metapelitic protolith. 
Contrary to the authors cited above, a recent geological map by the Brazilian Geological Survey (CPRM, 2013) classified the Vertentes Complex as banded orthogneiss and garnet-biotite-amphibole gneiss. The sillimanite-garnet micaschists, pelitic and psammitic paragneiss, leucogneiss, amphibole-biotite paragneiss, quartzites, marbles, calcsilicate rocks and paramphibolites were classified as part of the Surubim-Caroalina Complex. This unit's distribution overlaps the paragneiss unit presented in this study, thus according to the CPRM (2013) classification the Limoeiro intrusion country rock in assigned to the Surubim-Caroalina Complex.

Given above confusion of stratigraphic terms, the country rocks of the Limoeiro intrusion will be referred to by their lithological name (i.e., paragneiss and schist) in this study. Our purpose is to document and characterize the age, geotectonic setting, type of intrusion and the overprinted metamorphism of the Limoeiro intrusion, with no intention to characterize disputed regional stratigraphic units.

\section{The Limoeiro Ni-Cu-(PGE) deposit and its host intrusion}

This topic is described in detail in Mota-e-Silva et al (2013) therefore a brief review is presented in here as an introduction to the following discussions. The Limoeiro deposit is a lowgrade magmatic sulfide deposit (35Mt @ 0.25\% Ni, 0.27\% Cu, 0.40 ppm Pd, 0.16 ppm Pt; Votorantim Metais, 2013) hosted in a sub-horizontal, tubular (chonolith), concentrically-zoned, ultramafic intrusion. The 2 to $10 \mathrm{~m}$ outermost extent of the chonolith comprises amphibolite rocks, interpreted to be the product of metamorphism of the intrusion precursor sill (comparable to the metamorphism of a chilled margin or brecciated marginal zone). The inner part of the intrusion is composed of harzburgite enveloped by orthopyroxenite. The chonolith dimensions are $\sim 500 \times \sim 200 \mathrm{~m}$ in cross section by several kilometers long. It was formed by the emplacement and fractional crystallization of a dynamic multi-pulse mafic magma that has flowed through an open system magma conduit. The intrusion and its mineralization were affected by metamorphism and local britlle deformation. These features are especially dominant 
towards the outer parts of the intrusion. Despite the deformation and metamorphism, the mineralization still preserves its primary magmatic geometry. The intrusion hosts thick (up to $150 \mathrm{~m}$ ) and elongated (up to $1 \mathrm{~km}$ ) masses of disseminated sulfides (2-10 vol\%) broadly concordant and within the upper parts of the chonolith. Massive ore is also present, representing 3 vol\% of the current delineated Limoeiro deposit. It occurs as submeter-scale continuous layers located close to the base of the disseminated sulfide orebody.

\section{Analytical methods}

Zircon concentrates were extracted from rock samples using conventional gravimetric and magnetic techniques at the Geochronology Laboratory of the University of Brasília. Mineral fractions were hand-picked under a binocular microscope to obtain fractions of similar size, shape and color. For in situ U-Pb analyses, hand-picked zircon grains were mounted in epoxy mounts and polished to obtain a smooth surface. Before analyses, the mounts were cleaned using dilute ( 2\%) $\mathrm{HNO}_{3}$. Cathodoluminescence images were obtained using a scanning electron microscope FEI-QUANTA 450, working at $20 \mathrm{kV}$, at the University of Brasília.

The U-Pb LA-ICPMS analyses followed the analytical procedure described by Buhn et al. (2009) and were carried out at the Geochronology Laboratory of the University of Brasília. For LA-ICPMS U-Pb analyses, samples were placed in a specially adapted laser cell. A New Wave UP213 Nd:YAG laser $(\lambda=213 \mathrm{~nm})$, linked to a Thermo Finnigan Neptune Multi-collector ICPMS was used. Helium was used as the carrier gas and mixed with argon before entering the ICPMS. The laser was run at a frequency of $10 \mathrm{~Hz}$ and energy of $\sim 100 \mathrm{~mJ} / \mathrm{cm}^{2}$ with a spot diameter of $30 \mu \mathrm{m}$.

For the U-Pb LA-ICPMS zircon analyses, a fragment of zircon standard GJ-1 (Jackson et al., 2004) was used as the primary reference material in a standard-sample bracketing method, accounting for mass bias and drift correction. The resulting correction factor for each sample analysis considers the relative position of each analysis within the sequence of 4 
samples bracketed by two standard and two blank analyses (Albarede et al., 2004). An internal standard (PAD) was run at the start and end of each analytical session, yielding accuracy of around $2 \%$ and precision in the range of $1 \%(1 \sigma)$. Uncertainties in sample analyses were propagated by quadratic addition of the external uncertainty observed for the standards to the reproducibility and within-run precision of each unknown analysis. $\mathrm{U}-\mathrm{Pb}$ age data were calculated and plotted using ISOPLOT v.3 (Ludwig, 2003) and errors for isotopic ratios are presented at the $1 \sigma$ level.

A natural ${ }^{202} \mathrm{Hg} /{ }^{204} \mathrm{Hg}$ ratio of 4.346 was used to calculate and correct the ${ }^{204} \mathrm{~Pb}$ signal intensity. Common $\mathrm{Pb}$ correction using the common lead composition by Stacey and Kramers (1975) was applied for zircons with ${ }^{206} \mathrm{~Pb} /{ }^{204} \mathrm{~Pb}$ lower than 1000 . Plotting of $\mathrm{U}-\mathrm{Pb}$ data was performed using ISOPLOT v.3 (Ludwig, 2003) and errors for isotopic ratios are presented as $1 \sigma$.

\section{Results}

\section{Limoeiro conduit swarm and its country rocks}

The ultramafic chonolith that hosts the Limoeiro Ni-Cu-(PGE) sulfide deposit is at least $4 \mathrm{~km}$ long. The intrusion is formed by several magmatic sequences, each one formed by a single main mafic magma pulse within the magma conduit (Mota-e-Silva et al, 2013). Recent additional drilling and results from a ground magnetometry survey revealed several other deep seated intrusions broadly parallel to the mineralized chonolith. The intrusion that hosts the Limoeiro Ni-Cu-(PGE) sulfide deposit encompasses, from the east to the west, the targets Bofe, Piçarra, Retiro, Parnazo, Lagoa Comprida, Pirauá and Passassunga (Fig. 5.2). These targets were probably connected prior to structural dismemberment, forming a single $16 \mathrm{~km}$ long chonolith (Fig. 5.2). The ultramafic exposures on surface are relatively small (few tens to hundreds of meters), and the major known outcrop is over the Bofe target ( $1 \mathrm{~km}$ wide circular exposed area). Six additional parallel intrusions indicated by geophysical surveys were 
confirmed by diamond drilling carried out by the VM exploration activities. These recently discovered chonoliths vary from 1.5 up to $17 \mathrm{~km}$ long, and the summation of all of them extends for $46 \mathrm{~km}$ long array. Another group of intrusions, interpreted due to their magnetic high anomalies, extend for a total of $108 \mathrm{~km}$ long. This latter group has not been confirmed by drilling, but may indicate up to $154 \mathrm{~km}$ long of potential magma conduits related to the Limoeiro mafic magmatism occurring in an area of $70 \times 15 \mathrm{~km}$ (Fig. 5.3). In a similar geological setting, the intrusions of Kabanga-Musongati alignment in Tanzania and Burundi, were also recognized as mafic magma conduits occurring discontinuously through a hundreds $\mathrm{km}$ long aligment (Deblonde and Tack, 1999; Evans et al., 2000; Duchesne et al., 2004).

Close to the Limoeiro Ni-Cu-(PGE) sulfide deposit, in the core of the conduit swarm, the intrusions are at orientation N86․ Towards the periphery of the conduit swarm, where the intrusions are closer to mylonitic high strain zones (especially in the southwest part), the intrusions show a preferential orientation of $\mathrm{N}^{\circ} 5^{\circ}$, noticeably parallel to the dominant Brasiliano/Pan-African structural framework (Fig. 5.4). In these high strain zones the foliation in the para- and orthogneiss has a steeply dipping mylonitic foliation oriented 138/75 (dip direction notation). This structural context delineates tens of kilometer-scale lozenge-shaped paragneiss structural blocks, whose inner parts are characterized as low strain zones (Fig. 5.4). The central part of one of these lozenges is coincident with the core of the conduit swarm. In this area the foliation has a gentle dip with an average of $164 / 24$. The penetrative stretching lineation is very prominent in the paragneiss and schist with a clear dominance of plunge orientation of $251 / 4$ (parallel to most of ultramafic intrusions). However in the central part of the lozenge-shaped structure there are some outcrops exposing a sub-horizontal stretching lineation oriented SSENNW (perpendicular to most of ultramafic intrusions), which may be related to a pre-existing structural pattern that survived to the last Brasiliano/Pan-African deformation event (Fig. 5.4). 


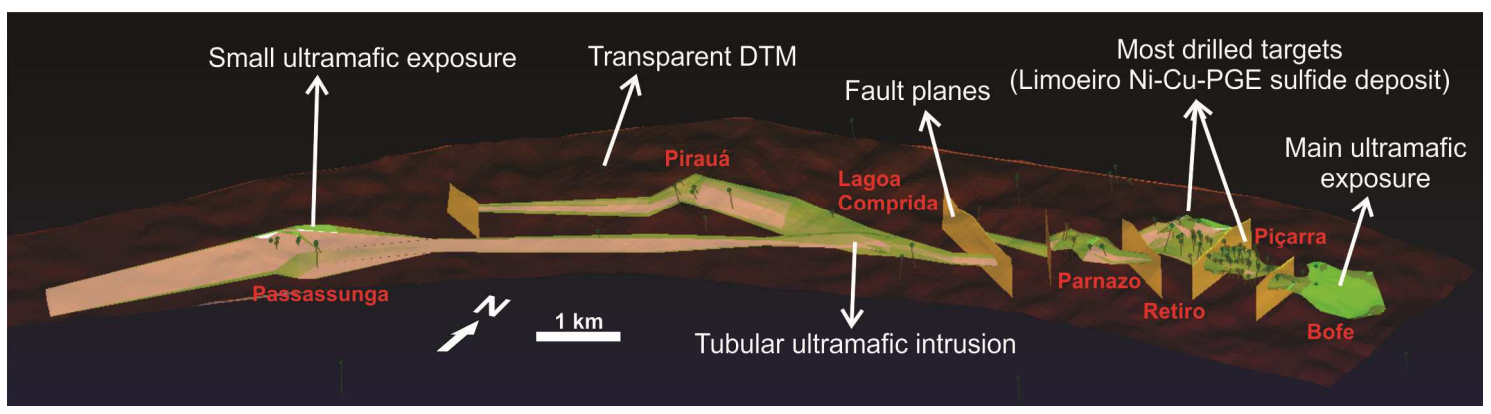

Fig. 5.2 - Schematic three-dimensional model of the main chonolith conduit in the Limoeiro region. Labels in red are the drill target names.

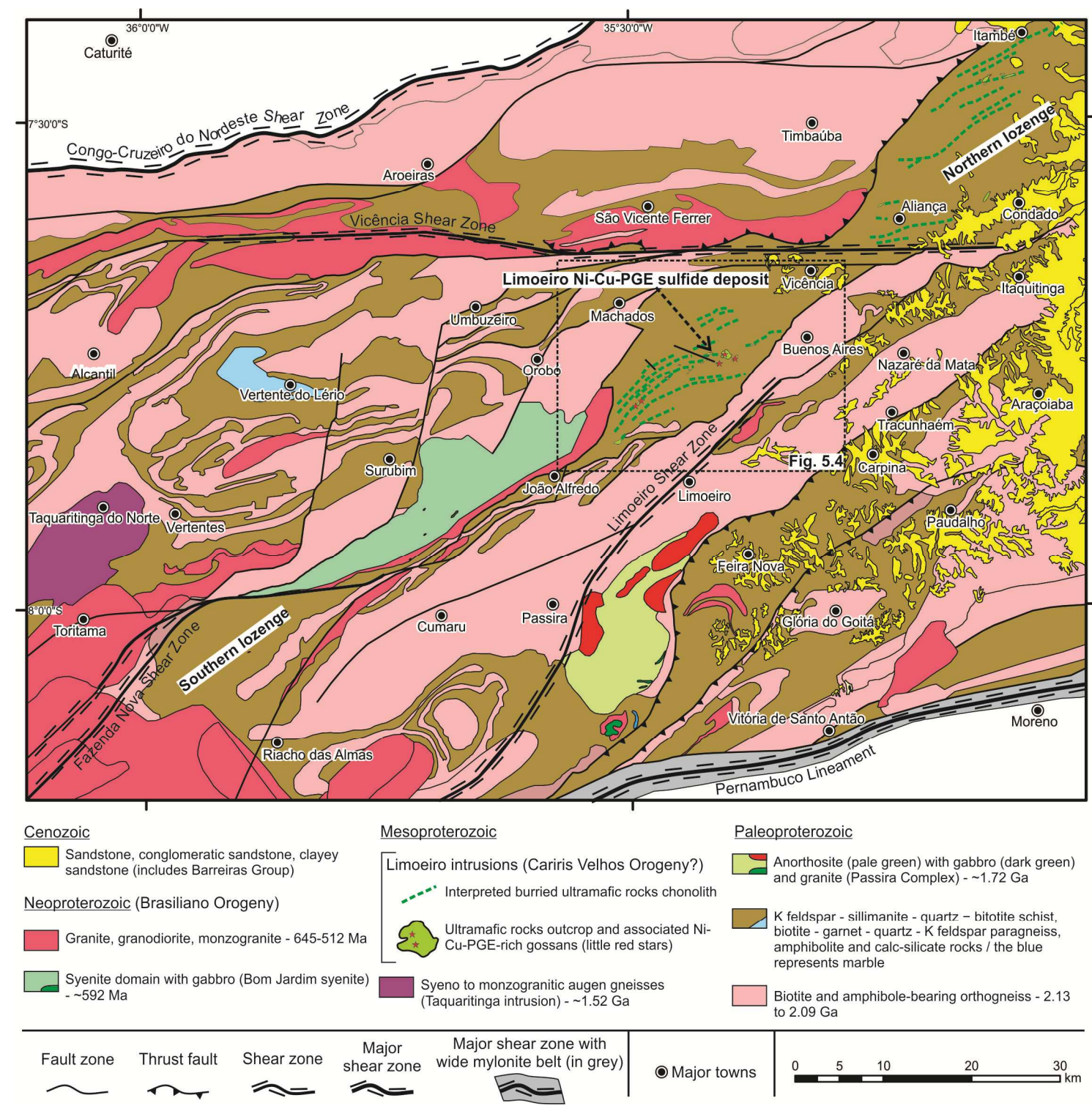

Fig. 5.3 - Geological map of the Limoeiro intrusion region. The rectangle with dashed outline refers to the detailed view of the central lozenge in Fig. 5.4. 


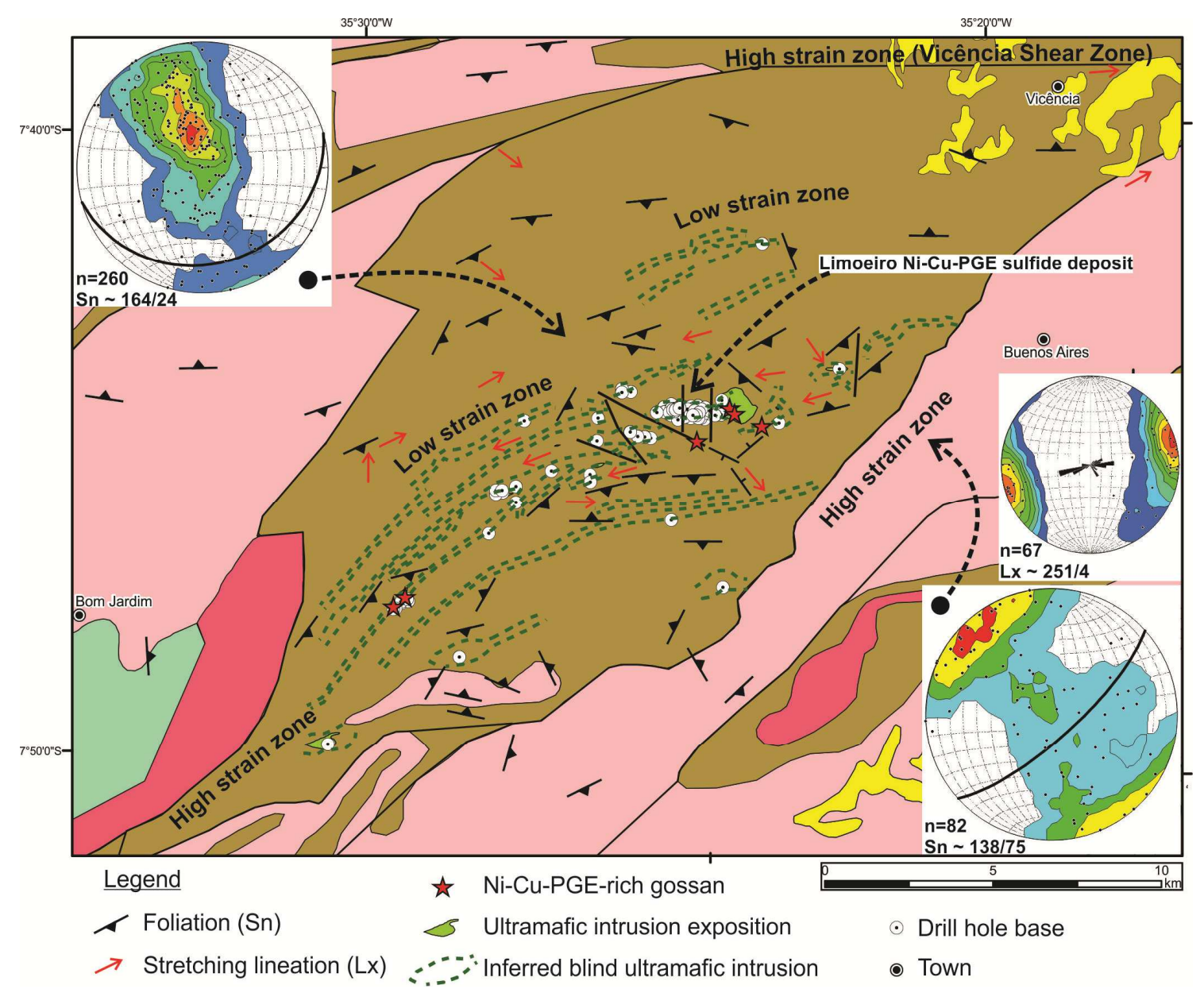

Fig. 5.4 - Detail of the central structural lozenge, highlighting the structural features associated with the ultramafic intrusions. Stereographic nets (equal area diagrams, lower hemisphere) show main foliation plane measurements for low-strain zones (top-left) and high-strain zones (bottom-right), as well as stretching lineation (central-right).

The Limoeiro conduit swarm appears to be restricted to one lithogical unit that comprises paragneiss and schist, which is interlayered with amphibolite and calcsilicate rocks (Mota-e-Silva et al., 2013). It is difficult to visually distinguish between the amphibolite, calcsilicate and the metamorphosed outer margin of the Limoeiro intrusion that is also composed of a rock dominated by metamorphic amphibole (hornblende and anthophyllite). Generally the amphibolite layers within the banded paragneiss are highly magnetic, whereas the other two amphibolite-rich rocks are not. The calcsilicate rock has gradational contacts with gneiss and schist, and occasionally has carbonate, epidote and quartz as accessory minerals. The amphibole-rich rocks form three distinct separate clusters in a principal component analyses (PCA) diagram considering all the 18 available elements in the VM database (Fig. 5.5). The amphibolite layer rocks form a cluster relatively enriched in $\mathrm{TiO}_{2}, V, \mathrm{P}_{2} \mathrm{O}_{5}$ and $\mathrm{Zn}$ 
(commonly with $\sim 5 \mathrm{wt} \% \mathrm{TiO}_{2}, \sim 400 \mathrm{ppm} \mathrm{V}, \sim 0.6 \mathrm{wt} \% \mathrm{P}_{2} \mathrm{O}_{5}$ and $\sim 150 \mathrm{ppm} \mathrm{Zn}$ ), whereas the amphibolite forming the outer margin of the Limoeiro intrusions is characterized by high values of $\mathrm{MgO}, \mathrm{Co}, \mathrm{Cr}$ and $\mathrm{Ni}$. The calcsilicate rocks are relatively poor in the above mentioned elements and oxides, but are relatively enriched in $\mathrm{BaO}, \mathrm{K}_{2} \mathrm{O}, \mathrm{Pb}$ and $\mathrm{Zr}$ (Fig. 5.5). These chemical associations are compatible with the geological interpretation by the VM team suggesting that the amphibolite layers represent metamorphosed basic volcanics, whereas the calcsilicate rocks are metamorphosed marl and the amphibolite in the outer parts of the intrusion is the metamorphic product of the intrusion chilled margin or marginal breccia. This interpretation indicates that the Limoeiro conduit swarm country rocks are a metamorphosed volcano-sedimentary sequence, formed by successive clastic sequences of pelitic and psammitic-rich sediments (turbidites), with minor carbonate contribution and interbedded with basaltic lava flows.

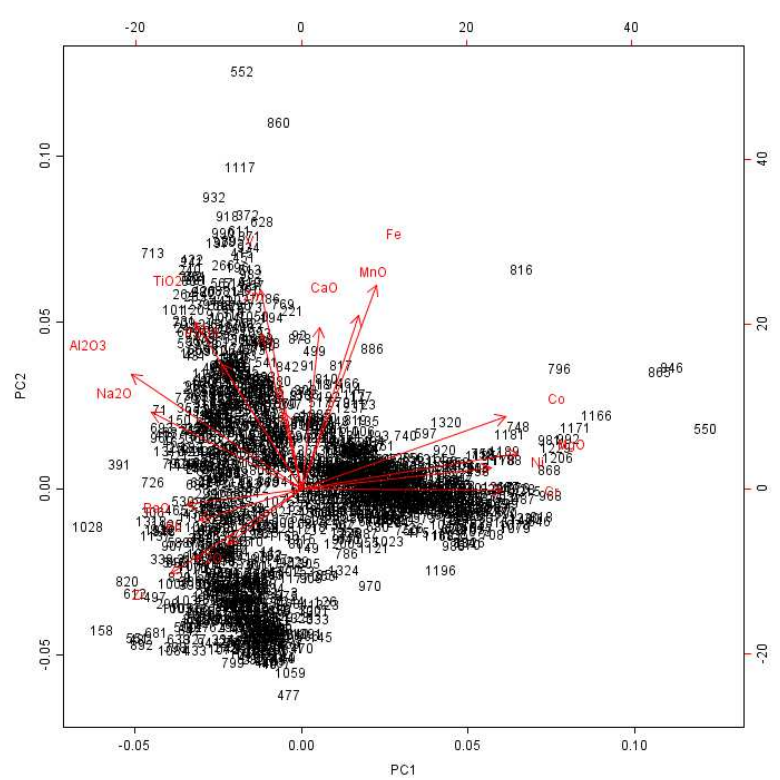

Fig. 5.5 - PCA diagram containing all drill core analyses of the most discriminatory elements $\left(\mathrm{Al}_{2} \mathrm{O}_{3}, \mathrm{BaO}, \mathrm{CaO}, \mathrm{Co}, \mathrm{Cr}\right.$, $\mathrm{Cu}, \mathrm{Fe}, \mathrm{K}_{2} \mathrm{O}, \mathrm{MgO}, \mathrm{MnO}, \mathrm{Na}_{2} \mathrm{O}, \mathrm{Ni}, \mathrm{P}_{2} \mathrm{O}_{5}, \mathrm{~Pb}, \mathrm{TiO}_{2}, \mathrm{~V}, \mathrm{Zn}$ and $\mathrm{Zr}$ ) for all amphibole-rich rocks from $\mathrm{VM}$ database. Clustering of samples are related to different "amphibolite" protoliths: (i) mafic volcanics to the top; (ii) calc-silicate to the bottom; (iii) tholeiitic precursor sill of the Limoeiro magmatism to the right. The PC1 has a standard variation of 2.24 and a proportion of variance of 0.28 , whereas the PC2 has standard variation of 2.06 and a proportion of variance of 0.24 .

\section{Paragneiss/schist petrography}


The country rocks located close to the Limoeiro deposit were described by Mota-eSilva et al. (2013) as banded rocks consisting of interlayered K-feldspar-sillimanite-quartzbearing biotite schists and biotite-garnet-quartz-K-feldspar-bearing paragneisses. This section provides additional data for the paragneiss and schist hosting the mafic-ultramafic intrusions, aiming to constrain the metamorphic events within the country rocks. These rocks, investigated throughout the region close to the ultramafic chonoliths (Fig. 5.3), are characterized by compositional banding and pronounced lineation (Fig. 5.6A). Medium-grained rocks with granolepidoblastic texture, consisting of mainly of variable proportions of K-feldspar + quartz + sillimanite + Ca-plagioclase + biotite + garnet, prevail (Fig. 5.6B,C). Zircon, apatite and rutile, the latter as fine-grained inclusions in garnet, are common accessory minerals.

Paragneiss and schist located in the northern structural lozenge (Fig. 5.3) are just slightly transformed by low-grade retrometamorphic minerals. On the other hand, retrograde assemblages overprint extensively the high-grade mineralogy of these rocks in the central structural lozenge (Fig. 5.3 and 4). The closer proximity of Brasiliano/Pan-African batholiths with the central block may have caused such extensive retrometamorphic alteration. Lower grade assemblages (i.e. post peak metamorphism) are indicated by the formation of biotite and muscovite at the expense of sillimanite (Fig. 5.6B), extensive replacement of biotite by chlorite (Fig. 5.6E) and mesoperthitic texture in K-feldspar (Fig. 5.6D). Among the accessory minerals titanite and ilmenite form at the expense of rutile (Fig. 5.6F), whereas prismatic zircons with preserved growth zoning are transformed into metamict grains. In some of these larger zoned zircons tiny inclusions of pristine crystals occur. Inclusions of titanite and needles of rutile in chlorite, suggesting biotite or garnet pseudomorphs, are very common features in the most altered rocks (Fig. 5.6G).

The amphibolite forms meter-scale layers parallel to the paragneiss/schist banding, consisting of hornblende + Ca-plagioclase + clinopyroxene + quartz + biotite (Fig. $5.6 \mathrm{H}$ ) or hornblende + Ca-plagioclase + garnet. Lower grade replacement of the high-grade metamorphic assemblage is limited to mild saussuritization of plagioclase and biotite partially altered to chlorite. As the amphibolite was sampled in the northern structural lozenge (Fig. 5.3), far from Brasiliano/Pan-African batholiths, no retrometamorphic alteration was recorded. 

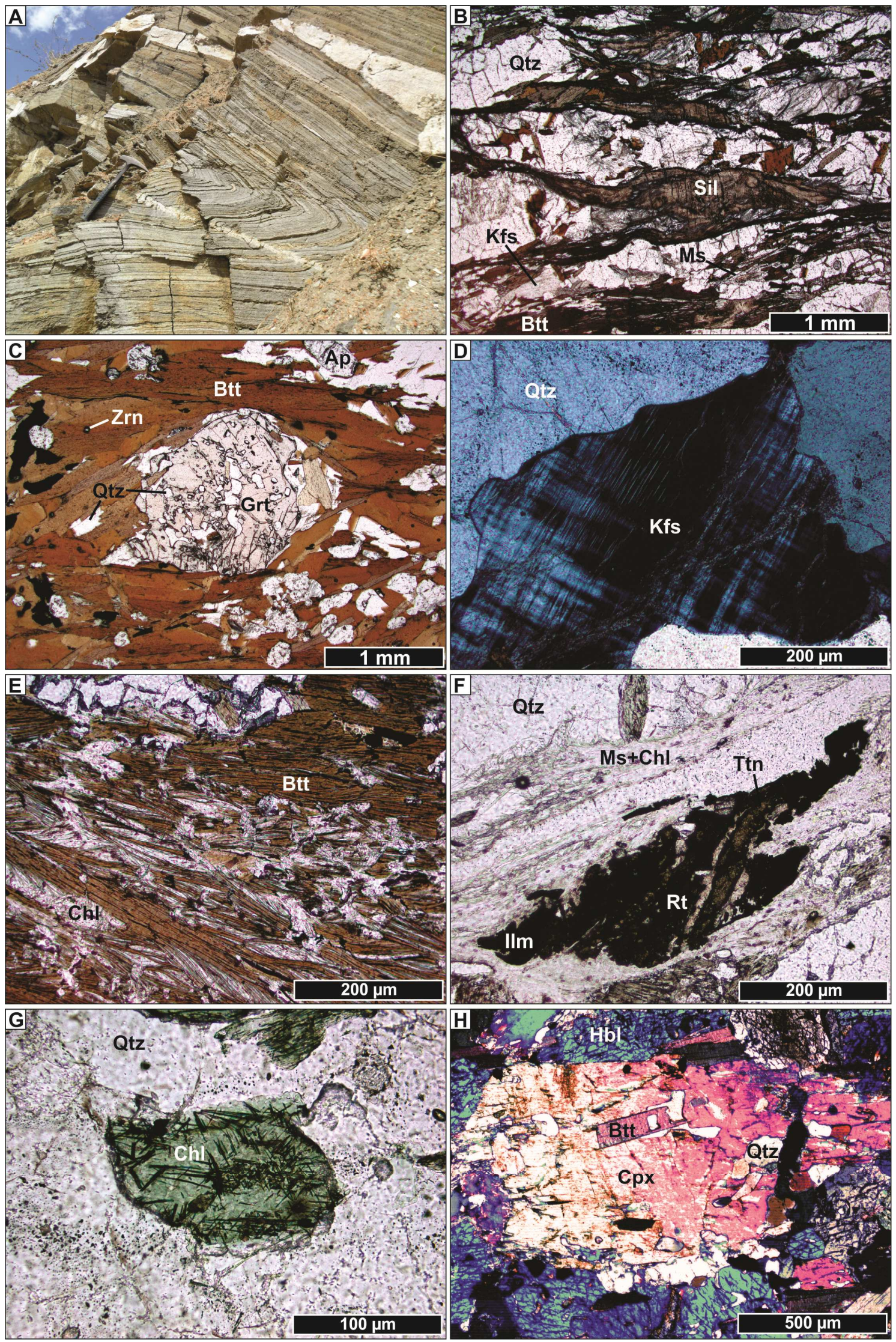

Fig. 5.6 - Macro- and microscopic examples of the country rocks of the Limoeiro intrusions. (A) Fine grained banded paragneiss with successive clastic sequences (turbidite?) of pelitic- and psammitic-rich metamorphosed sediments 
affected by a recumbent asymmetrical fold. Rock exposed in a quarry close to the city of Toritama. (B) K-feldsparsillimanite-biotite-plagioclase-quartz schist with retrograde muscovite (sample 100-097). In this sample the high-grade parageneses is relatively preserved. (C) Garnet-plagioclase-quartz schist with apatite, zircon and rutile (sample 1002219). The retrometamorphism assemblage is absent in this case. (D) Detail of a mesoperthite (high-grade parageneses) transformed to microcline (retrograde) in sillimanite-K-feldspar-quartz schist (sample 118-158). (E) Extensive retrograde crystallization of chlorite at the expense of biotite in paragneiss containing quartz + biotite + hornblende + plagioclase + garnet \pm apatite \pm sulfides \pm magnetite \pm ilmenite as the high grade assemblage (sample 118-152). (F) Detail of a titanite (high-grade parageneses) partly transformed to rutile and ilmenite (retrograde) in the same sample as Fig. 5.6D. (G) Chlorite grain with rutile needles as result of retrometamorphism of biotite (same sample as Fig. 5.6D,F). (H) Clinopyroxene, hornblende, biotite and quartz representing the high-grade metamorphic assemblage of an amphibolite layer in the paragneiss (sample 100-186).

The high-grade metamorphic assemblage of paragneiss and schist of the Limoeiro region is typical of Al-rich metapelites (Butcher and Grapes, 2011). These rocks have different metamorphic parageneses that are all characterized by the absence of orthopyroxene, as well as the absence of the muscovite + quartz pair. Together these features indicate that the highgrade metamorphic assemblage corresponds to the transition from the upper amphibolite to granulite facies of regional metamorphism, broadly bracketed by reactions 1 and 2 in figure 7 . Peak metamorphic paragenesis of amphibolite interlayered with metapelites, characterized by clinopyroxene + hornblende + Ca-plagioclase, is consistent with metamorphic conditions at the transition from granulite to amphibolite facies, as indicated by several studies of progressive metamorphism of mafic rocks (e.g., Raase et al., 1986; Ferreira Filho et al., 1998). The presence of clinopyroxene in the mafic rocks (Fig. 5.6H) and mesoperthite in paragneisses (Fig. 5.6D) suggest that peak metamorphism may be close to the lower limit of the granulite facies. Masberg et al. (1992) used the exsolution of string-perthites, mesoperthitic string-perthites and antiperthites in feldspar as one of the criteria to include orthopyroxene-free metapelites as low pressure granulite-facies metamorphic rocks in central the Damara Orogen (Namibia). The available petrographic information suggests that the host rocks of the Limoeiro mafic-ultramafic magmatism were metamorphosed at $750-800^{\circ} \mathrm{C}$ under moderate pressure conditions $(5-8 \mathrm{kbar}$; Fig. 5.7), at the lower granulite facies or right at the boundary between the upper amphiboliteand granulite-facies conditions.

The paragneiss and schist of the Limoeiro region are aluminous rocks that have pelites as protoliths. The mineral assemblage documented in this section shows that these 
rocks are orthopyroxene-free, which could indicate that the peak of metamorphism was under granulite-facies (Fig. 5.7). However, mafic layers have clinopyroxene in the metamorphic assemblage, which may indicate temperatures of $>750^{\circ} \mathrm{C}$ (Bucher and Grapes, 2011). Other evidence that the paragneiss and schist at Limoeiro have been metamorphosed under high temperature conditions is the presence of metamorphic mesoperthite (Fig. 5.6D). Masberg et al. (1992) used the exsolution of string-perthites, mesoperthitic string-perthites and antiperthites in feldspar as one of the criteria to classify orthopyroxene-free metapelites as granulite-facies metamorphic rocks. They concluded that this metamorphic facies may not be detected on the basis of mineral assemblages in the low-pressure central Damara Orogen, Namibia. A similar situation may be applied to the paragneiss and schist that are the Limoeiro intrusion country rocks. Using all the petrographic information available it is likely that these rocks were metamorphosed at $750-800^{\circ} \mathrm{C}$ under moderate pressure conditions (5-8kbar; Fig. 5.7). The related temperature range places the peak metamorphism of Limoeiro within the lower granulite facies with some overlap to the boundary between the upper amphibolite- and granulite-facies conditions.

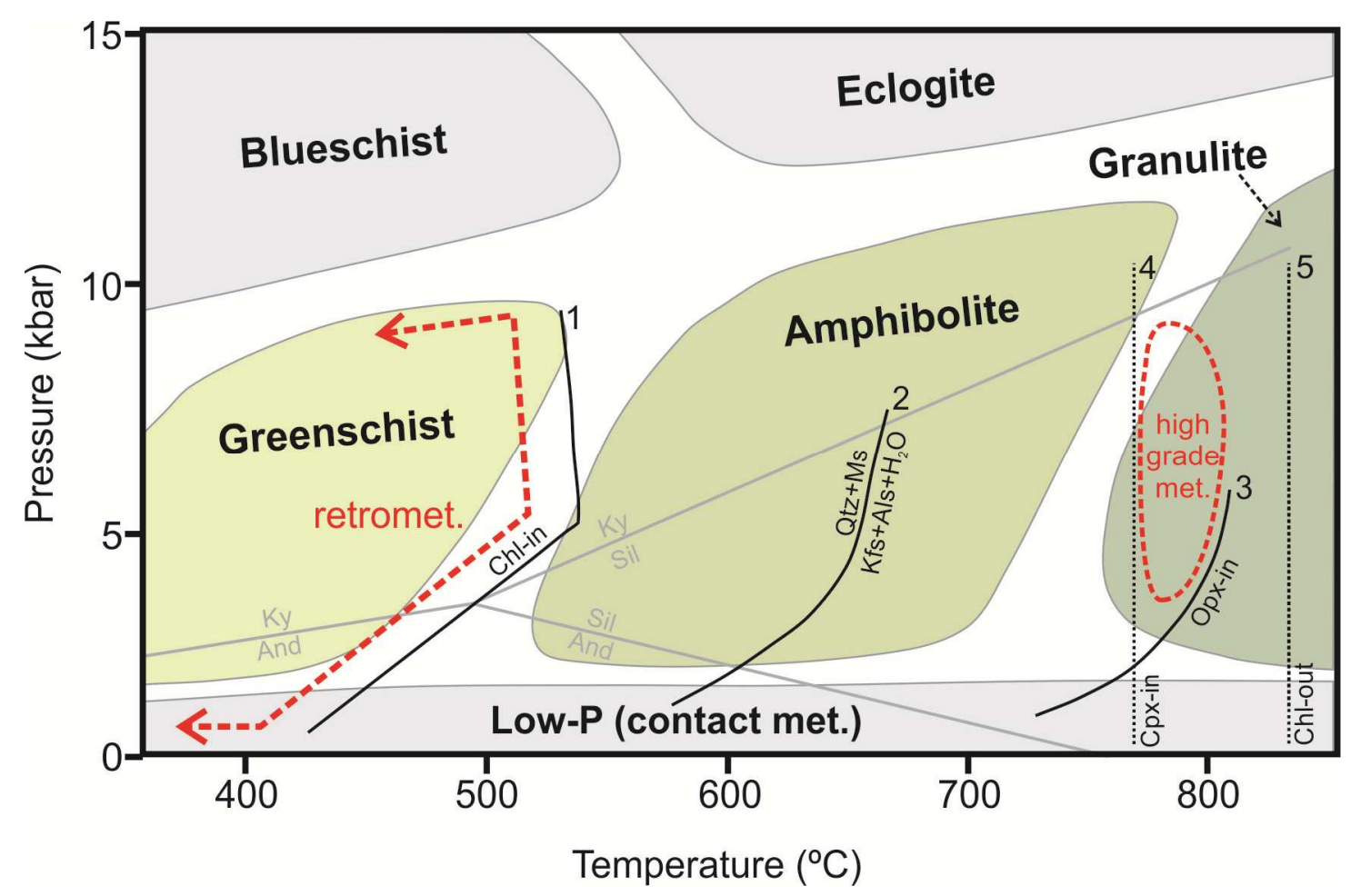

Fig. 5.7 - Metamorphic reactions and mineral stability fields in a temperature versus pressure diagram. The continuous lines are appropriate for metapelitic rocks that originally contained Chl-Ms-Qtz (model system KFMASH) and the dashed lines refer to mineral stability fields in ultramafic rocks. The chlorite stability field for metapelites (1) represents 
the growth of chlorite at the expense of garnet and biotite (Bucher and Grapes, 2011). The reaction (2) denotes the metamorphic formation of K-feldspar and sillimanite at the expenses of the destruction of the quartz-muscovite pair (taken from the bathozones concept definition by Carmichael, 1978). This reaction releases water and can lead the system to the formation of melt. The curve (3) was taken from the low-pressure and high-temperature FASH system assemblage diagram (Bucher and Grapes, 2011). Commonly the first occurrence of Opx+Qtz is considered the beginning of the granulite facies in the FASH system. The curves (4) and (5) refer to typical isograds defined for Albearing Iherzolite under low pressure metamorphism (Bucher and Grapes, 2011).

The petrographic evidence and mineral assemblages presented in this study cannot permit accurate metamorphic-grade estimate for the retrometamorphism. The chlorite and muscovite formation at the expense of biotite and garnet suggest a retrometamorphic grade equal to or below greenschist-facies (Fig. 5.7).

\section{Zircon LA-ICPMS U-Pb data}

Zircons identified by routine petrographic studies and/or high Zr concentrations on drill core geochemistry were used as criteria to select the samples for U-Pb dating (Table 5.1). Four samples representative of the Limoeiro ultramafic rocks were selected. In all these samples, zircons comprise similar populations, dominantly ovoid- and rounded-shape grains (Fig. 5.8) and more rarely showing soccer ball habit (e.g., Vavra et al, 1996; Schaltegger et al., 1999; DellaGiustina et al., 2011). These zircons are commonly attributed to metamorphic growth during high-grade metamorphism (e.g., Hoskin and Schaltegger, 2003). The zircons in samples 002-242 and 055-208 are $~ 75 \mu \mathrm{m}$ in diameter, whereas samples 187531 and 328722 contain coarser grains with $\sim 150 \mu \mathrm{m}$ diameter (Fig. 5.8). These rounded zircons have lowcathodoluminescence $(\mathrm{CL})$ cores (sometimes U-rich) with diffuse zoning, surrounded by brighter $\mathrm{CL}$ outer rims containing convoluted zoning, transgressive recrystallization, and/or sector zoning (Fig. 5.9). 
Table 5.1 - U-Pb LA-MC-ICPMS data

\begin{tabular}{|c|c|c|c|c|c|c|c|c|c|c|c|c|c|c|c|c|c|c|}
\hline & c & $f$ & & & 。 & $\begin{array}{l}0 \\
6)\end{array}$ & 0 & & 0 & $\begin{array}{l}10 \\
\text { (\%) }\end{array}$ & & ge & $\begin{array}{l}10 \\
\text { ha) }\end{array}$ & $\begin{array}{l}7 / 5 \\
\text { age }\end{array}$ & $\begin{array}{l}10 \\
\text { Ma) }\end{array}$ & $\begin{array}{l}6 / 8 \\
\text { age }\end{array}$ & $\begin{array}{c}10 \\
\text { (Ma) }\end{array}$ & $\begin{array}{l}\text { Conc } \\
\text { (\%) }\end{array}$ \\
\hline & 1 & & & & & & & & & & & & 7 & & 3 & & & \\
\hline & 2 & & & & & & & & & & & & & & 7 & & 6 & \\
\hline & 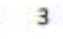 & & & & & & & & & & & & & & 6 & & & 99 \\
\hline & 4 & & & & & & & & & & & & 6 & & 3 & & 3 & 100 \\
\hline & 5 & & & & & & & & & 1 & & & 9 & & 3 & & 3 & 99 \\
\hline & 6 & & 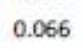 & & & & & & & 4 & & 6 & 9 & & 4 & & 4 & 0 \\
\hline & 7 & 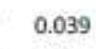 & & & & & & & & 4 & & & 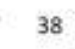 & & 9 & 619 & 6 & 50 \\
\hline & 8 & & & & & & & & & & & & 11 & & 5 & & 5 & 99 \\
\hline & 0 & & & & & & & & & & & & 12 & & 5 & & 5 & 99 \\
\hline & & & & & & & & & & & & & 36 & & 9 & & 6 & 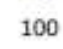 \\
\hline & & & & & & & & & & & & & & & 5 & & 5 & 100 \\
\hline & & & & & & & & & & 0 & & & 15 & & 5 & & 5 & 99 \\
\hline & & & & & & & & & & & & & & & 11 & & 11 & 98 \\
\hline & & & & & & & & & & & & & 20 & & 7 & & 0 & 98 \\
\hline & 16 & & & & & & & & & & & & & & 5 & & . & 09 \\
\hline & & & & & & & & & & & & & & & 7 & & 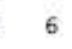 & \\
\hline & & & & & & & & & & & & & & & & & & 99 \\
\hline & & & & & & & & & & & & & & & 11 & & & 90 \\
\hline & & & 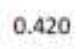 & & 69 & & & & & 9 & & & 6 & & & & 7 & 90 \\
\hline & & & & & & & & & & 4 & 0.87 & 2 & 7 & & 7 & 2050 & 3 & 100 \\
\hline & & & & & 0,060 & & & & & 7 & & & 25 & & 6 & & & 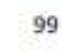 \\
\hline & & & & & & & & & & & & & 13 & & 5 & & 5 & 87 \\
\hline & & & & & & & & & & & & & & & 8 & & 3 & 96 \\
\hline & & & & & & & & & & & & & & & 7 & & 5 & 100 \\
\hline & & & & & & & & & & & & & & & & & & 98 \\
\hline & & & & & & & & & & & & & & & & & & 6 \\
\hline & & & & & & & & & & & & & & & & & & 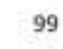 \\
\hline & 1 & & & & & & & & & & & & & & & & & \\
\hline & 2 & & & & & & & & & & & & & & & & & \\
\hline & 5 & & & & & & & & & & & & & & & & & \\
\hline & 6 & & & & & & & & & & & & & & & & & \\
\hline & 7 & & & & & & & & & & & & & & & & . & 100 \\
\hline & 8 & & & & & & & & & & & & & & & & 4 & 100 \\
\hline & 9 & 0.0 & & & & & & & & & & & & & & & 4 & 100 \\
\hline & & 0 & & & & & & & & & & & & & & & 5 & 101 \\
\hline & & & & & & & & & & & & & 14 & & 4 & & 4 & 100 \\
\hline & & & & & & & & & & & & & & & & & 4 & \\
\hline & & & & & & & & & & & & & & & & & 3 & \\
\hline & & & & & & & & & & & & & & & & & & 100 \\
\hline & & & & & & & & & & & & & & & 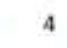 & & & \\
\hline & & & & & & & & & & & & & & & 5 & & 6 & \\
\hline 872 & a & & & & & & & & & & & & 2 & & 4 & 5 & & 99 \\
\hline
\end{tabular}




\begin{tabular}{|c|c|c|c|c|c|c|c|c|c|c|c|c|c|c|c|c|c|c|}
\hline mple & $\begin{array}{c}\text { Zire } \\
\text { on }\end{array}$ & $06) \%$ & Th/U & 4 ratio & $\begin{array}{l}1 / 6 \\
\text { itio }\end{array}$ & $\begin{array}{l}1 \sigma \\
(\%)\end{array}$ & $\begin{array}{l}7 / 5 \\
\text { atio }\end{array}$ & $\begin{array}{l}10 \\
(\%)\end{array}$ & $\begin{array}{l}6 / 8 \\
\text { ratio }\end{array}$ & $\begin{array}{l}1 \sigma \\
\text { (\%) }\end{array}$ & Rho & $\begin{array}{l}7 / 6 \\
\text { age }\end{array}$ & $\begin{array}{c}1 \sigma \\
\text { (Ma) }\end{array}$ & $\begin{array}{l}7 / 5 \\
\text { age }\end{array}$ & $\begin{array}{c}10 \\
\text { (Ma) }\end{array}$ & $\begin{array}{l}6 / 8 \\
\text { age }\end{array}$ & $\begin{array}{c}1 \sigma \\
\text { (Ma) }\end{array}$ & (\%) \\
\hline 2 & & 16 & & & & & & & & & 0.93 & 3 & 11 & 611 & 5 & 608 & 5 & 99 \\
\hline 328722 & , & 30 & 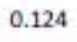 & 9532 & 0.061 & 0.48 & & & & & & 645 & 10 & 627 & 4 & 622 & & 99 \\
\hline . & & 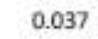 & $c$ & 47619 & & & & & & & & 6 & & & 5 & & 4 & o \\
\hline 9 & 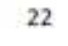 & 015 & 32 & 549 & 060 & 5 & 92 & 1.18 & 97. & 5 & 0.88 & 615 & 11 & 648 & 6 & 65 & 7 & 01 \\
\hline 328722 & 24 & 20 & 178 & 9 & 0 & - & 8. & 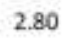 & 2 & 59 & 0.93 & 61 & 23 & 526 & 11 & so & 13 & 96 \\
\hline 328722 & 25 & 19 & 0 & 66 & 1 & 0.48 & 0 & 6 & 5 & 4 & 8 & 6 & 10 & 1 & 5 & 6 & 6 & 100 \\
\hline 3287 & 2 & 1 & 0 & & & & & & & & & & 9 & 618 & 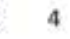 & 6 & 4 & 100 \\
\hline 3 & 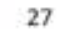 & 012 & 4 & 18 & 061 & 0.8 & 68 & 1.12 & 3 & 1 & 0.79 & 634 & 19 & 634 & 5 & 634 & & 100 \\
\hline & 28 & 009 & s & 199438 & 1 & t & -5 & +4 & 6 & 0.79 & 0.90 & 623 & 8 & 645 & 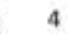 & 6 & 5 & 101 \\
\hline 328722 & 2 & 07 & 7 & & 1 & t & 0.837 & ? & & 7 & 0.81 & 6 & 11 & 6 & 4 & 614 & & 99 \\
\hline 328722 & 30 & 0.004 & 154 & 1 & 1 & $c$ & & 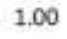 & & & 0.86 & 6. & & 6 & 5 & 6 & 5 & 100 \\
\hline 420902 & 2 & 2 & 0.034 & 5 & & & & & & & 9 & & & 6 & 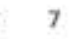 & & 5 & 100 \\
\hline 4 & 4 & & 032 & & 0.060 & 0.3 & 0.791 & 11 & 6 & & 0.94 & 60 & 8 & 59 & 5 & 58 & 6 & 99 \\
\hline & 9 & 08 & 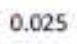 & & 0.060 & 8 & 0.789 & 113 & 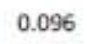 & 1 & 0.95 & 6 & 11 & 5 & 5 & 58 & 6 & 100 \\
\hline & 2 & 0.009 & 2 & & & ; & & & & 3 & 0.92 & 8 & 13 & 813 & 6 & & 7 & 98 \\
\hline 420902 & 2 & 0.027 & 23 & & & & & & & & 0.90 & 62 & 6 & 599 & 3 & & & 99 \\
\hline 420902 & 25 & 0.000 & 024 & 7 & 0 & 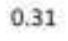 & & & & & 0.92 & 59 & & 58 & & & & 99 \\
\hline & $01 \mathrm{R}$ & 2 & 026 & & $0 \cap 60$ & & 0.815 & & & & 0.91 & 6. & 8 & 60 & 4 & & 5 & 99 \\
\hline & & 0.003 & & & 0.061 & stis & & & & 3 & 0.88 & 62 & 11 & 0 & 6 & 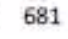 & 7 & 02 \\
\hline 4 & & 004 & & & & & & 0,66 & & 8 & 0.83 & 114 & 6 & 11 & 4 & 11 & 6. & 99 \\
\hline 0002 & 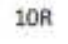 & 0.000 & 027 & & 0 & t & & & & & 0.94 & & & 5 & & & 6 & 100 \\
\hline 02 & 1 & 17 & 177 & & 4 & t & 1.023 & & & 3 & 0 & 7 & & 7 & & & & 99 \\
\hline & 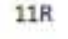 & . & & & & & & & & & 0 & & & 6 & & & & 98 \\
\hline & & & & & & & & & & & & & & & 9 & & 9 & 98 \\
\hline 2000 & 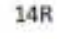 & & & & & & & & & 4 & 7 & & 7 & 58 & 3 & & (3) & 99 \\
\hline & 2 & 03 & 040 & & & & & & & & 0.93 & 60 & & 58 & & & & 99 \\
\hline & v & 4 & & & & & & & & & 0 & 6 & & & & & 5 & 01 \\
\hline 92 & 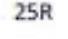 & 079 & & & & & & & & & & & & 58 & & & & 98 \\
\hline & 2 & 016 & & & & & & & & & & & & & 5 & & & 95 \\
\hline $002-242$ & 3 & & & & & & & & & & 0 & & & & & & 5 & 100 \\
\hline & 4 & & & & & & & & & & 0 & & & & & & 6 & 100 \\
\hline & 6 & 29 & ( & & & & & & & 70 & 0.75 & & & $61 \quad$ & & & & 95 \\
\hline & 9 & & & & & & & & & & 0.90 & & & & & & & 0 \\
\hline $002-242$ & 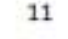 & 029 & & & & & & & & & $0 . t$ & & & & & & & 94 \\
\hline & 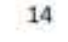 & & & & & & & & & & & & & & 6 & & 6 & 100 \\
\hline & & & & & & & & & & & 0 & & & & & & 4 & 00 \\
\hline & & & & & & & & & & & 0.76 & & & 67 & & & 5 & 0 \\
\hline & 19 & 18 & 0.5 & & & & & & & 4 & 0.6 & & & 7 & 8 & & 5 & 101 \\
\hline $002-242$ & 2 & 0.02 & 0 & & 0.062 & . & & & & & & & & 6 & 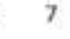 & & 6 & 10 \\
\hline & & & & & & & & & & & & & & & 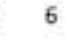 & & 3 & 98 \\
\hline & 2 & 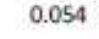 & $c$ & & & - & & & & 8 & 0 & $\epsilon$ & 24 & 6 & 8 & 6 & 7 & 97 \\
\hline $002-242$ & & 0.078 & 0.524 & (2) & (1) & . & . & 2.20 & . & 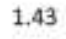 & 6.7 & . & & 678 & 10 & or & 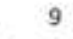 & 96 \\
\hline
\end{tabular}




\begin{tabular}{|c|c|c|c|c|c|c|c|c|c|c|c|c|c|c|c|c|c|c|}
\hline Sample & $\begin{array}{l}\text { Zirc } \\
\text { on }\end{array}$ & $f(206) \%$ & $T h / U$ & 0 & $\begin{array}{c}7 / 6 \\
\text { ratio }\end{array}$ & $\begin{array}{l}1 \sigma \\
(\%)\end{array}$ & $\begin{array}{l}7 / 5 \\
\text { ratio }\end{array}$ & $\begin{array}{l}1 \sigma \\
(\%)\end{array}$ & $\begin{array}{c}6 / 8 \\
\text { ratio }\end{array}$ & $\begin{array}{l}1 \sigma \\
(\%)\end{array}$ & Rho & $\begin{array}{l}7 / 6 \\
\text { age }\end{array}$ & $\begin{array}{c}1 \sigma \\
(\mathrm{Ma})\end{array}$ & $\begin{array}{l}7 / 5 \\
\text { age }\end{array}$ & $\begin{array}{c}1 \sigma \\
(\mathrm{Ma})\end{array}$ & $\begin{array}{l}6 / 8 \\
\text { age }\end{array}$ & $\begin{array}{c}1 \sigma \\
(\mathrm{Ma})\end{array}$ & $\begin{array}{l}\text { Conc } \\
(\%)\end{array}$ \\
\hline & & 13 & c & 5 & 6 & 4 & 4 & & & 1 & 2 & 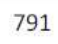 & 15 & 812 & 7 & 10 & 9 & 104 \\
\hline $002-242$ & 8 & 013 & 0 & 140983 & 060 & 0.93 & 837 & 7 & 1 & 14 & 6 & 602 & 20 & 617 & 7 & 622 & 7 & 103 \\
\hline 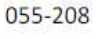 & 1 & 0.022 & 0 & 7 & 0.060 & 0 & 3 & & & 0.75 & 0.66 & & & 629 & 5 & 3 & 5 & 103 \\
\hline & 3 & 009 & 0 & & 0 & 0.7 & & 8 & 6 & 0.76 & 0.67 & 61 & 7 & GA & 5 & E & 5 & 105 \\
\hline 255 & 5 & 12 & 0 & & 0.061 & 0.6 & 77 & 2 & 5 & 1.38 & 0.91 & 633 & 13 & 639 & 7 & 641 & 0 & 101 \\
\hline 8 & 7 & 0.004 & 0.127 & 66 & 0.061 & 0.85 & 0.841 & 103 & 0.100 & 0.58 & 0.61 & 634 & 18 & 620 & 5 & 616 & 3 & 97 \\
\hline & 14 & 07 & 2. & 86 & 0.065 & 0.7 & 665 & 1.15 & 0 & 0.91 & 0.78 & 769 & 15 & 785 & 6 & 790 & 7 & 103 \\
\hline & 16 & 0.008 & 0.122 & 2 & 0.061 & 0.7 & ( & 1. & 0.108 & 0.81 & 0.69 & 638 & 7 & 658 & 5 & 66 & 5 & 104 \\
\hline בנ & 1 & 13 & 0.245 & 90 & 0.061 & 0.56 & 0.910 & 0.8 & 0.1 & 0.69 & 0.74 & 649 & 12 & 657 & 4 & 660 & 4 & 102 \\
\hline $055-$ & 18 & 0.021 & 0.144 & 5667 & 0.060 & 0.83 & 0.824 & 2.17 & 0.0 & 2.00 & 0.92 & 619 & 18 & 610 & 10 & 608 & 12 & 98 \\
\hline 055 & 19 & 0.010 & 0.162 & 173740 & 0.062 & 0.89 & 0.920 & 1.10 & 0.1 & 0.78 & 0.75 & 664 & 19 & 666 & 6 & 666 & 3 & 100 \\
\hline $055-208$ & 20 & 0.016 & 0.159 & 107483 & 0.060 & 0.85 & 0.864 & 1.13 & 0.104 & 0.76 & 0.63 & 612 & 18 & 632 & 5 & 638 & 5 & 104 \\
\hline
\end{tabular}
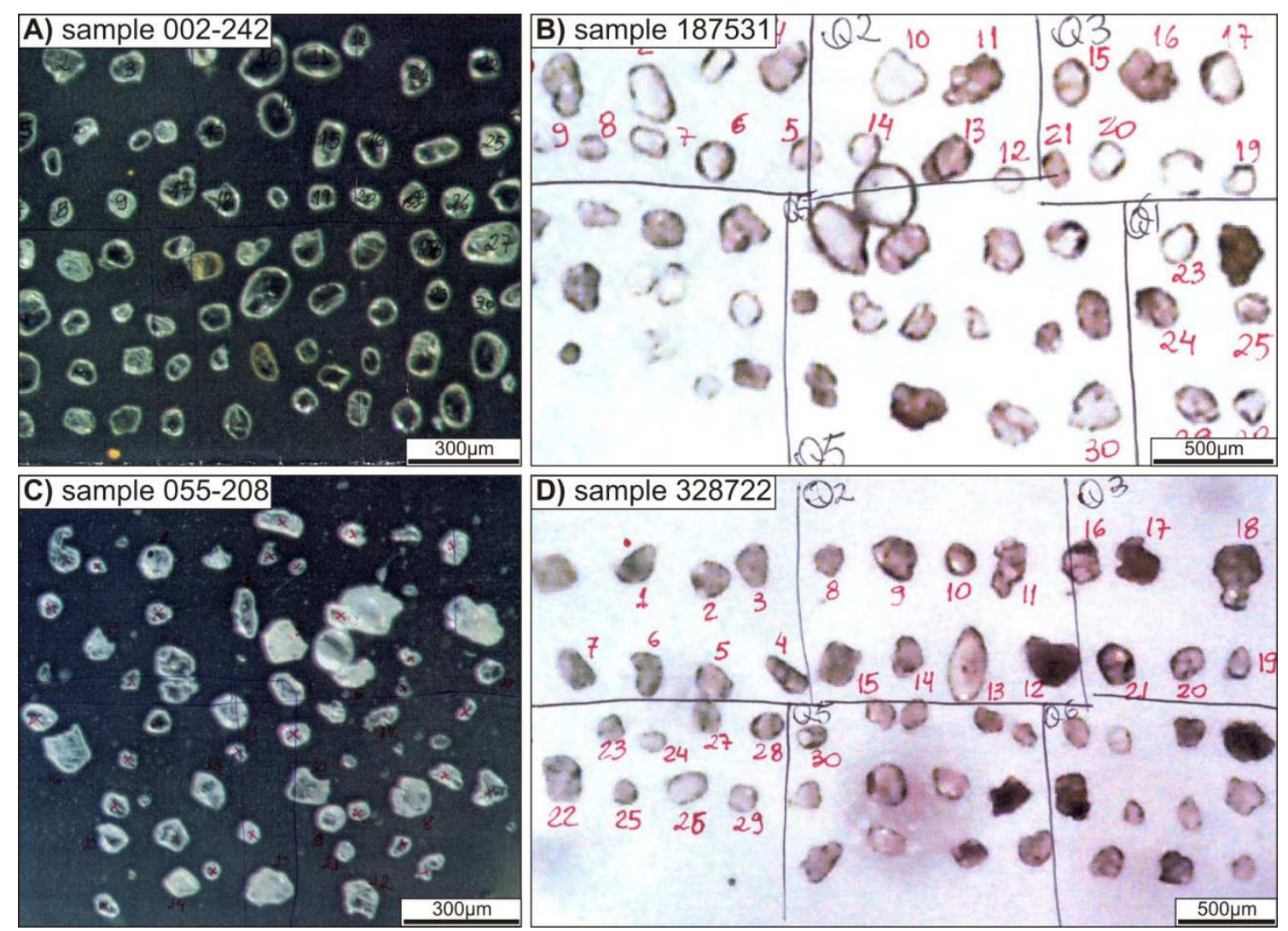

Fig. 5.8 - Epoxy zircon mounts prepared from ultramafic rock samples of the Limoeiro deposit. Note grain sizes and dominance of ovoid- and rounded-shape grains. The label beside each grain represents the zircon number exhibited in Table 5.1. 

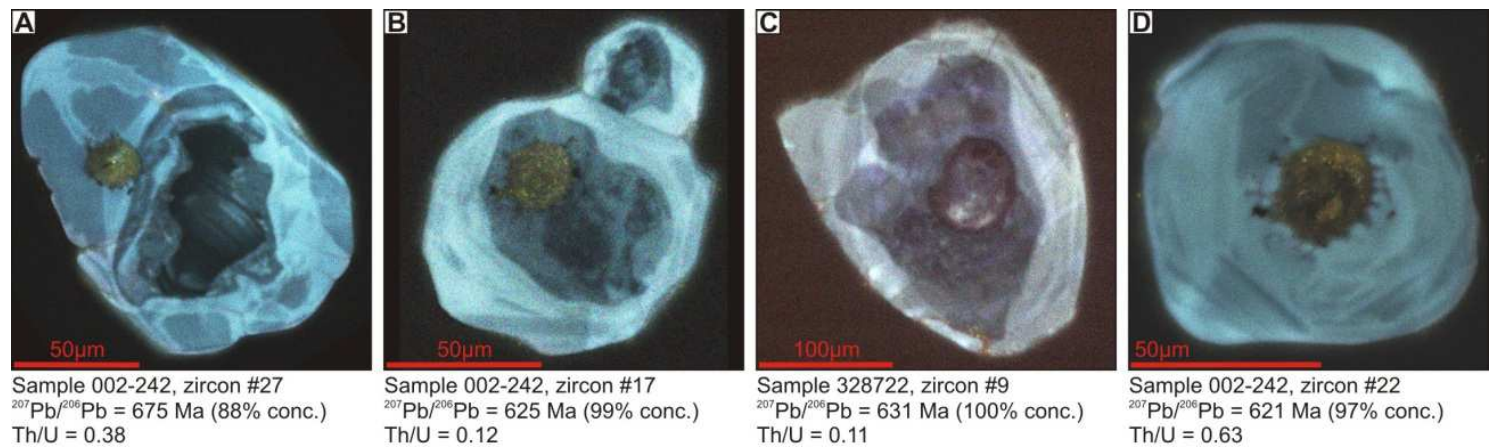

Fig. 5.9 - CL images of metamorphic zircons. Note the soccer ball habit ( $A, B$ and $C)$, diffuse zoning nucleus $(B$ and $C)$, convoluted primary zoning in the outer rim (D), transgressive recrystallization (D) and sector zoning $(A, B$ and $C)$.

$\mathrm{U}-\mathrm{Pb}$ isotopic analyses of zircons from ultramafic rocks have variable ${ }^{207} \mathrm{~Pb} /{ }^{206} \mathrm{~Pb}$ ages, that are positively correlated with $\mathrm{Th} / \mathrm{U}$ ratios (Fig. 5.10). This correlation forms a trend line between a cluster of $\mathrm{Th} / \mathrm{U} \sim 0.11$ and ${ }^{207} \mathrm{~Pb} /{ }^{206} \mathrm{~Pb}$ age of ca. $634 \mathrm{Ma}$ until scattered analyses whose end-member has $\mathrm{Th} / \mathrm{U}$ of 2.23 and ${ }^{207} \mathrm{~Pb} /{ }^{206} \mathrm{~Pb}$ age of $802 \mathrm{Ma}$ (Fig. 5.10). The positive correlation between $\mathrm{Th} / \mathrm{U}$ and ${ }^{207} \mathrm{~Pb} /{ }^{206} \mathrm{~Pb}$ age is interpreted to indicate a distribution from least recrystallized grains (older ages) to completely recrystallized zircons (younger ages forming a cluster $\sim 634 \mathrm{Ma})$. Similar results and interpretation were documented in zircon U-Pb isotopic studies of most high-grade metamorphic belts elsewhere (e.g., Williams and Claesson, 1987; Schaltegger et al., 1999; Hoskin and Black, 2000; Hoskin and Schaltegger, 2003). Some authors suggested a $\mathrm{Th} / \mathrm{U}$ value to distinguish metamorphic from primary igneous zircons (e.g., $\mathrm{Th} / \mathrm{U}=0.07$ in Rubatto, 2002), however the $\mathrm{Th} / \mathrm{U}$ ratio and other trace elements concentration of a given metamorphic zircon depends on the mineralogy that co-crystallizes with it (Hoskin and Schaltegger, 2003).

Sample $002-242$ (drill hole 2 at the depth of $242 \mathrm{~m}$ ) corresponds to an olivine-bearing orthopyroxenite of the Lower Sequence (for Limoeiro's stratigraphy review see Mota-e-Silva et al., 2013). Sixteen analyses render concordant to slightly discordant dates (Table 5.1), which define a Discordia line with an upper intercept age of $632 \pm 11 \mathrm{Ma}$ (MSWD=0.86; Fig. 5.11A), interpreted as the age of high-grade regional metamorphism. The older ages were obtained on zircon cores and, therefore, may represent older zircons (either primary igneous zircon or inherited zircon assimilated from country rocks during mafic magma emplacement) partially preserved from recrystallization during high-grade metamorphism. 


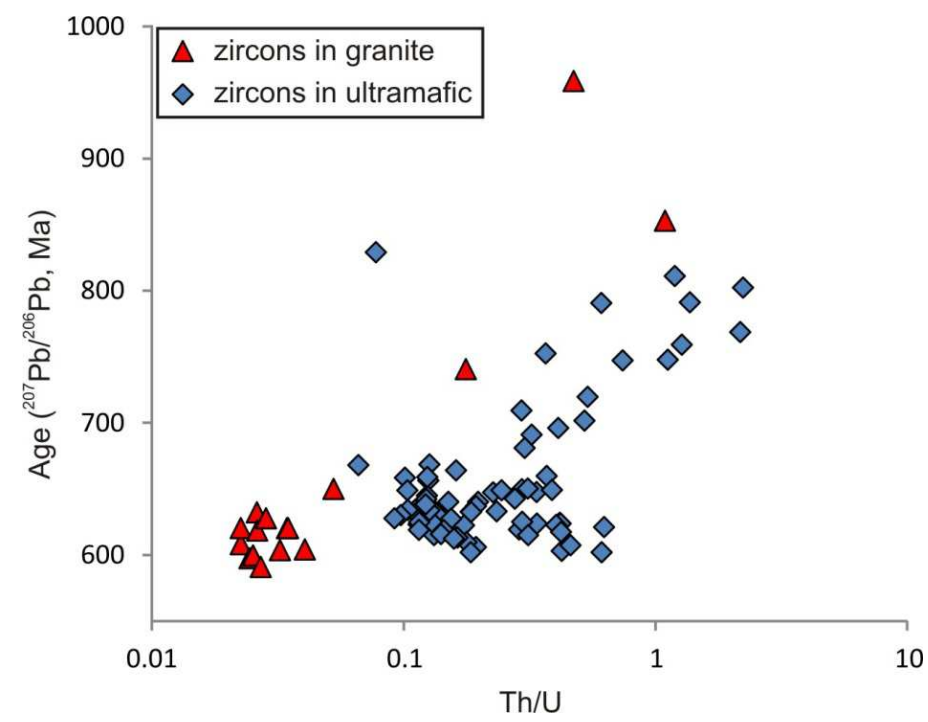

Fig. 5.10 - Biplot of Th/U (log scale) versus ${ }^{207} \mathrm{~Pb} /{ }^{206} \mathrm{~Pb}$ age of zircons from the Limoeiro ultramafics and the later granitic dyke. The positive correlation of these variables indicates different levels of zircon recrystallization. The completely recrystallized grains plot in the lower-left clusters.
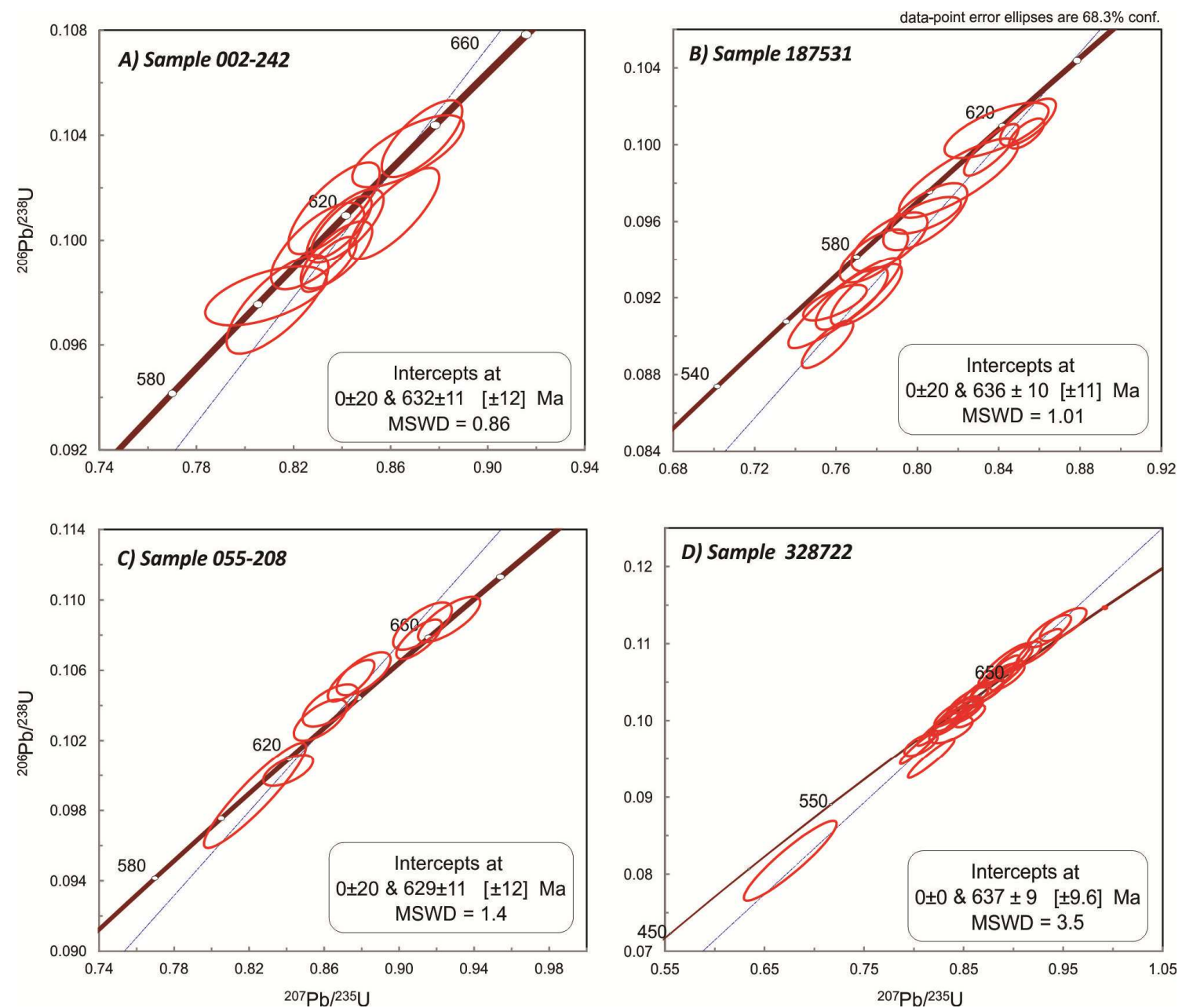

Fig. 5.11 - U-Pb concordia diagrams for zircons from samples of the Limoeiro ultramafics. 
Sample 187531 (drill hole 2 at the depth of $240.77-244-33 m$ ) is a larger sample of the same olivine-bearing orthopyroxenite as sample 002-242. Twenty-seven spot analyses yield mostly concordant data, rendering an upper intercept Discordia age of $636 \pm 10 \mathrm{Ma}$ (MSWD= 1.0; Table 5.1; Fig. 5.11B) which, similarly to the preceding samples, dates the peak of the metamorphic event imprinted on the Limoeiro deposit and country rocks. Older dates reside in the $650-800 \mathrm{Ma}$ interval, which may also represent less recrystallized older zircon grains. One grain shows ${ }^{206} \mathrm{~Pb} /{ }^{238} \mathrm{U}$ age of $2050 \pm 13 \mathrm{Ma}$, and is interpreted to be a preserved portion of an inherited zircon (Table 5.1).

Sample 055-208 (drill hole 55 at the depth of $208 \mathrm{~m}$ ) is an olivine-bearing orthopyroxenite of the Upper Sequence (for a review see Mota-e-Silva et al., 2013). Ten spot analyses reveal concordant to slightly discordant dates, which renders an upper intercept Discordia age of $629 \pm 11 \mathrm{Ma}(\mathrm{MSWD}=1.4$; Table 5.1; Fig. 5.11C), thus representing the age of the high-grade metamorphic event.

Sample 328722 (drill hole 55 at the depth of 206.25 to $209.98 \mathrm{~m}$ ) is a larger sample of the same olivine-bearing orthopyroxenite as sample 055-208. Twenty-six spot analyses render a Discordia upper intercept age of $637 \pm 9 \mathrm{Ma}(\mathrm{MSWD}=3.5$; Table 5.1; Fig. 5.11D), analogous to other described samples.

Sample 420902 (drill hole 1016 at the depth of $471.90-472.81 \mathrm{~m}$ ) corresponds to a thin undeformed biotite-bearing granitic dyke that crosscuts the ultramafic rocks. The sharp intrusive contact consists of irregular millimeter-scale biotitite in the contact zone (Fig. 5.12A,B). This sample provided long prismatic zircon grains with $\sim 200 \mu \mathrm{m}$ in the longest direction (Fig. 5.12C). A bright $C L$ nucleus with sector zoning has a sharp and angled contact with the low-CL outer rim, which contains growth zoning and euhedral termination (Fig. 5.12D). Rim analyses show a homogeneous $\mathrm{Th} / \mathrm{U}$ ratio of $\sim 0.03$, whereas the nuclei vary from 0.03 to 0.47 (Fig. 5.10). An upper intercept Discordia age of $604 \pm 6 \mathrm{Ma}(\mathrm{MSWD}=2.0$; Table 5.1; Fig. 5.13A) can be achieved using only the rim analyses, which is interpreted to be the igneous crystallization age of this granitic rock. Analyses of the high intensity $C L$ zircon cores render concordant to discordant 
dates spreading between 600 and 1150 Ma (Fig. 5.13B), likely to correspond to variably recrystallized autocrysts and xenocrysts assimilated by the granitic dyke.

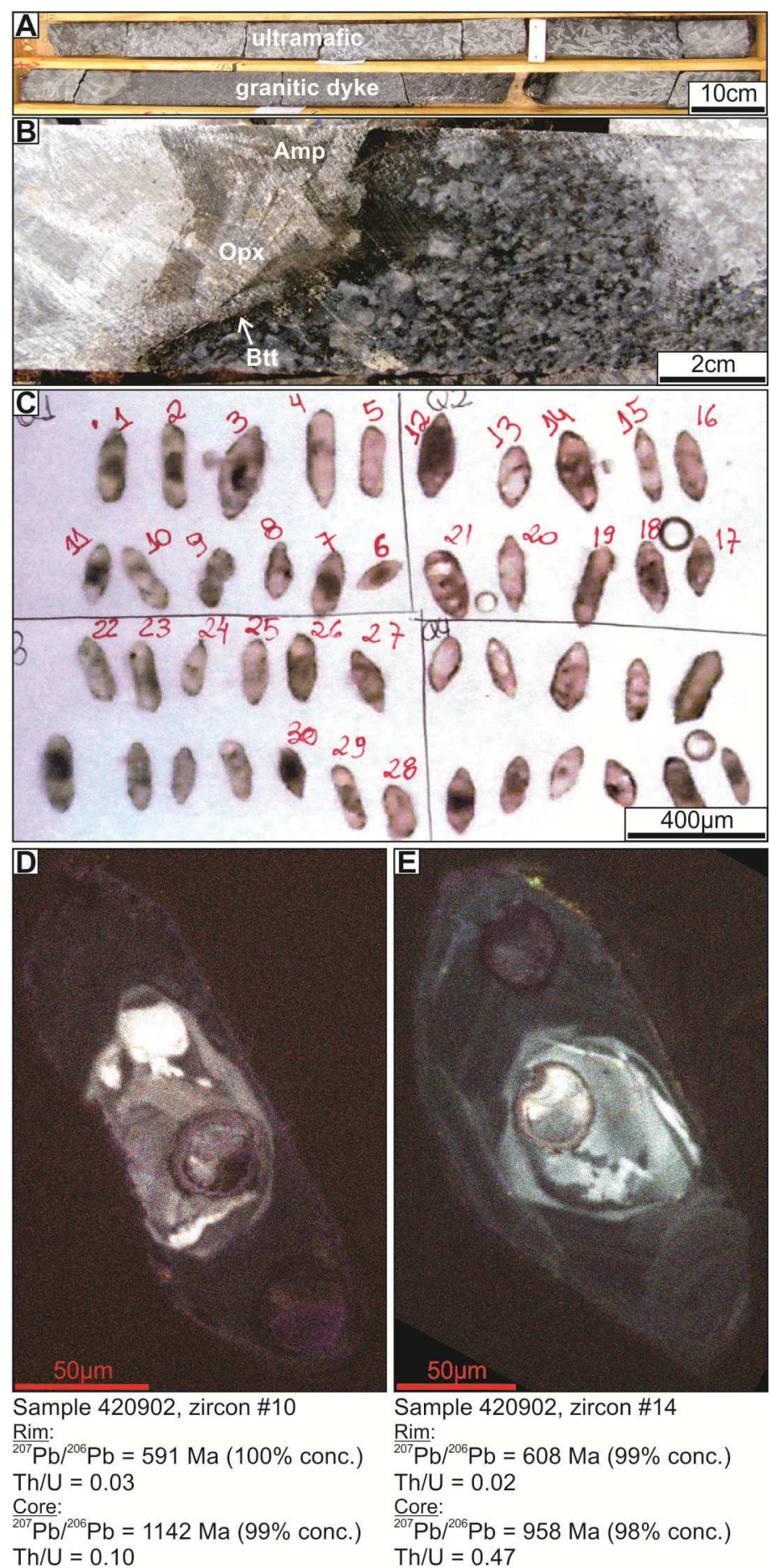

Fig. 5.12 - (A) Drill core showing thickness and intrusive relationships between the granitic dyke and the ultramafics. (B) Detail of the contact between granitic dyke and ultramafics. (C) Epoxy zircon mounts prepared from granitic dyke intrusive in the Limoeiro ultramafics. (D) and (E) refer to CL images of analysed zircons from the granitic dyke. 

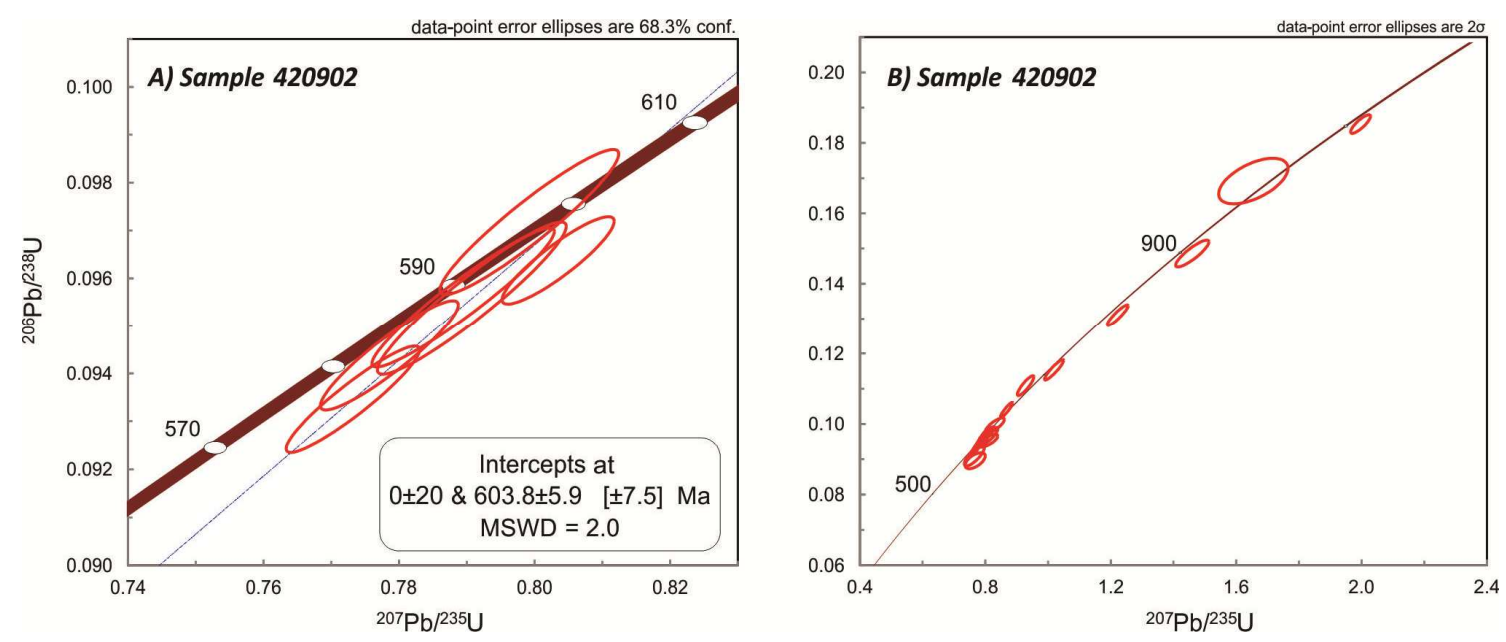

Fig. 5.13 - U-Pb concordia diagrams for zircons from the sample of the granitic dyke.

\section{Discussion}

\section{Structural controls on the emplacement of Limoeiro chonolith}

The Limoeiro intrusive complex was described by Mota e Silva et al. (2013) as a chonolith, consisting of subhorizontal irregular tube-like intrusions. Chonoliths are now widely accepted as the most important magmatic structure for hosting Ni-Cu-PGE deposits (e.g., Ripley and Li, 2011; Lightfoot and Evans-Lamswood, 2015), consisting of open system magma channels and conduits developed within collisional zones. The following discussion combines local and regional structures related to the ultramafic chonoliths of the Limoeiro deposit, providing the geological setting in which the intrusions were emplaced.

Despite the variable geometry of the chonoliths at Limoeiro, tubular intrusions with a saucer-shaped section are the predominant (Fig. 5.2). Sill intrusions generally develop saucer morphology in layered sedimentary basins (Polteau et al., 2008) and in a regional stress field of horizontal compression (Gretener, 1969). The Limoeiro chonolith intruded a volcanosedimentary sequence as a dynamic plumbing system setting fed from parental magma generated from partial melting of the mantle. The magma probably ascended from the mantle as plug- or dyke-like conduit using pre-existing deep crustal structures as pathways. The crustal level where the Limoeiro parental magma changed from vertical ascent to sub-horizontal 
emplacement into its host volcano-sedimentary strata must be related to a relatively shallow level in the crust, at which lithostatic pressure becomes lower than the magmatic driving pressure (Park, 1989) (Fig. 5.14).

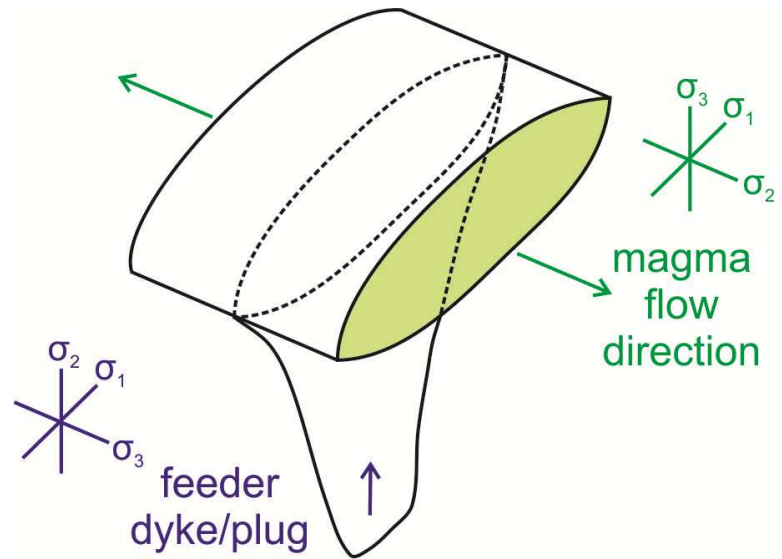

Fig. 5.14 - Schematic cartoon illustrating a precursor sill fed by its feeder dyke or plug. The decrease in confining pressure as the magma propagates vertically through the feeder zone (dyke or plug) results in change of flow direction to horizontal (sill). The zone where the least compressive stress $\left(\sigma_{3}\right)$ changes from horizontal to vertical results in such reorientation. Illustration adapted from Hornsey (1999).

Within the low strain zone in the host paragneiss former subhorizontal stretching lineation oriented in SSE-NNW direction (Fig. 5.4) are preserved. The dominant stretching lineation in the Limoeiro deposit region is subhorizontal, oriented WSW-ENE, which is a characteristic of the Brasiliano/Pan-African orogeny (650-500 Ma) structural framework in the TRC (Neves et al., 2012). This direction is parallel to sub-parallel to the dominant direction of the ultramafic intrusions. Intrusion orientations are governed by the stress regime prevailing at the time of emplacement (Anderson, 1951). Planar intrusions usually dilate in a direction parallel to the minimum compressive stress, subject to the pre-existing fracture and rheological country rock contrast conditions (Pollard, 1987) (Fig. 5.14). This suggests that at the time of the Limoeiro chonoliths emplacement there was a predominantly horizontal compressional stress regime, in which the maximum compression $\left(\sigma_{1}\right)$ was perpendicular to the intrusion elongation direction (WSW-ENE). Thus the $\sigma_{1}$ at the time of conduits emplacement was close to N-S (ignoring the Brasiliano/Pan-African blocks rotation), parallel to sub-parallel to the SSE-NNW stretching lineation (Fig. 5.4 and 14). Additionally, the intrusions long axes are parallel to subparallel to the asymmetrical folds' axial plans (WSW-ENE) that affects the foliation within the 
low-deformation zone within the central paragneiss structural lozenge (see stereogram in the Fig. 5.4 top-left).

To create space for the intrusion within the country rock, elastic compression (squeezing and folding of the wall rocks outwards) and inelastic processes (faulting and wedging apart due to pressure of intruding magma) may occur (Pollard, 1987; Paterson and Fowler, 1993). Additionally, mafic magmas are able to incorporate country rocks, particularly in dynamic systems as Limoeiro, within which new fresh magma is continuously being replenished from the feeder zones promoting hot and turbulent magma flow through a relatively narrow and long tubular conduit. The intrusive ultramafic rocks at Limoeiro, including the chilled margin or brecciated marginal zone, have a strong crustal contamination geochemical signature $\left[(\mathrm{Nb} / \mathrm{Th})_{\mathrm{PM}}\right.$ between 0.1 and 0.7 ; and $(\mathrm{Th} / \mathrm{Yb})_{\mathrm{PM}}$ between 4 and 28 ; according to Mota-e-Silva and Ferreira Filho, in prep].

It is likely that the Limoeiro conduit swarm was emplaced into open space structures (as WSW-ENE fold axis) but also compressing, faulting and assimilating the country rocks. The controlling stress field was under horizontal compression $\left(\sigma_{1} \sim N-S\right)$, which resulted in SSE-NNW stretching lineation that formed prior to, or during the early stages of, the Brasiliano/Pan-African orogeny in the TRC. The dominant WSW-ENE stretching lineation may represent postemplacement younger tectonics, which may have slightly reoriented and stretched the crustal segment that hosts the ultramafic intrusions.

\section{U-Pb ages}

The undeformed biotite-bearing granitic dyke intrusion into the Limoeiro ultramafics (Fig. 5.12A,B) has a crystallization age of $604 \pm 6 \mathrm{Ma}$ (Fig. 5.13A), which sets a minimum age for the ultramafic intrusion emplacement. The undeformed Bom Jardim syenite batholith located a few kilometers to the SW of Limoeiro conduit swarm (Fig. 5.3) was emplaced at $592 \pm 7.4 \mathrm{Ma}$ (Guimarães et al., 2004), which underpins the magmatic fabric preservation of intrusive bodies 
emplaced at $\sim 600 \mathrm{Ma}$. The magmatic event that resulted in the emplacement of the granitic dykes into the Limoeiro intrusion and batholiths in the surrounding region may be responsible for heating up the crust and promoting the extensive retrometamorphic alterations as described in the paragneiss (chlorite, muscovite and titanite) and in the ultramafic rocks (serpentine, talc, chlorite and carbonate; Mota e Silva et al., 2013). Neves et al. (2012) using a combination of $\mathrm{U} / \mathrm{Pb}$ and $\mathrm{Ar} / \mathrm{Ar}$ isotopic methods identified that the metamorphic regional temperature of the $\mathrm{RCT}$ remained near the closing temperature of amphibole $\left(\sim 500^{\circ} \mathrm{C}\right)$ for a long period $(\sim 40$ million years) after the peak of metamorphism. This suggests that retrograde reactions may have been favored by slow regional cooling. The $632 \pm 17$ Ma age obtained for the upper amphibolite facies metamorphism in the RCT (Neves et al. 2012) is interpreted to be the minimum age constraint for the onset of the Brasiliano orogeny. The metamorphic roundedshape containing soccer ball habit zircons sampled from the Limoeiro ultramafic intrusion yielded ages of $632 \pm 11,636 \pm 10,629 \pm 11$ and $637 \pm 9 \mathrm{Ma}$, forming a common overlapping age of $634 \pm 6 \mathrm{Ma}$. The latter provides an accurate age for the high-grade metamorphism in RCT. The Timbaúba pluton located $15 \mathrm{~km}$ to the north of the Limoeiro deposit (adjacent to the town of São Vicente Ferrer in Fig. 5.3) is described as an epidote-bearing biotite-hornblende granodiorite to monzogranite, deformed under high-T conditions and crystalized at $645 \pm 4.8 \mathrm{Ma}$ (Guimarães et al., 2004).

Zircons sampled from the granite dyke (sample 420902) also revealed seventeen concordant to discordant dates spread between 600 and $1150 \mathrm{Ma}$ (Fig. 5.13B), which are probably related to inheritance of the ultramafic intrusion and country rock (paragneiss and schist). The latter rocks have produced melt during metamorphism (migmatitic rocks) as recorded in petrographic and petrological study (Mota-e-Silva et al., 2013). The granite is postmetamorphic, therefore the inherited zircons record meaningless ages that are influenced by the $634 \pm 6$ Ma peak metamorphic event and the maximum depositional age of the paragneiss and schist.

The exact crystallization age for the Limoeiro complex is still unknown, as the $634 \pm 6$ Ma high grade metamorphism has extensively recrystallized the zircons in the ultramafic rocks (Fig. 5.9). The zircons with the highest $\mathrm{Th} / \mathrm{U}$ ratios represent the least recrystallized grains (e.g., 
Williams and Claesson, 1987; Schaltegger et al., 1999; Hoskin and Black, 2000; Hoskin and Schaltegger, 2003), and possibly the ones with the ages closest to the intrusion crystallization. The highest Th/U ratio zircons yields $\mathrm{Pb}^{207} / \mathrm{Pb}^{206}$ ages of ca. $800 \mathrm{Ma}$ (Fig. 5.10), which will be considered the crystallization age of the complex as a working hypothesis.

\section{The Limoeiro complex and geotectonics}

The ca. $800 \mathrm{Ma}$ age is in between the final stage of the 1000-920 Ma Cariris Velhos orogeny and the onset of the 650-500 Ma Brasiliano/Pan-African orogeny (Brito Neves et al., 2000; Santos et al., 2010). The Brasiliano/Pan-African tectonic and magmatic features prevail in the Borborema Province and in the Central African Fold Belt. However, this assumption may be biased due to great part of the Cariris Velhos rocks were extensively reset and intruded by numerous granite bodies during the Brasiliano collage (Fuck et al., 2008).

The timeframe between ca. 850 and $800 \mathrm{Ma}$ is recognized as a continental rifting phase in the Borborema Province (Brito Neves et al., 2001). This assumption based on geological evidences, was recently confirmed by the identification of oceanic crust metabasalts (Monte Orebe complex) with whole-rock Sm-Nd isochron age of $819 \pm 120 \mathrm{Ma}$ and $\varepsilon \mathrm{Nd}(\mathrm{t})$ of +4.4 in the southern part of the province (Caxito et al., 2014; Fig. 5.15). This provides an important tectonic marker for both Rodina dispersion and West Gondwana assembly in this area, representing the continuation of continental drift and the generation of new oceanic floor between the Borborema Province and the São Francisco craton (Caxito et al., 2014). Differently, the African side the timeframes of 870 to $840 \mathrm{Ma}$ and 750 to $700 \mathrm{Ma}$ were recognized as convergent events, which were named "premature orogeny" and "initial PanAfrican" respectively (Caby, 1998; Fig. 5.15). This aparrently inconsistent geotectonic setting between the African and the Brazilian counterparts may have similarities with Atlantic-type oceans evolution. The long-term ( 170 million years) extention that results in the formation of an oceanic lithosphere and continental margins is accompanied by intermittent compression along 
these margins and eventually terminates with collision of continents and formation of fold-andthrust belts (Knipper and Raznitsin, 2008).

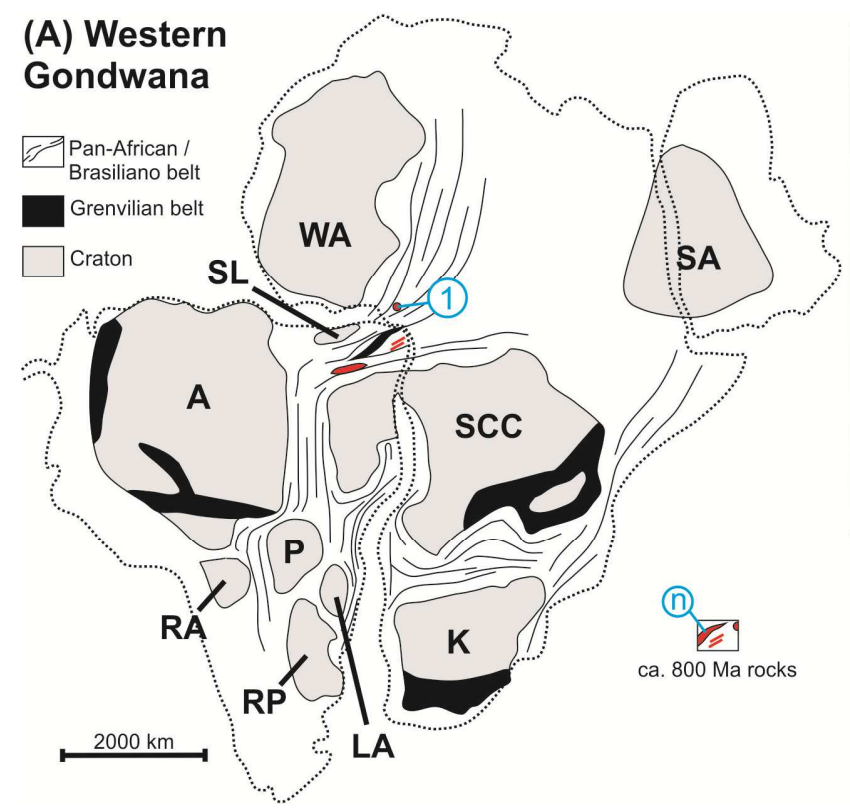

(B) Borborema Province (detail)

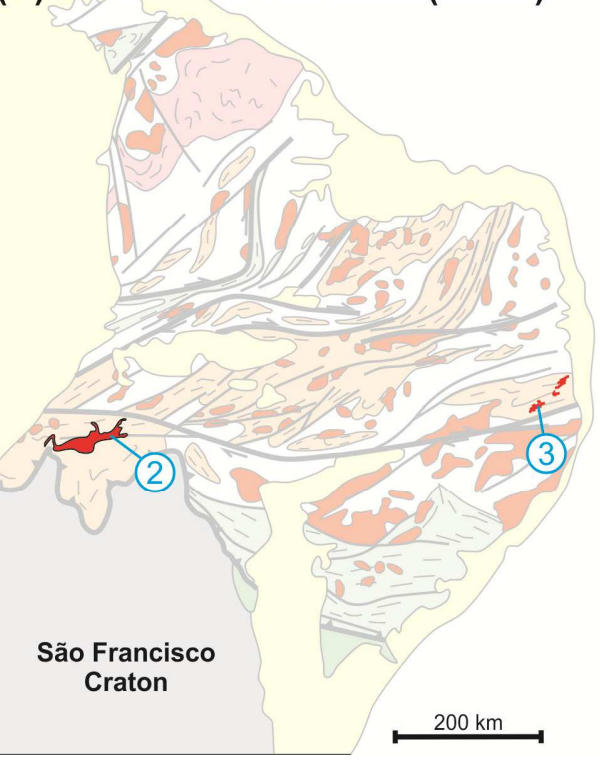

Fig. 5.15 - Occurrences of ca. 800 Ma rocks in the central part of Western Gondwana. (A) Map of the restored geometry of the western Gondwana cratonic blocks and intervening Pan-African/Brasiliano mobile belts (modified after Tohver et al., 2006). In red and labeled in blue are the ca. 800 Ma rocks in central part of western Gondwana: (1) 750$700 \mathrm{Ma}$ calc-alkaline plutonic rocks and ca $870 \mathrm{Ma}$ orogenic magmatism (Caby, 1998). (B) Detail of Borborema Province showing in the pale background the same geology presented in Fig. 5.1. In red and labeled in blue are the ca. 800 Ma rocks in Borborema Province: (2) 819 \pm 120 Ma metabasalts of Monte Orebe complex (Caxito et al., 2014); (3) ca. 800 Ma Limoeiro mafic magma conduit swarm (this study); Abbreviations for cratons: A, Amazonia; K, Kalahari; RP, Rio de La Plata; SA, Sahara Metacraton; SF, São Francisco and C, Congo; WA, West Africa; SL, São Luis; P, Paraná; LA; Luiz Alves; RA, Rio Apa.

In the previous structural control discussion, was suggested that the controlling stress field of the Limoeiro chonoliths emplacement was under horizontal compression, in which the maximum stress axe was parallel to north-south. Horizontal compression is generally related to nappe-tectonics and fold-and-thrust belts, which are common features in the external part of a collisional orogen. Given the approximate age constraint of the Limoeiro magmatism (ca. 800 Ma) a conjectural hypothesis is proposed: Limoeiro complex emplacement is related to the "premature" (ca. $840 \mathrm{Ma}$ ) or "initial" (ca. $750 \mathrm{Ma}$ ) stages of the Brasiliano/Pan-African orogeny, which is coeval to the onset of Rodinia break-up. In summary, Limoeiro complex may have 
emplaced in a localized compressional setting within a global dominant extensional tectonics (Fig. 5.16).
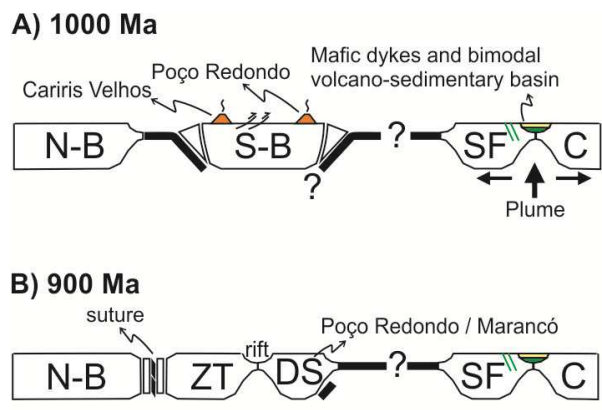

C) $800 \mathrm{Ma}$ (Western part of Borborema)
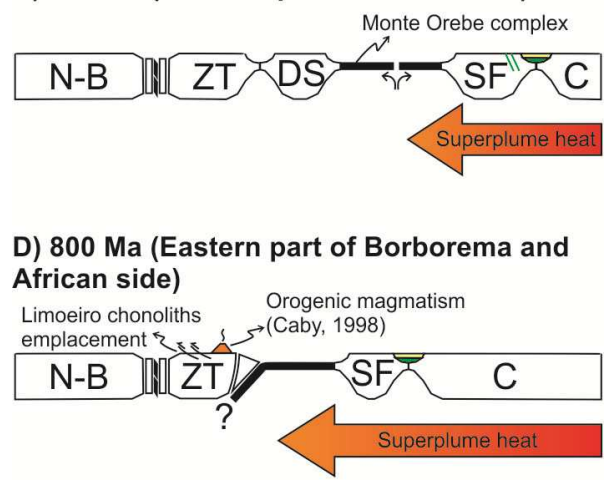

\section{E) $500 \mathrm{Ma}$}

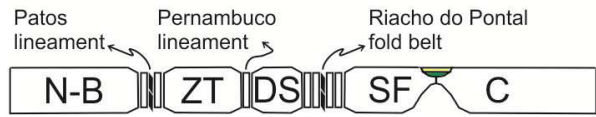

Fig. 5.16 - Schematic geotectonic evolution of the Borborema Province during the Neoproterozoic. Special emphasis is given to the Limoeiro chonolith emplacement. Abbreviations for blocks: N-B, Northern Borborema; S-B, Southern Borborema; SF, São Francisco craton; C Congo craton; ZT; Zona Transversal domain; DS, Southern domain.

At ca. $800 \mathrm{Ma}$, mantle avalanches, caused by the sinking of stagnated slabs accumulated at the mantle transition zone surrounding the supercontinent, plus thermal insulation by the supercontinent, led to the formation of a mantle superplume beneath Rodinia 40-60 million years after the completion of its assembly (Fig. 5.16). As a result, widespread continental rifting occurred between ca. $825 \mathrm{Ma}$ and $740 \mathrm{Ma}$, with episodic plume events at ca. $825 \mathrm{Ma}$, ca. $780 \mathrm{Ma}$ and ca. $750 \mathrm{Ma}$ (Li et al., 2008). The interval between 820 and $800 \mathrm{Ma}$ is well-known by a rapid rotation of Rodinia, which is is interpreted as a true polar wander event related to the occurrence of a high-latitude superplume (Evans, 1998, Li et al., 2008). The geological setting in which Ni-Cu-PGE sulfide deposits form in response to deep plumbing 
system where primitive magma ascend to shallow crustal levels, is now mainly related to supercontinent break-up and large igneous province magmatism at cratonic margins (Begg et al., 2010; Maier and Groves, 2011). The $\mathrm{TiO}_{2} / \mathrm{Yb}$ versus $\mathrm{Nb} / \mathrm{Yb}$ ratios of the Limoeiro parental magma are suggestive of shallow melting of an E-MORB mantle source (Mota-e-Silva and Ferreira Filho, in prep). According to Pearce (2008) this is indicative of volcanic-rifted margins, where hot mantle flows toward progressively thinner lithosphere (often becoming more depleted in the process).

The Limoeiro chonolith emplacement at ca. $800 \mathrm{Ma}$ in the Borborema Province may be the result of the combination of the following factors: (i) the existence of a global superplume that generated a superheated upper mantle; (ii) proximity to the southern margin of the Borborema province block; (iii) localized horizontal compressional setting related to collision of continents and formation of fold-and-thrust belts during the Rodinia supercontinent break-up.

\section{The Limoeiro complex and other mafic-ultramafic intrusions}

The Kabanga-Musongati mafic-ultramafic intrusions in Burundi and Tanzania are the most similar already described (e.g., Deblonde and Tack, 1999; Evans et al., 2000; Duchesne et al., 2004) geological province in comparison to the Limoeiro complex. The similarities include: (i) several open-system small intrusions (chonoliths) aligned through tens of kilometers long; (ii) concentrically zoned intrusions with mafic rocks in the margins and ultramafic rocks in the inner part of the intrusion; (iii) orthopyroxene and olivine cumulate rocks containing fine-grained chromite; (iv) fertile for Ni-sulfides; (v) metasedimentary rocks metamorphosed at upper amphibolite facies as country rocks of intrusions; (vi) emplacement prior to regional metamorphic peak, but intrusions are relatively preserved from pervasive deformation and metamorphism. Additionally, the Limoeiro complex and the Kabanga-Musongati intrusions are located within orogenic belts, respectively the Neoproterozoic Brasiliano/Pan-African and the Mesoproterozoic Kibaran. In a similar manner that is proposed in this study the KabangaMusongati intrusions are interpreted as formed within a compressional geotectonic setting 
(Evans et al., 2000). Despite the noticeable similaties, Limoeiro and Kabanga-Musongati intrusions were emplaced in distinct ages. The Kabanga-Musongati emplacement age is controversial. A previous 1275 Ma bulk zircon age (Tack et al., 1994) was challenged by a zircon SHRIMP set of measurements spreading from 1370Ma to $1200 \mathrm{Ma}$; the $1370 \mathrm{Ma}$ endmember is now assumed as the most probable intrusion age (Tack et al., 2002).

The most probable emplacement age of Limoeiro complex (ca. $800 \mathrm{Ma}$ ) is coincident with other two well-known mafic-ultramafic intrusions: the Lower series of the Niquelandia complex, in central Brazil, and the ultramafic intrusions that host the Jinchuan Ni-sulfide deposit, in northwest China. Supported SHRIMP-RG U-Pb data and Sm-Nd mineral isochron age, the eastern part of the Niquelandia complex, was aged at $797 \pm 10$ Ma (Pimentel and Armstrong, 2004). This complex is a large mafic-ultramafic layered intrusion, which is interpreted to be heavily contaminated with older sialic material (Ferreira Filho et al., 1994; Pimentel and Armstrong, 2004). The Jinchuan deposit is the one of the world's largest Ni-Cu-(PGE) sulfide deposits related to a magma conduit system. Recent U-Pb SHRIMP dating of zircon and baddelyeite indicate that the Jinchuan intrusion formed at $827 \pm 8 \mathrm{Ma}$ and is related to a mantle plume, whose emplacement resulted in the break-up of the Rodinia supercontinent (Li et al., 2005). These intrusions testify that the Rodinia break-up timming is prone to high degrees of mantle partial melting, primitive mafic magma generation and ascent, and $\mathrm{Ni}$-sulfide mineralization in crust.

Despite being only a conjecture at this stage, the presented evidences indicate that an ca. 800 Ma primitive mafic open-system took place at the southern margin of Borborema province within a compressional setting. This geological context was probably favored by the existence of global-scale superplume coeval to the Rodinia superconetinent break-up.

\section{Conclusions}

The principal conclusions of this study are the following: 
1. The Limoeiro complex comprises at least $46 \mathrm{~km}$ long array of tubular-shaped subhorizontal chonoliths, interpreted to be magma conduits, oriented WSWENE. An extra 108 kilometers of conduits are suggested based on interpretation of magnetometric surveys;

2. The intrusion country-rock ia a volcano-sedimentary sequence formed by successive clastic sequences (turbidite?) alternating between pelitic- and psammitic-rich horizons with variable carbonate contribution and with interbedded basaltic flows;

3. The Limoeiro chonolith swarm was emplaced under horizontally compressional stress field $\left(\sigma_{1} \sim N-S\right)$, which generated a SSE-NNW stretching lineation formed prior to the 500-650 Ma Brasiliano/Pan-African orogeny in the RCT. The dominant WSW-ENE stretching lineation represents younger postemplacement tectonics, which has slightly reoriented and stretched the crustal segment that hosts the ultramafic intrusions;

4. Both the intrusions and country-rock were metamorphosed at lower granulite facies $\left(750-800^{\circ} \mathrm{C}\right.$ and $\left.5-8 \mathrm{kbar}\right)$ at $634 \pm 6 \mathrm{Ma}$. Metamorphic zircons have ovoid- to rounded-shape and soccer ball habits. The external rim of these zircons shows bright $\mathrm{CL}$ containing convoluted zoning, transgressive recrystallization and/or sector zoning;

5. Extensive greenschist facies retrometamorphism overprints the high-grade metamorphic paragenesis. The retrograde event was probably prolonged due to intense and long-lived granitic magmatism that followed peak metamorphism;

6. The precise age of the Limoeiro magmatism is still unknown. The highest Th/U ratios in metamorphosed zircons suggest a crystallization age of ca. $800 \mathrm{Ma}$ for Limoeiro complex. This age is the same as recorded in Niquelandia Complex, in Brazil, and in the magmatic system that hosts the Jinchuan 
sulfide Ni deposit, in China. The primitive mafic magmatism at ca. $800 \mathrm{Ma}$ may be favored by the existence of global-scale superplume coeval to the Rodinia superconetinent break-up.

\section{Acknowledgments}

We are grateful to Votorantim Metais for permission to sample the Limoeiro deposit and publish the results. Thanks to the crew that runs the Geochronology Lab of IG/UnB; they were very patient and kind regarding our insistence in getting a crystallization age for the Limoeiro intrusion. We are very pleased to Elson Oliveira and Richard Hornsey reviews. This paper is part of first author's PhD thesis.

\section{References}

Accioly, A. C. A., McReath, I., Santos, E. J., Guimarães, I. P., \& Santos, A. C. (2003). The ages of crystallization and metamorphism of the Passira Anorthosite Complex, Borborema province, northeastern Brazil. In South American Symposium on Isotope Geology, 4th, Short Papers (pp. 487-490).

Accioly, A. D. A., Santos, C. D., Santos, E. D., Brito Neves, B. D., Rodrigues, J. B., \& McReath, I. (2010, July). Geochronology and geochemistry of the meta-volcanic rocks from Riacho do Tigre complex, Borborema province-northeastern Brazil. In South American Symposium on Isotope Geology (Vol. 7, pp. 13-16).

Albarede, F., Telouk, P., Blichert-Toft, J., Boyet, M., Agranier, A., \& Nelson, B. (2004). Precise and accurate isotopic measurements using multiple-collector ICPMS. Geochimica et Cosmochimica Acta, 68(12), 2725-2744.

Anderson, E. M. (1951). The Dynamics of Faulting and Dyke Formation with Application to Britain. $2^{\text {nd }}$ ed., 206pp., Oliver and Boyd, Edinburgh. 
Begg, C. B., Hronsky, J. A. M., Arndt, N. T., Griffin, W. L., O'Reilly, S. Y., Hayward, N. (2010). Lithospheric, cratonic, and geodynamic setting of Ni-Cu-PGE sulfide deposits. Econ. Geol. 105: 1057-1070.

Brito Neves, B. B., Santos, E. J., \& Van Schmus, W. R. (2000). Tectonic history of the Borborema Province, northeastern Brazil. In Tectonic Evolution of South America, International Geological Congress, Rio de Janeiro.

Brito Neves, B. B., Van Schmus, W. R., Kozuch, M., Santos, E. J. D., \& Petronilho, L. (2005). A Zona Tectônica Teixeira Terra Nova-ZTTTN: fundamentos da geologia regional e isotópica. Geologia USP. Série Científica, 5(1), 57-80. (in Portuguese)

Bucher, K., \& Grapes, R. (2011). Metamorphic rocks. In Petrogenesis of Metamorphic Rocks (pp. 21-56). Springer Berlin Heidelberg.

Caby, R. (1998). Tectonic History and Geodynamic Evolution of Northern Africa during Neoproterozoic. In: International Conference on Precambrian and Craton Tectonics / International Conference on Basement Tectonics, Ouro Preto, 1998. Abstracts. Ouro Preto, Universidade Federal de Ouro Preto, p. 72-75.

Caxito, F. D. A., Uhlein, A., \& Dantas, E. L. (2014). The Afeição augen-gneiss Suite and the record of the Cariris Velhos Orogeny (1000-960 Ma) within the Riacho do Pontal fold belt, NE Brazil. Journal of South American Earth Sciences, 51, $12-27$.

Cordani, U. G., D'Agrella-Filho, M. S., Brito-Neves, B. D., \& Trindade, R. I. F. (2003). Tearing up Rodinia: the Neoproterozoic palaeogeography of South American cratonic fragments. Terra Nova, 15(5), 350-359.

CPRM (2013). Geological map: Folha Surubim SB.25-Y-C-IV, 1:100.000. (in Portuguese).

Dalziel, I. W. (1997). Overview: Neoproterozoic-Paleozoic geography and tectonics: Review, hypothesis, environmental speculation. Geological Society of America Bulletin, 109(1), 16-42.

Dantas, E. L., Van Schmus, W. R., Hackspacher, P. C., Fetter, A. H., de Brito Neves, B. B., Cordani, U., ... \& Williams, I. S. (2004). The 3.4-3.5 Ga São José do Campestre massif, NE Brazil: remnants of the oldest crust in South America. Precambrian Research, 130(1), 113-137.

DeBlond, A., \& Tack, L. (1999). Main characteristics and review of mineral resources of the Kabanga-Musongati mafic-ultramafic alignment in Burundi. Journal of African Earth Sciences, 29(2), 313-328. 
DellaGiustina, M. E. S., Pimentel, M. M., Ferreira Filho, C. F., \& de Hollanda, M. H. B. M. (2011). Dating coeval mafic magmatism and ultrahigh temperature metamorphism in the Anápolis-Itauçu Complex, Central Brazil. Lithos 124(1): 82-102.

Duchesne, J. C., Liégeois, J. P., Deblond, A., \& Tack, L. (2004). Petrogenesis of the KabangaMusongati layered mafic-ultramafic intrusions in Burundi (Kibaran Belt): geochemical, $\mathrm{Sr}-\mathrm{Nd}$ isotopic constraints and $\mathrm{Cr}-\mathrm{Ni}$ behaviour. Journal of African earth sciences, 39(3), 133-145.

Evans, D. A. D. (1998). Supercontinental cycles and true polar wander. In: Bird, Robert, T., Powell, Christopher, McA., Wingate (Eds.), The Assembly and Breakup of Rodinia; Proceedings of a Workshop. Abstracts. Geological Society of Australia, Sydney, NSW, Australia, pp. 34-35.

Evans, D. M., Boadi, I., Byemelwa, L., Gilligan, J., \& Marcet, P. (2000). Kabanga magmatic nickel sulphide deposits, Tanzania: morphology and geochemistry of associated intrusions. Journal of African Earth Sciences, 30(3), 651-674.

Ferreira Filho, C.F., Moraes, R., Fawcett, J.J., Naldrett, A.J., 1998. Amphibolite to granulite progressive metamorphism in the Niquelândia Complex, central Brazil: Regional tectonic implications. J. S. Am. Earth Sci. 11: 35-50.

Fetter, A. H., Saraiva dos Santos, T. J., Van Schmus, W. R., Hackspacher, P. C., Brito Neves, B. B., Arthaud, M. H., \& Wernick, E. (2003). Evidence for Neoproterozoic continental arc magmatism in the Santa Quitéria Batholith of Ceará State, NW Borborema Province, NE Brazil: implications for the assembly of west Gondwana. Gondwana Research, 6(2), 265-273.

Gauert, C.D.K., de Waal, S.A., and Wallmach, T., 1995, Geology of the ultrabasic to basic Uitkomst Complex, eastern Transvaal, South Africa: an overview: African Journal of Earth Sciences, v. 21, p. 553-570.

Gomes, H. A. (2001). Geologia e recursos minerais do Estado de Pernambuco. Mapa Geológico do Estado de Pernambuco, Escala 1:500.000, CPRM/DIEDIG/DEPAT, 198 pp. (in Portuguese)

Goodgame, V. R., Johnson, J. R., MacTavish, A. D., Stone, W. E., Watkins, K. P., \& Wilson, G. C. (2010). The Thunder Bay North deposit: Chonolith-hosted Pt-Pd-Cu-Ni mineralization related to the Midcontinent Rift [abs.]. In International Platinum Symposium (Vol. 11).

Gretener, P. E. (1969). On the mechanics of the intrusion of sills. Canadian Journal of Earth Sciences, 6(6), 1415-1419. 
Guimarães, I. P., Da Silva Filho, A. F., Almeida, C. N., Van Schmus, W. R., Araújo, J. M., Melo, S. C., \& Melo, E. B. (2004). Brasiliano (Pan-African) granitic magmatism in the PajeúParaíba belt, Northeast Brazil: an isotopic and geochronological approach. Precambrian Research, 135(1), 23-53.

Guimarães, I. P., Da Silva Filho, A. F., Melo, S. C., \& Macambira, M. B. (2005). Petrogenesis of A-type granitoids from the Alto Moxoto and Alto Pajeu terranes of the Borborema Province, NE Brazil: constraints from geochemistry and isotopic composition. Gondwana Research, 8(3), 347-362.

Hoffman, P. F. (1991). Did the breakout of Laurentia turn Gondwanaland inside-out?. Science, 252(5011), 1409-1412.

Hornsey, R. A. (1999). The genesis and evolution of the Nkomati Mine Ni-sulfide deposit, Mpumalanga Province, South Africa. Unpublished M. Sc. thesis, University of Natal, Durban, South Africa.

Horsman, E., Morgan, S., de Saint-Blanquat, M., Habert, G., Nugent, A., Hunter, R. A., \& Tikoff, B. (2009). Emplacement and assembly of shallow intrusions from multiple magma pulses, Henry Mountains, Utah. Earth and Environmental Science Transactions of the Royal Society of Edinburgh, 100(1-2), 117-132.

Hoskin, P. W. O., \& Black, L. P. (2000). Metamorphic zircon formation by solid-state recrystallization of protolith igneous zircon. Journal of metamorphic Geology, 18(4), 423-439.

Hoskin, P. W., \& Schaltegger, U. (2003). The composition of zircon and igneous and metamorphic petrogenesis. Reviews in mineralogy and geochemistry, 53(1), 27-62.

Knipper, A. L., \& Raznitsin, Y. N. (2008). Synchronism in compression of the lithosphere in the central Atlantic and Western Tethys at the Tortonian-Messinian transition. Geotectonics, 42(1), 21-30.

Kosin et al., (2004). Folha Aracaju SD.24 In: Carta Geológica do Brasil ao Milionésimo. Brasília, CPRM. (in Portuguese)

Leite, P. R. B., Bertrand, J. M., de Lima, E. S., \& Leterrier, J. (2000). Timing of granitic magmatism in the northern Borborema Province, Brazil: a U-Pb study of granitoids from the Alto Pajeú Terrain. Journal of South American Earth Sciences, 13(6), 549-559.

Li X. H., Su L., Chung S.-L., Li Z. X. and Liu Y. (2005) Formation of the Jinchuan ultramafic intrusion and the world's third largest $\mathrm{Ni}-\mathrm{Cu}$ sulfide deposit: associated with the $825 \mathrm{Ma}$ south China mantle plume? Geochem. Geophys. Geosyst. 6, 1-16. 
Li, Z. X., Bogdanova, S. V., Collins, A. S., Davidson, A., De Waele, B., Ernst, R. E., .. \& Vernikovsky, V. (2008). Assembly, configuration, and break-up history of Rodinia: a synthesis. Precambrian research, 160(1), 179-210.

Lightfoot, P. C., \& Evans-Lamswood, D. (2015). Structural controls on the primary distribution of mafic-ultramafic intrusions containing $\mathrm{Ni}-\mathrm{Cu}-\mathrm{Co}-(\mathrm{PGE})$ sulfide mineralization in the roots of large igneous provinces. Ore Geology Reviews, 64, 354-386.

Ludwig, K. R. (2003). Isoplot/Ex, version 3: a geochronological toolkit for Microsoft excel: Berkeley. California, Geochronology Center Berkeley.

Maier, W. D., \& Groves, D. I. (2011). Temporal and spatial controls on the formation of magmatic PGE and Ni-Cu deposits. Mineralium Deposita, 46(8), 841-857.

Masberg, H. P., Hoffer, E., \& Hoernes, S. (1992). Microfabrics indicating granulite-facies metamorphism in the low-pressure central Damara Orogen, Namibia. Precambrian Research, 55(1), 243-257.

Medeiros, V. C. (2004). Evolução Geodinâmica e Condicionamento Estrutural dos Terrenos Piancó-Alto Brígida e Alto Pajeú, Domínio da Zona Transversal, NE do Brasil (Thesis), Universidade Federal do Rio Grande do Norte). (in Portuguese).

Mota-e-Silva, J., Ferreira Filho, C. F., \& Della Giustina, M. E. S. (2013). The Limoeiro Deposit: Ni-Cu-PGE Sulfide Mineralization Hosted Within an Ultramafic Tubular Magma Conduit in the Borborema Province, Northeastern Brazil. Economic Geology, 108(7), 1753-1771.

Mota-e-Silva, J., \& Ferreira Filho (in prep). Mineral and whole rock chemistry of the chonolith that hosts the Limoeiro Ni-Cu-(PGE) deposit: evidence of magma flow direction, siderophile element depletion and sulfide fractionation.

Neves, S. P., \& Alcantara, V. C. (2010). Geochemistry of orthogneisses and metasedimentary rocks across a proposed terrane boundary in the Central Domain of Borborema Province, NE Brazil: geodynamic implications. Journal of South American Earth Sciences, 29(2), 498-511.

Neves, S. P., Bruguier, O., Da Silva, J. M. R., Bosch, D., Alcantara, V. C., \& Lima, C. M. (2009). The age distributions of detrital zircons in metasedimentary sequences in eastern Borborema Province (NE Brazil): Evidence for intracontinental sedimentation and orogenesis?. Precambrian Research, 175(1), 187-205.

Neves, S. P., Bruguier, O., Vauchez, A., Bosch, D., Silva, J. M. R. D., \& Mariano, G. (2006). Timing of crust formation, deposition of supracrustal sequences, and Transamazonian and Brasiliano metamorphism in the East Pernambuco belt (Borborema Province, NE 
Brazil): Implications for western Gondwana assembly. Precambrian Research, 149(3), 197-216.

Neves, S. P., Monié, P., Bruguier, O., \& Rangel da Silva, J. M. (2012). Geochronological, thermochronological and thermobarometric constraints on deformation, magmatism and thermal regimes in eastern Borborema Province (NE Brazil). Journal of South American Earth Sciences, 38, 129-146.

Njonfang, E., Ngako, V., Moreau, C., Affaton, P., \& Diot, H. (2008). Restraining bends in high temperature shear zones: the "Central Cameroon Shear Zone", Central Africa. Journal of African Earth Sciences, 52(1), 9-20.

Park, R. G. (1989). Foundations of Structural Geology. Blackie, Glasgow, 135pp.

Paterson, S. R., \& Fowler Jr, T. K. (1993). Re-examining pluton emplacement processes. Journal of Structural Geology, 15(2), 191-206.

Pearce, J. A. (2008). Geochemical fingerprinting of oceanic basalts with applications to ophiolite classification and the search for Archean oceanic crust. Lithos, 100(1), 14-48.

Pimentel, M. M., \& Armstrong, R. A. (2004). SHRIMP U-Pb and Sm-Nd ages of the Niquelândia layered complex: Meso-(1.25 Ga) and Neoproterozoic (0.79 Ga) extensional events in central Brazil. Precambrian Research, 132(1), 133-153.

Pollard, D. D. (1987). Elementary fracture mechanics applied to the structural interpretation of dykes. Mafic dyke swarms, 34, 5-24.

Polteau, S., A. Mazzini, O. Galland, S. Planke, and A. Malthe-Sorenssen (2008), Saucershaped intrusions: Occurrences, emplacement and implications, Earth Planet. Sci. Lett., 261, 195- 204.

Powell, C. M., Li, Z. X., McElhinny, M. W., Meert, J. G., \& Park, J. K. (1993). Paleomagnetic constraints on timing of the Neoproterozoic breakup of Rodinia and the Cambrian formation of Gondwana. Geology, 21(10), 889-892.

Raase, P., Raith, M., Ackermand, D. and Lal, R.K. (1986). Progressive metamorphism of mafic rocks from greenschist to granulite facies in the Dharwar Craton of South India. Journal of Geology, 94: 26I-282.

Ripley, E. M., \& Li, C. (2011). A review of conduit-related Ni-Cu-(PGE) sulfide mineralization at the Voisey's Bay Deposit, Labrador, and the Eagle Deposit, northern Michigan. Reviews in Economic Geology, 17, 181-197. 
Rubatto, D. (2002). Zircon trace element geochemistry: partitioning with garnet and the link between U-Pb ages and metamorphism. Chemical Geology, 184(1), 123-138.

Sá, J. M., Bertrand, J. M., Leterrier, J., \& Macedo, M. H. F. (2002). Geochemistry and geochronology of pre-Brasiliano rocks from the transversal zone, Borborema Province, northeast Brazil. Journal of South American Earth Sciences, 14(8), 851-866.

Santos, E. J. (2000). Geological map of the "Folha Belém do São Francisco - SC.24-X-A" released by CPRM (Brazilian Geological Survey).

Santos, E. J., \& Medeiros, V. C. (1999). Constraints from granitic plutonism on proterozoic crustal growth of the Zona Transversal Domain, Borborema Province, NE Brazil. Brazilian Journal of Geology, 29(1), 73-84.

Santos, E.J., Brito Neves, B.B., Van Schmus, W.R., Oliveira, R.G., Medeiros, V.C., 2000. An overall view on the displaced terrane arrangement of the Borborema Province, NEBrazil. In: 31st International Geological Congress, 2000, Rio de Janeiro. Proceedings, in CD-Rom.

Santos, E. J., Schmus, W. R. V., Kozuch, M., \& Neves, B. B. D. B. (2010). The Cariris Velhos tectonic event in northeast Brazil. Journal of South American Earth Sciences, 29(1), 6176.

Santos, T. J. S., Fetter, A. H., Hackspacher, P. C., Van Schmus, W. R., \& Nogueira Neto, J. A. (2008). Neoproterozoic tectonic and magmatic episodes in the NW sector of Borborema Province, NE Brazil, during assembly of Western Gondwana. Journal of South American Earth Sciences, 25(3), 271-284.

Schaltegger, U., Fanning, C. M., Günther, D., Maurin, J. C., Schulmann, K., \& Gebauer, D. (1999). Growth, annealing and recrystallization of zircon and preservation of monazite in high-grade metamorphism: conventional and in-situ U-Pb isotope, cathodoluminescence and microchemical evidence. Contributions to Mineralogy and Petrology, 134(2-3), 186-201.

Seat, Z., Beresford, S. W., Grguric, B. A., Waugh, R. S., Hronsky, J. M., Gee, M. M., ... \& Mathison, C. I. (2007). Architecture and emplacement of the Nebo-Babel gabbronoritehosted magmatic Ni-Cu-PGE sulphide deposit, West Musgrave, Western Australia. Mineralium Deposita, 42(6), 551-581.

Stacey, J. T., \& Kramers, 1. (1975). Approximation of terrestrial lead isotope evolution by a twostage model. Earth and Planetary Science Letters, 26(2), 207-221. 
Tack, L., Liegeois, J.-P., Deblond, A., Duchesne, J.C. (1994). Kibaran A-type granitoids and mafic rocks generated by two mantle sources in a late orogenic setting (Burundi). Precambrian Research 68, 323-356.

Tack, L., Fernandez-Alonso, M., Tahon, A., Wingate, M., Barritt, S. (2002). The "Northeastern Kibaran Belt" (NKB) and its mineralisations reconsidered: new constraints from a revised lithostratigraphy, a GIS-compilation of existing geological maps and a review of recently published as well as unpublished igneous emplacement ages in Burundi. 11th Quadrennial IAGOD Symposium and GEOCONGRESS 2002, 22-26 July 2002, Windhoek, Namibia, Extended Abstract on CD-Rom and Synopsis in Conference Programme, p. 42.

Tohver, E., D’Agrella-Filho, M. S., \& Trindade, R. I. (2006). Paleomagnetic record of Africa and South America for the 1200-500Ma interval, and evaluation of Rodinia and Gondwana assemblies. Precambrian Research, 147(3), 193-222.

Toteu, S. F., Penaye, J., Deloule, E., Van Schmus, W. R., \& Tchameni, R. (2006). Diachronous evolution of volcano-sedimentary basins north of the Congo craton: insights from $\mathrm{U}-\mathrm{Pb}$ ion microprobe dating of zircons from the Poli, Lom and Yaoundé Groups (Cameroon). Journal of African Earth Sciences, 44(4), 428-442.

Trompette, R. (1997). Neoproterozoic ( $600 \mathrm{Ma})$ aggregation of Western Gondwana: a tentative scenario. Precambrian Research, 82(1), 101-112.

Van Schmus, W. R., de Brito Neves, B. B., Hackspacher, P., \& Babinski, M. (1995). UPb and SmNd geochronologic studies of the eastern Borborema Province, Northeastern Brazil: initial conclusions. Journal of South American Earth Sciences, 8(3), 267-288.

Van Schmus, W. R., Brito Neves, B. B., Williams, I. S., Hackspacher, P. C., Fetter, A. H., Dantas, E. L., \& Babinski, M. (2003). The Seridó Group of NE Brazil, a late Neoproterozoic pre-to syn-collisional basin in West Gondwana: insights from SHRIMP $\mathrm{U}-\mathrm{Pb}$ detrital zircon ages and $\mathrm{Sm}-\mathrm{Nd}$ crustal residence (TDM) ages. Precambrian Research, 127(4), 287-327.

Van Schmus, W. R., Kozuch, M., \& de Brito Neves, B. B. (2011). Precambrian history of the Zona Transversal of the Borborema Province, NE Brazil: insights from Sm-Nd and U$\mathrm{Pb}$ geochronology. Journal of South American Earth Sciences, 31(2), 227-252.

Vavra, G., Gebauer, D., Schmid, R., \& Compston, W. (1996). Multiple zircon growth and recrystallization during polyphase Late Carboniferous to Triassic metamorphism in granulites of the Ivrea Zone (Southern Alps): an ion microprobe (SHRIMP) study. Contributions to Mineralogy and Petrology, 122(4), 337-358. 
Votorantim Metais (2013). Annual report: Limoeiro Project. Internal report (unpublished).

Williams, I. S., \& Claesson, S. (1987). Isotopic evidence for the Precambrian provenance and Caledonian metamorphism of high-grade paragneisses from the Seve Nappes, Scandinavian Caledonides. Contributions to Mineralogy and Petrology, 97(2), 205-217. 


\section{Conclusão da tese}

Durante o percurso deste trabalho de pesquisa as técnicas aplicadas e os artigos planejados foram modificados/adaptados em função da indisponibilidade de certas técnicas analíticas (e.g., isótopos de enxofre) e oportunidade para utilização de outras (e.g., análise quantitativa de PGE em sulfetos via LA-ICP-MS). No entanto a tese atingiu seus objetivos propostos no plano de pesquisa quatro anos atrás: "Este trabalho tem por objetivo principal entender a gênese e evolução geológica do Complexo Limoeiro e sua mineralização de Ni-Cu(PGE) nas escalas local e regional".

As conclusões detalhadas da tese estão divididas em cinco partes cada uma no final de cada um dos capítulos em forma de artigos aqui apresentados. Entretanto, uma versão mais sintética das conclusões pode ser demostrada desta forma:

\section{Sobre a mineralização}

a. A mineralização sulfetada de Limoeiro é de origem magmática composta essencialmente por pirrotita ( 70\%), calcopirita $(\sim 15 \%)$ e pentlandita $(\sim 15 \%)$. Pequenas quantidades de magnetita e traço de MGP também ocorrem;

b. A mineralização conhecida é essencialmente disseminada com espessuras de até $150 \mathrm{~m}$ e comprimento de $\sim 1 \mathrm{~km}$. Níveis submétricos de sulfeto maciço ocorrem próximos da base deste envelope de sulfeto disseminado;

c. O sulfeto maciço apesar de pouco expressivo no depósito, mostra uma interessante geoquímica que evidencia segregação entre um sólido MSS e um líquido sulfetado rico em cobre (que pode da origem ao ISS). Este fato levanta possibilidades da descoberta de corpos de minério rico em cobre hospedados fora dos limites dos corpos ultramáficos;

d. O metamorfismo de alto grau $\left(750-800^{\circ} \mathrm{C}\right.$, entre $5-8 \mathrm{kbar}$ na idade de $634 \pm 6$ Ma) promoveu a recristalização dos sulfetos e provavelmente a fusão de alguns MGP, todavia a ausência de deformação concomitante não promoveu a remobilização dos sulfetos;

e. A deformação que afeta a intrusão ocorreu depois do pico metamórfico, concomitante ao metamorfismo de baixo grau. Localizadamente, este evento deslocou massas de sulfeto formando texturas stringer e "Durchbewegung" 
(brechas composta por matriz de sulfeto e fragmentos angulosos de rocha hospedeira);

f. Entre os MGP, Limoeiro apresenta uma ampla dominância de merenskyita $\left(\mathrm{PdTe}_{2}\right)$ com variadas quantidades de $\mathrm{Ni}$, Pt e Bi em solução sólida. A variação na concentração destes elementos na merenskyita é fruto do fracionamento magmático. Metamorfismo na fácies granulito-baixo provavelmente fundiu estes minerais que sequestraram boa parte dos EGP dos sulfetos de metal base adjacentes, fazendo um balanço de 84 a $88 \%$ do $\mathrm{Pd}$ hospedado em MGP. A esperrilita $\left(\mathrm{PtAs}_{2}\right)$ formou-se direto do líquido sulfetado em alta temperatura $\left(\sim 1000^{\circ} \mathrm{C}\right)$, e teve comportamento inerte frente ao metamorfismo de alta temperatura.

g. O intemperismo sobre a mineralização primária tem sua ação mais profunda a $\sim 50 \mathrm{~m}$ de profundidade, quando pentlandita e pirrotita são convertidas para violarita e pirita respectivamente. Calcopirita é o sulfeto de metal base mais resistente, alterando-se somente a partir da profundidade de $\sim 20 \mathrm{~m}$. Entre os MGP, a merenskyita é a primeira a alterar-se, perdendo Bi e Te (tornando-se um MGP metaestável rico em Pd) a uma profundidade.de $\sim 25 \mathrm{~m}$. Quanto mais próximo da superfície gradualmente a merenskyita torna-se somente um pseudomorfo preenchido por goetita. O Pd solubilizado reprecipita-se na forma de rosetas de Pd-Cu e de minerais raros de Pd e I (iodo). Este fenômeno deve relacionar-se com a natureza do clima semiárido e água subterrânea de alta salinidade da região.

2. Sobre a intrusão

a. A intrusão é concêntrica, zonada, sub-horizontal de seção perpendicular aproximadamente cilíndrica, mas irregular (conolito). Sua estrutura interna é composta por um núcleo de hazrburgito (olivina primária +ortopiroxenio primário +anfibólio metamórfico \pm cromita primária), envolto por ortopiroxenito

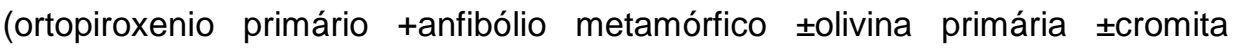
primária), e tudo isso circundado por uma auréola externa de anfibolitito metamórfico (hornblenda +antofilita);

b. A intrusão que hospeda a mineralização de Limoeiro tem várias outras intrusões satélites no entorno. Confirmados por sondagem existem hoje $46 \mathrm{~km}$ lineares de intrusões tubulares, com mais $108 \mathrm{~km}$ inferidos por dados de magnetometria; 


\section{Sobre o magmatismo}

a. O magmatismo de Limoeiro foi dinâmico, com magma passando constantemente pelo conduto, mas separado por pulsos principais (que formam as diferentes sequencias na estratigrafia da intrusão);

b. A intrusão é formada por pelo menos quatro sequencias: a sequencia de topo é a de Baixo- $\mathrm{Cr}$, que mostra uma assinatura geoquímica (MgO $~ 21 \%, \mathrm{Cr} \sim 400$ $\mathrm{ppm}, \mathrm{Cu} / \mathrm{Pd} \sim 7200, \mathrm{Fo}_{82}$ ) de um magma mais fracionado e que deixou sulfeto segregado para trás. A sequencia seguinte é a Superior que hospedada a maioria da mineralização. O gradativo aumento da razão Cu/Pd (de 5200 para 5800) desta sequencia em harmonia com a diminuição do tenor evidencia fluxo do magma para leste. A Sequencia de Transição é pouco espessa, descontínua, essencialmente ortopiroxenítica e eventualmente porta mineralização. A Sequencia Inferior é basicamente estéril na região do depósito Limoeiro, mostrando ali os mais baixos valores de Cu/Pd ( 2840). Este fato mostra que o magma que formou esta sequencia não segregou sulfetos em sua trajetória.

c. O magma parental formador de cada pulso magmático é similar entre eles. Trata-se de um magma toleítico picrítico de alto $\mathrm{MgO}$ com forte assinatura de contaminação crustal $\left[(\mathrm{Nb} / \mathrm{Th})_{\mathrm{MP}}<1 \quad\right.$ e $\left.\quad(\mathrm{Th} / \mathrm{Yb})_{\mathrm{MP}} \quad>5\right]$. 0 magma foi provavelmente gerado a partir de fusão parcial do manto enriquecido em níveis $<90 \mathrm{~km}\left[(\mathrm{~Tb} / \mathrm{Yb})_{\mathrm{MP}}=1,4\right]$.

4. Sobre a significância na geologia do leste da Província Borborema

a. O Complexo Limoeiro foi intrudido em ca. $800 \mathrm{Ma}$, na crosta superior, em um regime compressivo de máximo estresse horizontal, provavelmente em uma zona the domínio de empurrões e dobramentos.

b. O sul da Província Borborema e sua continuidade na Africa experimentaram de modo concomitante extensão com abertura de assoalho oceânico e colisão continental. Ao mesmo tempo em que se desenvolvia crosta oceânica na parte oeste (Riacho do Pontal), na parte leste dominava ambiente colisional compressivo (Limoeiro).

c. Em uma escala global a intrusão de Limoeiro é contemporânea à quebra do supercontinente de Rodínia e a existência de uma superpluma que tornou o manto extraordinariamente quente. Neste mesmo período de tempo formaramse também o sistema magmático que hospeda o depósito de Ni sulfetado de Jinchuan, na China e a Zona Inferior do complexo acamadado de Niquelândia, no Brasil central. 
As ciências exatas e principalmente as ciências da Terra, são obrigadas, a partir das limitadas fontes de evidência, a criar hipóteses de trabalho e a se aprofundar em temas mesmo que ainda conjecturais. Nesta tese não foi diferente. A planejada idade precisa de cristalização do Complexo Limoeiro não foi atingida, o que lança ao futuro a necessidade de trabalhos adicionais para testar a hipóstese de trabalho debatida no último capítulo desta tese. Perguntas foram feitas, algumas foram respondidas e muitas outras foram criadas. 